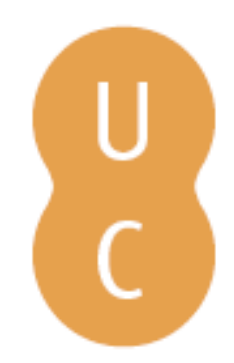

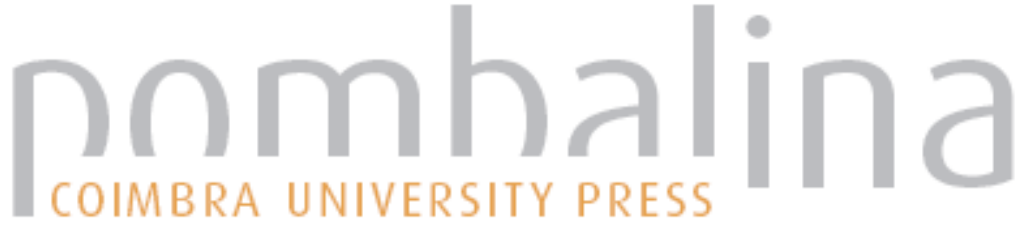

\section{Mobilidade poética na Grécia Antiga: uma leitura da obra de Simónides}

Autor(es): $\quad$ Ferreira, Luísa de Nazaré

Publicado por: Imprensa da Universidade de Coimbra

URL

persistente: $\quad$ URI:http://hdl.handle.net/10316.2/29840

DOI: $\quad$ DOI:http://dx.doi.org/10.14195/978-989-721-032-7

Accessed : $\quad$ 26-Apr-2023 11:01:53

A navegação consulta e descarregamento dos títulos inseridos nas Bibliotecas Digitais UC Digitalis, UC Pombalina e UC Impactum, pressupõem a aceitação plena e sem reservas dos Termos e Condições de Uso destas Bibliotecas Digitais, disponíveis em https://digitalis.uc.pt/pt-pt/termos.

Conforme exposto nos referidos Termos e Condições de Uso, o descarregamento de títulos de acesso restrito requer uma licença válida de autorização devendo o utilizador aceder ao(s) documento(s) a partir de um endereço de IP da instituição detentora da supramencionada licença.

Ao utilizador é apenas permitido o descarregamento para uso pessoal, pelo que o emprego do(s) título(s) descarregado(s) para outro fim, designadamente comercial, carece de autorização do respetivo autor ou editor da obra.

Na medida em que todas as obras da UC Digitalis se encontram protegidas pelo Código do Direito de Autor e Direitos Conexos e demais legislação aplicável, toda a cópia, parcial ou total, deste documento, nos casos em que é legalmente admitida, deverá conter ou fazer-se acompanhar por este aviso. 


\section{Mobilidade poética na Grécia antiga}

\section{Uma leitura da obra de Simónides}

\section{Luísa de Nazaré Ferreira}


(Página deixada propositadamente em branco) 


\section{Mobilidade poética na Grécia antiga}

Uma leitura da obra de Simónides

\section{Luísa de Nazaré Ferreira}




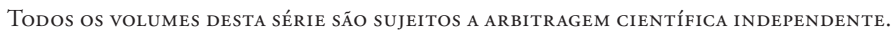

Título - Mobilidade poética na Grécia antiga: uma leitura da obra de Simónides Autora • Luísa de Nazaré Ferreira

\section{Série Hvmanitas Svpplementvm}

Coordenador Científico do plano de edição: Maria do Céu Fialho

\section{Conselho Editorial}

José Ribeiro Ferreira

Francisco de Oliveira

Maria de Fátima Silva

Nair Castro Soares

Director Técnico: Delfim Leão

Obra realizada no Âmbito das actividades da UI\&D

Centro de Estudos Clássicos e Humanísticos

\section{EDIÇÃo}

Imprensa da Universidade de Coimbra

URL: http://www.uc.pt/imprensa_uc

E-mail: imprensauc@ci.uc.pt

Vendas online:

http://livrariadaimprensa.uc.pt

CoORdenAÇÃo EDITORIAL

Imprensa da Universidade de Coimbra

Concepção gráfica \& Paginação

Rodolfo Lopes \& Nelson Ferreira

Pré-IMPRESSÃo

Imprensa da Universidade de Coimbra

\section{Depósito Legal}

$353373 / 13$

(C) JUNHO 2013.

Imprensa da Universidade de Coimbra

Classica Digitalia Vniversitatis Conimbrigensis (http://classicadigitalia.uc.pt)

Centro de Estudos Clássicos e Humanísticos da Universidade de Coimbra

Reservados todos os direitos. Nos termos legais fica expressamente proibida a reprodução total ou parcial por qualquer meio, em papel ou em ediçáo electrónica, sem autorizaçáo expressa dos titulares dos direitos. É desde já excepcionada a utilizaçáo em circuitos académicos fechados para apoio a leccionaçáo ou extensấo cultural por via de e-learning.

\author{
Impressão e Acabamento \\ SimốES \& LinHaRes \\ ISBN \\ 978-989-721-031-0 \\ ISBN DigITAL \\ 978-989-721-032-7 \\ DOI \\ http://dx.doi.org/10.14195/978-989-721-032-7 \\ 1a Ediçá́o: IUC • 2013
}




\section{SUMÁRIO}

$\begin{array}{ll}\text { Prefácio } & 9\end{array}$

NOTA PRELIMINAR 12

INTRODUÇÃo - A TRADIÇÃo dos AEDOS E DOS RAPSODOS

I. Mobilidade poética no mundo homérico 15

II. O testemunho de Hesíodo (Op. 650-662) 27

III. O aedo de Quios do Hino Homérico a Apolo (vv. 165-176) 33

IV. O Certamen Homeri et Hesiodi 41

V. A tradição dos rapsodos $\quad 49$

Parte I - Dados PRELiminares

I. As FEstas PÚblicas E A POLÍtítCa CULTURAL dos TIRANOS 63

II. As CONDIÇões DE MOBILIDADE, o ACOMPANHAMENTO MUSICAL E A EXECUÇão CORAL 97

Parte II - O espaço de mobilidade de Simónides

$\begin{array}{ll}\text { I. Dados biográficos } & 115\end{array}$

II. A mobilidade de Simónides $\quad 121$

II.1. As festas públicas $\quad 124$

1.1. A composição e execução de hinos $\quad 124$

1.2. A composição e execução de odes de vitória 126

1.3. As vitórias nas competições de ditirambos 131

II.2. Os patronos 136

2.1. Da Grécia Central e Insular 136

a) Em Atenas durante a tirania $\quad 136$

b) Os patronos da Eubeia 141

c) Simónides, cantor nacional das Guerras Medo-Persas 143

d) O testemunho do corpus epigramático 151

e) Os Oligétidas de Corinto 155

2.2. Da Tessália 156

a) As famílias aristocráticas $\quad 156$

b) Epinício para os filhos de Eácio 164

2.3. Da Magna Grécia 164

a) Os tiranos da Sicília 164

b) Mílon e Astilo de Crotona $\quad 172$

III. A criação de um clássico: os motivos biográficos da lenda de Simónides $\quad 173$

III.1. Um poeta ganancioso ou a profissionalização do ofício poético? 174 
III.2. O cultor da memória

III.3. Simónides, poeta sábio ou "proto-sofista"?

Parte III - Fragmenta Selecta: UMA leitura da obra de Simónides

I. O CANTO EM HONRA DOS HOMENS 189

I.1. Reflexões sobre a condição humana 191

$\begin{array}{ll}\text { Fr. } 520 & 191\end{array}$

Fr. $521 \quad 193$

$\begin{array}{lr}\text { Fr. } 522 & 195\end{array}$

$\begin{array}{ll}\text { Fr. } 523 & 196\end{array}$

$\begin{array}{ll}\text { Fr. } 526 & 197\end{array}$

$\begin{array}{lr}\text { Fr. } 527 & 198\end{array}$

$\begin{array}{lr}\text { Fr. } 541 & 199\end{array}$

$\begin{array}{ll}\text { Fr. } 542 & 203\end{array}$

\begin{tabular}{ll} 
Fr. 579 & 216 \\
\hline & 203
\end{tabular}

$\begin{array}{ll}\text { Fr. } 581 & 218 \\ & 216\end{array}$

\begin{tabular}{ll} 
Fr. 584 & 220 \\
\hline & 2218
\end{tabular}

Fr. eleg. $19 \quad 221$

$\begin{array}{ll}\text { Fr. eleg. } 20 & 224\end{array}$

$\begin{array}{ll}\text { Fr. eleg. } 21 & 228\end{array}$

$\begin{array}{ll}\text { Fr. eleg. } 22 & 231\end{array}$

I.2. O elogio de um esforço individual: a glória nas competições desportivas $\quad 239$

$\begin{array}{ll}\text { Fr. } 506 & 239 \\ & 239\end{array}$

$\begin{array}{ll}\text { Fr. } 507 & 241\end{array}$

$\begin{array}{ll}\text { Fr. } 509 & 246\end{array}$

$\begin{array}{ll}\text { Fr. } 511 & 249\end{array}$

Fr. 515

I.3. O elogio de um esforço colectivo: a glória nas lutas contra os Persas 255

\begin{tabular}{ll} 
Epigr. XVIII & 255 \\
\hline
\end{tabular}

$\begin{array}{ll}\text { Epigr. XIX } & 256\end{array}$

$\begin{array}{ll}\text { 3.1. Maratona } & 257 \\ & \end{array}$

$\begin{array}{lr}\text { Epigr. V } & 257 \\ & 257\end{array}$

$\begin{array}{lr}\text { Epigr. XX (b) } & 259\end{array}$

$\begin{array}{lr}\text { Epigr. XXI } & 260\end{array}$

3.2. Termópilas $\quad 262$

$\begin{array}{ll}\text { Fr. } 531 & 262 \\ & \end{array}$

$\begin{array}{ll}\text { Epigr. VI } & 267\end{array}$

$\begin{array}{ll}\text { Epigr. VII } & 270\end{array}$

$\begin{array}{lr}\text { Epigr. XXII (a) et (b) } & 270\end{array}$

$\begin{array}{ll}\text { Epigr. XXIII } & 273\end{array}$

\begin{tabular}{ll} 
3.3. Artemísio & 274 \\
\hline & 274
\end{tabular}

$\begin{array}{ll}\text { Epigr. XXIV } & 274\end{array}$

$\begin{array}{ll}\text { 3.4. Salamina } & 275 \\ & \end{array}$

$\begin{array}{ll}\text { Epigr. XIX (a) } & 276\end{array}$

$\begin{array}{lr}\text { Epigr. XI } & 277 \\ & 276\end{array}$

$\begin{array}{lr}\text { Epigr. XII } & 279\end{array}$

$\begin{array}{ll}\text { Epigr. XIII } & 280\end{array}$ 
\begin{tabular}{ll} 
Epigr.X & 281 \\
\hline Epigr.XIV & 283
\end{tabular}

$\begin{array}{ll}\text { Epigr. XIV } & 283\end{array}$

3.5. Plateias 285

$\begin{array}{ll}\text { Epigr. VIII } & 285 \\ & 285\end{array}$

$\begin{array}{ll}\text { Epigr. IX } & 286\end{array}$

$\begin{array}{ll}\text { Epigr. XV } & 287\end{array}$

$\begin{array}{ll}\text { Epigr.XVI } & 288 \\ & \end{array}$

$\begin{array}{lr}\text { Epigr. XVII (a) et (b) } & 290\end{array}$

Epigr. XX (a) 292

$\begin{array}{ll}\text { Fr. eleg. } 10 & 294\end{array}$

$\begin{array}{ll}\text { Fr. eleg. } 11 & 295\end{array}$

$\begin{array}{ll}\text { Fr. eleg. } 13 & 304\end{array}$

$\begin{array}{ll}\text { Fr. eleg. } 14 & 305\end{array}$

$\begin{array}{lr}\text { Fr. eleg. } 15 & 306\end{array}$

$\begin{array}{ll}\text { Fr. eleg. } 16 & 307\end{array}$

II. O mito: deuses e heróis na obra de Simónides 315

\begin{tabular}{ll} 
Fr. 575 & 318 \\
\hline
\end{tabular}

$\begin{array}{ll}\text { Fr. } 577 & 323\end{array}$

$\begin{array}{ll}\text { Fr. } 555 & 326 \\ & 331\end{array}$

$\begin{array}{ll}\text { Fr. } 543 & 331\end{array}$

$\begin{array}{ll}\text { Fr. } 553 & 338\end{array}$

$\begin{array}{ll}\text { Fr. } 545 & 340\end{array}$

$\begin{array}{ll}\text { Fr. } 567 & 341\end{array}$

\begin{tabular}{ll} 
Fr. 595 & 342 \\
\hline
\end{tabular}

$\begin{array}{ll}\text { Fr. } 550 & 344\end{array}$

$\begin{array}{ll}\text { Fr. } 551 & 346\end{array}$

$\begin{array}{lr}\text { Fr. } 559 & 347 \\ & 346\end{array}$

$\begin{array}{ll}\text { Fr. } 572 & 347\end{array}$

$\begin{array}{lr}\text { Fr. } 564 & 350\end{array}$

III. A PRESENÇA DA NATUREZA 353

$\begin{array}{ll}\text { Fr. } 508 & 356\end{array}$

$\begin{array}{ll}\text { Fr. } 586 & 362\end{array}$

$\begin{array}{ll}\text { Fr. } 597 & 363\end{array}$

$\begin{array}{ll}\text { Fr. } 593 & 364\end{array}$

$\begin{array}{ll}\text { Conclusões } & 367\end{array}$

BibLIOGRAFIA

I. Edições, traduções e comentários $\quad 379$

$\begin{array}{ll}\text { II. Estudos } & 387\end{array}$

ÍNDICES

$\begin{array}{ll}\text { Índice de fontes antigas } & 407\end{array}$

Índice de autores modernos $\quad 441$

Índice geral $\quad 453$

$\begin{array}{ll}\text { Índice de termos gregos } & 467\end{array}$ 
(Página deixada propositadamente em branco) 


\section{Prefácio}

Celebram-se no presente ano de 2012 duas décadas da publicação do P. Oxy. 3965, que veio confirmar a reputação de Simónides como intérprete notável da resistência helénica nas lutas contra os Persas. Desde esse ano de 1992, o 'Novo Simónides', como de imediato passaram a ser designados os fragmentos papirológicos então revelados, nos quais a batalha de Plateias parece ocupar lugar de relevo, tornou-se objecto das leituras mais distintas e interessantes. $\mathrm{O}$ estudo que agora se publica - graças ao incentivo generoso de amigos, de colegas, dos meus mestres, da Coordenadora Científica do Centro de Estudos Clássicos e Humanísticos, Professora Doutora Maria do Céu Fialho, e do Director da Classica Digitalia, Professor Doutor Delfim Ferreira Leão - é fruto da investigação realizada durante uma boa parte deste período cronológico e corresponde, com pequenas alterações, à dissertação de doutoramento apresentada à Universidade de Coimbra em Novembro de 2005.

Ao longo de vários anos procurei cumprir um sonho antigo de estudar com rigor e persistência a lírica grega do período arcaico. A eleição de Simónides como figura central deste trabalho devo-a ao Professor Doutor José Ribeiro Ferreira, meu orientador pedagógico de várias edições da cadeira de Literatura Grega. A Professora Doutora Maria Helena da Rocha Pereira, que aceitou orientar este estudo e o acompanhou até à sua conclusão, sugeriu a segunda linha de pesquisa: enquadrar o caso particular de um poeta de fama excepcional, e do qual haviam sido publicados recentemente fragmentos papirológicos, numa situação geral e pouco estudada, a mobilidade dos líricos arcaicos.

A mobilidade poética não é um fenómeno exclusivo da Época Arcaica nem tipicamente grego, mas inscreve-se numa tradição enraizada na própria 
maneira de ser do povo grego. Assim, no capítulo de introdução comento os testemunhos literários mais antigos sobre a existência de poetas itinerantes, os Poemas Homéricos e a obra de Hesíodo, que nos permitem caracterizar a actuação dos aedos, mas alarguei esse estudo à tradição dos rapsodos, que fizeram da mobilidade um modo de vida e continuavam activos no tempo de Xenofonte e Platão.

O plano da investigação previa o estudo da mobilidade dos líricos arcaicos sob duas vertentes: o exame das motivações principais desta prática e das condições em que se efectuava. Desta pesquisa resultou a primeira parte da dissertação. Em termos gerais, constitui uma reflexão sobre as condições de trabalho dos antecessores e contemporâneos de Simónides. No entanto, dada a escassez de fontes ou a falta de fidedignidade de algumas delas, tenho consciência de que constitui apenas uma descrição aproximada dessa realidade.

Por razões metodológicas, pareceu-me conveniente comentar à parte a documentação respeitante a Simónides, sendo o objectivo fundamental da investigação o estudo dos seus fragmentos principais, mas tendo em consideração as possíveis circunstâncias em que compôs e apresentou as suas obras, bem como os contactos que estabeleceu ao longo da sua vida. Assim, na segunda parte, depois do exame breve dos dados biográficos, comento os elementos, recolhidos dos testemunhos e dos fragmentos, que nos permitem esboçar o espaço de mobilidade de Simónides, tendo em vista dois aspectos principais: as ocasiões de execução da sua obra, designadamente as festas públicas, e as pessoas que celebrou ou com as quais contactou por razões profissionais. O último capítulo desta parte é dedicado às histórias sobre o carácter do poeta, transmitidas pela tradição pseudo-biográfica, fruto talvez de leituras erróneas da sua obra, mas que são também um testemunho da admiração que a figura de Simónides continuou a despertar muito tempo depois da sua morte.

O facto de não conhecermos, na maior parte das vezes, o subgénero dos fragmentos que nos chegaram ditou a opção, que segui na terceira parte, de um comentário organizado segundo os temas privilegiados no corpus de Simónides, que compreende fragmentos líricos, elegíacos e epigramas.

Embora tenha consultado numerosos estudos, será justo dizer que esta investigação muito deve aos trabalhos de C. M. Bowra, W. Burkert, D. A. Campbell, D. E. Gerber, J. H. Molyneux, D. L. Page, P. J. Parsons, O. Poltera, M. L. West, bem como aos dos meus mestres e colegas. Por outro lado, esta exposição fundamenta-se em muitas fontes antigas, designadamente nos testimonia que D. A. Campbell compilou para a segunda edição Loeb Classical Library da lírica grega do período arcaico. Uma vez que nas últimas décadas temos assistido à publicação em Portugal de traduções de qualidade dos autores gregos e latinos, algumas delas premiadas, e sendo esta tarefa tão exigente, 
pareceu-me mais correcto citar essas versões. As traduções dos fragmentos de Simónides são da minha autoria.

Como foi dito acima, no decurso desta investigação contei com o apoio de muitas pessoas e entidades. Reitero, por isso, o meu agradecimento sincero aos Mestres que orientaram este estudo, a Professora Doutora Maria Helena da Rocha Pereira e o Professor Doutor José Ribeiro Ferreira, aos meus familiares, amigos, colegas e funcionários do Instituto de Estudos Clássicos, do Centro de Estudos Clássicos e Humanísticos e da Faculdade de Letras da Universidade de Coimbra, aos meus alunos de Literatura Grega e demais cadeiras, bem como ao Dr. Nelson Ferreira, que acolheu com dedicada paciência a tarefa ingrata de formatar este estudo. Escusado será dizer que qualquer incorrecção é da minha inteira responsabilidade. Agradeço igualmente o apoio financeiro concedido pela Fundação Calouste Gulbenkian, sob a forma de três bolsas de curta duração, que durante o período de pesquisa aliviou as despesas de deslocação às bibliotecas da Sorbonne e da Universidade de Caen.

Estou grata a todos. Bem hajam.

Coimbra, 31 de Julho de 2012 Luísa de Nazaré Ferreira 


\section{NOTA PRELIMINAR}

Entendemos por corpus de Simónides o conjunto de composições líricas e elegíacas (poemas e epigramas) considerado nas edições organizadas por D. L. Page, M. L. West e D. A. Campbell. Os fragmentos líricos (fr.) são identificados pela numeração contínua de Poetae Melici Graeci, que Campbell adoptou na sua edição. Para os elegíacos (fr. eleg.), seguimos a estabelecida na segunda edição do vol. II de Iambi et Elegi Graeci ante Alexandrum cantati, e para os epigramas (epigr.) a de Further Greek Epigrams. Os testemunhos (test.) relativos aos poetas mélicos são os que figuram em Greek Lyric, de D. A. Campbell.

$\mathrm{Na}$ citação de autores gregos, seguimos, quase sempre, as abreviaturas de H. G. Liddell-R. Scott-H. Stuart Jones (edd.), A Greek-English Lexicon (Oxford $\left.{ }^{9} 1996=L S J\right)$. Para os autores latinos, as de P. G. W. Glare (ed.), Oxford Latin Dictionary (Oxford 1982). As publicações periódicas são identificadas pelas siglas de L'Année Pbilologique. Além das indicadas na bibliografia final, ocorrem também as seguintes:

Chantraine (P.): Dictionnaire Étymologique de la Langue Grecque. Histoire des Mots (Paris 2009).

LIMC: Lexicon Iconographicum Mythologiae Classicae (Zürich-München 1981-1997).

OCD: S. Hornblower, A. Spawforth (edd.), The Oxford Classical Dictionary. Third edition revised (Oxford ${ }^{3} 2003$ ).

P. Oxy.: Oxyrhynchus Papyri (London 1898-).

Ao longo da exposição, as edições, traduções, comentários e estudos citados na bibliografia final são identificados pelo apelido do autor e ano de publicação. Além dessas obras, indicam-se nas notas, por extenso, outros títulos que foram consultados pontualmente ou constituem, para este trabalho, bibliografia de carácter complementar. Justifica-se assim a existência de um índice de autores modernos.

Não adoptámos o itálico nas palavras e expressões latinas correntes, como vide, ad loc., in, supra, infra., que foi mantido nos termos gregos transliterados (e.g. arete).

Nas referências cronológicas seguimos E. J. Bickerman, Chronology of the Ancient World (London 1968). Salvo indicação em contrário, as datas são anteriores a Jesus Cristo. 


\section{INTRODUÇÃO}

A tradição dos AEdos E DOS RAPSODOS 
(Página deixada propositadamente em branco) 


\section{Mobiliddade POÉTICA NO MUNDO HOMÉRICO}

A actividade dos cantores profissionais não ocupa na Ilíada o lugar de destaque que lhe confere a Odisseia. Nesta podemos apreender, em traços gerais, os contornos da actuação dos aedos que se apresentam nos palácios de Ulisses, de Alcínoo, de Agamémnon e de Menelau, mas é aquela que nos dá conta de uma grande variedade de formas poéticas. Embora nada indique que sejam literárias, sugerem a existência de manifestações de carácter poético-musical em tempos muito remotos.

A primeira a ser referida é o péan ( $\pi \alpha$ lóv $)$ que os Aqueus entoam em coro para aplacar a ira de Apolo (1.472-473). A importância destes versos reside na estreita ligação que se estabelece entre o canto ( $\alpha \varepsilon i ́ \delta o v \tau \varepsilon \varsigma$, v. 473), a dança e a

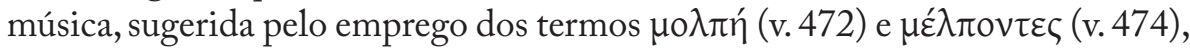
que designam um canto acompanhado de dança e, eventualmente, de música ${ }^{1}$. Por outro lado, o segundo hemistíquio do v. 474 centra-se na função do canto

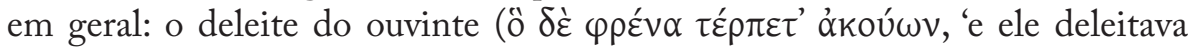
o seu espírito ao ouvi-los'). Neste caso, estamos perante uma execução coral que tem em vista um deus (v. 472) identificado pelo seu epíteto (દ́kó́cpүov, 'o archeiro', v. 474). Em 22.391-392 os Aqueus entoam um péan para celebrarem a morte de Heitor, mas neste contexto de morte não há referências a Apolo².

A descrição do escudo de Aquiles forjado por Hefestos, que ocupa a última parte do canto XVIII (vv. 478-608), é rica em momentos poéticos e musicais. O primeiro evoca os festejos de casamento (vv. 491-496), durante os quais se

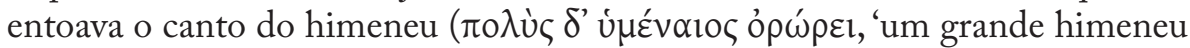
elevava-se até aos céus', v. 493), e que incluíam, além do canto, a dança (кoũpor

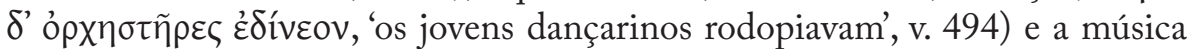

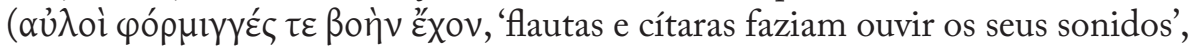
v. 495). O trabalho de Hefestos é tão hábil que permite vislumbrar os efeitos

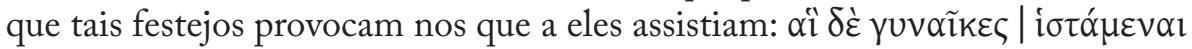

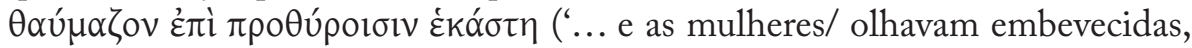
detendo-se cada uma nas entradas de suas casas', vv. 495-496).

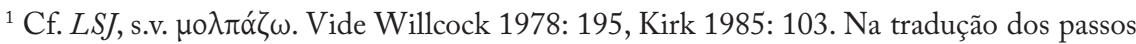
da Ilíada seguimos, em geral, a edição crítica de Van Thiel 1996.

${ }^{2}$ Trata-se, provavelmente, como julga Richardson 1993: 146, de um canto pela vitória sobre o inimigo, e não há razão que nos obrigue a supor que era dirigido a Apolo, sendo o deus um dos aliados dos Troianos. Para a etimologia do termo, vide Chantraine, s.v. raı́óv. Sobre a ligação do péan ao culto de Apolo, cf. Burkert 1993 [1977]: 288. Vide, em especial, Ian Rutherford, "The

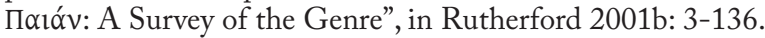


Os dois momentos descritivos seguintes transportam-nos para o ambiente do trabalho no campo. Se no primeiro o deleite dos pastores que tocam a flauta se torna fatal, porque os distrai e impede de preverem a emboscada de

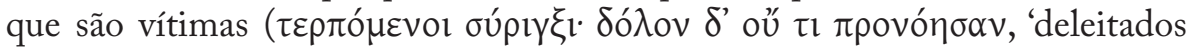
com a flauta; não pressentiram a emboscada', v. 526), no segundo assistimos a uma cena pacífica, na qual se destaca uma criança que toca a cítara e entoa a 'canção de Lino' ( $\lambda$ ívov $\delta$ ' úrò k $\alpha \lambda$ òv ớ $\varepsilon 1 \delta \varepsilon$, v. 570$)^{3}$, enquanto os vindimadores dançam, cantam e gritam (vv. 569-572).

À dança, que ocupa a penúltima camada do escudo, dedica o poeta dezassete versos desta ekphrasis (vv. 590-606). Na parte final, detém-se na atitude da multidão, que contempla os bailarinos com deleite ( $\varepsilon \varepsilon \rho \pi o ́ \mu \varepsilon v o r$, v. 604).

Estas cenas retratam manifestações de carácter público ou colectivo. A execução poética era também praticada em ambientes íntimos, como testemunha o passo conhecido do canto IX (vv. 185-191), no qual o poeta descreve a dedicação de Aquiles aos prazeres do canto e da música, enquanto está afastado das lides guerreiras. Tal como nos exemplos anteriores, o poeta

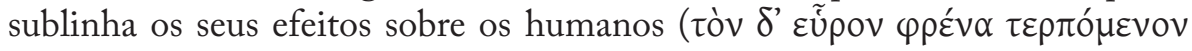

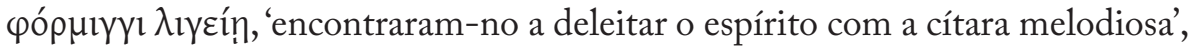

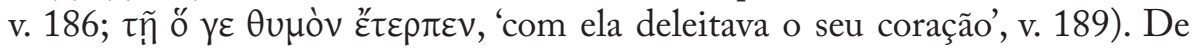
salientar ainda que, embora Aquiles seja um amador, o assunto do seu canto, $\kappa \lambda \varepsilon ́ \alpha \stackrel{\alpha}{v \delta} \delta \tilde{\omega} v$ ('as acções gloriosas dos homens', v. 189), integra o repertório dos profissionais que actuam nos palácios da Odisseia (cf. 8.73), pelo que temos aqui um dos exemplos da conexão profunda que liga o herói homérico e o cantor épico, como demonstrou bem Frederico Lourenço ${ }^{4}$.

${ }^{3}$ Depreende-se destes versos que era um cântico popular entoado na época das vindimas. A crer no escoliasta e nos versos que cita em abono da sua explicação (schol. B Hom. Il. 18. 570, IV. 558 Erbse = fr. $880 P M G$ ), era também um lamento fúnebre pela morte de Lino, figura mítica ligada à música e similar a Adónis (cf. Sapph. fr. 140 (b) L-P). Segundo o fr. 305 M-W de Hesíodo, era filho da Musa Urânia. Apolo matou-o, porque se vangloriava de cantar tão bem como o deus (cf. Paus. 9. 29. 6-7). No passo homérico, a menção dos gritos dos jovens vindimadores pode ser uma alusão ao grito ritual $\alpha$ î̉ıvov, que se ouvia durante a execução deste cântico (cf. Pind. Thren.3.6 = fr. 128c Ma.). Não obstante o carácter fúnebre, o fragmento de Hesíodo indicia que era adequado a ocasiões festivas. Segundo Heródoto, era comum na Fenícia, em Chipre e no Egipto (2. 79). Os estudiosos modernos, de facto, identificam diversas afinidades com cânticos populares orientais. Cf. Farnell 1921: 23-32, Burkert 1983: 108, Willcock 1984: 272, Lambin 1992: 143-148; West 1992b: 28-29, 45-46, 388; H. J. Rose, E. Krummen, $O C D$, s.v. Linus.

${ }^{4}$ Vide "Aedo e herói”, in Lourenço 2004:96-100. O aedo versa no seu canto temas tradicionais e outros inspirados num passado recente: as façanhas dos homens e dos deuses, como 'os amores de Ares e Afrodite' e 'o estratagema do cavalo de madeira' (Od. 1. 338, 8. 266-366, 8. 492-521), mas também as penas da Humanidade, como 'o regresso infeliz dos Aqueus' e 'a querela de Ulisses e Aquiles' (cf. Il. 6.357-358; Od.1.326-327, 8.75-83). Para um exame da diversidade do canto do aedo, vide Hainsworth 1993: 38-39, Pizzocaro 1999. 
Por conseguinte, se a Ilíada parece dar pouca visibilidade aos aedos, em benefício notório das figuras heróicas, há pelo menos um acontecimento que não dispensa a sua presença: as cerimónias fúnebres em honra de Heitor. Após os lamentos de Andrómaca, de Hécuba e de Helena, o corpo do filho de Príamo é transportado para os seus aposentos e colocado no leito (24.719-722):

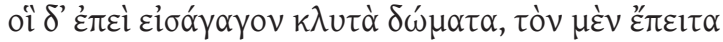

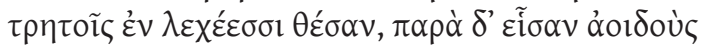

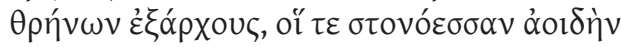
oî $\mu \varepsilon \dot{v}$ ớ

Trouxeram-no para os seus magníficos aposentos, depois deitaram-no num leito com relevos e junto dele sentaram-se os aedos que aos trenos deram início: um canto lamentoso entoavam, enquanto gemiam as mulheres.

Destaque-se que nesta cerimónia o canto fúnebre oficial, que contrasta

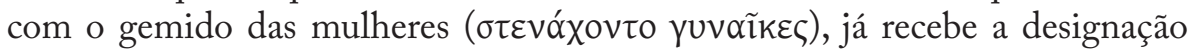

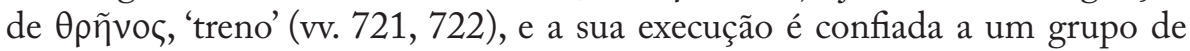

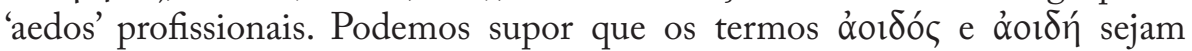
aqui empregues sobretudo para sublinhar a solenidade do canto fúnebre, pois as figuras referidas neste passo da Ilíada não se assemelham aos cantores épicos evocados na Odisseia que, de resto, apenas retrata a actuação a solo do aedo. Correspondem antes, como observou Colin MacLeod, a carpideiros profissionais ("hired mourners") $)^{5}$, e o seu canto não versa sobre os $k \lambda \varepsilon_{\varepsilon} \alpha \dot{\alpha} v \delta \rho \tilde{\omega} v$ nem tem a função de deleitar quem os escuta.

Merece ainda a nossa atenção um momento do "Catálogo das naus" do canto II, no qual o poeta enumera as tropas de Nestor (ou contingente de Pilos), que incluem aliados vindos das regiões da Élide e da Messénia. A referência a Dórion suscita a evocação do castigo do poeta Tâmiris (vv. 591-600):

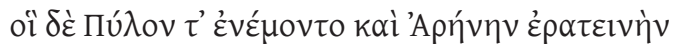

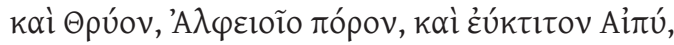

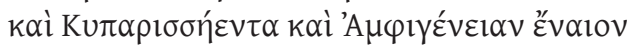

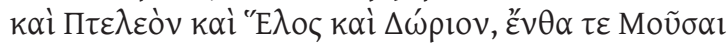

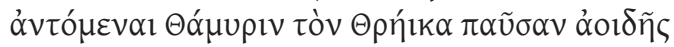

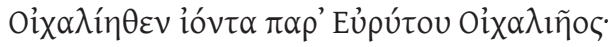

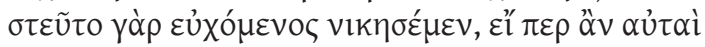

${ }^{5}$ MacLeod 1982: 148. Agradecemos a Frederico Lourenço a chamada de atenção para este comentário, bem como a interpretação global do passo. Recorde-se que no canto XXIV da Odisseia, quando as Musas executam o treno pela morte de Aquiles fazem-no à vez, alternando

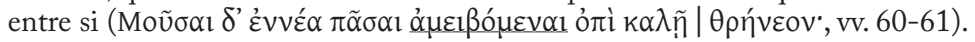




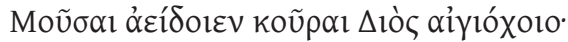

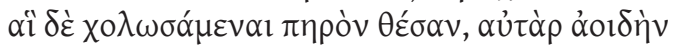

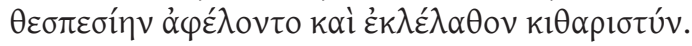

Os que viviam em Pilos e na agradável Arene,

em Trio, onde passa o Alfeu, na boa Épi,

na Ciparíssia, e os que habitavam Anfigenia,

Ptéleo, Helos e Dórion, onde as Musas

encontraram Tâmiris da Trácia e puseram fim ao seu canto,

quando vinha da Ecália, de junto de Êrito Ecaliense,

pois ameaçava em voz alta obter a vitória, ainda que fossem as próprias

Musas a cantar, as filhas de Zeus portador da égide.

E elas, iradas, mutilaram-no, do canto

divino o privaram e fizeram-no esquecer a arte da cítara.

Este episódio é um caso típico de hybris castigada pelos deuses, pois Tâmiris, oriundo da Trácia como Orfeu, vangloriava-se de ser mais excelente do que as próprias filhas de Zeus, constituindo também um exemplo oposto aos relatos da investidura poética de Hesíodo e Arquíloco, que tiveram ambos encontros auspiciosos com as patronas da poesia ${ }^{6}$. Sobre este tema, Sófocles compôs o drama perdido Tâmiras, no qual apresentava em cena o castigo das Musas: a cegueira. $\mathrm{O}$ passo homérico diverge neste pormenor, pois o poeta é impedido de exercer a sua arte, o que não aconteceria necessariamente se perdesse a visão ${ }^{7}$.

O passo homérico não está isento de alguma dificuldade, gerada sobretudo pela geografia imprecisa da Ilíada (cf. Kirk 1985: 216). Importa salientar que

${ }^{6}$ Hes. Th. 22-34; Archil. test. 3 Gerber (Mnesiepis inscriptio, SEG 15. 517, col. II). Cf. a célebre representação de um pastor e seis musas numa píxide ática de figuras vermelhas sobre fundo branco, preservada em Boston (Museum of Fine Arts 98.887, c. 460-450). Willcock 1978: 210 menciona outros exemplos, evocados na Ilíada, de mortais castigados pela sua bybris: Licurgo (6.130-140), Belerofonte (6.200-202) e Níobe (24.602-609). Vide a leitura do passo homérico por Wilson 2009: 56-59, que interpreta o antagonismo que opõe Tâmiris às Musas como uma representação "of this clash between two musical traditions that expressed ultimately in the different generic performances-types of hexameter epic and kitharodic lyric." (p. 58).

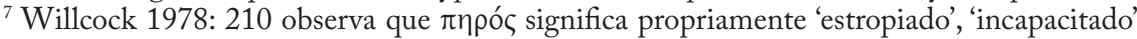
(cf. LSJ, s.v.), mas neste passo é tradicionalmente interpretado como 'cego'. Para uma opinião divergente, cf. Kirk 1985: 217. A perda da visão de Tâmiris é mencionada no fr. 65 M-W de Hesíodo e em fontes posteriores (e.g. Eur. Rh. 921-925, Apollod. 1. 3. 3, Paus. 4. 33. 3). Sobre a tragédia perdida de Sófocles ( $\operatorname{Tr} G F$ IV F 236-245) e a representação do castigo, vide Akiko Kiso, The Lost Sophocles (New York 1984) 2, 10, 53 (com indicações bibliográficas). O mito de Tâmiris teve alguma representação nas artes plásticas da Época Clássica, talvez por influência do teatro (cf. Kiso, ibidem, p. 127 n. 4). Cf. Anne Nercessian, LIMC VII. 1, s.v. Thamyris, Thamyras (München 1994) 902-904, VII. 2: 615-616. Vide ainda a discussão do tratamento dramático e iconográfico de Tâmiris por Wilson 2009: 59-79. 
Tâmiris se encontra com as Musas em Dórion da Messénia ${ }^{8}$, quando vinha da Ecália, situada na Tessália, o que pressupõe a realização de uma longa viagem. No comentário a este passo, Kirk observa que em Homero não surgem referências aos poetas itinerantes ("wandering singers"). Tâmiris não parece ter, de facto, esse estatuto, pois o segundo hemistíquio do v. 596 especifica que ia a caminho do Peloponeso, depois de ter beneficiado da hospitalidade de Êurito, rei da Ecália (cf. Il. 2. 730), pormenor que o aproxima dos aedos da Odisseia. Por outro lado, os vv. 597-598 sugerem um confronto num concurso poético ${ }^{9}$. No entanto, de concreto apenas sabemos que Tâmiris era um cantor excepcional, que dominava igualmente a arte da cítara. $\mathrm{O}$ texto não precisa se era um aedo (apesar de ảoı $\delta$ ', 'canto', nos vv. $595,599^{10}$ ), habituado a deslocar-se de corte em corte e a participar em concursos poéticos, mas também não exclui completamente estas hipóteses. Por conseguinte, em nossa opinião, este passo contém a única referência da Ilíada à mobilidade poética no mundo homérico, embora não nos ofereça uma caracterização precisa da actuação de Tâmiris.

A Odisseia transmitiu-nos um dos testemunhos mais antigos sobre a existência de profissionais itinerantes que viajavam pela Grécia e asseguravam o seu sustento com a prestação de serviços. Num passo conhecido do canto XVII, Eumeu acompanha Ulisses até ao palácio sem o reconhecer e Antínoo acusa-o de ter levado para o banquete um mendigo com o fim único de perturbar o bem-estar dos pretendentes. Indignado, o servo leal observa que só faz sentido acolher um profissional de fora se ele for útil à comunidade (vv. 380-387):

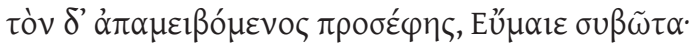
380

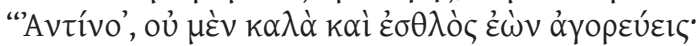

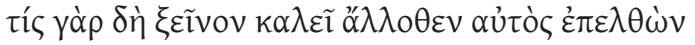

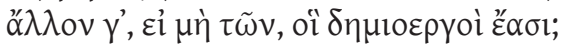

${ }^{8}$ Esta parece ser a versão mais difundida. Hesíodo, fr. $65 \mathrm{M}-\mathrm{W}$, situa o encontro na planície

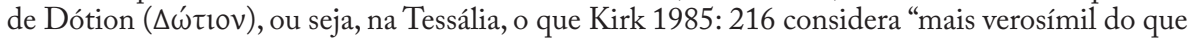
um encontro no sudoeste do Peloponeso". Cf. Wilson 2009: 47-52.

${ }_{9}^{9}$ As versões posteriores deste mito (e.g. Eur. Rh. 921-925, Apollod. 1. 3. 3, Paus. 10. 7. 2, Ps. Plu. de Mus. 3. 1132b) mencionam concretamente a participação de Tâmiris num concurso poético, no qual tem de enfrentar as Musas, um dado que o texto homérico, em nossa opinião, apenas sugere.

${ }_{10}$ Trata-se da primeira ocorrência da palavra óoı $\delta$, também presente num discurso de Polidamante a Heitor no canto XIII (v. 731), no qual evoca a dádiva divina da dança, da música e do canto. Muitos editores consideram o verso espúrio, pois está ausente de um papiro e de vários manuscritos. Para Willcock 1984: 222, "It certainly seems out of place". Na opinião de Janko 1992: 138, trata-se de uma interpolação rapsódica. Van Thiel, porém, considera o verso

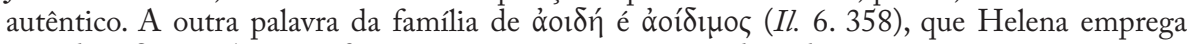
quando reflecte sobre os infortúnios que inspiram o canto do aedo. 


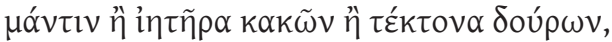

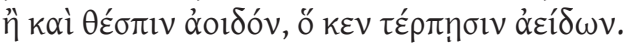

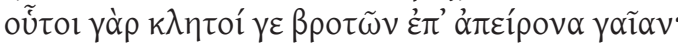

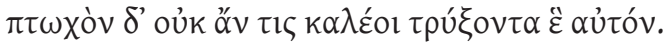

Foi então, ó porqueiro Eumeu, que lhe deste esta resposta:

"Antínoo, apesar de seres nobre, não são belas as tuas palavras.

Quem é que vai ele próprio chamar outro, um estrangeiro, de outra terra, a não ser que se trate de um demiurgo: um vidente, um médico, um carpinteiro de madeira, ou um aedo divino, que com o seu canto nos deleita?

Estes homens são sempre convidados na terra ilimitada.

Agora um mendigo ninguém convidaria como despesa para si próprio. $(\ldots)^{11}$

No comentário a estes versos, Joseph Russo observa que se trata do primeiro

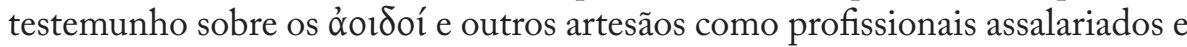
sublinha a valorização atribuída ao ofício de aedo, cuja menção ocupa um verso inteiro $^{12}$. O destaque é reforçado pelo epíteto e justifica-se pelo estatuto elevado que o cantor ocupa neste poema. A estes profissionais recrutados no exterior

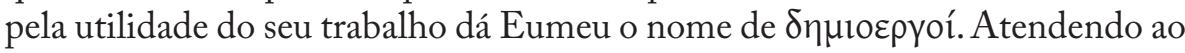
contexto e ao sentido etimológico da palavra ('os que trabalham para o povo') ${ }^{13}$, estas pessoas prestavam serviços em comunidades diversas e deslocavam-se conforme as solicitações. Além das que aqui são referidas, Penélope acrescenta o arauto (19.135), que ocupa igualmente um lugar de mérito na hierarquia social do mundo homérico.

As palavras de Eumeu deixam perceber que a mobilidade destes profissionais se justifica pelo dom ou habilidade invulgar que possuem, que os torna distintos e procurados por toda a terra. É notória a sua importância na sociedade homérica ${ }^{14}$, mas os testemunhos que nos chegaram sobre o sábio

${ }^{11}$ Nas citações da Odisseia transcrevemos a tradução de Lourenço 2003, que segue as edições críticas de T. W. Allen (1917-1919) e P. von der Mühll (1962).

${ }^{12}$ In Russo et alii 1992: 38-39.

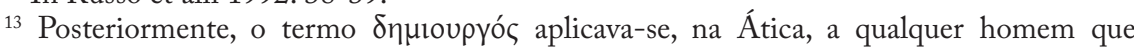
exercesse uma profissão manual, embora o artesão fosse especificamente chamado ßóv $\alpha$ vo Noutros locais da Grécia, como em Esparta, designava os magistrados mais importantes. Cf.

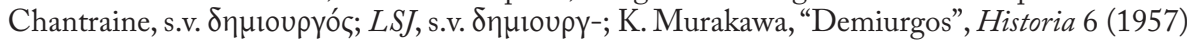
385-415.

${ }^{14} \mathrm{O}$ vidente é aquele que conhece tudo, diz-se nos vv. 384-385 do canto I da Ilíada, e o mais famoso deste poema é Calcas, que toma a palavra no v. 93 (cf. 13. 70). No v. 663 do canto XIII surge uma breve referência ao adivinho coríntio Poliido. Um dos mais célebres dos vários adivinhos da Odisseia é Tirésias de Tebas, mencionado pela primeira vez no canto X. Conserva as suas capacidades mesmo morto (vv. 492-495) e responde às interrogações de Ulisses (11. 90-151). Além dele, aparecem Haliterses de Ítaca, Teoclímeno, Télemo, Anfiarau e Polifido. 
Epiménides de Festos (Creta), o médico Democedes de Crotona e os muitos artistas gregos provam que na Época Arcaica e nas seguintes a mobilidade continuou a ser uma prática comum a vários ofícios ${ }^{15}$.

A resposta dada a Antínoo sublinha três aspectos da actuação do aedo: a ligação estreita com o divino, o deleite do seu canto (17.385) e a mobilidade como condição essencial da sua arte (v. 386). O primeiro é atestado pelo uso de fórmulas do tipo ơor $\grave{\eta} v$ $\theta \varepsilon \sigma \pi \varepsilon \sigma i ́ n v$, que caracteriza a voz de Tâmiris

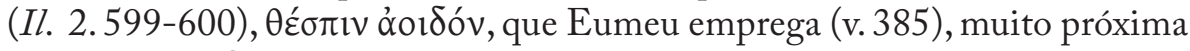

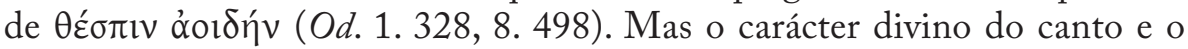
deleite que suscita revelam-se inseparáveis. Esta ideia está bem presente num momento do canto VIII da Odisseia, quando Alcínoo ordena que se prepare um banquete em honra de Ulisses com a presença do aedo Demódoco (vv. 43-45):

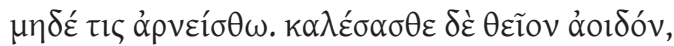

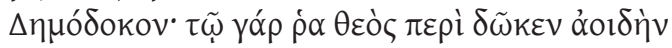

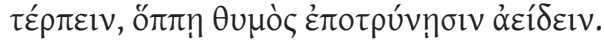

Que ninguém se recuse! E chamai ainda o divino aedo, Demódoco, pois a ele concedeu o deus o apanágio de nos deleitar, quando aquilo canta que lhe inspira o coração.

Diz-se no canto XI da Ilíada que 'um médico vale por muitos homens' (v. 514), mas é no "Catálogo das naus" que o poeta refere pela primeira vez os dois 'hábeis médicos' dos Aqueus: os irmãos Macáon e Podalírio, filhos de Asclépios e comandantes dos povos da Ecália (2.730-732). Mencionados em conjunto mais do que uma vez (cf. 11. 833, 16. 28), é sobretudo Macáon que vemos em acção, a socorrer Menelau no canto IV (vv.189-219) e no canto XI, quando Idomeneu é ferido (vv. 511-518). Tal como Eumeu afirma, os Poemas Homéricos destacam em especial o trabalho dos carpinteiros, responsáveis pela construção dos barcos (e.g. Il. 5. 61-63, Od. 5 . 249-250) e das habitações (e.g. Il. 6.313-315, Od.17.340-341). Por vezes, o artífice é nomeado, como no canto XIX da Odisseia, onde se diz que a cadeira de Penélope, com incrustações de marfim e prata, fora realizada pelo artesão Icmálio (vv. 55-57).

${ }^{15}$ Sobre Epiménides, cf. Plu. Sol.12. 7-12, que o inclui no grupo dos Sete Sábios, no lugar de Periandro de Corinto (12. 7), e D.L. 1. 109-115. As aventuras de Democedes são narradas por Heródoto $(3.125,129-137)$. A mobilidade dos videntes é examinada por Walter Burkert, "Itinerant Diviners and Magicians: A Neglected Element in Cultural Contacts", in R. Hägg (ed.), The Greek Renaissance of the Eighth Century BC: Tradition and Innovation (Stockholm 1983) 115-120. Sobre Epiménides, vide Dodds 1951, cap. V. A integração da história de Democedes na estrutura das Histórias é tratada por D. Asheri, Erodoto. Le Storie. Vol. III. Libro III (Milano 1990) 341-342, com indicações bibliográficas. Sobre a mobilidade e repartição dos artífices, vide A. Burford, Craftsmen in Greek and Roman Society (London 1972) 62-67, e "Crafts and Craftsmen", in Michael Grant \& Rachel Kitzinger (edd.), Civilization of the Ancient Mediterranean. Greece and Rome. I (New York 1988) 367-388, esp. 382-383. Sobre o seu estatuto social, vide Rocha Pereira 1997b. Para um estudo da mobilidade profissional na Grécia antiga, vide Baslez 1984: 50-54, André et Baslez 1993: 207-246. No que respeita à mobilidade dos poetas, vide a introdução de Hunter and Rutherford 2009: 1-22. 


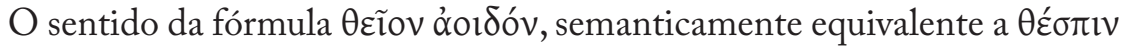
ơoı́óv, é explicitado no verso seguinte: o canto do poeta é de origem divina e tem a função de deleitar, pormenor sublinhado pela colocação do verbo

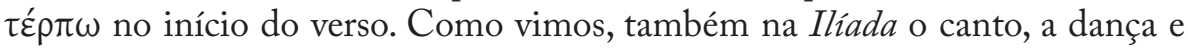
a música permitem atingir um estado de doce deleite, quer o ouvinte seja um ser divino (1. 474) quer seja humano $(9.186,189 ; 18.495-496,526,604)$. O

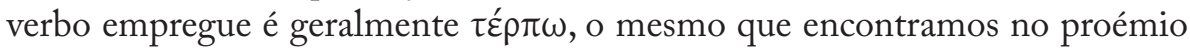
da Teogonia de Hesíodo (vv. 37, 51).

O próprio Alcínoo reconhece que a arte do aedo não depende apenas da vontade dos deuses, pois o poeta canta conforme a sua disposição, como nota também Telémaco, num célebre diálogo com a mãe (Od.1.346-347):

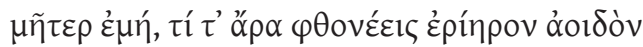

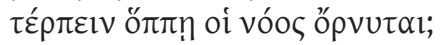

Minha mãe, porque razão levas a mal que o fiel aedo nos deleite de acordo com a sua inspiração?

Demódoco é amado pela Musa, que lhe concedeu o doce canto e a inspiração para celebrar as glórias dos homens, diz o poeta (8. 63-64, 73). Como os helenistas sublinham, este dom não é a inspiração sublime, ideia que não parece ocorrer antes do séc. $V$, mas o conhecimento do grande repertório de lendas (cf. Hainsworth 1988: 350) ${ }^{16}$. É esta dádiva ou instrução divina que, no entender de Ulisses, justifica a distinção de Demódoco (cf. 8. 479-481, 487-490, 496-499, vide infra, p. 24).

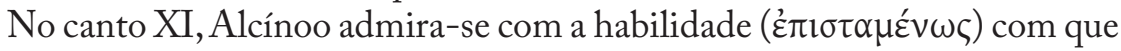
o seu hóspede relata as suas desventuras, e compara-o a um aedo (vv. 368-369). Esta admiração sobressai também num símile, por meio do qual Eumeu estabelece um paralelo entre os efeitos agradáveis sentidos pelo público de um aedo e os que ele sentiu, quando escutou Ulisses (17.518-521):

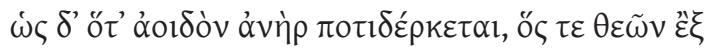

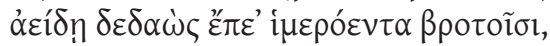

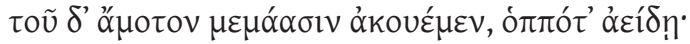

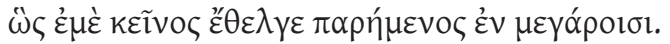

Ouvi-lo é olhar para um aedo, que para os mortais canta palavras cheias de saudade, que os deuses the ensinaram,

${ }^{16}$ Cícero, ao reflectir sobre a inspiração poética (de Orat. 2. 46. 194, Div. 1. 37. 80), evoca Demócrito (cf. frr. 17 e 18 D-K) e Platão (cf. Phdr. 245a). Cf. Dodds 1951: 80-82, Murray 1996: 6-12 e n. seguinte. 
e todos desejam ardentemente ouvi-lo, cada vez que cantaassim o estrangeiro me enfeitiçou, sentado no meu casebre.

Mais uma vez, é evidente a associação entre a origem divina do canto e o prazer que ele proporciona. Do mesmo modo, quando Fémio, no canto XXII, suplica a Ulisses que poupe a sua vida, declara (vv. 344-349):

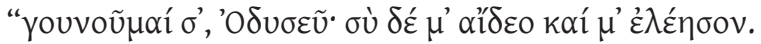

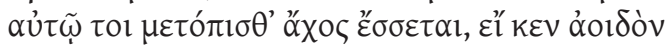

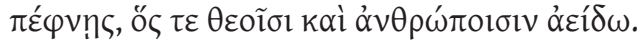

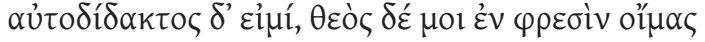

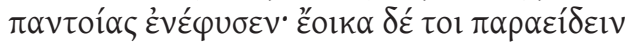

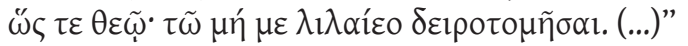
"Peço-te de joelhos, ó Ulisses, que me respeites e te apiedes de mim. Para ti próprio virá a desventura, se matares o aedo: eu mesmo, que canto para os deuses e para os homens. Sou autodidacta e um deus me pôs no espírito cantos de todos os géneros: sou a pessoa certa para cantar ao teu lado, como se fosses um deus. Por isso, não desejes degolar-me. (...)"

Se a afirmação inicial do v. 347 sublinha a capacidade de aprendizagem e a habilidade do aedo, a segunda proclama essa autoridade divina que faz dele um ser tão especial e distinto ${ }^{17}$. Demovido por Telémaco (cf. vv. 354-360), o rei de Ítaca poupa a vida ao arauto Médon e a Fémio. O epíteto que Ulisses então

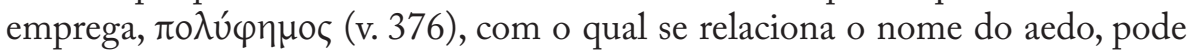
ser uma alusão à sua fama ('muito famoso') ou à variedade do seu repertório ('de muitos cantos', cf. vv. 347-348).

Em geral, o canto do aedo deleita ou encanta os mortais (cf. Od.1.337), e agrada em especial quando soa a novidade, afirma Telémaco (1. 351-352). Tanto os convivas da boda dos filhos de Menelau (4.17), como os que assistem ao banquete de despedida oferecido a Ulisses, no palácio de Alcínoo (13.27), se deleitam ( $\varepsilon \rho \pi o ́ \mu \varepsilon v o l)$ com o canto do aedo. Parece mesmo que só ele tem o poder de domar os ânimos exaltados dos pretendentes, que o escutam sentados e em silêncio (1. 325-326, 339-340). Por isso, quando Penélope, no canto I, regressa aos aposentos e os pretendentes vociferam, na sua insolência desmedida (1.368), Telémaco propõe, para os acalmar, que escutem antes o

17 Para uma análise destes versos e do sentido do termo $\alpha$ ủ Fernández-Galiano in Russo et alii 1992: 279-281; P. Murray, "Poetic Inspiration in Early Greece", JHS 91 (1981) 87-100; Dawe 1993: 799; P. Hummel, "Être ou apprendre: de

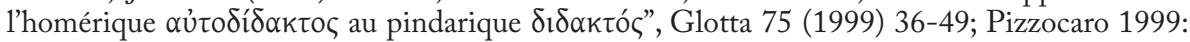
17-25; J. Assaël, "Phémios autodidaktos", RPh 75. 1 (2002) 7-21. Cf. infra, p. 57 n. 86. 
cantor divino, 'cuja voz na verdade à dos deuses se assemelha' $(1.371=9.4)$. Não é de espantar que protestem com veemência, quando Fémio termina o seu canto (cf. 17.358-360). No v. 330 do canto XXII, o poeta menciona o seu

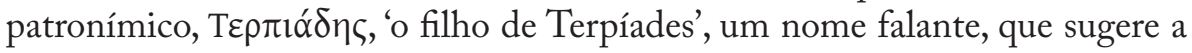
noção de deleite.

Ulisses diz a Alcínoo que escutar o aedo durante o banquete constitui uma condição essencial da felicidade humana (9.1-11), mas não é menos verdade que o canto poético, dado o seu grande poder evocativo, pode causar reacções diferentes nos seus ouvintes. Se para Penélope é muitas vezes fonte de uma amargura difícil de suportar, pela saudade que lhe traz à memória o canto triste do regresso dos guerreiros (1.340-342), em Ulisses suscita as lágrimas, enquanto nos restantes convivas do banquete de Alcínoo apenas provoca deleite (8.86-92), por não terem presenciado os acontecimentos que são objecto de canto ${ }^{18}$.

Esta breve análise confirma que Eumeu tinha razão em sublinhar a condição divina do aedo e o deleite do seu canto (17.385). Resta-nos verificar se encontramos na Odisseia provas da sua mobilidade.

Os passos referidos mostram que os aedos deste poema são figuras respeitadas e admiradas. Fémio é caracterizado com o epíteto $\pi \varepsilon p \iota k \lambda u \tau o ́ \varsigma$

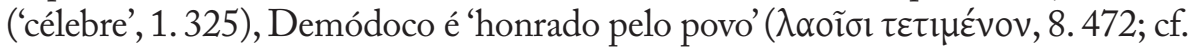

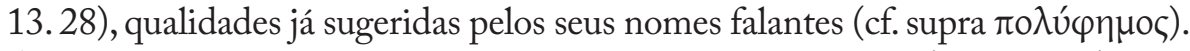
As seguintes palavras de Ulisses são também muito explícitas (8. 479-481):

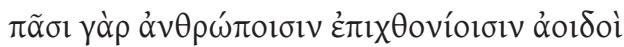

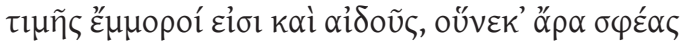

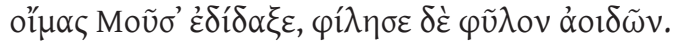

Pois entre todos os homens que estão na terra, os aedos granjeiam honra e reverência: a eles ensinou a Musa o canto porque estima as tribos dos aedos.

São também figuras em quem se deposita confiança, o que explica o uso

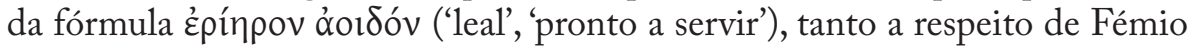
(1. 346), como de Demódoco (8. 62). A melhor ilustração desta qualidade é aquele curioso momento do canto III (vv. 262-272), no qual se evoca a sedução de Clitemnestra, que Agamémnon havia confiado zelosamente à guarda ( depositava que presidiu à decisão do Atrida, e para seduzir a rainha Egisto teve primeiro de desterrar o fiel cantor ${ }^{19}$.

\footnotetext{
${ }^{18}$ Sobre a matéria de canto do aedo, vide supra, n. 4.

${ }^{19}$ Trata-se da referência mais antiga a este episódio, que traça um retrato de Clitemnestra
} 
Este passo sugere também que os aedos não beneficiam das mesmas condições de trabalho, que são particularmente adversas no caso de Fémio. O poeta sublinha várias vezes que o aedo de Ítaca canta para os pretendentes forçado $(1.154,22.331)$. Este é um dos argumentos aduzidos quando suplica a Ulisses que lhe poupe a vida (22.350-353):

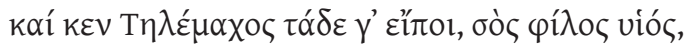

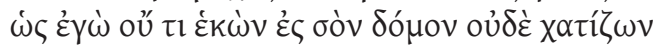

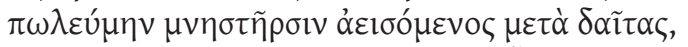

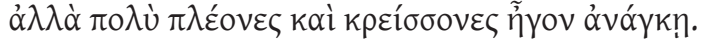

Telémaco, o teu filho amado, te dará testemunho disto: que não foi por minha vontade que vim para a tua casa, com tenção de cantar para os pretendentes após o jantar; mas eles, mais fortes e numerosos, me trouxeram à força.

Na opinião de Heubeck 1988: 96, os vv. 153-154 do canto I e os que acima citámos indicam que Fémio não se encontra entre os pretendentes, mas quando, no canto XVI, Telémaco enumera ao pai os homens que habitam no palácio, menciona o arauto Médon e o 'aedo divino' (v. 252). Portanto, o aedo pode residir no palácio (será provavelmente a situação do de Agamémnon e de Clitemnestra), mas é possível que só o fizesse quando era chamado pelos pretendentes, contra a sua vontade. $\mathrm{O}$ seu afastamento parece ser motivado apenas pela perturbação que assola o palácio de Ulisses.

O ambiente pacífico da casa de Alcínoo torna as condições de actuação de Demódoco bastante diferentes. É notório, porém, que apenas se exibe quando é chamado a fazê-lo. Acolhe de boa vontade os desejos dos convivas, como Ulisses, que the pede que cante sobre o cavalo de madeira (8.485-498), mas tem de cumprir as ordens do rei, quando lhe ordena que cesse o seu canto (8. 536-543). O seu estatuto social é equiparado ao do arauto, que o auxilia no exercício da sua arte. Quando no canto I coloca a cítara nas mãos de Fémio (vv. 153-154) não significa, como notou Heubeck (ibidem), que o aedo seja cego. Sendo uma extensão da autoridade, o gesto do arauto pode ser entendido

bastante distante do tradicional (cf. vv. 265-266). A tarefa do aedo intrigou os comentadores antigos (cf. S. West 1988: 176-177). Um epigrama de Antípatro de Sídon sobre a morte de Íbico evoca a má acção de Egisto e inspira-se provavelmente no passo da Odisseia $(A P 7.745=$ epigr. XIX Gow-Page, Ibyc. test. 5, cf. infra, p. 102). Para um comentário aos versos homéricos, vide D. Page, "The Mystery of the Minstrel at the Court of Agamemnon", in Studi Classici in onore di Quintino Cataudella I (Catania 1972) 127-131; Stephen P. Scully, "The Bard as the Custodian of Homeric Society: Odyssey 3, 263-272”, QUCC 8 (1981) 67-83; Ø. Andersen, "Agamemnon's Singer (Od. 3. 262-272)", SO 67 (1992) 5-26; Luigi Belloni, "L'Laedo del re (Od. III. 262-272)", Athenaeum 90.1 (2002) 95-109. 
como uma indicação da ordem para cantar. R. D. Dawe (1993: 58), no extenso comentário que dedica à Odisseia, propõe uma interpretação mais plausível, segundo a qual o modelo de aedo para o poeta é Demódoco, pelo que pode ter ocorrido neste passo uma transposição para Fémio da sua cegueira. De facto, a deficiência visual do aedo dos Feaces é segura (8.63-64) ${ }^{20}$ e Alcínoo tem de dizer ao arauto que o vá buscar, para animar o banquete de recepção a Ulisses (8. 43-47). É por ele conduzido (8.62) e levado para o exterior, quando o rei assim decide (vv. 105-108). Não chegamos, contudo, a saber se o aedo habita ou não no palácio.

Em conclusão, as várias cenas que na Odisseia permitem reconstituir as condições de actuação destes profissionais não nos fornecem elementos suficientes para confirmar a sua mobilidade. Sublinhe-se, todavia, que os aedos retratados no poema frequentam os palácios de pessoas importantes, que tinham meios para os sustentar durante muito tempo. Em nossa opinião, as palavras de Eumeu sobre a deslocação destas figuras podem reflectir uma prática do tempo do poeta, mas não se ajustam com exactidão à realidade descrita na Odisseia. Parece certo, porém, que nem Demódoco nem Fémio residem no espaço onde executam a sua arte e ambos têm de ser chamados para actuar, voluntariamente ou à força.

Os estudiosos mostram-se cépticos quanto à historicidade destas personagens (cf. Heubeck 1988: 96, Hainsworth 1988: 349-350), embora se pressuponha a existência de uma longa tradição poético-musical oral. Não há, porém, testemunhos sobre as condições em que os bardos desenvolviam o seu trabalho. A partir da Época Clássica, pelo menos, estava bem divulgada uma tradição, baseada na Odisseia, segundo a qual Fémio e Demódoco tinham de facto existido. Sócrates, no Íon de Platão, menciona o primeiro como o 'rapsodo de Ítaca', depois de referir outros poetas míticos, designadamente Olimpo, Tâmiris e Orfeu (533b-c). Este tipo de notícia encontrou grande receptividade numa obra como o De Musica, do Pseudo-Plutarco (3.1132b-c), que atribui ao 'músico antigo Demódoco de Corcira' As bodas de Afrodite e Hefestos e um Saque de Tróia (cf. Od. 8. 266-366, 499-520), e a 'Fémio de Ítaca' um Regresso dos heróis que deixaram Tróia com Agamémnon (cf. Od.1.325-327).

\footnotetext{
${ }^{20}$ Sobre a cegueira do poeta na tradição pseudo-biográfica, vide infra, p. 44 n. 62.
} 


\section{O testemunho de Hesíodo (OP. 650-662)}

A presença de dados autobiográficos na Teogonia e nos Trabalhos e Dias estabelece um contraste notável com os Poemas Homéricos ${ }^{21}$. O seu presumível autor apresenta-se na primeira obra: era um simples pastor que um dia encontrou as Musas, que lhe ensinaram um canto maravilhoso (vv. 22-23). Na segunda, diz que é filho de um homem que viera de Cime, da cidade eólica situada na costa asiática, um pouco ao sul de Lesbos, e se instalara em Ascra, junto do monte Hélicon, na Beócia (vv. 633-640). Recorda também um momento importante da sua carreira (vv. 650-662):

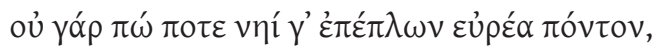
650

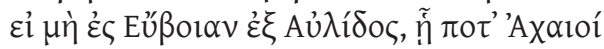

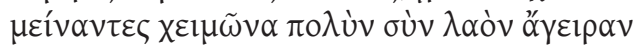

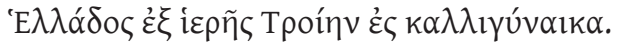
है $v \theta \alpha \delta$ '

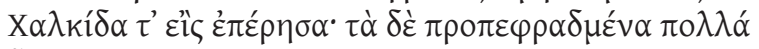

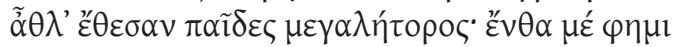

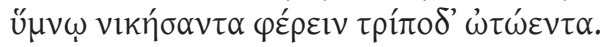

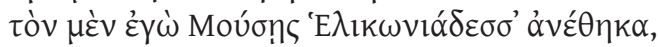

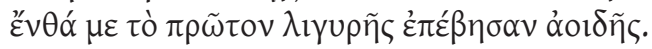

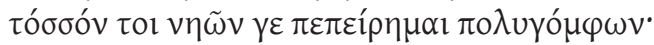

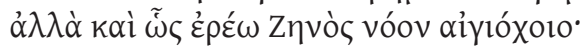

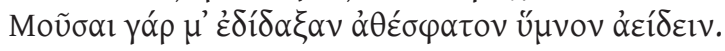

É que eu jamais embarquei no vasto mar, 650 a não ser até Eubeia, ido de Áulis, onde outrora os Aqueus esperaram que passasse uma grave tormenta, quando levaram

${ }^{21}$ Sublinhe-se que tem gerado grande controvérsia a fidedignidade dos dados autobiográficos que ocorrem na poesia de Hesíodo. R. Lamberton, Hesiod (New Haven 1988), não lhes atribui valor histórico, defendendo que são fruto de uma tradição que é, em si mesma, uma criação mitológica. Em seu entender, o poeta deve ser considerado "as collective expression rather than original talent." (pp. 22-23); "We must perceive Hesiod as a mask for many anonymous voices, all trained, and trained well, over generations to sound the same, to speak with the same identity and to pass on the same traditions." (p. 35). Esta posição, que nos parece extrema e se opõe, em vários aspectos, às teses de P. Walcot (1966) e de M. L. West (1966, 1978), não nos deve impedir de aceitarmos este testemunho, quer ele seja reflexo de uma experiência pessoal ou, como defende Lamberton, fruto de uma tradição. Para uma posição contrária, vide a nota de R. M. Cook, "Hesiod's Father", JHS 109 (1989) 170-171. Note-se que Walcot 1966: 109 situa o floruit do poeta em 730-705, com base nos dados biográficos fornecidos pela sua obra. 
grande massa de povo da sagrada Hélade para Tróia de lindas mulheres. Aí é que eu atravessei para Cálcis, a caminho dos jogos

do valente Anfidamante; haviam os filhos do magnânimo herói

proposto muitos prémios. Aí posso dizer que venci, cantando um hino. Tive uma trípode com duas asas, que dediquei às Musas do Hélicon, no lugar onde me ensinaram primeiro o canto harmonioso.

Tal é a minha experiência das naus de muitas cavilhas.

Mas dir-te-ei à mesma o pensamento de Zeus detentor da égide.

É que as Musas ensinaram-me um canto maravilhoso.22

Nos Poemas Homéricos somente o episódio de Tâmiris parece aludir à participação dos aedos em concursos poéticos, mas a sua interpretação está longe de ser segura, como vimos. Um passo de Trabalhos e Dias, porém, indica que a competição fazia parte da vida destes profissionais no tempo de Hesíodo (vv. 25-26):

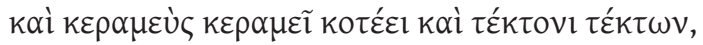

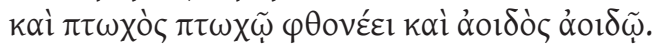

O oleiro tem inveja ao oleiro, o carpinteiro ao carpinteiro, o mendigo ao mendigo, o aedo ao aedo.

O autor de Trabalhos e Dias proclama uma grande experiência de vida, à luz da qual se sente no direito e no dever de proferir conselhos práticos, e de exortar o destinatário da sua obra (apresentado como Perses, seu irmão) a adoptar um comportamento justo. Os vv. 650-662 surgem em tom de desculpa por, no domínio da navegação, que o poeta considera em geral uma actividade arriscada, os seus conhecimentos serem muito escassos (cf. vv. 648-649). Se a 'experiência das naus de muitas cavilhas' se limita, como ele diz, ao trajecto entre o porto de Áulis e o de Cálcis, isso poderá significar que nasceu e cresceu na Beócia (cf. West 1978: 30), e que a sua vida profissional se limitou ao território da Grécia Continental. O poeta não revela as razões que o impediram de repetir a experiência ou de efectuar outras viagens através do 'vasto mar'. Tendo em conta o contexto da evocação, supomos que não terá sido uma viagem agradável. A travessia do estreito de Euripo é relativamente curta, mas arriscada, e para chegar ao porto de Áulis, desde a sua terra natal, teve ainda de percorrer uma distância significativa. Se considerarmos a hipótese de esse percurso terrestre ter sido difícil, já temos mais do que um motivo para justificar

${ }^{22}$ Nas citações de Hesíodo transcrevemos a tradução de M. H. Rocha Pereira (2009: 108, 114-115) e seguimos a edição crítica de West 1978. 
a pouca experiência do poeta em relação a esta matéria. No entanto, sobre as suas viagens por terra também nada nos diz, embora seja pouco plausível que nunca tenha saído da sua região ${ }^{23}$. Os vv. 651-653 denunciam que conhecia a tradição poética da expedição grega contra Tróia ${ }^{24}$, mas não cremos que se trate de uma alusão intencional à épica homérica (cf. Il.2.303-304), como propõem alguns investigadores ${ }^{25}$.

Hesíodo revela uma consciência muito clara do valor didáctico da sua poesia, da qual se serve como meio de transmissão dos seus conselhos, que têm em vista um horizonte político e social. No entanto, raramente se refere, como nestes versos, às ocasiões que proporcionavam a sua execução pública. Também não explicita em que momento da vida se deslocou à Eubeia, a fim de participar num concurso poético, por ocasião dos jogos fúnebres em honra de Anfidamante (vv. 654-656). Os epítetos que caracterizam o herói ( $\delta$ đï $\varphi \rho \omega v$, 'valente' ${ }^{\prime 26}, \mu \varepsilon \gamma \alpha \lambda \eta ́ \tau \omega \rho$, 'magnânimo') sugerem ter sido um guerreiro nobre. Segundo Plutarco, havia perdido a vida na Guerra Lelantina ${ }^{27}$. O terminus ante quem deste conflito, que opôs Cálcis e Erétria pela disputa da planície de Lelanto, foi determinado pelas escavações arqueológicas, que mostraram que o lugar foi destruído e não mais ocupado um pouco antes de $700^{28}$.

West 1978: 32 observa que o poeta teria participado nessa cerimónia porque, à partida, tinha algumas garantias de que podia vencer. Sendo assim, já teria alguma experiência. Se o 'hino' com o qual obteve a vitória foi a Teogonia ou

${ }^{23}$ Cf. West 1966: 46, 1978: 30-32. O helenista salienta "o alcance do conhecimento geográfico de Hesíodo", chamando a atenção para o catálogo dos rios de Th. 337-345 (1966: 41)

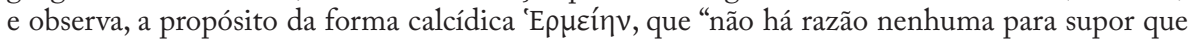
a excursão de Hesíodo foi um caso isolado de tráfego rapsódico entre a Eubeia e o continente" (ibidem, p. 90). Cf. infra, n. 32.

${ }^{24}$ Sobre a formação poética de Hesíodo, vide as hipóteses apresentadas por West 1978: 31-32.

${ }^{25}$ E.g. M. Ralph Rosen, "Poetry and Sailing in Hesiod's Works and Days", ClAnt 9 (1990) 99-113. Este investigador retoma uma sugestão de G. Nagy (cf. p. 100 n. 3) e defende que os vv. 650-662 não devem ser interpretados literalmente, mas como uma metáfora que permite ao poeta comentar a natureza da sua própria poesia. $\mathrm{Na}$ base desta tese está a conviç̧ão de que os vv. 651-653 aludem à poesia homérica, da qual Hesíodo procura distanciar-se.

${ }^{26}$ Tendo em conta a dupla significação do epíteto, há que atender ao contexto em que ocorre. Em Il. 2. 23, aplicado a Atreu, tem certamente o sentido de 'bravo', 'valoroso'. Em 11. 482, a atribuição a Ulisses sugere antes 'sábio', 'prudente'. Como observa West 1978: 320, o sentido no texto de Hesíodo parece ser o primeiro.

${ }^{27}$ Sept. sap. conv. 10.153f. Segundo o schol. Op. 654 (= Plu. fr. 84 Sandbach), Anfidamante morreu no confronto com os Erétrios numa batalha naval, mas este dado é difícil de conciliar com a informação de Aristóteles de que se tratou de uma guerra de cavalaria (Pol.1289b36-39). No Certamen Homeri et Hesiodi diz-se que era um rei da Eubeia (64 Allen = 6 W, cf. infra). Cf. West 1966: 43-44.

${ }^{28}$ Dados recolhidos em J. P. Barron and P. E. Easterling, "Hesiod", in Easterling and Knox 1985: 93. Outras referências à mesma guerra ocorrem em Hdt. 5. 99, Thuc. 1. 15. 3, Str. 10. 1. 12, Plu. Amatorius 760e-f. 
uma versão desse poema, como pensa o mesmo helenista ${ }^{29}$, não podemos saber, mas esta hipótese é plausível, visto que o poeta afirma ter dedicado o prémio às 'Musas do Hélicon', cuja epifania é recordada na abertura daquele poema (vv. 22-34). West 1978: 321 observa que a palavra ü $\mu v o \varsigma$ "is not yet specialized in the sense "hymn' but may be used equally of narrative and didactic poetry". Todavia, este termo tem um emprego muito restrito na poesia mais antiga. $\mathrm{Na}$ única ocorrência homérica $(O d .8 .429)$ é complemento de uma palavra que designa o canto do aedo (ảoı ñ ธŭuvov). Não aparece no proémio da Teogonia (vv. 1-115), mas o verbo úuvéw é empregue sete vezes para nomear a acção de 'celebrar', 'louvar' as divindades ${ }^{30}$. Assim, é de supor que o 'hino' com que Hesíodo se apresentou em Cálcis se aproximaria muito mais daquele poema, do seu proémio ou dos Hinos Homéricos, do que dos $k \lambda \dot{\varepsilon} \alpha \alpha \dot{\alpha} v \delta \rho \tilde{\omega} v$, sobre os quais versa habitualmente o cantor homérico.

Finalmente, diz o poeta que teve como prémio uma 'trípode com duas asas'. O segundo hemistíquio do v. 657 tem uma estrutura formular semelhante ao v. 513 do canto XXIII da Ilíada: nos jogos fúnebres em honra de Pátroclo, Diomedes, vencedor na corrida de carros, ganha uma cativa e uma trípode do

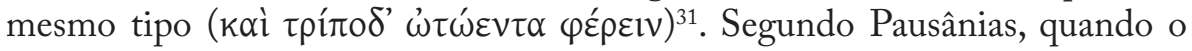
auleta Equêmbroto da Arcádia venceu no festival pítico de 586 foi premiado com uma trípode de bronze (10. 7. 4-6, cit. infra). Mas a remodelação das competições que se seguiu alterou a natureza dos prémios (vide infra, p. 85). Portanto, parece certo que este objecto monumental foi uma das gratificações mais antigas e habituais, quer dos agones atléticos quer dos musicais (cf. Morgan 1990: 207) ${ }^{32}$.

${ }^{29}$ West 1966: 44-45 (cf. 1978: 32, 321). A hipótese foi sugerida pela primeira vez por H. T. Wade-Gery, "Hesiod", Phoenix 3.3 (1949) 87 = Essays in Greek History (Oxford 1958) 8.

${ }^{30}$ Cf. Hes. Th. 11, 33, 37, 48, 51, 70 e 101. As ocorrências mais antigas do termo úuvo encontram-se nos Hinos Homéricos (3. 161, 5. 293), em Álcman (fr. 27. 3 P), em Simónides (fr. 519, fr. 78), na obra de Píndaro e na de Baquílides. Sobre o sentido e especialização desta palavra, vide R. C. T. Parker, in $O C D$, s.v. hymns (Greek).

${ }^{31}$ No mesmo canto da Ilíada são referidos, além dos jogos fúnebres em honra de Pátroclo (257-897), os de Amarinceu, rei dos Epeus da Élide (629-642), e os de Édipo em Tebas (677-680). Os de Aquiles são evocados na Odisseia (24. 85-92). Nos jogos de Pátroclo, os prémios a concurso são vasos (lebetes), trípodes, cavalos, mulas, bois e cativas (vv. 259-261). A descoberta destes objectos votivos veio confirmar a realização destes eventos no mundo grego. Sobre este assunto, vide Lynn E. Roller, "Funeral Games for Historical Persons", Stadion 8 (1981) 1-18. Como observa Walcot 1966: 119, o passo de Hesíodo não se refere a um culto de herói: "for Hesiod is describing a special rather than a regular occasion". Vide n. seguinte.

32 Segundo informa Pausânias, no seu tempo conservava-se no santuário do Hélicon uma trípode muito antiga que se dizia ser a consagrada por Hesíodo (9.31. 3). As escavações arqueológicas permitiram recuperar fragmentos de inscrições de trípodes e de lebetes oferecidos nos jogos fúnebres da Beócia (L. H. Jeffery, The Local Scripts of Archaic Greece, Oxford, 1961, 91-92, 94, pl. 7-8). Foi encontrado no santuário das Musas no Hélicon um fragmento da borda de um lebes de bronze arcaico com parte da inscrição dedicatória, cujas letras indicam o séc. VII. 
Em conclusão, os vv. 650-662 de Trabalhos e Dias de Hesíodo atestam a realização, na Época Arcaica, de competições poéticas por ocasião de cerimónias de carácter fúnebre e indiciam que a participação nesses eventos podia constituir um motivo para a deslocação dos cantores. Não é a primeira vez que surpreendemos a associação da poesia ao culto fúnebre em honra de pessoas ilustres. O poeta da Ilíada menciona a presença de 'aedos' profissionais nos funerais de Heitor (24. 719-722), embora não tenham sido convocados para uma competição nem sejam provavelmente verdadeiros cantores épicos. No entanto, parece-nos importante ponderar a possibilidade de existir continuidade ou semelhança entre os rituais fúnebres do início da Época Arcaica, que estes testemunhos presumivelmente evocam, e as homenagens que, dois séculos mais tarde, se realizarão em honra dos que perderam a vida na luta pela liberdade da Grécia.

\footnotetext{
A descoberta, na Acrópole de Atenas, de partes de cinco lebetes beócios com traços das inscrições comemorativas indiciam que atletas (ou poetas?) atenienses participavam nas competições da Beócia (c. 700-600?). Uma outra inscrição votiva, cujas letras sugerem o primeiro quartel do séc. VII, pertence a uma peça oriunda de Tebas, oferecida nos jogos fúnebres de um homem chamado Ekpropos e dedicada a Apolo Pítico por um tal Isodikos. Estas descobertas, na opinião de Walcot 1966: 119-120, confirmam que a realização destas cerimónias não era rara na Beócia da Época Arcaica.
} 
(Página deixada propositadamente em branco) 


\section{O AEDo DE Quios do HINO HoMÉRICO a APOLO (vv. 165-176)}

O Hino a Apolo, com 546 versos, é um dos quatro maiores e mais antigos dos trinta e três Hinos Homéricos, cujas datas de composição podem variar entre o séc. VII e o séc. IV-V d.C. (cf. Clay 1997: 490, West 2003b: 5). O título da colecção explica-se pelas características formais que aproximam estas composições de outros poemas da tradição épica, em especial dos Poemas Homéricos.

David Ruhnken, no séc. XVIII, foi o primeiro a observar que o Hino Homérico a Apolo que chegou até nós resulta da junção de dois poemas na sua origem independentes ${ }^{33}$, sendo que os vv. 1-178 se centram no nascimento do deus na pequena ilha de Delos, e os vv. 179-546 narram o seu triunfo sobre Píton e o estabelecimento em Delfos. Actualmente, muitos estudiosos continuam a defender a anterioridade da primeira parte ${ }^{34}$, o que em nosso entender não põe em causa a unidade do hino que hoje conhecemos ${ }^{35}$.

O passo que agora nos interessa situa-se na parte final do 'Hino délico'e permite fazer a transição para o 'Hino pítico' (vv. 165-176). Depois de tratar o nascimento de Apolo, o poeta detém-se na descrição da festa celebrada em Delos em honra do deus, na qual participa com o seu hino. Os vv. 146-155 atestam, por isso, a realização nesta pequena ilha, desde tempos antigos, de um grandioso festival pan-iónico, que reunia provas atléticas e musicais (v. 149),

${ }^{33} \mathrm{Na}$ segunda edição da Epistula Critica I (1782), segundo Lesky 1995 [1971]: 108. Cf. West 2003b: 9. Seguimos principalmente esta edição nas citações do Hino Homérico a Apolo.

${ }^{34}$ Desde, pelo menos, U. von Wilamowitz-Moellendorff, Die Ilias und Homer (Berlin 1920) 441, o 'Hino pítico' (ou 'Suite pítica') tem sido considerado uma continuação do 'Hino délico', observando-se, entre outros aspectos, que não tem um começo próprio. Cf. Kirk 1981: 163. In Easterling and Knox 1985: 73, Kirk escreve "a mais provável conclusão é que a parte délica deu a ideia e até certa medida o modelo da pítica”. Contra esta tendência, West 1975: 162 defendeu que a 'Suite pítica' é uma continuação, não do 'Hino délico', mas de outra coisa que desapareceu: "É um poema independente que perdeu a sua abertura". As duas partes do hino foram certamente compostas antes do fim do séc. VI (cf. Lesky 1995 [1971]: 109). Com base no exame linguístico e nas referências históricas, Janko 1982: 99-132 situou a composição do 'Hino délico' em 660 e a do pítico em 585 (cf. p. 200). Cf. Càssola 1975: 100-101, West 2003b: 10-11.

${ }^{35}$ Para uma resenha das principais teorias sobre a composição do hino, vide Càssola 1975: 97-100 (a favor da anterioridade da primeira parte); Andrew M. Miller, "The 'Address to the Delian Maidens' in the Homeric Hymn to Apollo: Epilogue or Transition?”, TAPhA 109 (1979) 173-176; Clay 1997: 501-502. No estudo publicado em 1986, From Delos to Delphi. A Literary Study of the Homeric Hymn to Apollo (Leiden), A. M. Miller propõe uma análise literária do hino segundo a perspectiva dos unitários. 
acontecimento importante na vida dos Iónios, que se apresentavam com 'os seus filhos e esposas respeitáveis' (v. 148) ${ }^{36}$. Se as suas lutas, danças e cantos suscitam em especial o deleite de Apolo (vv. 146,150), a sua beleza e jovialidade não deixariam indiferente o mais simples mortal que assistisse a tal celebração (v. 153): o deleite de presenciar tal evento não é uma graça exclusiva do deus.

O olhar do poeta demora-se depois numa 'grande maravilha' ( $\mu \varepsilon ́ \gamma \alpha$ Ө $\alpha \tilde{v} \mu \alpha$, v. 156): o coro das donzelas de Delos, servas do santuário, entoam hinos

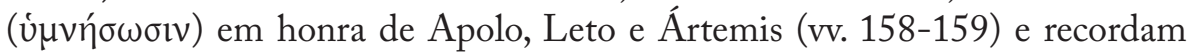
os homens e as mulheres do passado (v. 160). A sua glória, diz o poeta, jamais perecerá (v. 156), pois estas donzelas 'encantam as tribos dos homens' (v. 161), com a sua estranha capacidade de imitar as vozes e o balbuciar de todos os mortais (vv. 162-164) ${ }^{37}$.

Depois de descrever os Iónios 'de longas túnicas' e a actuação graciosa das servas de Apolo, o poeta centra-se na sua pessoa e no seu trabalho (vv. 165-176):

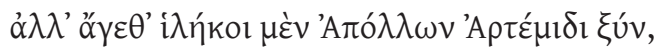
165

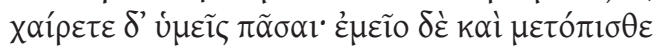

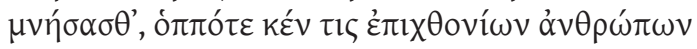

${ }^{36}$ Outro testemunho destas festas antigas é o de Pausânias sobre Eumelo de Corinto (cf. infra pp. 65-68).

${ }^{37} \mathrm{Na}$ edição de Allen, Halliday and Sikes, a última palavra do v. 162 é $\kappa \rho \varepsilon \mu \beta \alpha \lambda ı \alpha \sigma \tau u ́ v$, 'fazer soar as castanholas' (LSJ: 'rattling with castanets, to give the time in dancing'). Càssola $1975 \mathrm{e}$ West 2003b preferiram a v.l. $\beta \alpha \mu \beta \alpha \lambda$ i $\alpha \sigma \tau u ́ v$, 'balbucio' (LSJ, Suppl.: 'babbling', cf. $\beta \alpha \mu \beta \alpha i ́ v \omega$, 'make inarticulate sounds'), entendida, em geral, como referente ao som incompreensível de uma língua estrangeira. No comentário a este termo, Càssola 1975: 497 observa que no culto a Apolo Délio eram entoados cantos muito antigos, em língua não grega. Não cremos que seja esse o sentido dos vv. 162-164, nos quais, à semelhança do que acontece nos vv. 151-155, o poeta se situa no lugar do espectador. Alguns estudiosos sugeriram tratar-se de uma referência à possível imitação dos dialectos dos vários peregrinos (e.g. Allen, Halliday and Sikes 1936: 225, Kirk 1962: 276-277). Podlecki 1984: 24 rejeitou esta leitura argumentando que num festival pan-iónico deveria haver pouca diferença linguística entre os devotos. No entanto, a subdivisão do grupo dialectal ático-iónico estabelecida por Buck 1955: 10 não lhe dá razão. Também J. M. Cook, The Greeks in Ionia and the East (London 1962) 24, observou que os habitantes da Iónia constituíam uma miscelânea de elementos de origem diversa. Por conseguinte, julgamos que neste passo pode estar presente uma alusão às diferenças linguísticas dos povos iónicos, que não impediriam a completa fruição do hino entoado pelas servas de Apolo. Será também um modo de o poeta traduzir o sentimento de comunhão que dominaria o espírito de cada espectador, ao escutar um canto assim tão notável. Burkert 1993 [1977]: 226-227 cita dois interessantes paralelos do êxtase vivido pelas donzelas de Delos. No livro VIII, Heródoto recorda o estranho episódio do cário Mis que no santuário de Apolo Ptoo ouviu o oráculo, que sempre falara grego, pronunciar-se na sua língua bárbara (135). Outro paralelo, já referido por outros helenistas (cf. Allen, Halliday and Sikes 1936: 225; H. J. Tschiedel, "Ein Pfingstwunder im Apollonhymnos (Hymn. Hom. Ap. 156-164 und Apg. 2,1-13)”, ZRGG 27, 1975, 22-39), é o milagre do Pentecostes sobre as dispertitae linguae tanquam ignis, que conferem aos Apóstolos o dom divino de falarem outras línguas e de se fazerem entender por todos os povos (Actos 2.3-11). 


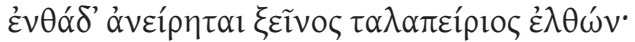

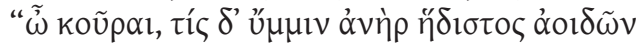

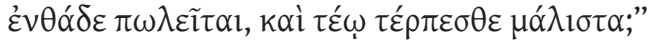

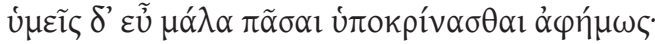

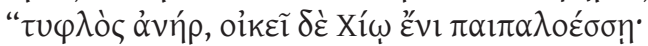

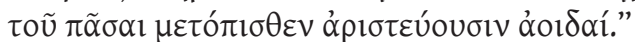

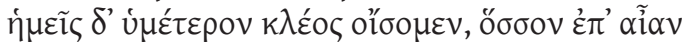

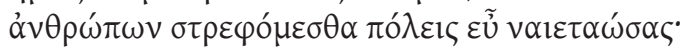

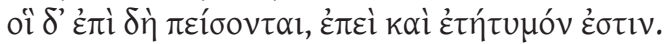

Mas vamos! Que Apolo possa ser benévolo, junto com Ártemis.

Passai bem, vós todas! E no futuro lembrai-vos também

de mim, quando algum dos homens que vivem sobre a terra,

um estrangeiro que muito tenha sofrido, chegue aqui e pergunte:

"Ó donzelas, qual é para vós o mais doce dos aedos,

que aqui vem muitas vezes, e com quem vos deleitais mais?"

E vós todas haveis de responder numa só voz:

"É um homem cego, e habita na Quios rochosa;

todos os cantos dele serão no futuro os melhores."

E nós levaremos a vossa glória enquanto sobre a terra

regressarmos às cidades aprazíveis dos homens.

E eles acreditarão, pois é verdade.

Estes versos evidenciam as fórmulas de conclusão características de outros Hinos Homéricos: a prece dirigida às divindades para que favoreçam o canto

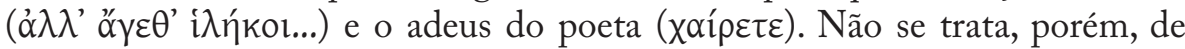
uma transição convencional. A fórmula de conclusão mais frequente - 'Eu

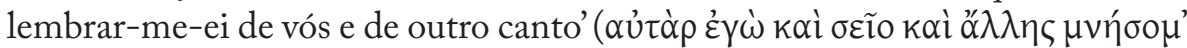
$\alpha_{\alpha}(\delta \tilde{\eta} \varsigma)^{38}$-, que encerra a promessa de uma nova actuação, é aqui modificada: o poeta pede às donzelas de Delos que se lembrem dele no futuro (vv. 166-167), assim como elas evocam com o seu canto os homens e as mulheres de antanho

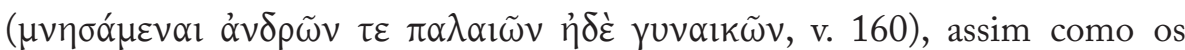
Iónios evocam ( $\mu \nu \eta \sigma \alpha ́ \alpha \varepsilon v o l)$ Apolo por meio da luta, da dança e do canto (vv. 149-150). Tornar-se presente pela memória significa ser evocado pelo canto (cf. v. 171). Como recompensa, o poeta promete levar a outras partes do mundo a glória deste coro tão singular (vv. 174-175). Por conseguinte, os vv. 165-173 aproximam-se muito mais do proémio da Teogonia de Hesíodo (cf. vv.

${ }^{38}$ E.g. h.Hom. 2. 495, 3. 546. A fórmula convencional de transição para outro hino é expressa nos vv. 177-178, que se seguem a este passo e indicam o regresso ao assunto principal: 'Mas eu não deixarei de celebrar Apolo, que atira de longe,/ deus do arco de prata, que Leto de

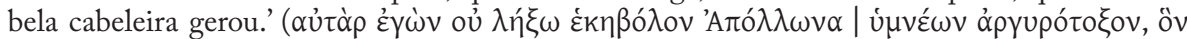

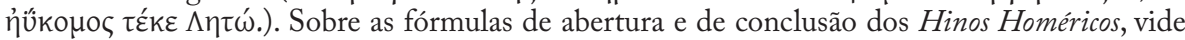
Clay 1997: 493. 
22-28), no qual a 'assinatura do poeta' (a $\sigma \varphi \rho \alpha \gamma$ ćc $^{39}$ )é, como aqui, dramatizada. A ênfase dada, desde o início da descrição, ao deleite (de Apolo, dos Iónios, cf. vv. $146,150,153)$ e ao encanto das donzelas (vv. 156, 161) culmina no v. 170

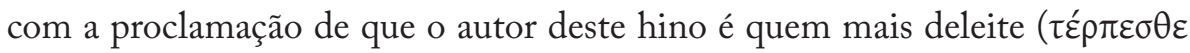

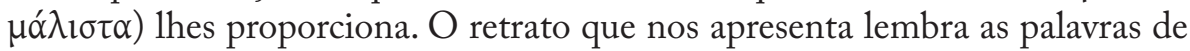
Eumeu sobre o aedo-demiourgos: um cantor que deleita, que vem muitas vezes a Delos (v. 170) ${ }^{40}$ e percorre as cidades a mostrar a sua arte (vv. 174-175).

Os vv. 1-2 do fr. eleg. 19 de Simónides (vide infra, pp. 221-222) atestam que no seu tempo, pelo menos, a expressão 'homem de Quios' designava o autor da Ilíada, Homero (cf. Burkert 2001: 217). Tucídides, por sua vez, para confirmar que no passado os Iónios realizavam em Delos um grandioso festival com competições, citou os vv. 146-150 e 165-172 do 'Hino délico', que designa

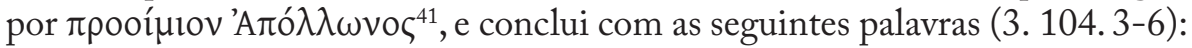
'Assim Homero testemunhou que antigamente havia também um grande concurso e um festival em Delos.' (

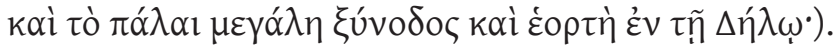

Para Tucídides e Aristófanes ${ }^{42}$ a autoria do 'Hino délico' estava atestada pelo próprio poema. O 'mais doce dos aedos' (v. 169), aquele cujos cantos no futuro seriam os melhores (v. 173), só poderia ser Homero. A repetição de $\mu \varepsilon \tau o ́ \pi ı \sigma \theta \varepsilon(v)(v v .166,173)$ denuncia a importância do reconhecimento na posteridade. Finalmente, o v. 172 é talvez o testemunho mais antigo da identificação de Homero com um aedo cego natural de Quios. A cegueira e a mobilidade são dois temas habituais nos relatos biográficos sobre o poeta (cf. infra, p. 44). Nestes versos, porém, depois de uma descrição pormenorizada do que de mais admirável se poderia ver na festa dos Iónios (cf. vv. 153-154), a sugestão de um poeta cego é paradoxal e situa-o já no mundo da lenda. Parece-nos que não é o único aspecto que aproxima o aedo de Quios do de

${ }^{39}$ Cf. Càssola 1975: XXV, Kirk in Easterling and Knox 1985: 72 ("sphragis or 'seal', a kind of signature by the composer, who declares himself to be a blind man from rugged Chios."). Sobre o paralelo com a Teogonia, cf. Clay 1997: 502.

${ }^{40}$ Que desde muito cedo este santuário de Apolo é um lugar de visita obrigatória, propício para a divulgação da poesia, prova-o a sua evocação no canto VI da Odisseia (vv. 162-167). A referência do v. 168 a um 'estrangeiro que muito tenha sofrido' parece quase uma alusão a este passo homérico.

${ }^{41} \mathrm{O}$ escoliasta explica que os hinos eram designados por $\pi \rho \circ o i ́ \mu \iota \alpha$ e funcionavam como prelúdios às recitações épicas. Como observa Lesky 1995 [1971]: 107, esta designação diz respeito ao facto de concluírem geralmente com a promessa de execução de um outro canto em honra da divindade (cf. supra n. 38). O proémio da Teogonia, além de ser um hino às Musas, é também um inventário dos temas que serão tratados mais tarde na obra. Sobre este assunto, vide Càssola 1975: XII-XIV, XVII-XXI; William Furley, “Types of Greek Hymns”, Eos 81 (1993) 21-41, esp. 24-29; "Praise and Persuasion in Greek Hymns", JHS 115 (1995) 29-46; Clay 1997: 494-498; West 2003b: 3-6.

${ }^{42} \mathrm{O}$ v. 575 de $A s$ Aves alude provavelmente ao v. 114 do 'Hino délico'. 
Alcínoo. Recorde-se que quando Demódoco canta os amores de Ares e de Afrodite, um coro de jovens feaces dança à sua volta (Od. 8. 258-366). Em nosso entender, um dos aspectos mais singulares do 'Hino délico' é a descrição e invocação do coro das donzelas, e a impressão com que ficamos é que elas estariam também a actuar ao lado do aedo. Elas são, aparentemente, instruídas por ele (cf. Nagy 1989: 60-61).

Um dos textos da tradição pseudo-biográfica, o Certamen Homeri et Hesiodi, que comentaremos a seguir, conta que Homero, depois de passar algum tempo em Argos, navegou para Delos a fim de participar na grande

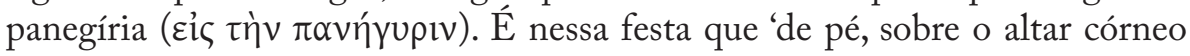

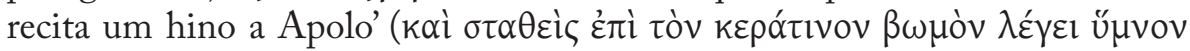

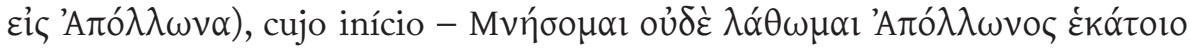
- coincide com o primeiro verso do 'Hino délico'. Portanto, o compilador do Certamen conhecia uma tradição que atribuía a Homero a composição da primeira parte do Hino Homérico a Apolo ou baseou-se nos vv. 165-172. Atente-se, porém, num pormenor: segundo este relato pseudo-biográfico,

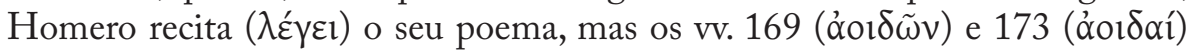
do 'Hino délico', e especialmente a actuação das donzelas (vv. 158, 161, 164), sugerem que o agon de Delos era de canto ${ }^{43}$.

Cremos que se inscreve também nesta tradição pseudo-biográfica um fragmento que figura no corpus de Hesíodo (fr. dub. $357 \mathrm{M}-\mathrm{W}$ ), citado pelo escoliasta da II Nemeia de Píndaro (schol. 1d, III. 31 Dr. = FGrHist 328 F 212):

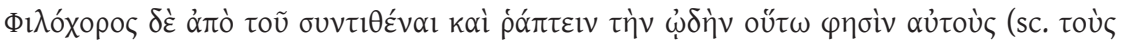

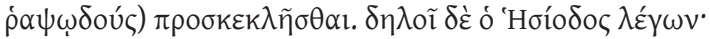

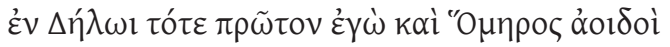

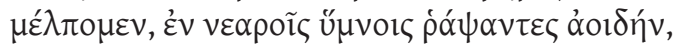

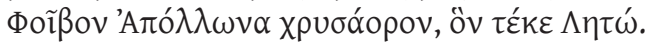

Filócoro diz que os rapsodos se chamam assim, porque compõem e costuram o canto. Mostra-o Hesíodo quando afirma:

Então, primeiro em Delos, eu e Homero, aedos, celebramos, costurando um canto em novos hinos, Febo Apolo da espada de ouro, que Leto gerou.

Segundo este fragmento, Homero e Hesíodo apresentaram-se pela primeira vez em Delos. Apesar de se especificar que eram 'aedos' e do emprego

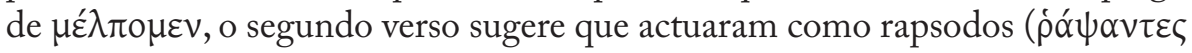

${ }^{43}$ No entanto, nos restantes Hinos Homéricos, que são peças rapsódicas, a designação do poema é habitualmente ỏotón. 


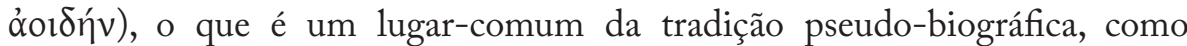
veremos. Repare-se que a citação pretende confirmar a definição de $\rho \alpha \psi \omega \delta$ ○́c de Filócoro de Atenas (séc. IV) ${ }^{44}$. Sublinhe-se ainda que o fragmento contradiz o que Hesíodo afirma nos vv. 650-651 de Trabalhos e Dias ${ }^{45}$, que jamais viajara por mar, a não ser até à Eubeia.

Um outro escólio da mesma ode de Píndaro causa grande desentendimento entre os estudiosos modernos. É a explicação que o escoliasta apresenta sobre os Homéridas (schol. 1c. Nem. 2. 1, III. 29 Dr. = FGrHist 568 F 5):

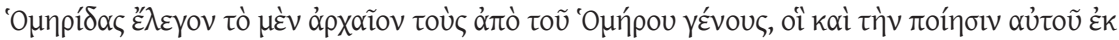

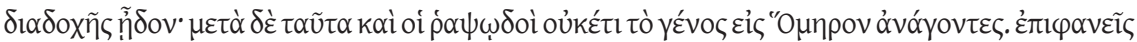

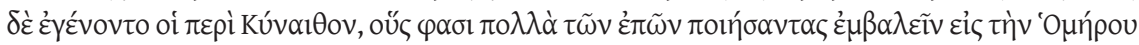

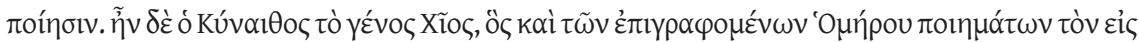

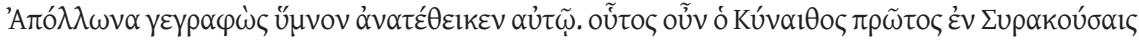

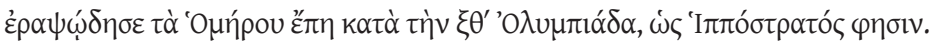

Antigamente diziam que os Homéridas eram os descendentes de Homero, que também cantavam a poesia dele por direito de sucessão. Mais tarde, os rapsodos fizeram o mesmo, mas já não remontavam a sua linhagem a Homero. Notáveis eram os que rodeavam Cineto, sobre os quais se diz que compuseram muitos dos versos que introduziram na poesia de Homero. Cineto era de uma família de Quios. Ele é que, dos poemas registados como sendo de Homero, lhe atribuiu o hino a Apolo, que ele próprio compôs. Este mesmo Cineto foi o primeiro a recitar em Siracusa os versos épicos de Homero na $69^{a}$ Olimpíada (= 504/500), como Hipóstrato diz.

A ligação de Homero a Quios é evocada na tradição pseudo-biográfica com frequência ${ }^{46}$. Este escólio é claro na distinção que estabelece entre os 'Homéridas', ainda cantores (ที్่రov), e os rapsodos do círculo de Cineto, que são acusados de falsificarem os poemas do grande épico ${ }^{47}$. Sugere também que estes profissionais tinham de viajar por causa do seu ofício, à semelhança dos aedos. O que indica sobre a introdução em Siracusa das recitações de épica homérica não pode estar completamente correcto, porque a data é muito tardia. West 1975: 166 defendeu a hipótese, muito plausível, de essa data

${ }^{44} \mathrm{O}$ escoliasta acrescenta ainda uma informação do historiador helenístico Nícocles,

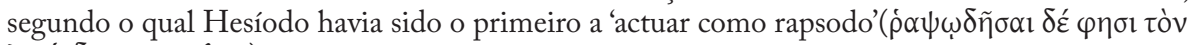

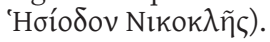

${ }^{45}$ Vide as razões que levam West 1967: 440 a considerar o fragmento espúrio. Cf. Janko 1982: 113-114, Burkert 2001: 213 n. 61.

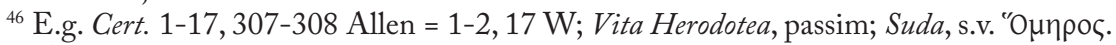

47 Alguns estudiosos, como Wade-Gery 1936: 57, forçam a interpretação do escólio e identificam Cineto como um dos famosos Homéridas. Todavia, o escólio estabelece uma distinção clara entre os antigos defensores da obra de Homero e os mais recentes rapsodos. Como a imagem destes é denegrida, os estudiosos modernos tendem a considerar que as insinuações sobre as suas fraudes foram divulgadas pelos próprios Homéridas. Cf. West 1975: 166, Burkert 1979: 56-57. 
representar antes a primeira entrada numa lista oficial de rapsodos vitoriosos ${ }^{48}$. Mais importante é a informação de que uma das falsificações era um 'Hino a Apolo'. Em nossa opinião, esta notícia não prova que o 'Hino délico' é uma criação de Cineto (nem sequer o pítico). Ao contrário do que se verifica nos testemunhos de Tucídides e do Certamen, neste caso não se cita nenhum verso. Não sabemos, de facto, a que hino se refere o escólio.

W. Burkert e R. Janko propuseram, em estudos independentes, a hipótese de a execução integral do Hino Homérico a Apolo ter acontecido num festival organizado em Delos, em 523 ou 522, promovido pelo tirano Polícrates de Samos: as festas délico-píticas ${ }^{49}$. Nesta altura estaria divulgada a lenda do poeta cego de Quios, de modo que o público teria associado essa simples referência a Homero. Como Hipóstrato, historiador siciliano do séc. III (?), indica que Cineto estava activo no último quartel do séc. VI, é plausível que tenha sido responsável, não pela composição, mas pela junção dos dois hinos. Não podemos saber se fez mais do que 'ligar versos', mas a nossa ignorância pode dever-se apenas aos acasos da transmissão literária. Sobre este ponto preferimos a observação de R. Janko de que as duas partes do hino parecem muito antigas para terem sido compostas por Cineto, o que leva a crer que foi apenas responsável pela recitação épica no festival de Polícrates ${ }^{50}$.

O facto de não conhecermos o autor do 'Hino délico' não diminui o seu valor documental, porque os vv. 165-176 apenas teriam sido considerados autênticos se evocassem uma situação verosímil para um grego da Época Arcaica (cf. v. 176). Na opinião de alguns helenistas, testemunham uma das primeiras tentativas de criação de um clássico ${ }^{51}$ ou de uma personalidade literária à qual é dada o nome "O $\mu \eta \rho \varsigma^{52}$. A pertinência destas teses não põe em causa o valor histórico-social dos vv. 165-176: falam-nos, na primeira

${ }^{48}$ Cf. Càssola 1975: 101 e Burkert 1979: 54-56, que propõe outra explicação: “the 'first' of Kynaithos was to start the same Homeric revival in the very homeland of Stesichorus".

${ }^{49}$ Cf. Burkert 1979: 59-62, 2001: 213; Janko 1982: 112-114. Polícrates pretendia com este festival celebrar a oferta da pequena ilha de Rénea a Apolo (cf. Thuc. 3. 104. 2). Cf. Phot. s.v.

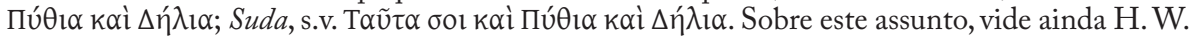
Parke, "Polycrates and Delos", CQ 40 (1946) 105-108.

${ }^{50}$ Janko 1982: 114. No exame da questão conclui que o 'Hino délico' deve ser atribuído aos Homéridas (pp. 114-115). De um modo geral, os estudiosos modernos identificam Cineto com o autor do Hino Homérico a Apolo (e.g. Allen, Halliday and Sikes 1936: 185-186) ou com o responsável pela sua forma definitiva, quer tenha, para isso, composto o 'Hino pítico', como defenderam Wade-Gery 1936: 57 e Kirk 1981: 173-174, quer tenha composto o 'Hino délico' (cf. West 1975: 165). Vide ainda Burkert 1979: 57-61, West 1999: 368-372, esp.

${ }^{51}$ Cf. Burkert 1979, 2001: 214 ("This is the clearest expression in epic diction of the notion of a classic, an absolute classic, that I can imagine. This is meant to be Homer.").

${ }^{52}$ Cf. West 1999. Para uma posição contrária, vide os artigos de G. S. Kirk, "The Search for the Real Homer", in Ian McAuslan and Peter Walcot (edd.), Homer (Oxford 1998) 38-52, e M. M. Willcock, "The Search for the Poet Homer", ibidem, pp. 53-64. 
pessoa, de um aedo iónico que se desloca a Delos com frequência, que conhece outras terras, participa em competições poéticas e se vangloria de ser o melhor. Quantos cantores itinerantes não diriam o mesmo de si? Lembremo-nos do castigo de Tâmiris (Il.2.597) e do apelo de Fémio a Ulisses (Od.22.344-349). Por tudo isto, em nossa opinião constituem um dos testemunhos fundamentais sobre a mobilidade poética da Época Arcaica.

Em jeito de apêndice, vale a pena referir que as fórmulas de conclusão de dois Hinos Homéricos atestam que estas composições eram apresentadas em contextos de competição.

No VIo Hino (a Afrodite), o poeta suplica à deusa que lhe conceda a vitória 'neste concurso' (vv. 19-20) ${ }^{53}$. Na opinião de West 2003b: 16, a ênfase no poder de Afrodite em Chipre (vv. 2-3) sugere que o poema pode ter sido aí apresentado, por ocasião da panegíria da antiga Pafos, mencionada por Estrabão (14. 6. 3). No $X X V I^{\circ}$ Hino (a Diónisos), o poeta formula o voto de que possa regressar nos anos seguintes (vv. 12-13), o que indicia a participação num festival de carácter anual.

${ }^{53}$ Cf. h.Hom. 11. 5, 15. 9, 24. 5, 25. 6. 


\section{O CERTAMEN HOMERI ET HESIODI}

O Certamen Homeri et Hesiodi ${ }^{54}$ é um texto de carácter pseudo-biográfico, do tipo das Vidas de Homero compiladas na Época Alexandrina, cuja génese assenta na ideia de que os dois maiores épicos gregos haviam sido contemporâneos e competido um contra o outro num concurso poético em Cálcis. Transmitido como anónimo por um manuscrito do séc. XIV (Laur. 56.1), a sua última redacção data do período antonino, mas é quase certo que reúne tradições mais antigas, algumas das quais remontam à Época Arcaica, e informações recolhidas em fontes diversas ${ }^{55}$. Citam-se, entre outros, o sofista Alcidamante e o historiador Helânico de Lesbos, dos fins do séc. V, o estóico Cleantes de Assos (séc. IV-III) e Eratóstenes (séc. III) ${ }^{56}$.

Parece evidente que o compilador do Certamen procurou "documentar" o seu relato com a inserção de excertos das obras atribuídas a Homero e a Hesíodo, como os vv. 6-11 do canto IX da Odisseia (quando Ulisses diz a

${ }^{54} \mathrm{Na}$ identificação dos passos do Certamen indicamos a numeração de Allen 1946: 225-238 e de West 2003b: 318-353. Seguimos estas edições na citação do texto grego. Para uma tradução, com introdução e notas, de todo o Certamen, vide Ana E. Pinheiro, in Pinheiro e Ferreira 2005: $135-159$.

55 Um dos episódios mencionados no Certamen é a consulta do oráculo de Delfos pelo imperador Adriano (séc. II d.C.), a fim de saber qual era a pátria de Homero (32-34 Allen = $3 \mathrm{~W}$ ). Plutarco recorda brevemente o concurso poético (Sept. sap. conv. 10.153f-154a, Quaest. conv. 5. 2. 674f-675a), que foi também evocado na Vida de Hesiodo de Tzetzes, mas está ausente das Vidas de Homero.

${ }^{56}$ De todos os autores citados (cf. 19-22 Allen = $3 \mathrm{~W}$ ), o que levanta mais discussão é Alcidamante, discípulo de Górgias e rival de Isócrates. No artigo publicado em 1967, West retomou a tese de F. Nietzsche, apresentada em 1870, de que a secção referente ao concurso poético e à morte de Hesíodo (54-239 Allen = 5-14 W) se baseia inteiramente no Mouseion, composto por aquele sofista na primeira metade do séc. IV. A tese de Nietzsche viria a ser corroborada pela publicação de dois papiros: o Flinders Petrie Papyrus (ed. 1891), datado do séc. III, contém 48 linhas que correspondem aproximadamente a uma parte do Certamen e veio confirmar que a lenda do confronto poético remontava aos tempos helenísticos, pelo menos, ou é mais antigo; o Michigan Papyrus 2754 (ed. 1925), datado do séc. II-III d.C., fornece o fim de uma narrativa muito semelhante ao do Certamen (linhas 1-14 do papiro), seguido de uma

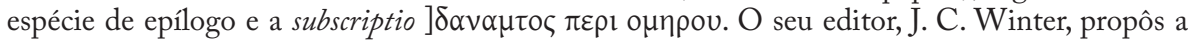
atribuição a Alcidamante com base nos mesmos argumentos de Nietzsche: 1) Estobeu (4. 52. 22) cita os hexâmetros dactílicos que ocorrem em 78-79 Allen $=7 \mathrm{~W}$ como sendo do Mouseion; 2) $\mathrm{O}$ Certamen indica esta obra como fonte $(239-240$ Allen $=14 \mathrm{~W})$. Sobre as questões relacionadas com a composição e transmissão do texto, vide West 1967 (cf. 2003b: 297-298); Robert Renehan, "The Michigan Alcidamas-Papyrus: a Problem in Methodology”, HSCPh 75 (1971) 85-105; George L. Koniaris, "Michigan Papyrus 2754 and the Certamen”, ibidem, pp. 107-129; Richardson 1981, O’Sullivan 1992. 
Alcínoo que não há coisa mais bela do que escutar o aedo durante um banquete onde reine a paz), sobre os quais informa que se 'chamavam de ouro' e que ainda 'no seu tempo' era habitual recitá-los nos sacrifícios, antes do banquete e das libações (cf. 90-94 Allen = $8 \mathrm{~W}$ ).

À semelhança do que é característico das Vidas dos poetas, a narração do concurso poético entre os dois épicos é antecedida de informações de carácter biográfico. No caso de Hesíodo, os vv. 639-649 de Trabalhos e Dias, nos quais se refere à instalação do pai em Ascra, cortaram as asas à imaginação dos biógrafos, mas a ausência de indicações sobre a pátria de Homero permitiu que muitas cidades se apresentassem como seu berço, designadamente Esmirna, Quios e Cólofon (cf. 1-17 Allen = 1-2 W) ${ }^{57}$. Sobre a filiação de Homero, o Certamen mostra que não havia consenso e o mesmo acontecia quanto à cronologia relativa entre os dois poetas ${ }^{58}$. É esta falta de unanimidade cronológica que deixa em aberto a possibilidade de terem sido contemporâneos e rivais, como se afirma na introdução à história do seu encontro em Cálcis (54-74 Allen = 5-6 W):

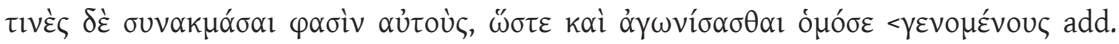

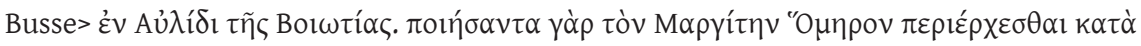

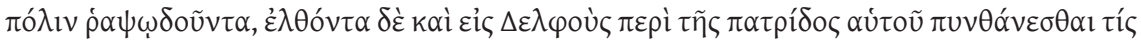

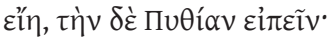

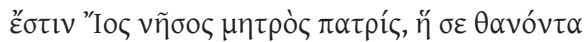

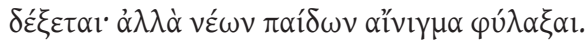

${ }^{57}$ Kirk 1962: 286 observa que em meados do séc. VII, mais ou menos na época de Arquíloco, o aedo anónimo começa a tornar-se numa figura obsoleta. O público interessa-se cada vez mais pela personalidade dos poetas, cujos sentimentos e experiências pessoais se tornam na própria matéria de canto. É possível que tenha começado então o interesse pela vida do pouco conhecido autor dos Poemas Homéricos. Segundo a tradição, Teágenes de Régio, que viveu no final do séc. VI, teria sido o primeiro a procurar informações sobre a vida e a data de Homero (fr. 8.1 D-K). Cf. Pfeiffer 1968: 10-11, Richardson 1993: 27.

${ }^{58}$ Esta é uma das velhas questões que continua a dividir os estudiosos. Heródoto afirma que os dois poetas viveram 400 anos antes, o que os situa c. 850-800 (2. 53. 2). West 1966: 40 observa que para a maioria dos Gregos do séc. V e IV os seus poetas mais antigos eram Orfeu, Museu, Hesíodo e Homero. Aquele helenista acredita que pudesse ser essa a ordem cronológica verdadeira e supõe que tenha sido a propaganda dos Homéridas que levou à inversão da ordem 'Hesíodo-Homero' (p. 47; na n. 4 comenta os testemunhos mais antigos sobre a prioridade de Homero: Xenófanes e Heraclides Pôntico; cf. Gel. 3. 11). A tendência com mais apoiantes privilegia a antiguidade de Homero, mas não há certezas. Lesky 1995 [1971]: 115, na sequência da afirmação de que os Antigos gostavam de nomear os dois poetas em conjunto (como Heródoto), observa que, não obstante o que têm em comum - a métrica, a linguagem épica e a tradição rapsódica -, Hesíodo pertence a um mundo social e culturalmente distinto, do qual ele próprio nos deu testemunho (cf. Ehrenberg 1964: 15). Estes aspectos, bem como a nuvem de desconhecimento que envolve a pessoa de 'Homero', devem ter contribuído para a tradição de que era um dos poetas mais antigos. Cf. supra n. 52. 


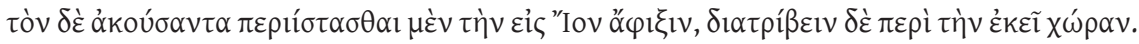

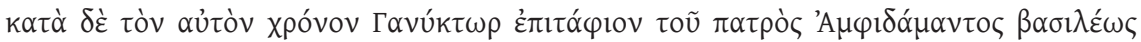

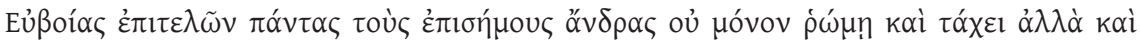

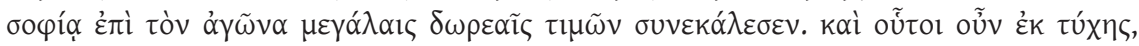

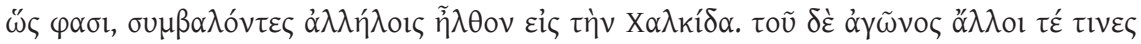

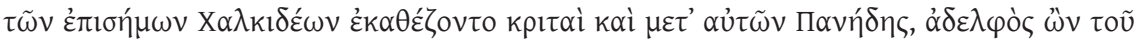

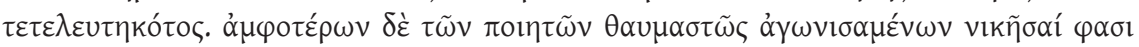

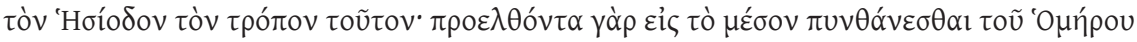

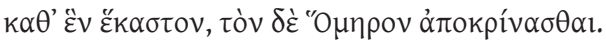

Alguns, porém, dizem que eram contemporâneos, de maneira que até competiram um contra o outro, quando se encontraram em Aúlis, na Beócia. Homero, na verdade, depois de ter composto o Margites, dizem, andava de cidade em cidade a recitar e, quando chegou a Delfos, perguntou qual era a sua pátria e a Pítia respondeu:

\section{É a ilha de Ios, a pátria de tua mãe, que quando morreres te receberá; mas tem cuidado com o enigma dos jovens rapazes.}

Depois de ouvir isto, dizem, evitou ir para Ios e permaneceu naquela região. Por volta desse tempo, Ganictor, na celebração dos funerais de seu pai Anfidamante, um rei da Eubeia, convidou para os jogos todos os homens notáveis, não só pela força e ligeireza de pés, mas também pela sabedoria, honrando-os com grandes dons. E estes, portanto, que por acaso se haviam encontrado, segundo dizem, foram para Cálcis. Como juízes do concurso sentaram-se alguns dos Calcídios notáveis e entre eles Panedes, que era irmão do falecido. Não obstante terem sido ambos admiráveis na competição, dizem que Hesíodo venceu do seguinte modo: tendo avançado para o centro, ia fazendo perguntas a Homero e Homero respondia.

Se o compilador do Certamen teve em consideração o que se diz no início da obra sobre o Margites, que segundo os habitantes de Cólofon fora o primeiro trabalho de Homero (15-17 Allen $=2 \mathrm{~W})^{59}$, então a mobilidade ('andava de cidade em cidade a recitar') era um traço característico que a

${ }^{59} \mathrm{~A}$ atribuição do Margites a Homero, que figura na Poética de Aristóteles (4.1448b-1449a), foi também afirmada por Arquíloco (frr. 201, 303 W), Cratino (fr. 368 K-A) e Calímaco (fr. 397 Pf.), segundo um comentador de Aristóteles (Eustratius in Arist. EN 6. 7 = Archil. fr. 303 W). Sobre o possível conteúdo e características formais do Margites, vide West 2003b: 225-228; para os testimonia e fragmenta, cf. pp. 240-253. West propõe como data plausível de composição o final do séc. VI (p. 227). Vale a pena referir a sua interpretação do fr. 1, de três versos, que fala

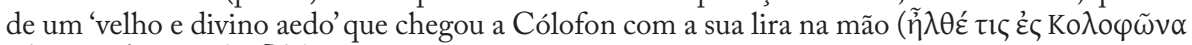

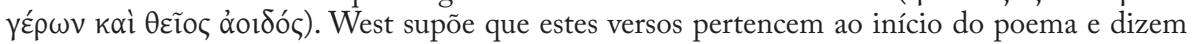
respeito ao seu narrador, quer ele fosse ou não identificado com Homero. Na sua opinião, é plausível que o Margites tenha sido composto em Cólofon, como se afirma no Certamen (pp. 226-227). A confirmar-se a sua interpretação, a mobilidade do poeta era uma das primeiras notas deste poema singular. 
tradição associava aos primórdios da sua carreira. Esta ideia vai ao encontro do que relata a Vida de Homero do Pseudo-Heródoto a propósito do mesmo assunto $^{60}$. Um mercador chamado Mentes convidou o jovem Melesígenes, que só mais tarde mudaria o nome para $\mathrm{Homero}^{61}$, a abandonar a escola e a acompanhá-lo nas suas navegações, para que assim pudesse conhecer terras estrangeiras, enquanto era novo. Curiosamente, o autor desta Vida observa que a ideia de viajar despertava certamente um grande interesse no jovem, pois já nesse momento ele deveria estar a pensar em tornar-se poeta (61-72 Allen = $6 \mathrm{~W}$ ). Ou seja, para o autor deste relato, mais do que uma formação escolar, são as viagens realizadas na juventude que explicam os vastos conhecimentos demonstrados pelo grande épico. Só mais tarde é que ele cegou completamente (73-87 Allen $=7 \mathrm{~W})$, depois de ter conhecido o mundo que descreve nos seus poemas. Contudo, continua o mesmo relato, a falta de visão não o impediu de viajar, agora com a finalidade de dar a conhecer a sua obra (288-313 Allen = 21-22 W $)^{62}$.

Voltando ao Certamen, é em Delfos que Homero ouve falar da celebração de jogos para honrar a memória de Anfidamante. Aí se havia dirigido para interrogar o oráculo sobre a sua pátria, uma questão que certamente despertava a curiosidade dos Gregos, já que eram muitas as cidades que disputavam essa honra. O Certamen começa por referir essa polémica, mas este passo desacredita o que aí se escreve: nem sequer o próprio Homero sabia onde nascera e a Pítia diz-lhe que fora em Ios, a ilha das Cíclades situada entre Naxos e Tera. Portanto, segundo a versão do Certamen, o poeta era oriundo de uma ilha cicládica, mas desde o início da carreira a mobilidade fizera parte da sua vida.

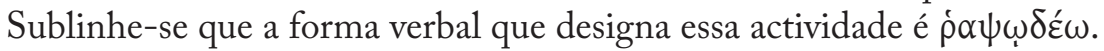

O oráculo da Pítia introduz um enigma que apenas será resolvido na parte final do Certamen e passa-se imediatamente à história do concurso poético em Cálcis. É evidente que esta versão dos jogos fúnebres em honra de Anfidamante desenvolve os escassos elementos fornecidos por Hesíodo em Trabalhos e Dias (vv. 654-659):

${ }^{60} \mathrm{Na}$ opinião de West 2003b: 301, este texto deve ter sido escrito entre c. 50 e c.150 d.C.

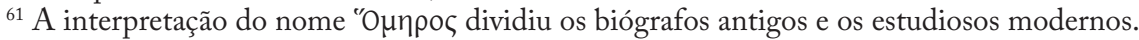
Para uma resenha das teorias principais, vide Càssola 1975: XXXII-XXXIV. Para uma análise global da questão, vide West 1999.

${ }^{62}$ Tem-se defendido que a deficiência visual de Homero (cf. Paus. 4. 33. 7) foi inspirada pela caracterização de Demódoco (e.g. Hainsworth 1988: 350, Zanker 1995: 166). Sobre a assiduidade deste motivo na tradição épica, cf. Ehrenberg 1964: 7-9. A ligação da cegueira à poesia e à profecia no mito é examinada por R. G. A. Buxton, "Blindness and Limits: Sophokles and the Logic of Myth", JHS 100 (1980) 22-37, esp. 27-30. John Miles Foley, "Individual Poet and Epic Tradition: Homer as Legendary Singer", Arethusa 31.2 (1998) 149-179, discute em especial os traços que caracterizam o chamado 'poeta lendário', quer nos relatos biográficos sobre Homero quer nos que existem sobre os bardos eslavos e de outros povos, designadamente a mobilidade, que não é afectada pela cegueira (como a Vita Herodotea sublinha). 
(1) O valente Anfidamante é nesta versão um rei da Eubeia.

(2) Os jogos são propostos por Ganictor, seu filho, e também se prometem 'grandes dons' (cf. Op. 655-656).

(3) As provas exigem destreza atlética e capacidades intelectuais. Este aspecto é importante, uma vez que o presente concurso, embora inclua provas de natureza poético-musical, é essencialmente de sophia, como indicia o último período do excerto ${ }^{63}$. O facto de se afirmar que Homero e Hesíodo se

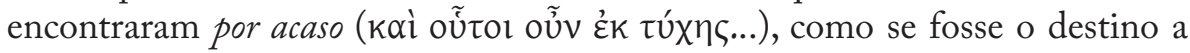
reunir os poetas que os Gregos consideravam sophotatoi, é um topos da tradição anedótica, como atesta uma história sobre Simónides (cf. infra schol. 29d. Pind. Ol. 2, p. 167).

(4) Hesíodo não refere os juízes. O compilador do Certamen detém-se neste aspecto, pois o público, constituído por 'todos os Gregos', fica maravilhado com a prestação de Homero e exige a sua coroação, mas Panedes atribui a vitória a Hesíodo por considerar que a sua poesia elogiava o trabalho agrícola e exortava à paz (205-210 Allen = $13 \mathrm{~W})$. A decisão a favor do poeta da Beócia confirma a dependência desta versão dos Trabalhos e Dias.

Esta introdução deixa perceber a natureza do concurso, que tem duas partes: na primeira avalia-se a sophia de Homero, sucessivamente interrogado por Hesíodo (74-177 Allen = 7-12 W); na segunda, cada um dos poetas recita, a pedido do rei Panedes, os melhores passos das suas obras (177-205 Allen = $12 \mathrm{~W}$ ). As formas verbais empregues indicam que este segundo momento é

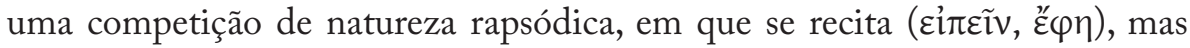
não se canta, uma situação poética diferente da descrita em Trabalhos e Dias (cf. vv. 657 e 662) ${ }^{64}$. Este aspecto tem a sua pertinência, porque Homero fora já apresentado como rapsodo (cf. supra).

Não obstante a discrepância, o compilador do Certamen procurou conciliar o desfecho do agon com o poema de Hesíodo e transcreve a inscrição que teria acompanhado a trípode dedicada às Musas do Hélicon (213-214 Allen $=13 \mathrm{~W}$ ), que parece inspirar-se nos vv. 657-658 de Trabalhos e Dias ${ }^{65}$.

${ }^{63}$ Sobre este aspecto, vide Richardson 1981: 2, que considera a ideia de um concurso rapsódico de sophia ao lado de um concurso atlético apropriada ao tempo de Xenófanes.

${ }_{64}$ É possível que os excertos apresentados por Hesíodo (Op. 383-392) e Homero (Il. 13. 126-133, 339-344) fizessem parte do repertório selecto dos rapsodos. Para Lesky 1995 [1971]: 117 , o Certamen é "um testemunho precioso de como Hesíodo era tido por rapsodo". Outro é o fr. dub. $357 \mathrm{M}-\mathrm{W}$.

${ }^{65} \mathrm{De}$ um modo geral, reconhece-se que a ideia de um concurso poético entre Homero e Hesíodo em Cálcis, que cedo se tornou num tema popular (cf. schol. Hes. Op. 657, Hes. fr. dub. 357 M-W, Simon. testt. 47 (j) e (k)), se baseia principalmente nos Trabalhos e Dias, mas é também fruto de uma tradição popular antiga, de um tempo em que se tornava comum especular e criar histórias sobre as vidas dos poetas. Cf. Richardson 1981: 1, O’Sullivan 1992: 96-97. 
Mas, no momento seguinte, somos informados de que Hesíodo, terminada a competição, se deslocara a Delfos para agradecer a vitória a Apolo. É esta referência que permite a transição para a matéria seguinte, a história da sua morte $(215-254$ Allen $=13-14 \mathrm{~W})$.

Dois aspectos nesta história merecem a nossa atenção. Hesíodo ouviu da Pítia que devia evitar o recinto sagrado de Zeus Nemeu, porque aí encontraria a sua morte. Julgando tratar-se do santuário de Nemeia no Peloponeso, foi para Oinóe da Lócrida, situada à beira-mar, onde existia um santuário dedicado a Zeus. Aí foi acolhido por 'Anfífanes e Ganictor, filhos de Fegeu'. Este passo é um testemunho da hospitalidade de que podiam beneficiar os poetas nas suas deslocações. Neste caso, porém, o costume é transgredido e o poeta sucumbirá às mãos dos dois jovens. O segundo ponto interessante é o facto de o seu corpo, lançado ao mar, ser recolhido por golfinhos, um topos da tradição clássica (vide infra, pp. 78-79 n. 40).

No que diz respeito a Homero, depois de ter participado nos jogos em honra de Anfidamante, 'andava de terra em terra e recitava os seus poemas'

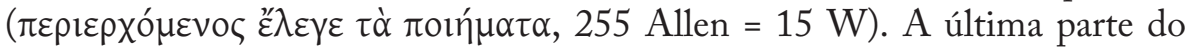
Certamen enumera as obras que compôs e as viagens que realizou para as divulgar. Em resumo, segundo o compilador:

- Homero pode ser o autor da Tebaida e de Epígonos ${ }^{66}$; compôs o epitáfio para o túmulo do rei Midas (séc. VIII-VII, cf. infra fr. 581), a pedido dos seus filhos, a Ilíada e a Odisseia, o 'Hino délico' a Apolo (255-321 Allen = 15-18 $\mathrm{W})$;

- as suas viagens permitiram-lhe apresentar as suas obras em cidades importantes, como Atenas, Corinto e Argos, bem como em Delos, tendo em todas as ocasiões recebido grandes honras (276-321 Allen $=16-18 \mathrm{~W})$;

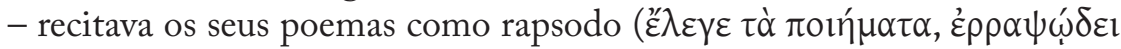

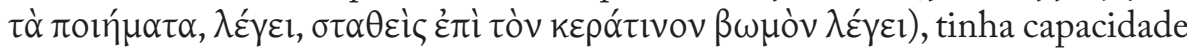

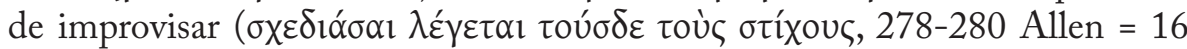
$\mathrm{W}$ ), adequava a sua actuação ao auditório (como faz em Argos), além de compor por convite epigramas funerários, bem como hinos, que apresentava nas grandes festividades religiosas. À semelhança de Hesíodo e de tantos outros poetas, beneficiava da hospitalidade de quem o admirava.

De Delos, o poeta rumou para Ios, onde permaneceu junto de Creofilo, sendo então um homem idoso. É nessa ilha que encontra a morte, cumprindo-se o oráculo que a Pítia lhe havia revelado no início da carreira (321-338 Allen $=18 \mathrm{~W})$.

${ }^{66}$ Recorde-se que a atribuição a Homero de uma Tebaida figurava nos versos de Calino (fr. 6 $\mathrm{W}=$ Paus. 9.9.5), o que constitui a referência mais antiga ao poeta épico. À autoria de Epígonos alude Heródoto (4. 32, 'se ao menos este poema é mesmo dele'). 
Parece haver uma contradição entre o que aqui se diz de Homero, que

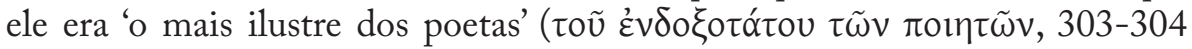
Allen $=17 \mathrm{~W}$ ), e o desenlace da competição em Cálcis, ainda que a assistência, constituída por todos os Helenos, quisesse a sua vitória. Ou seja, esta última parte atesta que este texto reúne tradições distintas. Ao contrário do que acontece noutras partes do Certamen, nesta secção o compilador não cita as suas fontes e apenas em duas ocasiões deixa transparecer que está a mencionar informações alheias. A consideração de alguns aspectos sugere-nos uma hipótese sobre a possível fonte.

Como dissemos, este poeta Homero aproxima-se muito mais dos rapsodos do que dos aedos retratados na Odisseia: a diferença mais evidente é que o aedo

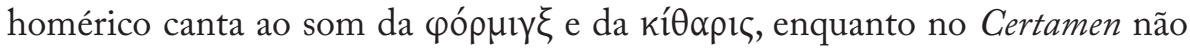
aparece qualquer referência ao acompanhamento musical. Por outro lado, a informação de que os Argivos decidiram enviar de cinco em cinco anos um sacrifício a Quios em sua honra $(307-308$ Allen $=17 \mathrm{~W})$ tem provavelmente subjacente uma tradição que indicava aquela ilha como a legítima pátria de Homero. Lemos no início do Certamen (13-15 Allen = 2 W):

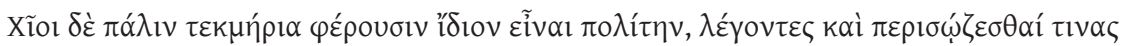

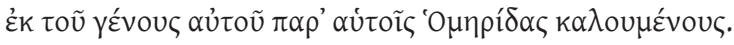

Os de Quios, por outro lado, apresentam provas defendendo que era seu cidadão e que sobreviviam entre eles alguns da sua família chamados Homéridas.

Devemos considerar a hipótese de o compilador do Certamen estar a citar uma tradição divulgada por estes profissionais, para quem o seu antepassado seria certamente 'o mais ilustre dos poetas', o 'divino Homero' ${ }^{67}$. A propaganda rapsódica é também atestada pela inscrição que os Argivos colocam na estátua do poeta, como sugere o primeiro dístico $(309-310$ Allen $=17 \mathrm{~W})$ :

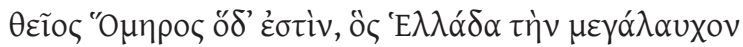

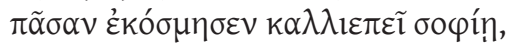

Este é o divino Homero que a Hélade toda orgulhosa ornamenta, com a sua arte eloquente, ...

Finalmente, a atribuição de um 'Hino a Apolo' ao grande épico corrobora a nossa hipótese. Em conclusão, apesar do carácter pseudo-biográfico, o

${ }^{67} \mathrm{Na}$ opinião de West 1967: 446-449, uma parte da secção sobre as viagens de Homero (275-321 Allen = 16-18 W) segue uma das suas Vidas, mas não a Vita Herodotea, na qual o poeta nunca chega ao continente grego, porque adoece a caminho de Atenas e fica retido em Ios. 
Certamen Homeri et Hesiodi deve, em nosso entender, ser considerado no âmbito de um estudo sobre a mobilidade poética na Época Arcaica. Para o seu compilador, e para as diversas fontes em que se baseia, era plausível que os dois grandes épicos tivessem participado em concursos poéticos e realizado muitas viagens. Essas experiências explicavam a difusão das suas obras. Por conseguinte, esta narrativa é um exemplo das histórias que os rapsodos faziam circular sobre os grandes poetas do passado, mas é também um testemunho de um modo de vida que esses recitadores profissionais conheciam bem, como veremos no capítulo seguinte. 


\section{A TRADIÇÃo dos RAPSODOS}

Os testemunhos de que dispomos sobre a actuação dos rapsodos na Época Arcaica são escassos. A sua influência junto do público foi reconhecida por Clístenes de Sícion, em fins do séc. VII ou inícios do VI. Segundo Heródoto (5.67.1), durante a guerra contra Argos o tirano proibiu a recitação da épica homérica nas competições rapsódicas, pois entendia que o seu autor celebrava com frequência os Argivos e a sua cidade ${ }^{68}$.

O orador Licurgo evoca no discurso Contra Leócrates uma lei antiga que tornou obrigatória a recitação por rapsodos $(\hat{\rho} \alpha \psi \omega \delta \varepsilon \tilde{\imath} \sigma \theta \alpha l)$ da épica de Homero nas Grandes Panateneias (102). Embora não mencione o legislador, provavelmente por despeito, os estudiosos modernos acreditam que se refere à regra que é atribuída ao filho de Pisístrato no Hiparco do Pseudo-Platão (228b-c):

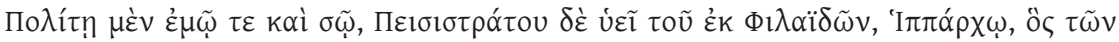

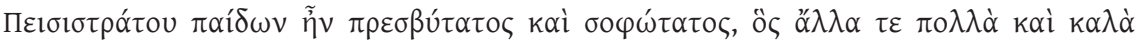

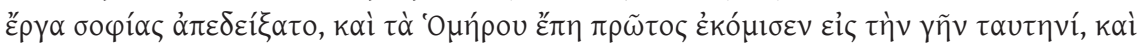

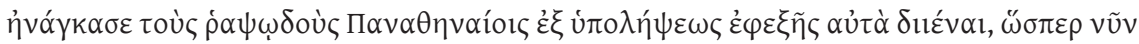

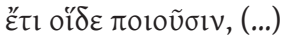

De um concidadão meu e teu, filho de Pisístrato de Filedes, Hiparco, o mais velho e o mais sensato dos filhos de Pisístrato, que executou muitas e belas acções ditadas pela sabedoria, entre elas, a de ter sido o primeiro que trouxe para esta terra as epopeias de Homero, e obrigou os rapsodos a recitá-las todas nas Panateneias, um após outro, tal como ainda hoje se faz; ${ }^{69}$

Este testemunho indica que, pelo menos desde a tirania dos Pisístratos, o festival ateniense incluía competições de recitação da épica homérica. A

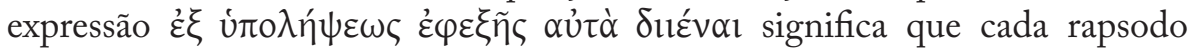
iniciava a sua actuação no ponto da narrativa a que o anterior havia chegado. Como escreveu R. Sealey, esta norma "provides an adequate motive for arranging the poems in order." ${ }^{70}$.

${ }^{68} \mathrm{Na}$ opinião de G. Nenci, Erodoto. Le Storie. Vol. V: Libro V (Milano 1994) 257, trata-se do testemunho mais antigo de uma censura, por parte de um tirano grego, a uma obra literária do passado. Para um comentário ao passo de Heródoto, vide E. Cingano, "Clistene de Sicione, Erodoto e i poemi del Ciclo Tebano", QUCC 20.2 (1985) 31-40.

${ }^{69}$ Tradução de M. H. Rocha Pereira (2009: 411-412).

${ }^{70}$ Sealey 1957: 346. Uma lei semelhante, pelo menos na intenção, foi atribuída a Sólon (D.L. 
No início da $I I^{a}$ Nemeia, dedicada a Timodemo de Acarnas por uma vitória no pancrácio, Píndaro evoca os 'O $\mu \eta p i ́ \delta \alpha$, 'cantores de versos ligados

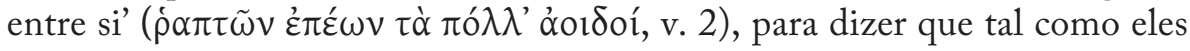
iniciavam as suas recitações épicas com um prelúdio em honra de Zeus, assim este atleta se coroava pela primeira vez no seu santuário de Nemeia (vv. 1-5). Vimos que o escólio a este passo (1c, III. 29 Dr., cit. supra) distingue os Homéridas, que descendiam de Homero e cantavam a sua poesia por direito de sucessão ( especial os do círculo de Cineto de Quios. Estes já não remontavam a sua linhagem ao grande épico, mas compunham poemas que faziam circular sob a sua autoria. Se, como informara Hipóstrato, estes profissionais desenvolveram a sua actividade no último quartel do séc. VI, é de supor que os Homéridas fossem mais antigos. Esta conjectura não é confirmada por

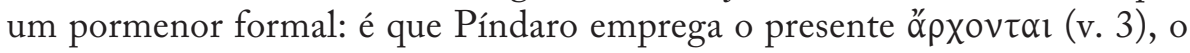
que numa interpretação literal do passo sugere que estes Homéridas eram contemporâneos do poeta. Não se exclui, porém, a hipótese de estar a aplicar uma designação antiga aos recitadores do seu tempo ${ }^{71}$. A representação do rapsodo nas pinturas de vasos do princípio do séc. $V$ pode ser também um reflexo da sua popularidade ${ }^{72}$.

Embora pertença já ao final do séc. V, a fonte mais importante sobre a formação e actuação de um rapsodo é o Íon de Platão, que reproduz uma conversa bem humorada entre Sócrates e um profissional famoso, cujo retrato se aproxima do caricatural. Ainda que o assunto principal seja a reflexão sobre a inspiração poética ${ }^{73}$, julgamos que algumas das informações que podemos colher neste diálogo se aplicam ao ofício de rapsodo em geral e não apenas aos do tempo do filósofo ${ }^{74}$.

1.57), arconte em 594/3. A confirmar-se esta informação, os concursos de rapsodos teriam sido introduzidos em Atenas cerca de um século antes. Segundo a interpretação de Herington 1985: 86, esta atribuição pode ser um indício de que os Pisístratos reorganizaram o festival, mas não o fundaram. Para uma discussão dos testemunhos sobre esta lei, vide Sealey 1957: 342-343, esp.; Pfeiffer 1968: 8, Shapiro 1989: 43-47 e Shapiro 1998, Janko 1992: 29-32, Burkert 2001: 207-208.

${ }^{71}$ Desconhece-se a data do triunfo de Timodemo celebrado pela II ${ }^{a}$ Nemeia. Bowra 1964: 407 chama a atenção para a referência a Salamina no v. 13, pois, como não alude à batalha, é de supor que a ode seja anterior a 480. A data mais plausível é 485, dado que o poeta não menciona a vitória seguinte em Olímpia (referida pelo escoliasta) e esta não figura na lista de vencedores olímpicos revelada pelo P. Oxy. 222, que cobre os anos 480-468 e 456-448.

${ }^{72} \mathrm{Cf}$. a ânfora ática de figuras vermelhas do Pintor de Cleófrades encontrada em Vulci, preservada no Museu Britânico (E 270, c. 490-480), que em princípio representa no lado A um rapsodo e no lado B um auleta.

${ }_{73}^{73}$ Sobre esta reflexão, vide Velardi 1982-1983: 39-40, esp.; Murray 1996: 98-99.

${ }^{74}$ Sobre as reservas a ter em conta quanto à fidedignidade destas informações e à sua aplicação a épocas mais antigas, cf. Herington 1985: 13. 
A primeira imagem que retemos de Íon é a de um artista que percorre o mundo grego por causa da sua profissão. É natural de Éfeso e acaba de chegar a Atenas, provavelmente a fim de participar nas Panateneias, como sugere Sócrates (530b), depois de ter obtido o primeiro prémio na competição de rapsodos realizada em Epidauro, por ocasião das festas em honra de Asclépios (530a). A seguinte pergunta confirma que a mobilidade é um aspecto característico do seu ofício (541b):

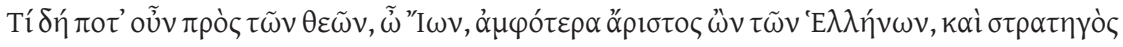

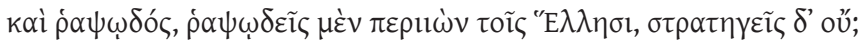

Mas, pelos deuses, ó Íon, sendo tu o melhor dos Gregos, quer como estratego quer como rapsodo, por que andas por aí a recitar para os Gregos e não comandas tropas?

Sócrates observa que a techne do rapsodo exige que ele cuide do seu aspecto físico, certamente a fim de impressionar as multidões que o escutam (cf. $535 \mathrm{~d})^{75}$, um conhecimento profundo de muitos e bons poetas, principalmente de Homero, não apenas das suas palavras, mas igualmente do seu pensamento (530b), e uma boa memória (539e). Neste sentido, não é um mero recitador, mas é essencialmente um intérprete. Íon confirmará esta avaliação: não só se considera um especialista de Homero (530d), como tem uma confiança excessiva nas suas capacidades interpretativas (533c, 536e, 541b). Em traços gerais, nas palavras de Sócrates, ser rapsodo significa falar acerca dos poetas, cantar os seus poemas (532c-d) e recitar versos épicos (535b). Os poetas são os intérpretes dos deuses e deles recebem a inspiração poética (534e), e os rapsodos são os intérpretes dos poetas (535a). Assim, a arte de Íon revela-se muito semelhante à do actor: consegue impressionar os espectadores e sente profundamente o que declama (535b-c, cf. 536a $)^{76}$, mas do alto do estrado onde actua também é capaz de ver os efeitos que provoca no seu público. A franca sinceridade acaba por revelar uma das principais motivações do seu trabalho: a ambição do dinheiro (535e).

75 As vestes coloridas e ornamentadas, a coroa de ouro e os adornos, evocados em $535 \mathrm{~d}$, constituem, certamente, alguns dos elementos que contribuem para o visual cuidado do rapsodo. Sobre a importância do aspecto físico deste profissional, vide Velardi 1982-1983: 38.

${ }^{76}$ Aristóteles evoca na Poética o rapsodo Sosístrato como exemplo de uma actuação marcada pelo exagero (26. 1462a5-7). Na longa secção dedicada a estes profissionais, Ateneu confirma que alguns 'representavam' em vez de recitar (14.620c-d). Sobre a associação entre rapsodos e actores, cf. P1. R. 395a, Alcid. Soph. 14, Arist. Rh. 1403b-1404a. Murray 1996: 110 observa que o termo ú aplicado ao rapsodo. Sobre este ponto, vide ainda Velardi 1982-1983: 38-40, Herington 1985: $11-13,51$. 
A caracterização de Íon tem levado alguns especialistas a considerarem o diálogo uma crítica à exegese dos Sofistas, com os quais revela algumas semelhanças (cf. infra, pp. 56-57). Um dos seus traços de carácter é a vaidade que sobressai, por exemplo, quando afirma que merecia ser premiado com uma coroa de ouro pelos Homéridas (530d) ou se proclama 'o melhor dos rapsodos gregos' (541a). O modo como fala das suas exibições sugere que exercia um grande fascínio sobre o público, mas não passa despercebida a censura de Sócrates pela forma como se considera o maior conhecedor de Homero e até de Hesíodo (531a-b).

Outras fontes confirmam que os poemas atribuídos a Homero ocuparam sempre o lugar de eleição no repertório dos rapsodos ${ }^{77}$. O segundo lugar parece ter pertencido a Hesíodo e Arquíloco, como sugerem as palavras de Sócrates (531a, 532a). Isto não significa que outros poetas não pudessem ser apresentados nos concursos, designadamente Sólon ${ }^{78}$.

O testemunho de Xenofonte confirma que as recitações rapsódicas eram muito populares na segunda metade do séc. $V$, o que teve como consequência a divulgação da épica homérica. Nicérato, um dos interlocutores do Banquete, diz que seria capaz de recitar toda a Ilíada e a Odisseia de cor, porque o seu pai, pretendendo que o filho se tornasse num homem bem formado (ảvì $\rho$ ảy $\alpha \theta$ ò

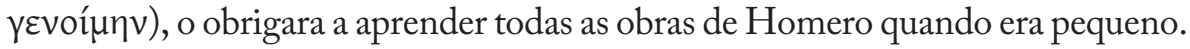
Mas logo a seguir confessa que, além desta aprendizagem solitária, tinha tido a oportunidade de assistir a recitações épicas praticamente diárias (3. 5-6).

É provável que, à semelhança de Ion, os rapsodos se considerassem autoridades em tudo o que dizia respeito à poesia homérica, talvez porque possuíam cópias dos textos, o que não era vulgar mesmo nos finais do séc. V. Esta sobranceria era censurada pela elite intelectual ateniense. Quando um dos intervenientes do mesmo diálogo de Xenofonte, Antístenes, observa que todos os rapsodos, não obstante o seu conhecimento dos Poemas Homéricos, constituem a 'raça mais estúpida'79, Sócrates aponta imediatamente a razão (3. 6. 4-7):

${ }^{77} \mathrm{O}$ testemunho mais antigo sobre a execução de poesia homérica em festivais é o fr. $42 \mathrm{D}-\mathrm{K}$ de Heraclito: 'Homero merece ser expulso dos concursos, e ser açoitado, bem como Arquíloco.' (trad. Rocha Pereira 2009: 153). Não é certo que o sábio de Éfeso se referia a recitações

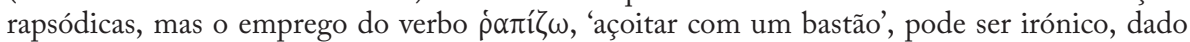
que os rapsodos actuavam habitualmente apoiando-se nesse objecto. Alguns testemunhos do séc. V referem especificamente a recitação da Ilíada e da Odisseia (e.g. Pl. Lg. 2. 658b-d, Xen.

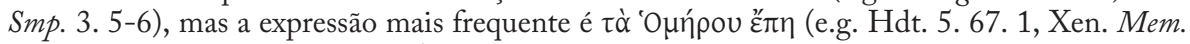
4. 2. 10, Ps. P1. Hipparch. 228b-c).

${ }^{78}$ Hesíodo: P1. Lg. 2. 658b-d, Isoc. Panath. 17-18, Athen. 14. 620c-d; Arquíloco: cf. n. anterior, Athen. 14. 620c; Sólon: P1. Ti. 21 b. Sobre o repertório dos rapsodos, vide West 1981: 125, Velardi 1982-1983: 39-40, Herington 1985: 174-175.

79 Segundo a $S u d a$, s.v. 'P $\alpha \psi \omega \delta$ oí, o aoristo $\rho \alpha \psi \omega \delta \tilde{\eta} \sigma \alpha$ l podia ser usado com o sentido de

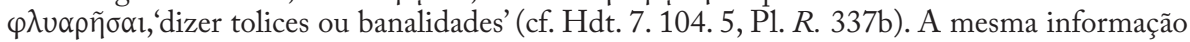
é dada no escólio a Pl. Ion 530a. 


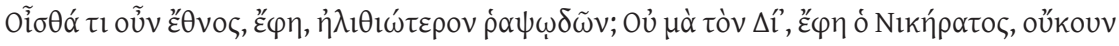

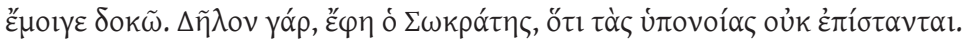

- Mas conheces alguma raça, perguntou o outro, mais estúpida do que a dos rapsodos?

- Não, por Zeus, respondeu Nicérato, por certo não me parece.

- Pois é evidente, disse então Sócrates, já que não conhecem o significado profundo dos poemas.

$\mathrm{Na}$ obra Memoráveis, ao tomar conhecimento de que Eutidemo reuniu uma colecção de livros, o filósofo pergunta-lhe se ele pretende ser médico, arquitecto, matemático, astrónomo ou rapsodo, já que possui toda a épica de Homero (4. 2. 10). À irónica pergunta de Sócrates, Eutidemo manifesta o mesmo desprezo e hostilidade de Antístenes:

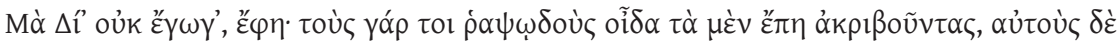

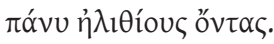

"Por Zeus, de modo nenhum", disse. "Pois eu sei bem que os rapsodos conhecem na perfeição os poemas épicos, mas eles próprios são muito estúpidos.”

A preservação e divulgação do legado homérico era reivindicada especialmente pelos Homéridas, que a tradição associava à ilha de Quios ${ }^{80}$. A abertura da $I I^{a}$ Nemeia de Píndaro contém a referência mais antiga a estes 'descendentes de Homero', mas, como dissemos, é possível que o poeta tenha usado aquele termo em sentido geral, talvez porque fossem os mais famosos $^{81}$. A alusão a estes rapsodos no Ion (530d, vide supra), quer tivessem ou não algum parentesco com os mais antigos, significa que no final do séc. $\mathrm{V}$ uma das suas funções era o reconhecimento dos profissionais que melhor interpretavam e divulgavam a obra de Homero. Outras referências em Platão

${ }^{80}$ Segundo Acusilau de Argos, contemporâneo de Píndaro, os Homéridas eram uma família de Quios (FGrHist 2 F 2). Cf. Helânico (FGrHist 4 F 20), Crates (FGrHist 362 F 5), Estrabão (14. 1. 35) e Cert. 13-15 Allen = 2 W (cit. supra). Registe-se que a naturalidade dos Homéridas não é referida no escólio que comentámos da $I^{a}$ Nemeia de Píndaro, que dá essa informação

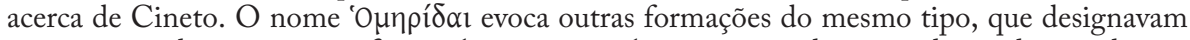
corporações de carácter profissional, cujos membros se consideravam descendentes de um antepassado comum. Era o caso dos Melampódidas, descendentes do vidente Melampo (Hdt. 7. 221, Pl. Ion 538e), dos Iâmidas, que descendiam de Íamo (Pind. Ol. 6. 71, Hdt. 5. 44. 2, 9. 33. 1), dos Taltibíadas, que viviam em Esparta e se diziam descendentes do arauto Taltíbio (Hdt. 7. 134. 1), e de outros grupos que exerciam determinados ofícios por tradição familiar (cf. schol. 1c. Pind. Nem. 2. 1, que refere o 'direito de sucessão'). Sobre os Homéridas, vide Sealey 1957: 312-318, Pfeiffer 1968: 11-12, Càssola 1975: XXIX-XXXV, West 1999, Burkert 2001: 206-207.

${ }^{81}$ Contra esta opinião, cf. Càssola 1975: XXXI. 
sugerem que dominavam todos os assuntos que lhe diziam respeito $(P h d r$. $252 \mathrm{~b}, R .599 \mathrm{e}$ ). Mas um passo de Isócrates indica que não constituíam um grupo homogéneo. Em Helena, depois de expor a história da Palinódia de Estesícoro, o orador acrescenta que alguns Homéridas do seu tempo também

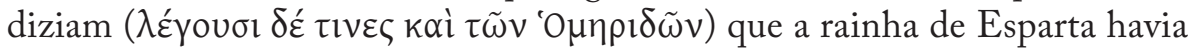
aparecido de noite a Homero e lhe tinha ordenado a composição de um poema sobre os que haviam combatido em Tróia (65). Este testemunho sugere que alguns Homéridas se interessavam pela divulgação de lendas sobre o seu antepassado, que viriam a fornecer o material das diversas Vitae. Filippo Càssola considerou a hipótese de Isócrates se referir a uma composição poética dos rapsodos (1975: XXXI), o que nos parece menos plausível, uma vez que usa a forma verbal $\lambda \dot{\varepsilon} \gamma o v \sigma$. No entanto, o passo acima referido do Fedro de Platão (252b) indicia que alguns desses Homéridas compunham versos, mas não muito perfeitos.

Uma notícia de Diodoro Sículo confirma que no princípio do séc. IV as recitações de poesia continuavam a ser populares, desde que as obras tivessem qualidade $^{82}$. Por ocasião da 98a Olimpíada $(=388)$, o tirano Dionísio de Siracusa enviou a Olímpia uma grande comitiva, comandada pelo seu irmão Teárides, na qual se incluíam os melhores rapsodos (14. 109. 1-2):

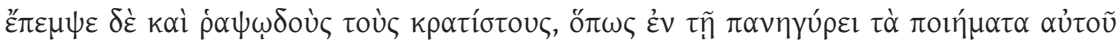

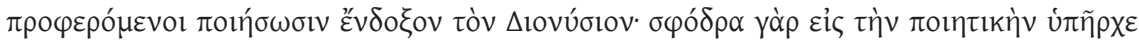
$\mu \varepsilon \mu \eta v \omega ́ c$.

Enviou também os melhores rapsodos, a fim de que apresentassem no festival os poemas dele e fizessem de Dionísio um homem célebre. É que ele andava completamente louco pela arte poética.

No início da recitação, as 'vozes harmoniosas' cativaram o público, mas logo os espectadores descobriram a pobreza dos versos de Dionísio e nessa altura ameaçaram destruir as tendas da comitiva. A corrida de carros não correu melhor e no regresso à Sicília o navio que transportava os artistas foi atingido por ventos muito fortes. Tanta desgraça não podia ser considerada obra do destino (14. 109. 5-6):

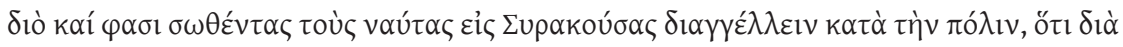

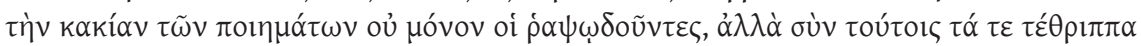

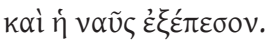

${ }^{82}$ A popularidade das recitações da Ilíada e da Odisseia em meados do séc. IV é atestada pelo passo acima referido das Leis (2. 658b-d), consideradas a última obra de Platão. Sobre a fama dos concursos rapsódicos na Época Helenística, vide Càssola 1975: LXI-LXII. 
Dizem que, por essa razão, os marinheiros que se salvaram a caminho de Siracusa espalharam na cidade que, por causa da má qualidade dos poemas, não só os rapsodos, mas com estes as quadrigas e a embarcação, se haviam perdido.

A falta de qualidade dos versos do tirano, que originou o insucesso da recitação rapsódica, é a única explicação que os sobreviventes do naufrágio encontram para o infortúnio da comitiva. Esta história confirma que as qualidades vocais e histriónicas do rapsodo por si só não garantiam o êxito da actuação, pelo que é natural que os recitadores seleccionassem os poetas e as passagens que mais possibilidades lhes oferecessem de sucesso. A proclamação de uma lei que regulamentasse as recitações nas Panateneias (vide supra) pode ter sido motivada por uma atitude selectiva da parte dos rapsodos, que escolhiam possivelmente os excertos épicos que mais lhes agradavam, em detrimento de outros que nunca chegavam a ser recitados (cf. Janko 1992: 30-31, Burkert 2001: 208).

Embora nos exponha um acontecimento do princípio do séc. IV, o relato de Diodoro Sículo testemunha a existência de rapsodos dependentes de casas reais. O texto não explicita se actuaram à vez ou em coro, mas supomos que eram como os outros obrigados a realizar longas viagens para exercerem o seu ofício. Por conseguinte, esta notícia é também um testemunho das dificuldades e riscos de deslocação destes artistas, que poderiam ser por vezes fatais.

Não temos conhecimento de outras fontes sobre a mobilidade dos rapsodos da Época Clássica, mas nos diálogos platónicos a deslocação através da Grécia surge claramente associada ao ofício da recitação. Quando Sócrates pergunta

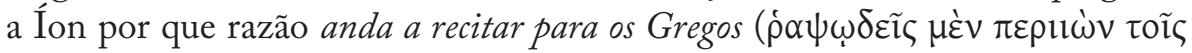

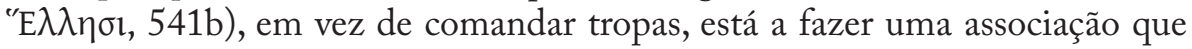
era provavelmente reconhecida na sua época e que também encontramos em A República (600d):

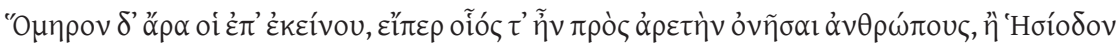

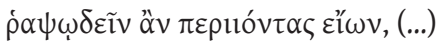

E os que viveram no tempo de Homero, se realmente ele era capaz de ajudar os homens a serem virtuosos, e de Hesíodo, haviam de os deixar andar de um lado para o outro a recitar, $(\ldots)^{83}$

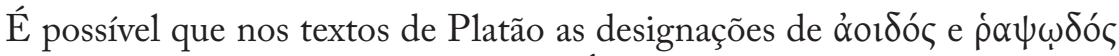
sejam equivalentes, visto que Sócrates no Ín chama rapsodo a Fémio (533c). No entanto, neste passo, o emprego de $\hat{\rho} \alpha \psi \omega \delta \varepsilon \dot{\varepsilon} \omega$ em relação a Homero e a

${ }^{83}$ Tradução de M. H. Rocha Pereira, Platão. A República (Lisboa $\left.{ }^{12} 2010\right) 460$. 
Hesíodo explica-se por ser usado num contexto em que o que está em causa é a apresentação pública da sua obra e essa tarefa é indissociável da mobilidade do poeta.

É na mesma linha de pensamento que interpretamos o testemunho de Diógenes Laércio acerca de Xenófanes (9.18 = fr. 21 A 1 D-K):

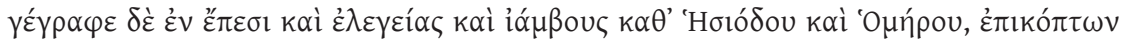

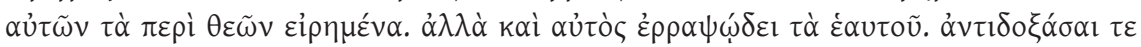

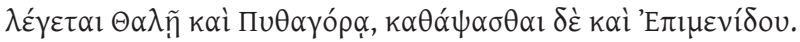

Escreveu em versos épicos, elegias e iambos contra Hesíodo e Homero, censurando o que haviam dito acerca dos deuses. Mas ele também recitava os seus próprios poemas. Diz-se que defendia opiniões contrárias às de Tales e de Pitágoras, e que também atacou Epiménides.

Carlo O. Pavese afirmou, com base neste testemunho, "Anche Xenophanes, compositore di propri poemi, è chiamato rapsodo." ${ }^{84}$. Na verdade, Diógenes Láercio não diz que o filósofo era rapsodo. Provavelmente queria dizer que recitava em público os seus poemas, sem acompanhamento musical. Não deixa de ser possível, contudo, que Diógenes Laércio, ao usar um verbo que remete para a técnica da execução rapsódica, tivesse em consideração a possibilidade de Xenófanes ter sido um filósofo e poeta itinerante, como sugere um dos seus fragmentos (fr. $8 \mathrm{D}-\mathrm{K})$ :

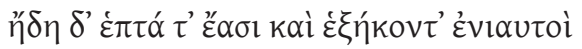

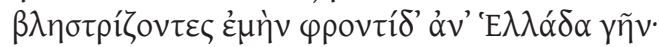

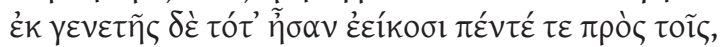

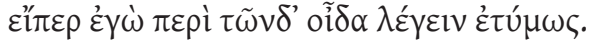

Já são sessenta e sete anos a agitar a minha preocupação por toda a terra da Hélade.

$\mathrm{E}$ do nascimento até esse momento são mais vinte e cinco, se, na verdade, sobre isso sei falar com exactidão.

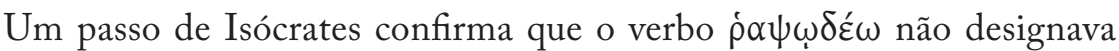
propriamente 'ser rapsodo', mas antes 'actuar como um rapsodo', 'recitar'. Em Panatenaico 18 descreve 'três ou quatro destes Sofistas vulgares', os quais, sentados junto do Liceu, dissertam sobre os poetas, sobretudo acerca de Homero e de Hesíodo, recitam ( $\hat{\rho} \alpha \psi \omega \delta$ ov $v \tau \varepsilon \varsigma)$ passagens das suas obras e recordam as interpretações feitas por outros. Estes Sofistas, 'vulgares',

${ }^{84}$ Pavese 1974: 18. Cf. G. S. Kirk, J. E. Raven, M. Schofield, Os Filósofos Pré-socráticos. Trad. port. C. A. Louro Fonseca (Lisboa 1994, da 2a ed. 1983) 168-169. 
comportam-se como se fossem rapsodos e recitam passagens que eles próprios não compuseram.

Os testemunhos aqui reunidos mostram que os rapsodos não constituíam um grupo profissional uniforme e a sua actividade sofreu alterações ao longo do tempo. Levam-nos também a questionar a tradicional oposição entre o óoı $\delta$ ć e o $\hat{\rho} \alpha \psi \omega \delta$ ós, sendo o primeiro considerado compositor e executante da própria obra e o segundo mero recitador profissional de poemas alheios. Todavia, não nos parece que tenham razão os estudiosos que defendem, com base em Platão geralmente, que $\hat{\rho} \alpha \psi \omega \delta$ ós designa especificamente o poeta épico, enquanto

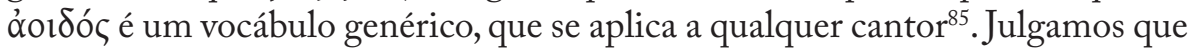
esta posição distorce os factos, pois o primeiro termo não ocorre no corpus da poesia arcaica ${ }^{86}$ e o segundo parece ter sido empregue em sentido geral, como afirmam, mas sobretudo em contextos encomiásticos, talvez porque evocava tradicionalmente os antigos e célebres cantores do passado ${ }^{87}$.

Mas, como defendem muitos estudiosos, cremos que há uma distinção fundamental no âmbito da execução: o aedo, pelo menos nos Poemas Homéricos, actua semprecom acompanhamento musical,enquanto o rapsodo recita segurando

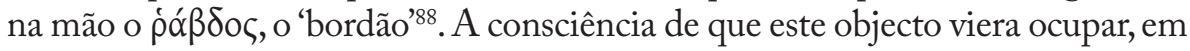

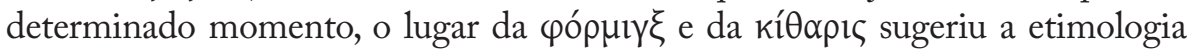
falsa, segundo a qual $\rho \alpha \psi \omega \delta$ ó́ deriva daquela palavra. Esta explicação figura no escólio $1 \mathrm{~d}$ da $I I^{a}$ Nemeia de Píndaro ${ }^{89}$, que compila as principais interpretações

${ }^{85}$ Nas palavras de Pavese 1974: 16, "In ogni modo il termine $\rho \alpha \psi \omega \delta$ бó e i suoi derivati erano usati dagli antichi per indicare sia ciò che i moderni chiamano «aedo» (cioè il compositore di poemi epici recitativi), sia ciò che essi chiamano «rapsodo» (cioè l'esecutore degli stessi poemi), e ciò fin da epoca arcaica. Gli antiqui dunque, quando distinguevano, non distinguevano come i moderni secondo compositore e esecutore, ma secondo genere di cantore." Cf. Càssola 1975: XXVI-XXVII.

${ }^{86}$ As ocorrências mais antigas conhecidas de $\rho \alpha \psi \omega \delta$ бó surgem em Heródoto, no passo sobre as recitações de Sícion (vide supra), e em Sófocles (OT391), que o aplica à Esfinge. Não aparece nos Poemas Homéricos, pois tem uma contracção pós-homérica, nem há referências explícitas à existência de executantes de poemas alheios. Todavia, Sealey 1957: 315-316 considera que a

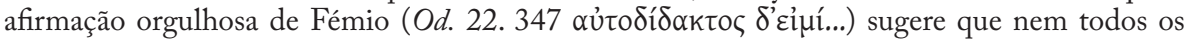
poetas eram $\alpha \dot{\tau} \tau o \delta i ́ \delta \alpha \kappa \tau o l$ ("so even in this time some poets made recitation, as distinct from composition, their primary function.”). A mesma opinião é partilhada por Burkert 2001: 205 ("this sets him apart not from divine inspiration but from merely reproductive performance of epic song.").

${ }^{87}$ Álcman aplica ơoıı́́ a uma donzela do 'Grande Partenéion' (fr. 1. 97 P) e à Musa (fr. 14

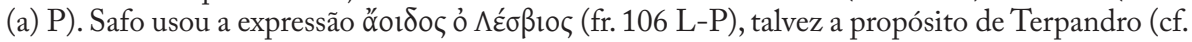
Terp. test. 9, infra p. 70 n. 17). Píndaro chama ỏorooí aos elementos do coro da Ia Pítica (v. 3) e aos Homéridas (Nem. 2.2). Heródoto usa o termo a propósito de Aríon, num momento em que recorda que era 'o melhor cantor entre os homens' (1.24. 5, cit. infra).

${ }^{88}$ Cf. Pind. Isth. 4. 38-39; Call. fr. 26. 5 Pf.; Suda, s.v. 'P $\alpha \psi \omega \delta$.í. Na opinião dos estudiosos

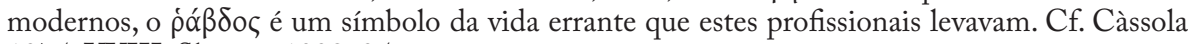
1975: XXIII, Shapiro 1998: 95.

${ }^{89} \mathrm{O}$ escoliasta cita Menecmo de Sícion (séc. III, cf. FGrHist 131 F 9), mas esta interpretação 
antigas do vocábulo. Cita também, como vimos, Filócoro de Atenas e o fr. dub. $357 \mathrm{M}-\mathrm{W}$ (cit. supra). De acordo com este autor do séc. IV, $\rho \alpha \psi \omega \delta$ ó é o nome

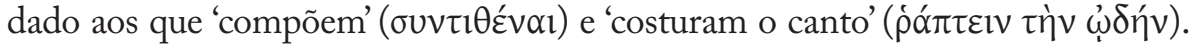

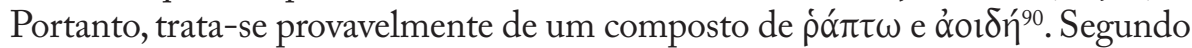
o escólio 1a, quando Píndaro chamou aos Homéridas 'cantores de versos ligados

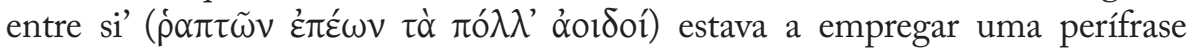

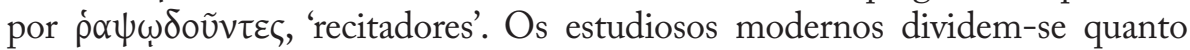
à interpretação da expressão do lírico de Tebas e do sentido de ṕá $\omega \dot{\delta} \eta v$ (cf. fr. dub. 357.2 M-W). Segundo alguns, é uma referência à recitação contínua dos versos épicos. Designa, portanto, uma particularidade da actuação do rapsodo ${ }^{91}$. Outros relacionam a expressão com o seu modo de compor, pois supõe-se que usavam o material herdado da tradição épica (fórmulas, epítetos, estruturas narrativas, etc.) e 'cosiam-no' às suas composições ${ }^{92}$. 'Ligar os versos entre si' é, de facto, o que faz o autor do Hino Homérico às Musas e a Apolo, quando baseia os vv. 2-5 no proémio da Teogonia de Hesíodo (vv. 94-97). Vale

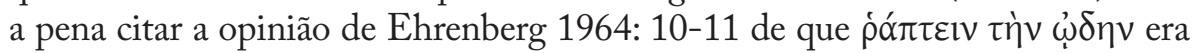
provavelmente uma metáfora que sugeria que o rapsodo já não era um artista criativo, mas um artesão.

É possível que tenha sido esta a origem da palavra $\rho \alpha \psi \omega \delta$ ós, que tem intrigado os estudiosos antigos e modernos. No entanto, em plena Época Clássica esse significado original parece ter sido suplantado pela ideia de que um rapsodo era um especialista da recitação $0^{93}$.

aparece também nos escólios de Pind. Isth. 4. 63, P1. Ion 530a, e continua a ter defensores. No entender de Barry B. Powell, Homer (Malden-Oxford 2004) 28, "Rhapsode probably means 'staff-singer', but the Greeks falsely etymologized it to mean 'stitcher of song."

${ }^{90} \mathrm{O}$ facto de o segundo termo pertencer ao domínio do canto não é indício da presença da música, mas da analogia com outras formações, como kı $\theta \alpha \rho \omega \delta$ ¿́s, $\alpha u ̉ \lambda \omega \delta$ óc. Cf. Ford 1988 : 300-301.

${ }^{91}$ E.g. I. Rumpel, Lexicon Pindaricum, s.v. ṕartós (Hildesheim 1961); Willcock 1995: 80. Ford 1988: 300 propõe como definição geral da arte do rapsodo a execução de poesia sem $\mu$ ćरoఢ, observando que sem música as peças são simplesmente acrescentadas, mas sem um padrão unificador: "To join independent pieces end to end, without modifying their internal structure, is like stitching." (p. 306).

${ }^{92}$ Cf. G. Tarditi, "Sullorigine e sul significato della parola rapsodo", Maia 20 (1968) 137-145, esp. 142-143. Este investigador discute o sentido de ṕá $\pi \tau \varepsilon ı v$, analisa os testemunhos e revê as opiniões de G. Else, H. Patzer, H. Fränkel e A. Pagliaro. Das suas conclusões destaque-se a ideia de que o termo $\dot{\rho} \alpha \psi \omega \delta$ ó começou por ser aplicado aos Epígonos da poesia épica, provavelmente com um certo valor pejorativo. Sobre esta matéria, cf. ainda Chantraine, s.v. $\rho \alpha \psi \omega \delta \delta$ ćs.

${ }^{93} \mathrm{Na}$ República, Platão inclui os rapsodos no grupo dos 'servidores dos poetas', ao lado dos que se ocupavam das representações dramáticas (actores, coreutas e empresários, 373b), o que significa que não os considerava verdadeiros compositores, mas profissionais que trabalhavam

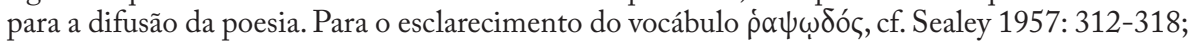
Kirk 1962: 312-315, 318-319; Càssola 1975: XXVI-XXVII; V. Ehrenberg, "War Hesiod ein Rhapsod?”, Gymnasium 89 (1982) 57-66; Herington 1985: 167-176, Murray 1996: 96-97, Burkert 2001: 205-206, Rocha Pereira 2006: 147. 
Em conclusão, se o objectivo dos Homéridas mais genuínos pode ter sido a preservação do legado homérico, sem interesses económicos, outros rapsodos haveria que, como Íon, pretendiam sobretudo ganhar muito dinheiro. Neste sentido, a participação nos concursos de recitação realizados no âmbito de grandes festivais, como as Panateneias, embora os obrigasse a percorrer longas distâncias através da Grécia, constituía um incentivo, pois significava a possibilidade de reconhecimento junto de um público maior e de obtenção de grandes lucros. A competição entre os rapsodos devia ser habitual, esforçando-se cada um por dar o seu melhor e agradar aos juízes e ao público. Por isso, a caracterização de Íon detém-se no seu aspecto físico, na postura do seu corpo, nas qualidades histriónicas da sua actuação e no seu desejo de glória. Com a sua vaidade e pretensões de sabedoria, os rapsodos do tempo de Sócrates suscitam o desprezo da sociedade culta de Atenas. Acreditamos, porém, que a sua acção tenha sido determinante para a difusão da poesia épica ${ }^{94}$. Finalmente, se alguns também recitavam as suas composições, parece que eram mais famosos os que se distinguiam na apresentação das obras de Homero.

${ }^{94} \mathrm{Na}$ opinião de Càssola 1975: XXXVII, a difusão pan-helénica da poesia épica na Época Arcaica leva a supor a existência de escolas (ou associações) de rapsodos em diversas cidades gregas. 
(Página deixada propositadamente em branco) 
Parte I

Dados PRELIMINARES 
(Página deixada propositadamente em branco) 


\section{As festas públicas e a política CULTURAL DOS TIRANOS}


(Página deixada propositadamente em branco) 


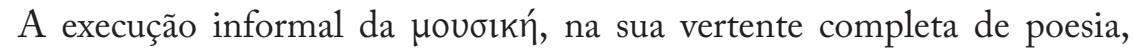
música e dança, podia ocorrer em diversas ocasiões, como mostram os Poemas Homéricos, e foi sempre um elemento fundamental dos rituais religiosos (cf. Herington 1985: 5-10). Pretendemos neste capítulo comentar os testimonia que associam a actuação dos líricos da Época Arcaica à realização de festas públicas que incluíam concursos oficiais de carácter poético-musical ( $\alpha$ ү $\tilde{\omega} v \varepsilon \varsigma$

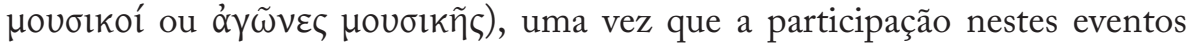
constitui, desde muito cedo, uma das principais razões de mobilidade poética. Mas é ainda na Época Arcaica que alguns líricos conhecem uma outra razão para se deslocarem: o apelo de ricos e generosos tiranos, que ascendem ao poder em diversas partes do mundo grego.

Aquele que é considerado actualmente o fragmento mais antigo de poesia lírica grega foi-nos transmitido por Pausânias no seu livro sobre a Messénia. Trata-se de dois versos que terão pertencido a um prosodion, composto por Eumelo de Corinto para ser executado em Delos (4. 33. 2 = fr. 1 (a) Campbell, $696 P M G)^{1}$ :

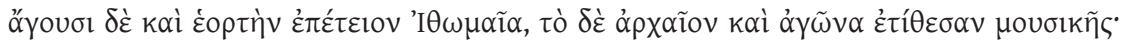

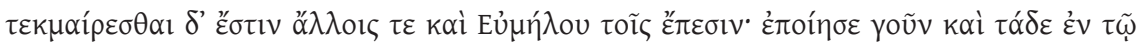
$\pi \rho \circ \sigma \circ \delta i ́ \omega \tau \tilde{\omega} \tilde{\varepsilon} \zeta \Delta \tilde{\eta} \lambda{ }^{\prime} v^{*}$

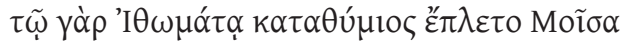

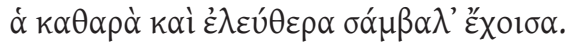

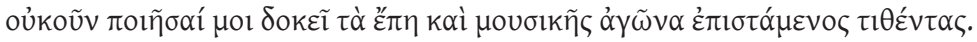

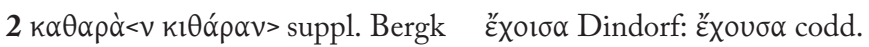

Celebram uma festa anual, as Itomeias, e em tempos antigos instituíram também uma competição musical. Disso dão testemunho, entre outras provas, os versos de Eumelo. Compôs, por exemplo, estes no seu prosodion para Delos:

pois o coração do deus de Itome deleitou-se com a Musa, a Musa pura, que calça as sandálias da liberdade. ${ }^{2}$

\footnotetext{
${ }^{1}$ Para a crítica textual e interpretação deste fragmento, vide especialmente Bowra 1963, De Martino e Vox 1996, D'Alessio 2009: 137-145.

${ }^{2} \mathrm{Ou}$ 'a que possui a cítara pura e as sandálias da liberdade', se considerarmos o suplemento de Bergk, que transforma o segundo verso num hexâmetro dactílico, à semelhança do primeiro. Todavia, vale a pena lembrar a observação de Bowra 1963: 145-146 de que a emenda não é necessária do ponto de vista métrico (teremos assim um hexâmetro e um pentâmetro dactílicos)
} 
Assim, parece-me que compôs estes versos com o conhecimento de que os Messénios realizaram uma competição musical.

A análise dos testimonia respeitantes a Eumelo permite saber que era de ascendência social elevada e se notabilizou pela composição de obras épicas ${ }^{3}$. Considerado um dos poetas mais antigos, não é possível estabelecer a sua cronologia exacta, mas supõe-se que teria desenvolvido a sua actividade no segundo quartel ou meados do séc. VIII ${ }^{4}$.

O excerto acima transcrito relaciona o poeta de Corinto com dois festivais: as Itomeias ('I $\theta \omega \mu \alpha \tilde{\imath} \alpha)$, que receberam o nome da montanha de Itome, onde anualmente os Messénios se reuniam para honrar Zeus Ithomatas, e um festival realizado em Delos, no qual se executavam prosodia ${ }^{5}$. Pausânias refere-se ao hino de Eumelo em mais dois passos da sua Descrição da Grécia. O que nos interessa encontra-se num dos primeiros capítulos do mesmo livro sobre a Messénia ${ }^{6}$ e fornece-nos alguns dados sobre as circunstâncias de execução daquele poema (4. 4. 1 = fr. 1 (b) Campbell, $696 P M G)$ :

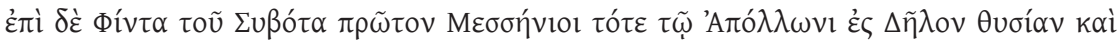

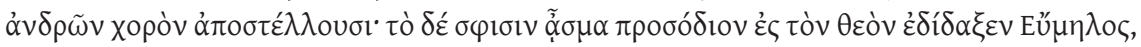

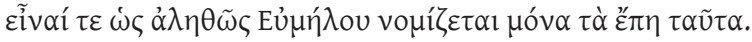

No tempo de Fíntis, filho de Sibota, pela primeira vez, os Messénios enviaram a Apolo Délio um sacrifício e um coro de homens. Foi Eumelo quem lhes ensinou o canto processional em honra do deus e somente estes versos se consideram realmente de Eumelo.

nem favorece o sentido do fragmento. Cf. D'Alessio 2009: 142-143.

${ }^{3}$ A tradição atribuía a Eumelo a composição, em versos épicos, de Bougonia, Europia, Korinthiaka, Nostoi e Titanomachia. Sobre estas obras, vide A. Bernabé, Poetae Epici Graeci I (Leipzig 1987) 106-114; M. Davies, Epicorum Graecorum Fragmenta (Göttingen 1988) 95-103; Musti e Torelli 1997a: 206; West 2002 (com referências bibliográficas) e 2003a: 26-31, 220-251.

${ }^{4}$ De acordo com Pausânias (2. 1.1 = test. 3), Eumelo era filho de Anfílito e pertencia à família real dos Baquíadas, que governaram Corinto desde c. 750 até ao tempo de Cípselo (c. 657, cf. Hdt. 5. 92. 3). A Crónica de Eusébio (test. 2) fornece-nos duas datas para o floruit do poeta: o primeiro ano da $5^{\text {a }}$ Olimpíada $(=760 / 759)$ e o primeiro da $9^{a}(=744 / 743)$. Sobre esta questão, vide Dunbabin 1948: 67, Bowra 1963: 47-48, Musti e Torelli 1997b: 205-206. Sobre a aristocracia dos Baquíadas, cf. Andrewes 1956: 43-45 e J. B. Salmon, Wealthy Corinth. A History of the City to 338 BC (Oxford 1984) 55-74.

${ }^{5}$ As descobertas arqueológicas atestam que o culto a Zeus Ithomatas foi praticado desde o final do séc. VIII até meados do séc. V, pelo menos. Cf. P. Cartledge, Sparta and Lakonia. A

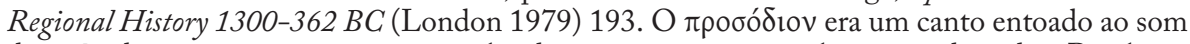
do aulos durante as procissões a caminho dos santuários ou templos, segundo indica Proclo na Chrestomathia (312a18-20 Bekker). As fontes relativas a esta forma poética são discutidas por Mathiesen 1999: 81-83, que cita também os versos de Eumelo. $P M G$.

${ }^{6}$ A outra referência ao prosodion encontra-se em Paus. 5. 19. 10 = fr. 1 (c) Campbell, 696 
Segundo informa Pausânias (4. 4. 4), Fíntis era pai de Ândrocles e de Antíoco, reis da Messénia no começo da Primeira Guerra, que durou vinte anos (cf. Tyrt. fr. 5. 7 W) e terminou por volta de 724 (cf. Paus. 4. 13. 7). Se considerarmos que o 'tempo de Fíntis' se situa nos vinte anos imediatamente anteriores a este reinado (i.e., c. 764-744), obtemos uma cronologia que coincide com o floruit tradicionalmente atribuído a Eumelo ${ }^{7}$. Este passo esclarece que o festival de Delos, para o qual Eumelo compõe o prosodion, era celebrado em honra de Apolo e, à semelhança do que acontecerá em épocas posteriores, o poeta foi responsável pela composição e pela instrução do coro de homens que executou o hino.

O fragmento de Eumelo tem suscitado interpretações diversas. Pausânias, baseado nestes versos, conjecturou que o festival celebrado em Itome havia incluído em tempos antigos um agon poético. Assim, numa leitura que podemos considerar 'poético-biográfica', alguns estudiosos entendem a referência à Musa em sentido figurado e ponderam a hipótese de o fragmento aludir a um momento da carreira de Eumelo, ao êxito alcançado, no passado, no agon musical em honra de Zeus de Itome, evocado pelo poeta numa composição destinada a um outro santuário, à semelhança do que faz Hesíodo, quando em Trabalhos e Dias recorda a vitória nos jogos fúnebres em honra de Anfidamante e o seu primeiro encontro com as Musas (vv. 654-659) ${ }^{8}$. Mas as palavras de Pausânias no passo acima citado são também um testemunho da importância de uma missão pioneira ( $\pi \rho \tilde{\omega} \tau o v)$, cujo significado pode não ter sido apenas religioso, dado que foi confiada a um poeta de linhagem distinta, por certo suficientemente conhecido no Peloponeso, natural de uma cidade que já nesta época liderava o comércio marítimo (cf. Andrewes 1956: 43-44). Julgamos, portanto, que merece ser considerada a leitura tradicional, segundo a qual o epíteto $\varepsilon \grave{\lambda} \varepsilon u ́ \theta \varepsilon \rho \alpha$ sugere uma alusão à situação política da Messénia ${ }^{9}$.

${ }^{7}$ Vide supra n. 4. A referência a Fíntis é discutida por Bowra 1963: 53 sqq. Cf. Musti e Torelli 1997b: 210-211. A cronologia tradicional da Primeira Guerra da Messénia é 743-720 (cf. A. J. Graham, in J. Boardman and N. G. L. Hammond, edd., The Cambridge Ancient History III. 3, 1982, p. 109; N. G. L. Hammond, ibidem, pp. 323-324). Todavia, registe-se que V. Parker, "The Dates of the Messenian Wars", Chiron 21 (1991) 25-47, propôs a datação c. 690-670 (apud Gerber 1999a: 45). A tendência de baixar a cronologia de Eumelo é seguida por West 2002 que retomou a hipótese, já admitida por Dunbabin 1948: 67 n. 71, de o prosodion de Eumelo ter sido composto durante a Segunda Guerra da Messénia, que se supõe ter ocorrido em meados do séc. VII (cf. Hammond, ibidem, pp. 351-352). Mais arrojada é a hipótese discutida por D'Alessio 2009: 143-145 de a composição transmitida sob a autoria do antigo poeta coríntio ser, na verdade, uma falsificação ("forgery") da Época Clássica.

${ }^{8}$ Cf. De Martino e Vox 1996, que remetem para C. O. Pavese, "Il più antico frammento di lirica corale greca", in Filologia e forme letterarie. Studi offerti a F. Della Corte. Vol. 1 (Urbino 1987) 53-57.

${ }^{9}$ Embora Pausânias situe o envio do prosodion em época anterior à Primeira Guerra, Bowra 
O envio de um sacrifício e de um coro de homens a um santuário longínquo, mas certamente importante, pode ter sido motivado pela necessidade que os Messénios sentiram de apelar à protecção de um outro deus ou de afirmar, perante os outros povos gregos aí representados, a sua independência. $\mathrm{O}$ testemunho de Pausânias, todavia, não nos esclarece sobre este aspecto nem sobre as condições de deslocação daquele coro, que não se adivinham simples, atendendo à distância considerável que separa a Messénia de Delos. $\mathrm{O}$ retrato de Eumelo que permite esboçar é o do compositor-demiurgo que temporariamente deixa a sua terra natal para atender ao pedido de uma cidade estrangeir ${ }^{10}$. Vale a pena recordar, porém, que a execução de composições corais no antigo festival délico é também sugerida pelos vv. 156-164 do Hino Homérico a Apolo.

Do grupo dos poetas mais antigos fazia parte também Terpandro de Lesbos, que desenvolveu todo o seu trabalho em Esparta, na primeira metade do séc. VII ${ }^{11}$. A tradição distinguiu as suas inovações no domínio da música $^{12}$ e o papel de relevo na vida artística de Esparta. Alguns estudiosos

1963: 57 pensa que teria acontecido durante o conflito. $\mathrm{Na}$ sua interpretação, o aoristo हैं $\lambda \varepsilon \tau$. significa que o canto não pode ser executado em Itome, porque os exércitos de Esparta já invadiram o território da Messénia (pp. 54-55), e o emprego do epíteto $\kappa \alpha \theta \alpha \rho \alpha ́$ pode ter tido a intenção de defender os Messénios das acusações de impiedade, que teriam estado na origem da guerra (pp. 55-56).

${ }_{10}$ A hipótese de A. Andrewes, citada por Bowra 1963: 57, de o coro ter sido enviado pelos Messénios exilados temporariamente na Eubeia, e que vieram depois a colaborar com os Calcídios na colonização do Ocidente, não põe em causa esta suposição, antes a reforça. Sobre as razões que terão levado os Messénios a encomendar o prosodion a Eumelo de Corinto, vide as conjecturas de Bowra 1963: 58.

${ }^{11}$ Os testemunhos não são unânimes quanto à naturalidade de Terpandro, mas a maioria indica-o como tendo nascido em Antissa (Lesbos). O floruit é situado em 645/644 pelo Marmor Parium (Ep. 34 = FGrHist 239 A 34 = test. 3) e no terceiro ou quarto ano da 34a Olimpíada (= 642/641 ou 641/640) por Eusébio (Chron. = test. 4), o que significa que viveu até essa altura, pelo menos. Com estes dados coincide a informação transmitida por Clemente de Alexandria (Strom. 1. 21. 131 = test. 5) de que Helânico de Lesbos afirmara que Terpandro já era vivo ou

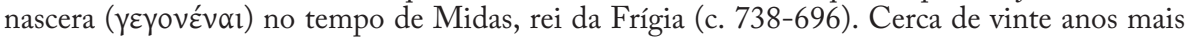
tarde alcançava a vitória nas competições de citaródia das Carneias (vide infra), que constitui a data mais segura sobre a carreira do poeta. Para um exame dos testemunhos antigos sobre a cronologia do poeta, vide Gostoli 1990: IX-XI.

12 Entre essas inovações conta-se o proverbial aumento do número de cordas da lira de quatro para sete (cf. Suda, s.v. Tép $\pi \alpha v \delta \rho \circ \varsigma=$ test. 1) e a invenção do barbitos (cf. Pind. fr. 125 Ma., citado em Athen. 14. 635d-e = Terp. test. 12), particularmente associado à lírica eólica. A phorminx dos aedos homéricos tinha quatro cordas. As cítaras representadas no sarcófago de Hagia Triada (Creta, c. 1400) mostram já sete cordas e os estudiosos alegam a suposta solução de continuidade entre a música cretense e a de épocas posteriores. As descobertas arqueológicas, porém, confirmaram o testemunho da $S u d a$, uma vez que a lira e a cítara de sete cordas aparecem representadas nas pinturas de vasos do tempo de Terpandro (cf. Anderson 1994: 10-15, 36, 62; Rocha Pereira 2006: 647). Sobre as inovações musicais do poeta, cf. West 1992b: 330. Sobre a 
modernos vêem-no como um sucessor dos aedos homéricos e um predecessor de Estesícoro, por ter desenvolvido a arte da citaródia ( $\kappa \imath \theta \alpha \rho \omega \delta i ́ \alpha)$, isto é, o canto acompanhado ao som da cítara, com a criação de melodias para os seus versos, ao que parece de conteúdo épico ${ }^{13}$, e para os de Homero, como havia afirmado Heraclides Pôntico, filósofo do séc. IV e discípulo de Platão ${ }^{14}$ :

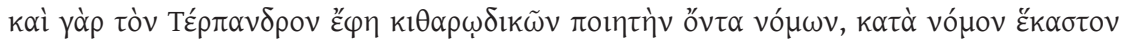

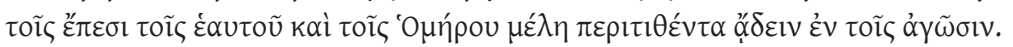

pois também dizia que Terpandro, compositor de nomoi citaródicos, atribuiu melodias, segundo cada nomos, aos seus próprios versos e aos de Homero, e os cantava nos concursos.

Se isso aconteceu realmente, Terpandro teria sido um dos primeiros divulgadores da poesia de Homero no Peloponeso. Mas para os propósitos deste capítulo merecem destaque os testemunhos que o associam aos primeiros tempos de funcionamento de dois importantes festivais: aos Jogos Píticos, que contemplavam então apenas o concurso de citaródia (vide infra), e às Carneias de Esparta. O autor do De Musica tinha conhecimento do registo das quatro vitórias sucessivas alcançadas em Delfos ${ }^{15}$, o que significa que durante três décadas - no séc. VII o festival realizava-se de oito em oito anos - Terpandro foi considerado o melhor citaredo pítico (cf. 4. 1132e = test. 6). Assim, não admira que, segundo contou o historiador do séc. V Helânico de Lesbos, tenha sido o primeiro vencedor no concurso de citaródia das Carneias, fundadas na 26a Olimpíada (=676/672), de acordo com Sosíbio de Esparta, gramático do séc. III ${ }^{16}$. Portanto, segundo estes testemunhos, o festival das Carneias, em geral associado a manifestações corais (vide infra), incluiu desde o seu início concursos de citaródia.

antiguidade da lira, vide A. Franceschetti, "L'armonia della lira tra storia, musica e archaeologia. L'evidenza egea del II millennio a.C.”, AC 75 (2006) 1-14.

${ }^{13}$ É o que se depreende de Plu. Instituta Laconica 17. 238c (= Terp. test. 17): '... mas até Terpandro, o mais antigo e distinto dos citaredos do seu tempo, que louvou as acções heróicas...'

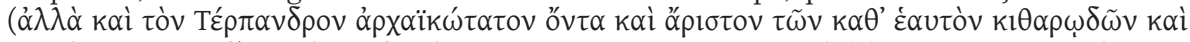

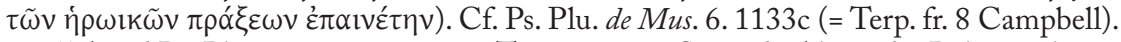

${ }^{14}$ Apud Ps. Plu. de Mus. 3. 1132c = Terp. test. 18. Segundo Alexandre Poliistor, historiador do séc. I, Terpandro 'procurou igualar os versos épicos de Homero e o canto lírico de Orfeu'

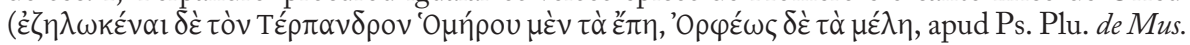
5. $1132 \mathrm{f}=$ Terp. test. 21). Para uma discussão dos testemunhos sobre a posição de Terpandro entre os aedos homéricos e a tradição dos citaredos, vide Lasserre 1954: 25-28, 153-155; West 1971: 307-309; Gostoli 1990: XXXIII-XXXVII, 91-92. Como veremos mais adiante, West integra Estesícoro na tradição dos citaredos, o que é discutível.

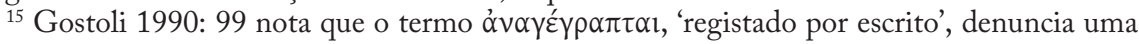
fonte epigráfica, que não é fácil de identificar.

${ }^{16}$ Helânico (FGrHist 4 F 85-86) e Sosíbio (FGrHist 595 F 3) são mencionados em Athen. 14. $635 \mathrm{e}-\mathrm{f}$ (= Terp. test. 2$)$. 
A Suda transmitiu-nos duas versões ligeiramente diferentes sobre as circunstâncias que motivaram a deslocação de Terpandro para o Peloponeso. Em ambas, são os Espartanos que, na iminência de uma guerra civil, vão buscar o poeta à sua terra natal e a harmonia e calma que inspirou nos cidadãos fizeram cessar os conflitos ${ }^{17}$. Mas outros poetas foram convidados a trabalhar em Esparta. A tradição preservou uma história semelhante a propósito de Taletas de Gortina, citada no De Musica e por Pausânias, segundo a qual o poeta chegara a Esparta de acordo com um oráculo e libertara a cidade de uma praga ${ }^{18}$. Por sua vez, Plutarco afirma em Vida de Licurgo que era aparentemente um poeta lírico, mas, na realidade, usava a sua

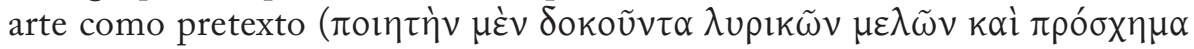

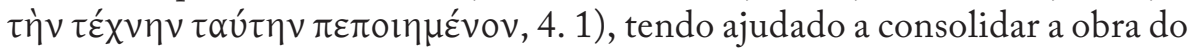
legislador. Licurgo tê-lo-ia convencido a viver em Esparta, dada a reputação de sabedoria e habilidade política que era reconhecida aos cretenses. As obras de Taletas teriam exercido uma influência notável no comportamento dos cidadãos, já que eram compostas em melodias e ritmos marcados pela ordem e tranquilidade, e exortavam à obediência e à harmonia (4. 2-3 = test. 6$)^{19}$.

Se a tradição sublinhou também o seu papel de guia político e social dos cidadãos espartanos, que faz de Taletas de Gortina (e de Terpandro) o poeta-demiurgo evocado por Eumeu no Canto XVII da Odisseia, pelo menos um testemunho associa o seu nome à vida artística de Esparta ${ }^{20}$ :

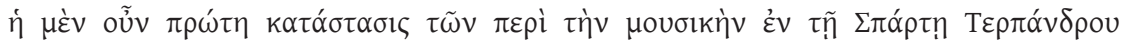

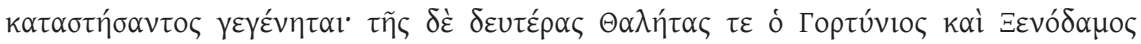

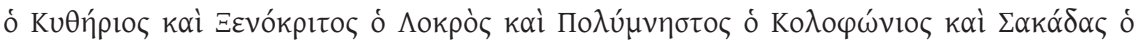

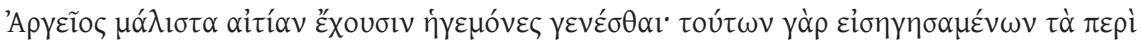

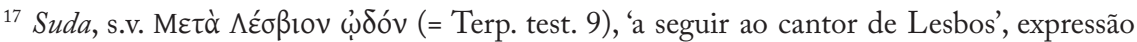
proverbial que se aplicava a alguém que ocupava um segundo lugar, porque os citaredos de Lesbos tinham sido os primeiros convidados dos Espartanos. Sobre esta tradição, cf. Lasserre 1954: 157, Campbell 1988: 301, Gostoli 1990: XIII-XIV.

${ }^{18}$ Ps. Plu. de Mus. 42. 1146b (= Thalet. test. 4), Paus. 1. 14. 4 (= Thalet. test. 5). A tradição deveria ser conhecida na Época Clássica, pois, como nota Campbell 1988: 267, a fonte do Pseudo-Plutarco é o poeta trágico Pratinas, cuja morte é anterior a 467.

${ }^{19}$ Campbell 1988: 325 cita outras fontes e observa que Aristóteles (Pol. 1274a26 sqq.) rejeitou a história por razões cronológicas. As notícias sobre o papel social dos poetas são frequentes na tradição biográfica. A Suda informa que Estesícoro tinha um irmão perito em

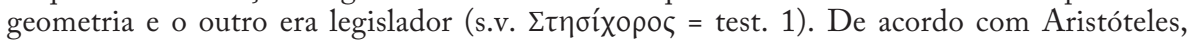
o próprio poeta interveio na política de Hímera $(R h .2 .20 .1393 \mathrm{~b}=$ test. 16$)$ e existia uma história sobre o poder pacificador da sua poesia (cf. Filodemo, Mus. 1. 30.31 sqq. = test. 18). A tradição pseudo-biográfica preservou notícias do mesmo género sobre Simónides (vide infra, p. 167).

${ }^{20}$ Ps. Plu. de Mus. 9. 1134b-c = Terp. test. 11, Thalet. test. 7. Para um comentário a este testemunho, vide D'Alfonso 1994: 81-88. 


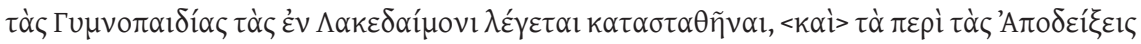

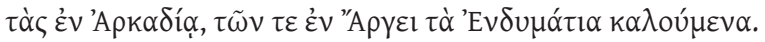

Pois, com efeito, a primeira das instituições musicais em Esparta deveu-se a Terpandro. A responsabilidade da segunda coube, como principais promotores, a Taletas de Gortina, a Xenodamo de Citera, a Xenócrito de Locros, a Polimnesto de Cólofon e a Sácadas de Argos. De facto, diz-se que foi sob a sua proposta que as Gimnopédias foram instituídas na Lacedemónia, as Apodeixeis na Arcádia e em Argos as chamadas Endymatia.

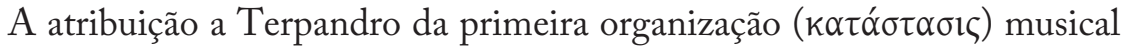
de Esparta tem sido interpretada como indicação de que o poeta de Lesbos teria tido um papel determinante nas Carneias ${ }^{21} \mathrm{e}$, embora este excerto suscite dúvidas de natureza cronológica, notadas por Campbell 1988: 324-325, indicia que no séc. VII e ainda no VI (Sácadas) o florescimento da cultura musical em Esparta, e noutras partes do Peloponeso, era fruto da actuação de poetas vindos de fora, sobre os quais hoje pouco sabemos. Recorde-se que Plutarco afirmou (vide supra) que Taletas era, formalmente, um poeta lírico e outros testemunhos reconhecem nele um cultor de lírica coral. Estrabão, baseado em Éforo, historiador do séc. IV, confirma que os Espartanos lhe atribuíam os seus

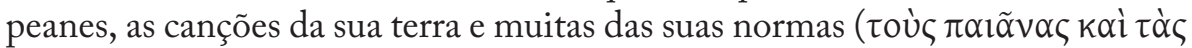

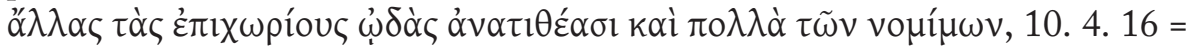
test. 9). O De Musica observa que se duvidava da composição de peanes, mas

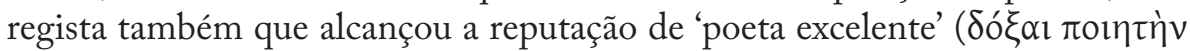
$\alpha \hat{\alpha} \gamma \alpha \theta$ òv $\gamma \varepsilon \gamma o v \varepsilon ́ v \alpha l$ ), porque, segundo afirmara um autor de finais do séc. $V$, Glauco de Régio, no seu tratado Sobre os poetas antigos, Taletas havia imitado

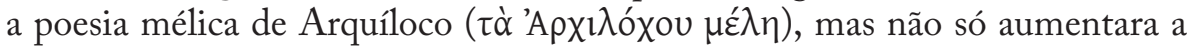
sua extensão, como lhe introduzira os ritmos peónicos e créticos, a partir da música para aulos do mítico Olimpo (10.1134d-e = test. 8).

${ }^{21}$ As Carneias eram o principal festival dórico (cf. Hdt. 6. 106. 3, 7. 206. 1). Em Esparta realizavam-se anualmente no fim do Verão e duravam nove dias. O culto incluía a prova dos

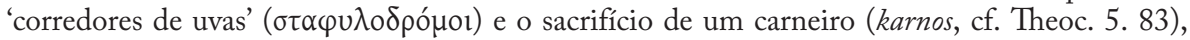
no qual pode ter tido origem a designação do festival. Segundo Demétrio de Cépsis, citado por Ateneu (4. 141e-f), em Esparta esta festa consistia 'numa imitação do modo de vida militar', o que era cumprido pelos participantes adultos através da partilha de uma refeição ritual. Sendo uma festa religiosa de natureza agrícola e de expiação, celebrada em honra de Apollo Karneios e provavelmente muito antiga, como pensam os estudiosos, a data de 676 indicada por Sosíbio (vide supra) e pela Crónica de Eusébio não deve dizer respeito à sua instituição, mas antes a uma reforma, marcada provavelmente pela valorização da componente poética. Supõe-se que Terpandro terá tido um papel decisivo nesta fase, que transformou o culto espartano num grande agon musical (cf. Burkert 1995 [1977]: 451, Gostoli 1990: XIV e 92). Como observa o grande especialista de religião grega (ibidem), do ambiente festivo faziam parte sobretudo as danças dos rapazes e das raparigas (cf. Call. Ap. 30-31, 71-87). Para um estudo dos diversos aspectos do festival, vide em especial Burkert 1995 [1977]: 450-455, Hooker 1980: 58-60, Pettersson 1992: 57-72 (testimonia pp. 134-137). 
De origem cretense, os ritmos peónico e crético, mais ligeiros, eram particularmente adequados ao hiporquema, observa Campbell 1988: 327. Ora, de acordo com um escólio de Píndaro ${ }^{22}$, Taletas foi o primeiro compositor desta canção coral que é acompanhada de dança e pantomima (cf. Mathiesen 1999: 88-94). Não chegou até nós, no entanto, nenhum fragmento que confirme este testemunho. Segundo Sosíbio, citado por Ateneu (15.678c = test. 11), as suas canções (ợ $\sigma \mu \alpha \tau \alpha)$ e as de Álcman, bem como os peanes de Dionisódoto de Esparta, eram cantados por coros nas Gimnopédias, o que não deixa de ser possível, já que o excerto acima transcrito relaciona o poeta com a fundação do festival ${ }^{23}$. Parece-nos, por isso, relevante o comentário de Pettersson 1992: 53-54, segundo o qual o testemunho de Ateneu indica que os cultos religiosos permitiram a preservação de um legado cultural transmitido de geração em geração, do qual faziam parte também as obras dos poetas do séc. VII.

As informações sobre Xenodamo de Citera, Xenócrito de Locros e Polimnesto de Cólofon, que devem pertencer ainda ao séc. VII, são mais escassas. Para os dois primeiros dependemos inteiramente do De Musica, no

${ }^{22}$ Schol. Pind. Pyth. 2.127 = Thalet. test. 10.

${ }^{23}$ Estabelecidas tradicionalmente em 668 (Euseb. Chron. O1. 28. 1), ao que parece na sequência da derrota infligida em Hísias pelo exército argivo no ano anterior (cf. Andrewes 1956: 40, Hooker 1980: 60, Campbell 1988: 325), este festival celebrado em honra de Apolo tinha uma forte componente militar e educacional. Talvez seja significativo que o De Musica associe a sua fundação ao nome de Taletas de Gortina, que a tradição retratava como um orientador da vida política e social de Esparta (cf. Plu. Lyc. 4. 2-3 = Thalet. test. 6, supra). Segundo um passo das Leis de Platão (1. 633c), o programa das Gimnopédias incluía exercícios de resistência física, cumpridos sob grande calor. Os escólios especificam que implicavam lutar e jogar à bola

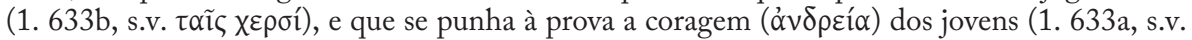

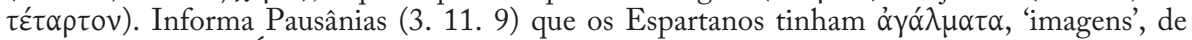
Apollo Pythaeus, de Ártemis e de Leto na ágora, espaço a que davam o nome de xopóc, 'o lugar da dança', por ser ali que durante as Gimnopédias os efebos executavam as danças (xopoí) em honra de Apolo. A competição de coros é atestada por Plutarco (Ages. 29. 2-3), além de

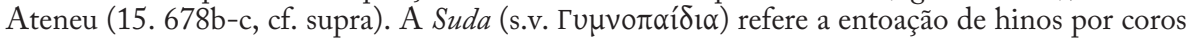

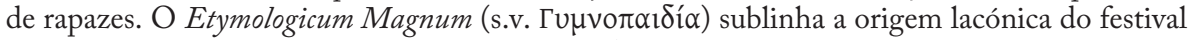
e especifica que rapazes nus cantavam peanes a Apolo. No entender de Pettersson 1992: 42, a

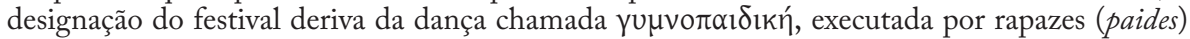
nus, que na sua opinião formaria o núcleo do culto. O mesmo helenista supõe (p. 43), com

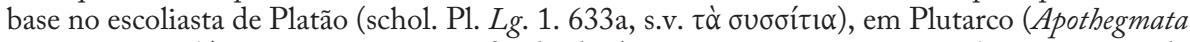
Laconica 238a-b) e no passo acima referido de Ateneu, que competiam também um coro de homens (andres) e, possivelmente, outro de anciãos (gerontes). É provável que as Gimnopédias tenham também evoluído para um festival organizado, à semelhança do que aconteceu com as Carneias, pois pelo menos três dos testemunhos acima citados (Ateneu, Suda e Etymologicum Magnum) observam que a execução coral tinha como objectivo honrar a memória dos que haviam tombado na disputa pela região de Tírea, que confinava com Argos (cf. Hdt. 1. 82), que os estudiosos situam na segunda metade do séc. VI. Sobre as Gimnopédias, vide H. T. Wade-Gery, "A Note on the Origin of the Spartan Gymnopaidiai", CQ 43 (1949) 79-81; A. J. Podlecki, "Poetry and Society in Archaic Sparta", in Harmatta 1984: 175-182; Pettersson 1992: 42-56 (testimonia pp. 132-134). 
qual se afirma que os seus discípulos haviam composto peanes (9.1134c), o que não significa, no entanto, que os mestres tenham cultivado esta forma poética. De facto, o mesmo tratado observa nas linhas seguintes que Xenodamo poderia ter composto hiporquemas em vez de peanes, e que Xenócrito criou peças inspiradas em temas heróicos com acção, o que alguns entendiam ser antes ditirambos (9.1134c, 10. 1134e). Por conseguinte, deduz-se destas notícias que cultivaram sobretudo composições líricas destinadas a serem executadas por coros.

Parece ter sido mais célebre Polimnesto de Cólofon, dado que foi recordado por Álcman (fr. 145 P) e Píndaro, como regista o De Musica (5. $1133 \mathrm{~b}=$ test. 2). De facto, num fragmento de dois versos citado por Estrabão (14. 1. 28 = test. 7), o lírico de Tebas menciona o 'canto que todos conhecem' do 'homem de Cólofon' (fr. 188 Ma.). Nada sabemos sobre esta

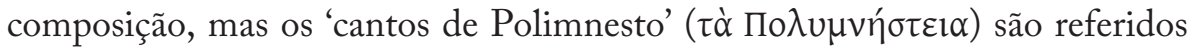
num fragmento de Cratino (fr. $338 \mathrm{~K}-\mathrm{A}$ = test. 8) e no De Musica, a propósito da enumeração dos nomoi aulódicos $(4.1132 \mathrm{~d}$ = test. 5), que teria também composto (cf. $10.1134 \mathrm{~d}$ = test. 4). O mesmo tratado regista que, de acordo com Heraclides Pôntico, o poeta cultivara o hexâmetro e o dístico elegíaco

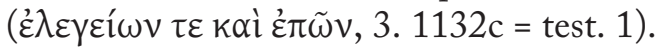

A origem distinta dos poetas agora tratados confirma que Esparta se afirmou nesta época como um centro cultural privilegiado e com condições para acolher e atrair poetas de diversas partes do mundo grego, da Ásia Menor (Cólofon), das ilhas (Lesbos, Citera, Creta), do próprio continente (Argos) e até da Magna Grécia (Locros) ${ }^{24}$. O excerto acima citado do De Musica mostra também que o espaço de mobilidade dos poetas arcaicos podia ser vasto, pois além de terem participado na segunda organização musical de Esparta, que diz respeito às Gimnopédias, foram também responsáveis pela instituição

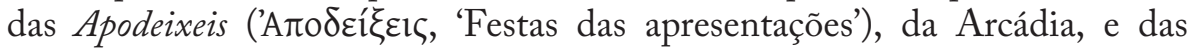

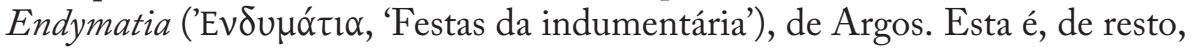
a única referência conhecida aos dois festivais. Como observa Herington 1985: 163, tendo em conta a cronologia dos poetas que com eles são associados, podem ter sido fundados no séc. VII ${ }^{25}$. Uma vez que se trata de um testemunho isolado, há alguma probabilidade de conter informações fantasiosas. Em nosso

${ }^{24}$ O Ps. Plu. de Mus. 10.1134e explicita que Xenócrito era oriundo de Locros da Itália.

${ }^{25}$ Com base no testemunho de Políbio, segundo o qual na Arcádia a aprendizagem da música era obrigatória até aos trinta anos (4. 20. 4-9), conjecturou-se que as Apodeixeis correspondiam à cerimónia anual na qual os coros de jovens se apresentavam aos seus concidadãos (cf. 4. 20. 9-12). Cf. K. Latte, De saltationibus Graecorum (Gießen 1913) 77 e H. Jeanmaire, Couroi et Courètes (Lille 1939) 441. Em relação ao festival de Argos, que tinha um culto importante dedicado a Hera, Webster 1970: 67 deduz a partir da sua designação que, presumivelmente, incluía como rito o vestir da estátua da deusa. 
entender, porém, atesta, pelo menos, a solidez da tradição sobre a mobilidade dos poetas da Época Arcaica.

Álcman representa aos olhos da crítica moderna o culminar do esplendor artístico e cultural que desde o princípio do séc. VII irradia de Esparta (cf. Rocha Pereira 2006: 214). Os Gregos da Época Clássica, no entanto, tiveram dificuldade em aceitar que um poeta tão notável pudesse ter tido como berço a capital da Lacónia. A questão da sua naturalidade - lídia ou espartana é matéria controversa desde a Antiguidade ${ }^{26}$, e pouco pertinente no âmbito deste estudo, uma vez que, ao que parece, o poeta viveu e trabalhou sempre em Esparta, em meados ou, com mais probabilidade, na segunda metade do séc. VII (cf. Campbell 1988: 268, Robbins 1997: 224), e aí foi sepultado (cf. Paus. 3. 15. 2 = test. 14). De facto, a mobilidade não parece ter feito parte da carreira deste homem que se notabilizou na composição de partheneia, em princípio executados em festivais espartanos, conforme sugerem os fragmentos preservados. O ‘Grande Partenéion’ do Louvre (fr. $1 \mathrm{P}$ ), no qual já se vislumbra a presença dos elementos principais da ode, as referências pessoais, o mito e as sentenças, pertence a um poema executado possivelmente no festival de Ártemis Órtia por um coro (ou coros) de donzelas ${ }^{27}$. O fr. $3 \mathrm{P}$, transmitido pelo $P$. Oxy. 2387, contém pedaços de um partheneion que teria, pelo menos, 126 versos e pode ter sido apresentado num festival em honra de Hera (cf. Campbell 1988: 379). De acordo com o escoliasta de Teócrito (5. 83, p. 170 sq. Wendel = fr. $52 \mathrm{P})$, Álcman falava do festival das Carneias nos seus versos.

\footnotetext{
${ }^{26}$ Para a polémica contribuiu certamente Aristóteles, que interpretou a referência ao homem de Sardes do fr. $16 \mathrm{P}$ como dizendo respeito ao próprio poeta. A dúvida sobre a sua naturalidade é evocada num epigrama da Antologia Palatina (7. 18. 5-6 = test. 4), atribuído a Antípatro de Tessalonica (finais do séc. I). O comentário preservado no P. Oxy. 2389, datado de 50-100 d.C., parece defender a naturalidade espartana (cf. fr. 9, col. 1.5 sq. = fr. 13 (a) P, test. 8). Para os estudiosos modernos a dificuldade reside na fragmentação da obra, que não permite esclarecer se as referências aparentemente autobiográficas dizem, de facto, respeito ao poeta. No comentário ao v. 3 do fr. 39 P, que contém a sphragis ('assinatura') e, ao mesmo tempo, a identificação do poeta com o compositor da música, Campbell 1988: 425 nota que a referência à $\kappa \alpha \kappa \kappa \alpha ß i ́ s$, à perdiz-chucar (Alectoris chukar), que se encontrava na Ásia Menor e nas ilhas do Egeu oriental, mas não no Ocidente, é para alguns estudiosos uma prova de que o poeta cresceu na Lídia e não em Esparta (cf. W. G. Arnott, "Some Peripatetic Birds: Treecreepers, Partridges, Woodpeckers", CQ 27, 1977, 336-337 e n. 1). Todavia, tal argumento não é seguro, dado que a menção de seres ou lugares exóticos não depende necessariamente do seu conhecimento directo. Além disso, a crer num testemunho de Élio Aristides (Or. 28. 54 = fr. 148 P), Álcman gostava de mencionar nos seus versos nomes de povos pouco conhecidos, o que confundiu os estudiosos na Antiguidade. Sobre a questão da naturalidade do poeta, cf. Lefkowitz 1981: 34-35. Para a distinção entre a perdiz-grega (Alectoris graeca) e a kakkabis, vide Thompson 1936: 129, 234238; Svensson \& Grant 2003: 108-109.

${ }^{27}$ Cf. Rocha Pereira 2006: 215; E. Robbins, “Alcman's Partheneion: Legend and Choral Ceremony", CQ 44.1 (1994) 7-16.
} 
Recorde-se ainda que segundo Ateneu (vide supra) as canções (ợ $\sigma \mu \alpha \tau \alpha)$ de Álcman eram cantadas por coros masculinos nas Gimnopédias.

Corinto é o berço de Eumelo, um dos primeiros cultores de lírica coral, que desenvolveu a sua actividade, presumivelmente, no segundo quartel ou meados do séc. VIII. Com esta cidade se relaciona Aríon de Metimna (Lesbos), sobre cuja identidade pesa uma nuvem de mistério. Não sabemos se foi, de facto, uma figura histórica, mas tornou-se célebre na tradição greco-latina, provavelmente não tanto pelo seu talento artístico, que não podemos agora avaliar, mas por ter sido objecto de um salvamento prodigioso protagonizado por um golfinho (vide infra), que Heródoto relatou nas suas Histórias (1. 23-24 = test. 3) ${ }^{28}$. Com esta versão da lenda, que situa Aríon no tempo de Periandro, tirano de Corinto entre c. 625 e 585 e seu patrono, coincide a datação indicada na Suda, que coloca o floruit do poeta na $38^{\text {a }}$ Olimpíada $(=628 / 624)^{29}$. Isto significa que foi contemporâneo (e conterrâneo) de Safo e Alceu, e também de Estesícoro.

A notícia deste léxico sobre Aríon centra-se na sua carreira poética. Apresenta-o como 'lírico', e o nome do pai, Cicleu, confirma que a tradição o associava à instituição dos coros circulares do ditirambo ${ }^{30}$. A informação de que para alguns fora discípulo de Álcman pode querer dizer que visitara o Peloponeso e corrobora a possibilidade de ter sido um cultor de lírica coral ${ }^{31}$. De facto, logo a seguir diz-se que compôs ợ $\sigma \mu \alpha \tau \alpha$, 'canções', termo que pode aplicar-se a composições executadas por um coro (vide supra). Alguns estudiosos, designadamente Campbell 1988: 17, consideram que a palavra se

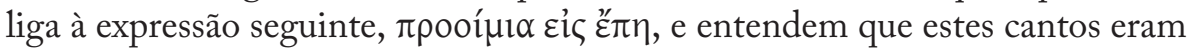
proémios que antecediam a execução de um poema épico.

${ }^{28}$ Aríon foi retratado nas moedas de Metimna e segundo Heródoto (1. 24. 8) existia uma estátua em bronze do poeta no Ténaro (referida por Pausânias: 3. 25. 7), o promontório mais meridional do Peloponeso (hoje cabo Matapan), que representava um homem sobre o dorso de um golfinho. Estes testemunhos arqueológicos não atestam a historicidade do poeta, pois tanto a sua naturalidade quanto o salvamento pelo golfinho são os aspectos mais referidos nos testemunhos e poderão ter sido os topoi mais estáveis da sua lenda. Para a iconografia do poeta, vide Richter 1984: 92, 94; Herbert A. Cahn, LIMC II. 1, s.v. Arion (München 1984) 602-603, II. 2: 434-435. Não chegou até nós nenhum fragmento da sua poesia e a composição que lhe é atribuída por Eliano (NA 12. 45) é considerada espúria pelos especialistas. Para uma análise deste poema, vide o nosso artigo "O canto de Aríon de Metimna (fr. adesp. 939 PMG)", Boletim de Estudos Clássicos 49 (Junho de 2008) 21-25.

${ }^{29}$ Suda, s.v. 'Apí $\omega v$ = test. 1 . A Crónica de Eusébio (Ol. 40. 2 = test. 2), porém, indica uma cronologia que se aproxima mais do final do séc. VII: o segundo ano da 40a Olimpíada (= 619/618 ou 610/609, segundo a versão arménia da Crónica).

${ }^{30}$ Outro exemplo da relação entre a actividade coral do poeta e o seu nome encontra-se em

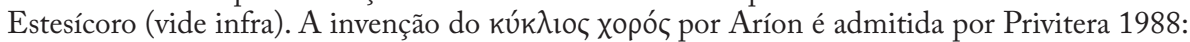
129 e Zimmermann 1992: 25, mas contestada por D’Angour 1997 (vide infra, nn. 35 e 92).

${ }^{31}$ Como observa Ieranò 1997: 190, dado que Helânico de Lesbos mencionava Aríon na sua Lista das vitórias em Carneias (FGrHist 4 F 86), é plausível que tenha participado neste festival. 
A parte final deste testemunho sublinha as inovações de Aríon, retratando-o como um predecessor dos poetas trágicos e um pioneiro no campo da poesia ditirâmbica. É neste sentido que se deve entender a afirmação 'foi o primeiro

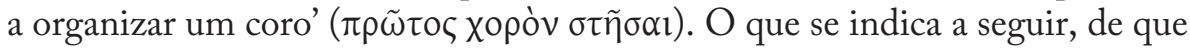
foi o primeiro 'a cantar um ditirambo e a dar um título ao que o coro canta'

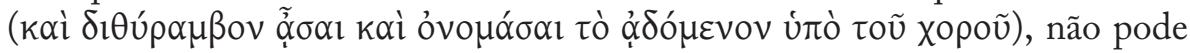
ser entendido à letra, pois esta forma coral é mencionada por Arquíloco, que viveu na primeira metade do séc. VII (fr. $120 \mathrm{~W}$ ):

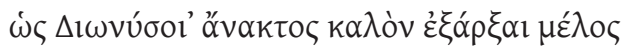

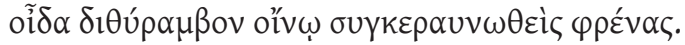

Sei entoar a bela melodia do príncipe Diónisos, o ditirambo, quando o vinho deflagrou como o raio no meu espírito ${ }^{32}$.

No entanto, a Suda não é o único testemunho a conceder a Aríon um lugar de destaque na história do ditirambo. O seu contributo original pode ter sido a transformação do canto ritual em honra de Diónisos numa composição artística, executada formalmente no âmbito de festas públicas por um coro instruído pelo poeta. Esta hipótese encontra apoio no escólio ao v. 1403 das

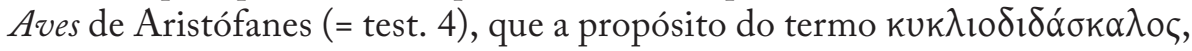
'instrutor de coros circulares', esclarece que o comediógrafo o usou por

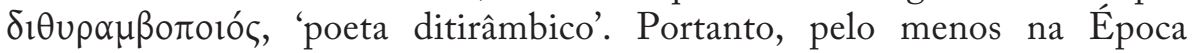
Clássica era sabido que cabia ao poeta a tarefa de treinar o coro ditirâmbico. O mesmo escólio cita a opinião de quatro autoridades sobre a instituição 'dos

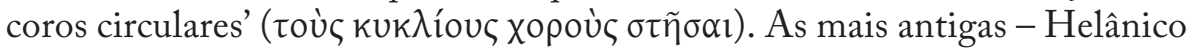
de Lesbos, na sua Lista das vitórias em Carneias, e Dicearco, gramático peripatético de finais do séc. IV, no seu tratado Sobre os concursos dionisiacos, - afirmavam que havia sido Aríon. Antípatro, um autor desconhecido, e o gramático alexandrino Eufrónio atribuíram o feito a Laso de Hermíone (vide infra). Mas é provável que a tradição sobre o poeta de Metimna fosse mais antiga. De facto, os vv. 17-19 da XIII ${ }^{a}$ Olímpica de Píndaro, embora não o mencionem, situam o nascimento do ditirambo em Corinto e sublinham a relação com o culto de Diónisos. À vertente coral de Aríon alude também Heródoto na sua apresentação: 'um citaredo não inferior a qualquer outro da sua época, o primeiro dos homens, de que temos conhecimento, a compor ditirambos, a dar-lhe esse nome ${ }^{33}$ e a fazê-los executar em Corinto' (1. 23.

32 Tradução de M. H. Rocha Pereira (2009: 125). Para a interpretação do fragmento e da relação de Arquíloco com a religião dionisíaca, vide Privitera 1957: 95-101, 1988: 123-126; Zimmermann 1992: 19-23.

${ }^{33}$ Uma vez que a designação 'ditirambo' já existia, Zimmermann entende que o particípio 
$1)^{34}$. Note-se que o historiador afirma citar uma lenda contada por Coríntios, com a qual concordavam os habitantes de Lesbos (cf. 1. 23. 1 e 1.24. 8), o que indicia a existência de uma tradição sólida, oral por certo, e conhecida já na Época Clássica sobre a aventura de Aríon e o golfinho. Mas estes testemunhos mostram que era igualmente consistente a tradição que lhe atribuía um papel decisivo na evolução do ditirambo ${ }^{35}$ e, a ser autêntica, a execução desta forma coral teria sido introduzida em Corinto um século antes de aparecer em Atenas, novidade que Periandro pode ter incentivado (cf. Podlecki 1980: 371-373, Zimmermann 1992: 24-29).

O relato de Heródoto centra-se no episódio do salvamento prodigioso ${ }^{36}$ e, ainda que não forneça muitos pormenores, permite recriar um momento (porque é de um momento que se trata) da carreira de um artista na transição do séc. VII para o séc. VI:

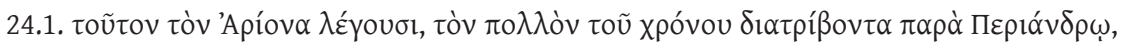

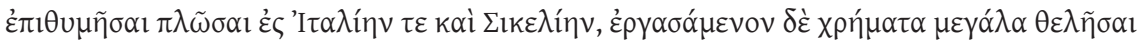

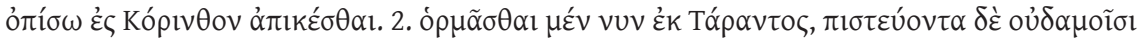

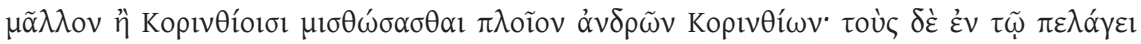

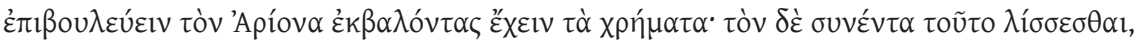

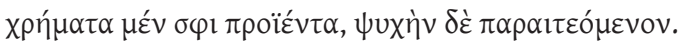

24. 1. Este Aríon, que viveu a maior parte do tempo junto de Periandro, contam eles, foi tomado do desejo de navegar para a Itália e para a Sicília e, depois de ganhar muito dinheiro, quis voltar de novo a Corinto. 2. Partiu então de Tarento e, como não confiava em mais ninguém senão nos Coríntios, contratou um barco de marinheiros Coríntios. Estes, no alto mar, maquinaram lançar Aríon pela borda, para se apoderarem das riquezas. Ao ter conhecimento disso, ele implorou-lhes piedade: entregava as riquezas, mas pedia a vida.

Embora a existência histórica de Aríon não seja segura, como dissemos, é o primeiro poeta a ser associado à protecção de um tirano, realidade que se tornará frequente a partir do séc. VI e caracteriza em particular a actuação dos

óvoứ $\sigma \alpha \nu \tau \alpha$ pode significar a aplicação de um nome tradicional a um novo tipo de poesia (cf. 1992: 24-25 e 2002: 152). Segundo outras interpretações, 'dar-lhe um nome' significa dar um título, ideia que está mais explícita na notícia da Suda (vide supra). É provável, como julga Giorgio Ieranò, “Arione e Corinto", QUCC 41.2 (1992) 40, que nos seus ditirambos Aríon tratasse uma determinada saga mítica, como farão mais tarde Simónides (cf. fr. 539, infra p. 133), Píndaro e Baquílides.

${ }^{34}$ Neste e nos excertos seguintes relativos a Aríon citamos a tradução de José Ribeiro Ferreira, in Rocha Pereira et alii 1994.

${ }_{35}$ Para uma discussão da génese da lenda de Aríon inventor do ditirambo, vide o artigo acima citado de G. Ieranò. Especificamente sobre o seu papel na evolução desta forma poética, vide Privitera 1957: 101-110, 1988: 126-129; Ieranò 1997: 187-194.

${ }_{36}$ Para uma análise do conteúdo filosófico-didáctico do logos de Aríon, com apreciação crítica da bibliografia, vide Soares 2003: 96-101. 
cultores de lírica coral, que conciliam a mobilidade que o ofício lhes exige com a permanência temporária na corte de um dirigente.

Corinto era uma das cidades mais ricas da Grécia, situada num lugar de passagem, com bons acessos, pelo que devia proporcionar boas oportunidades aos artistas e poetas gregos. É, por isso, natural que também tenha aqui surgido um festival pan-helénico, reorganizado em c. 581, que viria a incluir concursos musicais ${ }^{37}$. Mas o relato de Heródoto indicia também que no final do séc. VII a Magna Grécia era um destino atraente. Xenócrito de Locros é um dos primeiros poetas conhecidos a deixar a sua terra e a deslocar-se para o Peloponeso, mas é natural que o movimento contrário também se verificasse e o berço de Estesícoro e de Íbico afirma-se, principalmente a partir da segunda metade do séc. VII, um centro de cultura cada vez mais importante. Talvez não tenha sido por acaso que Safo viveu o seu exílio político nesta região do mundo grego ${ }^{38}$.

O episódio de Aríon é também um testemunho das condições arriscadas em que se viajava no mundo antigo, e não apenas na Época Arcaica. Para um poeta que havia sido bem sucedido na sua actuação internacional, êxito que se traduziu em muito dinheiro - indício da profissionalização do poeta ou simples indicação da natureza dos prémios - regressar a casa com a recompensa podia ser uma perigosa aventura. Facilmente se caía nas garras de criminosos, bandidos de estradas, piratas ou simples marinheiros desonestos ${ }^{39}$. Esta história tem um desfecho feliz e, não obstante as numerosas ocorrências do motivo do golfinho na tradição clássica, talvez seja uma das mais conhecidas ${ }^{40}$.

${ }^{37}$ Cf. K. Schneider, RE 9 (1916) col. 2248-2255, s.v. Isthmia, esp. col. 2252 (provas musicais:

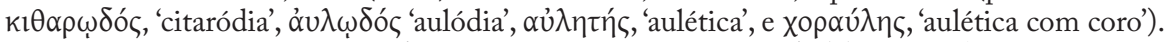

${ }^{38}$ Cf. Marm. Par. Ep. 36 (=603/2-596/5, Sapph. test. 5). Também Alceu conheceu o desterro, por diversas vezes, e evocou nos seus poemas esses momentos difíceis (e.g. frr. 129, 130 L-P). Cf. Andrewes 1956: 92-99 para os aspectos históricos e políticos das tiranias de Mitilene.

${ }^{39}$ Saliente-se que Heródoto não explica como Aríon se deslocou do Ténaro, onde é deixado pelo golfinho, até ao palácio de Periandro em Corinto (cf. 1. 24. 6-7). Sobre este momento da lenda, cf. Plu. Sept. sap. conv. 18. 160e-19. 162b, que preserva uma versão diferente da de Heródoto.

${ }^{40} \mathrm{~A}$ admiração dos povos do Mediterrâneo pelos golfinhos é muito antiga, como atesta o belo fresco do palácio de Cnossos. Um fragmento de Píndaro refere a excitação dos golfinhos ao ouvirem o som do aulos (cf. fr. 140b. 15-17 Ma.). No Hino Homérico a Diónisos (VII), o deus é raptado por piratas tirrenos, mas estes assustam-se com os seus prodígios, atiram-se ao mar e são transformados em golfinhos (v. 53). 'Diónisos no barco rodeado de golfinhos' é o tema da taça ática de figuras negras pintada por Exéquias (Munique, Staatliche Antikensammlungen 2044, c. 530), que pode ser uma alusão ou ter inspirado este mito (cf. West 2003b: 16-17). Plínio, o Antigo, na secção dedicada a estes mamíferos na sua Naturalis Historia evoca diversas lendas da tradição greco-latina que põem em evidência o comportamento amistoso destes animais, em especial para com as crianças (9. 20-33, cf. Gel. 6. 8). No diálogo acima citado de Plutarco (Sept. sap. conv. 19. 162c-20.163d), são evocadas duas histórias que demonstram a gentileza dos golfinhos para com os mortos (neste caso, Hesíodo) e para com os vivos (o 
Ao evocar o papel pioneiro de Aríon na organização de coros ditirâmbicos Heródoto pretendia sublinhar a sua versatilidade poética. No entanto, o seu relato evidencia em particular a habilidade na execução da cítara:

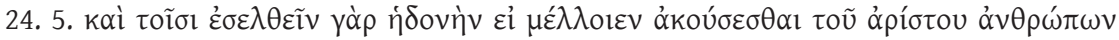

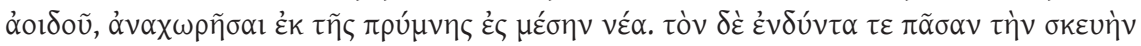

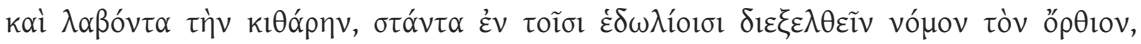

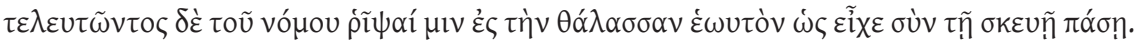

24. 5. Encantou-os a ideia de poderem ouvir o melhor cantor entre os homens e retiraram-se da popa para o centro do barco. Aríon pôs todos os seus enfeites, pegou da cítara e de pé, na coberta, executou o canto órtio. Terminado este, lançou-se ao mar, tal como estava, com todos os enfeites.

Uma interpretação literal deste passo sugere que Aríon conciliava no seu

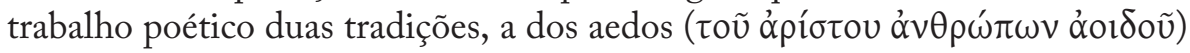

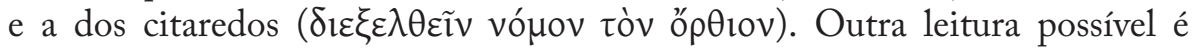
considerar que na época de Heródoto tal distinção já tinha perdido valor. Seja como for, o poeta adia a sua morte com a execução do nomos orthios, uma das melodias mais famosas, cuja invenção era atribuída a Terpandro ${ }^{41}$, e o historiador dá-nos alguns indícios sobre o modo de actuação dos citaredos: de pé, segurando a cítara com as mãos, e envergando uma indumentária elaborada. $\mathrm{Na}$ estrutura da narrativa as vestes de Aríon constituem um elemento de crucial importância, ao permitirem denunciar a Periandro a falsidade do discurso dos piratas (cf. 1. 24. 7). Do ponto de vista documental, este passo confirma que a aparência do citaredo constituía um elemento fundamental da sua actuação, como sugerem também as pinturas de vasos, que denunciam um cuidado com o aspecto físico que parece ter aumentado no decurso do tempo. As representações plásticas mostram figuras sofisticadas, que ostentam trajes com cortes e motivos invulgares, onde se adivinham decorações coloridas e brilhantes ${ }^{42}$. Seria uma forma de captatio benevolentiae, de chamar a atenção

salvamento de Énalo e da sua amada). Em De sollertia animalium, onde apresenta uma outra versão da história de Énalo (cf. 36. 984e), recorda que Estesícoro afirmava num poema (fr. $225 P M G)$ que o escudo de Ulisses ostentava um golfinho. Segundo contavam os cidadãos de Zacintos, este animal tinha salvo o pequeno Telémaco de se afogar (36. 985b). Uma estatueta em bronze arcaica, provavelmente de carácter votivo, proveniente das escavações na Acrópole de Atenas e preservada no Museu Nacional (6626), representa um jovem sobre o dorso de um golfinho.

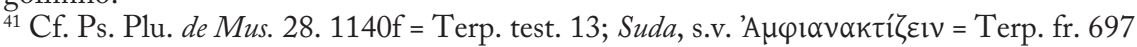
PMG. De acordo com este testemunho, o nomos orthios consistia num hino a Apolo. Cf. A. Gostoli, "Il nomos citarodico nella cultura greca arcaica", in Pretagostini 1993: 167-178.

${ }^{42}$ A ostentação e elegância dos citaredos e de outros artistas é documentada em particular pela cerâmica ática de figuras vermelhas. Cf. a análise que Shapiro 1989: 42-43 dedica à ânfora 
desde o início do espectáculo e de lhe imprimir uma solenidade que o tornaria distinto de um outro qualquer evento musical. Naturalmente apenas os poetas de sucesso teriam meios para assim se apresentarem. A preocupação dos citaredos com a sua aparência era, no entanto, partilhada por outros artistas e homens de letras ${ }^{43}$.

Em conclusão, se alguns poetas optaram por deixar a terra natal e fixar-se em Esparta, onde permanecem a maior parte do tempo, pelo menos num determinado momento da vida Aríon fez da mobilidade uma característica da sua profissão. Os testemunhos analisados sublinham o seu talento de citaredo, mas também o seu contributo para a evolução do ditirambo. Parece-nos um indício claro de que alguns poetas, pelo menos na Época Arcaica, não se dedicavam exclusivamente a um determinado género poético, o que põe em causa a divisão moderna que os distribui por 'lírica monódica' e 'lírica coral'44.

do Pintor de Andócides (Paris, Louvre G 1, c. 525-520) e ao calyx-krater pintado por Eufrónio (Paris, Louvre G 103, c. 515-510). Um dos aspectos mais interessantes da peça do Pintor de Andócides é precisamente o vestuário ornamentado das três figuras humanas, das quais se destaca, ao centro sobre um estrado, o citaredo em plena actuação. $\mathrm{O}$ vaso de Eufrónio ostenta no anverso a luta de Héracles com Anteu e no reverso o início da apresentação de um elegante auleta, provavelmente numa exibição em privado. Mais ornamentadas são as vestes de Prónomo, o famoso auleta do fim do séc. V que é a figura principal de um krater de volutas ático de figuras vermelhas (cf. infra, n. 68). Outro exemplo célebre da representação de um citaredo é a ânfora de figuras vermelhas atribuída ao Pintor de Brygos (Boston, Museum of Fine Arts 26.61, c. 490-470). Sobre este ponto, cf. Herington 1985: 17-18, que reproduz a representação de um elegante citaredo numa ânfora do Pintor de Berlim (Nova Iorque, The Metropolitan Museum of Art 56.171.38, c. 490).

${ }^{43} \mathrm{O}$ cuidado de Íon com o seu aspecto físico é evidente para Sócrates, como vimos no capítulo anterior (P1. Ion 530b, 535d, 541c). Sobre a extravagância dos citaredos é também interessante o testemunho de Luciano (Adversus Indoctum 8-9): Evângelo de Tarento apresentou-se em Delfos resplandecente de ouro e púrpura, e logo suscitou grande expectativa no público. Todavia, quando se ouviu a sua voz fina e desafinada, as gargalhadas do auditório foram tantas que os juízes decidiram expulsá-lo do concurso. Sobre a ostentação dos artistas, em particular no séc. IV, cf. Kemp 1966: 221.

${ }^{44}$ A distinção entre 'poetas monódicos' e 'poetas corais' não se apoia em fontes antigas,

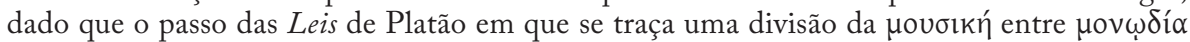
e $\chi 0 \rho \omega \delta$ ía (6. 764d-e) diz respeito apenas à nomeação dos juízes dos concursos musicais (cf. Harvey 1955: 159 n. 3). Esta divisão remonta ao séc. XIX e foi difundida por K. O. Müller, History of the Literature of Ancient Greece (London 1840). Para um exame da questão, vide Pfeiffer 1968: 282-283, Davies 1988, D’Alfonso 1994: 9-11, Cingano 2003: 18-22, esp. Cremos que o estado fragmentário do corpus da poesia grega arcaica, que nos fornece uma perspectiva incompleta e selectiva da obra de cada compositor, reforçou o estabelecimento desta divisão nos manuais, sendo hoje difícil fugir-lhe. Na opinião de Pffeiffer 1968: 283, esta distinção, embora moderna, "may well be used for the purpose of literary history." Davies, que a contestou vigorosamente no seu artigo, escreve: "... there was choral poetry and monodic poetry, but that it is dangerously misleading to talk of choral and monodic poets. Most lyric composers were versatile enough to practise both categories." (p. 61) Surpreende-nos, por isso, a sugestão que classifica de 'final paradox': a ideia de que Estesícoro e Íbico, menos versáteis (?), teriam provavelmente cultivado a lírica monódica. Concordamos, porém, com a afirmação "The use of anachronistic labels in literary history is always problematic." (ibidem). 
Esta questão assume contornos mais complexos quando se evoca o nome de Estesícoro, "o primeiro grande poeta do Ocidente grego", nas palavras de Campbell 1982: 253. Segundo a tradição, nasceu na Magna Grécia, no último quartel do séc. VII e desenvolveu a sua actividade na primeira metade do século seguinte. Foi, portanto, como pensamos, contemporâneo de Aríon, de Safo e de Alceu ${ }^{45}$. É caso para se perguntar se teria havido contactos entre eles, dado que Aríon viajou pela Magna Grécia e Safo viveu aí o seu exílio, mas não há provas concretas.

Os testemunhos associam Estesícoro a diversas cidades da Magna Grécia,

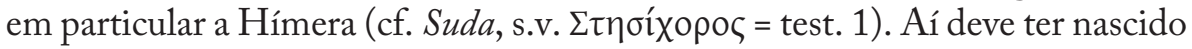
ou, pelo menos, passado alguma parte da sua vida. Estêvão de Bizâncio afirma que era natural de Metauro (s.v. Mó́ $\alpha$ vo convívio com os habitantes de Locros $(R h .2$. 21. 1394b-95a = test. 17) e a povoação de Cátana terá acolhido a sua sepultura (cf. Suda, Phot. Lex. I. $52 \mathrm{Naber}=$ test. $22, A P 7.75$ = test. 24$)$. Se é autêntica a notícia de que foi obrigado a deixar Palâncio, uma povoação da Arcádia (cf. Suda), também viveu no Peloponeso, o que pode ter motivado algumas inovações introduzidas nos seus poemas, como ter situado a história de Orestes em Esparta e não em Micenas (cf. fr. $216 P M G=$ Simon. fr. 549, infra p. 350) ${ }^{46}$.

Este assunto é também discutido pelos estudiosos citados infra, p. 111 n. 42 . Veja-se ainda uma pertinente resenha desta problemática por F. Budelmann, "Introducing Greek lyric", in Budelmann 2009: 11.

45 Simónides mencionava Estesícoro na sua obra (cf. fr. 564. 4) e segundo a Suda (s.v.

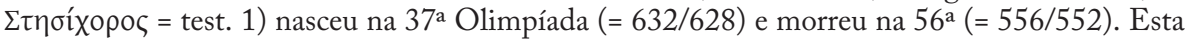
cronologia tem todo o aspecto de ser convencional, dado que situa o nascimento do poeta quarenta anos após o floruit de Álcman indicado por aquele léxico (s.v. 'A $\lambda \kappa \mu \alpha o ́ v=A l c m$. test. 1) e a morte na Olimpíada em que a tradição colocava o nascimento de Simónides (cf. infra, p. 117 n. 12). Esta datação, porém, ajusta-se ao testemunho da Crónica de Eusébio (= test. 3), que situa o floruit de Estesícoro no segundo ano da 42a Olimpíada (=611/610 ou 608/607, indica a versão arménia) e a morte no primeiro da $55^{\text {a }}$ Olimpíada ( $=560 / 559$ ou $558 / 557$, de acordo com a versão arménia), bem como à notícia da Suda sobre Safo $(\Sigma 107=$ Stesich. test. 4), que distinguia Alceu, Estesícoro e Pítaco entre os seus contemporâneos. Segundo escreve Plínio, o Antigo, o lírico de Hímera mencionou na sua obra um eclipse (Nat. 2.54 = fr. $271 P M G)$, que West 1971: 306 calcula ter sido o que ocorreu em 557. Sobre a cronologia de Estesícoro, cf. Campbell 1991: 3-4, Hutchinson 2001: 116.

46 Esta hipótese é admitida por Campbell 1991: 2-3. No artigo publicado em 1934, "Stesichorus in the Peloponnese", CQ 28: 115-119 (= 1961: 109-112), Bowra, no sentido de corroborar a tradição biográfica sobre a mobilidade de Estesícoro, procurou provar que a Palinódia a Helena e a Oresteia foram compostas no Peloponeso. Na sua opinião, a Palinódia permitiu-lhe criar a heroína adequada ao público espartano e a preocupação de agradar a este auditório influenciou igualmente a composição de Oresteia. Para uma opinião divergente, vide Arrighetti 1994: 22-26, esp. Do mesmo modo, Hutchinson 2001: 114 n. 1 considerou problemáticas tais interpretações políticas dos fragmentos mitológicos. Todavia, como veremos no comentário aos poemas de Simónides na terceira parte deste estudo, há indícios de que os poetas adequavam as suas obras às circunstâncias de composição e aos seus destinatários. Cf. M. 
Os títulos que conhecemos das suas composições, a evocação por Simónides, no fr. 564, como uma das autoridades em matéria mitológica, bem como os fragmentos que nos chegaram, em particular os que foram revelados por papiros, explicam por que razão o autor de Do Sublime

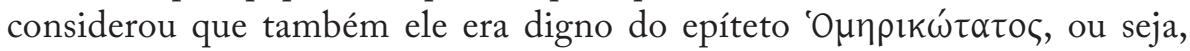
'o mais homérico' (13. 3 = test. 39 ). Embora se tenha perdido grande parte da sua obra, é sabido que compôs poemas muito extensos, dado que a Gerioneida tinha, pelo menos, 1300 versos (cf. P. Oxy. 2617 fr. 7 = fr. $27 S L G$ ) e a Oresteia ocupava dois livros (cf. frr. 213, $214 P M G$ ). Neles tratou temas épicos em ritmo predominantemente dactílico e num estilo elevado, que poderia até ter feito sombra a Homero, se não fosse redundante e prolixo, conforme observou Quintiliano (Inst. 10. 1. 62 = test. 41). Nas palavras da Suda, Estesícoro foi um grande poeta 'lírico', que compôs 'em dialecto dórico' ${ }^{\prime 4}$. A notícia termina com a indicação de que se chamou primeiro Tísias e mudou de nome, 'porque foi o primeiro a montar um coro

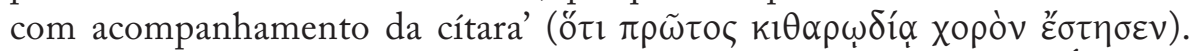
Esta informação não pode estar inteiramente correcta, pois antes já Álcman, referido no mesmo testemunho, havia composto cantos para coros de raparigas. $\mathrm{Na}$ opinião de alguns estudiosos, a notícia não merece por isso nenhum crédito (cf. Hutchinson 2001: 117 n. 5), mas não nos parece que a questão seja tão simples. Wilamowitz 1913: 238 sugeriu a hipótese de se tratar de uma modalidade em que o coro apenas dançava, acompanhando com os seus movimentos o canto a solo do poeta, entoado ao som da cítara, um tipo de espectáculo que tem como modelo o bailado dos jovens feaces à volta de Demódoco, que toca a phorminx (Od. 8. 258-366) ${ }^{48}$.

No entanto, a interpretação mais consensual e resistente vê na notícia da Suda um indício de que os poemas de Estesícoro eram executados por um coro que cantava e dançava. Uma entrada do mesmo léxico sobre as $\tau$ pía $\Sigma \tau \eta$ oxxópou (test. 30) tem sido evocada em abono da teoria. Estas 'três coisas de Estesícoro', que só uma pessoa sem cultura e ignorante poderia desconhecer, explica-se, consistiam em 'estrofe, antístrofe e epodo, pois toda a poesia de

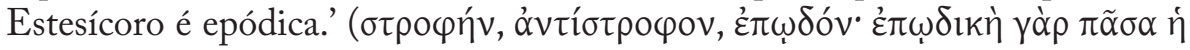

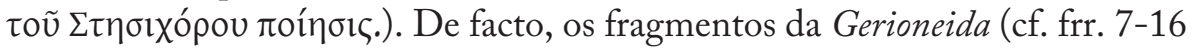

O. Pulquério, "O problema das duas Palinódias de Estesícoro", Humanitas 25-26 (1973-1974) 265-273. Para uma análise das fontes que associam Estesícoro à Itália do sul, a Hímera ou a outros locais, vide West 1971: 302-305.

${ }^{47}$ Cf. West 1971: 304 e n. 2. No exame do dialecto de Estesícoro, Hutchinson 2001: 114-116 salienta que parece ser mais afectado pela linguagem épica que o de Álcman e menos marcado pelas variantes regionais. Sobre o modo como o poeta se relaciona com a épica homérica, vide Burkert 2001: 208-209, Arrighetti 1994, Hutchinson 2001: 117-119.

${ }^{48}$ Para uma crítica à teoria de Wilamowitz, que foi retomada na segunda metade do séc. XX, vide D'Alfonso 1994: 41-50. 
$S L G$ ) e os versos do Papiro de Lille (fr. 222A Campbell) atestam que estes poemas, pelo menos, tinham uma estrutura triádica. $\mathrm{O}$ mesmo não se pode afirmar sobre o 'Grande Partenéion' de Álcman (cf. Hutchinson 2001: 78-

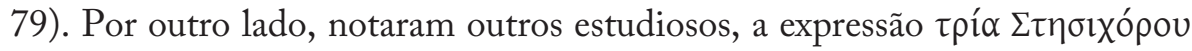

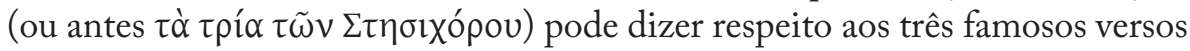
da Palinódia a Helena, citados no Fedro de Platão $(243 \mathrm{a}=\text { fr. } 192 P M G)^{49}$, na qual o poeta se retractava dos insultos que havia proferido contra a rainha de Esparta num poema anterior, uma explicação que nos parece menos convincente. Mas mesmo que Estesícoro tenha sido o inventor da tríade ao acrescentar o epodo, que era típico da sua poesia, de acordo com a notícia da $S u d a$, não é seguro que este modo de composição determine uma execução coral, como foi notado há muito tempo ${ }^{50}$. A tese tomou novo fôlego em 1971 com Martin West, ao defender que o modo de compor de Estesícoro ainda se inscreve na tradição dos citaredos, pois cantava a solo e em público (cf. fr. $212 P M G$ ) os seus próprios poemas (não os de Homero) ao som da cítara, uma arte que não teve continuadores à sua altura e fez dele um clássico no tempo de Simónides (cf. pp. 311, 313-314). Esta hipótese encontra algum apoio nos testemunhos antigos. O De Musica, num passo que parece ter como fonte Heraclides Pôntico, associa Estesícoro aos 'antigos poetas líricos que compuseram versos e lhes acrescentaram a melodia.' ( $\tau \tilde{\omega} v \alpha \dot{\alpha} \rho \chi \alpha i \omega v$ $\mu \varepsilon \lambda$ o 25). Esta descrição corresponde grosso modo ao juízo de Quintiliano já aqui evocado $^{51}$. O mesmo tratado informa que, segundo o crítico do séc. V Glauco

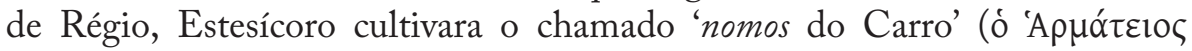
vónos), inventado pelo mítico auleta Olimpo (7. 1133e-f = test. 26), o que para West 1971: 310-311 é um indício de que a música do poeta de Hímera tinha afinidades com a dos auletas sem, no entanto, significar que cantava ao

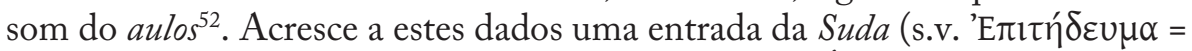
test. 20), que identifica Estesícoro como 'citaredo' e Ésquilo como 'auleta', o que pode ser uma alusão à música do teatro.

${ }^{49}$ Gerber 1994: 62 informa que esta explicação foi apresentada há mais de um século por B. L. Gildersleeve (AJPh 10, 1889, 382). Cf. Campbell 1982: 258 e M. Davies, "The Paroemigraphers on TA TPIA TSN TTH $\Sigma$ IXOPOY”, JHS 102 (1982) 206-210.

${ }^{50}$ A questão remonta a O. Crusius, "Stesichoros und die epodische Composition in der griechischen Lyric”, Commentationes Ribbeckianae (Leipzig 1888) 9-14, que atribuiu à tríade um valor puramente musical, negando que se referisse aos movimentos do coro (apud Cingano 1993: 348 e n. 5). Para uma discussão desta teoria, cf. D’Alfonso 1994: 19-21.

${ }^{51}$ Cf. Inst. 10.1 .62 = test. 41 : et epici carminis onera lyra sustinentem.

${ }^{52}$ Opinião diferente é a de A. Barker, "La musica di Stesicoro", QUCC 67.1 (2001) 7-20. No exame deste testemunho, no sentido de delinear o sistema melódico adoptado por Estesícoro (pp. 11-18), concluiu que se desenvolveu, ainda que de maneira independente, no contexto da música para aulos e não para instrumentos de corda (p. 18). 
M. West refutou a suposição de que o emprego da estrutura triádica significa que o poema se destinava a um coro (cf. 1971: 312-313), bem como a explicação de Wilamowitz para a notícia da $S u d a$, acima referida (ibidem, p. 309). É surpreendente, porém, que um dos argumentos daquele helenista (e dos seus seguidores) seja a extensão dos poemas, dado que sabemos muito pouco sobre as capacidades vocais e coreográficas dos coros da Época Arcaica ${ }^{53}$. Ao inscrever Estesícoro na tradição dos citaredos, West não deu grande valor ao testemunho da Suda sobre o nome do poeta ${ }^{54}$. Julgamos, porém, que merece ser considerado na reconstituição da sua actuação profissional, pois, como escreveu M. H. Rocha Pereira, é um cognome "indicativo da sua profissão: dirigia coros, provavelmente em partes várias do mundo grego." (2006: 216$217)^{55}$. Isto teria sido possível dado o carácter pan-helénico do conteúdo mitológico dos seus poemas, observou W. Burkert no estudo importante que dedicou à recepção da épica homérica no séc. VI (2001: 210). Ao contrário de West, Burkert considera a estrutura triádica um argumento abonatório da produção coral, notando que faz sentido relacionar a sua origem com a dança (p. 209) ${ }^{56}$. Supõe, por conseguinte, que as criações de Estesícoro foram apresentadas nos festivais por coros profissionais que se deslocavam através do mundo grego (cf. pp. 210-211).

Embora não fundamentada (cf. p. 210 n. 54), esta hipótese não nos parece fantasiosa e, supondo que tenha acontecido assim, o estilo de execução de Estesícoro, que dependia de um coro previamente treinado, significava uma ruptura absoluta com a actuação improvisada do aedo (cf. Burkert 2001: 211) e teria impressionado muito mais do que a apresentação a solo de um citaredo. No entanto, como temos vindo a referir, um traço típico dos poetas

${ }^{53} \mathrm{O}$ argumento de que a extensão dos poemas teria constituído uma dificuldade para a capacidade de execução de um coro que cantasse e dançasse ao mesmo tempo remonta aos estudiosos do início do séc. XIX (cf. Cingano 1993: 348 n. 4), mas ganhou nova projecção com as descobertas papirológicas do séc. XX. Para a discussão deste argumento, vide Cingano 1993: 361 e n. 52, D’Alfonso 1994: 51-59.

${ }^{54}$ Limita-se a afirmar, na evocação da teoria de Wilamowitz 1913: 238, "But the chorus there is brought in to explain the poet's name; the significant thing is that when it is brought in, it is combined with citharody." (1971: 309). West viria a admitir a presença do coro num estudo posterior: "It used to be assumed that these works were sung by a chorus, but it now seems altogether likelier that Stesichorus sang them solo, accompanying himself on the kithara. Possibly there was a chorus that danced while he sang." (1992b: 339).

${ }^{55}$ A ideia de que o cognome do artista é um reflexo da profissão de chorodidaskalos remonta, pelo menos, a meados do séc. XIX, a F. G. Welcker, "Stesichoros", in Kleine Schriften I (Bonn

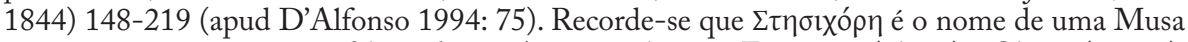
inscrito no Krater François, fabricado em Atenas c. 570 por Ergotimo (oleiro) e Clítias (pintor), hoje preservado no Museu Arqueológico de Florença (4209).

${ }_{56}$ D'Alfonso 1994: 19-40, no capítulo sobre a funcionalidade do esquema triádico, defende que a tríade decorre "de uma realidade de movimento, não só musical mas também físico, de dança” (p. 34). 
arcaicos parece ter sido a sua versatilidade. $\mathrm{O}$ modo vago como Estesícoro é referido nos testemunhos mais antigos sugere alguma incerteza quanto à natureza do seu trabalho ${ }^{57}$ e as divergências dos helenistas no que respeita à execução dos seus poemas apenas se dissiparão com o conhecimento mais amplo da sua obra ${ }^{58}$. No entanto, a tese de um Estesícoro citaredo não nos parece mais defensável que a tradicionalmente aceite. Por conseguinte, apesar da controvérsia, julgamos que se notabilizou na composição de poemas longos de conteúdo épico-mitológico, que se destinavam à apresentação pública a cargo de coros por ele treinados ${ }^{59}$.

O início do séc. VI em Delfos foi marcado pela reforma do festival pítico. $\mathrm{Na}$ sequência da Primeira Guerra Sagrada (c. 595-590), empreendida por Clístenes, tirano de Sícion, aliado dos Atenienses e dos Escópadas da Tessália, a cidade de Crisa, que se recusava a reconhecer a autonomia de Delfos, é destruída e o festival é remodelado (cf. Andrewes 1956: 59-60). A partir de 582 adquire carácter pan-helénico: celebra-se de quatro em quatro anos, no terceiro de cada

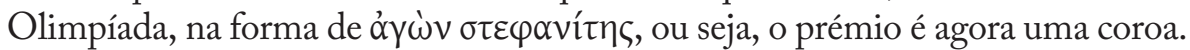
O programa das provas atléticas teve como modelo o de Olímpia (cf. Paus. 10. 7. 4-5), mas os Jogos Píticos nunca perderam o carácter original e a ligação a Apolo. Pelo contrário, a componente musical foi reforçada.

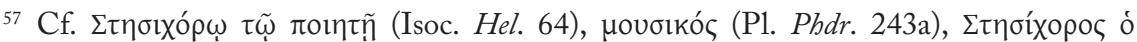

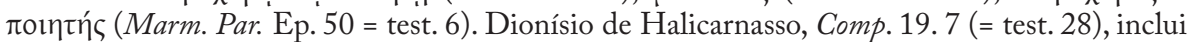

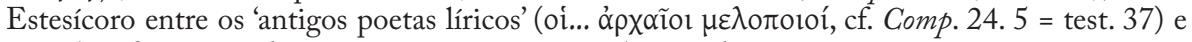
esta classificação predomina nos autores gregos e latinos da nossa era.

${ }^{58}$ Para uma resenha da divisão da comunidade científica, cf. Cingano 1993: 347 n. 3. O exame mais aprofundado desta problemática exige a análise dos fragmentos, que não podemos aqui fazer. Além dos estudos já referidos, vide ainda Cingano 1990: 209-224 e Cingano 2003; A. Gostoli, "Stesicoro e la tradizione citarodica", QUCC 59.2 (1998) 147-152, a propósito de D'Alfonso 1994; E. Robbins, "Public Poetry: Stesichorus", in Gerber 1997: 232-234; Hutchinson 2001: 116-117, Krummen 2009: 194-198. D’Alfonso 1994 discute os testemunhos antigos respeitantes a esta controvérsia, no sentido de mostrar a fragilidade das provas que inserem Estesícoro na tradição dos citaredos e de pôr em relevo a importância que o coro ocupou na sua carreira.

${ }^{59}$ Um fragmento que West também considerou (1971: 309), ainda que não isento de dificuldades, merece uma atenção especial. No fr. 212 PMG, pertencente à Oresteia e citado pelo escoliasta da Paz de Aristófanes como fonte de inspiração dos vv. 797-798 (p. 125 Holwerda), Estesícoro evoca os cantos de Primavera 'entoados em público' ( $\delta \alpha \mu \omega ́ \mu \alpha \tau \alpha)$ segundo o modo

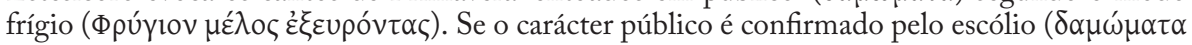

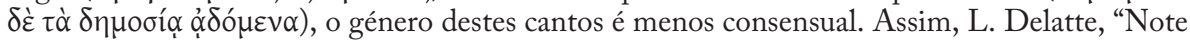
sur un fragment de Stésichore (37 Bergk, 14 Diehl)”, AC 7.1 (1938) 23-29, considerou que eram peanes, entoados nos festivais de Primavera como complemento do ritual de purificação dos participantes (cf. pp. 25-26). Cingano 1993: 353-358 supôs a partir destes dados que a Oresteia teria sido executada por um coro profissional, no âmbito de festas públicas em honra de Apolo. A execução coral do poema é também defendida por D'Alfonso 1994: 105-119, que dedica ao fragmento um extenso comentário. No entanto, Ieranò 1997: 196, tendo em conta o modo frígio da sua execução, supôs que se pudesse tratar de um ditirambo. 
Aos primeiros tempos da reforma do festival de Delfos se associam os nomes de Equêmbroto da Arcádia e de Sácadas de Argos. Segundo informa Pausânias (10. 7. 4), no terceiro ano da 48 alimpíada (= 586), os Anfictíones, organizadores do festival, acrescentaram à prova de citaródia, que existira desde a fundação e na qual brilhara Terpandro, as competições de canto a solo ao som do

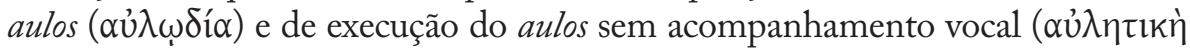
$\tau \varepsilon ́ \chi \vee \eta)^{60}$. Na citaródia distinguiu-se Melampo, da ilha de Cefalénia, na aulódia Equêmbroto e na aulética Sácadas. Por estas breves linhas se atesta o carácter pan-helénico dos novos Jogos Píticos e a diversidade geográfica dos músicos e poetas que neles participavam. São muito poucas, no entanto, as notícias sobre os artistas laureados. Do primeiro conhecemos somente o nome. Do segundo chegou-nos apenas o testemunho do Periegeta. No mesmo capítulo informa que Sácadas se sagrou vencedor nos dois festivais seguintes, portanto em 582 e 578 (10. 7. 4-5) ${ }^{61}$. Equêmbroto, ao que parece, não pôde voltar a competir neste certame, pois 'nos segundos Jogos Píticos', os Anfictíones eliminaram a prova de aulódia, 'considerando que o som não era auspicioso' ${ }^{62}$. Segundo supôs Pausânias, as melodias aulódicas eram as mais tristes produzidas pelo aulos e a audição consistia em lamentos cantados ao som daquele instrumento

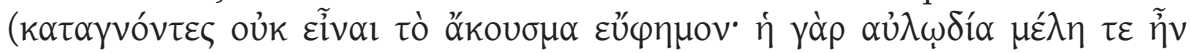

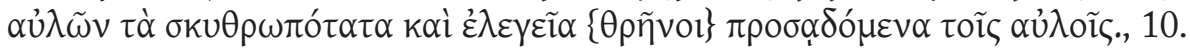
7. 5-6). A sua conjectura baseia-se na inscrição que acompanhava a trípode de bronze dedicada a Héracles por Equêmbroto, que cita (10. 7. 6):

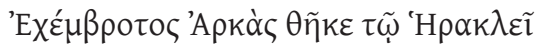

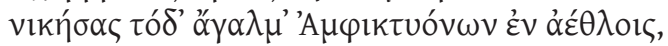

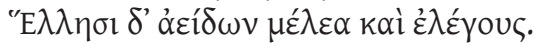

${ }^{60}$ Antes da reforma, o agon era exclusivamente citaródico, em memória do que fora miticamente instituído por Apolo a fim de celebrar a destruição da serpente Píton (cf. Str. 9. 3.

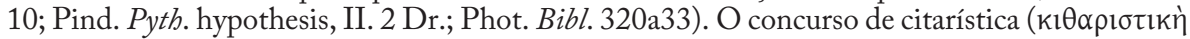

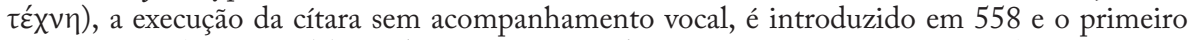
vencedor foi Agelau de Tégea (cf. Paus. 10. 7. 7). Segundo informa Plínio, o Antigo, houve também competições de pintura nos Jogos de Delfos e de Corinto (Nat. 35. 58), mas trata-se de um testemunho isolado. Gentili 1995: XXIII-XXVIII discute os testemunhos relativos à fundação, reforma e funcionamento dos Jogos Píticos.

${ }^{61}$ A observação de Pausânias de que o auleta de Argos venceu em Delfos antes de serem concedidas coroas como prémio e duas vezes depois, quando já era essa a recompensa pela vitória (6. 14. 9-10), testemunha que os Jogos Píticos se iniciaram oficialmente no terceiro ano da 49a Olimpíada, isto é, em 582, como é geralmente defendido.

${ }^{62}$ As competições de aulódia, todavia, faziam parte do programa das Panateneias (cf. Ps. Plu. de Mus. 8. 1134a), tendo sido suprimidas após as Guerras Medo-Persas (cf. Arist. Pol. 8. 6. 1341a37-1341b8). Foram reintegradas por Péricles em 443, quando estabeleceu o regulamento definitivo do concurso musical (Plu. Per. 13. 6). Estas competições faziam também parte das Amphiarea de Oropo, dos festivais beócios de Téspias, de Orcómeno e de Tânagra (cf. Kemp 1966: 216). 
Equêmbroto da Arcádia dedicou a Héracles

esta oferta pela vitória nos concursos dos Anfictíones, ao cantar para os Helenos melodias e lamentos.

Se a autenticidade destes versos pode suscitar reservas, eles dão-nos uma ideia de como seriam as inscrições votivas dos poetas na Época Arcaica. Há, porém, outros aspectos a considerar. Recorde-se que Hesíodo também recebeu uma trípode, quando venceu nos jogos fúnebres em honra de Anfidamante $(O p$. 657). A trípode de bronze era provavelmente a recompensa do laureado antes da remodelação do festival pítico. Estes versos atestam que o agon original em

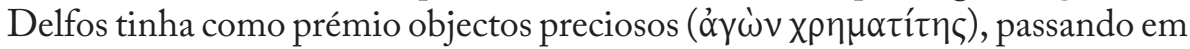
582 (isto é, 'nos segundos Jogos Píticos', nas palavras de Pausânias, nos quais já não participou Equêmbroto) a áy ponto a salientar é a afirmação do v. 3, que sublinha o carácter pan-helénico das competições de Delfos. Finalmente, o último verso, que traduzimos seguindo

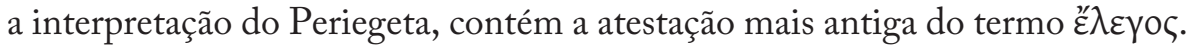
Nas ocorrências do séc. V (em Aristófanes e Eurípides) (3) $^{3}$ significa 'lamento cantado', sem implicações métricas. Como West 1974: 5 observa, a inscrição não confirma que foi a suposta tristeza do canto que levou à exclusão da prova de aulódia. Indica, porém, que Pausânias empregou no seu texto a palavra

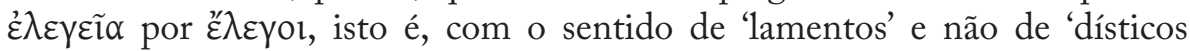
elegíacos' (daí a intromissão da glosa $\theta \rho \tilde{\eta} v o r)$. No entanto, nota Bowie 1986:

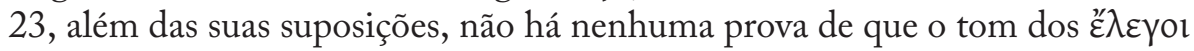
de Equêmbroto era de lamento ${ }^{64}$.

A prova de execução a solo do aulos continuou a fazer parte do programa dos Jogos de Delfos, como confirma a XIIa Pítica de Píndaro, composta em honra do auleta Midas de Agrigento, vencedor naquela categoria em 490, que é também um testemunho da vitalidade cultural da Magna Grécia no crepúsculo da Época Arcaica.

Ao mencionar o memorial de Sácadas erguido em Argos, Pausânias escreve que o músico fora o primeiro a fazer soar o aulos em Delfos (2. 22. 8 = test. 5), o que sugere um papel activo na promoção deste género musical. Recorde-se que o De Musica também associa o seu nome à organização dos festivais do Peloponeso (cf. supra 9. 1134b-c), sem especificar qual teria sido

${ }^{63}$ Cf. Ar. Av. 217; Eur. Hel. 185, Hyps. Iiii), IT 146 (cf. 1091), Tr. 119.

${ }^{64}$ Para a discussão da inscrição e do termo है' $\bar{\varepsilon} \gamma \circ \varsigma$, vide ainda D. A. Campbell, "Flutes and Elegiac Couplets”, JHS 84 (1964) 67 (cf. 1991: 201 n. 3); Rosenmeyer 1968: 224-225; Fowler 1987: 87-88; D. Gerber, "Elegy", in Gerber 1997: 94-96; Aloni 2009: 168-169, esp. 
o seu papel. A tradição reconheceu-lhe a excelência na execução do aulos ${ }^{65}$, mas também o seu talento para inovar, por exemplo, na composição de ritmos ( $\rho$ $\theta \mu$ orotía), como informa o De Musica $(12.1135 \mathrm{c}=\text { test. } 3)^{66}$. Não admira,

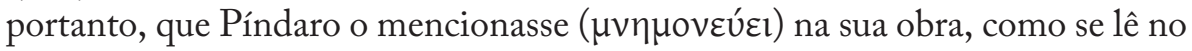
mesmo tratado $(8.1134 \mathrm{a}$ = test. 1$)$. Ora, de acordo com Pausânias, o poeta de Tebas compôs mesmo um prelúdio ( $\pi \rho \circ o$ ínıov) sobre Sácadas, que integraria eventualmente uma ode dirigida a um auleta vencedor, supomos nós ${ }^{67}$. Nestes versos se baseou o escultor que fez a estátua do músico para ser erguida no monte Hélicon, ao lado das de outras figuras distintas, como Orfeu, Tâmiris, Hesíodo e Aríon. Em pleno séc. IV, informa ainda Pausânias, as melodias ( $\mu \varepsilon ́ \lambda \eta)$ para aulos de Sácadas continuavam a ser escutadas, rivalizando com as de Prónomo, o célebre auleta tebano do séc. V (4.27. 7 = test. 7$)^{68}$.

A confirmar o que parece ter sido típico dos poetas da Época Arcaica, o De Musica refere outras facetas da carreira de Sácadas. Depois de dizer que foi também um compositor de melodias e de versos elegíacos com acompanhamento

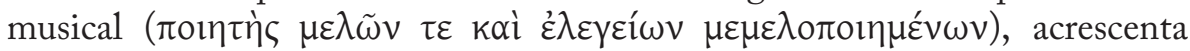
(8. $1134 \mathrm{a}-\mathrm{b}=$ test 1$)$ :

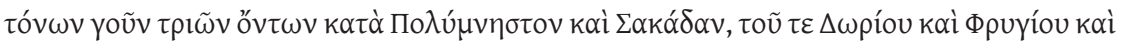

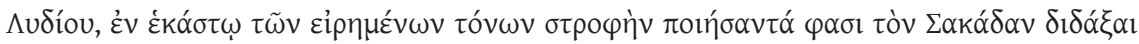

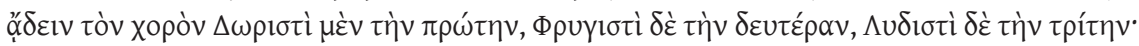

Havia três tonalidades no tempo de Polimnesto e de Sácadas: a dórica, a frígia e a lídia. Dizem que Sácadas compôs uma estrofe em cada uma delas e ensinou o coro a cantar a primeira na tonalidade dórica, a segunda na frígia e a terceira na lídia.

Esta inovação, porém, informa o capítulo, figurava sob a autoria de Clonas, compositor do séc. VII, nos registos dos poetas em Sícion. Todavia, se Sácadas desenvolveu algum trabalho na área da composição coral, essa actividade

${ }^{65} \mathrm{O}$ De Musica observa que era um 'exímio auleta' (ou 'poeta', segundo a lição dos códices) e atesta o registo ( $\alpha$ $v \alpha \gamma \varepsilon ́ \gamma \rho \alpha \pi \tau \alpha \mathrm{l})$ das três vitórias sucessivas em Delfos (8.1134a-b).

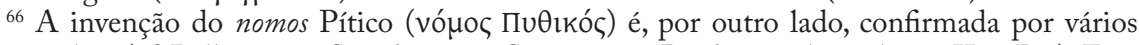
testemunhos (cf. Poll. 4. 78 = Sacad. test. 4, Str. 9. 3. 10, Pind. Pyth. hypothesis, II. 2 Dr.). Esta famosa peça de aulética tinha cinco movimentos e imitava, com o duplo aulos, a luta de Apolo

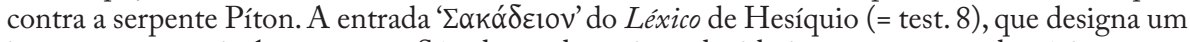
instrumento musical, sugere que Sácadas pode ter introduzido inovações neste domínio.

${ }^{67}$ Paus. 9. 30. 2 = Sacad. test. 6, Pind. fr. 269 Ma. A evocação de um predecessor está bem representada na poesia grega arcaica. Sobre este tópico, vide Francesca D’Alfonso, "Sacada, Xanto e Stesicoro", QUCC 51.3 (1995) 49-61, especialmente pp. 54 sqq.

${ }^{68}$ Como dissemos acima, Prónomo é a figura central do famoso krater de volutas ático de figuras vermelhas do final do séc. V, hoje no Museu Nacional de Nápoles, reproduzido em Rocha Pereira 2006: 656. Segundo Pausânias, Prónomo gozava de grande popularidade e deleitava o público com as expressões faciais e movimentos do seu corpo enquanto actuava (9. 12. 5-6). De acordo com Ateneu, foi mestre de música de Alcibíades (4. 184d). 
pode ter sido cumprida, como supõe Campbell 1991: 5, no âmbito da sua participação nos festivais do Peloponeso, designadamente nos Endymatia, que se realizavam na sua terra natal (cf. supra Ps. Plu. de Mus. 9. 1134b-c).

A mobilidade poética conhece novos contornos ao longo do séc. VI, durante o qual se assiste ao desenvolvimento dos festivais pan-helénicos e à difusão do regime político da tirania. O tirano típico é um protector das artes e dos poetas que acolhe na sua corte, dos quais espera gratidão e louvor. Assim, em plena Época Arcaica a actuação de alguns líricos assemelha-se à dos aedos da Odisseia: beneficiam da hospitalidade de homens de poder e em troca favorecem os seus interesses políticos ou pessoais ${ }^{69}$. Um dos exemplos mais ilustrativos é a chamada 'Ode a Polícrates' de Íbico de Régio (fr. 151 $S L G=$ fr. 282 (a) $P M G$ ), composta provavelmente enquanto viveu na corte de Samos, quer tenha sido chamado pelo próprio Polícrates, que dirigiu a ilha entre c. 533 e 522 (cf. Mossé 1969: 17), quer pelo pai deste, Éace, na

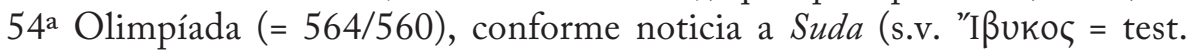
$1)^{70}$. Apesar das dúvidas, este é um dos dados mais seguros do pouco que se sabe acerca da vida e obra deste lírico oriundo, como Estesícoro, da Magna Grécia.

O reduzido corpus que hoje se preserva mostra que pertenceu à mesma tradição poética, pois compôs em metros líricos sobre temas mitológicos,

${ }^{69}$ Sobre este tópico, vide Woodbury 1968, Podlecki 1980, Harrell 2002. Como é sabido, a veneração das letras e artes não é exclusiva dos tiranos gregos, mas antes um traço característico dos déspotas de todos os tempos, como observa Ismail Kadaré no ensaio La Légende des Légendes (Paris 1995) 32, a propósito do ditador chinês Mao Zedong. No que respeita à mobilidade dos poetas durante a Época Arcaica, vide Bowie 2009, que considera no seu estudo, além de Alceu, Íbico, Anacreonte e Simónides, os cultores mais conhecidos de metros elegíacos e iâmbicos, bem como Krummen 2009, especificamente sobre Álcman, Estesícoro e Ibico.

${ }^{70} \mathrm{O}$ mesmo passo da Suda situa a ida para Samos no tempo de Creso, que reinou c. 560-546. Registe-se que o testemunho de Himério sobre a ida para Samos de Anacreonte (vide infra) atribui a iniciativa ao pai do famoso tirano. As contradições dos testemunhos antigos sobre a cronologia destas personalidades tem sido motivo de controvérsia. MacLachlan 1997: 187-189 traça uma resenha dos principais aspectos da polémica. Contra a tendência da crítica moderna, Barron 1964 pôs em causa o relato de Heródoto sobre a tirania de Samos e defendeu que existiram dois tiranos, pai e filho, ambos chamados Polícrates. $\mathrm{Na}$ sua opinião (cf. p. 226), Íbico foi chamado pelo primeiro c. 564-560, como indica a Suda, e esse foi o destinatário da ode a que pertence o fr. 282 (a) PMG. Para uma opinião divergente, vide Woodbury 1985. Depois de dedicar a primeira parte do artigo (com um elenco bibliográfico notável) à análise do fr. 282 (a) $P M G$ e à revisão de outras interpretações anteriores, centra-se nas dúvidas sobre a cronologia de Íbico e Anacreonte na corte de Samos. Woodbury concluiu não haver razões plausíveis para rejeitar o testemunho de Heródoto sobre o pai de Polícrates, mas concordou com a hipótese de Barron de que teria sido ele a chamar o poeta de Régio (p. 217). Sobre este assunto, cf. Podlecki 1980: 376-377, Hutchinson 2001: 231-234. Sobre a tirania de Samos, cf. G. Shipley, A History of Samos 800-188 BC (Oxford 1987) 70-80. 
num estilo e linguagem típicos do poeta de Hímera ${ }^{71}$. Esta semelhança e o facto de ter usado a estrutura triádica (cf. P. Oxy. 2735, fr. $1=166 S L G$, 282A Campbell) terão sido determinantes para a inclusão de Íbico no grupo dos cultores de lírica coral. No entanto, o carácter erótico e profundamente intimista de alguns versos preservados, de que os frr. 286 e $287 P M G$ são o melhor exemplo, revela uma outra faceta do seu talento poético. É significativo que Aristófanes (Th. 159-163 = test. 10) e Cícero (Tusc. $4.71=$ test. 12 ) louvem Íbico pela sua poesia amorosa e o coloquem ao lado de Alceu e de Anacreonte, que também residiu na corte de Samos. Por tudo isto, alguns estudiosos defenderam a possibilidade de algumas das suas obras terem sido executadas a solo, contra a opinião dominante na crítica moderna ${ }^{72}$. Mas, se de facto é plausível que Íbico tenha criado composições mais curtas sobre temas pessoais, destinadas a serem cantadas a solo no banquete, há pelo menos indícios de que praticou outro tipo de poesia. Um dos escólios ao v. $631 \mathrm{da}$ Andrómaca de Eurípides (II. 293 Schw. = fr. 296 PMG) informa que Íbico tratou o reencontro entre Menelau e Helena em Tróia num ditirambo ${ }^{73}$. Por outro lado, alguns estudiosos observam que nem sempre é possível distinguir os temas mitológicos dos eróticos, designadamente quando tratou o mito de Ganimedes (fr. $289 P M G$ ) ou o da rainha de Esparta (frr. 296, $297(P M G)$. Não cremos, portanto, que seja prudente apoiar qualquer uma das conjecturas, uma vez que o corpus de Íbico está muito mutilado e não permite conhecer a extensão real das suas composições nem sequer a temática dominante. Um outro argumento diz respeito a uma suposta inovação formal. Ao que parece, o poeta de Régio foi tão original no tratamento de alguns

${ }^{71}$ Cf. Hutchinson 2001: 229. Esta semelhança formal e temática confundiu os autores antigos, que tinham dúvidas quanto à autoria do poema sobre os jogos fúnebres em honra de Pélias (cf. Athen. 4. 172e = Stesich. fr. $179 P M G$, vide infra pp. 350-351). Dificuldades do mesmo tipo enfrentam os estudiosos modernos, por exemplo a propósito da atribuição dos fragmentos contidos no P. Oxy. 2735 (= 166-219 SLG, Ibyc. fr. 282A Campbell). Sobre esta problemática, vide especialmente Cingano 1990: 189-208.

${ }^{72}$ Campbell trata Íbico no capítulo 'monody', que escreveu para The Cambridge History of Classical Literature I. Greek Literature (Oxford 1985) 214-216, ainda que comece por observar "It is not certain that he wrote monody". Além disso, quando se refere à ode escrita para Polícrates considera-a um 'poema coral' (p. 216). Quanto aos argumentos que aponta para justificar o tratamento de Íbico neste capítulo - a natureza fortemente pessoal dos fragmentos mais importantes e a eventual convivência com Anacreonte, cujos poemas foram provavelmente executados a solo - remetemos para o comentário de Rocha Pereira 2006: 216 n. 81, que os considera frágeis, observando que se algumas das obras de Íbico podem ter sido executadas a solo "a existência de tríades de sua autoria opõe-se à generalização.” Refira-se que em Campbell 1991, o poeta de Régio figura entre os cultores de lírica coral, mas em Gerber 1997 é tratado na secção 'Personal Poetry', entre Safo e Anacreonte (pp. 187-197).

${ }^{73}$ A importância deste testemunho para a história do ditirambo é posta em relevo por Cingano 1990: 215-219 e Ieranò 1997: 195-196. 
mitos como Estesícoro (cf. Campbell 1982: 305), mas é possível que também tenha criado outras formas poéticas. Um dos efeitos do desenvolvimento dos festivais pan-helénicos foi o costume de perpetuar a glória dos vencedores

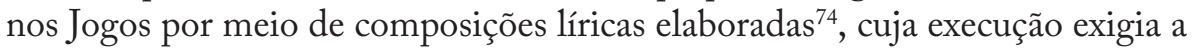
deslocação do poeta (ou de um representante) ao lugar das competições ou à pátria dos atletas. A invenção do epinício foi durante muito tempo atribuída a Simónides (cf. infra, pp. 126 sqq.), mas na segunda metade do séc. XX, graças às descobertas papirológicas, vários estudiosos defenderam a possibilidade de Íbico ter composto odes de vitória ${ }^{75}$, que seriam, em princípio, cantadas e

${ }^{74}$ Cf. J. R. Ferreira, "A heroização do vencedor na poesia grega”, in Oliveira 2000: 45-55. Outras formas de celebrar o triunfo atlético foram a cunhagem de uma moeda comemorativa, como fez Anaxilas de Régio (cf. infra, pp. 253-254), a consagração de uma estátua do vencedor ao santuário onde se realizavam os Jogos, além das representações em pinturas de vasos. Sobre este assunto, vide Rocha Pereira 2000b: 25-43, Smith 2007.

${ }^{75}$ Vide Barron 1984 e, em especial, Jenner 1986. Os fragmentos principais em que se baseia esta hipótese são quatro e foram revelados por dois papiros:

- no v. 17 de $166 \operatorname{SLG}$ (P. Oxy. 2735, fr. 1 = fr. 282A (i) Campbell) são mencionados 'Castor, domador de cavalos' e 'Polideuces, excelente no pugilato'; o v. 36 parece conter uma

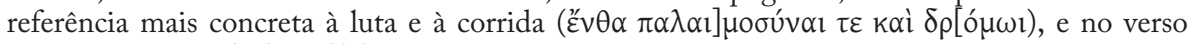

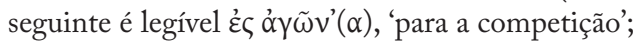

- o fr. 11 do mesmo papiro (= $176 S L G, 282 \mathrm{~A}$ (viii) Campbell) contém 21 linhas muito mutiladas, nas quais surgem termos que nos remetem para um contexto de competição atlética, mas situado no âmbito do mito; a presença dos nomes Iolau (linha 9) e Héracles (6) sugere um momento dos jogos fúnebres em honra de Pélias, nos quais Iolau, cocheiro do grande herói grego, venceu a corrida de quadrigas (linhas 7-9?, cf. Paus. 5. 17. 11); nestes jogos também participou Peleu, que foi derrotado na prova de luta por Atalanta (cf. Apollod. 3. 9. 2), o que parece ser referido nas linhas 11-14; por conseguinte, é evidente que este fragmento pertence a um poema de conteúdo mitológico, mas será excessivo concluir que se tratasse de um epinício; Jenner 1986: 63 defende que o tema principal era o elogio de um atleta, talvez lutador, cuja força era comparada com a de Héracles;

- o P. Oxy. 2637 (= 220-257 SLG, 282B Campbell) revelou fragmentos de um comentário sobre poesia lírica; dado que o fr. 1 (a) 1-31 (= 220 SLG) contém referências ao monte Crónio (Kpóviov), situado perto da povoação siciliana de Leontinos, a noroeste de Siracusa, à caça aí praticada e a um atleta vitorioso na prova de corrida, os estudiosos julgam que se trata do comentário a uma ode composta em honra de um atleta natural ou das redondezas de Leontinos (cf. Jenner 1986: 69);

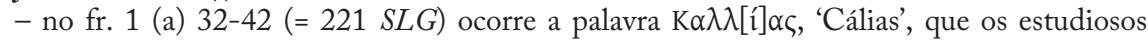
supõem tratar-se do nome do destinatário do poema, usado como título, observando que um ateniense assim chamado venceu a prova de carros na 54a Olimpíada (=564); cf. Barron 1984: 22, Jenner 1986: 61, Campbell 1991: 8-9.

Vários são os estudiosos que consideram provável que Íbico tenha composto epinícios. Assim pensa Parsons (OCD, s.v. Simonides, cf. 2001: 59, 63), bem como Gerber, que na recensão à edição Budé de Baquílides, publicada em 1993 por J. Irigoin, J. Duchemin e L. Bardollet, contestou a afirmação da p. 74 de que aquela forma poética começou com Simónides, contrapondo "there is now evidence that Ibycus also composed this type of poetry (see especially S 220-1).” (CR 44.2, 1994, 269). Os fragmentos em que fundamentou o seu juízo, dado o estado de conservação, não asseguram, quanto a nós, uma opinião tão definitiva, mas em conjunto com os frr. 166 e 176 SLG constituem indícios a ter em conta, no estado actual dos nossos conhecimentos, num estudo sobre a invenção do epinício. Estes fragmentos, porém, 
dançadas por um coro. Esta controvérsia sobre o carácter da produção de Íbico mostra, mais uma vez, como pode ser errónea a distinção moderna entre 'lírica monódica' e 'lírica coral'.

Polémicas deste tipo sobre a natureza e o modo de execução dos poemas não preocupam os estudiosos de Anacreonte de Teos. Segundo os autores antigos, e o corpus confirma-o, cultivou essencialmente os temas típicos das composições destinadas ao symposion, como o amor e o vinho ${ }^{76}$, embora pelo menos dois fragmentos evidenciem referências políticas (cf. frr. 348, 353 $P M G)$.

A crer nos testemunhos que nos chegaram, ao longo dos seus oitenta e cinco anos, vividos entre c. $575 / 570$ e c. $490 / 485^{77}$, não só lidou com os tiranos e homens de poder mais distintos do seu tempo, como gozou de grande popularidade junto das classes sociais menos favorecidas. Assistiu à subjugação de Sardes ao império persa (em 546) e à perda da independência da maior parte das cidades da Ásia Menor. Quando o invasor se aproximou da sua terra natal, os habitantes partiram rumo à Trácia, onde fundaram Abdera (c. 540), e Anacreonte integrou provavelmente esta expedição ${ }^{78}$.

São vários os testemunhos que associam o poeta aos governantes de Samos, desde os mais sérios aos anedóticos ${ }^{79}$. Nas palavras de Eliano (VH9. 4. = test. 4), Polícrates, grande amante das Musas, regozijou-se com Anacreonte e com a sua arte. A mesma ideia é reiterada no testemunho do orador Himério (Or. 29. 22 = fr. $491 P M G$ ), segundo o qual, a pedido do jovem Polícrates, Éace mandou chamar o poeta de Teos e incumbiu-o de ensinar música ao filho ${ }^{80}$. Estrabão afirmou que a sua poesia estava cheia de referências ao tirano

pouco ou nada nos dizem sobre o grau de evolução destes cantos de louvor nem sobre o modo como seriam executados. A hipótese é admitida, entre outros, por Cingano 1990: 219, Dillon and Garland 1994: 50, MacLachlan 1997: 190 n. 14, Schneider 1997: 80. Convém lembrar ainda que a atribuição do P. Oxy. 2735 a Íbico, defendida por D. L. Page (PCPhS 17, 1971, 89-93), não é consensual. Cf. Cingano 1990: 193 n. 14, Campbell 1991: 227.

${ }^{76}$ Cf. Cic. Tusc. 4.71 (= Anacr. test. 20); Paus. 1.25.1 (= test. 10); Clem. Alex. Strom. 1. 78;

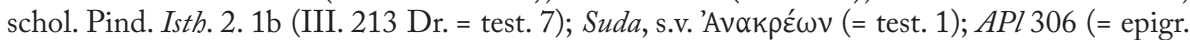
XXXI Gow-Page, test. 11); AP 7. 27 (= epigr. XV Gow-Page, test. 12).

${ }_{77}$ Anacreonte integrou o grupo dos homens célebres pela sua longevidade (cf. Ps. Luc. Macr. 26 = test. 8, e infra, p. 119 n. 15) e nos seus poemas falava da sua idade avançada (frr. 358, $379 \mathrm{PMG}$ ). Os dados cronológicos indicados na notícia da Suda sobre o poeta (cf. n. anterior) são confusos e foram sujeitos a diversas emendas. Vide as notas de Campbell 1988: 22-23; cf. Woodbury 1985: 215-216. Eusébio (= test. 2) situa o seu floruit no primeiro ano da $61^{\text {a }}$ Olimpíada $(=536 / 535)$, ou seja, cerca de três anos antes da subida ao poder de Polícrates. Cf. Campbell 1988: 4, Zanker 1995: 24.

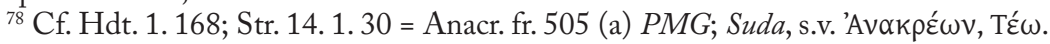

${ }^{79}$ Sobre as anedotas acerca de Anacreonte, cf. Max. Tyr. 21. 7, Tz. H. 4.131. 235 sqq.

${ }^{80}$ Para uma discussão do testemunho de Himério, designadamente dos problemas causados pelas lacunas do texto, vide Barron 1964: 219-222 e Woodbury 1985: 209-213. 
(14. $1.16=$ fr. $483 P M G)^{81}$, mas do corpus actual apenas os frr. 348 e $353 P M G$ aludem possivelmente à política de Samos.

$\mathrm{Na}$ segunda metade do séc. VI a generosa corte de Polícrates tornara-se espaço aliciante de convívio de vários poetas e artistas (cf. Athen. 12. 540d-e), mas esta situação mudou certamente quando, em 522, o tirano é assassinado por Oretes, o governador persa de Sardes ${ }^{82}$. É possível que Íbico, de quem não ouvimos falar mais, tenha falecido por esta altura ${ }^{83}$, mas segundo conta Heródoto (3. 121), Anacreonte estava junto de Polícrates quando Oretes pôs em prática a sua vingança. É provável que o poeta tenha então deixado Samos. Fontes não anteriores ao séc. IV indicam que o filho de Pisístrato, Hiparco, se rodeou igualmente de poetas e artistas famosos ${ }^{84}$. A simpatia que Anacreonte alcançou entre o povo de Atenas é confirmada por pinturas de vasos do final do séc. VI, onde surge retratado, e pela estátua erguida em sua honra na Acrópole ${ }^{85}$.

$\mathrm{Na}$ corte dos Pisístratos, o poeta de Teos conviveu provavelmente com Simónides e Laso de Hermíone. A seguir ao assassínio de Hiparco em 514

${ }^{81}$ Cf. Max. Tyr. 37.5 (= fr. 471 PMG), Himer. Or. 28. 2 (= fr. 483 PMG). A convivência de Anacreonte com Polícrates é também mencionada por Pausânias (1. 2. 3, vide infra, p. 168).

${ }^{82}$ Sobre o episódio de Polícrates nas Histórias de Heródoto (3. 39-43, 120-125), vide M. F. Silva, "A história de Polícrates de Samos. Mais um capítulo na biografia da Humanidade", Humanitas 47 (1995) 55-70, e Soares 2003, especialmente pp. 88-96. Sobre a actuação política deste célebre tirano, vide Andrewes 1956: 117-122, Mossé 1969: 15-20.

${ }^{83}$ Segundo um epigrama anónimo da Antologia Palatina (7. 714 = anon. LII Gow-Page, Ibyc. test. 6), Íbico foi sepultado em Régio.

${ }^{84}$ Ps. P1. Hipparch. 228b-c (= Anacr. test. 6), Arist. Ath. 18.1 (= Simon. test. 10), citados infra, p. 136. Zanker 1995: 22 supõe que o poeta tenha sido chamado pelos Pisístratos na sequência da morte do tirano de Samos. Sobre a convivência de Anacreonte com Polícrates e Hiparco, cf. Podlecki 1980: 378-381.

85 Cf. Rocha Pereira 1997b: 35. Pausânias menciona a existência de uma estátua de Anacreonte, erguida na Acrópole ao lado da de Xantipo, pai de Péricles, que representava um homem ébrio a cantar (1.25.1 = Anacr. test. 10). Há grande probabilidade de ser esta a escultura retratada nos epigramas 307-309 da Antologia Planudea. Supõe-se que foi preservada uma cópia romana, actualmente em Copenhaga (Ny Carlsberg Glyptotek IN 491), embora Gow and Page 1965: 340-341 e Campbell 1988: 31 defendam que a identificação não é segura. Outro é o parecer de Paul Zanker, que nos propõe uma interpretação deste monumento, no âmbito das suas reflexões sobre a imagem do intelectual na Antiguidade (1995: 22-31). Segundo um epigrama da Antologia Palatina atribuído a Teócrito, Teos também tinha a sua estátua de Anacreonte (9. 599). Parsons 2001: 56 observa que Anacreonte causou muito mais impressão entre as camadas populares, notando que os pintores de vasos não retratam nem Simónides nem Píndaro, que seriam bem mais famosos entre os nobres e ricos, enquanto o nome de Anacreonte aparece em várias peças de cerâmica. As representações do poeta foram compiladas por Richter 1984: 83-86, figs. 47 e 48. Cf. MacLachlan 1997: 199-200. Para o estudo dos vasos, vide M. H. Rocha Pereira, “Anakreon”, Das Altertum 12 (1966) 84-96;Jane McIntosh Snyder, “Aristophanes' Agathon as Anacreon", Hermes 102.2 (1974) 244-246; D. C. Kurtz and J. Boardman, "Booners", in Greek Vases in the J. Paul Getty Museum. Vol. 3 (Malibu 1986) 35-70, esp. 65-70; Sarah D. Price, “Anacreontic Vases Reconsidered”, GRBS 31 (1990) 133-175. 
(Hdt. 5. 56), ou à expulsão de Hípias em 510 (Arist. Ath. 19. 6), pode ter ficado em Atenas, mas há indícios de que foi acolhido pelas famílias reais da Tessália, tal como o poeta de Ceos. Esta possibilidade apoia-se em dois epigramas dedicatórios atribuídos a Anacreonte, transmitidos pela Antologia Palatina, que dizem respeito a uma das principais famílias tessálias do final do séc. VI ${ }^{86}$. Ao que parece, o poeta regressou depois à Ática. Segundo um escólio do Prometeu Agrilhoado, conviveu também com Crítias, avô do político ateniense, e admirou ainda a obra de Ésquilo (schol. M. Pr. 128, p. 15 Dindorf = fr. $412 P M G$ ), que se estreou entre c. 499 e 496. Sócrates, no Cármides, recorda que o lírico de Teos havia celebrado Crítias na sua poesia $(157 \mathrm{e}=$ fr. $495 P M G)$. As honras que o povo de Atenas lhe dedicou sugerem que passou a última fase da vida nesta cidade. Assim, embora a sua representação na arte e na literatura como um ancião possa ter sido inspirada pelos poemas, é plausível que se trate de um dado realista e não meramente convencional ${ }^{87}$. $\mathrm{Na}$ apreciação do trajecto de vida de Anacreonte, G. O. Hutchinson, que não considera uma eventual visita do poeta à Tessália, escreveu: "His mobility reflects, not only the impact of Persia, but the interest of the exceptionally rich in attracting poets from elsewhere. There is a more obvious resemblance with Ibycus and Simonides' career than with that of earlier poets.” (2001: 256).

Os concursos de ditirambos cantados por um coro de homens são oficialmente incluídos nas Grandes Dionísias por volta de 509/8 (cf. Marm. Par. Ep. 46$)^{88}$ e a crítica moderna associa habitualmente esta novidade à actuação de Laso de Hermíone. Como bem notou Ieranò 1997: 197, as fontes antigas não são tão explícitas quanto ao seu papel na história do ditirambo ${ }^{89}$, mas há razões para crer que tenha sido uma figura de relevo no ambiente cultural ateniense durante a tirania dos Pisístratos.

De acordo com a Suda (s.v. $\Lambda \alpha ́ \sigma o \zeta=$ test. 1), o poeta nasceu na 58 Olimpíada $(=548 / 544)$ e os poucos testemunhos que sobre ele existem

${ }^{86} A P$ 6. 136 (= 108D, epigr. VII $\left.F G E\right)$ e 6. 142 (= 107D, epigr. XIII $\left.F G E\right)$, citados infra, pp. 160-161.

${ }^{87}$ Cf. Athen. 13. 599c-d = fr. adesp. 953 PMG; APl 306. 1 (= epigr. XXXI Gow-Page, test. 11), $A P 7.27$ (= epigr. XV Gow-Page, test. 12), AP 9.239. 3 (= epigr. VII Gow-Page, test. 13).

${ }_{88}$ Outros festivais de Atenas contemplavam a execução de ditirambos, como as Targélias, as Panateneias menores, as Prometeias e as Heféstias. Cf. Lys. 21. 1-4, Ps. Xen. Ath. 3. 4. Por enquanto, não pode ser provada a hipótese de competições ditirâmbicas nas Antestérias, sugerida por K. Friis Johansen, Eine Dithyrambos-Aufführung (Copenhagen 1959) 20. Cf. PickardCambridge 1968: 16-17, Simon 1983: 98-99 e n. 47. Os concursos trágicos datam de c. 534 e os cómicos, posteriores aos ditirâmbicos, foram introduzidos em 486. Sobre o desenvolvimento dos concursos dramáticos de Atenas, vide Pickard-Cambridge 1962, 1968; Parke 1977; Rocha Pereira 2006: 354-368 (com referências bibliográficas).

${ }^{89}$ Cf. schol. Ar. Av. 1403 (= Arion, test. 4, supra); schol. Pind. Ol.13. 26b (= Lasus, test. 5); Suda, s.v. $\Lambda$ áбoৎ = Lasus, test. 1). Sobre o papel de Laso, cf. Pickard-Cambridge 1962: 13-15. 
relacionam-no com Simónides e com Píndaro. Os versos 1411-1412 das Vespas de Aristófanes (= test. 3) indiciam que foi adversário do primeiro, provavelmente numa competição de ditirambos. Do segundo terá sido mestre de música, a crer noutros testemunhos mais tardios ${ }^{90}$. Portanto, tudo indica que, pelo menos durante algum tempo, desenvolveu a sua carreira em Atenas. Neste sentido aponta a informação de Heródoto de que Onomácrito, editor dos oráculos de Museu, foi obrigado a sair de Atenas por ordem de Hiparco, depois de ter sido apanhado por Laso a forjar um oráculo (7. 6. 3 = test. 2). Este testemunho sugere também uma relação de proximidade com o filho de Pisístrato, pelo que deve ter beneficiado da sua protecção. E ainda que tenha sido acolhido na sua corte, como geralmente se admite, é plausível que não tenha deixado Atenas quando Hípias foi expulso, se de facto contribuiu para a instituição dos concursos ditirâmbicos nesta cidade ${ }^{91}$.

Os testemunhos sugerem que o estudo dos sons deve ter ocupado um lugar importante no seu trabalho. Ateneu preservou três versos de um hino a Deméter de Hermíone (14. 624e-f = fr. $702 P M G$ ), que apresentava a característica de ser assigmático, como informa o mesmo autor $(10.455 \mathrm{c}-\mathrm{d})^{92}$. Lê-se na Suda que foi por alguns considerado um dos Sete Sábios, no lugar de Periandro ${ }^{93}$, e também que 'foi o primeiro a escrever um tratado sobre música, a tornar o ditirambo competitivo e a introduzir argumentos polémicos.'

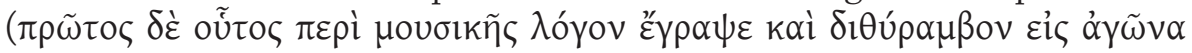

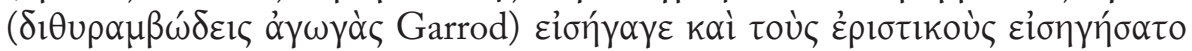
$\lambda$ óyouc.). Esta última afirmação relaciona-se, possivelmente, com a reputação

${ }^{90}$ Cf. schol. Pind. Vita Thomana (I. 4 Dr. = Lasus, test. 4), Eust. prooem. Pind. 27 (III. 299-300 Dr.). A participação de Simónides nas competições ditirâmbicas é tratada infra, pp. 131 sqq.

${ }^{91}$ Cf. Lasserre 1954: 35, Privitera 1965: 20. Ieranò 1997: 198 avança a hipótese de Laso ter levado para Atenas as tradições poéticas e musicais do Peloponeso, por certo já experimentadas na sua terra natal, com base no testemunho de Pausânias (2.35.1) de que se realizavam em Hermíone concursos musicais em honra de Diónisos Melanaigis.

92 A sibilante $\sigma / \varsigma$ era também evitada na ode intitulada Centauros (Athen. 10. 455c $=$ fr. $704 P M G$ ). Ao contrário do que defendem alguns helenistas, não é certo que a abertura do $I^{\circ}$ Ditirambo de Píndaro (fr. 70b Ma.), no qual se evoca o desenvolvimento desta forma coral, testemunhe que os ditirambos de Laso eram também assigmáticos. Para uma discussão deste assunto, vide o artigo de D’Angour 1997, no qual analisa também os testemunhos sobre as

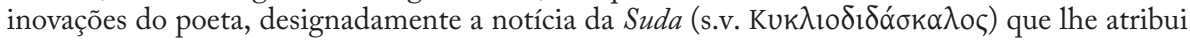

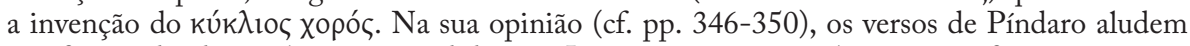
à reforma do ditirambo empreendida por Laso, que passou pela sua transformação numa dança circular (inovação que algumas fontes atribuem a Aríon, vide supra), com o propósito de melhorar o modo como o canto era ouvido nas competições.

${ }^{93}$ Como observa Rocha Pereira 2006: 205 n. 43, a lista de nomes dos Sete Sábios é bastante variável. Periandro figura na de Pausânias (10.24.1) e de Diógenes Laércio (1. 94-100), mas não na de Platão (Prt.343a), que atesta a referência mais antiga a um grupo de sete sapientes. Cf. infra, p. 219 n. 77. 
de que era muito hábil com as palavras ${ }^{94}$. A única referência do De Musica a Laso diz respeito à variedade fónica que imprimiu à música do seu tempo (29. $1141 \mathrm{c}=$ test. 6 ).

Nas palavras de Privitera 1965: 110, "Laso dovette trascorrere ad Atene la maggior parte dei suoi anni: è sintomatico che la tradizione, benché insista sui suoi atteggiamenti di sofista ante litteram, ignori che egli abbia viaggiato come fu costume dei Sette sapienti, del rivale Simonide e dei sofisti del V secolo.” A sua evocação neste capítulo confirma que nos finais do séc. VI Atenas é uma cidade de grande prestígio cultural, que atrai artistas e poetas de diversas partes do mundo grego. A mesma razão nos leva a referir brevemente Pratinas de Fliunte. Era também natural da região da Argólida, de uma cidade situada perto de Corinto e Sícion, e desenvolveu a sua actividade profissional em

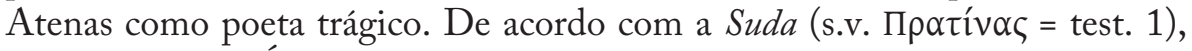
competiu contra Ésquilo e Cérilo na 70a Olimpíada $(=500 / 496)$ e foi o primeiro a escrever dramas satíricos. O De Musica, porém, parece incluí-lo entre os poetas líricos (31. 1142b), e o género do seu fragmento mais importante (fr. $708 P M G$ ), no qual se insurge contra as novas tendências musicais do séc. $\mathrm{V}$, foi transmitido por Ateneu como hiporquema (14. 617b-f), mas tem sido diversamente interpretado pelos helenistas ${ }^{95}$.

${ }^{94}$ Deste talento deriva o termo $\Lambda \alpha \sigma i ́ \sigma \mu \alpha \tau \alpha$, registado no Léxico de Hesíquio (= Lasus, test. 11). Os seus jogos de palavras são evocados por Ateneu (8. 338b = test 10; cf. Plu. De vitioso pudore 5) e as suas sentenças por Estobeu (3.29.70 = test. 12). Sobre este ponto, cf. Privitera 1965: 49-50.

${ }^{95}$ Esta questão é tratada por R. Seaford, “The 'Hyporchema' of Pratinas”, Maia 29-30 (1977-1978) 81-94. Numa análise do tema e das circunstâncias da composição do poema, o autor retoma a hipótese de se tratar de um drama satírico (cf. pp. 82, 84-85) e, entre outros

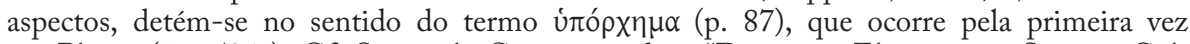
em Platão (Ion 534c). Cf. Soteroula Constantinidou, "Dionysiac Elements in Spartan Cult Dances", Phoenix 52.1/2 (1998) 15-30, esp. 26-28 (“Appendix: Pratinas and Sparta"). 


\section{As CONDIÇÕES DE MOBILIDADE, O ACOMPANHAMENTO MUSICAL E A EXECUÇÃO CORAL}


(Página deixada propositadamente em branco) 
Até à Época Romana o mar é a via de comunicação privilegiada no mundo grego, apesar da existência de estradas que permitiam a ligação entre as cidades e, sobretudo, entre estas e os centros religiosos mais importantes ${ }^{1}$. O desenvolvimento da navegação e do comércio, que suscitou a descoberta da bacia do Mediterrâneo e o aparecimento dos primeiros périplos, foi por certo motivado pelo fenómeno da colonização grega ${ }^{2}$. Supõe-se, aliás, que o interesse pelo Egipto, manifestado por personalidades célebres, como Tales, Hecateu, Sólon e Heródoto, surge na sequência da fundação, nos fins do séc. VII, da estação comercial de Náucratis, no Delta do Nilo, por comerciantes de Mileto $^{3}$. Plutarco, a propósito das viagens de juventude do legislador ateniense, recorda que 'alguns mantêm que foi mais na busca de experiência e de conhecimentos do que de lucro que Sólon empreendeu as suas viagens' (Vita Solonis 2. 1) ${ }^{4}$.

No entanto, qualquer deslocação por terra ou por mar envolvia dificuldades e riscos temidos. Hesíodo deu-nos o seu testemunho sobre as condições de navegação no Egeu na Época Arcaica (Op. 618-694), mas, ao que parece,

${ }^{1} \mathrm{Na}$ Época Arcaica, além dos santuários de Delos e de Delfos, eram também muito importantes o de Zeus em Dodona (Epiro), já mencionado nos Poemas Homéricos (Il.16. 234, Od. 14. 327-330), o de Zeus Ámon, situado num oásis do deserto da Líbia (cf. Pind. Pyth. 4. 16, fr. 36 Ma.), e o de Apolo na cidade de Dídime, perto de Mileto, na Ásia Menor.

${ }^{2}$ Sobre as viagens de exploração geográfica, os relatos dos pioneiros neste domínio e a descrição do mundo conhecido, vide Pédech 1976, André et Baslez 1993: 317-372, Pérez Jiménez y Cruz Andreotti 1997, Gómez Espelosín 2000, Rubio Tovar et alii 2008.

${ }^{3} \mathrm{O}$ irmão de Safo dedicava-se ao transporte de vinho entre Lesbos e Náucratis (cf. Sapph. frr. 5, 202 L-P; P. Oxy. 1800 fr. 1 = Sapph. test. 1; Athen. 13. 596c-d = test. 15) e eram estas viagens comerciais que permitiam a circulação de pessoas entre as diversas regiões do Mediterrâneo.

${ }^{4}$ Nas citações desta obra, transcrevemos a tradução de D. F. Leão (1999). Uma lista de poetas e sábios gregos que visitaram o Egipto foi registada por Diodoro Sículo (1. 96. 2-3). Cf. Marasco 1978: 45-69, André et Baslez 1993: 283-285, Rodrigues 2004: 483, esp. As viagens de Sólon, em particular as que terá realizado após a proclamação do seu código de leis (cf. Plu. Sol. 25. 6, 26) e o lendário encontro com Creso da Lídia (Hdt. 1. 29-33, Plu. Sol. 27-28) constituíam um tema bastante popular. Por outro lado, a realização de muitas viagens é um topos nas tradições helenísticas sobre a formação do legislador, como demonstra A. Szegedy-Maszak, "Legends of the Greek Lawgivers", GRBS 19 (1978) 199-209, esp. 202. Sobre as viagens de Sólon, vide Hans-Dieter Reeker, "Solons Reisen", Antike und Abendland 17 (1971) 96-104; A. J. Podlecki, "Solon's Sojourns", in P. T. Brannan (ed.), Classica et Iberica. A Festschrift in Honor of the Rev. Joseph M.-F. Marique, S.J. (Worcester, Mass. 1975) 31-40; M. Manfredini e L. Piccirilli, Plutarco. La Vita di Solone (Milano 1977) 117-119; S. Alessandrì, "I viaggi di Solone”, CCC 10 (1989) 191-224; Leão 2001: 246-250, 275-277 e, sobre o encontro lendário com Creso da Lídia, "Sólon e Creso: fases da evolução de um paradigma”, Humanitas 52 (2000) 27-52. 
apenas se aventurara numa travessia marítima até Cálcis (vv. 650-662, cf. supra pp. 27-31).

A violência do mar inspirou um dos topoi literários mais perenes. O tema do naufrágio (ou da tempestade), que já aparece nos mais antigos contos egípcios ${ }^{5}$, torna-se frequente na literatura grega desde a Odisseia. $\mathrm{O}$ P. Oxy. 2310, de meados do séc. II d.C., contém fragmentos de um poema de Arquíloco (fr. 1 col. i. 22-39 = fr. 24 W), no qual a persona loquens exprime a sua alegria pelo regresso de Gortina de um ente querido, depois de uma atribulada viagem por mar $^{6}$. Remonta ainda a Arquíloco um outro tema que alcançou grande fortuna. Heraclito, autor de uma obra intitulada Alegorias Homéricas, que pode ter vivido no séc. I da nossa era, observa que o poeta de Paros compôs sobre as lutas da Trácia como se falasse de uma tempestade no mar e cita três versos que confirmam as suas palavras (fr. $105 \mathrm{~W}$ ). Heraclito também notou que a chamada 'Alegoria da nau do Estado' foi retomada por Alceu em muitas das suas composições (Allegoriae Homericae 5), como atestam os frr. 6, 73, 208 e 305 L-P7.

$\mathrm{O}$ episódio de Aríon mostra que um outro grande perigo das viagens marítimas era a pirataria que, tal como o saque, foi durante séculos considerada um meio legítimo de subsistência (e.g. Od. 3. 71-74, Thuc. 1. 5-8) ${ }^{8}$. No entanto, as deslocações por terra não eram muito mais seguras. Um passo da Vida de Sólon de Plutarco testemunha a preocupação do legislador ateniense com este problema (21. 5): 'Também sobre as deslocações, manifestações de luto e festividades das mulheres estabeleceu uma lei que reprimira a desordem e o excesso: determinou que não saíssem com mais de três vestes, que não levassem comida e bebida de custo superior a um óbolo, nem um cesto de comprimento superior a um côvado, que não viajassem de noite, a não ser transportadas num carro e precedidas por uma luz acesa. (...)'. Se a primeira parte da lei denuncia sobretudo a intenção de controlar os movimentos das mulheres e limitar o tempo em que podiam estar ausentes, as disposições sobre as suas viagens sugerem antes a preocupação com a sua segurança, principalmente se viajassem de noite ${ }^{9}$.

${ }^{5}$ Segundo observa Rodrigues 2004: 490, o Conto do Náufrago remonta ao IIo milénio.

${ }^{6}$ Recorde-se que as descobertas papirológicas permitiram recuperar fragmentos de um poema no qual Safo comentava o regresso do irmão do Egipto $(P$. Oxy. $7+2289.6=\mathrm{fr} .5$ L-P, cf. supra n. 3). Sobre este tipo de composição em que se exprime o desejo de boa viagem (propemptikon), vide infra p. 170 e n. 130.

${ }^{7}$ Para um estudo deste tema, vide F. Rodríguez Adrados, "Origen del tema del nave del Estado en un papiro de Arquíloco”, Aegyptus 35 (1955) 206 (= El mundo de la lírica griega antigua, Madrid, 1981, 167-171); F. J. Cuartero, "La metáfora de la nave, de Arquíloco a Esquilo", BIEH 2.2 (1968) 41-45.

${ }^{8}$ Sobre a pirataria no mundo antigo, vide H. A. Ormerod, Piracy in the Ancient World (Liverpool 1978), Philip de Souza, Piracy in the Graeco-Roman World (Cambridge 1999).

${ }^{9}$ Sobre as disposições de Sólon acerca das mulheres, vide D. F. Leão, "Legislação relativa às mulheres na Vita Solonis de Plutarco”, in J. R. Ferreira (coord.), Plutarco Educador da Europa. 
Na tragédia Rei Édipo de Sófocles, Jocasta observa que a morte de Laio era atribuída a ladrões que teriam atacado o monarca num entroncamento de três caminhos ${ }^{10}$. Mais tarde, Édipo revelará à rainha um encontro infeliz que tivera no passado, mas alimentando a esperança de não existir qualquer relação entre os dois acontecimentos. Tal encontro tivera um desfecho fatal, porque o condutor do carro e o seu acompanhante insistiram em afastar do caminho, por certo estreito, um peregrino, Édipo, que tardou em dar passagem (vv. 800-812). Além do significado literário e da sua importância na estrutura da tragédia, estes dois passos testemunham uma realidade que provavelmente não deveria parecer estranha aos Atenienses que no último quartel do séc. V assistiam pela primeira vez à sua representação ${ }^{11}$.

Assim, além dos riscos de assaltos, uma viagem implicava quase sempre um grande esforço, pois a manutenção das estradas não despertava grande interesse por razões de natureza geográfica, política e económica. Os numerosos sistemas montanhosos que dominam a paisagem grega, fruto da intensa actividade tectónica, o solo rochoso e acidentado, bem como os declives acentuados das vertentes, dificultavam a abertura de vias e constituíam um dos maiores obstáculos à circulação por terra ${ }^{12}$. O passo de Heródoto sobre o envio de forças lacedemónias a Maratona indicia que eram necessários pelo menos dois dias para se percorrer a distância entre Esparta e Atenas (6.120). Mesmo na época de Xenofonte era difícil viajar de Atenas até Olímpia (cf. Mem. 3. 13. 5). Por outro lado, a organização política da Grécia em pequenos estados independentes, cuja autoridade terminava, muitas vezes, nos limites das muralhas, não era favorável a uma política de desenvolvimento e manutenção das vias de comunicação, ao contrário do que acontecia no Império persa e se viria a verificar mais tarde no Império romano. As viagens a pé seriam, por isso, frequentes e bastante difíceis, sobretudo se era necessário transportar bagagens. O recurso a um escravo, quando não era possível utilizar um carro ou um animal de carga, seria uma situação vulgar (cf. Xen. Mem. 3. 13. 6), já que aparece retratada com alguma frequência na comédia aristofânica ${ }^{13}$.

\footnotetext{
Actas (Porto-Coimbra 2002) 81-91.

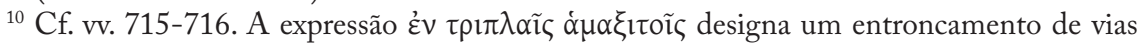
carroçáveis.

${ }^{11}$ Para a datação da tragédia, que terá ocorrido entre 427 e 425, vide as considerações de Maria do Céu Fialho, in Rocha Pereira et alii 2003: 171.

12 Sobre os condicionalismos de natureza climática e geológica, vide Susan E. Alcock, "Environment", in Paul Cartledge (ed.), The Cambridge Illustrated History of Ancient Greece (Cambridge 1998) 13-34; A. Andrewes, The Greeks (London 1967) 1-13; N. G. L. Hammond, $A$ History of Greece to 322 B.C. (Oxford $\left.{ }^{3} 1991\right)$ 1-18; Osborne 1996: 53-55, 58-60.

${ }^{13} \mathrm{O}$ aproveitamento cómico desta realidade é analisado por M. F. Silva, "Execução dramática do tema 'viagem' na comédia de Aristófanes”, Máthesis 5 (1996) 105-121.
} 
As condições de mobilidade não terão melhorado substancialmente dado que, vários séculos após a representação de Rei Édipo, Pausânias repara na antiguidade da rede rodoviária do seu tempo e nas limitadas capacidades de utilização por veículos ${ }^{14}$. Não será por acaso que um dos topoi da tradição pseudo-biográfica tenha sido inspirado pelos riscos e dificuldades das deslocações. Nestes relatos raras vezes o poeta cumpre a sua existência alheio aos perigos que espreitam quem viaja. Aríon foi vítima de piratas, mas salvou-se. Íbico foi assassinado por salteadores num lugar isolado, de acordo com uma tradição célebre, citada por Antípatro de Sídon $(A P 7.745=$ epigr. XIX Gow-Page, test. 5) e na Suda (s.v. "I ßukoৎ = test. 1). Himério também conta que uma vez o poeta escorregou do carro em que seguia, de Cátana até Hímera, e magoou de tal maneira a mão que teve de deixar de compor durante algum tempo, pelo que dedicou a sua lira a Apolo (Or. 69. 35 = Ibyc. fr. 343 $P M G)$.

Não obstante o elevado grau de fantasia destes relatos, eles remetem para problemas reais, dos quais nos chegaram outros testemunhos mais credíveis ${ }^{15}$. Quando discutimos a mobilidade dos rapsodos, citámos o testemunho de Diodoro Sículo sobre os artistas que o tirano de Siracusa enviou a Olímpia no ano de 388 e viriam a perder a vida num naufrágio (14. 109. 1-6, vide supra, pp. 54-55). Um desastre semelhante ficara na memória dos povos da Sicília. $\mathrm{Na}$ descrição das estátuas consagradas ao santuário de Zeus em Olímpia, Pausânias informa que os cidadãos de Messana (actual Messina, cf. infra p. 253) cumpriam o costume antigo de enviar a Régio um coro de trinta e cinco rapazes, o seu mestre e um auleta, a fim de participarem num festival local. Um dia, a embarcação que os transportava foi apanhada por uma tempestade no Estreito, naufragou e levou à morte todos os seus tripulantes. Profundamente amargurados, os cidadãos de Messana consagraram ao santuário de Olímpia estátuas em bronze de todos os náufragos. Este desastre terá ocorrido na segunda metade do séc. V, pois Pausânias explicita que a inscrição foi composta pelo filósofo Hípias e o autor das estátuas foi Cálon de Élis (5. 25. 2-4) ${ }^{16}$.

Franco Mosino observou que esta notícia atesta a pervivência da tradição lírica coral nas cidades do Estreito, muito depois do tempo de Estesícoro e de

${ }^{14}$ Cf. Paus. 1. 44. 6, 2. 11. 3, 2. 15. 2, 10. 5. 5, 10. 32. 8. Para um estudo das vias de comunicação e condições de mobilidade no mundo grego, vide Rougé 1975, Marasco 1978: 15-41; W. Kendrick Pritchett, "Ancient Greek Roads", in Studies in Ancient Greek Topography. Part III: Roads (Berkeley 1980) 143-196; André et Baslez 1993: 373-448, 483-540; Casson 1994: 65-94, Gómez Espelosín 2000: 23-35, Araújo e Rodrigues 2006.

15 Nestes testemunhos se incluem as numerosas inscrições fúnebres sobre vítimas de naufrágios, ainda que nem todas sejam autênticas. Cf. o nosso comentário aos epigr. LXXXIV e LXXXV, integrados no corpus de Simónides, infra, pp. 121-122.

${ }^{16}$ Cf. Vallet 1958: 306-307. Sobre Cálon de Élis, cf. Paus. 5.27. 8. 
Íbico. Notou também que, embora o número de trinta e cinco coreutas seja invulgar ${ }^{17}$, o $\delta 1 \delta \alpha ́ \sigma \kappa \alpha \lambda$ oৎ que os acompanhava não seria apenas mestre do coro, mas também poeta, portanto um epígono dos dois famosos líricos ${ }^{18}$. Estas observações remetem-nos para um outro assunto: as condições de produção e de execução coral.

$\mathrm{Na}$ Época Arcaica o poeta lírico era responsável pela composição e execução da sua obra. Quando a interpretação estava a cargo de um coro, tinha a tarefa acrescida de lhe ensinar a letra e a música, bem como a coreografia. Desde os primórdios que assim era, como se depreende do testemunho de Pausânias acerca do prosodion de Eumelo de Corinto, mas não dispomos de muitos dados sobre esta matéria, além dos que podemos recolher nos textos dos próprios poetas e de alguns testemunhos de épocas posteriores.

No 'Grande Partenéion' de Álcman, o coro actua sob a direcção de

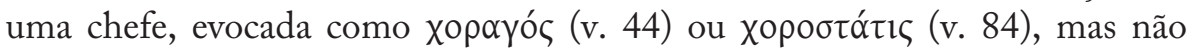
alude, pelo menos na parte conservada, ao papel do poeta. Com ele parece identificar-se, todavia, a persona loquens do fr. $26 \mathrm{P}$, que se lamenta de já não conseguir acompanhar (na dança?) as donzelas de voz melodiosa. O relevo é dado à actuação do coro, à sensualidade do canto e graciosidade da dança (cf. frr. 27, $28 \mathrm{P}$ ). O fr. $39 \mathrm{P}$, porém, não deixa dúvidas quanto à identificação de Álcman com o inventor da melodia inspirada pelo canto da perdiz (cf. fr. 40 P). Ocorrem ainda no seu corpus breves referências ao acompanhamento

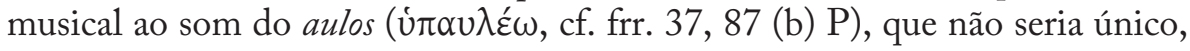
dado que no fr. $38 \mathrm{P}$ as donzelas elogiam o executante da cítara (cf. frr. 41, 101 $\mathrm{P})$, possivelmente o próprio poeta.

Nos versos de Anacreonte o sujeito poético é também o executante a solo de um instrumento de cordas, que pode chamar-se pektis (frr. 373. 3, 386 PMG) ou magadis (fr. $374 P M G)^{19}$. O fr. $375 P M G$ sugere que o som do 'meio-aulos'

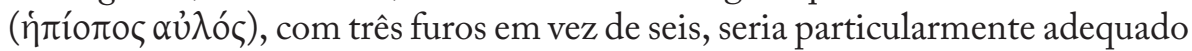
ao acompanhamento de uma dança.

${ }^{17} \mathrm{O}$ número de elementos de um coro parece ter sido variável, mas não existem muitos dados. Os versos e escólios do ‘Grande Partenéion’ de Álcman indicam que foi executado por dez ou onze donzelas (cf. fr. 1. 98-99 P) e os coros ditirâmbicos tinham cinquenta membros. Heródoto menciona que no início do séc. V os cidadãos de Quios enviaram a Delfos um coro de cem jovens (6. 27. 2). Macan 1973 [1895]: I 289 notou que seria provavelmente um coro duplo ou dois coros, que os cidadãos teriam enviado para executar ditirambos em honra de Diónisos.

${ }_{18}$ Franco Mosino, "Lirica corale a Reggio: una notizia trascurata", QUCC 26 (1977) 117-119.

${ }^{19}$ Sobre a $\pi \eta \kappa \tau i ́ \varsigma$, cf. Sapph. frr. 22. 11, 156 L-P, Pind. fr. 125. 3 Ma. Ateneu, que transmite o fragmento de Píndaro, indica que este instrumento era de origem lídia (14. 635b). A $\mu \alpha{ }_{\gamma} \alpha \delta$ เ é referida por Álcman no fr. 101 P. Em Athen. 14. 634f designa um instrumento de sopro. Cf. West 1992b: 71-75. 
Em princípio, o péan era entoado ao som do aulos $^{20}$, bem como o ditirambo ${ }^{21}$, mas é possível que a combinação deste som com o de um instrumento de cordas tenha sido privilegiada na execução coral. Supomos que o poeta tocava a cítara e se faria acompanhar de um auleta (cf. supra Paus. 5. 25. 2). A mistura do som do aulos com o da cítara e das castanholas ( $\kappa \rho o ́ \tau \alpha \lambda \alpha$ ) é mencionada nos vv. 24-25 do fr. 44 L-P de Safo, que pode ter integrado uma composição na qual a poetisa de Lesbos evocou o casamento de Heitor e de Andrómaca. No P. Oxy. 2735, fr. 1.5 (= $166 S L G, 282 \mathrm{~A}$ Campbell), atribuído a Íbico, lê-se

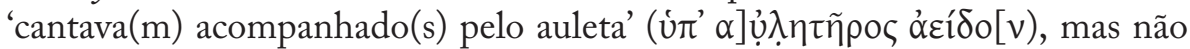
é seguro que se trate de uma indicação sobre as circunstâncias de execução do poema, que para alguns estudiosos seria um epinício, como dissemos (cf. supra, p. 91 n. 75). A combinação dos sons do aulos e de um instrumento de cordas é atestada pelas odes de Píndaro, que refere, além dos auloi, a lira, a cítara e a phorminx (possivelmente em sentido figurado) ${ }^{22}$.

Estes exemplos sugerem que os poetas por norma mencionavam nas suas obras os instrumentos musicais e até os executantes, mas parece que se abstinham de comentar a preparação do coro, de que em princípio se ocupavam. Um papiro do séc. I ou II da nossa era transmitiu-nos um comentário sobre a vida de Álcman, no qual se lê que, apesar da origem lídia do poeta, os Espartanos confiaram-lhe a preparação coral das suas donzelas e dos seus efebos $^{23}$. Como vimos já, a Suda atribui a Aríon a primeira organização de um coro ditirâmbico (s.v. 'Apí $\omega v=$ test. 1) e associa o nome de Estesícoro à actividade coral (s.v. $\Sigma \tau \eta \sigma^{\prime} \chi 0 \rho \circ \zeta=$ test. 1 ). São também tardias as fontes que atribuem a Simónides (vide infra, pp. 126 sqq.) e a Píndaro o ofício de

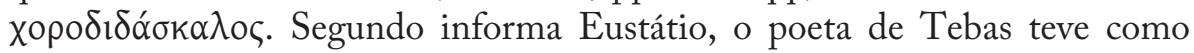
mestre, além de Laso de Hermíone, um tal Apolodoro que em Atenas tinha a seu cargo o treino dos coros circulares (do ditirambo). Quando se ausentava da

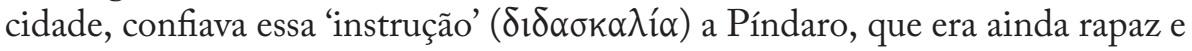
se saía tão bem na tarefa que logo alcançou grande fama ${ }^{24}$.

Supondo que estas notícias têm um fundo de verdade, o poeta tinha a seu cargo uma tarefa exigente. Se a prática de anotar a música não é anterior à segunda metade ou final do séc. $V$, como se pensa, os coreutas aprendiam de cor não só a letra, mas também a melodia ${ }^{25}$. Este tipo de aprendizagem,

${ }^{20}$ Cf. Archil. fr. $121 \mathrm{~W}$; Pind. fr. 52c. 94, 52g. $11 \mathrm{Ma}$.

${ }^{21}$ Cf. Pind. fr. 75. 18 Ma., Bacch. Dith. 23.

${ }^{22}$ Vide as referências em Rocha Pereira 2006: 196-197 n. 12.

${ }^{23}$ P. Oxy. 2506, fr. 1 col. ii $=$ Alcm. test. 9. Para uma análise deste testemunho, vide Herington 1985: 24.

${ }^{24}$ Eust. prooem. Pind. 27, III. 299-300 Dr., citado por Campbell 1991: 294-295.

${ }^{25}$ Segundo escreve West 1992b: 254, em meados do séc. III, pelo menos, estava em uso um sistema de notação musical entre profissionais, sobre o qual o nosso melhor informador é o tratadista Alípio. No entanto, as pinturas de vasos, em especial um krater de volutas do Pintor 
pelo menos no tempo de Sócrates, era treinado desde a instrução básica, como testemunha o Protágoras de Platão (326a-b): as crianças começavam por decorar as obras dos grandes poetas e aprendiam depois o acompanhamento musical.

A organização dos coros das Grandes Dionísias era um reflexo do sistema democrático e obedecia a regras estabelecidas pela pólis. Cada uma das dez tribos de Atenas fornecia cinquenta homens e cinquenta rapazes para os coros ditirâmbicos (cf. Simon. epigr. XXVIII. 4, infra p. 131). Doze eram os coreutas das tragédias (mais tarde quinze) e vinte e quatro os das comédias. A organização do festival envolvia, portanto, um grande número de participantes. Compreende-se que as despesas da sua preparação fossem custeadas por um cidadão muito rico, o choregos (cf. infra, p. 132 n. 35).

Não dispomos deste tipo de dados sobre a preparação e funcionamento dos coros líricos na Época Arcaica. Píndaro alude com frequência aos custos e à generosidade dos seus patronos, e alguns estudiosos relacionam este topos com as condições de produção da lírica coral mais tardia ${ }^{26}$. Se, por um lado, a execução de um poema por um coro treinado implicava maiores custos do que a apresentação a solo num banquete, por outro, a partir da segunda metade do séc. VI, a lírica coral deixa de existir apenas no âmbito dos festivais religiosos e passa a ser promovida também por patronos ricos. A introdução de um modelo económico nas relações entre poeta e patrono é atribuída pela tradição a Simónides e é possível, como supõem alguns helenistas, que tenha sido ditada pelas despesas que exigia uma produção sofisticada, designadamente de um epinício, que deviam agora ser custeadas pelo cidadão abastado que a requisitava a título particular (vide infra, p. 175).

Um dos aspectos mais interessantes da obra de Píndaro e de Baquílides é o seu carácter pan-helénico. O corpus de Píndaro, muito mais extenso, mostra que celebrou atletas de Tebas, da Grécia Continental, das ilhas de Egina, Rodes e Ténedos, de Cirene e da Magna Grécia ${ }^{27}$. Os fragmentos atestam que compôs peanes, ditirambos e partheneia a pedido dos seus concidadãos, mas foi também requisitado por muitas outras cidades gregas. Em 476, com cerca de quarenta e dois anos, Píndaro tem plena consciência da sua condição de poeta pan-helénico, quando afirma na ode dedicada a Hierão de Siracusa:

de Sísifo (Munique, Staatliche Antikensammlungen F 3268, c. 425-400), indiciam que já no séc. V havia uma forma, ainda que incipiente, de anotar a melodia. Cf. Gentili e Pretagostini 1988: viii, Rocha Pereira 2006: 647-650, que reproduz o referido krater nas pp. 639 e 648.

${ }^{26}$ E.g. Ol. 5. 15, Pyth. 5. 106-107, Isth. 1. 42, 5. 57, 6.10. Para uma análise desta questão, vide o estudo de Kurke 1991 e Carey 2007.

${ }^{27}$ Alguns destes atletas pertenciam a famílias que se notabilizaram pelos muitos triunfos conquistados nos Jogos, como Diágoras de Rodes (Ol.7), Xenofonte de Corinto (Ol.13, cf. infra, p. 155) e Alcímidas de Egina (Nem.6). 
'A ti te seja dado passar o tempo a trilhar as alturas,/ e a mim juntar-me aos vencedores,/ espalhando a minha arte por toda a Grécia. ${ }^{28}$.

Embora nem todas as suas odes possam ser datadas, e o corpus não esteja completo, depreende-se que em certas épocas estaria bastante ocupado. No referido ano de 476, por exemplo, compôs a $I^{a}$ Olímpica para Hierão, que venceu a corrida de cavalos, bem como a $I I^{a}$ e a $I I I^{a}$ Olímpicas para Téron de Agrigento, pelo triunfo na corrida de quadrigas de cavalos. Foi também convidado a celebrar a vitória de Hagesidamo da Lócrida Ocidental na prova de boxe para paides, mas nos versos iniciais da ode, a $X^{a}$ Olimpica, o poeta confessa que se havia esquecido do contrato. A XIa Olimpica celebra o mesmo triunfo e é plausível a hipótese de A. Boeckh de que esta ode, de vinte versos apenas, teria sido cantada no lugar dos Jogos, ficando prometida uma composição mais elaborada para mais tarde (apud Race 1997a: 174; cf. Willcock 1995: 55). Nos vv. 99-102 da $X^{a}$ Olimpica, em princípio posterior, o poeta recorda que viu o atleta vencer em Olímpia. A linguagem dos epinícios é muitas vezes convencional ou figurada, mas neste caso a afirmação parece verosímil, porque neste festival competiram os patronos mais importantes e é natural que o poeta se encontrasse entre os espectadores.

Também na $I^{a}$ Ístmica, que não podemos datar, na qual celebra um concidadão que triunfara na corrida de carros, Píndaro revela nos versos de abertura que privilegiou este trabalho em prejuízo do pouco tempo que tinha para compor o péan encomendado pelos cidadãos de Ceos, a fim de ser executado em Delos (o $I V^{o}$ Péan = fr. 52d Ma.), em princípio porque os atletas tebanos haviam conquistado seis coroas nos Jogos Ístmicos (cf. vv. 10-11).

Baquílides não alcançou a reputação de Píndaro, mas os catorze epinícios que se preservam indicam que celebrou atletas de Ceos (1, 2, 6, 7 e 8), Egina $(12,13)$, Atenas (10), Fliunte (9), Tessália (14) e Magna Grécia (3, 4, 5 e 11). O restante corpus atesta contactos com diversas cidades: o Dith. 16 foi executado em Delfos, o Dith. 17 em Delos por concidadãos, os Dith. 18 e 19 foram encomendados por Atenienses e o Dith. 20 foi composto para Espartanos. Finalmente, o fr. $4 \mathrm{Ma}$. pertence a um péan destinado ao santuário de Apolo em Ásine, situada a sudeste de Argos. O patrono mais ilustre do poeta foi Hierão, para quem compôs as odes 3, 4 e 5, e um encómio (fr. 20C Ma.).

No último dia dos Jogos realizava-se a festa de consagração do vencedor e os cânticos eram entoados durante o banquete festivo, à noite (cf. Pind. Ol. 10. 73-77). A colecção de epinícios de Píndaro e de Baquílides mostra que era muito variável o número de versos. Podiam ser organizados em tríades ou repetir a mesma estrofe (monostróficos), como o IVo Epinício de Baquílides,

${ }^{28}$ Ol. 1. 115-116, tradução de M. H. Rocha Pereira (2009: 185). Para um estudo da noção de pan-helenismo em Píndaro, vide Ferreira 1992: 314-328. 
composto em honra da vitória de Hierão na corrida de carros dos Jogos Píticos de 470, que tem apenas vinte versos. O mesmo triunfo foi cantado por Píndaro na grandiosa $I^{a}$ Pitica, uma ode com cem versos e estrutura triádica.

Alguns epinícios dão-nos indícios sobre o local da sua apresentação. Para Lácon de Ceos, vencedor da corrida de estádio na categoria de paides, na 82a Olimpíada (= 452), Baquílides compôs uma pequena ode monostrófica, com apenas dezasseis versos, que foi executada perante a casa do atleta (6. 14-15). Na opinião de Webster 1970: 109-110, o VII Epinício, sobre o mesmo triunfo, foi possivelmente apresentado no local dos Jogos, dado que o poeta invoca o $16^{\circ}$ dia do mês olímpico (vv. 2-3), o dia da entrega das coroas da vitória.

Por vezes, os indícios apenas nos permitem fazer conjecturas. Os dois primeiros epinícios da colecção de Baquílides celebram a vitória de Argeu, seu compatriota, na prova de pugilato para paides dos Jogos Ístmicos. O segundo tem apenas catorze versos e é de supor que tenha sido cantado no festival, porque o primeiro, uma composição elaborada que desenvolve um mito de Ceos, é mais adequado a uma cerimónia de homenagem realizada na pátria do atleta (cf. Webster 1970: 109, Campbell 1992: 125).

Portanto, as odes podiam ser cantadas no local dos Jogos, à porta do vencedor ou no seu palácio. Um topos dos epinícios de Píndaro e de Baquílides é o elogio da hospitalidade do patrono, pois certamente lhe cabia o dever de acolher o poeta e os coreutas ${ }^{29}$.

Estes exemplos dão-nos uma ideia da dimensão das relações sociais de Píndaro e Baquílides, que provavelmente supervisionavam na maioria das vezes a execução das suas odes. No entanto, parece que nem sempre isso seria possível nem sequer necessário, porque há indicações de que podiam ser enviadas $^{30}$.

A $V I^{a}$ Olimpica de Píndaro celebra o triunfo de Hagésias de Siracusa na corrida de mulas (em 472 ou 468), mas foi executada em Estinfalo, na

${ }^{29}$ E.g. Pind. Ol. 1. 103-105, 4. 14-16, 13. 1-8; Pyth. 10. 64-66; Nem. 7. 61-63; Bacch. 13. 224-226. Sobre as relações de xenia entre Simónides e o vidente Megístias da Acarnânia, vide infra, pp. 269-270. A protecção dada aos poetas líricos por homens de poder deve ter conduzido a situações de exagero tal que mereceu da parte de Aristófanes um tratamento paródico. Nas Aves, levadas à cena em 414, o primeiro visitante é um poeta pelintra e andrajoso, que se apresenta para entoar um hino de louvor à nova cidade, mas em breve revela os verdadeiros intentos: mendigar o sustento (vv. 904-952). Para um estudo desta paródia do poeta oportunista e sem talento, vide os comentários de M. F. Silva, in Silva e Jesus 2010: 438-442 (cf. 1987: 418-419 e n. 17), e o artigo de M. Hammou, "Kukliodidaskalos, Didaskalos, Poétès. Les personnages de poètes dans les Oiseaux d'Aristophane”, Cabiers du GITA 15 (2002-2003) 101-120.

${ }^{30}$ Esta questão foi tratada por Bowra 1964 e Herington 1985: 30-31, 189-191, mas o estudo mais detalhado é o de Tedeschi 1985. Depois de examinar um largo número de odes passíveis de terem sido enviadas, reflecte nas pp. 53-54 sobre as circunstâncias que legitimavam o recurso a esta prática, designadamente a existência de uma relação próxima com o destinatário e a falta de actualidade da ocasião agónica (ou a sua ausência). 
Arcádia, terra da linhagem materna do atleta (vv. 77-78). Nos vv. 87-88, o poeta invoca Eneias, identificado pelo escoliasta como chorodidaskalos (148a, 149a Dr.), e dá-lhe indicações precisas sobre a execução da ode (vv. 88-96). Os versos seguintes sugerem que o coro regressaria a Siracusa, pelo que é de supor que fosse formado por compatriotas de Hagésias (cf. v. 98), como conjectura também Herington 1985: 190. Os votos finais para que o poema faça boa viagem (vv. 103-105) confirmam o seu envio. Parece não haver dúvidas, portanto, de que Píndaro não só enviou o epinício como também o coro que o executou. Uma vez que uma das orientações dadas a Eneias é o louvor de Hierão (vv. 92-97), supomos que o poeta fosse seu hóspede nesta altura.

$\mathrm{Na} I I^{a}$ Pítica, que celebra uma vitória do tirano na corrida de carros, o poeta declara na abertura que chegou a Siracusa, vindo de Tebas, com a ode

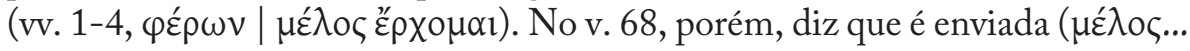
$\mu \varepsilon ́ \mu \pi \varepsilon \tau \alpha l)$ e nos versos seguintes explicita o modo musical da sua execução (vv. 70-71). A incoerência dissipa-se se considerarmos, como defendem alguns estudiosos, que no começo do epinício o poeta falava em sentido figurado. Em nossa opinião, este exemplo é problemático, por não ser possível estabelecer uma datação segura (cf. Race 1997a: 228) e pelas muitas dificuldades de interpretação da própria ode ${ }^{31}$.

A III ${ }^{a}$ Pítica, composta entre 476/5 (fundação da cidade de Etna, cf. v. 69) e 467 (morte de Hierão), foi incluída pelos gramáticos alexandrinos entre os epinícios, porque alude à vitória pítica alcançada pelo cavalo Ferenico (provavelmente em 478, cf. Bacch. 5. 37-41). Todavia, é mais propriamente uma ode de carácter consolatório, que Píndaro dedicou ao seu patrono de Siracusa, quando ele já se encontrava muito doente. Os vv. 68-76 sugerem que o poeta não pôde sair de Tebas e optou por enviar a composição. Nada indica, porém, que não pudesse ter sido executada ${ }^{32}$. Por conseguinte, talvez não seja adequada a designação 'epístola poética', que lhe deu Wilamowitz e foi adoptada por outros helenistas ${ }^{33}$.

${ }^{31}$ C. M. Bowra, "Pindar, Pythian II", HSPh 48 (1937) 1-28 (= Problems in Greek Poetry, Oxford, 1953, 66-92), defende que se trata de uma 'epístola poética', composta quando Hierão venceu a corrida de carros olímpica em 468 (cf. 1964: 135, 361). Tedeschi 1985: 34-35 sugere que nos vv. 1-4 a persona loquens é o coro que levava a ode consigo e sublinha que os escoliastas não tinham dúvidas quanto ao seu envio (cf. p. 35 n. 21). Cf. infra a posição divergente de D. C. Young.

${ }^{32}$ Cf. Frank J. Nisetich, Pindar's Victory Songs (Baltimore-London 1980) 168, Herington 1985: 190.

${ }^{33}$ U. von Wilamowitz-Moellendorff, Die Textgeschichte der griechischen Lyriker (Berlin 1900) 148, Pindaros (Berlin 1922) 280, considerou 'epístolas poéticas' (poetischen Brief) as $I I^{a}$ e $I I I^{a}$ Piticas e a II Ístmica. Cf. Bowra 1964: 408, Herington 1985: 47. A existência de 'epístolas poéticas' no tempo de Píndaro é contestada por David C. Young, "Pindar Pythians 2 and 3:

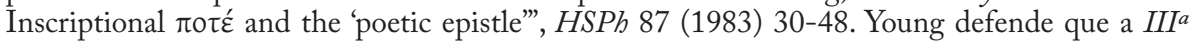
Pítica foi composta em honra da vitória de Hierão na corrida de cavalos do festival pítico de 478 , 
A III ${ }^{a}$ Nemeia, cuja data de composição desconhecemos, celebra a vitória de Aristoclides de Egina no pancrácio. O poeta diz nos vv. 76-77 que envia

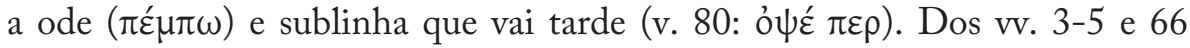
deduzimos que foi cantada na terra do atleta por um coro de jovens, ao som do aulos (v. 79). Não nos parece, no entanto, que haja razões para supor que estes executantes teriam sido também enviados pelo poeta ${ }^{34}$.

A IIa Ístmica, talvez composta o mais tardar até 470 (cf. Race 1997b: 144), é a última das odes referentes à família dos Eménidas de Agrigento, que também foram patronos de Simónides. Píndaro dirige-se a Trasibulo (vv. 1, 31), mas a ode é dedicada a seu pai, Xenócrates, já falecido (cf. vv. 36-42), cuja vitória ístmica é recordada nos vv. 12-17 (cf. infra, p. 171). A terminar, o poeta invoca um tal Nicasipo e declara que será ele o portador da sua ode (vv. 47-48). Como não faz qualquer comentário a respeito das condições de execução, o título 'epístola poética' parece-nos mais adequado neste caso ${ }^{35}$. Todavia, se Nicasipo fosse um chorodidaskalos, como conjectura Herington 1985: 190, a inclusão do seu nome na ode podia ter sido uma forma de validar o seu papel de representante do poeta junto do patrono siciliano. Ao que parece, Píndaro enviou-lhe também um encómio, do qual nos chegou o fr. 124ab (cf. vv. 1-2) ${ }^{36}$. Herington 1985: 191 regista ainda o testemunho de

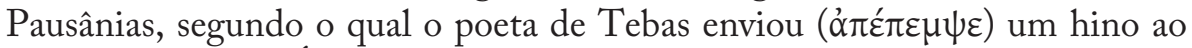
santuário de Zeus Ámon (9. 16. 1).

O corpus de Baquílides atesta também a prática do envio de poemas. Pelo menos, é o que depreendemos de algumas afirmações. Como já referimos, Píndaro celebrou a vitória de Hierão de Siracusa na corrida de cavalos da $76^{a}$ Olimpíada (= 476) na $I^{a}$ Olimpica. Para honrar o mesmo triunfo, Baquílides enviou-lhe de Ceos um longo epinício, organizado em cinco tríades (5. 10-16, 195-200), no qual elogia a sua hospitalidade (v. 49), mas é provável que ainda não a tivesse experimentado. Ao mesmo soberano enviou também um encómio, do qual se conserva o fr. 20C Ma. (cf. vv. 2-7), posterior à fundação

o mais tardar até 477 (p. 42). Em relação à $I I^{a}$ Pítica, avança a hipótese de ter havido um erro na sua classificação e ser, na verdade, a ode que celebrou o triunfo de Hierão na corrida olímpica de carros, em 468, cantado por Baquílides no $I I I^{\circ}$ Epinício (pp. 46-47).

${ }^{34}$ Como defende Tedeschi 1985: 38. Para uma análise mais detalhada, vide o nosso estudo “Nos passos da Musa ao encontro da luz: Nemeia III", in Lourenço 2006b: 131-147, esp. 144-146.

${ }_{35}$ Cf. Bowra 1964: 124, 410. No estudo que dedicou a esta ode, Frank J. Nisetich, "Convention and Occasion in Isthmian 2", CSCA 10 (1977) 133-156, chama a atenção para o

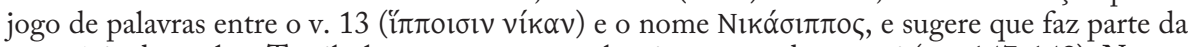
estratégia do apelo a Trasibulo para que mantenha viva a arete de seu pai (pp. 147-148). Na sua opinião, no epodo final o poeta "may in fact be urging Thrasyboulos to accept and perform this song." (p. 149).

${ }^{36}$ Interpretação de Herington 1985: 191 e de Tedeschi 1985: 40-41, contra Bowra 1964: 360 n. 3. 
da cidade de Etna, evocada no v. $7^{37}$. Em princípio, foi também enviado o encómio composto para Alexandre, rei da Macedónia entre 498 e 454, do qual nos chegou o fr. 20B Ma. (cf. vv. 1-4) ${ }^{38}$.

A possibilidade de Píndaro e de Baquílides terem, em determinadas circunstâncias, optado por enviar as suas odes, prática não atestada pelo corpus de Simónides, não é de certo modo compatível com as teorias que se difundiram no início da última década do séc. XX sobre o modo de execução dos epinícios do poeta de Tebas. Estas teorias remontam aos estudos sobre o 'eu' lírico na sua obra $^{39}$ e foram influenciadas em particular pelas teses a favor da execução a solo dos poemas de Estesícoro (vide supra, pp. 82-85). A dúvida principal reside em saber se a persona loquens corresponde à voz do poeta, à do coro ou ao coro como porta-voz do poeta ${ }^{40}$, o que nem sempre é fácil de esclarecer, como já vimos a propósito da II ${ }^{a}$ Pítica (cf. vv. 1-4 e 68), dado o carácter convencional da linguagem da lírica coral, em especial em Píndaro, que emprega com frequência expressões metafóricas ${ }^{41}$. Há casos, porém, em que é indiscutível a identificação da primeira pessoa com a voz do poeta, como nos versos finais da $I^{a}$ Olímpica (cf. supra, pp. 105-106). Trata-se, portanto, de uma polémica de carácter interpretativo, que não reconhece validade a argumentos externos. Todavia, os escólios de Píndaro informam que os epinícios, à semelhança dos peanes, ditirambos, partheneia..., eram executados por um coro treinado pelo poeta. A validade desta e de outras indicações, designadamente a identificação de Eneias da VIa Olimpica (v. 88) com o chorodidaskalos, aceites em geral pela crítica moderna, foi particularmente contestada em 1988 por Mary Lefkowitz

${ }^{37}$ Cf. Webster 1970: 105, 107, Herington 1985: 191, Tedeschi 1985: 40 e n. 37 (aceitam o envio destas composições). A hipótese de o epinício 5 ter sido um meio de Baquílides se apresentar a Hierão, e não uma encomenda oficial, foi defendida especialmente por W. Steffen, "Bacchylides'Fifth Ode", Eos 51 (1961) 12. Para uma opinião divergente, vide D. A. Schmidt, "The Performance of Bacchylides Ode 5", CQ 37.1 (1987) 20-23, que discute a bibliografia anterior sobre esta questão. Schmidt não contesta explicitamente que o poema tenha sido enviado, mas a tese de que não foi encomendado. Supõe ainda que o poeta de Ceos podia ter sido apresentado a Hierão antes de 476, pelo seu tio, Simónides (p. 22). De facto, nada indica que o tirano de Siracusa não conhecia Baquílides antes dessa data, mas ele apenas sucedeu ao irmão, Gélon, em 478 e a tradição situava a ida de Simónides para a sua corte apenas no ano de 476. Sobre este ponto, vide infra, pp. 131-132, 164-165.

${ }^{38}$ Herington 1985: 191 inclui este fragmento na lista dos poemas enviados. Tedeschi 1985: 41, apesar das dúvidas sobre o sentido dos vv. 1-4, aceita a tese do envio do encómio.

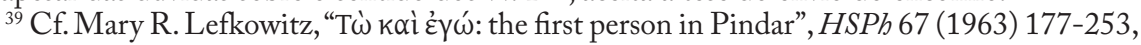
artigo retomado na colectânea de estudos publicada em 1991 (pp. 1-71).

${ }^{40}$ Cf. Edwin D. Floyd, “The Performance of Pindar, Pytbian 8. 55-70”, GRBS 6.3 (1965) 187-200, esp. 187-190, para uma resenha das interpretações principais. Floyd retomou neste artigo a teoria de F. Thiersch (1820) sobre a execução distribuída das odes de Píndaro, segundo a qual alguns passos eram executados pelo coro inteiro, outros por uma parte apenas e outros somente pelo mestre do coro (p. 190).

${ }^{41}$ Um levantamento dessas expressões foi realizado por C. Rueda González, "Imágenes del quehacer poético en los poemas de Píndaro y Baquílides”, $C F C(G) 13$ (2003) 115-163. 
e Malcolm Heath. No ano seguinte, Anne Burnett e Christopher Carey refutaram os seus argumentos em defesa da perspectiva tradicional ${ }^{42}$.

Em nosso entender, a $V T^{a}$ Olimpica contém indícios claros de que a sua execução estava a cargo de um coro. A invocação de Eneias constitui para nós um processo retórico que tinha como objectivo a confirmação do seu papel de representante do poeta ${ }^{43}$. No entanto, não nos parece correcto deduzir a partir deste caso particular que as odes de vitória eram sempre cantadas e dançadas por um coro. Mais errada nos parece a perspectiva contrária, adoptada sobretudo por M. Heath, ou seja, deduzir do exame de um número reduzido de composições (por vezes de passos isolados) que o epinício era um canto a solo entoado pelo poeta (ou por um representante) ${ }^{44}$. Parece-nos que o erro de base destas posições é pressupor que a persona loquens se identifica sempre (ou quase sempre) com o executante. Estas teorias não valorizam a componente ficcional que está presente em muitas odes de Píndaro ${ }^{45}$, nem consideram a possível influência de factores sócio-económicos no modo de execução do epinício: uma actuação coral é mais exuberante e magnificente do que um canto a solo, e seria provavelmente privilegiada se o destinatário tivesse possibilidades financeiras ${ }^{46}$. Por conseguinte, em nossa opinião, este debate teve principalmente o mérito de despertar o interesse de outros helenistas para o estudo das circunstâncias de produção e de execução das odes de Píndaro ${ }^{47}$.

${ }^{42}$ M. Lefkowitz, "Who Sang Pindar's Victory Odes", AJPh 109 (1988) 1-11 (= 1991:

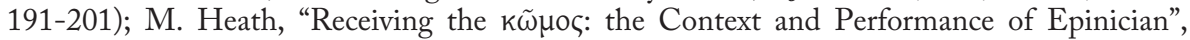
ibidem, pp. 180-195; A. Burnett, "Performing Pindar's Odes", CPh 84.4 (1989) 283-293; C. Carey, "The Performance of the Victory Ode", AJPh 110 (1989) 545-565. Lefkowitz e Heath retomaram a discussão, assinando em conjunto o artigo "Epinician Performance", $C P h$ 86 (1991) 173-191, ao qual respondeu Carey, na mesma revista, com "The Victory Ode in Performance: the Case for the Chorus" (pp. 192-200). Registe-se que a execução a solo de alguns epinícios já havia sido considerada por outros helenistas, designadamente Herington 1985: 31 e, muito antes, Wilamowitz-Moellendorff (Pindaros, Zürich 1922), como recorda Lourenço 2009: 22.

${ }^{43} \mathrm{Na}$ análise deste passo da VIa Olimpica, Lefkowitz, "Who Sang Pindar's Victory Odes",

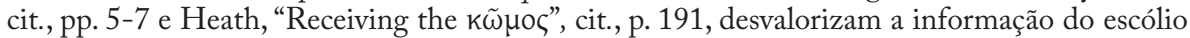
sobre Eneias e apresentam diferentes argumentos no sentido de provarem a interpretação a solo do epinício. Em nossa opinião, estes argumentos foram correctamente contestados por Burnett, "Performing Pindar's Odes", cit., p. 284 n. 9, e Carey, "The Performance of the Victory Ode", cit., pp. 556-557.

${ }_{44}$ No artigo escrito em conjunto, Heath e Lefkowitz adoptam uma posição mais moderada: "We still incline therefore toward the solo hypothesis, although it would be foolish to claim that the choral hypothesis is demonstrably incorrect." (p. 181).

${ }^{45}$ A esta componente ficcional, que está presente, por exemplo, na abertura da $I I I^{a}$ Nemeia, dado que o poeta fala da composição da sua ode como um acto a cumprir, quando já está a ser executada, deu Carey ("The Performance of the Victory Ode", cit., pp. 551-553) a designação de 'subterfúgio oral' (oral subterfuge).

${ }^{46}$ Este argumento é defendido especialmente por Burnett, "Performing Pindar's Odes", cit., pp. 292-293, que voltou a reforçar na monografia publicada em 2005 (cf. pp. 5-9, esp.).

${ }^{47}$ Vide K. A. Morgan, "Pindar the Professional and the Rhetoric of the $\kappa \tilde{\omega} \mu \circ \varsigma^{\prime}, C P h 88.1$ 
Em conclusão, a mobilidade não distingue especialmente os poetas líricos nem é exclusiva da Época Arcaica. Referimo-nos de passagem à viagem ao Egipto realizada no séc. VI por figuras célebres que os Antigos consideravam Sábios. Segundo a Vita Aeschyli, Esquilo deslocou-se à Sicília quando Hierão fundou a cidade de Etna, em cuja celebração participou com o drama perdido Aetnaeae $^{48}$. No mundo helenístico e romano, a mobilidade continuou a fazer parte da vida de muitos profissionais. Cícero transmitiu-nos um testemunho singelo sobre um homem de letras do seu tempo, que atesta a perenidade da mobilidade poética. Nascido em Antioquia no seio de uma família nobre, o poeta Árquias cedo iniciara uma promissora carreira que o levara a divulgar a sua obra em diversas regiões da Ásia e na Grécia inteira, onde era sempre acolhido com grande expectativa e admiração, como sublinhou o orador no discurso pronunciado em sua defesa no ano de 62 (Pro Archia 4).

(1993) 1-15; Michael J. Schmid, "Speaking Personae in Pindar's Epinikia”, CFC: egi 8 (1998) 147-184, "Skytála Moisân: Song and Writing in Pindar", Minerva 12 (1998) 57-81; Anna Bonifazi, "Sull'idea di sotterfugio orale negli epinici pindarici", QUCC 66.3 (2000) 69-86; Viviana Vigneri, "Il coro dell'epinicio pindarico negli scholia vetera", ibidem, pp. 87-103. No comentário a esta polémica, Race 1997a: 15 observa que as provas a favor da execução a solo ou coral não são conclusivas, mas dado que outras formas poéticas tratadas por Píndaro, como o péan, o ditirambo, o partheneion e o hiporquema, eram executadas por um coro e, tendo em conta que as características formais do epinício são similares às dos coros trágicos, considera provável que algumas odes de vitória fossem executadas por um coro que cantava e dançava. Para um exame do estado da questão, vide a revisão crítica desta problemática por Lourenço 2009.

${ }^{48} \operatorname{Tr} G F$ III, T 1.9. 33-34. Sobre as circunstâncias da composição desta obra, vide Bremer 1991: 39-41. Vide ainda infra, p. 144 n. 64. 
PARTe II

O ESPAÇO DE MOBILIDAdE DE Simónides 
(Página deixada propositadamente em branco) 


\section{DAdos Biográficos}

Simónides nasceu em Iúlis, na ilha de Ceos, situada a sudeste da Ática, no seio de uma população de raça iónica e origem ateniense ${ }^{1}$. A filiação paterna do poeta é um dos dados biográficos mais recordados, como atesta um dístico de um epigrama 'sobre os nove líricos', transmitido num escólio de Píndaro (I. 11 Dr. = test. 44):

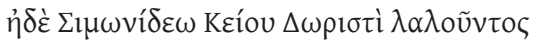

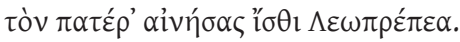

E se falares do pai de Simónides de Ceos, cujo dialecto era dórico, sabe que ele era Leóprepes.

Um passo do orador Élio Aristides (Or. 28. 59-60 = fr. eleg. 89, cit. infra) sugere que esta informação figurava na obra de Simónides, uma hipótese plausível, mas que não podemos confirmar. No entanto, não cremos que tenha sido a necessidade de o distinguir do seu avô que levou os autores antigos a usarem, por vezes, o patronímico, como defendeu Stella 1946: 18-19. Na verdade, segundo escreveu Calímaco num dos seus poemas iâmbicos (fr. 222 Pf. = test. 3, cit. infra), Simónides pertencia a uma família distinta de Ceos, descendente de Hílico, pelo que o seu pai pode ter sido também uma pessoa conhecida ${ }^{2}$.

Como era costume, e o epigrama acima transcrito assim o confirma, os autores antigos evocavam o poeta como 'Simónides de Ceos' ou 'Simónides, filho de Leóprepes'3. Por vezes, uma breve referência à sua ilha é suficiente

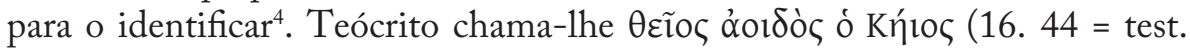
13), mas o escoliasta tem o cuidado de explicar a alusão que, no seu tempo, já não seria, talvez, tão óbvia.

${ }^{1}$ Informação dada por Heródoto (8.46.2), quando enumera as forças gregas que participaram na batalha de Salamina. Cf. Thuc. 7.57. O nascimento de Simónides em Iúlis, mencionado por Estrabão (10.5.6, cit. infra), é referido na nota biográfica sobre o poeta transmitida pelo $P$. Oxy. 1800 fr. 1, col. 2. 36-40, e na Suda $\Sigma 439$ (= test. 1).

${ }^{2}$ Dado que os nomes 'Y $\lambda_{\imath x} \delta \delta_{\alpha} \alpha$ e $\Lambda \varepsilon \omega \pi \rho \varepsilon ́ \pi \eta \varsigma$ figuram numa inscrição de Ceos (IG XII. 5. 609. 102-103; cf. 5. 637), supõe-se que a família de Simónides fosse nobre, como observa Suárez de la Torre 1988b: 210.

${ }^{3}$ Hdt. 5.102 .3 = fr. 518 e 7.228 .4 = epigr. VI, respectivamente; Call. Aet. fr. $64.8-9$ Pf. $=$ test. 21 ; Cic. de Orat. 2. 86. 351 = fr. 510; Plu. Them. 5. 6 = test. 12 ; Paus. 6. 9.9 = epigr. XXIX; Him. Or. 31. 5 = fr. 580; AP 7. $348=$ epigr. XXXVII; Suda $\Sigma 439=$ test. 1.

${ }^{4} A P$ 13. 31 (= Timocr. fr. $10 \mathrm{~W}$, vide infra, p. 148), Call. Iamb. fr. 222 Pf. (= test. 3), Hor. Carm. 2.1.37-38 (= test. 38 ), Athen. 1 (epit.) 32b (= fr. eleg. 24). 
O testemunho mais detalhado sobre a naturalidade do poeta encontra-se na obra de Estrabão, que escreveu (10.5.6 = test. 2):

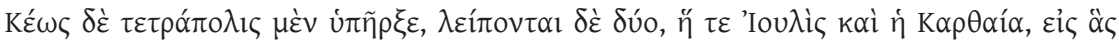

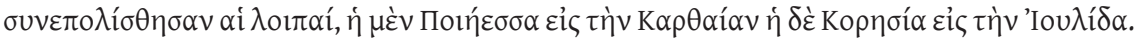

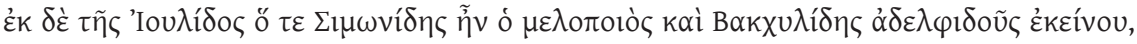

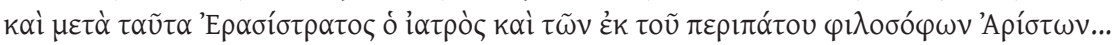

Ceos tinha quatro cidades, mas apenas se mantêm duas, Iúlis e Carteia, às quais foram anexadas as restantes, Poiessa a Carteia e Corésia a Iúlis. De Iúlis era natural Simónides, o poeta lírico, e Baquílides, seu sobrinho ${ }^{5}$, e mais tarde o médico Erasístrato e o filósofo peripatético Aríston...

Nenhuma fonte válida nos informa acerca da infância e formação de Simónides ${ }^{6}$. Os testemunhos e fragmentos revelam que dominava bem Homero, Hesíodo, Estesícoro e Íbico, pelo menos ${ }^{7}$, e é natural que tenha aprofundado os seus conhecimentos ao longo da vida. Sabemos, por outro lado, que a ilha de Ceos foi pátria de atletas premiados ${ }^{8}$ e se tornou famosa pelos seus coros que celebravam Apolo ${ }^{9}$. Por essa razão, alguns helenistas supõem que a vocação lírica do poeta e o gosto pelo canto coral é uma herança cultural, que despertou quando ainda era muito jovem ${ }^{10}$. Curiosamente, segundo uma

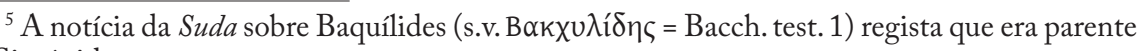
de Simónides.

${ }^{6}$ Cf. Bowra 1961: 309 e n. 8, Huxley 1978: 234.

${ }^{7}$ Cf. testt. 47 (j) e (k), frr. 558, 561, 564, 579 e fr. eleg. 19. No que respeita a Homero e a Hesíodo, vide Brillante 2007, que nas pp. 114-115 comenta os testt. 47 (j) e (k).

${ }^{8}$ Cf. IGXII. 5. 608, lista dos atletas vencedores de Ceos, que estava inscrita no templo de

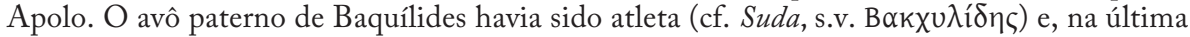
fase da sua carreira, o poeta compôs especialmente para vencedores da sua ilha (cf. supra, p. 106).

${ }^{9}$ Como foi dito no capítulo anterior, os sucessos alcançados pelos habitantes de Ceos nos Jogos e na arte das Musas são louvados por Píndaro num péan composto para esta ilha (Pae. 4. 21-24 = fr. 52d Ma.). Baquílides escreveu um ditirambo para ser executado em Delos por cidadãos da sua terra natal (cf. 17. 130 sqq.) e alude também ao talento poético dos seus conterrâneos (cf. 19.11). Portanto, os dois líricos confirmam a continuação da tradição coral em Ceos e as obras referidas dão-nos uma ideia do ambiente cultural e religioso que the era característico. Registe-se ainda que dos tesouros do templo de Atena em Carteia fazia parte uma coroa de ouro consagrada pelo chefe de um coro. Cf. C. Michel, Recueil d'inscriptions grecques (Paris-Brussels 1927) 834 (apud Bowra 1961: 308 n. 5).

${ }^{10}$ A tradição coral da ilha de Ceos relaciona-se provavelmente com uma forte devoção ao culto religioso, no qual se distinguia o de Apolo. Roux 1984: 99 observa que o hestiatorion, a 'sala de banquete', dos peregrinos de Ceos foi um dos poucos edifícios que Heródoto encontrou em Delos em meados do séc. V (cf. 4. 35. 4). Do carácter e modo de vida das gentes de Ceos, os helenistas destacam a simplicidade de costumes e a austeridade moral, que se depreende, por exemplo, das leis respeitantes aos funerais (cf. IG XII. 5. 1. 593 = SIG III. 2. 1218, Buck 1955: 191-192) e uma proverbial crueldade para com os idosos, segundo conta Estrabão (10. 5. 6). 
tradição transmitida por Ateneu (10.456f), Simónides iniciou-se na actividade de mestre de coros (chorodidaskalos) ainda na sua ilha e já então trabalhava fora

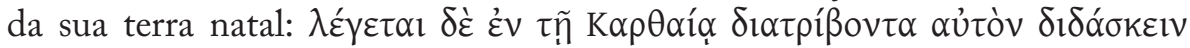

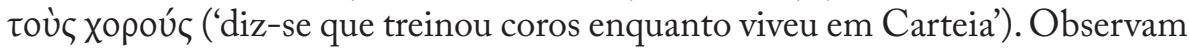
alguns estudiosos que não é prudente dar grande valor a uma notícia que se pode basear, embora não seja claro, num ensaio sobre o poeta escrito por Cameleonte do Ponto (cf. Athen. 10. 456c), filósofo peripatético e gramático da segunda metade do séc. IV, que tinha um gosto particular por assuntos triviais e nem sempre fundamentados ${ }^{11}$. No entanto, a crer numa fonte mais tardia, Simónides foi premiado nos concursos de ditirambos desde a juventude (Syrian. in Hermog., cit. infra). Na ausência de dados mais concretos, apenas podemos concluir que estas notícias pretendem sublinhar o seu talento precoce como mestre de coros. Não são, porém, inverosímeis e é legítimo supor que tenha começado por exercer a sua arte na terra natal, dado que o ambiente social e cultural parece ter sido bastante propício.

Não são anteriores à Época Helenística, nem pouco problemáticos, os testemunhos que nos permitem calcular a cronologia de Simónides, embora este assunto nunca tenha suscitado grande discussão. A notícia da Suda $(\Sigma 439$ = test. 1$)$, depois de indicar a cronologia relativa do poeta $-\mu \varepsilon \tau \grave{\alpha}$

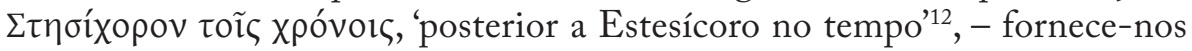
duas datas ${ }^{13}$ :

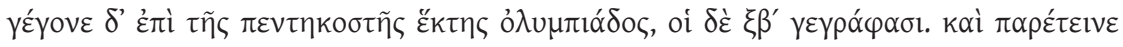

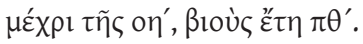

Nasceu na $56^{\mathrm{a}}$ Olimpíada $(=556 / 552)$, mas outros indicam a $62^{\mathrm{a}}(=532 / 528)$, e viveu até à $78^{\mathrm{a}}(=468 / 464)$, portanto oitenta e nove anos.

A informação de que o poeta teria vivido oitenta e nove anos apoia, à partida, a primeira data, embora os cálculos só possam ser aproximados, porque uma Olimpíada corresponde a quatro anos e os testemunhos não são precisos quanto a este ponto. De acordo com a cronologia mais baixa, o poeta teria vivido

Cf. Bowra 1961: 308-309; Huxley 1966: 132-134, 1978: 231-232; Lesky 1995 [1971]: 214.

${ }^{11}$ Huxley 1978: 234 rejeita a validade do testemunho com este argumento, mas Lesky 1995 [1971]: 214-215 aceita a tradição. O método de trabalho dos Peripatéticos no tratamento das fontes sobre a vida dos poetas antigos é discutido por Bell 1978: 62-63.

${ }^{12}$ Segundo uma tradição preservada no De Republica de Cícero (2. 20 = Stesich. test. 2), Estesícoro faleceu no ano em que nasceu Simónides, na 56a Olimpíada. Como já dissemos, a cronologia relativa entre os dois poetas é confirmada pelo fr. 564, no qual Simónides evoca Homero e Estesícoro como seus antecessores no tratamento do mito de Meleagro. Sobre a cronologia do lírico de Hímera, vide supra, p. 81 n. 45.

${ }^{13}$ Para uma explicação da existência desta dupla cronologia, que remonta possivelmente a uma interpretação errónea do termo үéүove da fonte da Suda, vide Molyneux 1992: 315. 
no máximo sessenta e oito anos, hipótese que não é confirmada pelos restantes testemunhos. Mas se considerarmos a data de nascimento na 62a Olimpíada e a informação de que Simónides teria vivido oitenta e nove anos (o que nos parece uma interpretação abusiva do texto da $S u d a$ ), a data da sua morte desce para 443/439. O esclarecimento deste ponto é de especial importância, porque dele depende também a fixação do extenso corpus epigramático atribuído ao poeta. $\mathrm{Na}$ edição de Page, os epigramas XLV-LVIII dizem respeito a acontecimentos posteriores a 468 e não podiam ter sido testemunhados por Simónides, de acordo com a cronologia geralmente aceite: 556-468. A análise dos outros testemunhos, em nosso entender, corrobora esta datação, mas não elimina todas as dificuldades.

O Marmor Parium (Ep. 57 = test. 8) regista a morte de Simónides em 468/7, aos noventa anos, apoiando, portanto, a primeira data de nascimento indicada pela Suda. No entanto, é ambíguo o testemunho de Eusébio de Cesareia sobre ofloruit do poeta $($ Chron. = test. 6):

(a) O1. 60 (p. 103b Helm): Simonides lyricus et Phocyl[I] ides clari habentur...

(b) O1. 73 (p. 108 Helm): Pindarus et Simonides lyrici poetae insignes habentur.

(a) 60a Ol. (=540/536): O poeta lírico Simónides e Focílides são considerados famosos...

(b) 73a Ol. (= 488/484): Píndaro e Simónides são considerados poetas líricos distintos.

A primeira informação exclui a possibilidade de o poeta ter nascido na 62a Olimpíada e, a ser verdade, corrobora a hipótese de ter iniciado a carreira muito cedo, pois já era conhecido aos dezasseis/vinte anos. A segunda informação, porém, situa o auge da sua actividade aos sessenta e oito anos, o que é uma idade avançada para o reconhecimento de um poeta tão famoso. Todavia, se tivesse nascido na $62^{\mathrm{a}}$ Olimpíada, esse momento de consagração situar-se-ia aos quarenta e quatro anos, o que corresponde aproximadamente a metade dos anos de vida que os testemunhos atribuem ao poeta. No entanto, a segunda informação não põe totalmente em causa a data mais antiga. $\mathrm{Na} 73^{\mathrm{a}}$ Olimpíada o poeta teria sessenta e oito anos e Píndaro trinta. Esta cronologia relativa encontra eco na Vita Pindari Ambrosiana (I. 2-3 Dr. = test. 7), onde se observa que os dois poetas evocaram na sua obra factos contemporâneos, referindo-se como exemplos a batalha naval de 480 e a actuação política de Cadmo, tirano de Cós (cf. Hdt. 7. 163-164):

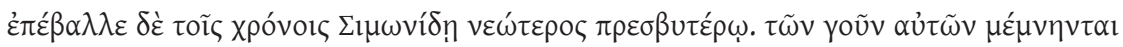

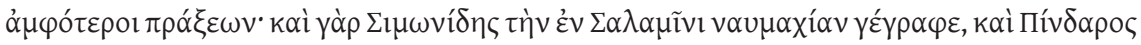

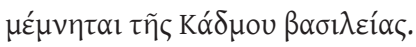

[A vida de Píndaro] coincidiu com a de Simónides como a de um jovem com a de um 
ancião. Pelo menos, os dois mencionam os mesmos acontecimentos, pois Simónides escreveu A Batalha de Salamina e Píndaro (fr. 272 Ma.) menciona o reino de Cadmo.

Finalmente, de acordo com o epigr.XXVIII (= test. 5 , cit.infra), certamente helenístico, embora tenha sido atribuído a Simónides, no ano em que Atenas teve como arconte Adimanto (=477/6), o poeta tinha oitenta anos (à letra, 'era octogenário'). Portanto, o autor desta composição conhecia uma fonte que situava o nascimento do poeta na $56^{\text {a }}$ Olimpíada.

A cronologia 556-468 é hoje praticamente aceite por todos os especialistas, mas foi contestada por Stella 1946, que defendeu a segunda data indicada pela Suda (532/528), supondo que o poeta faleceu c. 450. Não vamos retomar aqui este assunto, uma vez que os seus argumentos foram longamente discutidos por Molyneux 1992, que se pronunciou a favor da cronologia mais antiga ${ }^{14}$.

Em conclusão, um dado essencial sobre a vida de Simónides é a longevidade e a dedicação ao ofício poético até ao fim dos seus dias, o que não é surpreendente nem caso único, como sabemos, mas mereceu a admiração dos autores antigos e causou estranheza e cepticismo a alguns helenistas ${ }^{15}$. Talvez por ter sido uma figura de excepção no seu tempo, o poeta sofreu, mais do que qualquer outro lírico, uma espécie de mitificação e torna-se numa figura da lenda, na qual nem sempre é fácil separar os elementos históricos dos fantasiosos. Julgamos, porém, que deve ser levada a sério a tradição de que passou os últimos anos da sua vida nas cortes dos tiranos da Sicília e foi sepultado em Agrigento (cf. Call. Aet. fr. 64.3-4 Pf. = test. 21).

${ }^{14}$ Veja-se, no entanto, Poltera 1997: 21 e 543-544, que mostra alguma simpatia pelas teses de Stella, notando que o vocabulário de Simónides é "trop jeune pour un poète ancré dans le VI ${ }^{\mathrm{e}}$ s. av. J.C.”. Na recensão à sua obra, Ma Carmen Barrigón observa que, de facto, Simónides emprega vocábulos que parecem mais adequados ao séc. V, mas avança a hipótese de o corpus preservado remontar "sólo a la última etapa de su producción" (Eikasmos 9, 1998, 497). Para um exame sucinto e rigoroso dos dados biográficos e do percurso profissional de Simónides, vide Hutchinson 2001: 285-288, esp.

${ }^{15}$ Cf. Cic. Sen. 7. 23, Plu. An seni sit gerenda res publica 3. 785a, Ps. Luc. Macr. 26. A cronologia convencional 632-556 dá a Estesícoro setenta e seis anos de vida. Anacreonte faleceu com oitenta e cinco anos (cf. supra, p. 92), Píndaro com oitenta (518-438), Platão com oitenta e um (c. 427-346), Xenofonte com setenta e cinco (c. 430-355?). Como são muitos os exemplos que poderíamos apontar, na opinião de Poltera 1997: 19, a longevidade de Simónides "parece (sobretudo) lendária”. Esta é também a posição de outros helenistas. Zanker 1995: 22 observa que na imaginação dos Gregos todos os grandes intelectuais eram anciãos e, nas palavras de Hunter 2001: 243, Simónides "was one of the conventional makrobioi of antiquity." A lista tradicional incluía Homero, Hesíodo, Estesícoro, Anacreonte, Simónides, Sófocles. Na opinião destes investigadores, a longevidade é um topos inevitável das representações dos grandes poetas e pensadores do passado, que remonta provavelmente ao séc. III (cf. Zanker 1995: 68-75, Hunter 2001: 251). Para uma opinião divergente (e mais esclarecida), vide H. D. F. Kitto, Os Gregos. Trad. port. José Manuel Coutinho e Castro (Coimbra ${ }^{31990)}$ 56-57. 
(Página deixada propositadamente em branco) 


\section{A mobilidade de Simónides}

No corpus epigramático atribuído a Simónides figuram duas composições funerárias, que para nós têm apenas interesse no âmbito da tradição de mobilidade do poeta. Foram ambas transmitidas pelo livro VII da Antologia Palatina como sendo da sua autoria. Este último ponto não merece ser discutido, pois partilhamos da opinião de Page 1981: 299, que as considera bons exemplos do epigrama fictício, criado especialmente para acrescentar cor e verosimilhança a uma anedota sobre um homem célebre. $\mathrm{O}$ seu interesse, a nosso ver, reside na história que motivou a sua composição, que tem como protagonista um Simónides cumpridor dos rituais fúnebres e poeta itinerante.

O epigr. LXXXIV (128 B, $81 \mathrm{D}=A P 7.516, A P l)$ é dedicado a um homem que foi assassinado por bandidos. Simónides encontrou o corpo numa certa ilha e deu-lhe sepultura, tendo também composto a seguinte inscrição funerária:

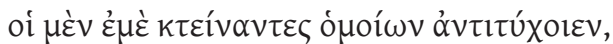

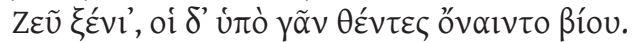

Oxalá os que me mataram possam encontrar semelhante destino, Zeus protector dos hóspedes, e os que me deram sepultura tirar proveito [da vida.

Com este acontecimento se relaciona uma outra história, que está na origem do segundo epigrama (LXXXV, $129 \mathrm{~B}, 82 \mathrm{D}=A P$ 7. 77). $\mathrm{O}$ fantasma do homem que foi sepultado aparece num sonho a Simónides e aconselha-o a não prosseguir a viagem marítima no dia seguinte. $\mathrm{O}$ poeta, ao contrário dos seus companheiros, acolheu o conselho e escapou ao naufrágio. Em reconhecimento, acrescentou à sepultura do homem uma outra inscrição:

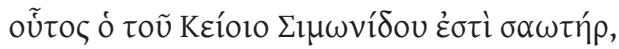

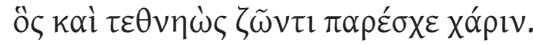

Este é de Simónides de Ceos o salvador, que até morto mostrou a quem vivia a sua gratidão.

Esta história, que mistura elementos religiosos e fantásticos, teve grande 
fama entre os autores romanos a partir do séc. $\mathrm{I}^{16}$ e confirma a difusão da imagem de Simónides como poeta itinerante. Não é de excluir que alguns traços deste retrato tenham sido acentuados pela tradição biográfica de carácter anedótico, que se começa a desenvolver a partir do séc. IV. Cremos, todavia, que a mobilidade de Simónides é um facto histórico, que, em nosso entender, deve ter sido determinada, tal como a dos seus antecessores, pela ligação próxima entre a poesia e os centros de cultura e de poder político, que emergem na segunda metade do séc. VI e na primeira do V.

Os estudos modernos que incluem dados biográficos sobre o poeta não raras vezes traçam um percurso de vida algo linear: depois dos anos de formação na terra natal, Simónides é convidado a viver na corte dos Pisístratos em Atenas por Hiparco e, à morte deste em 514, ou quando Hípias é expulso em 510, instala-se nas casas reais da Tessália; durante ou após as Guerras Medo-Persas encontra-se de novo em Atenas, onde permanece até 476, ano em que terá ido viver para a corte de Hierão ${ }^{17}$.

O que sabemos sobre o ambiente em que os cultores de lírica coral exerciam o seu ofício suscita-nos algum cepticismo quanto à linearidade deste percurso, que teria sido basicamente motivado por circunstâncias históricas e políticas. Se Simónides foi, de facto, o criador ou exímio cultor da forma poética destinada a exaltar uma vitória desportiva, como se pensa, se obteve nos concursos de ditirambos um número notável de vitórias e se também compunha hinos em honra de Apolo (o que deixa pressupor a composição de outros hinos), como seria próprio da actividade de um cultor de lírica coral, a necessidade de se deslocar através do mundo grego deve ter sido uma experiência quotidiana, acentuada provavelmente em determinados momentos da sua longa vida. Terá sido a disponibilidade para atender às solicitações que recebia de diferentes partes da Hélade que o fez compreender, com uma percepção singular, a importância e significado das vitórias gregas nas lutas contra os Persas? Terá sido uma visão abrangente do mundo conhecido e da sua diversidade que o não impediu de trabalhar, por vezes ao mesmo tempo, para pessoas tão diferentes ou mesmo rivais? Os testemunhos de que actualmente dispomos não nos permitem encontrar respostas definitivas. O nosso objectivo é examinar essas fontes, no sentido de reconstruir, na medida do possível, a actuação profissional de Simónides,

${ }^{16}$ As fontes são citadas e discutidas por Boas 1905: 98-101, que concluiu que as quatro versões da história - transmitidas por Cícero (Div. 1. 27. 56, 2. 66. 135), por Valério Máximo (1. 7. ext. 3), pelo escoliasta de Élio Aristides (III. 533 Dindorf) e pelo Pseudo-Libânio (Narr. 13) - podem remontar a escritores estóicos (p. 101). Cf. Schneider 1997: 65-68, que discute também os epigr. LXXXIV e LXXXV.

${ }^{17}$ Cf. Bowra 1961: 317, 321, 323, 340, 358; Kegel 1962: 90, Gerber 1970: 309, Lesky 1995 [1971]: 215. 
quer no âmbito das festas públicas, quer no que diz respeito às relações com os seus patronos, ou com outras pessoas que fizeram parte do seu espaço de mobilidade. 


\section{II.1. As FESTAS PÚBLICAS}

\subsection{A composição e execução de hinos}

O canto em honra de deuses é provavelmente uma das manifestações mais antigas do espírito humano e está documentado na literatura grega desde os Poemas Homéricos. Como já dissemos, não é seguro falar ainda em formas literárias. O fragmento lírico mais antigo conhecido é de um prosodion de Eumelo, mas no tempo de Simónides a lírica coral havia atingido um desenvolvimento já muito sofisticado. A solicitação do poietes torna-se então de norma. A distinção, que podemos comprovar na obra preservada de Píndaro e de Baquílides, entre hinos, peanes, ditirambos e prosodia confirma o grau de especialização que a lírica coral do séc. $V$ alcança neste domínio. Vimos também que os dois líricos foram solicitados por diversas póleis da Hélade e, caso se tenham ocupado da tarefa de ensaiar o coro e de dirigir a apresentação de cada obra, como se pensa, teriam sido obrigados a deslocarem-se com frequência.

Tendo em conta a tradição poética em que Simónides se insere, a sua versatilidade e talento, não é difícil supor que, já no seu tempo, o canto dirigido especificamente a uma divindade, e executado no contexto de uma celebração religiosa, tenha alcançado um desenvolvimento pleno. Infelizmente, as fontes de que dispomos sobre o trabalho que realizou neste âmbito são vagas e nem sempre nos permitem estabelecer relações com a questão da sua mobilidade. $\mathrm{O}$ escoliasta das Aves de Aristófanes, no comentário à alusão do Poeta aos 'cantos no estilo de Simónides' (v. 919), cita como exemplo 'hinos, peanes, prosodia e outros géneros afins ${ }^{18}$. Um escólio do v. 5 da Medeia de Eurípides (II. 142 Schw. = fr. 576, vide infra, p. 340 n. 67) menciona a existência de um hino a Poséidon da sua autoria, mas centra-se num pormenor mitológico. Numa das epístolas, o imperador Juliano (332-363 d.C.) alude a um canto lírico no qual Simónides deve ter tratado a luta de Apolo com a serpente Píton $\left(E p .24\right.$ = fr. 573, $\left.68 \mathrm{P}, 26^{\mathrm{A}} \mathrm{B}\right)$, que pode ter sido composto, supomos, por ocasião do envio de uma delegação a Delfos. Mas, mais nada sabemos. A vaga (e confusa) notícia da Suda sobre a obra do poeta refere, além de poemas líricos e elegíacos sobre as Guerras Medo-Persas, 'trenos, encómios, epigramas, peanes, tragédias e outras obras' ${ }^{\prime 19}$. O De Musica atribui ainda a

\footnotetext{
${ }^{18}$ Schol. Ar. Av. $917-919$ (p. 174 White) = test. 33. Cf. supra, p. 107 n. 29.

${ }_{19}$ Suda $\Sigma 439$ = test. 1 . A menção de 'tragédias' pode ser uma referência incorrecta ao
} 
Simónides 'grande número de partheneia', compostos na 'tonalidade dórica' (17. 1136f), mas o estado actual dos nossos conhecimentos não permite confirmar este testemunho.

Mais interessante para os propósitos do nosso estudo é um passo das Orações de Himério (39.1 = fr. 589, 84 P, 20 B), que pressupõe uma tradição de mobilidade poética:

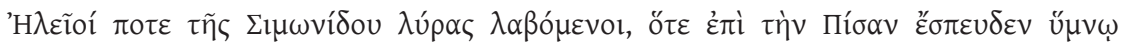

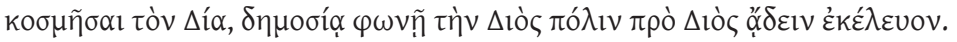

Uma vez os Elidenses agarraram na lira de Simónides, quando ele se apressava para Pisa, a fim de celebrar Zeus com um hino, e por público consenso ordenaram-lhe que cantasse a cidade de Zeus em vez de Zeus.

Este testemunho do séc. IV da nossa era, embora de contornos anedóticos, além de sugerir que os deuses tinham lugar de eleição na poesia de Simónides, sublinha dois aspectos que provavelmente influenciavam a actuação de um cultor de lírica coral: a necessidade de se deslocar aos grandes santuários religiosos, como Olímpia, Delfos ou Delos, a fim de presidir à execução das suas peças, e a imposição de compor os seus cantos de acordo com os valores e as características da assistência. No que diz respeito ao primeiro, as referências dispersas a esses locais sagrados, que ocorrem nos testimonia e nos fragmenta de Simónides, não nos permitem formar qualquer ideia precisa no âmbito da mobilidade. No entanto, a publicação do P. Oxy. 2430 por Lobel, em 1959, veio dar razão aos comentadores antigos, que atribuíam a Simónides a composição de peanes. A este assunto Ian Rutherford dedicou um estudo exaustivo em 1990, embora o material não seja tão significativo como é o de Píndaro. Para os propósitos deste trabalho interessam apenas, por enquanto, algumas linhas deste papiro (= fr. 519).

Há fortes indícios de que o fr. 35 preserva os dez últimos versos de um péan que se destinava a ser apresentado em Delos por Atenienses - suposição que se apoia na referência do v. 1 ao monte Parnes (situado entre a Beócia e a

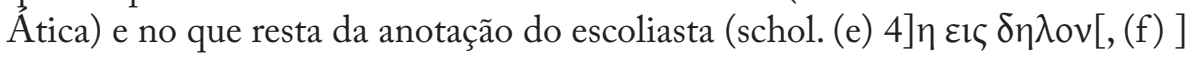
$\tau \omega \nu \alpha \theta \eta v \alpha i \omega \nu \pi \alpha \rho[)$-, e o início de um outro, para ser executado por homens

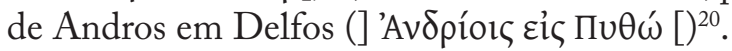

Lobel 1959: 45 e Rutherford 1990: 172 repararam na semelhança entre a forma deste título (executante no dativo plural + Ei $\mathbf{\zeta}+$ centro de culto ou local de execução) com os que apareceram nos papiros que revelaram os peanes de

ditirambo ou à sua forma dramática (Bowra 1961: 319, Lesky 1995 [1971]: 219).

${ }^{20}$ Cf. Lobel 1959: 45 n.1, Lloyd-Jones 1961: 18, Rutherford 1990: 172, Campbell 1991: 387, 391. 
Píndaro (cf. frr. 52g, 52h, 52i, 52p, 52s Ma.), embora Rutherford não exclua completamente a possibilidade de outros géneros poéticos terem recebido títulos com esta forma.

Se aceitarmos, como Lobel 1959: 56 e Lloyd-Jones 1961: 18, que o escólio diz respeito ao fr. 35, teremos de concluir que Simónides compôs, pelo menos, um péan para um coro de Atenienses apresentar na festa délica ${ }^{21}$ durante a Primavera (cf. v. 5), no âmbito de uma tradição que, como sabemos, tinha raízes muito antigas e continuou a ser cumprida (cf. Pind. fr. 52e Ma.). A composição de obras para Atenas nada tem de excepcional, pois muitas outras fontes atestam a presença do poeta nesta pólis. $\mathrm{O}$ fr. 35 adquire, porém, um valor singular, pois constitui a única prova, quanto é do nosso conhecimento, de uma ligação profissional entre Simónides e a ilha de Andros. No entanto, não é surpreendente, uma vez que aquela ilha se situa relativamente perto de Ceos. Este péan pode ter sido composto por ocasião do envio de emissários às festas de Delfos, possibilidade que deve ser considerada, pois a descoberta de uma inscrição no séc. XIX confirmou que Andros enviava regularmente uma theoria ao santuário de Apolo Pítico, pelo menos em finais do séc. $\mathrm{V}^{22}$.

\subsection{A composição e execução de odes de vitória}

A crítica moderna concedeu a Simónides os louros de um papel decisivo no desenvolvimento da forma coral destinada a celebrar uma vitória desportiva. A dimensão reduzida dos fragmentos preservados destas odes, sobretudo quando os comparamos aos de Píndaro e de Baquílides, explica naturalmente que poucos helenistas tenham procurado aprofundar o sentido a atribuir a esse papel. Ainda assim, alguns não hesitam em afirmar, como Race 1997a: 11, que "Simonides began the practice of composing elaborate odes in honor of athletic victors", atribuindo-lhe o papel de pioneiro ${ }^{23}$. No entanto, o início da $I X^{a}$ Olimpica de Píndaro (vv. 1-4) alude a um refrão de Arquíloco cantado em Olímpia em honra do atleta vencedor, ao qual podem pertencer os seguintes versos $(\mathrm{fr} .324 \mathrm{~W})^{24}$ :

${ }^{21}$ Rutherford 1990: 173-176 discute a hipótese de o fr. 35 pertencer a um péan délfico. Cf. Podlecki 1984: 188-189.

${ }^{22}$ Cf. Rutherford 1990: 176. Sobre a inscrição de Delfos, talvez do último quartel do séc. V, vide G. Daux, “Un règlement cultuel d'Andros”, Hesperia 18 (1949) 59-72; Buck 1955: 190, Dillon and Garland 1994: 362.

${ }^{23}$ A esta conclusão chegou Kegel 1962. Lesky 1995 [1971]: 215-216 observou que não temos notícias de que, antes de Simónides, um coro tenha interpretado um canto composto especialmente em homenagem a um vencedor olímpico por um poeta importante, pelo que é legítimo supor que tenha sido Simónides a inaugurar esta prática. Do mesmo modo, Bernardini 1980: 93 considera que o poeta foi o primeiro a conferir autoridade ao epinício e a fazer da ode de vitória um elemento essencial da cerimónia de homenagem ao atleta.

${ }^{24}$ Estes versos foram reconstituídos pelos editores modernos a partir das informações dos escólios e a autenticidade não é segura. West 1974: 138-139 rejeita a atribuição a Arquíloco 


\author{
$\tau \eta ́ v \varepsilon \lambda \lambda \alpha \kappa \alpha \lambda \lambda i ́ v i k \varepsilon$

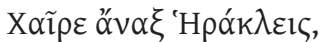

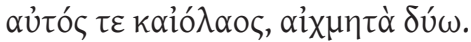

Salve, ó feliz vencedor!

Saudemos o Senhor Héracles, tu mesmo e Iolau, um par de guerreiros!

Não é prudente depreender desta evocação que Arquíloco iniciou o costume de honrar o vencedor com uma ode coral elaborada, uma vez que este canto em honra de Héracles deveria ser muito simples, já que era adequado a qualquer atleta e a qualquer prova, segundo indica um dos escólios (cf. I. 268. 5-10 + 12-14 Dr.) $)^{25}$. A alusão de Píndaro indicia que a composição de epinícios se filia numa tradição poética com raízes antigas, quer remontem ao tempo de Arquíloco quer a épocas mais longínquas ${ }^{26}$.

Como já dissemos na primeira parte, a criação de odes corais formalmente elaboradas deve relacionar-se com a importância e o desenvolvimento dos festivais pan-helénicos no primeiro quartel do séc. VI, a realização dos Jogos Píticos de quatro em quatro anos, a partir de 582, a fundação dos Ístmicos em 581 e dos Nemeus em 573, e também com a manutenção de valores tipicamente aristocráticos, o que explica o declínio deste subgénero lírico por volta da morte de Píndaro (c. 438) ${ }^{27}$. Assim, se a evolução do canto de vitória não se pode dissociar de circunstâncias históricas, culturais, económicas e sociais, o papel de Simónides nesta evolução relaciona-se, certamente, com uma nova concepção do ofício poético, que pode ter sido iniciada com Íbico, como crêem alguns helenistas (cf. supra, pp. 91-92). Vale a pena sublinhar que, embora nenhum testemunho antigo atribua ao nosso poeta a criação do epinício, não

e propõe a inclusão do fragmento no corpus de carmina popularia. Sobre esta questão, cf. Race 1997a: 148-149, Gerber 1999b: 282-287.

${ }^{25}$ Cf. Drees 1968: 64, Rocha Pereira 2003: 13. Para um comentário ao fragmento, vide Gerber 1970: 41-42. Para uma discussão das origens da ode de vitória, vide Thomas 2007, que examina o fragmento de Arquíloco nas pp. 144-145.

${ }^{26}$ Outros passos das odes de Píndaro aludem à antiguidade do canto em honra dos atletas

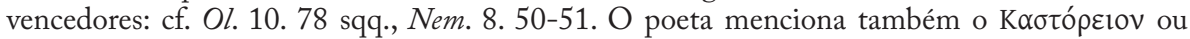
'Canção de Castor' (Pyth.2.69, Isth.1.16), um canto de celebração de uma vitória equestre e, por essa razão, dedicada àquele herói. Fränkel 1975: 435 n. 18 considerou aquele termo simplesmente sinónimo de Ėđıvíkıov. No entanto, segundo informa o De Musica, os Lacedemónios entoavam

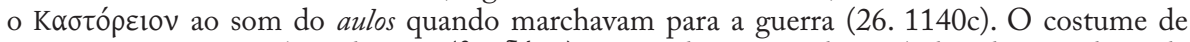
avançarem para o combate devagar $(\beta \rho \alpha \delta \varepsilon ́ \omega \varsigma)$ e segundo o ritmo das melodias dos tocadores de aulos é referido por Tucídides (5.70), mas não alude ao canto.

${ }^{27}$ Cf. Bernardini 1980: 81-84, Race 1997a: 5, 12. Se, por um lado, dificilmente algum poeta teria alcançado a grandeza do lírico de Tebas, o declínio da ode de vitória relaciona-se provavelmente também com o profissionalismo que caracterizará a actuação dos atletas a partir do séc. IV. 
faltam indicações de que foi o primeiro a impor uma remuneração em troca do seu trabalho. Aprofundaremos este ponto no último capítulo desta parte.

Por conseguinte, cremos que o papel de Simónides foi determinante, como defendeu Bowra 1961: 310-311. Na opinião do mesmo helenista, o seu epinício pode ter estado mais próximo da canção simples que da forma elaborada e grandiloquente em que se transformou a ode de Píndaro. Apesar do estado mutilado em que se encontram muitos dos versos que podemos atribuir, com alguma segurança, aos epinícios de Simónides, conseguimos identificar alguns elementos característicos desta forma poética, como:

(1) as referências à vitória e ao laureado (e.g. frr. 506, 507, 511);

(2) os exemplos mitológicos ( $\mu \tilde{v} \theta \circ \varsigma)$, geralmente em conexão com a pátria do atleta ou com a sua família (e.g. frr. 509, 510, 511);

(3) as sentenças $(\gamma \nu \tilde{\omega} \mu \alpha \mathfrak{l})$, que podiam ter intenção moralista ou política, e outras reflexões ${ }^{28}$.

Registe-se ainda que o fr. 2 do P. Oxy. 2623 (= 320 SLG, 519A Campbell) atesta o emprego da tríade, que é a estrutura métrico-rítmica predominante nas odes de Píndaro e de Baquílides.

Escusado será dizer que não encontramos no corpus atribuído a Simónides um único fragmento de epinício que reúna todos estes elementos. No entanto, uma parte considerável diz respeito a temas mitológicos (frr. 543-579) e as reflexões do poeta sobre a condição humana constituem um dos aspectos mais importantes da sua obra. Além disso, é longa a lista de sentenças que a tradição atribui a Simónides e consolidou a sua reputação de poeta sábio (vide infra, pp. 183 sqq.).

Dos elementos que formam a ode, as referências à ocasião da vitória e ao destinatário são, naturalmente, as mais importantes para a reconstituição da actuação profissional de um cultor de lírica coral. No entanto, como o corpus de Simónides depende, em grande parte, de citações de autores antigos, que quase nunca, salvo raras excepções (cf. fr. 515), contextualizam as fontes, é muito difícil reconstituir as circunstâncias de produção e de execução dos seus epinícios. O que os testemunhos e fragmentos permitem deduzir resume-se a poucas palavras:

(1) É provável que o número de composições seja muito maior do que os fragmentos deixam supor. O P. Oxy. 2430 (= fr. 519) dá-nos uma pequena ideia da quantidade imensa de versos que se perderam.

(2) O poeta cantou as vitórias obtidas na prova olímpica mais importante, a corrida de quadrigas (fr. 512) ${ }^{29}$, mas compôs também em honra de atletas

${ }^{28}$ Cf. Bowra 1961: 311, Lesky 1995 [1971]: 216, Hamilton 1974: 14-17, Rocha Pereira 2006: 222-223.

${ }^{29} \mathrm{O}$ escoliasta de Os Cavaleiros de Aristófanes, apresentados em 424, observa que a 
vencedores nas outras modalidades desportivas: corredores, como Astilo de Crotona (fr. 506), lutadores, como Crio de Egina (ou o seu adversário, fr. 507), pugilistas, como o jovem Glauco de Caristo (frr. 509 e 510), atletas do pentatlo (fr. 508), vencedores na corrida de cavalos, como os filhos de Eácio da Tessália (fr. 511), e na corrida de carros de mulas, como Anaxilas de Régio (fr. 515. Aristóteles, que transmitiu o fragmento, observou que o poeta exigiu um bom salário!).

(3) Ainda que as lacunas da tradição não nos permitam tirar conclusões definitivas, parece que as odes mais antigas foram compostas para atletas da Grécia Continental e as mais recentes para laureados da Magna Grécia. É compreensível que o poeta tenha começado por celebrar vencedores oriundos das regióes próximas da sua terra natal, como Glauco de Caristo, cuja vitória olímpica na prova de paides ocorreu provavelmente em 520, e Eválcides de Erétria, mencionado por Heródoto (5. 102. 3 = fr. 518), que perdeu a vida na revolta da Iónia em 498. Por outro lado, se o poeta passou os últimos anos de vida na Magna Grécia, não é de estranhar que tenha sido solicitado por atletas desta parte do mundo grego. A fase de consagração de Astilo de Crotona situa-se entre 488 e 476, Anaxilas de Régio triunfou em Olímpia provavelmente em 480 e as datas das vitórias píticas e ístmicas de Xenócrates de Agrigento situam-se neste período. Mas Simónides cantou também as proezas desportivas de nobres da Tessália, e a tradição preservou em especial a memória de Escopas, que faleceu nos finais do séc. VI. Os testemunhos que analisaremos a seguir referem-se a um atleta desconhecido e, apesar de tardios, em nosso entender, são um contributo relevante para a reconstituição do ambiente cultural em que Simónides construiu a sua carreira poética.

Ateneu, para exemplificar o emprego do $\omega$ por ou na pronúncia dórica,

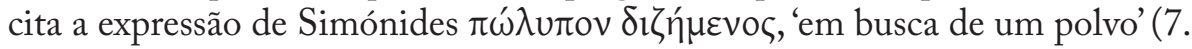
$318 \mathrm{f}=\mathrm{fr} .514,9 \mathrm{P}, 11 \mathrm{~B}, 15 \mathrm{D})$, que os editores modernos relacionam com dois textos das colectâneas de provérbios:

Cod. Paris. suppl. gr. 676 (ed. L. Cohn, Zu den Paroemiographen, Breslau, 1887, 79) ó

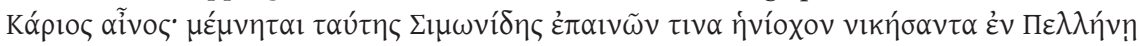

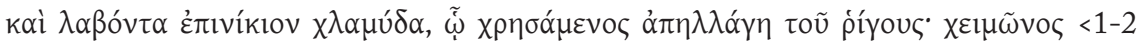

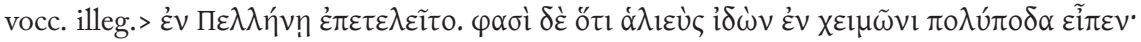

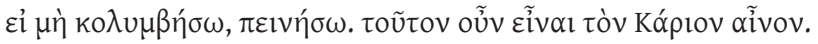

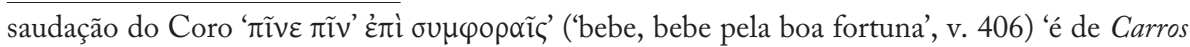

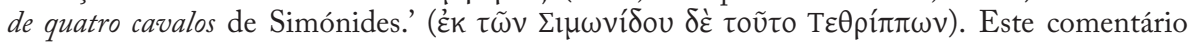
indica que os epinícios foram agrupados segundo as modalidades desportivas. Esta suposição é corroborada pelo testemunho de Fócio sobre 'os dias da alcíone', que cita como fonte os

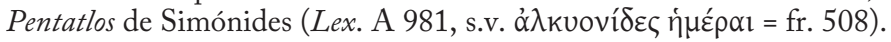




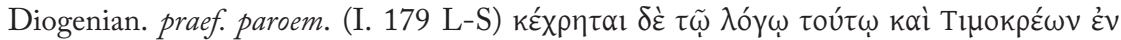

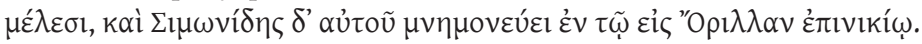

Cod. Paris. suppl. gr. 676 (ed. Cohn) A lenda cária: Simónides menciona esta história ao elogiar um certo auriga, que vencera em Pelene e recebera pela vitória uma clâmide, que usava para se proteger do frio... os jogos realizavam-se em Pelene durante o Inverno. Dizem que um pescador, ao ver um polvo no Inverno, disse: 'se não mergulhar, terei fome'. E esta é, por certo, a lenda cária.

Diogenian. praef. paroem.: Timocreonte usa esta história nos seus poemas e Simónides evoca-a no seu epinício em honra de Orilas.

Como observa Henderson 1998: 15, o conteúdo do primeiro testemunho permite de algum modo clarificar o sentido da expressão de Simónides citada por Ateneu: o atleta que se atreveu a participar nos Jogos de Inverno de Pelene, e alcançou como prémio uma clâmide ${ }^{30}$, agiu como o homem cário que ao ver um polvo teve de mergulhar para evitar a fome, correndo o risco de morrer de frio. Supondo que os dois textos acima citados dizem respeito ao mesmo poema e são autênticos, constituem o único testemunho de que Simónides compôs um epinício em honra de um auriga ${ }^{31}$. Mais importante talvez, pois nada sabemos sobre Orilas, e por isso não podemos situar esta composição, é a ideia de que o poeta evocou uma lenda popular, de origem oriental, mas suficientemente conhecida para também ser tratada por Timocreonte (fr. 734 $P M G$ ). Finalmente, Pelene é uma cidade da Acaia (Hdt. 1. 145) situada a noroeste de Sícion, à beira do golfo de Corinto. Esta história, se for autêntica, confirma que o poeta não celebrava apenas os atletas que competiam nos festivais pan-helénicos e, portanto, o seu espaço de mobilidade foi, por certo, muito mais vasto do que os seus fragmentos de epinícios sugerem ${ }^{32}$.

${ }^{30} \mathrm{Na}$ opinião de Bernardini 1980: 94, trata-se dos Jogos Teoxénios. De facto, segundo informa Pausânias (7. 27. 4), estas competições realizavam-se em Pelene em honra de Apolo

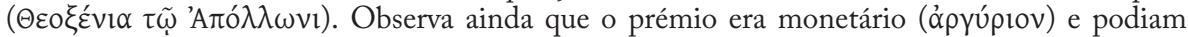

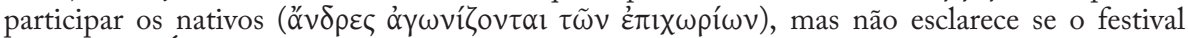
remontava à Época Arcaica. Os jogos de Pelene são igualmente citados no epigrama dedicatório de Nicoladas de Corinto, atribuído a Simónides (epigr. XLIII, cf. infra, p. 155). Píndaro confirma que o prémio era um agasalho (e.g. Ol. 9. 97-98, Nem. 10. 44). Sobre os prémios dos jogos, vide infra, n. 59.

31 Bernardini 1980: 94-95 nota, com razão, que se foi Orilas quem recebeu o prémio principal, era talvez ele o proprietário dos animais. Por conseguinte, se não era de estatuto social superior, como supõe, Orilas teria recursos financeiros que lhe permitiam participar nos Jogos e encomendar uma ode a um poeta célebre. A avaliar pelos exemplos que colhemos em Píndaro, a celebração dos aurigas não seria frequente, mas acontecia (e.g. Ol. 6. 22-28, Pyth. 5. 23-53), e a $I^{a}$ Ístmica é dedicada a Heródoto de Tebas, que conduziu o seu próprio carro.

${ }^{32}$ Qualquer atleta almejava triunfar nos quatro maiores jogos pan-helénicos e alcançar o título de $\pi \varepsilon \rho 1 o \delta o v i ́ k \eta \varsigma$, mas não deixaria de competir noutros importantes certames, como as Panateneias. As muitas referências de Píndaro aos jogos regionais, em particular na XIII ${ }^{a}$ Olimpica (vv. 106-113), e o acima mencionado epigrama de Nicoladas atestam a existência 


\subsection{As vitórias nas competições de ditirambos}

A referência mais antiga à participação de Simónides em competições poéticas encontra-se nas Vespas de Aristófanes, apresentadas em 422, numa fala de Filócleon, geralmente interpretada como alusão a um triunfo sobre Laso de Hermíone num concurso ditirâmbico ${ }^{33}$. Dois conhecidos epigramas do corpus de Simónides constituem os testemunhos principais sobre as suas vitórias nestas competições, mas pertencem provavelmente à Época Helenística.

Como dissemos já, segundo informa Siriano, comentador do séc. V da nossa era, o poeta iniciou a sua actividade como mestre de coros ditirâmbicos na juventude e ainda foi laureado aos oitenta anos, antes de partir para junto de Hierão (Syrian. in Hermog., I. 86 Rabe = epigr. XXVIII, 147 B, 77 D):

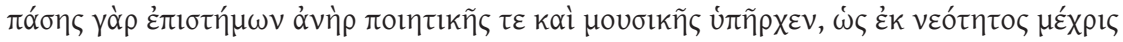

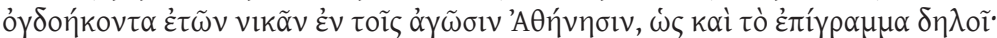

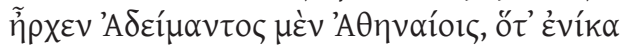

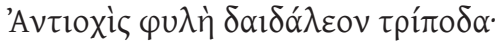

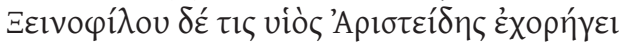

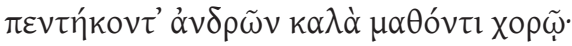

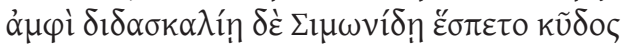

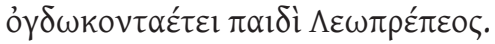

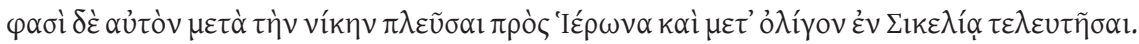

Pois Simónides era iniciado no conhecimento de toda a poética e música, visto que desde a juventude até aos oitenta anos venceu nos concursos atenienses, como mostra a seguinte inscrição:

Era Adimanto arconte em Atenas quando

a tribo Antióquide venceu uma trípode bem lavrada.

Um tal Aristides, filho de Xenófilo, era corego

de um coro de cinquenta homens que havia aprendido bem.

Por este ensinamento, a glória tocou Simónides,

filho de Leóprepes, aos oitenta anos.

Dizem que após a vitória navegou para junto de Hierão e pouco tempo depois faleceu na Sicília.

de competições atléticas na Arcádia, em Argos, Egina, Elêusis, Epidauro, na Eubeia, em Fliunte, Maratona, Mégara, Sícion, Tebas e nas cidades sicilianas de Etna e Siracusa, pelo menos.

${ }^{33}$ Ar. V. 1411-1412 = Lasus, test. 3. Cf. Bowra 1961: 318, Pickard-Cambridge 1962: 13, Herington 1985: 250 n. 66, Campbell 1991: 299, Molyneux 1992: 99. A confirmar-se esta conjectura, supomos que a competição em que haviam participado os dois poetas ocorreu durante a tirania dos Pisístratos. 
O epigrama situa o acontecimento (477/6), indica o nome da tribo vencedora, o do corego e o do poeta, responsável pela composição e execução do ditirambo. Aparentemente, como admitiu Pickard-Cambridge 1962: 16 (cf. 1968: 78), trata-se da inscrição corégica que figurava na base da trípode consagrada pela tribo vencedora e teria sido composta pelo próprio poeta. Esta era também a opinião de vários helenistas ${ }^{34}$, mas Stella 1946: 5-10 demonstrou, com argumentos sólidos, a incerteza de tal possibilidade. Entre outros aspectos, observou que as inscrições da primeira metade do séc. V se distinguem pela sobriedade, ao passo que a presente composição evidencia um "estilo elaborado e artificial" e, ao contrário do uso clássico, não centra o seu interesse na divindade e no objecto dedicado, mas na figura e idade do poeta.

Embora não totalmente de acordo com as observações de Stella, Page 1981: 242 reconheceu que um dos seus argumentos mais persuasivos é a formulação do v. 3, visto que o emprego do pronome indefinido $\tau ı \zeta$ não é conciliável com a hipótese de o epigrama ter sido composto por Simónides ou pouco depois de ter ocorrido a competição. Seria invulgar que o autor da inscrição não conhecesse o cidadão distinto que havia custeado todas as despesas da tribo vencedora, inclusive o trabalho do poeta e a consagração da trípode ${ }^{35}$. Por outro lado, Page (ibidem) não deixou de notar, com base em Pickard-Cambridge 1962: 36 (cf. 1968: 76), que os registos oficiais das vitórias ditirâmbicas nas Grandes Dionísias relativos aos séc. V e IV $\left(I G \mathrm{II}^{2}\right.$. 2318) indicam o nome da tribo e do corego. Mas o nome do poeta e, no séc. IV, o do auleta, só eram registados em monumentos tribais e privados.

Igualmente importante, em nosso entender, é o facto de outros autores da nossa era conhecerem o epigrama, mas nem Plutarco nem Siriano o atribuem a Simónides ${ }^{36}$, pelo que a sua inserção no corpus do poeta é fruto das conjecturas dos filólogos modernos. É provável, no entanto, que remonte a uma tradição verdadeira, já que a vitória a que se refere foi registada no Marm. Par. Ep. 54. Curiosamente, esta estela da Época Helenística regista que foi também nesse ano que Crítios e Nesiotes realizaram o grupo escultório dos Tiranicidas, cuja inscrição teria sido composta por Simónides (cit. infra).

${ }^{34}$ Hauvette 1896: 59, Boas 1905: 177-178. Cf. C. Gallavotti, "Letture epigrafiche: 1. Monumentum Simonidis", QUCC 20 (1975) 165-171.

${ }^{35}$ Não nos parece que tenha razão H. White, "A new Chapter on Greek Epigrams”, Orpheus

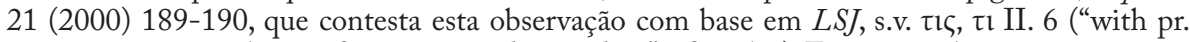
names $\tau \iota \zeta$ commonly signifies one named so-and-so", cf. Il. 5.9). Fica por esclarecer se esta regra se aplicava às inscrições autênticas. Sobre as obrigações do choregos, vide Pickard-Cambridge 1968: 75-78, Rocha Pereira 2006: 360-361.

${ }^{36}$ Cf. Plu. An seni sit ger. 3. 785a; Val. Max. 8. 7. 13; schol. Tzetz. H. 1. 624, pp. 552-553 Leone. 
A autenticidade do epigr. XXVII (145 B, 79 D), pelo contrário, foi contestada pelos filólogos mais antigos (cf. Hauvette 1896). Transmitido pela Antologia Palatina (6.213), que o atribuiu a Simónides, e aparentemente destinado a um pinax votivo (v. 2) pela quinquagésima sexta vitória do poeta, foi decerto composto na Época Helenística. No entender de Page 1981: 241, por alguém que conhecia o epigr. XXVIII:

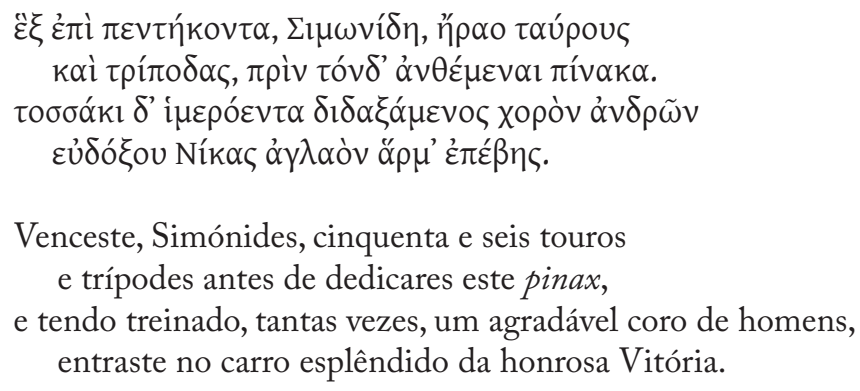

Embora não seja autêntico, este epigrama, bem como o anterior, é fruto de uma tradição que atribuía a Simónides um número notável de vitórias nos concursos de ditirambos e destacava o seu talento de chorodidaskalos. A preparação de um conjunto de cinquenta homens deveria ser uma das actividades mais exigentes para um poeta, ainda que as possíveis dificuldades fossem, à partida, atenuadas pela formação musical que os executantes recebiam desde a instrução básica (cf. supra, pp. 104-105). Vêm a propósito as palavras de Siriano, que atribuía a Simónides o 'conhecimento de toda a poética e música' resultante do trabalho realizado neste domínio. Dessa vasta obra, todavia, apenas nos chegou um título, Mź $\mu \nu \omega v$, preservado num passo de Estrabão (15.3.2 = fr. 539, 34 P, 27 B):

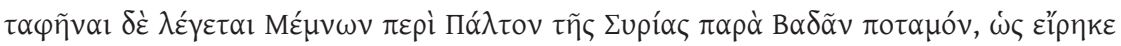

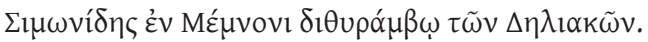

Diz-se que Mémnon foi sepultado perto de Palto, na Síria, junto do rio Bada, como diz Simónides no ditirambo Mémnon, pertencente a Deliacas.

A atribuição de um título ao ditirambo, indicativo do mito tratado, é confirmada pela obra de Píndaro e de Baquílides ${ }^{37}$. Convém, por isso, mencionar

${ }^{37}$ Cf. Pind. Dith. 2 = fr. 70b Ma.; Bacch. Dith. 15, 17, 18, 19, 20 e 23. A seguir ao título do poema figurava a menção dos destinatários e, eventualmente, do local de execução. Sobre o tratamento do mito de Mémnon, o rei mítico dos Etíopes, que combateu em Tróia, vide Bowra 1961: 318-319; A. Kossatz-Deissmann, LIMC VI. 1, s.v. Memnon (Zürich und München 1992) 448-462, VI. 2: 230-239. 
a informação do gramático Aristófanes de Bizâncio (fr. 124 Slater = fr. 562,

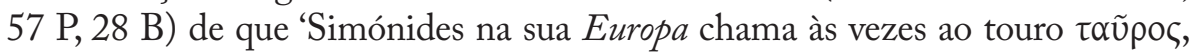
outras $\mu \tilde{\eta} \lambda o v$, outras $\pi \rho o ́ \beta \alpha \tau o v . '$ Este testemunho não especifica o subgénero da composição, na qual o poeta tratou possivelmente o mito do rapto da princesa Europa por Zeus, transformado em touro. Podemos supor que fosse um ditirambo, o que foi admitido por Bergk, mas contestado em geral por outros helenistas (cf. Bowra 1961: 319, Pickard-Cambridge 1962: 17). O significado da expressão

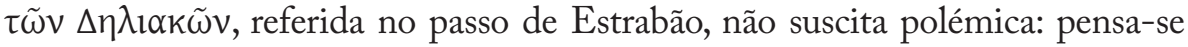
que diga respeito a uma colectânea de ditirambos executados nas festividades de Delos e, eventualmente, aí preservados ${ }^{38}$. Por conseguinte, é legítimo supor que outros fragmentos, em especial os que dizem respeito a temas mitológicos, pertençam também a ditirambos. De facto, um dos traços característicos desta forma poética parece ter sido a narração mitológica ${ }^{39}$.

Os dados de que dispomos são, portanto, escassos, mas se a tradição do sucesso de Simónides como mestre de coros ditirâmbicos tem fundamento histórico, supomos que esta actividade o tenha obrigado a deslocar-se com frequência a Atenas, ou a qualquer outra cidade da Hélade em que se realizassem competições poéticas com coros circulares ${ }^{40}$. A este propósito, há alguns pontos que merecem reflexão.

De um modo geral, os estudiosos consideram que um número de cinquenta e seis vitórias alcançadas apenas com o coro de homens é demasiado elevado e improvável (cf. Page 1981: 241, 243) e Pickard-Cambridge 1962: 2, 36 (cf. 1968: 78 e n. 7) notou que as provas de que o prémio atribuído ao poeta era um touro não se referem especificamente aos concursos atenienses (cf. Pind. Ol.13. 18-19, schol. P1. R. 394c). Devemos supor, portanto, que o número indicado pelo epigr. XXVII é apenas simbólico ${ }^{41}$ e que o poeta também foi premiado fora de Atenas ${ }^{42}$. Por outro lado, aquele helenista chamou a atenção para o facto, notável, de grande parte dos participantes nos concursos das Grandes Dionísias não ser de nascimento ateniense e o mesmo se verificar com os mais

${ }^{38}$ Cf. Bowra 1961: 318, Pickard-Cambridge 1962: 17, Campbell 1991: 431, Rutherford 1990: 203-205.

${ }^{39}$ Cf. P1. R. 394c, Ps. Plu. de Mus. 10.1134e. Sobre este aspecto, vide Zimmermann 2002.

40 Cf. Pickard-Cambridge 1962: 3-4, 37. Os concursos atenienses realizavam-se na Primavera. Em Delfos, três meses do ano eram dedicados à execução do ditirambo em honra de Diónisos, o que acontecia no início do Inverno (cf. Plu. De E apud Delphos 9. 388e, 389b-c).

${ }^{41} \mathrm{O}$ número de cinquenta e seis vitórias corresponde a uma vitória por ano de 532 a 476, o que significa, numa base teórica, que o poeta participou em todos os concursos das Grandes Dionísias, se apresentou em Delfos todos os anos, e noutras póleis da Hélade (em Corinto e Delos, por exemplo). Mas a hipótese de Simónides ter iniciado a sua carreira como mestre de coros circulares em 532 (na terra natal?, vide supra, pp. 116-117) vai ao encontro das palavras de Siriano, segundo o qual o poeta havia conhecido o sucesso nas competições ditirâmbicas desde a juventude.

${ }^{42}$ Cf. Pickard-Cambridge 1962: 16, Herington 1985: 251 n. 72. 
famosos auletas (1962:31,1968: 76). De facto, o primeiro vencedor registado no Marm. Par. Ep. 46 (= 509/8) é Hipódico de Cálcis ${ }^{43}$. Em 496, o prémio coube a Píndaro (P. Oxy. 2438, col. 1, linhas 9-10), e em 494/3 a Melanípides de Melos (Marm. Par. Ep. 47) ${ }^{44}$. Não podemos deixar de recordar que um passo das Aves de Aristófanes (vv. 1403-1404) confirma que a escolha do poeta estava sujeita a grande disputa por parte das tribos ${ }^{45}$. Esta tradição de mobilidade tinha raízes antigas, como vimos na primeira parte: o primeiro cultor do ditirambo, Aríon, era de Metimna, mas trabalhou em Corinto, e Laso, que desenvolveu o seu ofício em Atenas, era de Hermíone. A obra preservada de Píndaro e de Baquílides confirma que esta tradição se manteve no séc. V.

${ }^{43}$ Uma vez que se atribui a Laso a iniciativa da introdução dos ditirambos em Atenas (cf. supra, pp. 94-95), Pickard-Cambridge 1962: 15 supôs que este registo dizia respeito à primeira vitória nas Dionísias organizadas sob o regime democrático.

${ }^{44}$ Sobre este poeta ditirâmbico, vide Henderson 1989: 35-36.

${ }^{45}$ Cf. Pickard-Cambridge 1968: 75-76. As fontes disponíveis sobre o processo de selecção são escassas e pertencem ao séc. IV (Antiph. 6.11, D.21.17). 


\section{II.2. Os PATRONOS}

\subsection{Da Grécia Central e Insular}

\section{a) Em Atenas durante a tirania}

Não são anteriores ao séc. IV as fontes mais antigas que associam os nomes de Simónides e de Hiparco: o tratado homónimo do Pseudo-Platão (228b-c) e a Constituição dos Atenienses atribuída a Aristóteles (18.1 = test. 10). De acordo com a primeira, Hiparco 'mandou um barco de cinquenta remos buscar Anacreonte de Teos para a cidade; tinha sempre junto de si Simónides de Ceos, atraindo-o com elevadas recompensas e donativos. Fazia isto com a intenção de educar os seus concidadãos, a fim de mandar num povo superior, entendendo, na sua qualidade de homem perfeito, que a sabedoria não devia

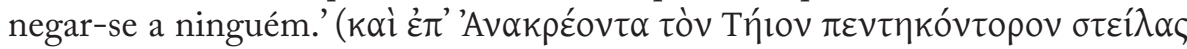

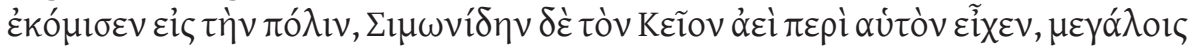

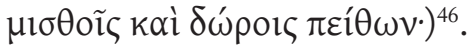

$\mathrm{Na}$ segunda fonte, a caracterização de Hiparco não é tão favorável e, neste sentido, a atenção que dedicou aos poetas já não é entendida como exemplo das suas preocupações sociais e da sua política cultural ${ }^{47}$, mas antes fruto da propensão para a busca de prazer: 'Quanto a Hiparco, era dado aos divertimentos, ao amor e às Musas: foi ele quem mandou chamar a Atenas Anacreonte e Simónides, bem como os restantes poetas.' (ò $\delta \dot{\varepsilon}$ "I $\pi \pi \alpha \rho \chi \circ \zeta$

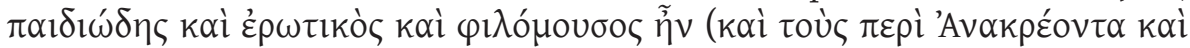

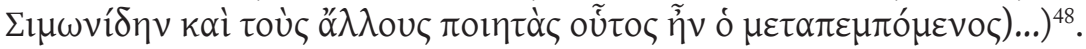

Os dois testemunhos, que podem remontar a uma fonte comum, sugerem que Simónides se demorou junto de Hiparco e pode ter convivido com outros poetas, como Anacreonte, que era mais velho, de acordo com a cronologia tradicional que lhe é atribuída, e Laso de Hermíone, seu rival nos concursos ditirâmbicos.

A análise do passo acima referido do Pseudo-Platão suscita ainda duas reflexões. Em primeiro lugar, trata-se de uma das fontes sobre o motivo biográfico da avareza de Simónides, que trataremos no último capítulo desta

${ }^{46}$ Tradução de M. H. Rocha Pereira (2009: 412). O passo citado segue-se ao que foi transcrito no capítulo dedicado à tradição dos rapsodos (supra, p. 49).

${ }^{47}$ Sobre a política cultural dos Pisístratos, vide especialmente Shapiro 1989, Ferreira 1990: 32-33 e n. 1.

${ }^{48}$ Tradução de Delfim F. Leão, Aristóteles. Constituição dos Atenienses (Lisboa ${ }^{32011) . ~}$ 
parte, confirmando que esta tradição estava bem difundida no séc. IV, pelo menos. Outro ponto de interesse reside nas linhas que antecedem o passo citado, nas quais se atribui a Hiparco a introdução na Ática das 'epopeias de Homero' e a norma que tornou obrigatória a sua recitação sucessiva nas Panateneias (vide supra, p. 49). Como veremos na última parte deste estudo, o corpus de Simónides denuncia um conhecimento apurado dos Poemas Homéricos e supomos que essa formação possa ter sido aprofundada enquanto viveu em Atenas.

Como se sabe, estes testemunhos não são absolutamente fidedignos e não provam por si só que o poeta tenha frequentado a corte dos Pisístratos. Mas as pistas que neles colhemos adquirem mais valor quando relacionadas com outros dados fornecidos pelo corpus atribuído a Simónides.

Em 1935, G. Zuntz publicou e analisou um pedaço de um papiro da primeira metade do séc. II d.C. (P. Berol. 13875), que continha um fragmento de um comentário a um poema desconhecido de Píndaro ( $C R$ 49: 4-7). Esse texto figura no corpus lírico de Simónides como fr. 607 (= 102 P):

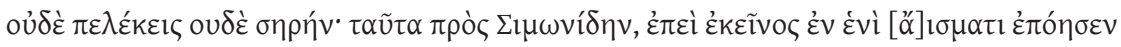

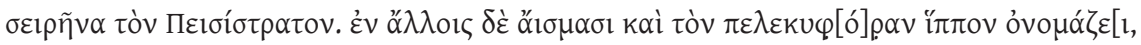

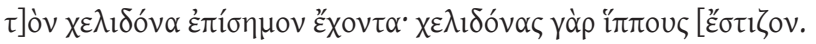

'nem machados nem sereia' (Pind. fr. 339 Ma.): estas palavras são para Simónides, pois ele num canto chamou 'sereia' a Pisístrato. Noutros cantos também nomeia o cavalo portador do machado, o que tem a andorinha marcada, pois [marcavam] os cavalos com andorinhas.

Se, como pensa Zuntz, ao chamar 'sereia' a Pisístrato, Simónides pode ter pretendido elogiar a eloquência do tirano (cf. Arist. Ath. 15.4), este testemunho indicia uma relação de cordialidade entre os dois homens. No entanto, sereia é também o símbolo da eloquência que conduz à perdição, pelo que outras interpretações seriam possíveis. Mas não teremos de enveredar por este caminho, porque apenas nos interessa sublinhar que este testemunho sugere que Simónides conhecia ou chegou a conviver com Pisístrato ${ }^{49}$. Ou seja, a tradição de que foi Hiparco o responsável pela ida de Simónides para Atenas pode não passar de uma lenda, sugerida pela convivência do poeta com a sua família. É plausível que essa deslocação tenha acontecido antes de 527, data da morte de Pisístrato. Por essa altura, Simónides estaria perto dos trinta anos e, provavelmente, o seu talento era já reconhecido além das fronteiras da terra natal ${ }^{50}$.

\footnotetext{
${ }^{49}$ Para uma análise do fragmento, vide Bowra 1961: 322-323.

${ }^{50}$ A hipótese geralmente admitida é que o poeta residiu na corte dos Pisístratos entre 527 e 514 (cf. Huxley 1978: 234-235). Embora o texto citado nada adiante sobre o subgénero do poema de Simónides, julgamos pertinente recordar que existe registo de um acontecimento que podia ter motivado a composição de um canto lírico em honra do tirano. $\mathrm{Na} 61^{\text {a }}$ Olimpíada
} 
A crer nas palavras do comentador, parece desenhar-se um quadro de rivalidade poética entre Simónides e Píndaro ${ }^{51}$. Os outros textos que relacionam Simónides com a família de Pisístrato encontram-se no corpus epigramático e o mais polémico é o que abre a colectânea. Heféstion, metricista e gramático do séc. II d.C., ao comentar a estrutura do hexâmetro, cita a título de exemplo um dístico elegíaco que atribui a Simónides.

Epigr. I [131 B, 76 D] Heph. 4.6 (pp. 14-15 Consbruch) + lapis ed. Meritt 1936:

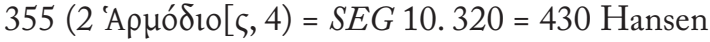

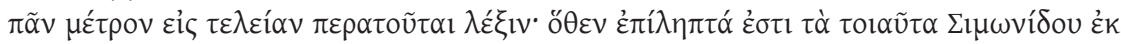

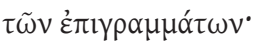

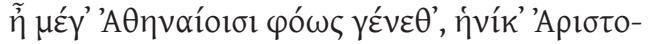

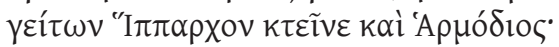

[

[ i i

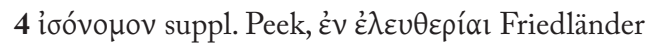

Cada verso termina com uma palavra completa. Por isso é que são reprováveis estes versos dos epigramas de Simónides:

Aos Atenienses chegou, por certo, uma luz imensa, quando Aristogíton e Harmódio mataram Hiparco.

a terra pátria tornaram [isónoma?]

Já no séc. XX, a descoberta na ágora de Atenas de uma pedra, na qual ainda era legível uma parte dos dois pentâmetros, permitiu supor que estas palavras pertencem à inscrição que figurava na base do monumento de homenagem aos Tiranicidas, esculpido por Crítios e Nesiotes no arcontado de Adimanto (477/6, cf. Marm. Par. Ep. 54), e que teria substituído o que foi levado pelos Persas em 480, realizado por Antenor algum tempo após a expulsão de Hípias (cf. Paus. 1. 8. 5: $\left.I G \mathrm{I}^{2} .485\right)^{52}$.

(= 536), Pisístrato foi proclamado vencedor na prova de quadrigas, embora o proprietário dos animais fosse Címon, filho de Esteságoras, de Atenas (pai de Milcíades), que, encontrando-se exilado, negociou deste modo o regresso à pátria (Hdt. 6. 103. 1-3). Cf. Moretti 1957: 72, 73. O facto de o fr. 607 evocar um contexto agónico também apoia esta conjectura.

${ }^{51}$ Parece-nos difícil de apurar se esta animosidade teve uma motivação política, devido à hostilidade entre os seguidores continentais dos aristocratas e os amigos iónicos dos tiranos, e depois entre aqueles e os democratas, como pensa Zuntz (pp. 6-7). Em nosso entender, não é de excluir a hipótese de a suposta rivalidade entre Simónides e Píndaro ter sido uma invenção dos escoliastas deste último (cf. infra, pp. 168-169).

${ }^{52}$ Cf. Meritt 1936: 356; A. F. Stewart, OCD, s.v. Antenor (2). Alguns estudiosos defendem que o monumento de Antenor foi colocado após a batalha de Maratona. Cf. J. Boardman, Greek Sculpture. The Classical Period (London ${ }^{21991)}$ 24-25; Stewart 1990 I: 249; Rausa 1994: 15 e n. 5. 
Do ponto de vista ideológico, ecoam neste epigrama as palavras de ordem e as doutrinas que se ouviram em Atenas nos anos que se sucederam à expulsão de Hípias. Faz sentido, por isso, que W. Peek tenha sugerido o adjectivo iøóvouo para o início do v. 4, que é um leitmotiv nas canções de mesa sobre este tema (cf. 893. 4, 896. 4 PMG). Meritt 1936: 358 concluiu da análise epigráfica da inscrição que esta tinha sido gravada em 477 , supondo, porém, que fosse uma cópia da que havia sido composta para o primeiro monumento. Page 1981: 188 defendeu, pelo contrário, que é mais provável que este epigrama tenha sido escrito para a segunda escultura, observando que, com o passar dos anos, o episódio da morte de Hiparco adquiriu o carácter mítico que esta composição testemunha ${ }^{53}$. $\mathrm{Na}$ análise do primeiro dístico, aquele especialista destaca a descrição do "tiranicídio" em termos apropriados aos heróis homéricos, um aspecto que podia abonar a favor da autoria de Simónides, questão que não discute.

São várias as razões apontadas pelos especialistas que põem em causa esta atribuição, designadamente o desleixo notado por Heféstion na construção do hexâmetro (cf. Page 1981: 188-189), ou mesmo a credibilidade desta fonte. Menos válido nos parece o argumento de que um poeta acolhido na corte dos Pisístratos dificilmente teria composto uma inscrição para um grupo escultórico que celebrava simbolicamente o fim da tirania em Atenas, pois tal actuação significaria uma prova de deslealdade e de ingratidão para com os antigos patronos ${ }^{54}$. Na verdade, a obra de Crítios e de Nesiotes foi edificada trinta e sete anos depois da morte de Hiparco. O elogio dos Tiranicidas em breve se tornaria popular e passou a ser cantado nos banquetes ${ }^{55}$, mas, no fim das Guerras Medo-Persas, Aristogíton e Harmódio eram essencialmente um símbolo do triunfo da democracia ${ }^{56}$. Assim, não julgamos que seja possível afirmar, com segurança, que Simónides tenha sido o autor do epigr. I, mas não

Do grupo escultórico de Crítios e Nesiotes preserva-se uma cópia romana no Museu Nacional de Nápoles. Vide Richter 1970: 152, 154-156, 1984: 124-125; Ferreira 1990: 37; Stewart 1990 II: 227.

${ }^{53}$ Sobre a morte de Hiparco às mãos de Aristogíton e de Harmódio, durante a procissão das Grandes Panateneias (Thuc. 6. 54-59), vide J. Ribeiro Ferreira, A Grécia Antiga. Sociedade e Política (Lisboa 22011). Sobre o significado político do culto do tiranicídio, vide Podlecki 1966.

${ }^{54}$ Cf. Meritt 1936: 356, Stella 1946: 19-20, Bowra 1961: 321-322, Gerber 1970: 328-329, Campbell 1982: 394.

${ }_{55}$ Cf. frr. 893-896 PMG (in Campbell 1993: 284-287) e a tradução em Ferreira 1990: 245. Sobre estas canções de mesa, vide Bowra 1961: 391-396.

${ }^{56}$ Este ponto de vista foi defendido por Hauvette 1896: 52 e Podlecki 1966: 136. Na opinião deste investigador, o responsável pela 'versão oficial' da morte de Hiparco, que ofuscava a luta dos Alcmeónidas contra a tirania, teve como principal instigador Temístocles, possibilidade que reforça, em seu entender, a atribuição do epigrama a Simónides (pp. 138-139). Cf. Podlecki 1973: 31-32, 1984: 198-199. 
podemos excluir esta hipótese. Em nosso entender, na discussão deste ponto devemos ter presente o epigrama seguinte.

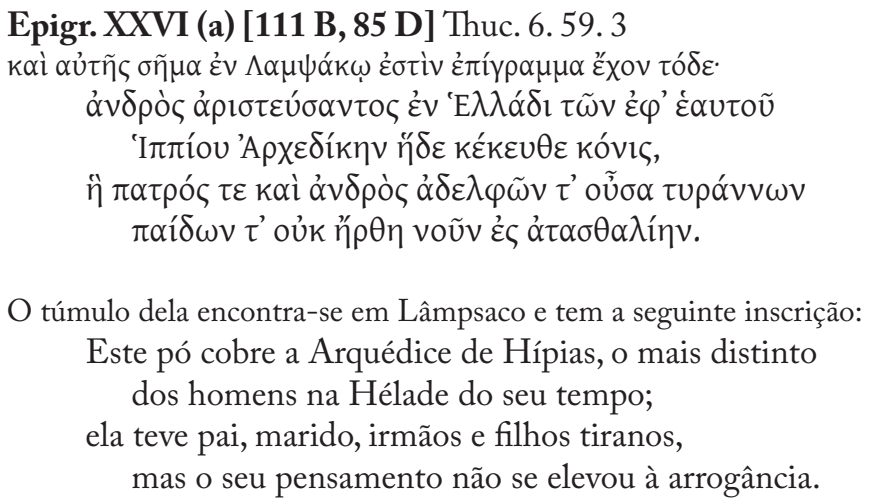

Trata-se do epitáfio de Arquédice, filha de Hípias e esposa de Eântides (filho de Hípoclo, tirano de Lâmpsaco), transmitido por Tucídides e atribuído a Simónides por Aristóteles (Rh.1.9.20,1367b). Nas linhas que antecedem a citação, o historiador regista que Hípias, depois da morte de Hiparco, receava uma revolta contra o regime. O casamento da filha com um membro de uma família que tinha grande influência junto de Dario, rei dos Persas, poderia garantir um refúgio no exterior. Não obstante a forma elogiosa como o tirano de Atenas é evocado, a ênfase é colocada no último termo, a $\alpha \tau \alpha \sigma \theta \alpha \lambda i ́ \alpha$, que significa 'orgulho', 'insolência', e a negação acaba por ser o aspecto dominante de todo o epigrama. Page 1981: 239 desvalorizou o testemunho do filósofo, observando que na segunda metade do séc. IV era costume atribuir a Simónides epigramas que haviam sido compostos no seu tempo. Não contestamos inteiramente esta prudente opinião. Assim, as palavras de Aristóteles confirmariam apenas que no séc. IV a imagem do poeta estava claramente associada à família dos Pisístratos. Todavia, a qualidade literária do epitáfio, designadamente o modo habilidoso como o elogio de Hípias é articulado com a censura velada da tirania, incentiva-nos a aceitar o seu testemunho. Neste ponto, partilhamos inteiramente da opinião de Bowra 1961: 323, quando escreve: "The danger of tyrants was that they might fall into ü $\beta p \iota s$, and here Simonides shows that he recognized this and honoured those who escaped it. He consorted with tyrants, but there is no reason to think that he was servile to them.". Por outro lado, como defendem outros helenistas, parece-nos francamente injusto não ter em conta a opinião de um dos maiores eruditos da Antiguidade ${ }^{57}$.

${ }^{57}$ Para Bowra, a autoria do epitáfio é estabelecida por Aristóteles (cf. 1938: 192). Esta opinião já fora defendida por Hauvette 1896: 48-49, que chamou a atenção para as semelhanças 
Julgamos que há menos razões para aceitarmos a integração no corpus de Simónides do seguinte dístico elegíaco, que nenhuma autoridade antiga lhe atribui (epigr. XXVI (b) = IG $\mathrm{I}^{2} .761=305$ Hansen):

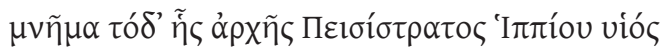

$\theta \tilde{\eta} \kappa \varepsilon v$ 'А

Memória do seu arcontado, este é o dom de Pisístrato, filho de Hípias, no santuário de Apolo Pítico.

Também transmitida por Tucídides (6. 54.6-7), esta inscrição pertencia a um altar edificado por um filho de Hípias, que foi arconte em Atenas c. 522/1, se se aceitar a conjectura $\Pi \varepsilon 1 \sigma l] \sigma \tau \rho \alpha \tau[o \zeta$ na lista de arcontes de $S E G$ 10.352.6, observa Page 1981: 240. O estilo do epigrama apenas confirma que se trata de uma inscrição arcaica $^{58}$, pelo que a integração no corpus de Simónides é apenas uma suposição dos editores modernos, que tiveram em conta, provavelmente, a tradição que associava o nosso lírico à família dos Pisístratos.

\section{b) Os patronos da Eubeia}

Ao tratar a revolta da Iónia contra a Pérsia, Heródoto distingue, entre os que perderam a vida nesta luta, Eválcides, comandante dos Erétrios, acrescentando 'que venceu nas competições que têm como prémio uma coroa e foi muito

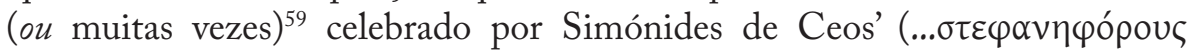

formais com o epigrama de Megístias (epigr. VI). Este aspecto foi também notado por Campbell 1982: 396-397, que, no entanto, manifestou muitas dúvidas quanto à atribuição a Simónides. A autenticidade do epigrama é defendida por Brian M. Lavelle, "The Dating and Patronage of the Archedike-Epigram", Hermes 114 (1986) 240-244, que discute em particular o sentido de ỏ $\tau \alpha \sigma \theta \alpha \lambda$ í $\alpha$, destacando um contraste entre a efemeridade da glória de Hípias (e da tirania) e a eternidade da pureza de Arquédice. Por sua vez, Petrovic 2007: 55 considera que a atribuição do epigrama a Simónides por Aristóteles constitui "the first explicit and fairly certain attribution of an epigram to this poet."

${ }^{58}$ Para um estudo detalhado da inscrição, vide Meiggs and Lewis 1975: 19-20. O altar em pedra foi preservado com a inscrição legível (Atenas, Epigraphicum Museum). Vide Strassler 1998: 391.

${ }^{59}$ Sobre as implicações desta dúvida, vide Molyneux 1992: 45-46 e n. 68, que conclui não ser possível optar entre 'muito ou muitas vezes celebrado'. Hutchinson 2001: 288 n. 6 observa que não significa 'com frequência' ('often'), remetendo para Hdt. 1. 90.1 1, 2. 135. 6, 8. 124. 3. Na sua opinião, há grande probabilidade de o poema composto para Eválcides ser anterior a 500. Não há acordo quanto ao ano da morte do comandante dos Erétrios. Parsons 2001: 56 considera que ocorreu em 498.

$\Sigma \tau \varepsilon \varphi \alpha v \eta \varphi o ́ \rho \circ \varsigma \alpha ̉ \gamma \omega ́ v=\sigma \tau \varepsilon \varphi \alpha v i ́ \tau \eta \varsigma$, 'competição que tinha como prémio uma coroa' $(L S J)$, pode ser entendido como referindo-se aos quatro grandes festivais pan-helénicos (cf. supra, p. 85). No locus classicus sobre os prémios dos jogos, Pausânias indica a coroa de oliveira sagrada (Olímpicos), de loureiro (Píticos), de pinheiro (Ístmicos) e de aipo (Nemeus), e acrescenta que a maioria concedia uma coroa de palma (8. 48. 2). No entanto, como já dissemos, nos 


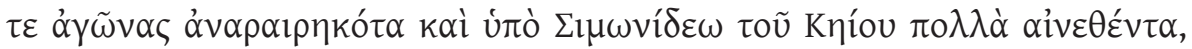
5. 102.3 = fr. 518, 13 P, 9 B).

O conflito que opôs a força conjunta de Atenienses, Iónios e Erétrios aos Persas decorreu entre 499 e 493, e como Eválcides se empenhou desde o seu início, as suas vitórias atléticas devem ter ocorrido muito tempo antes. Nada sabemos de concreto, nem mesmo se Simónides compôs um ou vários epinícios. Este testemunho atesta, contudo, que antes de findar o séc. VI o poeta de Ceos era solicitado por atletas da Eubeia. Não se trata do único exemplo, visto que celebrou a vitória do pugilista Glauco de Caristo, alcançada provavelmente na $65^{\text {a }}$ Olimpíada ( $=520$, vide infra fr. 509), que foi considerado um dos atletas mais valentes da Época Arcaica (Moretti 1957: 76).

Um testemunho muito mais tardio sobre um cliente da Eubeia não oferece qualquer dado cronológico. Ao comentar o topónimo Tauúval, o lexicógrafo Harpocrácion, que terá vivido no séc. I ou II d.C., escreve (I. 286-287 Dindorf $=$ fr. 530,25 P, 35 B):

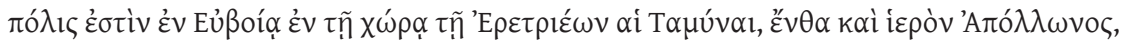

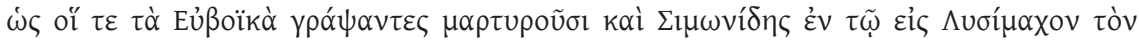

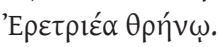

Taminas é uma cidade da Eubeia situada na terra dos Erétrios, onde existia um templo de Apolo, como testemunham os que escreveram Euboica e Simónides, no treno em honra de Lisímaco de Erétria.

Uma vez que nada sabemos sobre este homem (Heródoto menciona em 8. 79. 1 um Lisímaco, mas de Atenas), nem sobre o seu treno, este testemunho confirma somente que o poeta não compôs apenas odes de vitória para atletas da Eubeia. A título de curiosidade, registe-se que o editor do P. Oxy. 2624 (= fr. 519B Campbell) levantou a hipótese de o fr. 48 conter uma referência

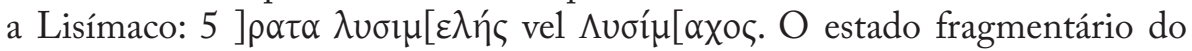
papiro, datado de 100-150 d.C., não permite ir além desta conjectura ${ }^{60}$.

jogos de Pelene o vencedor recebia uma clâmide, nos de Argos um escudo de bronze (cf. Pind. Ol. 7. 83), taças de prata nos de Maratona e Sícion (Ol.9.89-90, Nem. 10. 43). Segundo informa Aristóteles (Ath.60.3), nas Panateneias os vencedores nos concursos musicais eram

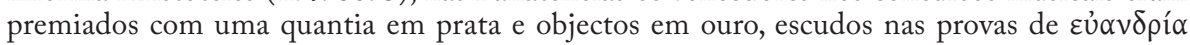
(beleza masculina), e ânforas cheias de azeite das oliveiras sagradas de Atena nas competições atléticas e equestres. Estes eram os prémios oficiais, mas os campeões eram aclamados nas suas pátrias e, naturalmente, gozavam de muitos privilégios, como documentam diversas fontes. Sobre esta questão, que tem sido muito debatida, vide Bernardini 1980, esp. 87-88; Rocha Pereira 2000b: 23-24; Delfim F. Leão, "Os honorários dos atletas vencedores (a propósito de Plutarco, Sol. 23. 3)”, in Oliveira 2000: 73-83.

${ }^{60}$ Molyneux 1992: 47 contesta a opinião de Wilamowitz 1913: 139, que considerava que as odes compostas para Erétrios deviam ser anteriores a 490, observando que a cidade da Eubeia 
Na opinião de Molyneux 1992: 46, as odes para patronos da Eubeia, dada a situação geográfica desta região, nem distante de Atenas nem de Ceos, podem ter sido escritas em qualquer altura, antes de o poeta partir para a Sicília em 476. Mas outros factores podem ter pesado mais que os geográficos na actuação profissional de Simónides. Segundo informa Estrabão (10. 1. 10), na Época Arcaica, Erétria exercia o seu domínio sobre algumas ilhas próximas, designadamente Andros, Teos e Ceos. Assim se explica, observou Ph. Gauthier ${ }^{61}$, que alguns nomes de magistrados (os probouloi), bem como algumas denominações administrativas (os choroi), fossem comuns. Tendo em consideração esse elo político antigo, julgamos que é legítimo supor que os poemas compostos para Glauco de Caristo, Eválcides e Lisímaco de Erétria se incluem entre os mais antigos de Simónides, como concluiu Huxley $^{62}$.

\section{c) Simónides, cantor nacional das Guerras Medo-Persas}

O envolvimento profissional de Simónides na grande luta pela liberdade da Hélade contra a submissão aos Persas foi definitivamente confirmado em 1992 com a publicação de novos fragmentos elegíacos ${ }^{63}$. Subsistem, porém, muitos pontos obscuros, que nos impedem de formular juízos definitivos no que diz respeito à sua mobilidade durante este período. Como existem também muitas dúvidas sobre a autenticidade dos epigramas que lhe são atribuídos, salvo o que foi composto em honra do vidente e seu amigo Megístias (epigr. VI), o valor documental das composições relativas a este conflito, que estudaremos na terceira parte, não pode ser apreciado por inteiro.

É bastante conhecido um passo da Vida de Ésquilo, que associa Simónides às comemorações da vitória de Maratona ( $\operatorname{Tr} G F \mathrm{III}, \mathrm{T} 1.8 .27-30$ = test. 15):

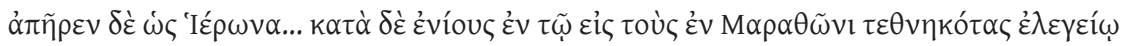

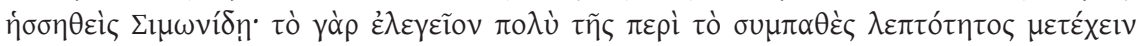

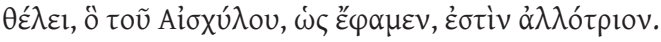

recuperou rapidamente do saque persa, a ponto de enviar homens para os confrontos de 480-479. Por conseguinte, na opinião de Molyneux, é possível que o poeta tenha composto a ode para Lisímaco numa data posterior a 490.

${ }^{61}$ Symbola. Les étrangers et la justice dans les cités grecques (Nancy 1972) 356. Ph. Gauthier baseia-se em C. C. Dunant et J. Thomopoulos, "Inscriptions de Céos”, BCH 78 (1954) 316-322, que neste artigo publicaram um tratado antigo de 'isopolitia' descoberto em Iúlis e assinado entre Erétria e Ceos. O Bulletin de Correspondance Hellénique pode ser consultado online em: http://cefael.efa.gr/site.php?site_id=1 [acedido em 6/07/2012].

62 1966: 134. Sobre as relações antigas entre a Eubeia (do sul, especialmente) e Ceos, vide pp. 133-134. Cf. Huxley 1978: 234.

63 O P. Oxy. 3965 (ed. Parsons 1992: 5-50), dada a sobreposição com o P. Oxy. 2327 (ed. Lobel 1954: 67-76), permitiu recuperar fragmentos elegíacos sobre as batalhas travadas contra os Persas e sobre outras temáticas, aparentemente apropriadas ao ambiente do symposion. 
[Ésquilo] afastou-se para junto de Hierão (...), segundo outros, por ter sido vencido por Simónides no dístico elegíaco sobre os que morreram em Maratona. De facto, o dístico elegíaco exige forçosamente a delicadeza do que suscita a simpatia, o que, como dissemos, é estranho a Ésquilo.

Nenhum outro testemunho confirma que alguma vez se realizou tal competição, mas a notícia pode ter algum fundamento, embora seja provavelmente falsa a informação de que Ésquilo deixou Atenas na sequência deste episódio ${ }^{64}$. Este testemunho indicia, por um lado, que os Atenienses deram grande importância à inscrição com que homenagearam os soldados que haviam perdido a vida no campo de Maratona. Sugere, por outro, que as palavras de Simónides corresponderam ao espírito de tão solene momento, sublinhando-se, deste modo, a sua mestria na execução do trabalho. Não sabemos, porém, se a obra premiada figura no corpus epigramático que actualmente se atribui ao poeta, que inclui, pelo menos, três composições sobre a batalha de Maratona. Vale a pena citar o que Lesky 1995 [1971]: 218 escreveu sobre esta questão: "A tentativa de identificar os dois epigramas numa inscrição da ágora ateniense é totalmente problemática." ${ }^{65}$.

A notícia da Suda sobre Simónides informa que compôs em dialecto dórico "O reinado de Cambises e Dario", "A batalha naval de Xerxes", "A batalha naval junto do Artemísio" em dísticos elegíacos, e "A batalha naval

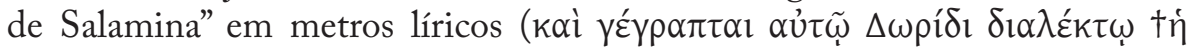

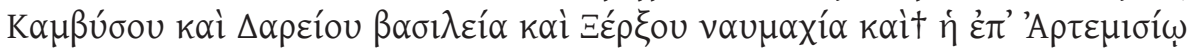

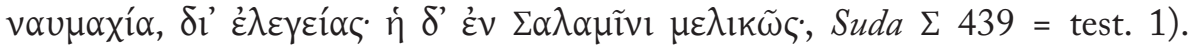
Supõe-se que este passo seja fruto de uma leitura errónea da fonte, que teria

${ }^{64}$ West 1992a: 136 inclui este testemunho na rubrica 'Incertum an ex epigrammatis'. Alguns estudiosos rejeitam totalmente a sua validade, em parte porque a competição entre poetas célebres, como Homero e Hesíodo (cf. Certamen..., Hes. fr. dub. 357 M-W), Píndaro e Corina (cf. Paus. 9. 22. 3; Ael. VH 13. 25; Suda K 2087, s.v. Kópıvva), e mesmo entre Píndaro e Simónides (schol. Pind. Ol.9.74b, I. 285 Dr. = fr. 602), é um topos da tradição pseudo-biográfica. Lefkowitz 1981: 71 considera que as histórias preservadas na Vita Aeschyli sobre a derrota do poeta por Simónides e Sófocles forneciam uma explicação para o facto de o túmulo de Ésquilo se encontrar em Gela. Cf. Campbell 1982: 378, Podlecki 1984: 186.

Ésquilo combateu em Maratona e era cerca de trinta anos mais novo do que Simónides. Uma derrota perante um poeta tão conceituado não seria razão suficiente para abandonar Atenas. Vale a pena ter presente o testemunho de Plutarco, segundo o qual o lírico de Ceos foi para a Sicília antes de Ésquilo (de exilio 13. 604f). Recorde-se que Hierão apenas se torna regente em Gela em 485, tirano de Siracusa em 478 e funda a cidade de Etna em 476/5 (cf. supra, pp. 108, 112). Para um exame dos testemunhos, cf. C. J. Herington, "Aeschylus in Sicily", JHS 87 (1967) 74-85.

${ }^{65}$ Epigr. XX (a) e XX (b), que analisamos em separado na terceira parte. Cf. infra, pp. 259-260 e n. 11. 
antes dito que o poeta compôs durante os reinados de Cambises (530-522) e de Dario (521-483), e, no decurso da invasão de Xerxes, celebrou as batalhas travadas junto do cabo Artemísio e da ilha de Salamina, em ritmo elegíaco e lírico, respectivamente ${ }^{66}$. Recorde-se que este último poema é também referido no testemunho que citámos da Vita Pindari Ambrosiana (pp. 118-119), que não especifica o metro ${ }^{67}$. Quanto ao primeiro, sobre a naumaquia junto do cabo Artemísio, segundo o gramático romano Prisciano (inícios do séc. VI d.C.), fora composto em metros líricos ${ }^{68}$. Todavia, os fragmentos revelados pelo P. Oxy. 3965 vieram dar crédito ao testemunho da Suda, confirmando a existência de um outro poema, em dísticos elegíacos, sobre esta batalha ${ }^{69}$.

Portanto, Simónides compôs várias obras sobre as naumaquias travadas em Agosto e Setembro de 480. É natural que tenha conhecido as personalidades que mais se destacaram nestas campanhas militares e nas que se sucederam. Segundo uma tradição preservada por Cícero (Fin. 2. $32.104=$ test. 25) e Plutarco, uma dessas pessoas foi o ateniense Temístocles, o herói de Salamina (Them. 5.6-7 = testt. 12, 27):

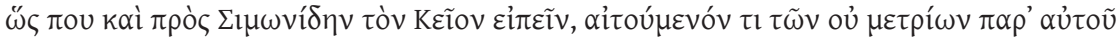

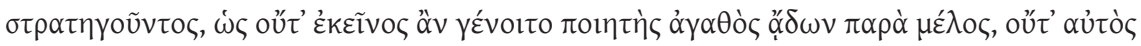

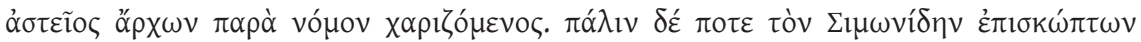

${ }^{66}$ Cf. Campbell 1991: 331; West 1992a: 114, 1993b: 2.

${ }^{67}$ Plutarco alude a uma obra de Simónides sobre a batalha de Salamina na Vida de Temistocles (15. 4 = fr. eleg. 5), mas também não diz em que ritmo foi composta. Não é claro se o seu testemunho é uma paráfrase de alguma parte do poema. Cf. Molyneux 1992: 188-189, Poltera 1997: 93-94.

${ }^{68}$ Prisc. de metr. Terent. 24 (= G.L. 3. 428). Este testemunho corresponde ao fr. 533 (28 P, 1

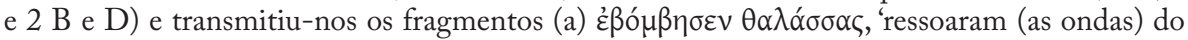
mar', e (b) ảं

${ }^{69}$ Cf. frr. eleg. 1-9. West 1992a: 114-116 supôs que alguns destes fragmentos pertenciam a um poema elegíaco sobre Salamina, mas posteriormente reconsiderou esta hipótese (cf. West 1993b: 2-3). O mesmo estudioso notou (ibidem, p. 3) que a composição sobre a batalha de Artemísio terá sido especialmente importante, a avaliar pelo testemunho do escoliasta de Apolónio de Rodes (1.211-215c, p. 26 Wendel = fr. 534, cf. fr. eleg. 3), que a cita simplesmente

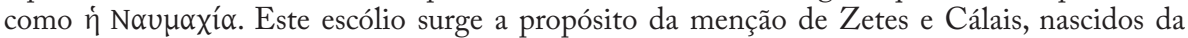
união de Bóreas e Oritia, cujo rapto era um dos temas do poema de Simónides. A possível

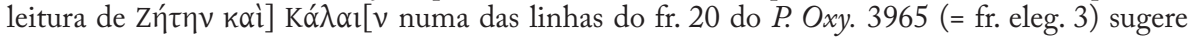
que a história, narrada por Heródoto (7.189), do socorro divino que o vento do Norte prestou aos Atenienses, era também tratada no poema. Wilamowitz 1913: 206-208 associou à mesma composição o testemunho de Himério sobre uma ode que Simónides cantou ao vento após uma naumaquia (Or. 47. 14, cf. 12. 32-33 = fr. 535). Por seu turno, Bowra 1961: 343-344 argumentou a favor da composição lírica sobre a batalha de Salamina. No estado actual dos nossos conhecimentos, e dado o estado precário dos fragmentos, não nos parece que se possa ir além de meras conjecturas. Para a análise do fr. 20 do P. Oxy. 3965, vide Parsons 1992: 41, West 1993b: 3-4. Para uma discussão do escólio de Apolónio de Rodes, vide Molyneux 1992: 158-166. Os testemunhos e fragmentos sobre as duas naumaquias são também discutidos por Obbink 2001: 78-79 e Rutherford 2001a: 35-38. O testemunho da Suda sobre as composições de Simónides é examinado em pormenor por Kowerski 2005: 4-16, esp. 


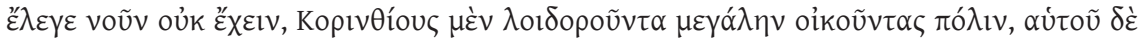

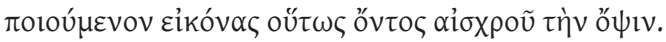

Então respondeu a Simónides de Ceos, quando este lhe fez um pedido impróprio enquanto era estratego, que nem ele viria a ser um bom poeta se cantasse desafinado nem ele próprio um brilhante dirigente se concedesse favores contra a lei ${ }^{70}$. De novo Temístocles, fazendo uma vez troça de Simónides, dizia que não tinha ele juízo, por insultar os Coríntios que viviam numa grande cidade e fazer retratos de si próprio quando tinha um aspecto tão feio.

O testemunho de Plutarco denuncia uma relação de estreita proximidade, mas as duas histórias seguem um padrão que se detecta igualmente na conversa entre o poeta e Temístocles preservada por Cícero. As réplicas do estratego revelam inteligência, honestidade e visão política, enquanto Simónides é retratado como um jovem poeta dependente, que não olha a meios para se tornar conhecido. A fonte é provavelmente alguma obra que enaltecia as qualidades políticas de Temístocles, em confronto com os que frequentavam o seu meio, mas que não tinha em conta a diferença de idades entre os dois homens ${ }^{71}$. Assim, pensamos que o poeta travou relações de amizade com o principal obreiro da batalha de Salamina, mas não nos moldes em que a tradição anedótica sugere ${ }^{72}$. Um testemunho válido dessa amizade pode ser

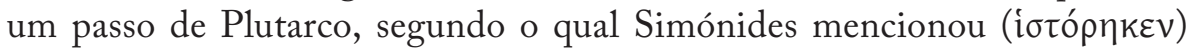
num poema, talvez encomendado por Temístocles, o restauro, a expensas do general, do telesterion situado no demo ático de Flia, que havia sido incendiado pelos Persas e era propriedade comum dos Licómidas. Esse acto de generosidade, no entender de Plutarco, atestava os laços de parentesco entre Temístocles e aquela antiga família ateniense (Them. 1.4 = fr. 627, 122 $\mathrm{P}, 222 \mathrm{~B})^{73}$.

Remonta talvez a este período de convivência com este político a inimizade ou desentendimento entre o nosso lírico e o poeta Timocreonte de Rodes, segundo informa Diógenes Laércio (2. 46 = test. 16): 'Como diz Aristóteles no terceiro livro sobre poesia (...) Timocreonte gostava de competir com

${ }^{70}$ Esta história figura também em Plu. De vitioso pudore 534e, Praecepta ger. reipubl. 807b, e em Ps. Plu. Regum et imperat. apoph. 185c-d.

${ }^{71} \mathrm{Em} 480$, Simónides teria cerca de setenta e seis anos. Temístocles, cujo nascimento é situado c. 528, podia ter quarenta e oito.

${ }^{72}$ Stella 1946: 12 considera natural a relação entre Simónides e Temístocles, vivendo o poeta em Atenas e sendo um entusiasta da vitória ateniense. Bowra 1961: 342 notou o valor trivial das notícias sobre os dois homens, considerando, porém, que teriam alguma validade histórica. Esta é também a opinião de Podlecki 1968: 273. E. Culasso Gastaldi, “Temistocle, Eschilo, Simonide et il culto della vittoria”, in E. Corsini, La Polis e il suo teatro (Padova 1986) 41 sqq., defende sobretudo que o poeta, bem como Ésquilo, contribuiu para a acção propagandística de Temístocles após a vitória de Salamina.

${ }^{73}$ Cf. Podlecki 1968: 273, 1969, 1984: 196-197; Huxley 1978: 243. 


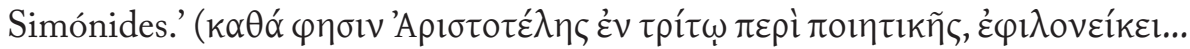

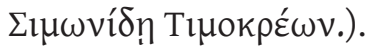

Visto que se baseia em Aristóteles, a notícia merece ser considerada, e sendo a fonte um tratado de poética, o motivo da contenda seria provavelmente de natureza profissional. A entrada da Suda sobre Timocreonte $($ T $625=$ Timocr. test. 1) centra-se em particular neste episódio, informando que o poeta de Rodes '...não se entendia nem com Simónides, o poeta lírico, nem com Temístocles de Atenas, contra quem teceu censuras numa das

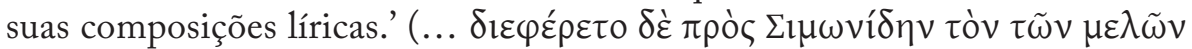

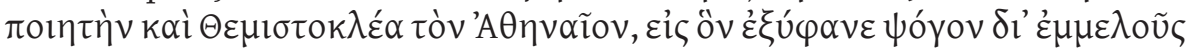

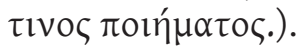

Segundo a Vida de Temistocles de Plutarco ( $\$ 21)$, que preservou vinte versos de três poemas compostos contra as acções daquele dirigente, Timocreonte queixava-se de não ter sido ajudado a regressar do exílio. Além disso, o estratego teria votado contra ele, quando o poeta foi acusado de medismo (cf. Athen. 10. $416 \mathrm{a}=$ Timocr. test. 2 ). Aquele testemunho sugere que o desentendimento não foi pontual. Um primeiro poema (fr. $727 P M G$ ) foi escrito após as batalhas de Salamina e de Plateias, mas Plutarco observa que Timocreonte reforçou as críticas (cf. frr. 728-730 $P M G$ ) após o processo de ostracismo que condenou Temístocles ao exílio c. 471, igualmente acusado de medismo. Sublinhe-se que em nenhum momento o nome de Simónides é associado a esta querela ${ }^{74}$. Assim, se o poeta foi também alvo dos ataques de Timocreonte, como testemunharam Aristóteles e a fonte da $S u d a$, não podemos afirmar que o motivo tivesse sido a suposta amizade entre o nosso lírico e Temístocles, embora essa hipótese não deva ser rejeitada. Em nosso entender, o conhecimento desta tradição, que remonta ao séc. IV pelo menos, levou o Corrector da Antologia Palatina a atribuir a Simónides o célebre epigrama satírico sobre Timocreonte (7. 348, APl. = epigr. XXXVII, 169 B, 99 D):

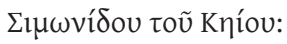

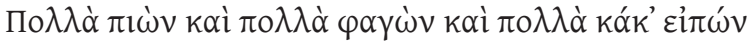

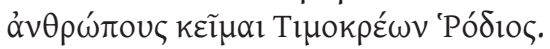

De Simónides de Ceos:

Depois de ter bebido bem, comido bem e falado bem mal dos homens, aqui repouso eu, Timocreonte de Rodes.

${ }^{74}$ Para mais pormenores, vide Bowra 1961: 349-358, que analisa os fragmentos de Timocreonte, e R. M. McMullin, "Aspects of Medizing: Themistocles, Simonides, and Timocreon of Rhodes”, CJ 97.1 (2001) 55-67. A representação das relações entre o político e os dois poetas no tratado de Plutarco é discutida por Alexei V. Zadorojnyi, "Plutarch's Themistocles and the Poets", AJPh 127.2 (2006) 261-292. 
A concisão singular, a qualidade literária e a graça desta composição levam muitos helenistas a aceitar a sua autenticidade ${ }^{75}$. Abona, talvez, a favor desta hipótese o facto de o autor se deter em dois traços particulares do carácter de Timocreonte, a gula (cf. Athen. 10. 415f-416a = Timocr. test. 2) e a maledicência, que pode ser uma alusão aos ataques a Temístocles. Além disso, os frr. 542 e 581, em particular, indicam que Simónides recorreu por vezes à crítica directa nos seus poemas.

Parece não haver grandes dúvidas, no entanto, de que é dirigida a Simónides uma composição atribuída a Timocreonte na Antologia Palatina $(13.31=$ fr. $10 \mathrm{~W})$ :

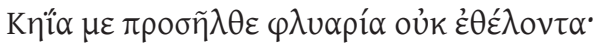

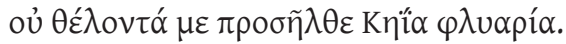

A tolice de Ceos veio ter comigo, contra a minha vontade; contra a minha vontade, veio ter comigo a tolice de Ceos.

Crêem os filólogos que se trata de uma paródia da que a precede na mesma colecção, que é atribuída a Simónides $(A P 13.30 \text { = fr. eleg. 92, } 170 \mathrm{~B}, 162 \mathrm{D})^{76}$ :

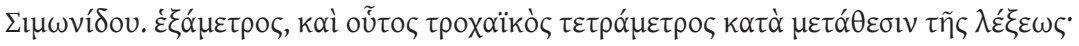

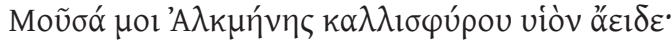

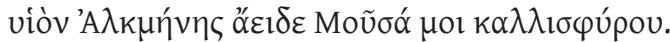

De Simónides, um hexâmetro e este tetrâmetro trocaico, formado pela transposição das palavras:

Ó Musa, canta-me o filho de Alcmena de belos tornozelos;

O filho de Alcmena de belos tornozelos canta-me, ó Musa.

Há, portanto, vários indícios de que a relação entre os dois poetas se pautava pelo confronto ${ }^{77}$. Mas vale a pena lembrar que, segundo uma fonte tardia, ambos haviam tratado nos seus poemas a 'fábula cária' (cf. supra fr. 514), o que, na ausência de dados mais concretos, significa apenas que partilharam o mesmo legado cultural e poético.

${ }^{75}$ Cf. Bowra 1961: 356-357, Huxley 1978: 244. Lesky 1995 [1971]: 215, porém, tem dúvidas.

${ }^{76}$ Cf. Campbell 1992: 97. Bowra 1961: 357-358 propõe uma interpretação diversa e discute a autenticidade das composições. Vide ainda Marina F. A. Martelli, "Gli epigrammi AP 7.348 (=37 FGE) e AP 13.30: la presunta attribuzione a Simonide”, Acme 61.2 (2008) 261-272.

${ }^{77}$ Para uma opinião diversa, vide Poltera 1997: 24 e n. 31. 
É provavelmente antiga a tradição que associava Simónides ao herói de Plateias, o espartano Pausânias, embora sejam parcos os testemunhos que a atestam. É o caso de um passo da II E Existola do Pseudo-Platão $(311 \mathrm{a}=$ test. 17): 'Assim, sempre que os homens conversam sobre Hierão e o espartano Pausânias gostam de evocar a relação deles com Simónides, o que fez e lhes

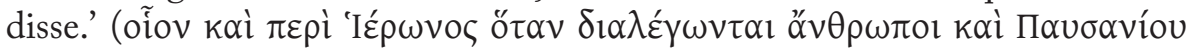

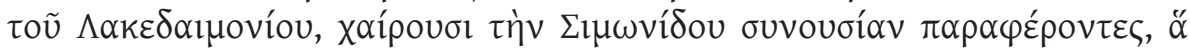

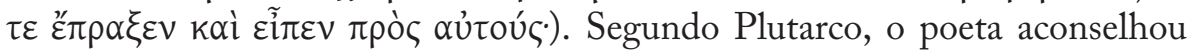
Pausânias a lembrar-se de que era um homem (Cons. Apoll. 6. 105a).

Tucídides (1. 132. 2) preservou um epigrama dedicatório composto a pedido do chefe espartano, que o Periegeta (3. 8. 2) atribui a Simónides (cf. epigr. XVII (a), infra). A publicação de fragmentos elegíacos sobre a batalha de Plateias, em 1992, se não atesta a autenticidade deste dístico elegíaco, confirma pelo menos que Pausânias foi celebrado pelo poeta, pois apesar do estado precário do fr. eleg. 11, é evidente a ênfase dada nos vv. 33-34 à sua actuação. Menos fundamentada nos parece a hipótese, avançada por Aloni 1994: 21-22, de que a partida de Simónides para a Sicília foi motivada pela sua associação com aquele político, que cai em desgraça c. $477^{78}$.

$\mathrm{Na}$ opinião de alguns helenistas, durante o período em que decorreram as Guerras Medo-Persas, Simónides privilegiou a actividade profissional desenvolvida no espaço ático. Abonam eventualmente a favor desta hipótese, além da história preservada na Vida de Ésquilo, os frr. eleg. 86 e 91, que West 1992a: 136-137 integrou na rubrica "Incertum an ex epigrammatis".

O fr. eleg. 86 (81 B, 62 D) foi citado num escólio de $A$ Paz de Aristófanes, a propósito dos vv. 736-738 (schol. V, p. 114 Holwerda) ${ }^{79}$ :

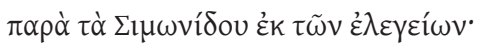

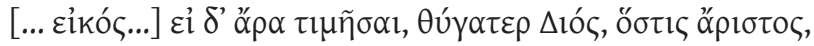

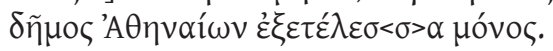

tais versos inspiram-se em Simónides, nos seus versos elegíacos:

Mas se [é justo] prestar honras, filha de Zeus, a quem é o melhor, assim fez o povo ateniense, sozinho.

${ }^{78}$ Cf. infra, p. 311. Razão semelhante já haviam proposto Stella 1946: 22-23 e Bowra 1961: 358-359, quando sugeriram que o declínio de Temístocles a partir de 476, que cumpriu nesse ano o seu último acto político de relevo como choregos das Fenícias de Frínico (cf. Plu. Them. 5. 5), pode ter incentivado Simónides a deixar Atenas.

${ }^{79}$ Pax 736-738: 'Mas se, apesar de tudo, ó filha de Zeus, for preciso homenagear alguém como o primeiro e o mais notável entre os comediógrafos, nesse caso, o nosso poeta julga-se com direito aos maiores elogios.' (trad. Maria de Fátima Silva, in Silva e Jesus 2010: 264-265). 
As palavras do escoliasta não esclarecem se estes versos pertencem a um poema ou a um epigrama composto em metro elegíaco. A primeira hipótese faz mais sentido e, se não podemos ir além de meras conjecturas quanto ao seu conteúdo, depreende-se destas palavras que nessa composição Simónides louvava um feito alcançado pelo povo de Atenas, como a vitória de Maratona ou de Salamina, ou então, tendo em consideração o sentido dos versos aristofânicos, o poeta referia-se a alguém (ele próprio?) que havia sido devidamente homenageado pelos Atenienses ${ }^{80}$.

O fr. eleg. 91 (113 B, $84 \mathrm{D}$ = epigr. LXXV) não tem a ver com estas lutas e não é tão relevante, pois a atribuição a Simónides depende inteiramente da Antologia Palatina (7.511), o que representa, à partida, um problema quanto ao estabelecimento da sua autenticidade:

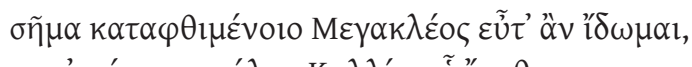

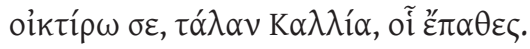

Sempre que vejo o túmulo do falecido Mégacles, tenho compaixão de ti, Cálias desventurado, pelo teu sofrimento.

A autenticidade deste dístico que constituiu, aparentemente, um epitáfio, foi contestada em particular por Page 1981: 295 ("LXXV is one of a series taken en bloc from the Sylloge Simonidea"), observando que Mégacles e Cálias, na passagem do séc. VI para o V, eram nomes frequentes entre as famílias nobres de Atenas, pelo que a atribuição a Simónides facilmente se impôs aos compiladores de epigramas da Época Helenística. Page não rejeita, porém, a hipótese de o fragmento pertencer a um poema elegíaco. Na opinião de Bowra

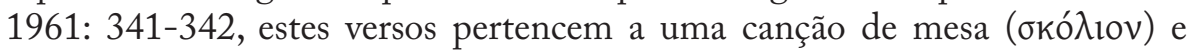
confirmam a relação de Simónides com Atenas ${ }^{81}$. Todavia, este mesmo investigador defendeu que é durante o período das Guerras Medo-Persas que se evidencia a personalidade pan-helénica do poeta (p. 323, cf. 1938: 184). De facto, se é incontestável a ligação profissional a Atenas, sabemos que Simónides não trabalhou em exclusivo para esta pólis. Um dos fragmentos mais célebres do corpus pertence à homenagem dos soldados que perderam a vida nas Termópilas ao lado de Leónidas (cf. fr. 531). Além das composições

${ }^{80}$ Não há unanimidade quanto a este ponto. Barigazzi 1963: 74 viu neste fragmento uma referência à vitória de Maratona. Molyneux 1992: 150 ponderou esta hipótese, embora com reservas (cf. p. 153). Podlecki 1968: 269-271 propôs antes Salamina. Rutherford 2001a: 37-38 cita estas hipóteses e avança outras possibilidades, designadamente a batalha de Artemísio.

${ }^{81}$ Hauvette 1896: 145 integrou o fr. eleg. 91 nos epigramas "vraisemblablement authentiques" (cf. pp. 101-102). A autenticidade não é, de resto, a questão mais polémica. Menos consensual é a identificação de Mégacles e de Cálias. Sobre este ponto, vide Campbell 1982: 396 e Molyneux 1992: 155-156, que faz a resenha das teses propostas. 
sobre as naumaquias acima referidas, um dos trabalhos mais importantes terá sido o poema elegíaco dedicado à vitória de Plateias. Uma das questões que tem intrigado os estudiosos é precisamente o relevo que Simónides teria dado a cada um dos contingentes gregos, uma vez que o exército de Esparta, chefiado por Pausânias, parece surgir em evidência, pelo menos na parte preservada do papiro. No entanto, Plutarco deixou-nos o seu testemunho sobre o modo como os Coríntios eram evocados nessa obra (cf. frr. eleg. 15-16). Por outro lado, segundo informa o Periegeta, no campo de Plateias, os túmulos dos Atenienses e dos Espartanos estavam assinalados com epigramas de Simónides (9. 2. 5, cf. epigr. VIII e IX). Supomos que a composição de todas estas obras ocupou o poeta durante alguns meses de 480/479 e que a sua execução o obrigou a realizar várias deslocações, visto que participaram no conflito contingentes de diversas póleis e os confrontos ocorreram em diferentes locais da Grécia ${ }^{82}$. $\mathrm{Na}$ terceira parte, no comentário a alguns dos fragmentos voltaremos a este assunto.

\section{d) O testemunho do corpus epigramático}

O corpus epigramático atribuído a Simónides inclui quatro composições dedicatórias e uma funerária que dizem respeito a atletas da Grécia Continental e Insular, mas é provável que não sejam todas autênticas. Pausânias transmitiu-nos uma dessas peças, sublinhando a sua singularidade (6. 9. $9=$ epigr. XXIX, 152 B, 148 D):

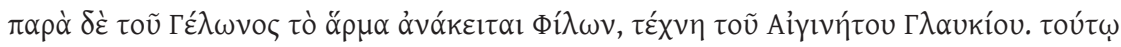

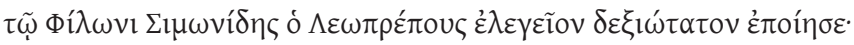

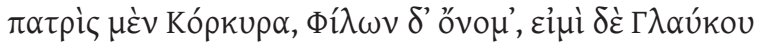

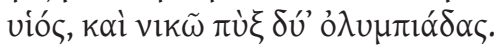

Junto do carro de Gélon ergue-se a estátua de Fílon, obra do egineta Gláucias. Para este Fílon, Simónides, filho de Leóprepes, compôs este singular dístico elegíaco:

Minha pátria é Corcira, Fílon é o meu nome, de Glauco sou filho e com o meu punho venço duas Olimpíadas.

Pausânias admirou o estilo conciso e elegante destes versos, cuja informação se restringe ao essencial: naturalidade, nome, filiação do atleta e vitórias alcançadas. Tal concisão leva a supor que se trata de uma inscrição

${ }^{82}$ Nas conclusões sobre a actividade de Simónides neste período, Molyneux 1992: 202 reconhece que a composição de um largo número de obras para diferentes cidades teria levado o poeta a realizar diversas viagens, observando que não é possível saber que lugares, de facto, visitou. O que afirma a seguir - "even choral odes could be sent, and performed in the poet's absence" - depreende-se dos versos de Píndaro e de Baquílides (vide supra, pp. 107-110), mas não há nenhum indício relativamente ao nosso lírico. 
arcaica, o que por si só não assegura a atribuição a Simónides (cf. Page 1981: 244). Mas há outros dados a ter em conta.

Este passo de Pausânias é também um testemunho dos contactos que se podiam estabelecer na Época Arcaica entre artistas e atletas oriundos de diversas partes do mundo grego. De facto, a estátua olímpica do famoso Mílon de Crotona foi realizada por um compatriota (Paus. 6.14.5, vide infra), mas a de Fílon é uma obra de Gláucias de Egina, que desenvolveu a sua actividade nos inícios do séc. $\mathrm{V}^{83}$. Os dados de que dispomos sobre as vitórias do atleta coincidem com esta cronologia. Alguns estudiosos identificam-no com o Fílon de Corcira mencionado por Pausânias em 6.14. 13, cuja estátua em Olímpia comemorava uma vitória no estádio na categoria dos paides, que Page 1981: 243 situa nos anos 504 ou $500^{84}$. Na sua opinião, as vitórias na prova do pugilato devem ter ocorrido em 492 e $488^{85}$. Mas, para Moretti 1957: 79, a identificação não é segura, uma vez que o epigrama não faz alusão a vitórias precedentes $^{86} \mathrm{e}$ o próprio Pausânias em 6.14.13 não esclarece que está a falar de um atleta já referido nos capítulos anteriores. Assim, situa a primeira vitória de Fílon na 70a Olimpíada (= 500) e a segunda na Olimpíada seguinte (496).

Embora divergentes, nenhuma das datações representa um obstáculo à autoria de Simónides, nem cremos que a sua intensa actividade o teria impossibilitado de compor um singelo epigrama em honra de um jovem atleta,

${ }^{83}$ Campbell 1991: 549. Moretti 1957: 75 e Fontenrose 1968: 99 situam o floruit do escultor c. 480. De acordo com Paus. 6.10.3, este artista realizou também a estátua olímpica do pugilista Glauco de Caristo (cf. fr. 509), dedicada pelo filho do atleta.

${ }^{84}$ Moretti 1957: 79 situa este triunfo na 69a Olimpíada (= 504) e supõe que na Olimpíada seguinte, na mesma categoria, tenha vencido Meneptólemo de Apolónia, também referido por Pausânias em 6.14.13.

${ }^{85}$ Page baseia-se nas propostas de A. Raubitschek ( $R E$ 19, 1938, col. 2528-2529). Esta hipótese é conciliável com os dados reunidos por Moretti 1957: 82 e 84, segundo os quais na $72^{\text {a }}$ Olimpíada $(=492)$ a vitória no pugilato coube a Cleomedes de Astipaleia e na Olimpíada seguinte $(=488)$ a Diogneto de Creta, mas ambos foram desclassificados por terem matado o adversário (cf. Paus. 6.9.6 e infra, n. 111), pelo que outro atleta foi declarado vencedor. A identificação do Fílon de Corcira de Paus. 6. 14. 13 com o que é mencionado no passo anterior foi proposta pela primeira vez por T. Preger (apud Moretti 1957: 79, Page 1981: 243 n. 1).

${ }^{86}$ Esta omissão pode ter sido voluntária. Note-se que o epigrama foi composto na primeira pessoa e as formas verbais se encontram no presente do indicativo. É possível que Gláucias tenha esculpido o atleta na posição característica de skiamachein, ou seja, em plena acção contra um adversário imaginário, tal como representara Glauco de Caristo (cf. Moretti 1957: 75; Rausa 1994: 23, 93). Se o epigrama pretendia ser uma ilustração viva da estátua, não faria sentido evocar uma vitória anterior numa prova completamente diferente. Segundo informam Raubitschek, ibidem, e Moretti 1957: 80, numa data posterior ao ano 394 da nossa era, a estátua de Fílon foi levada para Constantinopla e fazia parte das que decoravam as galerias das termas de Zeuxipo, onde foi contemplada pelo poeta Cristodoro de Copto (Egipto, séc. V-VI d.C.), que a mencionou na sua obra (Ekphrasis 229, poema incluído no livro II da Antologia Palatina). Para uma leitura deste texto, vide A. Kaldellis, "Christodoros on the Statues of the Zeuxippos Baths: A New Reading of the Ekphrasis”, GRBS 47 (2007) 361-383. 
ainda que oriundo de uma longínqua pólis. Segundo Quintiliano (Inst.11.2.14 = fr. 510 , infra), entre os laureados que a tradição atribuía ao poeta contava-se um tal Agatarco e há registo de que um atleta de Corcira com este nome obteve uma vitória no estádio na $61^{\text {a }}$ Olimpíada $(=536)$. A confirmar-se a identificação entre os dois homens ${ }^{87}$ e a tradição citada pelo retórico romano de que Simónides havia composto um epinício, teria sido um dos seus primeiros trabalhos ${ }^{88}$.

Na VIII ${ }^{a}$ Pítica, composta para Aristómenes de Egina, por uma vitória alcançada supostamente em $446^{89}$, Píndaro evocou os triunfos atléticos de Teogneto e de Clitómaco, tios maternos do laureado (vv. 35-37, cf. Race 1997a: 326). É de supor que este passo tenha de algum modo sugerido a atribuição a Simónides, o poeta da geração anterior à do grande lírico de Tebas, do epigrama dedicatório de Teogneto, preservado na Antologia de Planudes (2 = epigr. XXX, 149 B, 111 D). Segundo Pausânias (6. 9. 1), este atleta de Egina venceu em Olímpia a prova de luta na categoria de paides e supõe-se que esta vitória tenha

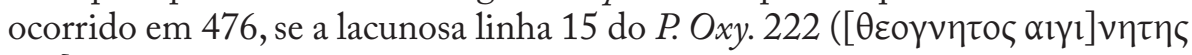
$\left.\pi \alpha l^{\delta} \pi \alpha \lambda \eta v\right)$ lhe diz respeito ${ }^{90}$. Se aquela data não é obstáculo à autoria de Simónides, Page 1981: 244 notou, com razão, que o estilo do epigrama sugere tratar-se, provavelmente, de uma criação de um erudito alexandrino ${ }^{91}$.

Píndaro celebrou num epinício uma vitória obtida por Cásmilo de Rodes nos Jogos Ístmicos (frr. 2-3 Ma., cf. Race 1997b: 224-225), mas nada mais sabemos sobre este pugilista nem sobre as datas dos seus triunfos. Page 1981: 245 não chega a uma conclusão definitiva sobre a autenticidade do epigrama dedicatório que a Antologia de Planudes atribui a Simónides (23 = epigr. XXXI,

${ }^{87}$ Cf. Moretti 1957: 72. As fontes são D.H. 4. 41.1 e Iulius Africanus.

${ }^{88}$ Cf. supra (n. 50) a nossa conjectura sobre a celebração, por Simónides, de uma vitória de Pisístrato alcançada também nesta $61^{\text {a }}$ Olimpíada.

${ }^{89}$ A confirmar-se a informação do escoliasta, trata-se da ode mais recente da colecção de epinícios (cf. Race 1997a: 326).

${ }^{90}$ Cf. Grenfell and Hunt 1899: 91, Page 1981: 244, Campbell 1991: 549. O P. Oxy. 222, datado do séc. III d.C., contém uma lista de vencedores olímpicos respeitante aos anos 480468 e 456-448, como já foi referido. Vide a edição moderna, com tradução e comentário, em Christesen 2007: 28-30, 202-215, 382-384.

${ }^{91}$ Page notou a omissão da naturalidade do atleta, o que não seria vulgar num epigrama contemporâneo, sobretudo quando a metáfora do v. 4 sublinha a importância da vitória para a terra de seus pais. Diversamente da concisão singular que caracteriza o epigr. XXIX, a dedicatória de Teogneto evidencia processos tipicamente literários, como o imperativo inicial, que evoca a

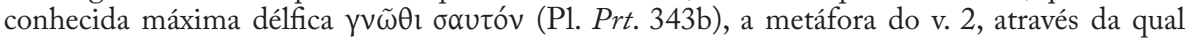
se revela a especialidade do atleta, o elogio hiperbólico do seu aspecto no v. 3, que lembra um passo da VIII ${ }^{a}$ Olimpica de Píndaro (vv. 19 sqq.), composta em honra de Alcimedonte de Egina, vencedor na prova de luta de paides em 460. Molyneux 1992: 89-91 rejeitou a autoria de Simónides com base na hipótese de o fr. 507 pertencer a um epinício em que insultava Crio de Egina e na convicção de que há indícios de que o poeta, ao contrário de Píndaro, nunca celebrou atletas desta ilha. Julgamos, porém, que não é legítimo evocar o fr. 507 como prova de que o epigr. XXX não foi composto por Simónides. Como veremos na terceira parte, não há consenso quanto ao sentido a atribuir ao fragmento lírico. 
154B,149 D).De facto,evidenciam-se as mesmas características que destacamos a propósito do epigr. XXIX: concisão, clareza e informação essencial, próprias da inscrição de uma estátua. No entanto, o emprego da forma dialogada e a elaboração fónica do dístico, sobretudo no v. 1, não excluem a hipótese de se tratar de uma composição literária da Época Helenística. Todavia, ainda que aceitemos a sua autenticidade, a ausência de dados sobre as datas das vitórias de Cásmilo de Rodes não nos ajuda na análise da questão da mobilidade de Simónides ${ }^{92}$.

Duas linhas do P. Oxy. 222 registam o triunfo do corredor Dândis de Argos no diaulos $(400 \mathrm{~m}$ ), no ano de 476 (linha $8[\delta \alpha] v \delta 1 \varsigma \alpha \rho[\gamma] \varepsilon l[0] \varsigma$

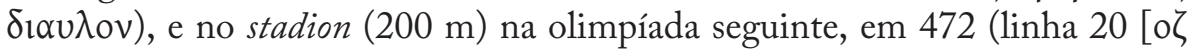
$\left.\delta \alpha v] \delta ı \iota_{1} \alpha \rho \varepsilon 10 \zeta \sigma \tau \alpha \delta 10 v\right)^{93}$. Estas vitórias coincidem com os últimos anos da vida de Simónides, pelo que, do ponto de vista cronológico, há uma ligeira possibilidade de o poeta ter composto o epitáfio que a Antologia Palatina lhe atribui (13. 14 = epigr. XXXV, 125 B, 98 D):

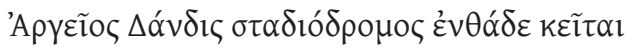

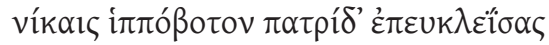

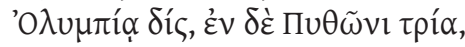

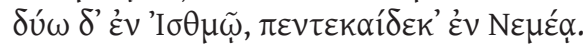

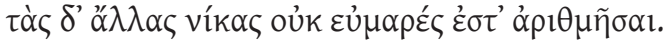

Aqui jaz Dândis de Argos, corredor de estádio, que glorificou com suas vitórias a pátria criadora de cavalos, duas vezes em Olímpia, três em Delfos, duas no Istmo, quinze em Nemeia.

Não é fácil contar as outras vitórias.

O elenco dos triunfos de Dândis parece respeitar a hierarquia tradicional dos quatro grandes festivais pan-helénicos e não a cronologia das suas vitórias, o que abona a favor da autenticidade da composição ${ }^{94}$. Page 1981: 250 observa ainda que uma personagem sobre a qual praticamente nada se sabe não pode ter sido objecto de um epitáfio fictício na Época Helenística. A confirmar-se a autoria de Simónides, este epigrama provaria que o poeta que vivia agora na Magna Grécia, de acordo com o retrato que a tradição nos legou, não deixava

\footnotetext{
${ }^{92}$ Hauvette 1896: 135 rejeitou a autenticidade do epigrama.

${ }^{93} \mathrm{O}$ triunfo na corrida do estádio em 472 é também registado por Dionísio de Halicarnasso (9.37. 1) e Diodoro Sículo (11.53.1).

${ }^{94}$ Sobre esta questão, vide em particular P. Angeli Bernardini, "Lepitafio dell'atleta Dandis di Argo (APXIII 14)", Eos 69 (1981) 195 sqq. (cf. 1980: 96-97). A favor da autenticidade do epigrama (p. 191), a análise de Bernardini tem como objectivo o confronto entre a formulação linguística nos epigramas de atletas e no epinício. Sobre a carreira de Dândis, cf. Moretti 1957: 89, 91.
} 
de continuar a compor em honra de homens distintos da Grécia Continental. Mas sobre este ponto, dispomos apenas do testemunho da Antologia Palatina, o que é muito pouco.

No mesmo livro da Antologia Palatina figura, sob a autoria de Simónides, o epigrama dedicatório do corredor Nicoladas de Corinto, que se distingue principalmente pela sua dimensão singular (doze versos) e pelo metro ${ }^{95}$ ( $A P$ 13. 19 = epigr. XLIII, 155 B, 147 D). Na opinião de Page 1981: 262, trata-se da cópia de uma inscrição e a atribuição a Simónides, nas suas palavras, "pode ser uma indicação de que é relativamente antiga". Como não possuímos quaisquer dados biográficos sobre Nicoladas, não podemos tirar conclusões sobre a relevância deste epigrama na questão da mobilidade de Simónides. O facto de o dialecto ser o dórico convencional (Page 1981: 263) pode ser um indício de que o poeta fosse alguém com uma personalidade pan-helénica. Em nossa opinião, se Simónides tivesse comemorado as vitórias do atleta num epigrama, tê-lo-ia feito de forma mais concisa e elegante.

\section{e) Os Oligétidas de Corinto}

Em 464, Píndaro celebrou a consagração olímpica de Xenofonte, vencedor no estádio e no pentatlo, numa ode em que evoca o triunfo em Olímpia de seu pai, Téssalo, pela vitória no estádio, mas também os muitos outros feitos desportivos alcançados em diversos festivais pela sua família, os Oligétidas de Corinto (Ol.13.1, 24-48, 93-113).

É bem provável, como crêem alguns helenistas, que Simónides tenha celebrado algumas das muitas vitórias desta família mas, por enquanto, essa possiblidade baseia-se apenas nas propostas de reconstituição dos frr. 21 e 22 do P. Oxy. 2623 (= 339-340 SLG, 519A Campbell), datado dos inícios do séc. II d.C. e publicado em 1967 por Lobel ${ }^{96}$. As palavras mais legíveis sugerem que ambos pertencem a epinícios e supõe-se que estejam relacionados (cf. Lobel 1967: 66, Campbell 1991: 405, 407).

A hipótese de pertencerem a uma ode de vitória dedicada a alguém da linhagem dos Oligétidas apoia-se nos vv. 6-7 do fr. 21, onde se pode ler 'E]

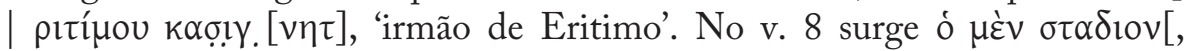
o que pode significar uma referência a uma vitória no estádio. Embora a

\footnotetext{
${ }^{95} \mathrm{O}$ metro é uma combinação de hexâmetros dactílicos e de hiponacteus. Este assunto e os vários problemas que o epigrama apresenta no âmbito da crítica textual são tratados por Bruna M. Palumbo Stracca, "La carriera di Nicolada (AP xiii 19)", BollClass 5 (1984) 106-117. Page 1981: 262 enumera os traços originais da composição, sublinhando que o modelo literário é o catálogo do epinício, do tipo que se encontra em Píndaro (e.g. Ol. 7. 81-87, 13. 106-113).

${ }_{96} \mathrm{O}$ estudo mais importante sobre esta matéria continua a ser o de Barrett 1978. Vale a pena lembrar que é posterior à publicação deste artigo a confirmação, por Lobel 1981: 21-22, de que o P. Oxy. 2623 deve ser atribuído a Simónides, o que Barrett já supunha (cf. p. 5).
} 
identificação do grau de parentesco de Eritimo constitua uma dificuldade, a ode de Píndaro dedicada a Xenofonte, na qual é evocado (v. 42), atesta que pertencia àquela família ${ }^{97}$. Por sua vez, o fr. 22 reforça esta relação, pois são legíveis os topónimos referentes a Delfos (3 ]ov• ПuӨoĩ yó (5 ] $ı ı$. 1 Kopı ı̣[ $[\theta-)$. O primeiro evoca um dos santuários em que os Oligétidas triunfaram (cf. Pind. Ol. 13. 43), o segundo a sua pátria. Por conseguinte, cremos que podem ter razão os estudiosos que incluem entre os patronos de Simónides os Oligétidas de Corinto ${ }^{98}$.

É provável que o poeta tenha celebrado outros cidadãos desta pólis. A história evocada por Plutarco na Vida de Temistocles $(5.7$ = test. 27, cit. supra), segundo a qual Simónides insultara os cidadãos coríntios, além de ser incompreensível pela ausência de um contexto, não passa certamente de uma anedota, que os fragmentos não confirmam e as palavras do próprio Plutarco desmentem (cf. epigr. XIV, frr. eleg. 15 e 16). Talvez tenha sido o conhecimento desta associação profissional à cidade do Istmo que levou a tradição a atribuir-lhe o epigrama do pintor Ífion de Corinto ${ }^{99}$ e o epitáfio de Xantipa, esposa de Arquenauta e bisneta do tirano Periandro ${ }^{100}$.

\subsection{Da Tessália}

\section{a) As famílias aristocráticas}

É antiga a tradição, e hoje unanimemente aceite, de que em determinado momento da sua vida Simónides beneficiou da protecção das famílias aristocráticas da Tessália. Com toda a probabilidade, tal convivência deve ter sido interrompida, ou mesmo cessado, quando o exército persa invadiu a Hélade ${ }^{101}$. Os elementos de que dispomos, todavia, não nos permitem

${ }^{97}$ Os escólios de Píndaro não esclarecem esta dificuldade. Cf. Barrett 1978: 2-9, Race 1997a: 193 n. 3.

${ }^{98}$ Cf. Barrett 1978: 10 sqq., que examinou e tentou reconstituir os fragmentos. As suas propostas são aceites por Parsons 2001: 59, 62.

${ }_{99}$ Epigr. XXXII (AP 9. 757). A atribuição a Simónides encontra-se apenas na Antologia de Planudes, o que é uma prova muito frágil, ainda que possa ser uma cópia de uma inscrição autêntica. Na mesma antologia, o epigr. XXXIII (b), que pretende ser uma assinatura do pintor Címon de Clonas, figura também sob a autoria de Simónides. Cf. Page 1981:245-246, que situa o floruit dos dois pintores c. 500 .

${ }^{100}$ Epigr. XXXVI. Hauvette 1896: 145 considera-o um dos epigramas "vraisemblablement authentiques", opinião corroborada por Page 1981: 251-252, que analisa a composição e defende tratar-se da cópia de uma inscrição verdadeira. No entanto, a atribuição a Simónides depende somente da Antologia Palatina (13. 26).

${ }^{101}$ Esta conjectura fundamenta-se na suposição de que as manobras militares dos Persas devem ter posto em perigo as comunicações com a região da Tessália e não tanto no medismo de alguns dos seus chefes, como defenderam alguns estudiosos. Cf. Molyneux 1992: 134 e n. 115. 
determinar com exactidão em que momento Simónides aceitou trabalhar para chefes tessálios. Muitos helenistas acolhem como facto a hipótese de o poeta ter deixado Atenas na sequência do assassínio de Hiparco em 514 (cf. Sordi 1958: 84) e regressado por volta do início das Guerras, ou logo após a tragédia que se abateu sobre a família dos Escópadas e abalou provavelmente a sua influência. B. Helly situou este acontecimento c. $515^{102} \mathrm{e}$, talvez devido à proximidade desta data com a da morte de Hiparco, considerou a possibilidade de Simónides ter sido acolhido na corte de Escopas antes ou imediatamente a seguir à convivência com o filho de Pisístrato (Helly 1995: 108, cf. Sordi 1958: 62).

Mais relevante nos parece o que escreveu acerca das características geográficas da Tessália: uma região rodeada de montanhas, que não funcionavam, porém, como obstáculos às comunicações com as regiões vizinhas, porque o conjunto de vales e caminhos que as atravessam (que receberam a designação geral de Tempe), em todas as épocas permitiram a deslocação de viajantes, mercadores e exércitos (OCD, s.v. Thessaly). Podemos supor que, pelo menos até ao início das Guerras Medo-Persas, a deslocação a essa região do mundo grego não representaria uma dificuldade excepcional, mas também não cremos que fosse muito simples ${ }^{103}$. Como já dissemos, é provável que Simónides tenha sido acolhido na corte de Pisístrato antes da morte do tirano (em 527), o que não significa que aí residisse em permanência. Não nos parece, portanto, que se deva rejeitar a hipótese de se ter deslocado à Tessália antes da morte de Hiparco. Mesmo aceitando essa possibilidade, é natural que os poetas que haviam convivido de perto com os filhos de Pisístrato tenham procurado protecção noutras paragens, sobretudo após a expulsão de Hípias $^{104}$. Em finais do séc. VI, as cortes das famílias aristocráticas da Tessália, aliadas dos Pisístratos, devem ter sido tão acolhedoras como foram, mais tarde, as dos tiranos da Sicília, já que detinham uma riqueza considerável, apoiada na posse de grandes domínios e na criação de animais, que permitiria certamente grandes generosidades, mas também relações e influência importantes, quer

102 OCD, s.v. Crannon. Morrison 1942: 61 não avançou nenhuma data precisa ("The disaster of the Scopads must have occurred towards the end of the sixth century"). Sordi 1958: 67 situa a morte de Escopas, que perdeu a vida nessa catástrofe, "numa data imprecisa entre 510 e 500 ". Vide a recensão das diferentes propostas, nenhuma isenta de dificuldades, em Molyneux 1992: 137.

103 A descrição que Heródoto nos fornece do itinerário seguido pelas forças terrestres enviadas pela Grécia Central à Tessália c. 480 (7. 173. 1-2) é muito vaga, mas sugere que o percurso se fazia (ou podia fazer) em duas etapas: primeira, através do Mar Egeu, atravessando o estreito de Euripo e desembarcando em Alo, na Acaia-Ftiótida, ao sul da Tessália; segunda, por terra, entrando na Tessália através do desfiladeiro de Tempe. No mesmo capítulo, refere o itinerário seguido pelo exército de Xerxes.

${ }^{104}$ Huxley 1978: 235 sugere que Simónides pode ter beneficiado das relações diplomáticas entre Hípias e os chefes tessálios. 
no interior da Tessália quer além fronteiras (cf. Sordi 1958: 84, Helly 1995: 107).

A fonte mais antiga a atestar a convivência de Simónides com um chefe tessálio é o Protágoras de Platão, que nos transmitiu um dos fragmentos mais importantes do seu corpus, pertencente a um poema composto a pedido de Escopas de Crânon (339a-346d = fr. 542). Se nada sabemos sobre as circunstâncias de composição e execução (cf. infra, pp. 212-213), os intervenientes no diálogo platónico confirmam que era muito conhecido no séc. V (Prt. 339b). Supomos que outras composições tenham também sido célebres, porque no Idílio XVI, que versa sobre a importância da convivência dos homens de poder com os poetas, Teócrito evoca como exemplo antigo a imortalidade que os nobres tessálios haviam alcançado graças a Simónides (vv. 42-47 = test. 13):

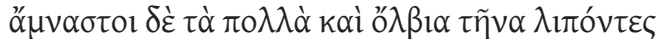

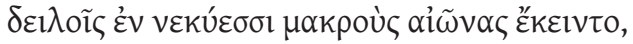

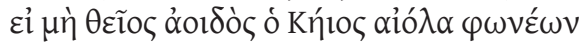

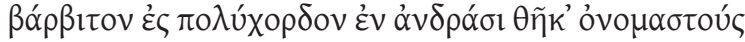

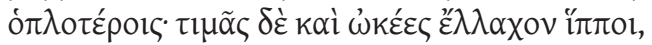

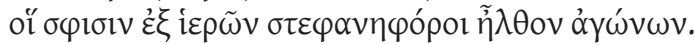

Tivessem eles deixado para trás aquelas riquezas numerosas, ficariam esquecidos entre os infelizes mortos por largo tempo, se um aedo divino, o homem de Ceos, entoando cantos variados ao som do barbitos de muitas cordas, não os tornasse célebres entre os homens mais jovens. E até os cavalos velozes receberam honras, ao regressarem coroados das sagradas competições.

Nos versos que antecedem este passo, Teócrito menciona 'Avtíoxoৎ

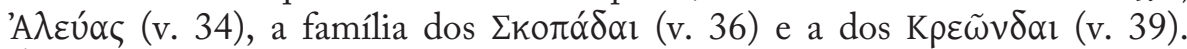
É interessante notar o retrato anacrónico de Simónides como um aedo homérico (vv. 44-45), embora não seja totalmente fantasioso supor que na Tessália tivesse andado de corte em corte e acedido a compor para as diversas famílias, independentemente das relações que estas mantinham entre si (que permanecem uma incógnita ${ }^{105}$. Vale a pena lembrar que a fonte de Estrabão sobre os nomes dos diferentes povos que viviam nesta parte da Grécia arcaica é precisamente o nosso lírico (9. 5. 20 = fr. 632, $127 \mathrm{P}, 198 \mathrm{~B})$.

${ }^{105}$ West 1992b: 58 n. 47 supõe que a menção do barbitos, geralmente associado ao simpósio nas pinturas de vasos, possa ser uma referência a um encómio composto por Simónides em honra da família dos Escópadas. Chama ainda a atenção para a ocorrência do vocábulo $\beta \alpha \rho \beta r[\tau$ na linha 3 do fr. 7 do P. Oxy. 3965 (= fr. eleg. 29). Na interpretação de Hunter 1996: 101-102, ao mencionar este instrumento de cordas, Teócrito pretendia sublinhar o profissionalismo de Simónides. Sobre o barbitos, cf. West 1992b: 57-59, Mathiesen 1999: 249-253, Pereira 2001: 204-210. 
A crer no testemunho de Teócrito, Simónides contactou especialmente com três famílias: a de Antíoco, a dos Alévadas e a dos Escópadas ${ }^{106}$. É interessante a menção de Alevas, pois a sua família, estabelecida em Larissa desde o início do séc. VI até ao fim do séc. IV, era uma das mais poderosas da Tessália. Deduz-se da informação dos escólios de Teócrito (ad 16. 34-35)

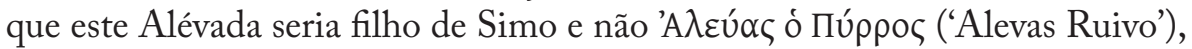
o mais célebre dos membros desta família. Esta questão não é, no entanto, consensual nem vale a pena ser aqui tratada. $\mathrm{Na}$ verdade, em nossa opinião, não é de admirar que os Alévadas tenham convidado Simónides a permanecer na sua corte algum tempo, mas esta hipótese não é confirmada por nenhum outro testemunho nem pelos fragmenta. Sabemos, contudo, que solicitaram a Píndaro um epinício, pelo menos. A Xa Pítica, composta em 498 (de acordo com o escólio) para Hipócleas da Tessália, por uma vitória no diaulos dos paides, foi aparentemente encomendada por Tórax (v. 64). Líder dos Alévadas no início do séc. $V$, este chefe e os seus dois irmãos foram os principais instigadores do medismo tessálio (Hdt. 7. 6. 2, 7. 130. 3), mas viriam naturalmente a perder a sua influência após as Guerras (B. Helly, OCD, s.v. Aleuadae; Helly 1995: 114). Fica, assim, em aberto a possibilidade de Simónides ter contactado com membros desta família ${ }^{107}$.

O tratamento desta questão não está isento de dificuldades, uma vez que as fontes mais importantes sobre os aristocratas tessálios da Época Arcaica são as que a tradição literária nos legou acerca das relações profissionais do poeta. A título de exemplo, Helly 1995: 104 considerou os vv. 34-39 do idílio acima citado o testemunho mais significativo sobre Antíoco. O escólio aos vv. 34-35, depois de explicar o sentido das palavras de Teócrito, conclui com a seguinte observação (p. 327 Wendel = fr. 528): 'Antíoco era filho de Equecrátides e de

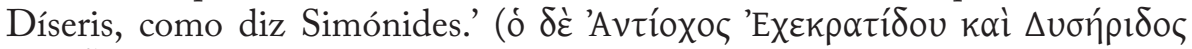

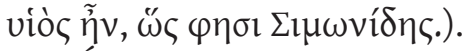

É de supor que o poeta tenha composto uma obra na qual evocava a filiação de Antíoco, um motivo vulgaríssimo num poema da Epoca Arcaica. Mas os editores de Simónides relacionaram este comentário com um passo de Élio Aristides (Or.31.2 = fr. 528, 23 P, 34 B):

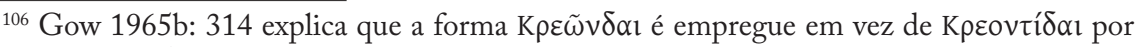
razões métricas. Assim, o poeta está, provavelmente, a referir-se à mesma família, pois Escopas era filho de Creonte (vide infra schol. Theoc. 16. 36-37 = fr. 529). A identificação dos Escópadas com os Creondas foi também defendida por Morrison 1942: 60.

107 Stella 1946: 20 e Podlecki 1980: 386 negam a existência de provas que atestem esta possibilidade. Para uma opinião contrária, vide Molyneux 1992: 118-121. O investigador invoca uma fonte do séc. V d.C. (Sozomenus, Historia Ecclesiastica, Praef. 5, p. 2 Bidez), que não nos parece relevante, uma vez que remonta provavelmente aos versos ou aos escólios de Teócrito. 


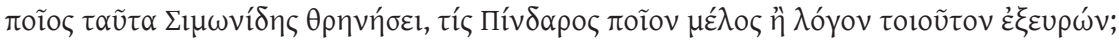

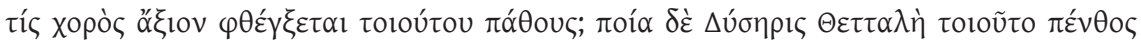

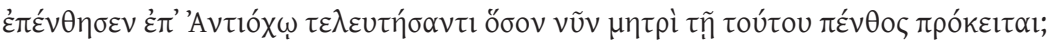

Que Simónides lamentará estas coisas, que Píndaro, com que canto, com que palavras? Que coro entoará um canto digno de tal desgraça? Que Díseris Tessália padeceu tanto pela morte de Antíoco que iguale a dor que habita agora a mãe deste jovem?

Díseris, mãe de Antíoco, que terá falecido jovem, é evocada como exemplo paradigmático da mulher que sofre dolorosamente a perda de um filho. A hipótese de Simónides, ou Píndaro, ter composto o elogio fúnebre do príncipe não é sustentada por nenhum testemunho antigo. Todavia, no que diz respeito ao nosso lírico, convém ter presente o conteúdo dos escólios ad Theoc. 16. 36-37 e 44 (pp. 327-328 Wendel = fr. 529, 24 P, 33 B):

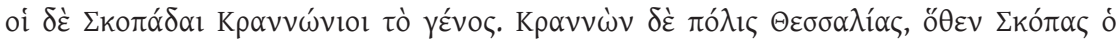

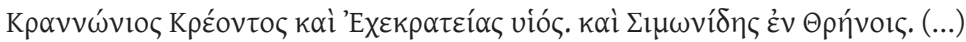

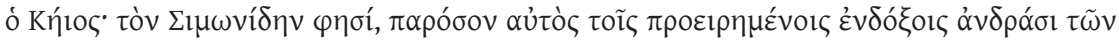

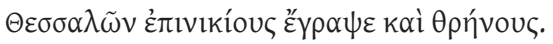

Os Escópadas eram uma família de Crânon. Crânon é uma cidade da Tessália à qual pertencia Escopas, o Cranónio, filho de Creonte e de Equecrateia. Cf. Simónides nos seus trenos. (...)

'O homem de Ceos': ele quer dizer Simónides, porquanto ele compôs epinícios e trenos para os distintos tessálios acima mencionados.

A confiar nestas informações, Simónides compôs epinícios em honra dos patronos tessálios, como o próprio poema de Teócrito sugeria (vv. 46-47), mas também trenos, e um deles pode muito bem ter sido o de Antíoco.

A informação de que o seu pai se chamava Equecrátides (cf. supra) e a mãe de Escopas Equecrateia leva a supor que as duas famílias se tenham unido pelo casamento ${ }^{108}$. A identificação dos seus membros representa, no entanto, um problema, porque os mesmos nomes foram usados de geração em geração (Helly 1995: 104). É o caso, como vimos, de Alevas, mas também de Equecrátides e de Escopas.

Morrison 1942: 60 n. 4 propôs a identificação dos pais de Antíoco com as pessoas a que dizem respeito dois epigramas dedicatórios atribuídos a Anacreonte, transmitidos pelo livro VI da Antologia Palatina $(136=$ VII FGE,

108 Cf. Gow 1965b: 312-313. Esta hipótese, já considerada no final do séc. XIX (G. Busolt, Griechische Geschichte. Vol. II, Gotha, 1885-1904, 474 n. 2, apud Molyneux 1992: 129) é também defendida por Helly 1995: 105. Sobre a conjectura de Antíoco ser um Alévada, defendida por Morrison 1942: 60-61, vide Molyneux, ibidem. 
108 D; 142 = XIII $F G E, 107$ D):

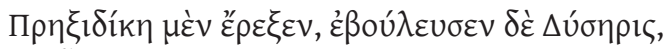

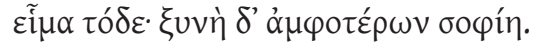

Prexídice executou, por desígnio de Díseris, esta veste. Em comum têm a mesma arte.

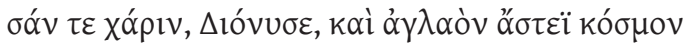

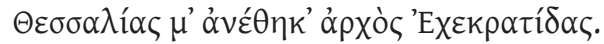

Em tua homenagem, Diónisos, e como adorno esplêndido para a cidade me consagrou o chefe tessálio Equecrátides.

Por prudência, Helly 1995: 105 preferiu não tomar posição sobre este ponto, considerando-o "pouco claro". Alguns filólogos, porém, supõem que os epigramas possam ser autênticos ${ }^{109}$. A confirmar-se esta hipótese, significaria que a família de Equecrátides havia acolhido na sua corte não só Simónides, mas também o lírico de Teos e, eventualmente, outros poetas.

Lamentamos não existirem dados mais seguros sobre esta família aristocrática de Farsalo e não ser fácil a identificação dos seus elementos, designadamente de Equecrátides ${ }^{110}$. A aceitarmos a reconstituição dos especialistas, este nome ocorre num fragmento elegíaco do 'Novo Simónides' (fr. eleg. 22.9, vide infra), que pode ter pertencido a um poema apresentado durante um banquete. Infelizmente, o seu estado de conservação não permite saber em que circunstâncias foi composto e executado. Não deixa, porém, de ser uma prova de que Simónides conviveu com Equecrátides ou, pelo menos, com elementos da sua família.

Uma das histórias mais célebres que a tradição literária nos legou acerca do poeta desenvolveu-se a partir do acontecimento trágico que atingiu a família de Escopas. No decurso de um banquete realizado no seu palácio, o tecto desabou e soterrou os convivas, entre os quais se encontravam amigos e familiares ${ }^{111}$. Segundo Favorino de Arles, orador do séc. II d.C., evocado

${ }^{109}$ Cf. Gow 1965b: 312, Campbell 1988: 151.

${ }^{110}$ Convém distinguir o Equecrátides mencionado no escólio ad Theoc. 16. 34 de um outro chefe tessálio referido por Tucídides (1.111), pai de Orestes (ou Orestas), que é posterior. Cf. Morrison 1942: 61, Helly 1995: 106-107.

${ }^{111} \mathrm{Na}$ opinião dos historiadores, esta tragédia terá sido o motivo principal da perda de influência política da família tessália. Morrison 1942: 61 não rejeitou a hipótese de se ter tratado de uma conspiração política. As fontes não são esclarecedoras. Sobre este aspecto, cf. Molyneux 1992: 125. O desabamento de um tecto pode ser provocado por um terramoto, por exemplo, mas a tradição grega conservou também uma história da Época Arcaica com contornos semelhantes à de Sansão e Dalila. Segundo informa Pausânias (6. 9. 6-7), na 72a 
por Estobeu (4. 41. 62), o nosso lírico tratou a desgraça dos Escópadas num poema, cujo subgénero não especifica. No entanto, cita dois dos quatro versos do fr. 521, que aquele antologista nos transmitiu como pertencentes aos trenos de Simónides (4. 41. 9). Estes testemunhos, porém, não provam que o poeta tenha tratado aquele acontecimento num elogio fúnebre, como defendem alguns estudiosos, mas é verosímil que o tenha evocado na sua obra e causado grande impressão. Note-se que a fonte mais antiga sobre este episódio trágico é um fragmento do livro III dos Aetia de Calímaco (fr. 64. 11-14 Pf. = test. 21), que tem como sujeito poético o próprio Simónides, o que pode ser entendido como uma alusão a um dos seus poemas. Em nosso entender, estes versos indiciam que a partir do séc. III, pelo menos, esta história, que provavelmente terá um fundo de verdade ${ }^{112}$, incluía o motivo do salvamento do poeta ${ }^{113}$, um dos convivas do malogrado banquete, por intervenção dos Dioscuros. Dois ou três séculos mais tarde, um episódio da história trágica da Tessália havia dado origem a uma lenda que gozava de grande popularidade no mundo greco-romano e que conhecemos principalmente graças a Cícero (de Orat. 2. 86. 351-353) e Quintiliano (Inst. 11. 2. 11-16 $)^{114}$. Estes dois testemunhos constituem na edição de Page do corpus lírico de Simónides o fr. 510, porque neles se alude às circunstâncias de composição de um epinício.

$\mathrm{Na}$ versão de Cícero, que citamos mais adiante, o banquete realizou-se na casa real de Crânon e foi depois da execução de um poema (carmen), composto a pedido de Escopas, que aconteceu o terrível desastre. $\mathrm{Na}$ versão de

Olimpíada (= 492) o pugilista Cleomedes de Astipaleia foi desclassificado pelos Helanódices por ter matado o seu adversário. Ao regressar à pátria, num gesto de vingança, o atleta destruiu o pilar que segurava o tecto de uma escola primária e o desabamento provocou a morte a sessenta meninos.

112 A historicidade desta tradição foi posta em causa por estudiosos do séc. XIX (cf. Molyneux 1992: 141 n. 60) e, no séc. XX, principalmente por Slater 1972: 237-238 e Lefkowitz 1981: 55. Para estes investigadores, trata-se apenas da interpretação literal ou errónea de uma afirmação figurada. Slater considerou improvável que um acidente deste tipo pudesse provocar uma tragédia tão grande, a ponto de tornar irreconhecíveis os convivas, e se recorda que Heródoto contou que apenas uma criança, de 120, sobreviveu ao colapso de uma escola em Quios c. 496 (6. 27), é sobretudo para provar que o desabamento de um tecto era um motivo popular com intenções éticas (cf. nota anterior). Contra esta posição céptica, vide Huxley 1978: 238 n. 44.

${ }_{113}$ Como bem observa Bell 1978: 61 n. 128, esta história pertence ao tipo 'salvamento maravilhoso de um poeta', como é também a de Aríon. Lefkowitz 1981: 55 chama a atenção para a semelhança com a notícia do salvamento de Simónides por um fantasma (cf. epigr. LXXXV, supra).

${ }^{114}$ Cf. outros testemunhos em Page 1962: 242 e Campbell 1991: 379. Vide também Rawles 2005: 64-66, esp., que examina a hipótese de o conteúdo do verso do papiro Princeton inv. AM87-59, publicado em 2004, se referir a esta lenda. Para uma análise do fr. 64 Pf. de Calímaco, vide Acosta-Hughes 2010: 171-179. 
Quintiliano, trata-se de um epinício para um pugilista e o orador observa que havia grande desentendimento nas fontes quanto à identidade desse atleta e ao local da tragédia (Inst.11.2.14-16 Winterbottom ${ }^{115}$ :

est autem magna inter auctores dissensio Glaucone Carystio an Leocrati an Agatharcho an Scopae scriptum sit id carmen, et Pharsali fuerit haec domus, ut ipse quodam loco significare Simonides uidetur utque Apollodorus et Eratosthenes et Euphorion et Larissaeus Eurypylus tradiderunt, an Crannone, ut Apollas Callimach<i>us (corr. Preller), quem secutus Cicero hanc famam latius fudit. Scopam nobilem Thessalum perisse in eo conuiuio constat, adicitur sororis eius flius, putant et ortos plerosque ab alio Scopa qui maior aetate fuerit. quamquam mibi totum de Tyndaridis fabulosum uidetur, neque omnino huius rei meminit umquam poeta ipse, profecto non taciturus de tanta sua gloria.

Há, no entanto, entre os autores uma grande divergência sobre se este poema foi escrito para Glauco de Caristo, para Leócrates ou Agatarco, ou para Escopas, se a casa estava em Farsalo, como o próprio Simónides parece indicar num certo passo e Apolodoro, Eratóstenes, Eufórion e Eurípilo de Larissa informaram, ou em Crânon, como em Apolas, discípulo de Calímaco, que Cícero seguiu quando difundiu largamente esta notícia. É um facto conhecido que Escopas, um nobre da Tessália, morreu no banquete, bem como o filho da sua irmã. E pensa-se que também muitos descendentes de um outro Escopas mais velho. No entanto, parece-me que tudo isto sobre os Tindáridas é efabulação e nem o próprio poeta menciona alguma coisa na sua obra, e certamente não pretenderia guardar silêncio sobre tamanha glória.

Além dos pormenores de que foi Cícero o responsável pela divulgação da história, que pode ter recolhido em Calímaco (no poema a que pertence o fr. 64 do livro III dos Aetia, que também situa o desastre em Crânon?), e a nota final de que o motivo do salvamento pelos Dioscuros é pura fábula, que não remonta às palavras do poeta, saliente-se a referência aos laços de parentesco dos convivas que faleceram: além de Escopas, um filho da sua irmã e muitos outros elementos da mesma família ${ }^{116}$. Alguns estudiosos identificaram este sobrinho do chefe tessálio com Antíoco, filho de Díseris e de Equecrátides, concluindo que Simónides havia tratado o colapso do palácio de Crânon no seu elogio fúnebre, hipóteses que nos parecem, acima de tudo, impossíveis de comprovar com os testemunhos de que dispomos ${ }^{117}$.

115 Helly 1995: 110 n. 101 chamou a atenção para a incerteza sobre a cidade em que residiam os Escópadas. Heródoto atesta que esta família estava estabelecida em Crânon (6. 127. 4). Sordi 1958: 64 n. 1 fez uma interpretação política do texto de Quintiliano, concluindo que a influência dos Escópadas se estendia à cidade de Farsalo. Assim também pensou Molyneux 1992: 122.

${ }^{116} \mathrm{Na}$ opinião de Helly 1995: 111, a família deve ter sobrevivido ao desastre, porque Eliano (VH12.1) e Diógenes Laércio (2.25) referem um Escopas da Tessália contemporâneo de Sócrates.

${ }^{117}$ A identificação desta personagem com Antíoco foi defendida por Morrison 1942: 60, 
É curioso notar que a convivência de Simónides com Escopas parece ter ofuscado a sua relação com outros chefes tessálios. A explicação reside, talvez, na tradição que se criou à volta desta figura. A riqueza da sua família era proverbial ${ }^{118}$, embora o seu papel na história da Tessália seja difícil de precisar, observa Helly 1955: 111. O próprio Escopas foi recordado como um chefe autoritário, que apreciava a bebida e tinha hábitos excêntricos. Este retrato ${ }^{119}$, como veremos, influenciou algumas leituras do fr. 542.

\section{b) Epinício para os filhos de Eácio}

Testemunho importante, porque transmitido por via directa, da convivência do poeta com gentes da Tessália é o fr. 1 do P. Oxy. 2431 (= fr. 511, 6 P), que contém a identificação e o início de um epinício composto 'para os filhos de Eácio', por uma vitória na corrida de cavalos.

A participação nas provas equestres estava, geralmente, reservada aos cidadãos mais abastados (Theoc. 16. 46-47 também alude a vitórias nestas provas), mas pouco mais sabemos sobre esta família. A sua origem tessália depreende-se das palavras do poeta (cf. (b), v. 8) e foi confirmada pelos filólogos (vide infra, pp. 250-251), mas o estado de conservação do fragmento não nos permite colher elementos sobre a ocasião em que o epinício foi composto.

\subsection{Da Magna Grécia}

\section{a) Os tiranos da Sicília}

Da análise breve da documentação relativa à presença de Simónides nas cortes de Hierão de Siracusa e de Téron de Agrigento chegamos rapidamente a algumas ideias gerais:

- A nossa fonte mais antiga é o filósofo peripatético Cameleonte, que não nos merece confiança absoluta (cf. supra, p. 117). Por outro lado, o termo post quem da ida de Simónides para a corte de Hierão, i.e. 477/476, encontra-se numa obra que pertence ao séc. V da nossa era (Syrian. in Hermog., I. 86 Rabe = epigr. XXVIII, cit. supra).

- Uma parte considerável dos testimonia inscreve-se na tradição anedótica ou pseudo-biográfica, destacando-se especialmente as histórias que desenvolvem o motivo da avareza de Simónides.

Sordi 1958: 64 e n. 3; Huxley 1978: 236 n. 36, 237 n. 41; Podlecki 1980: 385, Brillante 2000: 34 n. 18.

${ }^{118}$ Cf. Plu. De cupiditate divitiarum 527c, Cato Maior 18. 5, Cimon 10. 5.

119 Este retrato foi traçado por Fânias de Éreso (séc. IV) na obra intitulada $A$ morte dos tiranos por vingança (Tupávv FGrHist 1012 F 3). Cf. Theoc. 16. 39. 
- No que diz respeito aos fragmenta, apenas é seguro considerar um verso de um poema elegíaco (fr. eleg. 26, cit. infra) ${ }^{120}$.

No entanto, não julgamos que se deva pôr em causa a tradição de que o nosso lírico viveu a última fase da sua vida na Magna Grécia. O fr. 64 do livro III dos Aetia de Calímaco (= test.21), que era um poeta talentoso e erudito sério, a ponto de declarar que não cantava nada que não estivesse documentado (fr. 612 Pf.), confirma que Simónides foi sepultado em Agrigento ${ }^{121}$.É na mesma linha de pensamento que interpretamos um passo da Retórica de Aristóteles (2. 16. $1391 \mathrm{a} 8-12$ = test. $47(\mathrm{~d}))$ :

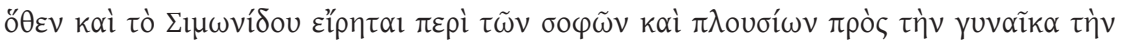

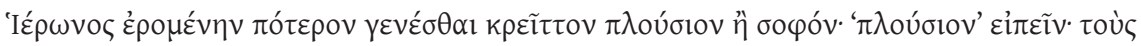

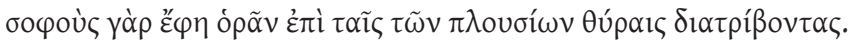

Daí a resposta de Simónides acerca dos sábios e dos ricos à esposa de Hierão, quando ela lhe perguntou se era melhor ser rico ou sábio. 'Rico', pois dizia ver os sábios passarem os seus dias às portas dos ricos.

Sócrates, na República (489b-c), alude a este dito, não nomeia o seu autor, mas diz que mentiu ao pronunciá-lo. Isto pode significar que existia já nos finais do séc. V um repertório de sentenças de Simónides ou que na segunda metade do séc. IV, à semelhança do que aconteceu com os epigramas, a tradição lhe atribuía muitos ditos e provérbios que até então circulavam como anónimos. É legítimo considerar que Aristóteles acreditava, de facto, que o poeta havia frequentado a corte de Hierão, mas o seu testemunho, em

${ }^{120} \mathrm{O}$ escoliasta da $I^{a}$ Pítica de Píndaro (152b, II. 26 Dr.) preservou uma inscrição anónima que teria acompanhado a dedicatória de Gélon, irmão de Hierão, de trípodes de ouro ao santuário de Delfos. Na Antologia Palatina, a autoria é atribuída a Simónides (6. 214), pelo que a composição foi incluída no seu corpus (epigr. XXXIV), embora a autenticidade não seja consensual. Hauvette 1896: 123-127 considerou o epigrama aprócrifo. Vallet 1958: 365 n. 4 aceitou a autenticidade, bem como Molyneux 1992: 221-224. Para a sua discussão, vide B. Gentili, "I tripodi di Delfi e il carme di Bacchilide", PP 8 (1953) 199-208, esp. 204-205; Podlecki 1979: 6, Page 1981: 247-250. Sobre as circunstâncias da consagração do monumento, vide Harrell 2002: 453-455, que detecta no epigrama (apócrifo) a influência de Píndaro.

${ }^{121}$ Lefkowitz 1981: 55 desvaloriza esta fonte, observando que a sepultura longe da pátria é um topos da tradição pseudo-biográfica, presente nas Vidas de Homero e de Hesíodo, que pretende sublinhar a sua consagração como poeta pan-helénico. Para uma opinião divergente, cf. Suárez de la Torre 1988b: 210 e Parsons 2001: 56. A noção de que um homem sábio pode andar por toda a terra, e vir inclusive a morrer longe da sua pátria, desenvolve-se a partir do séc. V (cf. Democr. fr. 249 D-K), mas nos Poemas Homéricos e na poesia da Época Arcaica é o sentimento de apego à amada terra natal que prevalece, como mostrou M. H. Rocha Pereira em "Sentido de amor à terra pátria entre os Gregos", Nova Renascença 5 (Junho/Setembro 1985) 212-219. 
rigor, apenas confirma a existência no seu tempo de uma colecção de sentenças, aparentemente proferidas por Simónides durante uma conversa com a esposa do tirano. A celebridade desta tradição é atestada por um papiro datado de c. 250 (cit. infra), que preservou duas sentenças atribuídas ao poeta. A esposa de Hierão é mais uma vez um dos interlocutores, e se a resposta de Simónides é uma manifestação de sabedoria, deixa também transparecer um espírito pragmático orientado para a avareza.

Esta não é a única fonte em que o motivo da avareza tem como cenário a corte de Hierão. Para a difusão deste topos pode ter contribuído Cameleonte, como se depreende de um passo de Deipnosophistae (14.656d-e = test. 23, cit. infra). É possível que o filósofo tenha dedicado especial atenção à convivência do poeta com o tirano de Siracusa, porque no parágrafo anterior Ateneu escreve o seguinte $(14.656 \mathrm{c}=$ fr. eleg. $26,171 \mathrm{~B}, 68 \mathrm{D})$ :

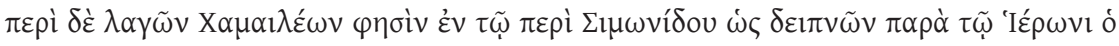

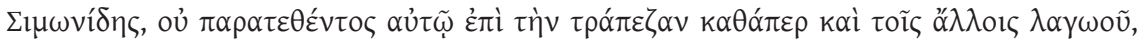

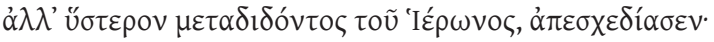

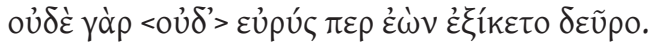

A respeito de lebres, Cameleonte diz no seu livro sobre Simónides que o poeta, num banquete de Hierão, no qual não lhe foi servida uma lebre, como fora aos outros, quando depois Hierão a ofereceu, improvisou:

pois embora fosse grande não chegou até aqui!

Independentemente das circunstâncias em que foi composto este verso, sobre as quais apenas dispomos do testemunho frágil de Cameleonte, o facto de Simónides ter parodiado um passo da Ilíada (14. 33-34) ${ }^{122}$, como notou Eustátio (in Od. 1821.37), é um dado interessante sobre o seu modo de trabalhar. A intenção da história, porém, não é chamar a atenção para este aspecto, mas sublinhar a graça e versatilidade de Simónides. De facto, o Certamen Homeri et Hesiodi demonstra que para os Gregos antigos a arte de improvisar era apenas reconhecida aos grandes poetas. Assim, mais uma vez nos deparamos com um testemunho em que a presença do poeta na corte de Hierão é apenas um aspecto secundário, que tem uma função meramente ornamental.

Mas há outros exemplos. Quando Cícero, em Da natureza dos deuses 1. 22.60 (= test. 47 (c)), evoca uma conversa entre Simónides e o tirano de Siracusa sobre a natureza do divino, retoma o topos antigo da associação

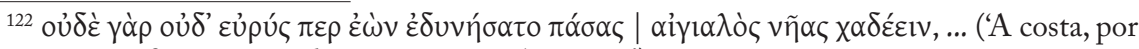
mais vasta que fosse, não podia conter tantos barcos...'). 
entre um sábio e um soberano (vide infra, p. 184) ${ }^{123}$. Em nosso entender, é ainda no âmbito da tradição pseudo-biográfica sobre os poetas antigos que se deve interpretar um testemunho que Robbins 1997: 245 considerou "the most famous story related about a sojourn of Simonides in Sicily". Trata-se do escólio 29d da $I I^{a}$ Olimpica de Píndaro, composta em honra de Téron de Agrigento pela vitória na corrida de carros em 476, como já indicámos (= test. 19):

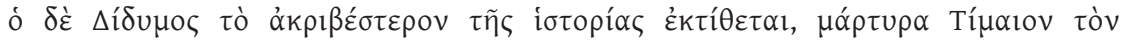

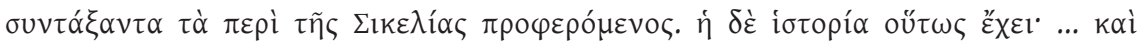

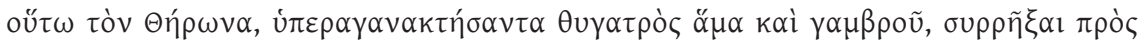

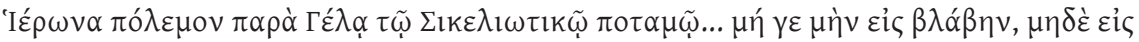

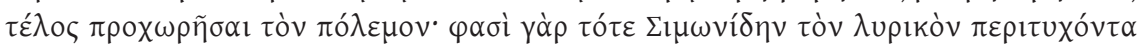

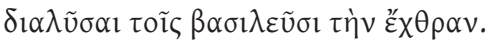

Dídimo fornece a versão mais exacta da história, citando como testemunho Timeu, que organizou o que diz respeito à Sicília. A história apresenta-se assim: Téron, a ferver com a filha e o genro ${ }^{124}$, declarou guerra a Hierão nas margens do Gela, rio siciliano... mas a guerra nem causou dano nem levou a nenhum fim, pois dizem que nessa altura Simónides, o poeta lírico, tendo aparecido por acaso, fez cessar as hostilidades entre os reis.

Note-se que o escoliasta toma conhecimento deste episódio através de Dídimo, gramático alexandrino do séc. I, que, por sua vez, citava o historiador siciliano Timeu de Tauroménio (c. 350-260), contemporâneo de Cameleonte. Embora o assunto seja agora mais sério, de novo o núcleo da história não se centra na actividade profissional de Simónides, mas antes numa qualidade que alguns estudiosos consideraram um traço de carácter do poeta: a diplomacia que, supostamente, lhe teria permitido trabalhar ao mesmo tempo para pessoas de diferentes regimes políticos, para famílias rivais (e.g. os Alévadas e os Escópadas) e, neste caso, para tiranos que eram ocasionalmente inimigos (cf. Molyneux 1992: 154). Todavia, este testemunho é para nós, sobretudo, um exemplo de uma tradição muito antiga, que mencionámos na primeira parte a propósito de Terpandro de Lesbos e de Taletas de Gortina (vide p. 70), segundo a qual os poetas têm o dom de apaziguar a cólera dos homens. Por outro lado, o facto de Simónides surgir em plena contenda como por acaso confere ao relato traços de efabulação ${ }^{125}$.

${ }^{123}$ Como demonstra Schneider 1997: 73, o assunto da conversa - a natureza do divino para o qual o poeta não encontra uma resposta imediata, observando que 'quanto mais tempo penso tanto mais vaga me parece a esperança de uma resposta' (quanto diutius considero tanto mibi spes uidetur obscurior), é também um topos da tradição biográfica.

${ }^{124}$ Polizelo, irmão de Hierão.

${ }^{125}$ Trata-se de um topos da tradição pseudo-biográfica, que já constatámos no comentário ao 
Conhecemos, no entanto, outros testemunhos que dizem respeito especificamente à convivência do poeta com os tiranos da Sicília. O que nos merece menos confiança é o passo já referido da $I I^{a}$ Epistola do PseudoPlatão $(311 \mathrm{a}=$ test. 17, p. 149). Mais interessante nos parece um testemunho de Pausânias que insere a ida de Simónides para a Sicília numa tradição de mobilidade poética (1.2.3 = test. 18$)$ :

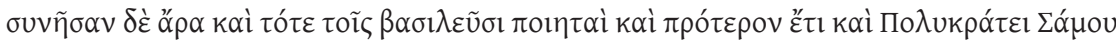

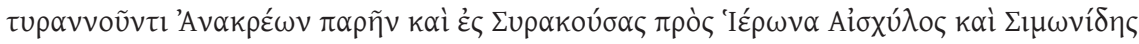
$\dot{\varepsilon} \sigma \tau \alpha \dot{\lambda} \lambda \eta \sigma \alpha v$.

Então, nesse tempo, os poetas viviam junto dos reis e ainda anteriormente Anacreonte privava com Polícrates quando era tirano de Samos, e Ésquilo e Simónides partiam para Siracusa para junto de Hierão.

Pausânias menciona Ésquilo (cf. Vit. Aesch., Plu. de exilio 13.604f, supra pp. 143-144 e n. 64), mas não Píndaro nem Baquílides, que também conviveram com os tiranos mais famosos da Sicília. Um passo da II ${ }^{a}$ Olímpica, composta no ano em que a tradição situa a ida de Simónides para a corte de Hierão, tem sido interpretado como um indício de rivalidade profissional entre estes poetas (vv. $86-89$ = test. 20$)$ :

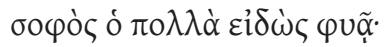

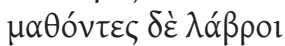

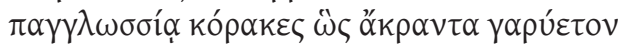

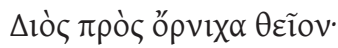 \\ Artista é aquele \\ que sabe muito por natureza. Os que tiveram de aprender, \\ quais corvos loquazes, \\ que grasnem em vão contra a ave divina de Zeus! $!^{126}$
}

Segundo informa o escoliasta (157a, 158d, I. 99 Dr.), ao empregar o

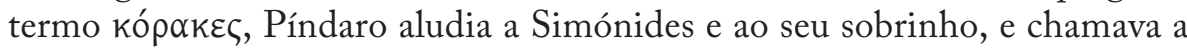

Certamen Homeri et Hesiodi (cf. supra, p. 45). Diodoro Sículo (11. 48-49) situa a reconciliação entre Hierão e Téron no arcontado de Fédon (476/5), mas não menciona Simónides. Para uma análise do test. 19 numa perspectiva diferente da nossa, vide Stella 1946: 14, Molyneux 1992: 224-226. Na opinião de Lesky 1995 [1971]: 215, a reconciliação entre Hierão e Téron assegurou ao poeta uma posição privilegiada nas cortes dos dois tiranos. Schneider 1997: 71-72, embora não se pronuncie sobre a historicidade do relato, sublinha a coerência cronológica das fontes disponíveis.

${ }^{126}$ Tradução de M. H. Rocha Pereira (2003: 45). 
si mesmo 'ave divina de Zeus' (v. 89). Esta interpretação, corroborada pelo

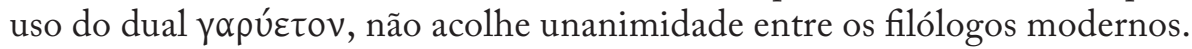

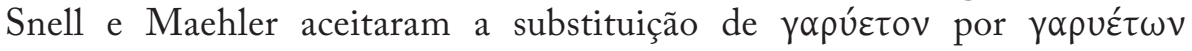
(interpretado como um plural desde a edição de Schröder, em 1900), proposta por Bergk, que alarga o alcance da censura de Píndaro ao dissolver a alusão quase explícita a 'dois' poetas. $\mathrm{Na}$ opinião de outros estudiosos, a emenda não se justifica, pois a noção de dualidade é inerente à referência ao corvo que, sendo uma ave que acasala para toda a vida, é geralmente avistado aos pares. Por conseguinte, o uso do dual pode ser apenas o reflexo desta ideia tradicional, que diversas histórias atestam ${ }^{127}$. Admitindo que a leitura do escólio possa ser a correcta, não nos é possível deduzir que Píndaro se refere especificamente ao trabalho desenvolvido na Sicília. Todavia, tal hipótese não é fantasiosa e parece-nos mesmo plausível, se considerarmos as circunstâncias em que os cultores de epinícios produziam as suas obras. De um modo geral, os estudiosos acreditam que Baquílides também frequentou a corte de Hierão (cf. Ael. VH 4. 15) ${ }^{128}$. É legítimo supor que Píndaro visse no sobrinho de Simónides um rival, que viria a celebrar a última vitória olímpica do tirano (em 468, no $I I I^{\circ}$ Epinício). Por outro lado, o facto de o lírico mais antigo, na sua idade avançada, continuar a agradar aos famosos patronos da Sicília podia suscitar um certo despeito nos poetas mais novos, o que não significa necessariamente uma hostilidade manifesta, que está longe de ser confirmada. Contudo, a frequência obsessiva com que os escoliastas de Píndaro recordam a sua suposta aversão aos dois líricos de Ceos parecenos sobretudo fruto da dificuldade em explicar a linguagem figurada que predomina nas reflexões do poeta ${ }^{129}$.

${ }^{127}$ Interpretação de G. M. Kirkwood, "Pindar's Ravens (Olymp. 2. 87)", CQ 31.2 (1981) 240-243, que discute em detalhe o problema aqui esboçado. Willcock 1995: 162-163 privilegia esta explicação. Molyneux 1992: 248-249 discorda, observando que o dual não se refere apenas ao símile, pois é o verbo da oração principal. Ou seja, ao empregar aquele processo literário Píndaro tem em vista um par de poetas. Nas pp. 250-255 discute as interpretações de outros estudiosos. Sobre os hábitos do Corvus corax, cf. Svensson \& Grant 2003: 336.

${ }^{128}$ A hipótese de Píndaro e Baquílides terem ido para a Sicília logo a seguir a Simónides é sugerida por Bowra 1961: 359 e reiterada na p. 361, onde comenta este passo. Stella 1946: 14 defendeu que o poeta terá sido responsável pela introdução do sobrinho na corte de Hierão, mas não considera seguro que o dual yopúctov designe os dois líricos de Ceos. Esta é também a opinião de Huxley 1978: 246. Completamente diversa e pouco plausível é a leitura de R. Stoneman, "The 'Theban Eagle”, CQ 26 (1976) 188-197, que rejeita a interpretação do escólio, considerando que 'ave divina de Zeus' não designa o poeta, mas é antes um elogio ao destinatário da ode.

${ }^{129}$ É o que se depreende da compilação de escólios em Campbell 1992: 104-109 = Bacch. testt. 8-10. Por isso, alguns estudiosos não excluem a hipótese de a rivalidade entre estes poetas ter sido uma invenção dos comentadores antigos (cf. H. Maehler, OCD, s.v. Bacchylides). O fr. 602 de Simónides, cujo texto e interpretação suscitam muitas dúvidas, é citado no escólio aos vv. 48-49 da $I X^{a}$ Olimpica (74b, I. 285 Dr.) para confirmar que neste passo Píndaro aludia a um 
Stella 1946: 15 observou que mudar de ambiente aos oitenta anos e continuar activo é algo desconcertante. Como notámos no início deste capítulo, esta desconfiança não faz grande sentido. No entanto, no que diz respeito à actuação profissional de Simónides na corte de Hierão, além do testemunho de Cameleonte (vide supra, p. 166), apenas podemos citar Himério, que pertence já ao séc. IV da nossa era (Or. 31. 5 = fr. 580, 75 P, $61 \mathrm{D})$, quando diz: 'Pois também Simónides de Ceos, quando deixava ir Hierão da Sicília para outra

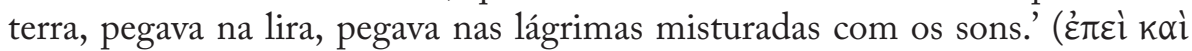

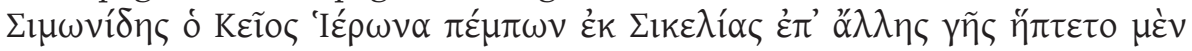

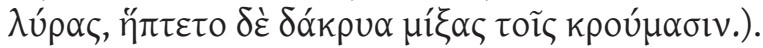

Este testemunho relata as circunstâncias em que Simónides teria improvisado um poema que seria, talvez, um propemptikon ( uma pequena composição a desejar boa viagem, como sugerem Bowra 1961: 359 e Campbell 1991: 465 ${ }^{130}$. Mas o orador Himério evoca uma situação informal, não propriamente o contexto de execução de uma peça encomendada ${ }^{131}$.

Mais relevante nos parece um escólio à $I I^{a}$ Ístmica de Píndaro, segundo o qual Simónides celebrou os feitos desportivos do irmão mais novo de Téron de Agrigento (argum. III. 212 Dr. = fr. 513, 8 P, 6 B):

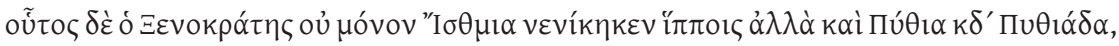

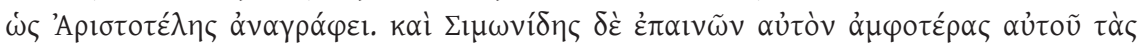

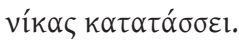

Este Xenócrates não só venceu nos Jogos Ístmicos com os seus cavalos, mas também nos Píticos, na 24a Pitíada (= 490), como Aristóteles escreve (fr. 617 Rose). Também Simónides, quando faz o seu elogio, descreve as suas duas vitórias.

Em honra destes triunfos, Píndaro compôs a VIa Pítica em 490 e enviou a II I Ístmica quando Xenócrates já havia falecido (cf. supra, pp. 109). Baseado, em parte, em Aristóteles, o presente testemunho merece-nos alguma credibilidade. Podlecki 1979: 7, no entanto, embora não o rejeite totalmente, avançou a hipótese de o escoliasta ter cometido o lapso de trocar o nome de Píndaro pelo de Simónides, pois na sua opinião este comentário adapta-se bem aos

poema do lírico de Ceos. Para a interpretação do fragmento de Simónides, vide Bowra 1961: 361-362, Henderson 1989: 30-32, Molyneux 1992: 255-263.

${ }^{130}$ Para um exame do propemptikon na literatura grega e latina, vide R. G. M. Nisbet and M. Hubbard, A Commentary on Horace: Odes, Book I (Oxford 1970) 40-43.

${ }^{131}$ Para uma opinião diferente, vide Molyneux 1992: 226. Podlecki 1979: 9, na sequência de Wilamowitz, considera este testemunho uma invenção da tradição pseudo-biográfica. Da análise das notícias que relacionam Simónides com Hierão, Schneider 1997: 70-77 concluiu serem frágeis as indicações sobre uma carreira ocidental. Não exclui, porém, a hipótese de ter composto epinícios para outros destinatários ocidentais (cf. p. 77-79). 
vv. 49-51 da $I I^{a}$ Olímpica, nos quais as duas vitórias são evocadas. Parece-nos estranho que um erro deste tipo surgisse precisamente no escólio de uma ode

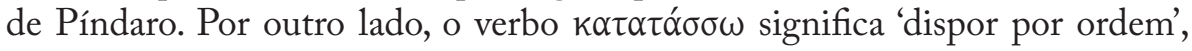
'narrar'. Portanto, não se aplica a uma simples evocação de proezas desportivas, que é o que o poeta de Tebas faz na $I I^{a}$ Olímpica. Esta ode indica-nos que a vitória ístmica de Xenócrates é anterior à que Téron alcançou em Olímpia, mas podiam ter ocorrido no mesmo ano, a primeira em Abril e a segunda em Agosto. Era natural que Píndaro recordasse o triunfo de Xenócrates, mesmo se não tivesse tido tempo de elaborar uma ode, pois nesse ano esteve demasiado ocupado com as composições olímpicas (cf. supra, p. 106). Mas também é possível que esse epinício tenha sido solicitado a Simónides, como admitem alguns helenistas, e que nele evocasse o sucesso anterior do atleta ${ }^{132}$. Esta suposição é cronologicamente plausível, visto que segundo a tradição Simónides teria ido viver para a Magna Grécia em 476. O comentário do escoliasta, no entanto, permite uma outra hipótese, tendo em conta o sentido

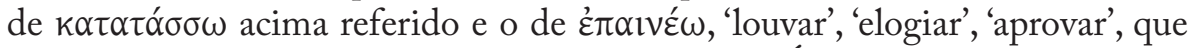
não significa especificamente 'compor um epinício'. É, portanto, legítimo supor que o poeta dedicou a Xenócrates um encómio, o que pode ter acontecido até à data da sua morte, no qual prestou atenção especial às suas duas proezas atléticas ${ }^{133}$. Se foi isso que aconteceu, quando Trasibulo solicitou a Píndaro que celebrasse a vitória ístmica de seu pai estava, na verdade, a compensar uma falta.

Em conclusão, não são substanciais as informações sobre a actuação de Simónides nas cortes da Sicília. Julgamos, todavia, que permitem supor que o poeta conviveu com a família dos Eménidas de Agrigento, em particular nos últimos tempos da sua vida, o que explicaria as honras fúnebres que lhe prestaram os Agrigentinos, evocadas nos versos de Calímaco. Com esta ideia coincide a tradição de que Simónides foi primeiro acolhido pelo tirano de Siracusa (e.g. Pausânias, Siriano) ${ }^{134}$.

${ }^{132}$ Cf. Stella 1946: 10 n. 1, Molyneux 1992: 233. Para uma análise das diversas propostas de datação da vitória ístmica de Xenócrates, questão que o historiador considera de grande interesse para o estabelecimento da cronologia de Simónides, vide pp. 234-235. Molyneux acaba por considerar o período compreendido entre 488 e 476, no qual aquela vitória podia ter ocorrido, "at any rate too vague to help decide the central question of Simonidean chronology" (p. 235).

${ }^{133}$ Molyneux 1992: 234 considera também a possibilidade de o poeta ter composto um poema mais tarde, não necessariamente um epinício ("a more general ode in honour of Xenocrates", p. 234; "in an epinician or encomium", p. 257), mesmo depois da morte de Xenócrates (citando o exemplo das odes de Píndaro, como a $I I^{a}$ Ístmica, que nem sempre dizem respeito a vitórias recentes, p. 234 n. 116), hipótese que nos parece menos provável.

134 Podlecki 1979 considera que tem bases muitos frágeis a hipótese de Simónides ter permanecido na Sicília durante muito tempo e privado com Hierão. Põe igualmente em dúvida a tradição biográfica que situava a sua morte e sepultura em Agrigento (cf. pp. 15-16), mas o 
Curiosamente, são mais sólidos os testemunhos que relacionam o poeta com Anaxilas, tirano de Régio desde 494 a 476 e pai de uma das esposas de Hierão ${ }^{135}$, que comentaremos na terceira parte (cf. fr. 515).

\section{b) Mílon e Astilo de Crotona}

Mílon de Crotona foi um dos lutadores mais célebres da Época Arcaica e a sua reputação atravessou os séculos, tornando-o numa figura lendária ${ }^{136}$. Um escólio ao Idílio IV de Teócrito (schol. IV c-d) informa que o atleta alcançou na $60^{\text {a }}$ Olimpíada $(=540)$ a vitória na prova de luta na categoria de paides ${ }^{137}$. De acordo com Pausânias, Mílon era filho de Diotimo e a sua estátua foi realizada por Dâmeas, um conterrâneo (cf. Moretti 1957: 73-74). O atleta venceu seis vezes a prova de luta em Olímpia. Obteve também em Delfos uma vitória na categoria de paides e seis na dos adultos. O Periegeta menciona ainda uma sétima coroação olímpica, concedida pela desistência do adversário $(6.14 .5)^{138}$.

Do ponto de vista cronológico, é possível que Simónides tenha acompanhado a carreira gloriosa de Mílon, que se terá iniciado por volta de 540 e se prolongou até c. 510. Não podemos, no entanto, evocar como testemunho o epigrama comemorativo que figura na Antologia de Planudes sob a sua autoria ( 24 = epigr. XXV, $156 \mathrm{~B}, 153 \mathrm{D})$, uma vez que pesa sobre ele a suspeita de se tratar de uma criação literária da Época Helenística ${ }^{139}$. Mas sabemos, graças a Fócio, que Simónides compôs para um outro atleta natural de Crotona, o corredor olímpico Astilo, que alcançou a sua última vitória em 476 (cf. fr. 506). Os testemunhos disponíveis não excluem a possibilidade de o poeta ter celebrado os seus triunfos mais antigos.

investigador não tem em conta o testemunho de Calímaco.

${ }_{135}$ Cf. B. M. Caven, OCD, s.v. Anaxilas (1), Hieron (1).

${ }^{136}$ Para um exame sistemático das fontes sobre o atleta, que põe em evidência as diversas feições, por vezes contraditórias, da sua lenda, vide Visa-Ondarçuhu 1997.

${ }^{137}$ Cf. Moretti 1957: 72, Molyneux 1992: 82 n. 6, Visa-Ondarçuhu 1997: 37 n. 11.

138 Pausânias relata em seguida algumas das histórias que se contavam acerca deste atleta (6. 14. 6-8). Outras vitórias são referidas por D.S. 12.9.6, Afric. apud Euseb. Chron.1.202 Sch. (Page 1981: 238, Molyneux 1992: 81 n. 2).

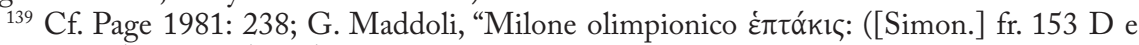
Paus. VI 14,5)”, PP 47 (1992) 46-49, esp. p. 46 e n. 2; Molyneux 1992: 81-83; Visa-Ondarçuhu 1997: 37 e n. 12 . 


\section{A CRIAÇÃo DE UM CLÁSSICO: os Motivos Biográficos DA LENDA DE Simónides}

Ao longo de cerca de noventa anos, vividos em diferentes partes do mundo grego, Simónides terá despertado sentimentos diversos nos seus contemporâneos. $\mathrm{Na}$ tentativa de apreciarmos a sua personalidade literária, em particular a que se manifesta na relação com os que fizeram parte do seu meio cultural, deparamos com a emaranhada rede da tradição anedótica. De Simónides se disse que tinha forte apego ao dinheiro, uma memória excepcional (e uma influente acção neste domínio), e a sua sabedoria foi proclamada por toda a Antiguidade. A notável persistência destes motivos sugere, em princípio, um fundamento histórico. Todavia, as lendas sobre Simónides podem ter surgido da interpretação incorrecta de alguns passos dos seus poemas. É suficientemente ilustrativa a discussão que se gera na casa de Cálias à volta do significado do poema composto a pedido de Escopas e que sugere leituras antagónicas da parte de Sócrates e de Protágoras (P1. Prt. 339a-346d = fr. 542). No entanto, os dois intervenientes no diálogo platónico afirmam conhecer aquela composição de cor. Assim, é possível que a partir do séc. IV, pelo menos, a obra de Simónides se tenha tornado cada vez menos acessível, a ponto de suscitar interpretações erróneas, enquanto despertava o interesse pela sua vida, que, na ausência de fontes, abriu caminho ao desenvolvimento da lenda ${ }^{140}$.

${ }^{140}$ Bell 1978 oferece-nos o estudo mais completo sobre a construção da tradição biográfica de Simónides, em especial no que diz respeito aos traços de avarento e de sábio. Cf́. Slater 1972: 235, Lefkowitz 1981: 49-56, Parsons 2001: 56-57. 


\section{III.1. UM POETA ganANCIOSO OU A PROFISSIONALIZAÇÃo DO OFÍCIO POÉTICO?}

Há indícios de que a acusação de Simónides ter grandes ambições financeiras foi proferida por um dos seus colegas de ofício. A rivalidade entre poetas, motivada pela inveja, é um conflito vulgar e ancestral, que até Hesíodo parece ter conhecido (Op. 25-26, supra p. 28). Todavia, no último quartel do séc. V, o desejo de lucro de Simónides, aliado a uma vida de penúria e privação, tornara-se num tema de comédia, como confirma um passo de $A$ Paz, representada em 421 (vv. 695-699 = test. 22):

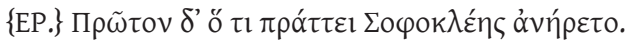

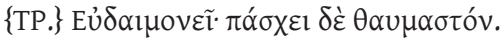

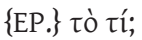

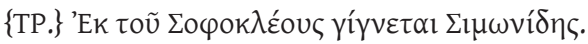

\{EP.\} $\Sigma ı \omega \omega v i ́ \delta \eta \varsigma ; \pi \tilde{\omega} \varsigma ;$

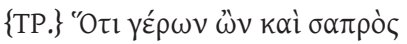

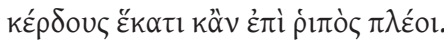

Hermes: Para começar - perguntou a deusa -, o que é feito de Sófocles?

Trigeu: Está bem. Mas aconteceu-lhe uma de pasmar.

Hermes: $\mathrm{O}$ que foi?

Trigeu: De Sófocles, tornou-se num Simónides.

Hermes: Num Simónides? Como é isso?

Trigeu: Velho e caduco como está, por dinheiro, ia nem que fosse ao inferno ${ }^{141}$.

As últimas palavras de Trigeu evocam a imagem de um Simónides que, apesar da idade avançada e dos perigos que podia correr, não hesitava em deslocar-se desde que lhe pagassem. Por outro lado, a associação da avareza à velhice é um topos da comédia, que teve grande fortuna na Antiguidade ${ }^{142}$. Além disso, o escólio ad loc. (pp. 107-108 Holwerda = test. 22) sustenta a

${ }^{141}$ Tradução de Maria de Fátima Silva, in Silva e Jesus 2010: 260-261. A tradutora observa em nota que o v. 699, que traduz livremente, constitui uma "deturpação paródica do provérbio grego que diz: «se fosse da vontade dos deuses, até sobre um caniçado se poderia navegar»." (p. 261 n. 112). Para uma análise do passo de Aristófanes, vide M. Grazia Fileni, "Sofocle, Simonide e Cratino in Aristofane, Pace 693-706”, QUCC 114.1 (2007) 81-87.

142 Bell 1978: 38-39 sugere a hipótese de o comediógrafo ser responsável pelo detalhe iconográfico da idade avançada de Simónides em muitas anedotas posteriores, retrato que se adapta bem ao seu papel de sophos. 
hipótese de o poeta ter sido acusado de avareza na sequência de uma querela poética ou por causa de um equívoco:

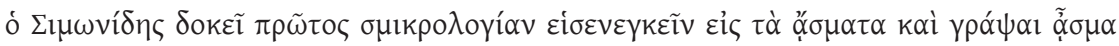

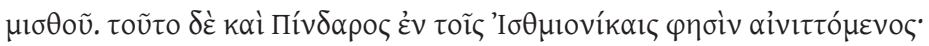

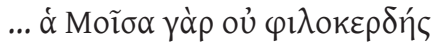

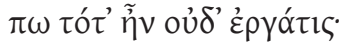

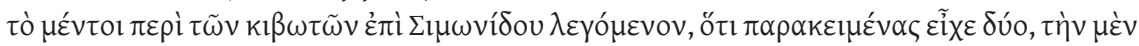

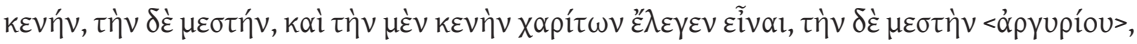

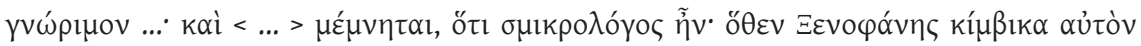

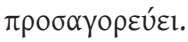

Parece que Simónides foi o primeiro a introduzir a mesquinhez na poesia lírica e a escrever um canto por dinheiro. É isto que Píndaro diz nas suas Ístmicas de forma velada:

... pois a Musa não era então amiga

do lucro nem mercenária! (2. 6)

É certo que a história sobre Simónides, de que tinha perto de si duas arcas, uma vazia e outra cheia, e que dizia que a vazia era a dos favores e a cheia <a do dinheiro>, é conhecida...; e $\langle\ldots\rangle$ menciona que era um açambarcador. Por isso é que Xenófanes lhe chama avarento (fr. $21 \mathrm{~W})$.

Este testemunho não prima pela clareza nem é absolutamente fidedigno, como aliás se depreende do emprego de o escoliasta relaciona a mesquinhez ( $\sigma \mu \imath \kappa \rho o \lambda o \gamma i ́ \alpha)$ com uma postura profissional que Simónides teria inaugurado e cita como prova um passo de uma das odes que Píndaro compôs para Xenócrates de Agrigento (cf. supra). Mas, em rigor, as palavras do lírico de Tebas reflectem antes a consciência da evolução da lírica coral, em particular da relação entre o poeta e o seu patrono, e não necessariamente uma alusão ao papel pioneiro e controverso do seu antecessor ${ }^{143}$. Seria notável, por outro lado, que censurasse um tipo de actuação profissional que ele próprio havia prosseguido e à qual alude com frequência nas suas odes ${ }^{144}$. No entanto, esta foi provavelmente a interpretação de Calímaco, que afirma num dos fragmentos de Iambos (fr. 222 Pf. = test. 3), retomando as palavras de Píndaro ${ }^{145}$ :

${ }^{143}$ Cf. C. O. Pavese, "XPHMATA, XPHMATA' ANHP ed il motivo della liberalità nella seconda Istmica di Pindaro”, QUCC 2 (1966) 103-112; Austin 1967: 6-7, Woodbury 1968: 533 sqq., Bell 1978: 37, Molyneux 1992: 255-259.

${ }^{144} \mathrm{O}$ poeta sublinha constantemente que a riqueza é um elemento essencial da arete do laureado, que deve ser bem utilizada, para suportar as despesas de participação nos jogos e as da composição e execução do canto. De facto, é o seu trabalho poético que imortaliza a glória do vencedor. Sobre esta matéria, vide em particular Woodbury 1968: 536 sqq., Bernardini 1980: 103-104, Willcock 1995: 15-16, e supra, p. 105 e n. 26.

${ }^{145} \mathrm{O}$ fragmento é citado no escólio a Pind. Isth. 2. 6 como prova de que Simónides 


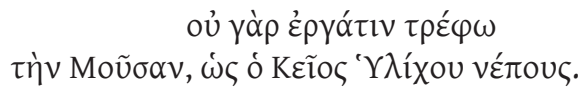

pois eu não sustento uma Musa

mercenária, como o homem de Ceos, de Hílico descendente.

Num segundo momento, o escoliasta de Aristófanes cita outras fontes e, não obstante as lacunas do texto, sugere-se que Xenófanes se indignou com a actuação de Simónides e, supomos nós, exprimiu o que pensava num poema. Um pouco mais velho do que o nosso lírico, o poeta de Cólofon é considerado o mais antigo geólogo e fundador da paleontologia, pelas suas observações sobre fósseis, mas é sobretudo recordado pelo seu pensamento revolucionário no domínio da religião (cf. Rocha Pereira 2006: 275-276), e pela crítica das honras, na sua opinião excessivas, concedidas aos vencedores dos grandes Jogos (cf. fr. $2 \mathrm{D}-\mathrm{K})^{146}$. Não é uma fantasia supor que Xenófanes tenha incluído na sua crítica quem, com a sua poesia, imortalizava a glória destes atletas ${ }^{147}$. E, provavelmente, a sua indignação teria sido maior se um cultor de poesia coral tivesse adoptado uma posição sem precedentes, ao que sabemos, exigindo uma remuneração elevada pelo exercício da sua arte. De facto, os textos de Platão confirmam que mesmo em finais do séc. $V$ não era bem aceite que a dedicação às letras e a procura do saber tivessem uma contrapartida financeira, da qual não abdicavam os Sofistas ${ }^{148}$. Assim, cremos que tem fundamento a hipótese

iniciou o costume de compor epinícios em troca de uma remuneração. Como notou Austin 1967: 10, outros escólios de Píndaro expressam a mesma ideia (cf. Ol. 2. 157a, Ol. 9. 74b, Nem. 4. 60b).

${ }^{146} \mathrm{Na}$ opinião de Finley and Pleket 1976: 117, esta elegia deve ter sido composta um pouco antes de 520 (Xenófanes nasceu c. 565), porque evoca o programa olímpico completo, à excepção da corrida com armas, que foi introduzida naquele ano. Segundo a interpretação de Bernardini 1980: 88-90, neste fragmento formula-se pela primeira vez a antítese entre a actividade física e a intelectual, sugerindo-se a superioridade da segunda. Observa, porém, que as vozes de discórdia contra o ideal agonístico se começam a ouvir desde o séc. VII, com

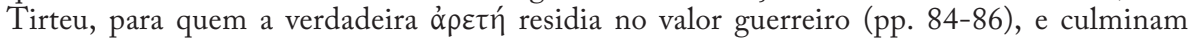
na crítica directa do Autólito de Eurípides, no qual se declara abertamente o desprezo do intelectual pela força física, que tem como único fim a conquista de prémios desportivos (pp. 89-92).

${ }^{147}$ Bell 1978: 34-37 dedica larga atenção à crítica de Xenófanes, supondo que os dois poetas se tivessem encontrado na corte de Hierão, como também sugeriu Huxley 1978: 247, cenário privilegiado das histórias sobre a avareza do poeta, como vimos. Antes destes investigadores, já Woodbury 1968: 536 havia admitido a possibilidade de aquela reputação se ter desenvolvido na corte de Siracusa. Podlecki 1979: 13 mostra-se céptico quanto aos eventuais contactos entre Simónides e Xenófanes.

${ }_{148}$ Cf. Pl. Ap. 19e-20a, Hp.Mi. 364d. Vide outras fontes sobre a censura do ensino remunerado dos Sofistas em Rocha Pereira 2006: 451-452 e n. 7. Sobre o modo como Platão realça os elevados lucros destes profissionais, estabelecendo comparação com os preços de 
apresentada pelo escoliasta, que relacionava a mesquinez de Simónides com uma atitude profissional de ruptura face à tradição lírica ${ }^{149}$.

Que o poeta tenha sido, de facto, um avarento é questão de menor importância. É fácil adivinhar que, se Xenófanes proferiu tal acusação, independentemente das suas razões e do seu alcance, esta terá tomado dimensões grandiosas e adquirido novos contornos com o passar dos tempos, a ponto de se tornar num topos da tradição biográfica ${ }^{150}$. Assim, é provável que a história das duas arcas mencionada no escólio seja já um desenvolvimento posterior do motivo da avareza ${ }^{151}$. Recorde-se que o autor do tratado Hiparco afirma que o filho de Pisístrato mantinha Simónides junto de si 'com elevadas recompensas e donativos' (cf. supra, p. 136) e chegaram-nos várias notícias deste teor. Uma das mais graciosas é a que transmite Aristóteles a propósito da composição do epinício encomendado por Anaxilas (fr. 515). Os escritos do filósofo preservaram outras histórias, que teriam no seu tempo larga difusão, que corroboram o retrato de um Simónides amigo do lucro ${ }^{152}$. Como dissemos, um passo de Deipnosophistae atribui responsabilidades a Cameleonte (Athen. 14. $656 \mathrm{~d}-\mathrm{e}=$ test. 23$)$ :

escultores célebres, vide Rocha Pereira 1997b: 30.

${ }^{149}$ No entanto, observa Bowra 1961: 360, o relato de Heródoto sobre Aríon (1. 24. 1, vide supra, p. 77), que juntou uma pequena fortuna com a viagem pela Sicília, sugere que antes de Simónides já havia poetas que ganhavam muito dinheiro. Parsons 2001: 63 põe igualmente em causa a ideia de que o nosso lírico tenha sido o primeiro a exigir uma remuneração pelo seu trabalho. Contra estas posições, Woodbury 1968: 535-536 e n. 11 distingue entre o que seriam simples gratificações ou recompensas (cf. Od. 8. 474-481) e a prática formal de estabelecer um preço, que na sua opinião surge apenas com Simónides, o que parece ser atestado pelo uso de uma expressão

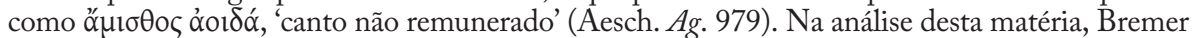
1991: 45-46 chamou a atenção para um fragmento curioso, composto em hexâmetros, preservado na Vida de Homero do Pseudo-Heródoto (§ 32, cf. West 2003b: 390-395) e atribuído também a Hesíodo (fr. $302 \mathrm{M}-\mathrm{W}$ ). Em traços gerais, uma corporação de oleiros solicitou a um aedo que celebrasse a bênção do seu forno pela deusa Atena. Falando na primeira pessoa, o poeta insiste

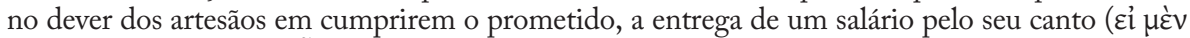

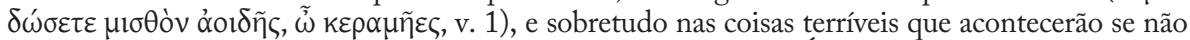
o fizerem. Há alguma probabilidade de esta composição ser da Época Arcaica ou, pelo menos, anterior à Oresteia de Ésquilo (de 458). Cf. West 2003b: 304.

${ }^{150}$ Lefkowitz 1981: 52 concluiu da informação do escólio acerca de Xenófanes que as anedotas sobre Simónides podem ter começado a circular durante a sua vida, no início sob a forma de paródia. Esta hipótese, ainda que plausível, não pode ser confirmada pelas outras fontes, que não são anteriores aos finais do séc. V.

${ }^{151}$ Note-se que o escoliasta observa que se trata de uma história conhecida. De facto, foi citada por Plutarco (de curios. 10.520a, de ser. num. vind. 11. 555f) e por outras fontes (cf. Thuc. 2. 44. 4, schol. Theoc. arg. 16, Stob. 3.10. 38, Suda $\Sigma$ 440, Tzetz. H. 8. 807-808). Na análise do testemunho, Bell 1978: 68-70 avança a hipótese de a anedota ter sido inspirada por um poema de Simónides, observando que um escoliasta da Ilíada registou que o poeta fizera uso do termo

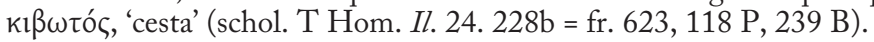

${ }^{152}$ Cf. Arist. EN 4.1, Rh. 2. 16.1391a8-12 = test. 47 (d), cit. supra. 


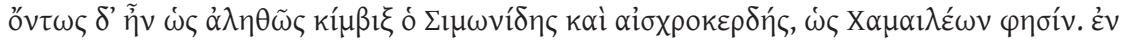

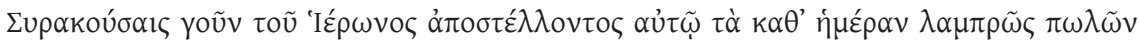

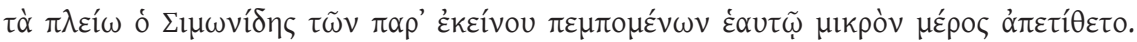

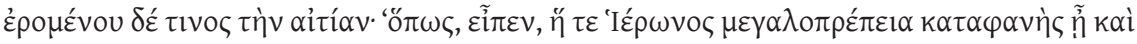

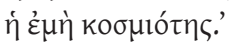

$\mathrm{Na}$ realidade, Simónides era um verdadeiro avarento e um açambarcador, como diz Cameleonte. Por exemplo, em Siracusa, quando Hierão lhe enviava as provisões para um dia, Simónides vendia às claras a maior parte do que ele lhe mandava e guardava para si a parte menor. Quando lhe perguntaram o motivo, respondeu: 'A fim de que seja evidente a magnificência de Hierão e a minha modéstia.'

Este testemunho põe em evidência um outro traço de carácter que a tradição atribuiu a Simónides, a sabedoria prática que aqui se confunde com astúcia. A anedota, todavia, nada tem a ver com a actuação profissional do poeta e, por conseguinte, filia-se numa tradição diferente daquela a que pertence a notícia sobre Anaxilas, transmitida por Aristóteles, bem como o fragmento de Calímaco anteriormente citado. Nessa tradição, que tanto pode remontar a Cameleonte como à comédia do séc. $\mathrm{V}$, a avareza do poeta, proporcionada pela convivência com patronos abastados, é simplesmente um traço de carácter que se agudiza na velhice ${ }^{153}$ e deixa de ser perceptível a relação efectiva com a atitude profissional de Simónides.

${ }^{153}$ É bem ilustrativo um passo de Plutarco (An seni sit gerenda res publica $5.786 \mathrm{~b}=$ test. 47 (e)), segundo o qual 'Simónides dizia aos que o acusavam muito de avareza que, por causa da velhice, estava privado de todos os outros prazeres e por um só ainda era assistido: o de ganhar

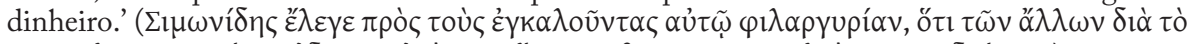

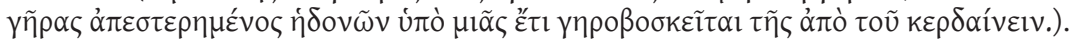




\section{III.2. O CULTOR DA MEMÓRIA}

Élio Aristides transmitiu-nos o seguinte testemunho (Or. 28. 59-60 = fr. eleg. 89, 146 B, 78 D), ao qual nos referimos no início desta segunda parte:

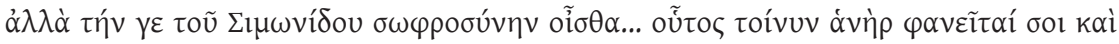

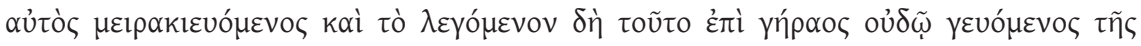

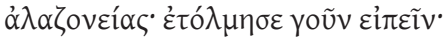

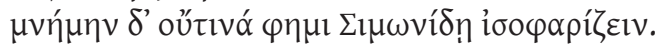

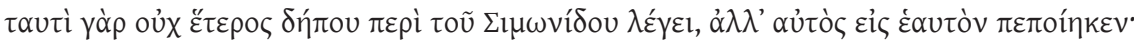

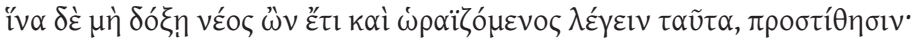

ỏ $\delta \omega \kappa o v \tau \alpha \varepsilon ́ \tau \varepsilon l ~ \pi \alpha 1 \delta i ~ \Lambda \varepsilon \omega \pi \rho \varepsilon ́ \pi \varepsilon \circ \zeta$,

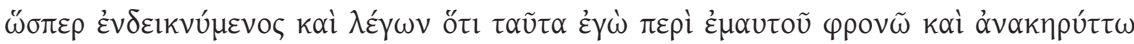

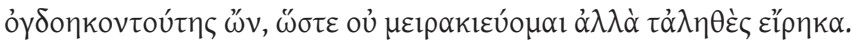

Mas tu conheces a moderação de Simónides... Portanto, até este homem te há-de dar a impressão de se comportar como um jovem e, no limite extremo da velhice, como diz o ditado, de se entregar à sobranceria. De facto, ousou dizer:

pois declaro que na memória Simónides não tem rival.

Isto não é, sem dúvida, um outro a falar de Simónides, mas ele sobre si mesmo o escreveu. E, para não dar a impressão de dizer isto quando era novo e estava na flor da idade, acrescenta: aos oitenta anos, o filho de Leóprepes,

de modo a dizer com clareza 'isto é o que eu penso e declaro acerca de mim próprio com a idade de oitenta anos. Portanto, não me estou a comportar como um jovem, mas disse a verdade.'

Uma vez que o orador, do séc. II da nossa era, atribui ao poeta um pentâmetro que ocorre num epigrama presumivelmente helenístico (XXVIII. 6, cit. supra), é prudente levantar alguma dúvida quanto à autenticidade do primeiro verso citado ${ }^{154}$. A sua formulação, aliás, não invalida que tenha sido composto por uma outra pessoa e figurasse, como o segundo, num epigrama sobre Simónides. Mas a possibilidade de estes versos remontarem à sua obra, quer tenham ou não sido recolhidos numa edição das suas composições elegíacas, é corroborada, de certo modo, por um passo do fr. 64 dos Aetia de Calímaco, segundo o qual Simónides foi 'o primeiro a reflectir na memória'

${ }^{154}$ No exame dos versos atribuídos a Simónides e no contexto da sua transmissão centra-se o estudo de Goldhill 1988. O autor discute também a opinião de Slater 1972: 235-236, que contestou a autenticidade dos versos atribuídos a Simónides. Molyneux 1992: 311 defende a atribuição, na sequência de Boas 1905: 111. 
(v. 10). Tanto no verso atribuído ao poeta como no de Calímaco surge o termo $\mu v \eta ́ \mu \eta$, que significa propriamente 'faculdade de se recordar', 'memória', e se distingue de $\mu \nu \tilde{\eta} \mu \alpha$ e de $\mu \nu \tilde{\eta} \sigma \tau \iota \varsigma^{155}$.

Inspirada ou não pelas suas próprias palavras, a tradição biográfica

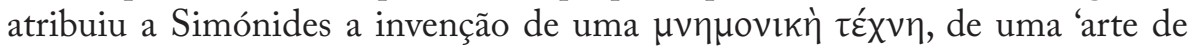
recordar', como atestam diversas fontes, desde o Marmor Parium à Suda $a^{156}$. Alguns dos testemunhos põem em evidência os aspectos técnicos desta criação e são meramente informativos ${ }^{157}$. Outros devem pertencer à tradição pseudo-biográfica, visto que a descoberta e aplicação de uma mnemónica é "ficcionada", o que não significa, no entanto, que algumas das notícias não tenham um fundo de verdade. Como já dissemos, segundo Quintiliano (Inst. 11.2.16) esta tradição foi divulgada em Roma por Cícero, que nos transmitiu um dos testemunhos mais interessantes sobre a convivência do poeta com os chefes da Tessália (de Orat. 2. 86. 351-353 Kumaniecki = fr. 510, 5 P, p. 389 adnot. B):

'non sum tanto ego' inquit 'ingenio, quanto Themistocles fuit, ut obliuionis artem quam memoriae malim; gratiamque habeo Simonidi illi Cio, quem primum ferunt artem memoriae protulisse. dicunt enim, cum cenaret Crannone in Thessalia Simonides apud Scopam, fortunatum bominem et nobilem, cecinissetque id carmen, quod in eum scripsisset, in quo multa ornandi causa poetarum more in Castorem scripta et Pollucem fuissent, nimis illum sordide Simonidi dixisse se dimidium eius ei, quod pactus esset, pro illo carmine daturum; reliquum a suis Tyndaridis, quos aeque laudasset, peteret, si ei uideretur. paulo post esse ferunt nuntiatum Simonidi, ut prodiret; iuuenes stare ad ianuam duo quosdam, qui eum magno opere uocarent; surrexisse illum, prodisse, uidisse neminem. hoc interim spatio conclaue illud, ubi epularetur Scopas, concidisse; ea ruina

${ }^{155} \mathrm{O}$ termo $\mu v \tilde{\eta} \mu \alpha$ designa um objecto concreto que permite a recordação ('memorial', 'monumento comemorativo', 'sepultura', cf. epigr. VI), enquanto $\mu \nu \tilde{\eta} \sigma \tau \iota \varsigma$ significa mais exactamente 'acção de pensar, de evocar pelo pensamento; lembrança, recordação' (cf. Od. 13. 280, Simon. fr. 531.3, Hdt. 7. 158.3, Theoc. 28.23). Menos raro é $\mu v \eta ́ \mu \eta$ que aparece em Thgn. 798 e percorre depois toda a literatura grega. Cf. Chantraine, s.v. $\mu \iota v \eta ́ \sigma \kappa \omega ; ~ G o l d h i l l ~ 1988 ;$ Poltera 1997: 59-60.

${ }^{156}$ Cf. Marm. Par. Ep. 54, P. Oxy. 1800, fr. 1, col. 2. 40 sqq., Ael. NA 6. 10, Philostr. VA 1. 14, Amm. Marc. 16.5. 8, Suda $\Sigma$ 439. Vide n. seguinte.

${ }^{157}$ Cf. Plin. Nat. 7.89 = test. 24: 'Finalmente, uma mnemónica foi inventada pelo lírico Simónides e aperfeiçoada por Metrodoro de Cépsis, para que se repetisse com as mesmas palavras tudo o que fosse ouvido.' (ars postremo eius rei facta et inuenta est a Simonide melico, consummata a Metrodoro Scepsio, ut nibil non isdem uerbis redderetur auditum.); Longin. Rh. 718 = test. 26: 'Simónides e muitos outros depois dele ensinaram já os métodos de recordar, propondo a comparação de imagens e lugares para a recordação de nomes e palavras. Mas isto não é outra coisa senão o confronto do que é similar com o que parece novo e a sua relação

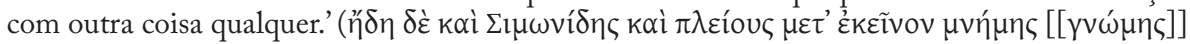

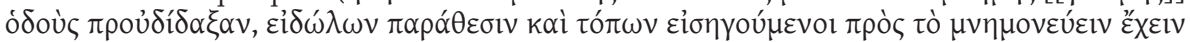

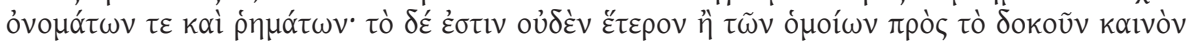

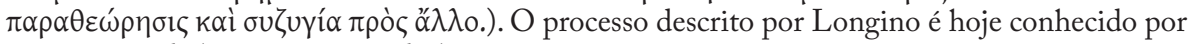
mnemónica de lugares ou método loci. 
ipsum cum cognatis oppressum suis interisse. quos cum humare uellent sui neque possent obtritos internoscere ullo modo, Simonides dicitur ex eo, quod meminisset quo eorum loco quisque cubuisset, demonstrator unius cuiusque sepeliendi fuisse. hac tum re admonitus inuenisse fertur ordinem esse maxime, qui memoriae lumen adferret.'

'Não sou eu homem de tão grande talento quanto o foi Temístocles', diz, 'que prefira a arte de esquecer à de recordar. E estou grato ao famoso Simónides de Ceos, do qual se diz ter sido o primeiro a revelar a arte da memória. Dizem, na verdade, que durante um banquete em Crânon, na Tessália, na casa de Escopas, homem afortunado e da nobreza, depois de Simónides executar o poema que para ele tinha escrito, no qual, como é costume dos poetas, menciona as muitas razões para se honrar Castor e Pólux, aquele, com grande mesquinhez, disse a Simónides que lhe ia dar por aquele poema metade do que havia sido combinado. Se lhe conviesse, que pedisse a outra metade aos seus Tindáridas, que havia igualmente louvado. Dizem que, pouco tempo depois, vieram anunciar a Simónides que saísse. Junto da porta estavam de pé dois jovens que o chamavam com grande insistência. Ele levantou-se, saiu e não viu ninguém. Entretanto, durante este tempo, a sala onde comia Escopas abateu-se. Ele próprio morreu esmagado neste desmoronamento, juntamente com os seus parentes. Quando quiseram sepultá-los e não podiam de modo nenhum distinguir os corpos esmagados dos parentes do seu, diz-se que foi Simónides, porque se tivesse lembrado do lugar em que cada um deles estivera deitado, que os identificou para serem enterrados individualmente. Então, instigado por esta situação, diz-se, descobriu que é sobretudo a ordem que ajuda a iluminar a memória.'

É evidente que o orador romano tem o cuidado de explicitar que todo o relato se baseia na tradição (quem primum ferunt... dicunt enim... paulo post esse ferunt... Simonides dicitur ex eo... fertur... $)^{158}$, talvez porque contém elementos históricos (a convivência de Simónides com Escopas, o desabamento do tecto $^{159}$ ), fantásticos (o salvamento miraculoso do poeta pelos Dioscuros) e outros verosímeis, que não é possível confirmar: a presença do poeta no banquete, o desentendimento sobre a remuneração acordada com Escopas e mesmo a invenção da mnemotecnia.

Não obstante o comentário de Quintiliano, de que tudo o que é dito sobre os Tindáridas é pura invenção (Inst. 11. 2. 16), cremos que têm razão os estudiosos que consideram o louvor a Castor e Pólux um aspecto essencial

${ }^{158}$ Quintiliano (Inst. 11. 2. 11-16), que segue de perto Cícero, notando que a história da descoberta de uma arte de lembrar era bem conhecida (uulgata fabula est), detém-se, como vimos já (p. 163), nas discrepâncias da transmissão literária. Para uma análise comparativa das duas versões, centrada no motivo da mnemotecnia, vide V. D'Agostino, "Simonide inventore della mnemotecnica in Cicerone e in Quintiliano", RSC 1.2 (1953) 125-127. Sobre a recepção desta lenda em Horácio, vide I. Marchesi, "In memory of Simonides: Poetry and Mnemotechnics chez Nasidienus", TAPhA 135 (2005) 393-402.

${ }^{159}$ Como já foi dito, a historicidade deste elemento não é unanimemente aceite. Vide supra, n. 112 . 
da história, sugerindo a importância destes heróis na poesia de epinícios (cf. Robbins 1997: 245). Ou seja, a descoberta de uma arte de lembrar é apenas um pretexto para o encadeamento de outros elementos, à primeira vista biográficos, mas que podem ser apenas o resultado de interpretações forçadas dos poemas de Simónides. Na opinião de Page 1962: 243-244, a lenda de que o poeta devolveu os corpos aos parentes, lembrando-se da ordem em que cada conviva tomara lugar à mesa, foi inspirada pelo treno em que tratou o desastre dos Escópadas (vide supra). Por sua vez, E. Suárez de la Torre salientou que os versos do poeta, em particular o fr. 531, proclamam amiúde a necessidade do elogio por meio da palavra para lutar contra o tempo, o destino fatal e o esquecimento, e considerou a hipótese de estes temas terem influenciado o desenvolvimento do motivo da invenção da mnemotecnia (1998b: 31-32 e n. 15, cf. 1998a: 91-92).

Se, por um lado, estas duas leituras põem em causa a historicidade da tradição, por outro corroboram os testemunhos de Calímaco e de Aristides, segundo os quais a memória havia ocupado as reflexões do poeta. A invenção de uma mnemónica é, de resto, uma prova da singularidade de Simónides, de alguém que conhecia 'coisas raras', como escreveu Calímaco (Aetia, fr. 64.9 Pf.), que a tradição procurou consolidar com a atribuição de outras descobertas (cf.

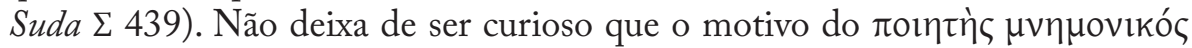
tenha suscitado um outro tipo de anedota, na qual o talento de Simónides é posto à prova por Temístocles, que rejeita a oferta de uma 'arte da memória', e antes lhe sugere uma 'arte do esquecimento'. Evocado noutras ocasiões por Cícero ${ }^{160}$, este tema inspirou a Elegia I de Camões e se remonta, como já dissemos, a alguma obra que enaltecia as qualidades militares do general ateniense, ilustra bem o confronto secular entre o pragmatismo dos homens de acção e o idealismo dos cultores das letras. 


\section{III.3. SiMÓNIDES, POETA SÁBIO OU “PROTO-SOFISTA”?}

Uma parte substancial dos fragmentos de Simónides é de conteúdo gnómico, como é característico dos cultores de lírica coral, destacando-se as suas reflexões sobre a precaridade da existência humana e os ideais de conduta nos desafios desportivos e na defesa da pátria. Como veremos na terceira parte, o modo como construiu alguns dos poemas, começando por refutar (ou reformular) afirmações proferidas por homens sapientes ou poetas do passado (cf. frr. 542, 579,581 , fr. eleg. 19), indicia uma atitude crítica que pode ter influenciado os que o consideraram um guia moral. Não sabemos se era essa a opinião dos seus contemporâneos, porque é somente na República de Platão que surge claramente associado aos sábios da Época Arcaica $(335 \mathrm{e}=$ test. 35), num passo em que se analisa a sua definição de justiça (cf. 331e = fr. 642 (a)). Como já dissemos, aquela obra, bem como o Protágoras, sugere que as sentenças atribuídas ao poeta tinham larga circulação na segunda metade do séc. V e continuavam a despertar o interesse dos homens de letras e dos filósofos.

Esta faceta de Simónides inspirou igualmente a tradição anedótica, como atestam alguns testemunhos, nos quais o poeta protagoniza episódios em que a sua sapiência é usada em proveito próprio ou denuncia um espírito avarento (cf. Athen. 14. 656d-e = test. 23, cit. supra). Um dos melhores exemplos é um fragmento de um papiro que circulou no Egipto em meados do séc. III e contém uma colecção de sentenças sobre despesas $(\grave{\alpha} \vee \eta \lambda \omega ́ \mu \alpha \tau \alpha)$. Não é por certo casual que mencione Simónides (P. Hibeh $17=$ test. $47(\mathrm{f}))^{161}$ :

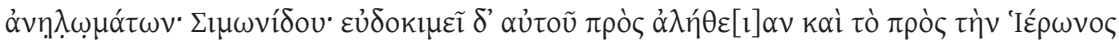

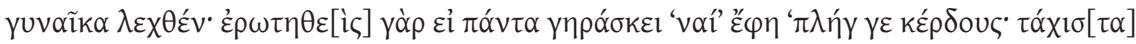

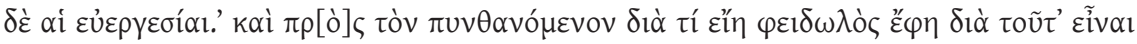

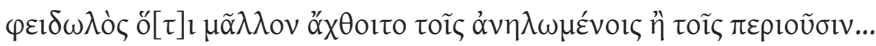

Sobre despesas, de Simónides, goza de grande reputação, pela sua verdade, o que respondeu à esposa de Hierão. Tendo-lhe sido perguntado se todas as coisas envelhecem, respondeu: 'pois, por certo, excepto o dinheiro; e muito mais depressa as boas acções'. E quando the perguntaram por que era poupado, respondeu que era poupado, porque lhe pesavam mais as despesas do que os bens excedentes...

${ }^{161}$ Cf. B. P. Grenfell, A. S. Hunt (edd.), The Hibeh Papyri I (London 1906) 64-66. Disponível online: http://archive.org/details/hibehpapyri01egypuoft [acedido em 10/07/2012]. 
Na opinião de helenistas como Bell 1978: 84 e Robbins 1997: 246, a reputação de sábio de Simónides pode ter sido sugerida pela convivência com figuras importantes do seu tempo, pois é longa a tradição de associar os sábios aos dirigentes políticos, como Tales de Mileto e Periandro, Creso e Sólon, Anaxágoras e Péricles. Como se sabe, este topos inspirou a Xenofonte a composição de Hierão, uma conversa imaginária entre Simónides e o tirano da Sicília sobre o despotismo ${ }^{162}$. É igualmente evocado por Cícero em $\mathrm{Da}$ natureza dos deuses 1. 22. 60 (= test. 47 (c)), num passo em que se diz que Simónides 'foi não só um poeta agradável, mas também um homem instruído e sábio, porque lhe ocorriam muitas ideias inteligentes e subtis...' (...non enim poeta solum suauis uerum etiam ceteroqui doctus sapiensque traditur, quia multa uenirent in mentem acuta atque subtilia...).

A longa lista de apotegmas que a tradição lhe atribuiu, alguns notáveis, embora outros sejam certamente apócrifos (talvez a maior parte), permite supor que na Antiguidade tenham sido reunidos numa colecção, como pensou Wilamowitz ${ }^{163}$. Uma vez que as fontes são tardias, é plausível que sejam fruto sobretudo das ilacções dos comentadores da sua obra. Mesmo assim, merece destaque, pela sua fortuna, a reflexão sobre a proximidade entre a arte da poesia e a da pintura, transmitida por Plutarco (De gloria Atheniensium 3.346f = test. $47(\mathrm{~b}))^{164}$ :

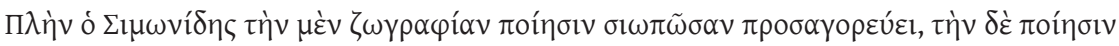

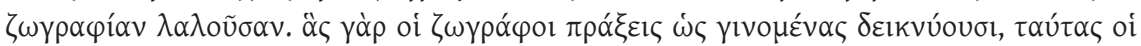

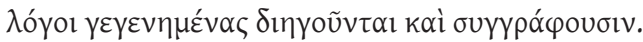

Mas Simónides chama à pintura poesia silenciosa e à poesia pintura falante. Pois as acções que os pintores representam como se estivessem a acontecer, as palavras narram-nas e descrevem-nas em pormenor depois de terem acontecido.

Devemos também a Plutarco a transmissão de uma máxima que ilustra, de forma exemplar, a sabedoria e prudência que a tradição reconhecia em Simónides (De garrulitate 23. 514f-515a = test. $47(\mathrm{~h}))^{165}$ :

${ }^{162}$ Vide V. J. Gray, "Xenophon's Hiero and the Meeting of the Wise Man and Tyrant in Greek Literature”, CQ 36 (1986) 115-123; Hunter 1996: 98-100.

${ }_{163}$ Cf. Campbell 1991: 363, 507. Wilamowitz 1913: 149 n. 4 e Bell 1978: 64 n. 141

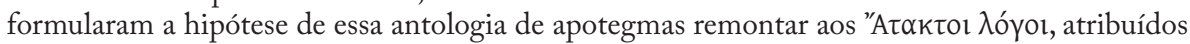
a Simónides num comentário a um passo da Metafísica de Aristóteles (N 3. 1091a.5, cf. fr. 653 e o comentário de Page ad loc.).

${ }^{164} \mathrm{Cf}$. Plu. De audiendis poetis 3. 17f-18a, De adulatore 15. 58b, Quaest. conv. 9. 748a. Vide a análise de Lesky 1995 [1971]: 220 e Bell 1978: 81. Para uma leitura dos fragmentos de Simónides a partir da interpretação desta máxima, vide Ferreira 2007.

${ }^{165}$ Cf. Plu. Quaest. conv. 3. 644e-f, Stob. 3.33. 12. 


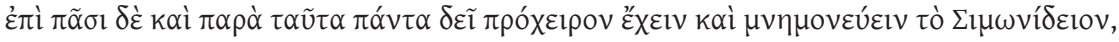

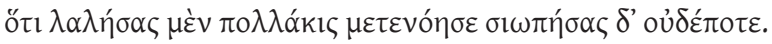

Em todas as coisas e por todas estas razões é preciso ter à mão e recordar o dito de Simónides: que muitas vezes se arrependeu depois de ter falado, mas nunca quando guardou silêncio.

Talvez mais generalizada entre os filólogos, embora nos pareça um pouco discutível, é a opinião de que Simónides foi um "proto-sofista" ${ }^{166}$. É quase inevitável a comparação do poeta com os Sofistas, que encontraram na dedicação ao saber uma actividade rentável e fizeram da mobilidade um modo de vida (Pl. Ap. 19e-20a, Hp.Mi. 363c-d, Prt. 315a-b). Ao que sabemos, o único testemunho antigo é a declaração de Protágoras, no diálogo homónimo de Platão (316d = test. 34), de que a sofística é uma arte antiga, que no passado foi praticada por Homero, Hesíodo e Simónides sob a forma de poesia ${ }^{167}$. Por outro lado, o mesmo diálogo platónico põe em evidência uma atitude de reflexão constante sobre a tradição, bem como o gosto pela polémica que surpreendemos em alguns dos fragmentos de teor gnómico (cf. frr. 542, 579, 581, fr. eleg. 19). Não é certo, porém, que a atribuição a Simónides do título de "proto-sofista" esteja claramente fundamentada e parece-nos muito mais uma das ideias sobre o poeta que agrada aos estudiosos modernos, mas que a fragmentação da sua obra não permite esclarecer.

${ }^{166}$ Cf. Lesky 1995 [1971]: 219-220, Segal 1985: 185, Suárez de la Torre 1988b: 213, Robbins 1997: 246, Graziosi and Haubold 2009: 110-111.

${ }^{167}$ Cf. o comentário ao passo platónico de Pinheiro 1999: 156-157 n. 24. 
(Página deixada propositadamente em branco) 


\section{Parte III}

FRAGMENTA SELECTA:

UMA LEITURA DA OBRA DE SimóNides 
(Página deixada propositadamente em branco) 
I. O CANTO EM HONRA DOS HOMENS 
(Página deixada propositadamente em branco) 


\section{I.1. REFLEX̃̃ES SOBRE A CONDIÇÃO HUMANA}

A condição humana é uma temática constante na literatura e uma das mais importantes para os poetas gregos da Época Arcaica. Uma parte significativa do corpus de Simónides confirma este apreço e o presente capítulo reúne os fragmentos em que este tema surge em evidência. $\mathrm{Na}$ organização deste comentário tomámos como linha orientadora a ordenação estabelecida nas edições de Page 1962 e Campbell 1991 (fragmentos líricos) e de West 1992a (fragmentos elegíacos), nas quais se baseia o texto grego. Foi principalmente destas obras que recolhemos os dados do aparato crítico que, embora não sendo exaustivo, nos permite assinalar os passos mais duvidosos, mostrar a diversidade de leituras e esclarecer a nossa interpretação.

Fr. 520 [15 P, 39 B, 9 D] Plu. cons. Apoll. 11. 107a-b

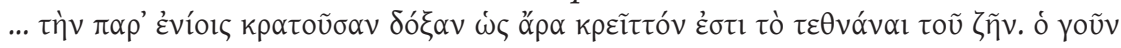

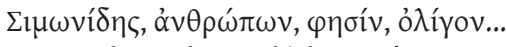

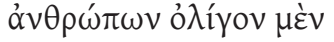

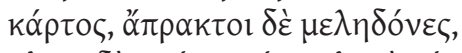

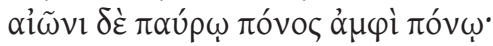

ó $\delta$ '̊́ $\varphi$

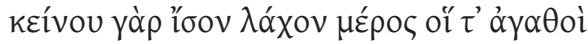

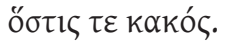

1-3 'divisio incerta' scripsit Page $3 \delta^{\prime}$ żv Pflugk (et Schneidewin): $\delta \grave{c}$ codd.

... a opinião dominante em alguns é que é melhor estar morto do que viver. Simónides, por exemplo, diz:

Dos homens pequena

é a força, vãs as preocupações,

na sua breve vida, penas sobre penas;

e, inevitável, do mesmo modo sobre todos impende a morte;

pois dela igual parte cabe em sorte aos bons

e a quem é mau.

São diversas as motivações que levam um autor a inserir na sua obra um excerto de um poeta antigo. Muitas vezes, como é o caso, pretende-se conferir credibilidade a um determinado juízo. No entanto, o sentido geral do fragmento não sustenta que para Simónides era 'melhor estar morto do que viver'. Compreende-se, todavia, esta interpretação, dado o tom pessimista destes versos. 
Num primeiro momento, deparamo-nos com uma reflexão sobre a vida humana. Todo o peso da oração recai no substantivo, sem artigo, $\alpha v \theta \rho \omega ́ \pi \omega v$, a ocupar uma posição privilegiada em início de verso. A ideia de que a debilidade,

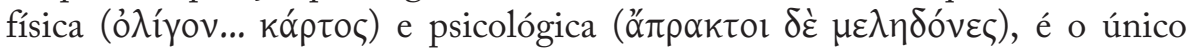
apanágio da raça humana culmina no pessimismo do melodioso v. 3: a vida é breve, mas plena de sofrimento. O estilo é sóbrio e conciso, sem abundância de adjectivos, marcado pela frase nominal e pela parataxe. No plano fónico, há uma insistência nos sons fechados e nas nasais, em particular no v. 3, no qual sobressai a aliteração em labial. Em nosso entender, esta elaboração formal confere ao fragmento um tom de solenidade apropriado à mensagem.

A reflexão sobre a morte ocupa o segundo momento do fragmento (vv. 4-6). A nossa atenção detém-se primeiro no adjectivo ó $\varphi v k \tau o \varsigma$ que, formado a partir de $\varphi \varepsilon u ́ \gamma \omega$, significa à letra 'do qual não se pode fugir'1. A morte é, portanto, entendida como uma presença constante e negativa para a Humanidade. $\mathrm{Na}$ última oração, de teor conclusivo ( $\gamma \alpha ́ \rho)$, emerge o aspecto mais pessimista desta concepção: a morte não opera escolhas, não olha ao carácter das pessoas, não tem sentido de justiça... é de supor.

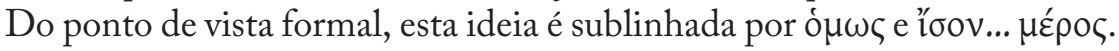
Se na morte não há lugar para diferenças entre os homens, o poeta distingue na raça humana ợ $\alpha \theta$ oí e kokoí, o que não quer dizer que empregue estas

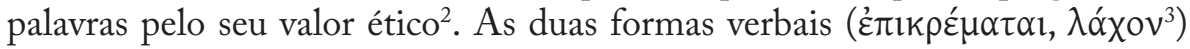
de todo o fragmento dizem respeito à morte, concebida como uma ameaça iminente e inexorável. Por mais negativa que seja esta visão da condição humana, será legítimo considerarmos que no pensamento de Simónides 'é melhor estar morto do que viver'?

A noção de que a humanidade está sujeita ao sofrimento, a uma vida breve e à inevitabilidade da morte é um topos familiar à cultura e literatura gregas, que outros líricos cultivaram ${ }^{4}$. Por conseguinte, este fragmento, que

${ }^{1}$ Poltera 1997: 84 salienta que a aplicação de ớ $\varphi$ neste passo.

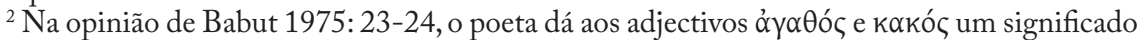
tradicional, sem nenhum valor propriamente moral, enquanto a ideia do carácter inexorável da morte, do nivelamento que ela impõe a todos os destinos humanos, é um dos temas correntes da épica e da lírica antigas, que se exprime, por exemplo, nas palavras que Heitor dirige a Andrómaca em Il. 6. 488-489: ‘. .. digo-te não existir homem algum que à morte tenha fugido,/ nem o cobarde, nem o valente, uma vez que tenha nascido.' (trad. Lourenço 2005: 146). Por seu lado, Campbell 1982: 382 evoca como paralelo dos vv. 4-5 as palavras de Aquiles em Il. 9. 319-320: 'Na mesma honra são tidos o cobarde e o valente:/ a morte chega a quem nada faz e a quem muito alcança.' (trad. Lourenço 2005: 189). Registe-se que West, entre outros editores, considera o v. 320 espúrio, mas não é este o parecer de H. van Thiel.

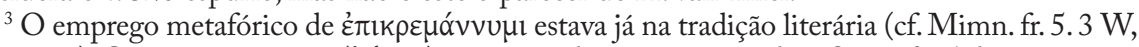
Thgn. 206). O aoristo gnómico ( $\lambda$ áxov) é apropriado ao momento da reflexão final do poeta.

${ }^{4}$ Nas palavras de Bowra 1961: 324, "Simonides saw death and disaster in a typically Greek 
alguns editores modernos inserem entre os $\operatorname{Trenos}^{5}$, podia ter pertencido a um epinício, do qual raramente estão ausentes as reflexões sobre a condição humana (e.g. Pind. Pyth. 3.80 sqq., 8. 95-97) ${ }^{6}$. Lobel 1981: 21 demonstrou a coincidência de algumas letras entre o fr. 520 e o fr. 14 do P. Oxy. 2623 (= 332 $S L G$, 519A Campbell). Se, por um lado, esta descoberta reforçou a atribuição do papiro a Simónides, por outro, o facto de conter partes de epinícios (cf. frr. 21 e 22) corrobora a hipótese de o fr. 520 pertencer também a este género de composição. Note-se, porém, que a linguagem evidencia formas épicas (кó coral $^{7}$.

Fr. 521 [16 P, 32 B, 6 D] Stob. 4. 41.9

$\Sigma \uparrow \mu \omega v i ́ \delta$ ov $\Theta \rho \eta ́ v \omega v$.

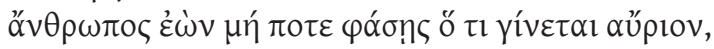

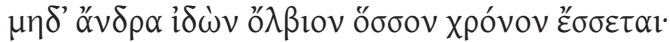

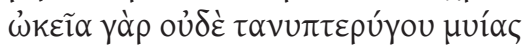

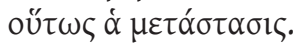

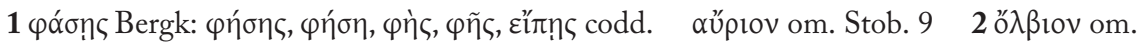
Stob. 9

Dos Trenos de Simónides:

Homem que és, nunca digas o que acontece amanhã, nem, se vires um homem afortunado, por quanto tempo o será;

pois nem tão rápido é o volver da mosca de longas asas como o da fortuna.

Mais uma vez, a primeira palavra do fragmento estabelece o tema central da reflexão sobre a condição humana, mas se no fr. 520 o poeta se detém no topos da brevidade e dureza da vida, neste sublinha principalmente que

spirit." (cf. p. 326). Sobre o tema da fragilidade humana na poesia grega arcaica, vide M. H. Rocha Pereira, "Fragilidad y poder del hombre en la poesía griega arcaica", Est. Clás. 10 (1966) 301-318; Campbell 1983: 202-251.

${ }^{5}$ As hipóteses propostas por F.W. Schneidewin - que o fragmento fazia parte de um treno e não constituía o seu início - continuam a ter aceitação entre os estudiosos, e.g. Gerber 1970: 312 ('presumably'). Na opinião de Campbell 1982: 382, os versos pertencem certamente a um treno, notando que o poeta escreve com o pessimismo de Semónides (cf.fr. $3 \mathrm{~W}$ ) ou de Mimnermo (fr. $5.3 \mathrm{~W}$ ).

${ }^{6}$ Sobre este aspecto, cf. Rutherford 1990: 202 e A. Pardini, "P. Oxy. 2623 fr. 14 e Simon. PMG 520: alcune osservazioni”, ZPE 95 (1993) 23-27, esp. 27.

${ }^{7} \mathrm{~A}$ análise métrica não reúne consenso. Note-se que não há certezas quanto à colometria dos vv. 1-3, cuja citação não se destaca do texto de Plutarco. Sobre esta questão, vide as propostas de Perrotta 1952: 254-256, Gerber 1970: 312, Campbell 1982: 382 (que observa que o metro é difícil de classificar), Poltera 1997: 150-151 e o artigo de Pardini citado na nota anterior. 
ela está sujeita à mudança imprevisível ${ }^{8}$ e, deste modo, qualquer estado de felicidade não chega a ser muito mais do que um momento de ilusão. $\mathrm{O}$ tom pessimista destes versos, citados por Estobeu no âmbito das suas reflexões sobre a instabilidade da prosperidade humana ${ }^{9}$, é ainda mais sombrio que o do fragmento anterior. Para isso contribui certamente o carácter sentencioso

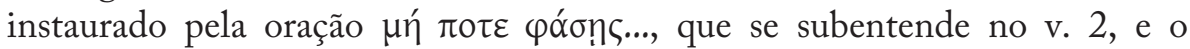

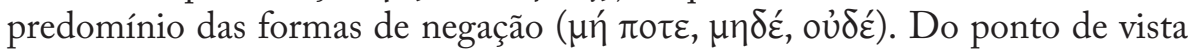
formal, é evidente o contraste entre a acumulação verbal dos vv. 1-2 ( $\varepsilon \dot{\omega} v$,

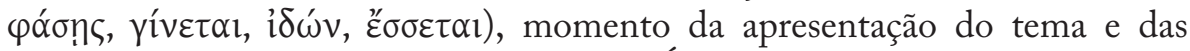
advertências, e a sua ausência dos vv. 3-4. É nestes versos que se concretiza a reflexão final do poeta, introduzida, como no fr. 520 (v. 5), por үó $\rho$, através de uma comparação singular entre uma realidade visível e familiar (a rapidez do volver da mosca de asas largas) e um conceito abstracto e elevado (a 'mudança de fortuna' $)^{10}$.

Este excerto exemplifica na perfeição o estilo conciso do poeta e o cuidado extremo com que construía os seus versos, pois as palavras mais importantes

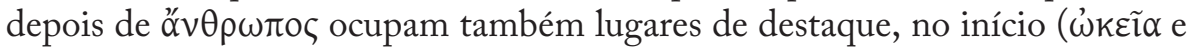

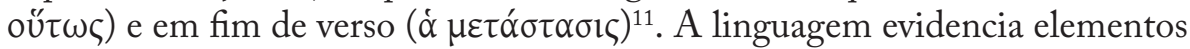
do dialecto iónico, eólico e dórico.

O facto de Estobeu citar estes versos como pertencentes aos 'Trenos de Simónides' pode apenas significar que foi sob esta forma que chegaram ao seu conhecimento, pois o topos da instabilidade da fortuna humana também ocorre nos cantos de vitória ${ }^{12}$. Como observa Perrotta 1952: 259, a desgraça inesperada e a morte de quem é considerado afortunado e poderoso dá uma

${ }^{8}$ A noção de que o amanhã ( $\left.\alpha u ̂ p r o v\right)$ é incognoscível pode ter sido desenvolvida num outro

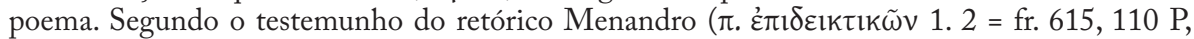

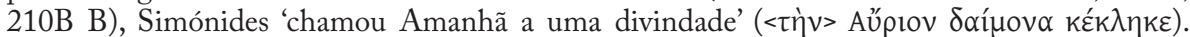
Sobre o significado dos termos $\alpha u ̈ p ı v$ e ő $\lambda \beta ı$ ı no fr. 521, cf. as considerações de Perrotta 1952:

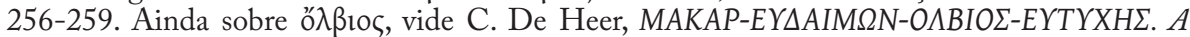
study of the semantic field denoting happiness in ancient Greek to the end of the 5th century B.C. (Amsterdam 1969) 34.

${ }_{9}^{9}$ Os problemas de crítica textual devidos à transmissão do fragmento são analisados por Perrotta 1952: 256-262. A ordem das palavras do v. 3 é confirmada por um escólio (ad Hom. Il. 7. 76) citado no P. Oxy. 1087, col. i 30, viii 102-103.

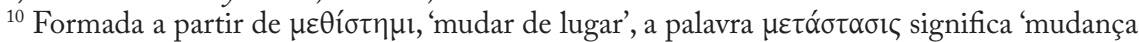
de direcção' ('change of position', LSJ, Suppl.) e diz respeito quer ao voo da mosca quer às

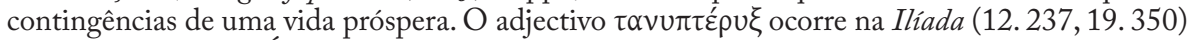

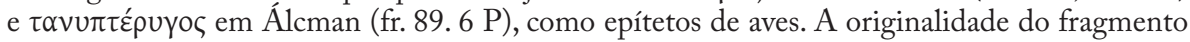
de Simónides reside na sua aplicação a um ser tão ínfimo como é a mosca (cf. Egoscozábal 2000: 16-17).

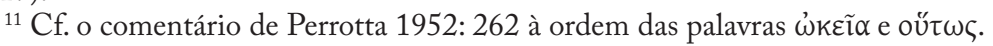

${ }^{12}$ Cf. e.g. Pind. Ol.5.23-24, 7.94-95, Pyth. 8.88-94, Isth.5.12-16. Confirmam a permanência deste topos na literatura grega, por exemplo, o encontro fictício entre Sólon e Creso, relatado por Heródoto e Plutarco (cf. supra,p. 99 n. 4), e as palavras finais do Rei Édipo de Sófocles. 
ideia mais viva da caducidade humana. Se Simónides tratou o desastre dos Escópadas num treno, como diz a tradição, ou num outro poema, o tema da mudança repentina da fortuna não podia ser mais adequado ${ }^{13}$.

\section{Fr. $522[17$ P, 38 B, 8 D] Stob. 4. 51.5}

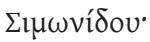

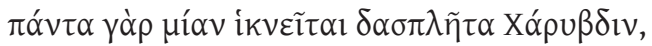

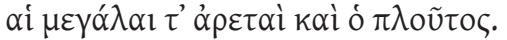

De Simónides:

Pois tudo chega a uma única horrível Caríbdis, as grandes qualidades e a riqueza.

A propósito da inevitabilidade da morte, Estobeu transmitiu-nos esta reflexão de Simónides, cuja proveniência não indica. A ideia é a mesma da dos vv. 4-5 do fr. 520: um único destino horrível e temido aguarda tanto as

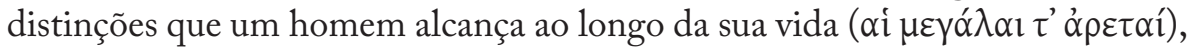
como os bens preciosos que consegue acumular (ó $\pi \lambda$ oṽ $\tau o \zeta)^{14}$. A presença de үó́ sugere uma construção formal semelhante à dos dois fragmentos anteriores ${ }^{15}$. Portanto, Estobeu cita apenas a afirmação conclusiva do poeta. A sua formulação é surpreendente, pela insistência na unicidade ( $\mu$ í $\alpha$ v) e pela criação de um novo epíteto ( $\delta \alpha \sigma \pi \lambda \eta ́$ ', 'tremendo, horrível, assustador'), muito próximo do que na Odisseia (15.234) designa a deusa Erínia ( $\delta \alpha \sigma \pi \lambda \tilde{\eta} \tau \iota \varsigma$ 'Epıvúৎ), aplicado a um monstro que no mesmo poema já possuía aqueles

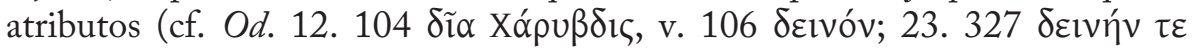

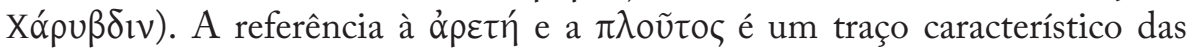
odes de vitória ${ }^{16}$, mas os editores incluem este fragmento nos 'trenos', o que é

${ }^{13}$ Como referimos na segunda parte (pp. 161-162), os vv. 1-2 do presente fragmento são de novo citados por Estobeu em 4. 41.62 com um comentário de Favorino, que os relaciona com a tragédia dos Escópadas, embora não especifique o subgénero do poema.

${ }^{14}$ Segundo Babut 1975: 24 n. 17, se a ideia de que ninguém entra no Hades com a sua fortuna estava já presente na poesia elegíaca (cf. Sol. fr. 24. 7-10 W = Thgn. 725-728), ao acrescentar

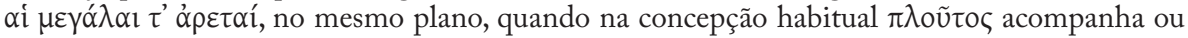
é uma consequência da arete (Od.19. 109-114; Hes. Op. 225-237, 289-292), Simónides sugere o carácter efémero dos valores mais altos da moral tradicional. Note-se que não é unânime a

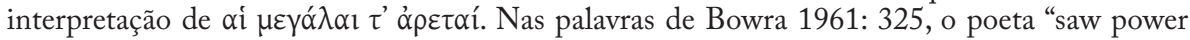
and wealth suddenly brought to an end...”. Já West 1993a: 162 traduziu o verso por 'all great distinction and wealth'. É possível que a intenção do poeta seja realmente ambígua, englobando

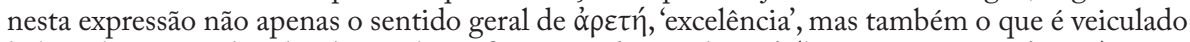
habitualmente pelo plural, i.e., 'manifestações da excelência' ('forms of excellence', LSJ), mais concretamente, 'actos de valor', 'feitos gloriosos' (cf. Hdt. 1. 176. 1, 9. 40). Sobre a concepção de

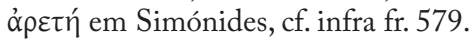

${ }^{15}$ Sobre o metro, vide Gerber 1970: 314.

${ }^{16}$ Píndaro exprime um pensamento semelhante em Nem.7.17-20. 
geralmente aceite, tendo em conta a semelhança de pensamento com os frr. 520 e 521 (cf. Gerber 1970: 314).

A ideia de que a morte é inevitável encontra expressão lapidar no fr. $\mathbf{5 2 4}$ [19 P, 65 B, 12 D], transmitido também por Estobeu (4. 51. 7) e constituído

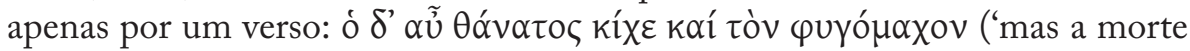
apanha até mesmo o desertor'). $\mathrm{O}$ tom sentencioso do verso é ditado pelo

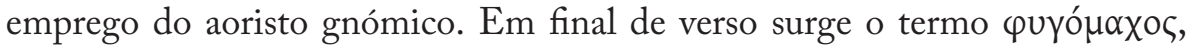
apenas atestado em Simónides.

Fr. 523 [18 P, 36 B, 7 D] Stob. 4. 34. 14

$\Sigma \iota \mu \omega v i ́ \delta \circ v \Theta \rho \eta ́ v \omega v$.

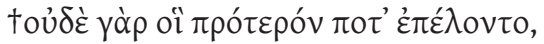

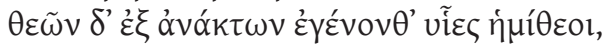

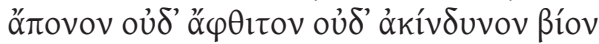

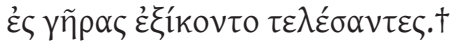

Dos Trenos de Simónides:

†Pois nem mesmo os que outrora viviam, de deuses soberanos gerados, filhos semideuses, à velhice chegaram sem cumprirem uma vida de penas, sem mortes, sem riscos. $\dagger$

O texto deste fragmento, citado por Estobeu como tendo pertencido aos 'Trenos de Simónides', suscita dúvidas aos editores. Do ponto de vista formal e temático, no entanto, são evidentes as semelhanças com os outros fragmentos já comentados, com a diferença de que o poeta não está a falar da raça humana, mas dos semideuses ( $\left.\dot{\eta}^{\prime} \hat{\theta}^{\theta} \theta \varepsilon \mathrm{l}\right)^{17}$, provavelmente evocados como exemplo mitológico, a título de comparação com a situação dos homens ${ }^{18}$. Assim se explica a presença de үó́ $\rho$, que nos fragmentos anteriores inicia a sentença final do poeta. Retoma-se, por conseguinte, a ideia-chave do fr. 520 de que a vida é um percurso pleno de sofrimento e de perigos, mas que tem

${ }^{17}$ Cf. Il. 12. 23. A designação de $\mathfrak{\eta} \mu$ í $\varepsilon$ col é dada por Hesíodo aos heróis da quarta idade (Op. 159-160), que haviam combatido em Tebas e em Tróia. Ao contrário de Simónides, que sublinha a amargura da sua existência, o poeta da Beócia centra-se na sua morte (vv. 161, 166) e no destino bem-aventurado que distinguiu alguns deles (vv. 167-168, 170-173). Nota, porém, Barrigón 2000: 2-4 que é evidente a sua influência, pois Simónides emprega o mesmo epíteto quando se refere à limitação da vida dos heróis (cf. fr. eleg. 11. 18). Vide West 1978: 191, que regista as ocorrências mais importantes do termo, e infra p. 301 n. 92.

${ }^{18}$ Cf. L. Rossi, "Lamentazioni su pietra e letteratura 'trenodica': motivi topici dei canti funerari”, ZPE 126 (1999) 29-42, esp. 41, que distingue a intenção de consolar como uma das funções do exemplo mitológico deste fragmento, leitura plausível, mas que não podemos confirmar. 
de ser cumprido. Mais uma vez, acumulam-se as formas de negação (oủ $\delta$,

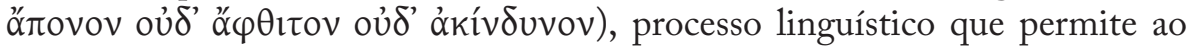
poeta acentuar os aspectos mais sombrios da sua concepção ${ }^{19}$.

Fr. 526 [21 P, 61 B, 10 D] Theophilus Antiochenus ad Autolycum 2. 8

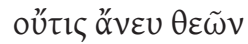

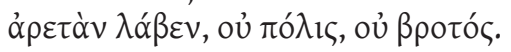

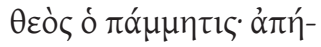

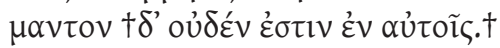

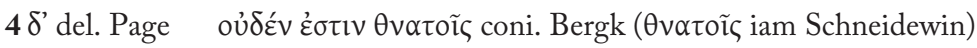

Nunca ninguém sem os deuses alcançou a excelência, nem uma cidade nem um mortal. Um deus é omnisciente; sem dor †nada está ao alcance dos mortais. $\dagger$

Neste fragmento transmitido por um autor cristão do séc. II d.C., o tema das limitações da vida humana surge articulado com o da supremacia dos deuses, concebidos como entidades benfeitoras. $\mathrm{O}$ tom, não sendo de pessimismo, é de resignação. De acordo com a emenda proposta por Bergk, que seguimos na nossa tradução, o homem não tem a capacidade de concretizar os seus objectivos sem auxílio divino. É, de novo, o reconhecimento da fragilidade humana patente nos vv. 1-3 do fr. 520. Formalmente, a expressão

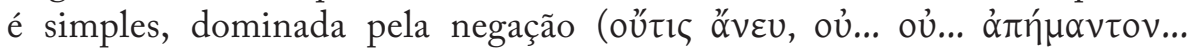
oủঠév), pelo assíndeto, pela frase nominal e ausência de artigos. $\mathrm{O}$ aoristo gnómico $(\lambda \alpha ́ \beta \varepsilon v)$ acentua o tom sentencioso. Os termos principais ocupam lugares de destaque, em fim ( $\theta \varepsilon \tilde{\omega} v, \beta \rho o \tau o ́ \varsigma, ~ \theta v \alpha \tau o i ̃ \varsigma)$ e início de verso ( $\theta \varepsilon o ̀ \varsigma$

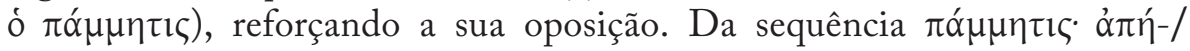
$\mu \alpha v \tau o v$ resulta um jogo fónico, que não é raro nos fragmentos de Simónides. A escolha dos dois adjectivos ilustra uma forma de compor que concilia a linguagem da tradição épica com a renovação contínua, através da criação de novas palavras, numa busca constante pela precisão da escrita poética.

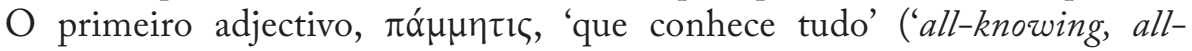
planning', LSJ), tem aqui a sua única ocorrência e na base da sua formação a palavra $\mu \tilde{\eta} \tau \iota \varsigma$. Portanto, na concepção de Simónides, a essência divina, que

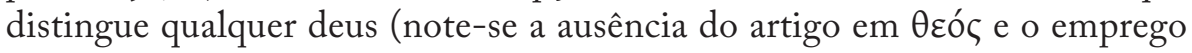

${ }^{19}$ Robbins 1997: 248 distingue a forte tendência do poeta para se expressar por meio de afirmações de sentido negativo como um dos traços estilísticos mais notáveis destes fragmentos. Para uma análise bastante pessoal deste tópico, vide Anne Carson, "Simonides Negative", Arethusa 21.2 (1988) 147-157, esp. 151 (comentário ao fr. 521). 
no singular), reside na sua sabedoria universal, enquanto a raça humana está condenada à dependência total e à ignorância (cf. Balasch 1967: 52). O segundo adjectivo, ả $\pi \eta ́ \mu \alpha \nu \tau o$, 'incólume', 'são', 'ileso', provém da tradição épica e aplica-se ao que escapa à desventura ou desgraça $(\pi \tilde{\eta} \mu \alpha)^{20}$. Todavia, este sentido positivo é anulado pela presença de oủdév, acentuando o tom fatalista do fragmento.

Esta ideia tradicional da subserviência da raça humana em relação aos deuses ocorre também na segunda citação do mesmo autor.

Fr. 527 [22 P, 62 B, 11 D] Theophilus Antiochenus ad Autolycum 2. 37

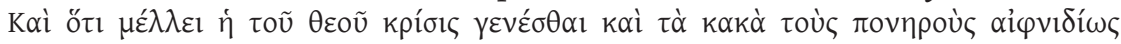

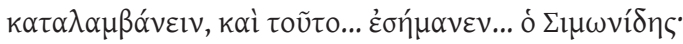

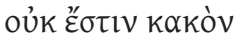

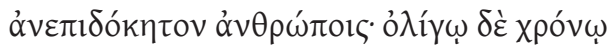
$\pi \alpha^{\prime} \tau \tau \alpha \mu \varepsilon \tau \alpha \rho \rho i ́ \pi \tau \varepsilon \imath \theta \varepsilon o ́ \varsigma$.

E que certamente o julgamento de Deus há-de chegar e os males se hão-de apoderar de súbito dos miseráveis, isto também (...) demonstrou (...) Simónides:

não existe um mal

inesperado para os homens; em breve tempo tudo deita a perder um deus.

Este fragmento demonstra bem que a recepção de um autor clássico é claramente influenciada pelos valores predominantes na época que o acolhe, pois no caso presente as palavras de Simónides não significam exactamente o que Teófilo de Antioquia pretendia comprovar. Em primeiro lugar, na sua relação com a divindade, a raça humana é concebida como um todo ( $\alpha v \theta \rho \omega ́ \pi$ orc), não se estabelecendo qualquer distinção de natureza ética entre 'homens bons' e 'maus' (cf. fr. 520). Formalmente, 'homens' e 'divindade' ocupam no fragmento posições simétricas e antitéticas, em fim de oração.

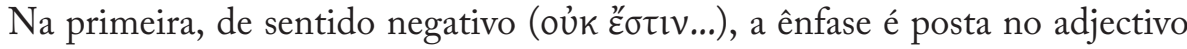

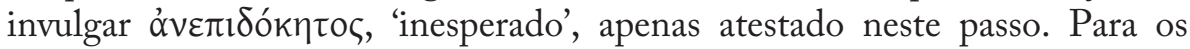
homens (não apenas para os 'miseráveis'), um mal nunca surpreende, porque é

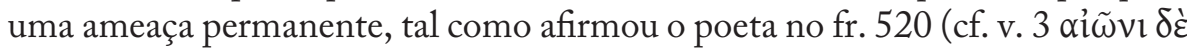

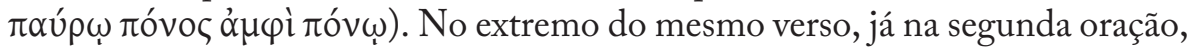
o tema da mudança repentina da fortuna (cf. fr. 521), é articulado com o do poder (negativo) da divindade. O tempo nunca é favorável aos homens. O verbo $\mu \varepsilon \tau \alpha \rho p i ́ \pi \tau \omega$, 'revoltar' ('turn upside down', $L S J)$ ), com um complemento tão

${ }^{20}$ Segundo LSJ, Suppl., 'free from harm' (Od. 19. 282), 'free from sorrow or misery' (Hes. Th. 955, Pind. Ol. 8. 87). Este último sentido é o mais adequado ao fragmento de Simónides, que inclui também a noção de 'esforço, risco pessoal'. 


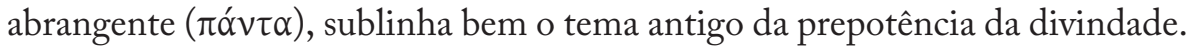
Recorde-se que a ideia de que os bens e os males da vida dos homens são fruto da vontade dos deuses surge nas palavras que Aquiles dirige a Príamo, quando o recebe na sua tenda, no último canto da Ilíada (24. 525-533).

Fr. 541 [36 P] P. Oxy. 2432

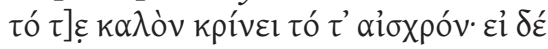

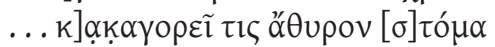

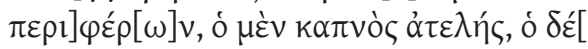

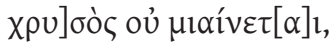

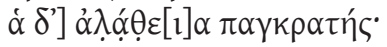

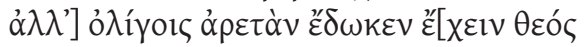

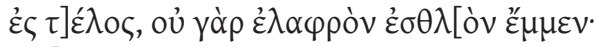

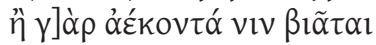

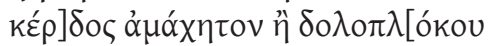

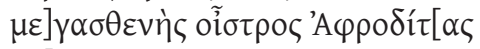

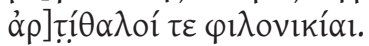

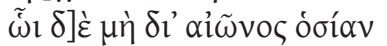

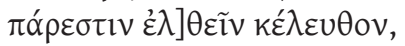

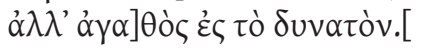

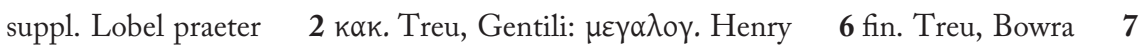

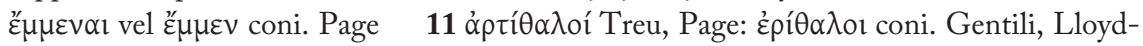

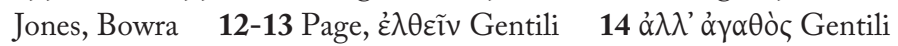

... o belo e o torpe distingue. E se

alguém profere calúnias, uma boca sem freios

exibindo, o fumo é vão, mas o...

ouro não se mancha,

e a verdade é omnipotente.

[Mas] a poucos concede [um deus que possuam] a excelência

até ao fim, pois não é leve [ser] nobre:

ou, contra a sua vontade, o impele

a sede de lucro incombatível ou o poderoso

moscardo da maliciosa Afrodite

ou as vigorosas rivalidades.

Mas aquele a quem ao longo da vida não é

dado seguir o caminho da rectidão,

[será uma boa pessoa] o mais possível.

O P. Oxy. 2432 contém um único fragmento de vinte e um versos, dos quais citamos apenas os catorze primeiros, dado o estado precário em que se encontram os restantes. Quando em 1959 E. Lobel sugeriu a atribuição a Simónides, notando "the strong similarity of the sentiments" dos vv. 6 sqq. com 
os do poema composto para Escopas, que comentaremos a seguir, reconheceu igualmente a fragilidade de tal argumento ${ }^{21}$. Poucos anos após a publicação do papiro, Lloyd-Jones e Bowra defenderam a autoria de Baquílides ${ }^{22}$, mas a maioria dos comentadores aceita a sugestão do editor e Page 1962: 281 nem sequer a questionou (cf. Henry 1998).

A antítese com que se inicia este fragmento leva-nos até ao mundo dos valores aristocráticos da Época Arcaica. O sujeito de kpível é habitualmente identificado com o homem 'aceitável' de que se falará nos versos seguintes, que tem a capacidade de distinguir as boas acções das torpes ${ }^{23}$. Cremos que a dificuldade em se ser uma boa pessoa durante toda a vida é o tema principal do fragmento e os primeiros cinco versos, na interpretação de Lobel 1959: 93, habitualmente seguida, parecem afirmar que se um homem bom é difamado, a sua reputação não é afectada, uma ideia também expressa por Baquílides (cf. 13. 199-209). As duas propostas de reconstituição do início do v. 2 -

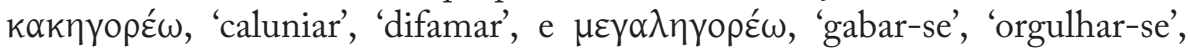
'ufanar-se' - vão ao encontro desta interpretação, embora nenhuma esteja atestada na poesia lírica arcaica ${ }^{24}$. A metáfora ớ $\theta$ pov $[\sigma] \tau o ́ \mu \alpha$, à letra, 'uma boca que é uma porta aberta', 'uma boca escancarada', sugere com grande clareza que o sentido do verbo não está muito longe de 'proclamar falsidades', 'maldizer' (cf. Thgn. 421-422). Segue-se uma gradação que vai até ao v. 5, por

21 "But I am uncertain what weight to attach to this. Poets do not repeat only themselves, and generalities of the same kind as are contained in 11.6 seqq., and also in 11.1 seqq., may be expected to appear in any of the composers of choral lyric." (Lobel 1959: 91).

${ }_{22} \mathrm{O}$ argumento de Lloyd-Jones 1961: 19 é, sobretudo, de ordem estilística: "The poem is written in lyric iambics of a sort not found in what we have of Pindar and Bacchylides; and that fact may be held to make against their authorship. But my subjective feeling, for what it is worth, would be against Simonides and in favour of Bacchylides; the verse seems to me rather too easy, neat, and superficial for the older poet." C. M. Bowra, "Simonides or Bacchylides?", Hermes 91 (1963) 257-267, da análise do metro, dos temas, do estilo e da linguagem concluiu que, não obstante as semelhanças temáticas dos frr. 541 e 542 , encontrou mais pontos coincidentes com a obra de Baquílides. Cf. Gentili 1964: 302. Para uma análise comparativa dos frr. 541 e 542, vide Donlan 1969.

${ }^{23}$ Cf. Donlan 1969: 92, Campbell 1991: 433 n. 2. Contra esta leitura, Ezio Pellizer, “«... E il bello e il turpe distingue». Simonide, fr. 36 P.M.G. 541", QUCC 28 (1978) 87-91, retoma uma proposta de Pfeiffer 1968: 33 n. 1 e defende que o sujeito de kpível é ó kaıpó ('a oportunidade',

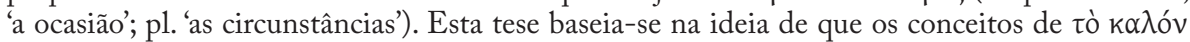

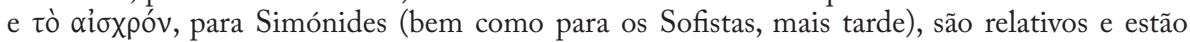
sujeitos às circunstâncias da vida, o que está de acordo com o sentido geral do fr. 541 (cf. fr. 542 . 14-18, 27-29, 40). Carson 1992a: 117 propõe como sujeito de kpível 'the poet'.

${ }^{24}$ A primeira forma está atestada em Platão ( $\left.S m p .173 \mathrm{~d}, R .395 \mathrm{e}\right)$ e a segunda em Xenofonte (An. 6. 3. 18). Na interpretação de Henry 1998: 303-304, que propôs $\mu \varepsilon \gamma \alpha \lambda \eta \gamma o \rho \varepsilon \tilde{\text {, }}$ "The braggart's chatter is ineffective, and the man of genuine worth retains his pre-eminence (3f.), for truth is all-powerful (5)", considerando-a próxima do pensamento expresso nos vv. 86-89 da II ${ }^{a}$ Olímpica de Píndaro (cit. supra, p. 168). Lobel 1959: 93 notou a semelhança de sentido dos vv. 3-4 com os vv. 24-25 da I ${ }^{a}$ Nemeia. 


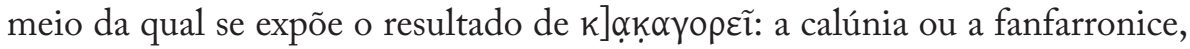
tal como o fumo, é desagradável, mas dissipa-se (à letra, 'é fumo sem fogo'), como tudo o que é insignificante ou falso ${ }^{25}$; o ouro, pelo contrário, é o símbolo da pureza que não se altera ${ }^{26}$, como se espera que seja o carácter de um homem bom, e a verdade é um valor ainda mais elevado, absoluto e inabalável ${ }^{27}$, que supera a difamação.

Como dissemos acima, a ideia de que a verdade é omnipotente aproximase do pensamento de Baquílides, mas não do que diz Simónides no fr. 598,

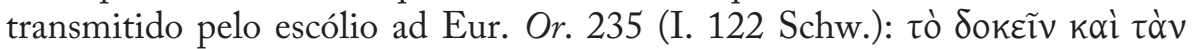

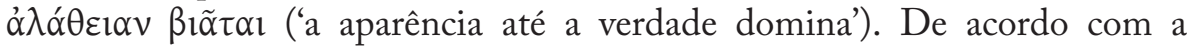
reconstituição do editor, que os investigadores aceitam por unanimidade,

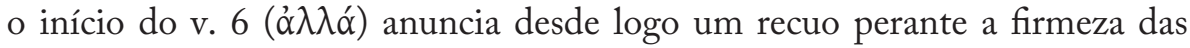
afirmações anteriores. O sentido é claro e revela semelhanças temáticas com o fr. 542: a excelência a poucos é concedida ad aeternum ( não é tarefa leve ser boa pessoa em todos os momentos da vida (vv. 6-7). A dificuldade textual reside no sujeito de $\tilde{\varepsilon} \delta \omega \kappa \varepsilon v$. A sugestão de Max Treu e de Bowra ( $\theta \varepsilon o ́ \varsigma)$, aceite por Campbell e seguida em geral, fora rejeitada por Lobel

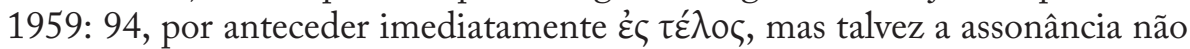
seja assim tão estranha ao verso de Simónides. Por outro lado, esta proposta estabelece uma ideia muito próxima da que é expressa nos vv. 1-2 do fr. 526.

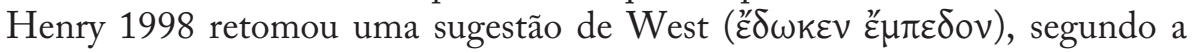
qual o sujeito só pode ser ó ả $\lambda \alpha{ }^{\theta} \theta \varepsilon 1 \alpha$ do v. $5^{28}$. Esta reconstituição desvaloriza o papel dos deuses no pensamento de Simónides e é de certo modo tautológica, o que vai contra o estilo conciso e incisivo do poeta: 'Mas [a verdade] a poucos concede uma excelência constante ( $\left.\varepsilon^{\prime} \mu \pi \varepsilon \delta o v\right)$ até ao fim'. Não é unânime o

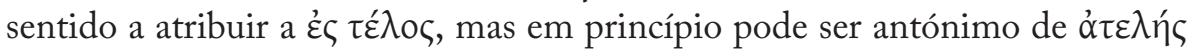
(v. 3). Por conseguinte, a arete que alguns homens alcançam com a ajuda dos deuses é, na sua essência, consistente e não se dissipa, ao contrário do fumo. Portanto, é a manutenção deste estado de graça - o ser continuamente bom - que se revela tarefa difícil. A sentença que encerra o v. 7, se o suplemento

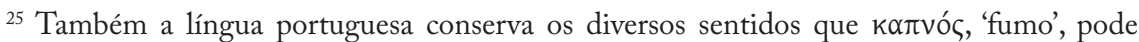
assumir neste fragmento: no singular 'coisa vã', e no plural 'pretensão', 'presunção', 'vaidade'.

${ }^{26} \mathrm{O}$ ouro como imagem de um valor verdadeiro e perene é uma noção comum na lírica mais tardia (e.g. Simon. fr. 511, frr. eleg. 16. 2, 21. 4; Pind. fr. 222 Ma.; Bacch. 3. 87). Para uma análise das imagens dos vv. 1-5 e 9-13, vide Henderson 1999: 97-98.

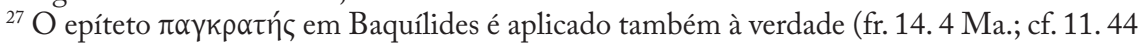
Hera, 17. 24 a Moira). Em Píndaro qualifica o fogo e o trovão $($ Nem. 4. 62; Dith. 2.15 = fr. $70 \mathrm{~b}$ Ma.), e nas Suplicantes de Ésquilo distingue Zeus (v. 815).

${ }^{28}$ Note-se que a tradução de West 1993a: 143 ('But God / grants few men such distinction as endures / throughout'), não segue o suplemento proposto por si em ZPE 37 (1980) 143. A

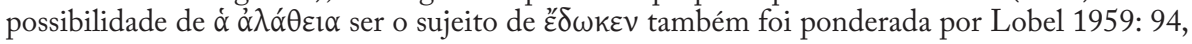
mas não aceite. 
$\varepsilon^{\prime} \mu \mu \varepsilon v \alpha l$ (ou $\left.\varepsilon \mu \mu \varepsilon v\right)$ estiver correcto, levanta aparentemente uma dificuldade, pois corresponde à afirmação do tirano Pítaco contestada por Simónides no fr. $542.13^{29}$. A incoerência formal sobrepõe-se o sentido particular que cada uma das sentenças adquire no contexto poético em que se inserem. De facto, não obstante as semelhanças, no fr. 541 o poeta discute a dificuldade em preservar-se a arete ao longo da vida, enquanto no fr. 542 o que está em causa é a definição de uma concepção particular e concreta de humanidade. Obviamente, trata-se de uma interpretação hipotética, dado o estado deteriorado do fr. 541 a partir do v. 14.

Nos vv. 8-11 alinham-se os perigos principais que atentam contra a firmeza de carácter do homem nobre: a avareza ${ }^{30}$, a paixão amorosa e a

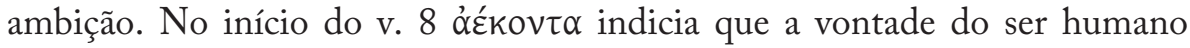
pode ser um baluarte da sua arete (cf. fr. 542. 28). A única forma verbal deste passo é a que ocorre no fr. 598 com o mesmo sentido de 'forçar', 'fazer mal', mas o que se destaca nestes versos é a profusão de epítetos e a acumulação de imagens. Do ponto de vista formal, destaque-se o trikolon, a sucessão de três expressões (formadas por nome e atributo) para enfatizar uma ideia, tal como acontece nos vv. 3-5, um processo literário que encontramos também em Anacreonte (cf. frr. 357. 1-3, 358. 1-3 $P M G$ ). Como já dissemos, na opinião de alguns comentadores a acumulação de formas ou expressões de sentido negativo é um traço marcante do estilo de Simónides, em particular nos

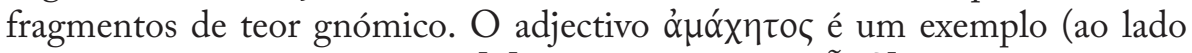

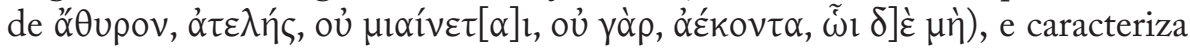

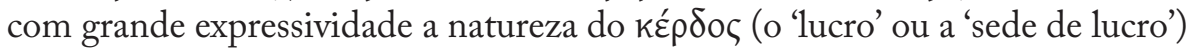
como algo que vicia e se transforma numa luta diária. Os vv. 9-10 contêm uma referência mitológica, o que é algo de novo em relação aos fragmentos gnómicos analisados nas páginas anteriores e ao fr. 542. Por certo mais

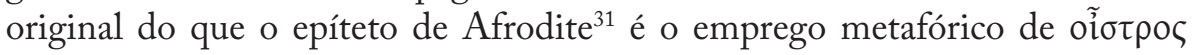
('moscardo', no sentido mais frequente) para evocar um desejo muito forte ou uma paixão insana, que é único na poesia grega arcaica e só encontra paralelo

${ }^{29}$ Opinião de Lobel 1959: 94. Gentili 1961: 339, porém, considera que a sentença do v. 7 do fr. 541 evoca, do ponto de vista métrico e conceptual, o v. 1 do fr. 542. Para Campbell 1982: 387, o v. 7 sugere que o fr. 541 deve ser anterior ao fr. 542, no qual Simónides procede à redefinição da sua terminologia.

${ }^{30}$ Também Baquílides considerou que a sede de lucro era prejudicial ao carácter do ser humano (cf. fr. 1 Ma.). Para uma outra leitura do v. 9, que adopta o suplemento $\kappa \tilde{\alpha} \delta$ o, , proposto

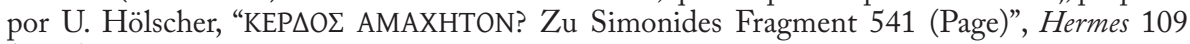
(1981) 410-415, vide Poltera 1997: 445.

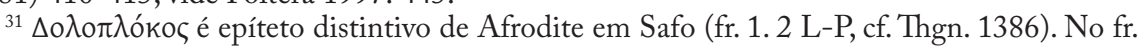

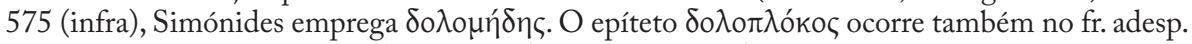
$949 P M G$, transmitido por Aristóteles (EN 1149b15-16), que os comentadores modernos atribuem a um poeta lírico desconhecido. Esta questão é analisada por H. Johnstone, "A Fragment of Simonides?”, CQ 47 (1997) 293-295. 
em Heródoto (2. 93. 1) e Eurípides (Hipp. 1300). Mas esse sentido é ainda reforçado por $\mu \varepsilon \gamma \alpha \sigma \theta \varepsilon v \eta ́ \varsigma$, 'poderoso'. No v. 11, a nota negativa é acrescentada

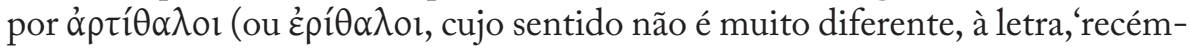
floridos', portanto, 'renovados', 'vigorosos') ${ }^{32}$, pois $\varphi \imath \lambda$ ovıkía significa apenas 'amor à vitória', 'rivalidade', 'competição'. Mas ảptí $\alpha \lambda$ ol $\varphi \imath \lambda o v i k i ́ \alpha ı$ designa as rivalidades que não são saudáveis, a luta desenfreada pelo poder. Portanto, o que impede um homem de manter a excelência é o excesso, a desmesura (cf. fr. 542. 34).

A partir do v. 12, na opinião de Lobel 1959: 94, o poeta quis dizer que se alguém não consegue seguir um rumo certo de justiça e de piedade ao longo da sua existência, mas se for boa pessoa até ao limite das suas possibilidades, pode

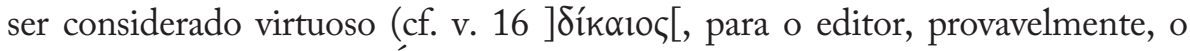
predicado da apódose $)^{33}$. É esta concessão que parece distinguir o pensamento de Simónides e que também surge expressa no fr. 542: aos conceitos tradicionais e aristocráticos de kalos e agathos, absolutamente opostos a aischros e kakos, o poeta propõe um conceito mais relativo de agathos, que traduz uma concepção do homem mais realista (e "humanística", como notou Gentili 1961: 340), de alguém que, vivendo em comunidade, é também por ela condicionado, por mais piedoso e justo que seja o seu carácter. Daí a chamada de atenção para

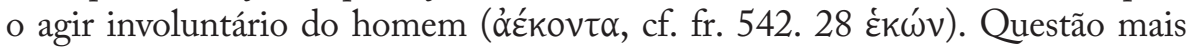
complexa é apurar se as reflexões de Simónides são marcadas, de facto, pelo signo da originalidade e assentam no sistema de valores em que acreditava, ou são sobretudo motivadas por factores externos, como o peso da tradição poética e, especificamente, as convenções do género do poema a que terá pertencido este fragmento. Retomaremos esta problemática na análise da próxima composição.

Fr. 542 [37 P, 5 B, 4 D] Pl. Prt. 339a-346d

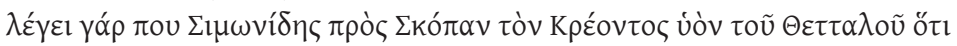

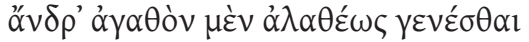

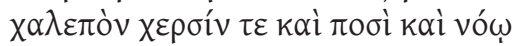

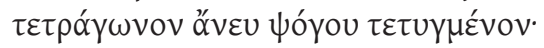

desunt vii versus

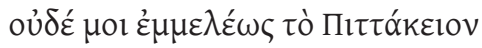

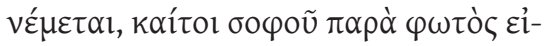

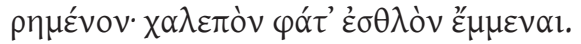

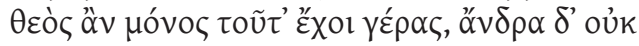

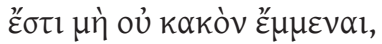

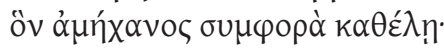

${ }^{32}$ Para uma discussão dos dois suplementos, vide Poltera 1997: 419-420.

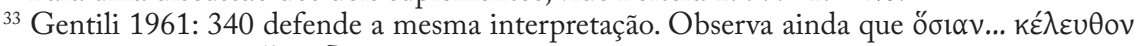
corresponde à expressão ő 


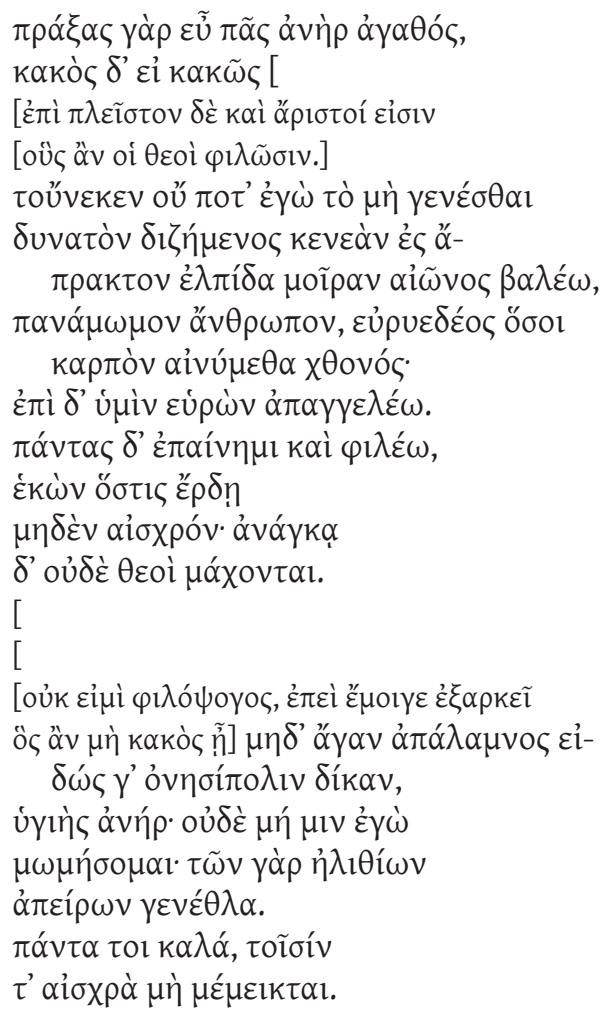

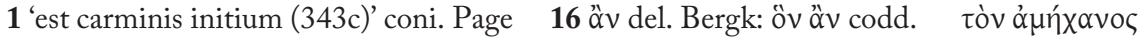

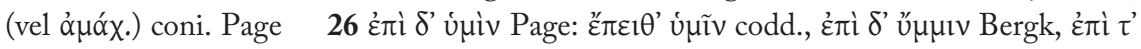

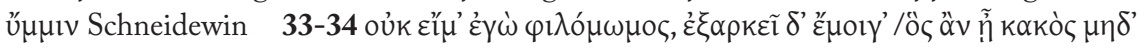

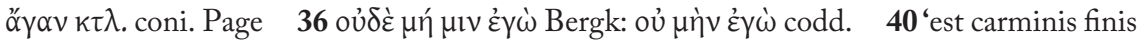
(343c, cf. 334b, 345d)' coni. Page

Pois Simónides diz algures a Escopas, filho do tessálio Creonte, que

Um homem tornar-se verdadeiramente bom

é difícil, de mãos e pés e espírito perfeito, sem falhas criado.

[lacuna de 7 versos]

Nem me soa harmoniosa a sentença

de Pítaco, embora dita por um homem sábio. Disse que é difícil ser bom.

Um deus somente poderia ter esta honra, mas não pode deixar de ser vil o homem que uma implacável desventura derrube.

Pois, se tiver boa sorte, todo o homem é bom, mas será mau se ela for má [

[e são por mais tempo melhores 
[aqueles que os deuses amarem.]

Por isso, eu jamais, por uma vã e ilusória

esperança, deitarei fora o lote de vida que me coube em sorte,

em busca do que não é possível encontrar,

um homem irrepreensível, entre todos quantos

colhemos o fruto da vasta terra.

Quando o encontrar, contar-vos-ei.

Mas louvo e estimo todo

aquele que, de bom grado, não faz

nada de vergonhoso: contra a necessidade

nem sequer os deuses lutam.

[

[

[não gosto de apontar defeitos, pois a mim basta-me

quem não seja mau] nem demasiado débil, que conhe-

ça a justiça útil à cidade,

um homem íntegro. Esse não hei-de

censurar, pois é infinita

a geração dos tolos.

Belas são todas as coisas

que não têm mistura de vergonha.

Dadas as circunstâncias em que o presente fragmento nos foi transmitido, os muitos comentários que tem suscitado dividem-se, de um modo geral, em duas grandes categorias: os que visam em especial esclarecer as questões de carácter filosófico que emergem do diálogo platónico ${ }^{34}$, e os que se detêm na análise do poema lírico e relegam para segundo plano o contexto da sua transmissão, embora não o ignorem completamente. É neste segundo grupo que se inscreve a nossa leitura. Como defendem alguns helenistas, julgamos que um comentário demasiado atento à apreciação crítica que Protágoras e Sócrates fazem do poema de Simónides pode, de algum modo, comprometer a sua interpretação, uma vez que aquelas personagens chegam a contradizerse e, ao que parece, a deturpar o seu sentido ${ }^{35}$. Apesar destas reservas e das

${ }^{34}$ Como notou Gerber 1994: 140, boa parte destas análises interessa mais aos estudiosos de Platão que aos de Simónides. Vide nas pp. 139-144 a bibliografia mais importante sobre o fr. 542 produzida até à edição do vol. 36 de Lustrum. Gentili 1964: 278-280 examina o estabelecimento do texto e o contexto da sua transmissão.

${ }^{35}$ Cf. Gerber 1970: 320. A apreciação do exame a que as duas personagens submetem o poema de Simónides tem variado consideravelmente na história da filologia e parece ser proporcional ao valor que tem sido atribuído ao diálogo de Platão. Para uma defesa minuciosa do valor da exegese platónica, vide Giuliano 1991, cujo objectivo é provar a validade desta discussão para a história da crítica literária na Antiguidade. Na opinião de Most 1994: 131, a interpretação socrática é séria e deve ser considerada paradigmática. Assim não pensa Hutchinson 2001: 291 (“The Platonic passage greatly distorts the poem”). Cf. Woodbury 1953: 135-150, Babut 
lacunas que contém ${ }^{36}$, o que podemos depreender do fragmento leva-nos a supor que o poeta pretendia exprimir a sua concepção do homem que merece ser louvado. Cremos que é este o tema principal da composição.

Como já observámos em relação a outros fragmentos, também este se inicia ${ }^{37}$ com duas palavras que, desde logo, estabelecem o assunto que será desenvolvido ao longo do poema. Partilhamos da opinião de que o aoristo infinitivo $\gamma \varepsilon v \varepsilon ́ \sigma \theta \alpha l$ não é no v. 1 sinónimo de عĩv $\alpha$ l, antes significando 'tornar-se', 'fazer-se', ou seja, o poeta não está a considerar o ser agathos como uma qualidade inata, mas como algo que se adquire ou se constrói ${ }^{38}$. Esta opinião é corroborada pelo sentido original do particípio perfeito

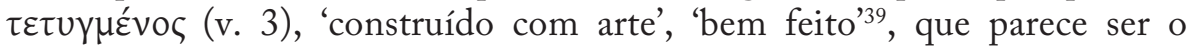
mais adequado a este contexto. $\mathrm{O}$ advérbio $\alpha \lambda \alpha \theta \dot{\varepsilon} \omega \varsigma$ recorda a referência à $\dot{\alpha} \lambda \eta ́ \theta \varepsilon 1 \alpha$ omnipotente do fr. 541. 5, que para o sujeito poético se sobrepõe ao que é fútil e vão. Decerto o poeta quer dizer que só em aparência é fácil

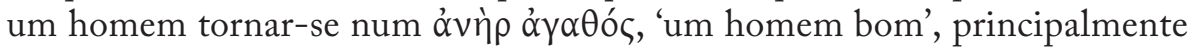
se os critérios que o definem forem tão exigentes. Na verdade, o singular adjectivo $\tau \varepsilon \tau \rho \alpha ́ \gamma \omega \nu$ o $\varsigma^{40}$, à letra, 'com quatro ângulos', 'quadrado', ao contrário do sentido que este termo adquiriu na língua portuguesa, designa metaforicamente um indivíduo perfeito, do ponto de vista físico e mental, como o v. 2 deixa bem claro. É possível, mas não é explícito, que o poeta tenha em vista a concepção homérica e aristocrática de aner agathos (e.g. Il. 15. 641-643, Od. 20. 365-366). Ainda menos provável nos parece a ideia de que estes versos sejam já uma antecipação da sentença de Pítaco citada mais adiante (cf. Bowra 1961: 326-327). Do ponto de vista formal, os versos iniciais evidenciam uma atenção dedicada à selecção e disposição precisa das palavras, daí decorrendo um grande efeito sonoro criado pelas aliterações em

1975: 30-50; R. Scodel, "Literary Interpretation in Plato's Protagoras", AncPhil 6 (1986) 25-37; A. Beresford, "Erasing Simonides", Apeiron 42.3 (2009) 167-200. Para um exame da questão, em especial do diálogo entre Protágoras e Sócrates, vide o comentário de Pinheiro 1999.

${ }^{36}$ De um modo geral, os estudiosos consideram que estas lacunas não são impedimento à compreensão do sentido do poema. De alguns passos apenas nos foi transmitida a sua paráfrase, indicada no texto entre parênteses. Cf. Campbell 1983: 239, Buongiovanni 1998: 1038, Hutchinson 2001: 296.

${ }^{37} \mathrm{O}$ início e o final do poema depreende-se do diálogo platónico (vide aparato).

${ }^{38}$ Wilamowitz 1913: 165 contestou esta distinção. Cf. Woodbury 1953: 155-157, Gentili 1964: 284-285, Gerber 1970: 321, Campbell 1982: 387.

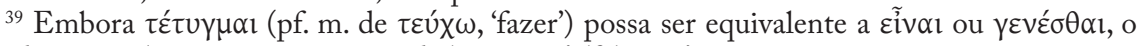
sentido original remete para a acção de 'construir', 'fabricar'.

${ }^{40}$ A possibilidade de o poeta ter ido buscar este adjectivo à linguagem dos Pitagóricos é aceite por Bowra 1961: 327-328 (que propõe outra leitura), Gerber 1970: 320-321, Campbell 1982: 386 (1983: 238-239), Poltera 1997: 388. Hutchinson 2001: 295 defende que não é necessário estabelecer esta relação. R. W. Johnston e D. Mulroy, "Simonides' Use of the Term

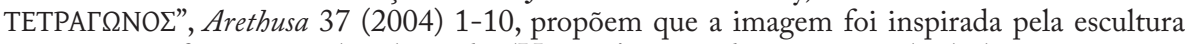
arcaica, especificamente pelos chamados 'Hermes', que se distinguiam pelas linhas rectas. 
dental no v. 1, em gutural no v. 2, conseguida através do polissíndeto, e em dental e gutural no v. 3 .

A maior parte dos estudiosos pensa que nos vv. 4-10 o poeta se referia directamente ao seu patrono e, portanto, de certo modo, se afastava do tema central do poema. Sabemos que Protágoras se dispensa de o citar na íntegra, porque o seu interlocutor também o conhece muito bem (cf. 339b-c) ${ }^{41}$, mas é notório que tem o cuidado de referir em particular os passos que, na sua opinião, confirmam que Simónides não foi coerente nas suas reflexões (cf. 339e sqq.). Não deixa de ser possível, portanto, que o conteúdo perdido destes versos estivesse relacionado com as afirmações proferidas no começo do poema ${ }^{42}$. Do mesmo modo, se o início do v. 11 com uma forma negativa não nos surpreende, uma vez que parece ser um traço característico dos fragmentos de teor gnómico

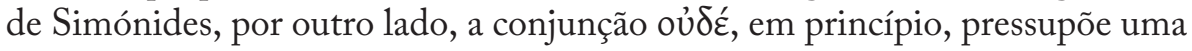
construção dependente de uma afirmação de sentido negativo contida no período anterior. Parece claro, portanto, que só temos acesso a uma parte do raciocínio do poeta. Podemos, todavia, seguir uma interpretação diferente, partindo do princípio de que oủ ź não diz respeito ao período imediatamente anterior, mas aos versos iniciais do poema, ou é um advérbio e introduz antes um novo ponto, como pensa Campbell 1982: 387. Julgamos, no entanto, que a

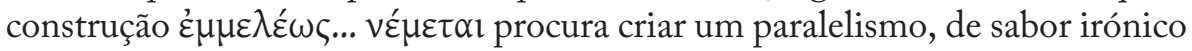

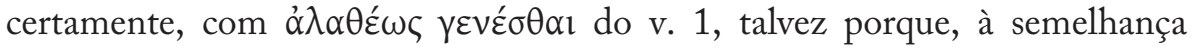
do que fez nos versos iniciais, o poeta vai agora também reflectir sobre uma opinião aceite pelos seus conterrâneos como uma verdade absoluta, mas que, aos seus ouvidos, simplesmente, não soava muito bem. O v. 11 evidencia, por conseguinte, um procedimento literário (ou ideológico) que parece ter sido caro a Simónides, a avaliar pelos fragmentos conservados (cf. frr. 579, 581, fr. eleg. 19): a refutação (ou reformulação) de afirmações proferidas por homens célebres do passado ${ }^{43}$, que haviam adquirido o estatuto de máximas.

Ao contrário do que defende Protágoras (cf. 339c-d), bem como alguns estudiosos modernos, não nos parece que haja contradição entre o conteúdo dos vv. 11-13 e as afirmações do início do poema. Simónides começa por questionar a ideia, consagrada pela tradição homérica e aristocrática, de que o aner agathos tem de ser um homem perfeito, não a pondo realmente em causa, mas apenas

${ }^{41}$ A fama do poema de Simónides é atestada igualmente pelas muitas citações que encontramos em autores tardios (cf. Page 1962: 283, Campbell 1991: 436, Hutchinson 2001: 46), mas que a ele tiveram acesso, provavelmente, por intermédio de Platão (Campbell 1982: 385).

${ }^{42}$ Cf. Campbell 1982: 386 ad 4-10. O mesmo especialista observa que $\mu$ ćv no v. 1 pode ter tido um $\delta \dot{~}$ nos vv. 4-10 e põe a hipótese de o poeta se ter referido nesses versos ao sucesso que Escopas havia alcançado na vida.

${ }^{43}$ Neste caso, trata-se de Pítaco de Mitilene, que a tradição considerava um dos Sete Sábios (cf. P1. Prt. 343a, Plu. de E apud Delphos 3. 385d). Cf. infra n. 77. 
observando a dificuldade da sua concretização. Ao evocar a sentença de Pítaco, o poeta não está a contradizer-se, mas a abordar a mesma questão - a natureza do homem de bem - segundo um ângulo diferente, dirigindo a sua atenção de uma formulação abstracta para uma afirmação concreta, proferida em determinado momento histórico e por uma pessoa célebre que havia existido de facto. Sublinhe-se que Simónides não contesta em absoluto a sentença do tirano de Mitilene, mas precisa, talvez intencionalmente, que foi expressa por

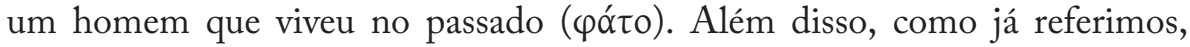

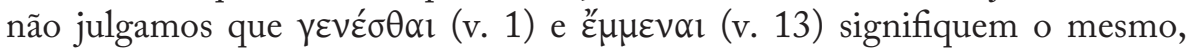
tendo em conta o sentido dos vv. 14 sqq. $\mathrm{Na}$ opinião do poeta, um homem pode tornar-se verdadeiramente ảy $\alpha \theta$ ó, embora reconheça ser difícil atingir os elevados padrões de excelência que a tradição homérica e aristocrática impunha (vv. 1-3). Mas a sentença de Pítaco também não era mais exacta, porque para um homem não é difícil ser bom ${ }^{44}$, é antes impossível: ser bom sempre é um privilégio a que só uma divindade pode aspirar (v. 14, cf. vv. 29-30). O ser humano, no entanto, não depende apenas das suas qualidades, mas de outras forças que lhe são superiores: das circunstâncias incontroláveis da vida (cf. vv. 14-18) e dos deuses (cf. vv. 19-20), ideias também expressas, respectivamente, nos frr. 541.8 sqq. e 526. 1-2. O teor dos vv. 14-18 é naturalmente pessimista e argumentativo, e o poeta sublinha os aspectos negativos, como se quisesse dizer que há mais probabilidade de um homem ser kakos do que agathos. As afirmações são curtas e incisivas, e a linguagem simples que encontramos nos fragmentos mais curtos cedeu o lugar à hipotaxe e à diversidade dos modos e

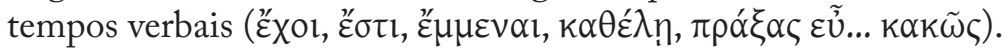

$\mathrm{Na}$ opinião de alguns estudiosos, a partir do v. 21 entra-se na segunda parte do poema (cf. Campbell 1982: 387), na qual Simónides caracteriza o homem que, em sua opinião, merece ser louvado (cf. v. 27). Julgamos que não

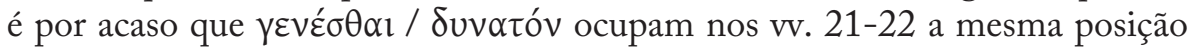
de $\gamma \varepsilon v \varepsilon ́ \sigma \theta \alpha l$ / $\chi \alpha \lambda \varepsilon \pi o_{v}$ nos vv. 1-2. Aparentemente, Simónides retoma a ideia com que iniciara o poema, mas agora para afirmar com mais convicção que é difícil encontrar 'um homem completamente isento de culpa' ( $\pi \alpha v \alpha$ ó $\mu \omega \mu \nu v$ ăv $\theta \rho \omega \pi \mathrm{ov})$. O tom marcadamente negativo do v. 21 e a adjectivação dupla

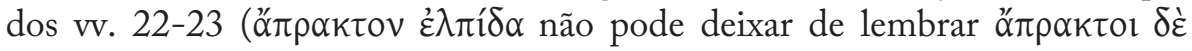
$\mu \varepsilon \lambda \eta \delta$ óveৎ do fr. 520. 1) acentuam o despropósito desta busca. Simónides

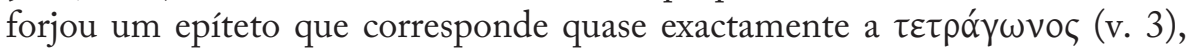

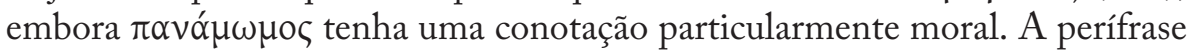

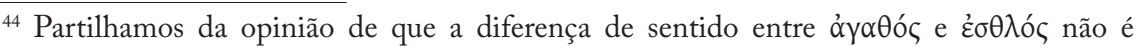
relevante no poema (cf. e.g. Parry 1965: 305-307, 315, Gerber 1970: 321, Most 1994: 137). Para uma leitura diversa, vide Woodbury 1953: 156, Donlan 1969: 81, na sequência de H. D. Verdam, "De Carmine Simonideo, quod interpretatur Plato in Protagora dialogo", Mnemosyne 56 (1928) 299-310, esp. 308. 
que ocupa os vv. 24-25, de nítido sabor homérico ${ }^{45}$, contrasta fortemente com o tom quase coloquial do v. 26, remate irónico do poeta ao assumir a promessa de revelar os frutos da sua investigação, caso ela se concretize.

A partir do v. 27, Simónides abandona a estratégia argumentativa e

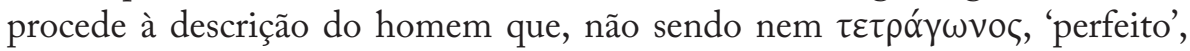
nem $\pi \alpha v \alpha$ $\mu \omega \mu$ os, 'irrepreensível', merece igualmente ser louvado. A linguagem é agora muito mais simples, desprovida de ornamentos, com privilégio da

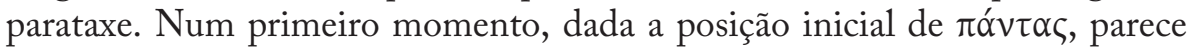
que todos os homens podem ser louvados e estimados pelo poeta. Mas esta ideia não se concretiza, porque na sua concepção somente aquele que não pratica voluntariamente aç̧ôes vergonhosas merece ser louvado (vv. 28-29) ${ }^{46}$. Trata-se de uma das ideias principais do fr. 541 (cf. v. 8), onde o poeta não menciona a óvó́ $\gamma \kappa \eta$, a 'necessidade', mas antes alguns exemplos concretos de constrangimento, que impedem o homem de atingir um estado de perfeição constante. O pensamento expresso nos vv. 29-30 é tradicional, mas está de acordo com o emprego do optativo ह̌xol no v. $14^{47}$.

Não temos possibilidade de saber se a paráfrase dos vv. 33-34 remonta às

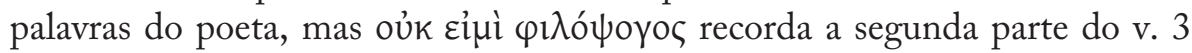

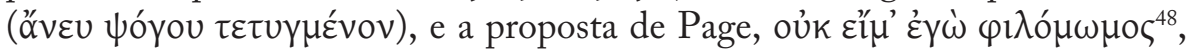

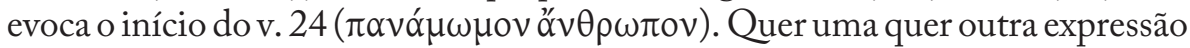
confirma que Simónides não põe verdadeiramente em causa o ideal homérico e aristocrático de aner agathos. Mas, se já o tinha feito antes (cf. v. 21 oü ro $\tau^{\prime}$ $\varepsilon \nmid \gamma(\omega)$, é na parte final do poema que proclama enfaticamente a sua liberdade de pensamento em relação aos freios dos valores tradicionais (cf. oủ $\delta \dot{\varepsilon} \mu \eta ́$ ulv

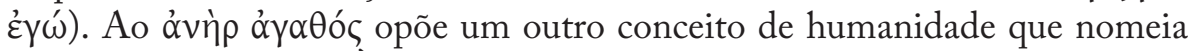
de úyiǹ åvńp (v. 36). À letra, 'um homem são', de corpo e mente ${ }^{49}$. Na única ocorrência homérica, o epíteto é aplicado a $\mu \tilde{U} \theta$ os numa fala de Heitor (Il. 8. 524), para caracterizar as palavras adequadas a um determinado momento (cf.

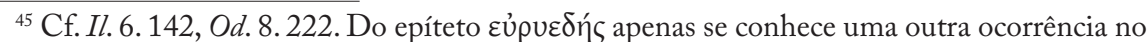
fr. 9 (b) do P. Oxy. 2624, atribuído a Simónides (= fr. 395 SLG, 519B Campbell).

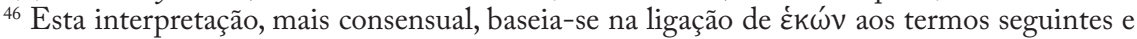
não aos precedentes. Diferente é a opinião de Sócrates, que Giuliano 1991: 146-147 defende como correcta. Neste ponto se apoia, em parte, a sua tese de que o tema do poema é o louvor forçado do tirano. Embora possível do ponto de vista gramatical, tal leitura não é corroborada pelo sentido global da composição nem pela comparação com o fr. 541 . O que está em causa não é 'il riferimento alla lode forzosa di un tiranno' (p. 181), mas o contrário: a liberdade do poeta em definir um conceito particular de humanidade numa obra para um nobre da Tessália.

${ }^{47}$ Merece destaque o comentário de Hutchinson 2001: 304 a este passo: "In 14 the gods had been used to show the impossibility of human perfection; here they are used, more encouragingly, to excuse human imperfection."

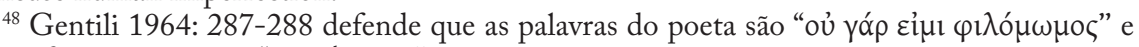
devem figurar a seguir a " $\mu \omega \mu \alpha \sigma_{\sigma o} \mu \alpha \imath$ ".

${ }^{49}$ Cf. Chantraine, s.v. úyı́n ('sain, en bonne santé, en bon état'); LSJ, s.v. úyılııóৎ, cf. Suppl. 


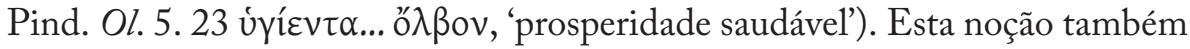

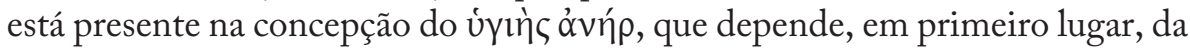

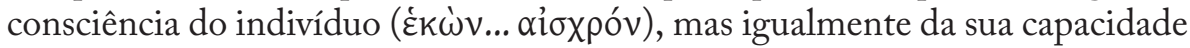
de adaptação às circunstâncias da vida (cf. vv. 14-18). Esta ideia é corroborada na parte final do poema, marcada por uma linguagem em que se evidenciam

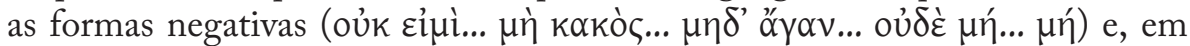
particular, tal como nos vv. 21-24, pelo emprego de epítetos. É possível, como pensam os comentadores modernos, que haja uma lacuna na paráfrase do início do v. 34 e se deva acrescentar vóov ('que não tenha pensamentos vis') 50 $^{50}$.

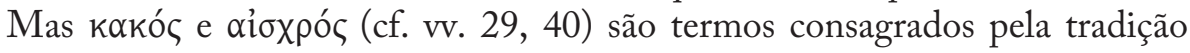

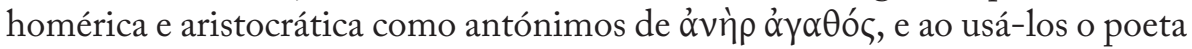
sugere que não está a renunciar completamente a estes valores ${ }^{51}$. Menos vulgar

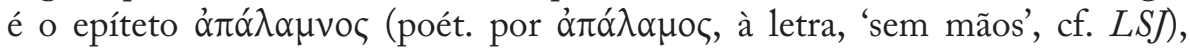
que ocorre uma única vez num símile da Ilíada (5. 597), para descrever um homem que enfrenta uma situação muito difícil. Designa, portanto, alguém 'desamparado', 'indeciso', 'impotente' ${ }^{52}$. O seu valor é, todavia, atenuado no poema de Simónides pela máxima $\mu \eta \delta$ ' ó $\gamma \alpha v$, 'nada em excesso', que estava gravada no templo de Apolo em Delfos (cf. Pl. Prt. 343b, Paus. 10. 24. 1) ) $^{53}$. O

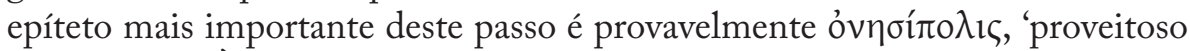

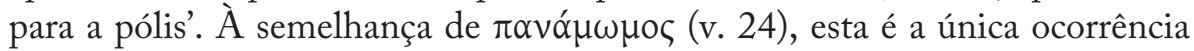
conhecida. Em resumo, embora não atinja os elevados padrões de excelência exigidos pelo código heróico e aristocrático da Época Arcaica, o conceito de úүı̀̀ $\alpha$ $v$ ń aqui descrito aplica-se sobretudo a alguém que, não sendo perfeito, actua em conformidade com as leis da sua pólis ${ }^{54}$. Não deixa de ser, portanto, uma figura distinta e, por isso, Simónides retoma na conclusão a ideia dos vv. 27-29, sublinhando que um homem assim não lhe merece censura.

O final do poema, marcado pelo tom sentencioso e pelas reminiscências homéricas ${ }^{55}$, confirma que a intenção de Simónides não era apresentar uma

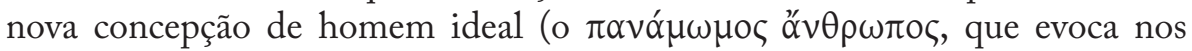
vv. 21-25) ou rejeitar completamente as ideias que no seu tempo vigoravam

${ }^{50}$ A inserção de vóov depois de ⿳亠丷 é uma proposta de Fränkel. Cf. Gentili 1964: 286-287, Campbell 1991: 437.

${ }^{51}$ Buongiovanni 1998: 1041-1042 nota, com razão, que o poeta emprega o termo kakó

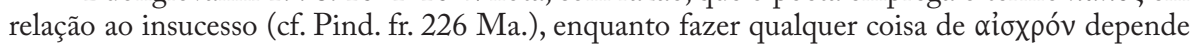
apenas da vontade da pessoa, independentemente do bom ou mau êxito.

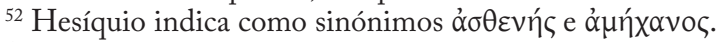

${ }^{53}$ Outras ocorrências em Thgn. 335, 401, Pind. fr. 35b Ma., Eur. Hipp. 265. Nem Platão nem Pausânias nomeiam o autor da máxima, que Crítias (schol. Eur. Hipp. 264) e Aristóteles (Rh. 1389b3-4) diziam ser de Quílon (cf. D.L. 1. 41). A atribuição a Sólon (cf. D.L. 1. 63) parece dever-se a Dídimo (Clem. Al. Strom. 1.18, p. 351). Cf. Snell 1952: 8-13.

${ }^{54} \mathrm{O}$ emprego de $\varepsilon i \delta \omega ́ \varsigma \varsigma$ pode, no entanto, ter um significado mais profundo. Para Campbell

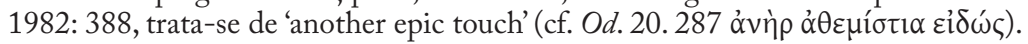

55 Sobre o emprego da expressão homérica róv $\tau \alpha . . . ~ \kappa \alpha \lambda \alpha ́$ (cf. Il.22. 73), vide Vernant 1979. 
acerca deste conceito. O poeta não diz que o ideal homérico e aristocrático está errado. Sugere que é demasiado selectivo e não se aplica à realidade do seu tempo. O conceito de úyı̀n ảvńp é mais modesto, mas também mais realista e abrangente.

Voltamos agora à questão que colocámos na parte final do comentário ao fr. 541, ou seja, a complexidade em apurar o que nestes dois fragmentos se inscreve nas convenções da tradição poética e o que, pelo contrário, é uma construção original de Simónides. A complexidade desta tarefa reside, por um lado, no facto de o fr. 542, não obstante ser um dos maiores, conter lacunas que se relacionam, provavelmente, com o contexto da sua composição e execução, por outro, na profusão e diversidade de leituras que tem suscitado.

A noção de acção voluntária/involuntária é inegável nos dois fragmentos (cf. frr. 541. 8 e 542. 28) e na opinião de Balasch 1967: 47 a consciência como fonte primária da moralidade é um contributo imenso de Simónides para o mundo grego. Esta noção, todavia, parece estar já presente num dos passos da Odisseia que analisámos no capítulo de introdução (cf. p. 25). Quando Fémio suplica a Ulisses que the poupe a vida (22. 350-353), evoca como argumento

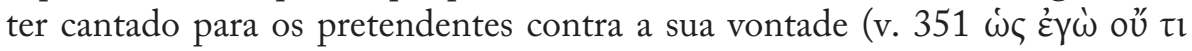

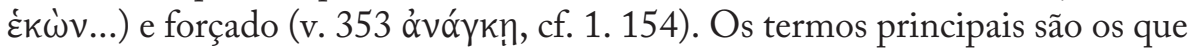

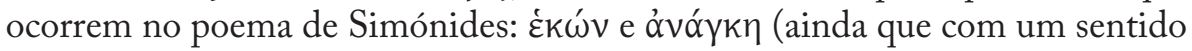
um pouco diferente). Por estranho que pareça, este antecedente literário raramente é mencionado na extensa bibliografia consagrada ao fr. 542. Além disso, o seu valor é apreciado de modo diverso pelos estudiosos que o evocam ${ }^{56}$. Como a distinção entre acto voluntário e involuntário já estava consignada na legislação de Drácon ( $\left.I G \mathrm{I}^{2} .115 .17,34\right)$, a originalidade de Simónides está certamente na consideração deste critério na discussão do conceito tradicional de aner agathos ${ }^{57}$. Por outro lado, tem razão Bowra 1961: 331 quando escreve que a doutrina expressa por Simónides parece algo trivial, mas era, de facto, revolucionária no seu tempo, porque "It removes the emphasis from what a man has or is and places it on what he does. First, he must do nothing aíxpóv

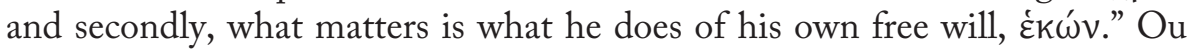
seja, a ideia já estava na tradição, mas não a sua aplicação à prática social e cultural.

${ }^{56}$ Cf. Parry 1965: 302, Giuliano 1991: 146-147, Most 1994: 141.

${ }^{57}$ Most 1994: 141 chega a uma conclusão um pouco diferente: "Thus, if there is indeed any moral novelty in this section of the poem, it is not in the introduction of the category of intentionality but rather in the use to which that category is put: not being $\dot{\varepsilon} \kappa \omega v v$ not only exculpates someone for Simonides, it is now rewarded with the poet's friendship and praise." O termo $\dot{k} \kappa \omega ́ v$ ocorre, de resto, com frequência na Ilíada e na Odisseia. No entanto, a existência de vontade própria no homem homérico é uma questão controversa, que tem sido debatida pelos maiores especialistas. Vide Snell 1992 [1975]: 19-46. 
A opinião de M. Balasch inscreve-se numa longa tradição filológica que sublinha em particular os elementos éticos do poema e tende, de um modo geral, a valorizar a sua originalidade ${ }^{58}$. De acordo com Donlan 1969, por exemplo, Simónides tentou redefinir conscientemente, em termos morais e

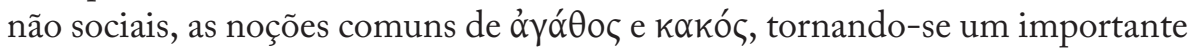
inovador na formulação de pensamentos éticos elevados. Alguns dos estudos que privilegiam esta leitura foram decisivamente influenciados pelo facto de Platão citar o poema de Simónides no momento alto de um debate acerca da

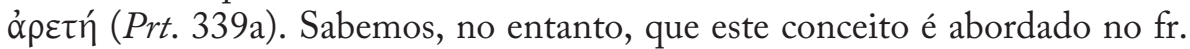
541 , mas não na parte conservada do fr. $542^{59}$.

Uma outra tendência ensaística sublinha os elementos convencionais do poema e defende que as suas ideias se inscrevem no domínio da poesia encomiástica $^{60}$. Dentro desta linha de leitura, alguns estudos valorizam especialmente as circunstâncias de composição e execução do poema e privilegiam a análise comparativa ${ }^{61}$. Nas palavras de Carson 1992a: 120, "Simonides' poem is not a poem about good, evil, gods, men, or Pittacus so much as it is a poem about praise. That is, a poem about Simonides himself in his role as epinician poet.” Mas não no papel que Fémio lamenta ter representado na ausência de Ulisses, ou seja, no de poeta de corte forçado pela necessidade a celebrar os poderosos pretendentes (cf. Giuliano 1991: 147).

Dentro destas duas linhas de interpretação, de certo modo antagónicas, mas também convergentes em determinados pontos, são vários os estudos que procuram explicar o sentido do poema através da reconstrução de um hipotético contexto histórico em que terá sido composto e executado ${ }^{62}$, uma metodologia

${ }^{58}$ Vide Wilamowitz 1913: 169-180; C. M. Bowra, "Simonides and Scopas", CPh 29.3 (1934) 231-239 (cf. 1961: 327-336); Woodbury 1953: 159-163; Gentili 1964: 290-295; Des Places 1969: 240; Donlan 1969: 71-90; Babut 1975: 26-27, 52-57; Segal 1985: 183. A provar que a leitura 'ética' do poema não está ultrapassada, Hutchinson 2001: 286 apresenta o fr. 542

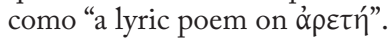

${ }_{59}$ Des Places 1969: 238 observa, no entanto, que o adjectivo ỏy $\alpha \theta$ ó

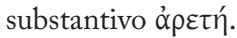

${ }^{60}$ Parry 1965: 304-310, Des Places 1969, Dickie 1978: 30-33.

${ }^{61}$ Cf. Dickie 1978, Carson 1992a, Most 1994, Buongiovanni 1998. Vide ainda Crotty 1982: 33-40, 143-144, que foi um dos primeiros helenistas a valorizar no poema a linguagem de 'louvor e censura' (praise and blame). Para uma opinião divergente, cf. Hutchinson 2001: 291-292.

62 Parry 1965: 299-300 discute as propostas de Schneidewin e de Wilamowitz, ambas com seguidores (cf. Babut 1975: 52-53). O primeiro relacionou o fr. 542 com a história transmitida por Cícero (de Orat.2.86.352 = fr. 510, supra), ou seja, o poema foi escrito para celebrar a vitória de Escopas numa corrida de carros, mas o poeta foi obrigado a incluir a defesa do seu patrono por algum crime cometido e para o consolar da sua fraqueza humana. No entender de Wilamowitz, Escopas esperava do seu bardo um cumprimento tradicional, mas o poeta teve a coragem de dizer ao seu patrono a verdade: que a arete é uma ideia puramente moral. Ao fazê-lo, refutou a opinião de Pítaco, que havia defendido a antiga crença de que a arete deve ser equacionada com o sucesso, tarefa difícil, ainda que possível, mas na visão de Simónides o homem verdadeiramente 
que, em nossa opinião, se pode revelar assaz perniciosa. $\mathrm{O}$ equilíbrio entre convenção e originalidade num poema relaciona-se certamente com a sua natureza genérica, que pode ser determinada pela ocasião da sua execução. Mas a forma imprecisa como Protágoras introduz o poema de Simónides (cf. $\lambda \varepsilon ́ \gamma \varepsilon 1$

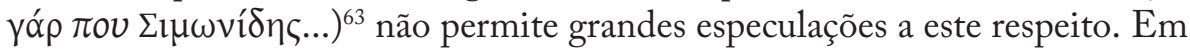
concreto, sabemos apenas que foi composto em honra de Escopas e é provável que fosse um encómio ${ }^{64}$. Se, por um lado, não possuímos informações precisas sobre o carácter e a acção política do chefe tessálio (cf. supra, p. 164), por outro, as lacunas do poema dizem certamente respeito a este assunto, pelo que a reconstrução das circunstâncias de composição e de execução, no estado actual dos nossos conhecimentos, deve ser guiada pela prudência. É certo que não podemos dissociar o sentido do poema da suposição de ter sido encomendado por um patrono poderoso e que estava provavelmente mais familiarizado com os ideais heróicos e aristocráticos tradicionais do que com a concepção modesta que o poeta lhe apresentou. Não sabemos, porém, como o poema foi recebido pelo seu destinatário. Menos razoável nos parece o pressuposto de que Simónides foi obrigado a obedecer aos ditames da tradição poética ou temia contrariar a vontade do seu patrono ${ }^{65}$.

perfeito não pode existir. A hipótese de Bowra, cit. (n. 58), p. 230 (cf. 1961: 327), não difere grandemente: o nobre tessálio pediu a Simónides a sua opinião sobre o dito de Pítaco, $\chi \alpha \lambda \varepsilon \pi \grave{v} v$

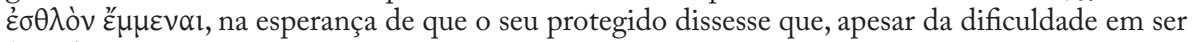

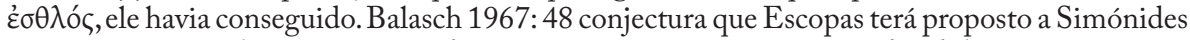
que compusesse sobre a arete, criando um pretexto para um momento de adulação, mas o poeta habilidoso não optou pelo caminho fácil e, embora não pudesse insultá-lo directamente, o seu poema é uma crítica nítida ao poder absoluto. As teses mais recentes de Giuliano 1991 e de Most 1994 baseiam-se igualmente numa apreciação negativa das relações entre o poeta e o seu patrono. Não obstante as diferenças, estas interpretações partem do pressuposto de que Escopas não possuía qualidades morais (de que governava como um déspota) e o poeta foi obrigado a proceder à sua defesa ou à sua censura.

${ }^{63}$ Esta falta de precisão talvez se deva atribuir ao método de citar de Platão, pois os protagonistas do diálogo afirmam conhecer bem o poema (339b-c). Giuliano 1991: 124 observa, retomando uma observação de Wilamowitz 1913: 160, que Protágoras actua de acordo com o uso sofista.

${ }^{64}$ No que respeita à estrutura formal do poema, a opinião mais consensual é a de que se trata de um encómio monostrófico, composto por quatro estâncias, das quais apenas a terceira está completa. Gentili 1964: 289 sqq., porém, defende que a estrutura é triádica, retomando uma antiga proposta de G. Hermann e de A. Boeckh. Parry 1965 interpretou o poema como consolatio. Lesky 1995 [1971]: 219 considera-o uma canção de mesa, Segal 1985: 182 um encómio ou treno. Carson 1992a: 113, com base em H. Jurenka, "Des Simonides Siegeslied auf Skopas in Platons Protagoras", Zeitschr. für die österr. Gymn. 57 (1906) 867-875, sugere tratar-se de um epinício (com pensavam também Schneidewin e Bergk). A discussão do metro do poema acolhe ainda menos unanimidade. Vide R. Merkelbach, "Zwei metrische Beiträge", Maia 15 (1963) 165-167, Gentili 1964: 297, 306; Gerber 1970: 319, Campbell 1982: 385, Hutchinson 2001: 293-294.

${ }_{65}$ Nem todos os estudiosos relacionam a análise do poema com um suposto contexto histórico de produção. Gentili 1964: 295 observou, por exemplo, que não é necessário associar 
A análise comparativa pode também conduzir a uma percepção errada dos

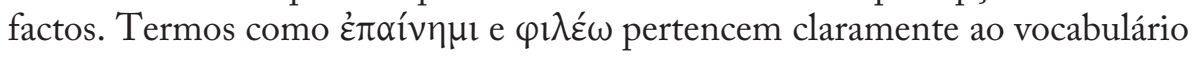
da poesia encomiástica, mas se alguns dos pensamentos expressos pelo poeta (em geral, tradicionais) figuram com frequência no repertório da poesia laudatória de Píndaro e Baquílides (a ideia de que a excelência é difícil de alcançar, de que a fortuna humana é incerta e depende do favor dos deuses, de

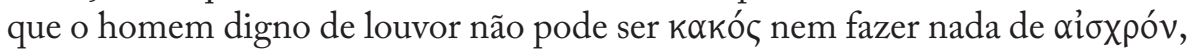
etc. $\left.{ }^{66}\right)$, que são empregues no sentido de valorizar as acções praticadas pelo laudandus, podemos pensar na existência de um fundo poético comum e na obediência a determinadas convenções literárias, mas não devemos rejeitar a possibilidade de ter sido Simónides o primeiro a introduzi-los nos seus cantos em honra dos homens. Embora não tenhamos possibilidade de estabelecer uma cronologia segura, é provável que o poema tenha sido composto no período em que o nosso lírico foi acolhido na Tessália, na sequência do processo que conduziu à expulsão de Hípias de Atenas ${ }^{67}$. Com a sua experiência de vida, Simónides podia realmente dizer com conviç̧ão que um homem é ảy $\alpha \theta$ ó quando a sorte o bafeja, mas passa a kokóc quando a sua sorte muda. Tal pensamento, todavia, como tantos outros, é tradicional e as reflexões sobre as limitações da vida humana encontram-se, como vimos já, em muitos outros passos da sua obra.

Em nosso entender, o fr. 542 pertence certamente ao género encomiástico, pelo que os temas e a linguagem remetem, naturalmente, para uma tradição poética comum ou que servirá de base de trabalho aos líricos da geração mais jovem. A natureza da reflexão que o poeta desenvolve presta-se a leituras diversas e persiste a impressão de que a sua intenção original se perde nas lacunas do poema. Todavia, não cremos que tenha razão Most 1994: 142 quando diz que o poema "is also full of terms describing the activity of

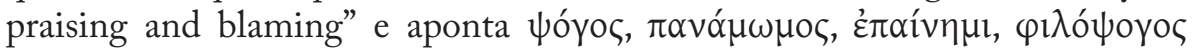
e $\mu \omega \mu$ ń $\sigma o \mu \alpha 1$. Se os dois primeiros lexemas não remetem necessariamente

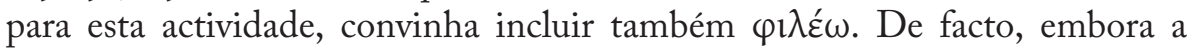
linguagem encomiástica esteja incontestavelmente presente neste fragmento, não cremos que as reflexões do poeta, quer elas sejam ou não de natureza ética, se esgotem nesta explicação.

o poema a um acontecimento, pois o fr. 541 não deixa dúvidas sobre a frequência dos conceitos éticos na poesia de Simónides.

${ }^{66}$ Para uma análise comparativa entre os temas tratados por Simónides e a sua presença em contexto encomiástico na obra de Píndaro e Baquílides, vide Buongiovanni 1998.

${ }^{67}$ Segundo Sordi 1958: 67, a morte de Escopas ocorreu entre 510 e 500 (cf. supra, p. 157 n. 102). De acordo com esta cronologia, o fr. 542 deve ser anterior ao epinício mais antigo preservado de Píndaro, a $X^{a}$ Pítica, a única ode da colecção dedicada a um Tessálio (cf. supra, p. 159). Cf. Robbins 1997: 247. 
De acordo com a nossa leitura, Simónides estabelece neste poema uma

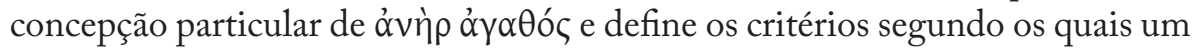
homem é digno de ser louvado e estimado (vv. 27, 36-37). Ao fazê-lo, o poeta criou a possibilidade de homens oriundos de condição social modesta serem legitimamente louvados, ainda que Barrigón 1994b tenha demonstrado que os destinatários dos seus epinícios pertenciam, na maioria, aos estratos sociais mais favorecidos. Há, pelo menos neste ponto, um afastamento claro em relação ao ideário social de Teógnis. Todavia, em nossa opinião, Simónides não contesta, de facto, os valores da tradição homérica e aristocrática, nem tão

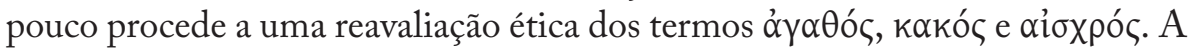
sua intenção não é propor um modelo de humanidade em termos universais, mas somente definir as condições mínimas que fazem de um homem um destinatário legítimo do seu louvor ${ }^{68}$. Reside, talvez, neste aspecto uma das marcas da sua originalidade. É tradicional a composição geral do poema, o encadeamento das ideias, com avanços e recuos (cf. Des Places 1969: 241 e n. 23). A linguagem revela reminiscências épicas, mas também o talento criativo de Simonides neste domínio. É singular, porém, a tendência para a formulação negativa ${ }^{69}$. Este procedimento retórico coaduna-se com o tema geral da composição (a constatação da inexistência do 'homem verdadeiramente perfeito'), e era possivelmente, como pensam alguns helenistas, um dos traços marcantes do estilo de Simónides, mas pode estar relacionado com o facto de ter sido um dos primeiros cultores do género laudatório ${ }^{70}$.

${ }^{68}$ Como observa Hutchinson 2001: 291-292, o elevado nível de abstracção do fr. 542 não deve ser menosprezado, mas uma das dificuldades maiores está no facto de não sabermos se o poeta está a falar em termos universais ou particulares.

${ }^{69}$ Snell 1961: 52-53 destaca no fr.542 a "mild resignation", uma característica da personalidade de Simónides que não se encontra em nenhum outro poeta do seu tempo. Parry 1965: 310 considera o "tom submisso do poema" um traço característico do género a que o poema pertence, a consolatio. Buongiovanni 1998: 1040-1041, 1046-1047 defende que a estratégia compositiva e os temas de Simónides são substancialmente análogos aos da lírica posterior, mas a tendência para a formulação negativa não tem paralelo nem em Píndaro nem em Baquílides (p. 1046). Sobre este aspecto, cf. supra n. 19 e nota seguinte.

${ }^{70}$ Cf. Carson 1992a: 114. Buongiovanni 1998: 1046-1047 relaciona a tendência para a formulação negativa com o carácter inaugural da poesia encomiástica de Simónides, partindo da ideia defendida por Vernant 1979, de que, ao contrário da poesia épica, que celebrava heróis e homens do passado, o louvor de homens vivos, ainda expostos à mudança de fortuna e à censura, só pôde encontrar espaço na poesia lírica através da negação dos temas de canto mais tradicionais e mais ligados à esfera do epos. Simónides é, pois, um herdeiro de uma tradição 'negativa' (cf. Sapph. fr. 16 L-P, Ibyc. fr. 282 (a) $P M G$ ), embora adopte uma estratégia mais sofisticada do que Íbico. Em nossa opinião, todavia, a recusatio de Íbico radica ao nível do sujeito poético, enquanto a de Simónides tem a ver com o objecto do seu canto. E a evolução em relação ao seu antecessor reside precisamente na sua preocupação em propor um outro destinatário para o seu louvor. A ausência do mito ou de referências mitológicas, que ocorrem no fr. 541. 9-10, pode relacionar-se com o carácter pioneiro do poema ou foi uma estratégia intencional do poeta de não evocar paralelos míticos. 
Fr. 579 [74 P, 58 B, 37 D] Clem. Al. Strom. 4. 7.48

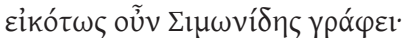

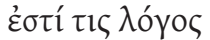

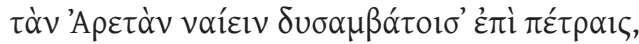

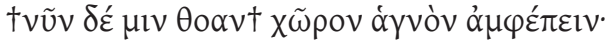

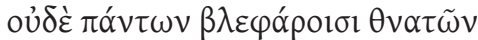

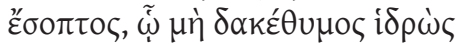

$\varepsilon ้ v \delta \circ \theta \varepsilon v \mu o ́ \lambda \eta ̣$,

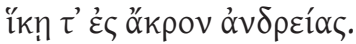

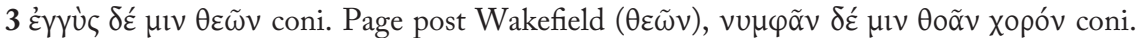

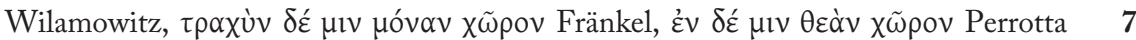

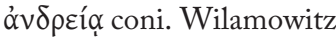

Com razão, por certo, escreve Simónides:

Há um ditado:

A Arete mora em rochedos inacessíveis,

e... um lugar sagrado vigia.

Nem aos olhos de todos os mortais

é visível, senão aos daquele que, a escorrer em suor

que lhe morde o ânimo,

alcança o auge da sua coragem.

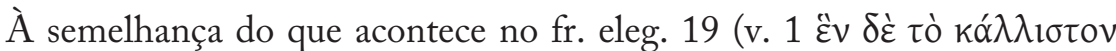

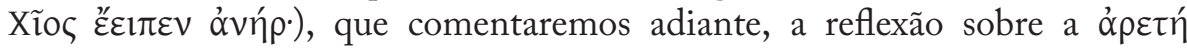

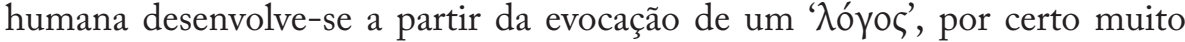
conhecido no tempo de Simónides, que remonta aos Trabalhos e Dias de Hesíodo $^{71}$. Do poeta da Beócia, o nosso lírico retomou a ideia do esforço que é exigido aos homens pela referência ao seu suor (Op. 289). Desenvolve-a, no entanto, através de uma imagem e acentua os tons sombrios com o emprego

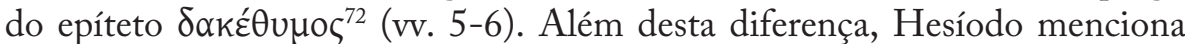
a dificuldade do longo e íngreme caminho a percorrer (Op. 290) para, no

${ }^{71}$ Op. 289-292: 'Mas ante o mérito, puseram os deuses o suor;/ longo e escarpado é o caminho que conduz até lá,/ e áspero a princípio; mas, depois de chegar ao cimo,/ em fácil se volve, por difícil que seja.' (trad. Rocha Pereira 2009: 112). Campbell 1982: 392 observa que a formulação do primeiro verso de Simónides tem ecos do fr. $42.1 \mathrm{~L}-\mathrm{P}$ de Alceu e encontra um paralelo na $I X^{a}$

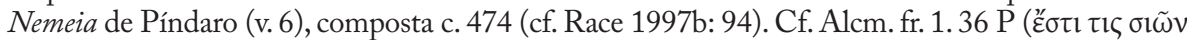
$\tau i ́ \sigma ı \zeta^{\circ}$. Estas referências não implicam uma influência directa entre os poetas, mas antes a partilha de expressões e processos literários convencionais da poesia lírica arcaica.

${ }^{72}$ Este composto raro, que à letra significa 'que morde, devora o ânimo', apenas atestado neste passo e num fragmento papirológico atribuído a Íbico (fr. 169. 1 SLG), baseia-se na inversão de $\theta u \mu o \delta \alpha \kappa n ́ s$, que em Od. 8.185 é aplicado a $\mu \tilde{\theta} \theta$ os. Cf. Perrotta 1952: 253, Gerber 1970: 327, Poltera 1997: 408-409. 
final, revelar que, uma vez iniciado e atingido o seu auge, a arete se torna fácil de alcançar (Op. 291-292). Simónides, porém, não deixando de sublinhar a acessibilidade difícil, pela imagem da sua deificação ${ }^{73}$, contrapõe que nem todos os mortais a avistam (vv. 4-5). Esta oposição reflecte-se na linguagem

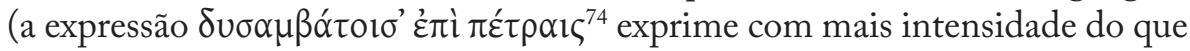
em Hesíodo a difícil conquista da 'excelência'), na alternância verbal entre a caracterização divina da Arete (modos indicativo e infinitivo) e o retrato do esforço que a sua conquista impõe aos homens (modo conjuntivo) ${ }^{75}$. É, pois, notória a influência de Hesíodo na expressão (cf. Op. 291 e v. 7) e na noção geral de que a arete exige dos homens um esforço imenso, mas este fragmento

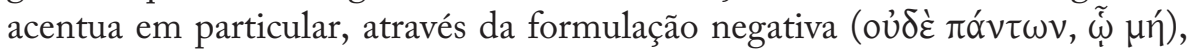

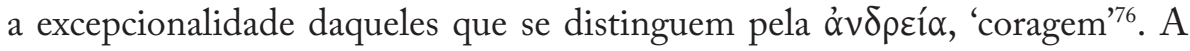
transição do plural para o singular nos vv. 4-5 reforça esta ideia e encontra um paralelo no fr. 542. 27-28.

Por conseguinte, Simónides não se opõe em rigor à formulação de Hesíodo, mas antes a enriquece do ponto de vista imagético e, ao que parece, ideológico. De facto, o poeta da Beócia começa por dizer que os deuses imortais impuseram aos homens o suor ante a arete (Op. 289-290). Que os homens sem a ajuda dos deuses não a alcançam afirma-o o fr. 526. 1-2 de Simónides, já analisado. No entanto, no presente fragmento o papel dos

${ }^{73}$ A corrupção da primeira parte do v. 3 não permite apreender o sentido exacto desta concepção, pois nenhuma das emendas propostas é consensual. Bowra 1961: 369 segue a solução de Wilamowitz ('na companhia de um coro sagrado de céleres ninfas', trad. Rocha Pereira 2009: 180). Gerber 1970: 63 concorda com Kegel 1962: 53, segundo o qual a ideia de que a Arete, nos rochedos inacessíveis, dança com um coro de ninfas não condiz com a dignidade séria e difícil da sua conquista. Não nos parece um argumento legítimo, visto que a dança é um elemento sério e indissociável da lírica coral, meio privilegiado para a preservação da arete humana. $\mathrm{Na}$ interpretação deste verso, parece-nos importante ter presente um passo de Píndaro a respeito

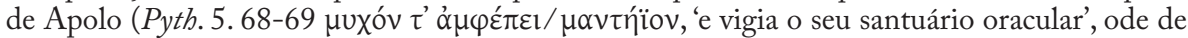
462), indicado por Fränkel 1975: 314 n. 23 e Campbell 1982: 392. Vide o exame desta questão textual por Perrotta 1952: 242-243 e Poltera 1997: 557-561.

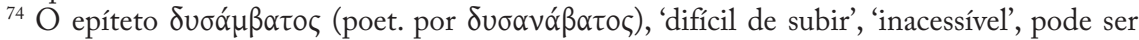
uma criação original de Simónides e ocorre apenas neste passo. Na mesma situação se encontra

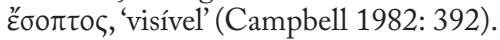

${ }_{75}$ Para uma análise do metro, vide Perrotta 1952: 249-251, Gerber 1970: 326, Campbell 1982: 392.

${ }^{76}$ Cf. Babut 1975: 58, Campbell 1983: 238. Desde Wilamowitz que os estudiosos se dividem

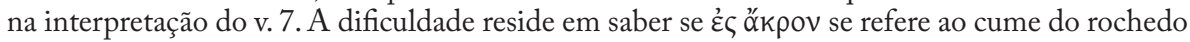
em que se encontra a Arete (sentido mais próximo de Hesíodo; cf. Tyrt. fr. 12. 43 W, Pind. Nem. 6. 23-24) ou ao auge da coragem humana. De facto, a óv $\delta \rho \varepsilon i ́ \alpha$ é o meio que permite alcançar a arete, o que legitima a presença do dativo. $O$ genitivo não põe em causa esta leitura, mas exprime com mais força a ideia de que essa conquista obriga o homem a uma dedicação plena. Discordamos, porém, da opinião de Babut, ibidem, segundo a qual nos vv. 5-7, além do esforço físico, está presente a noção de ascese moral. Vide Perrotta 1952: 248-249, Gerber 1970: 327, Babut 1975: 59-60, Campbell 1982: 392. 
deuses é transferido para a concepção divina da arete (vv. 2-3), mas na parte

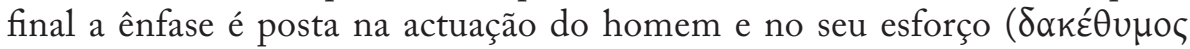

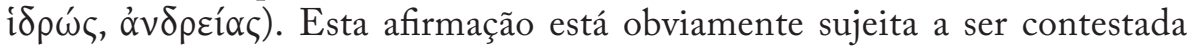
porque, embora o fragmento tenha sentido completo, o poeta pode ter orientado a sua reflexão numa direcção diferente nos versos perdidos ou modificado o seu ponto de vista. Nem nos parece legítimo especular, com base nestes versos, que Simónides, na sua visão do mundo, desvalorizou o papel dos deuses. De facto, o conteúdo ideológico deste fragmento pode ter sido motivado pela natureza genérica da composição a que pertenceu. Pela ênfase dada a $\alpha \hat{\alpha} \delta \rho \varepsilon i ́ \alpha$, que se depreende da posição que ocupa no verso e por ser a atestação mais antiga de uma palavra rara (Woodbury 1953: 154), supomos que se tratasse de um epinício.

\section{Fr. 581 [76 P, 57 B, 48 D] D.L. 1. 89-90}

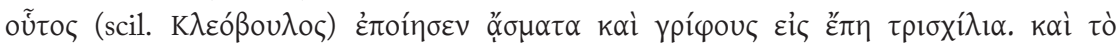

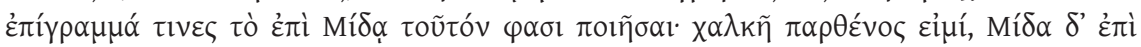

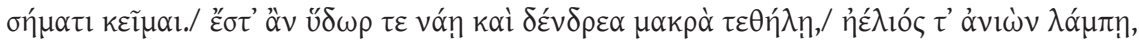

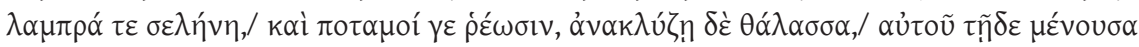

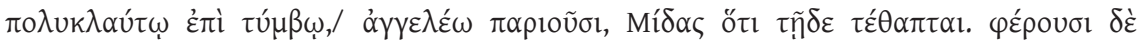

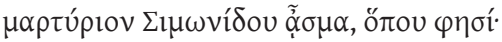

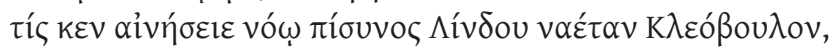

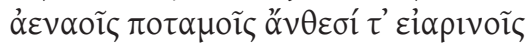

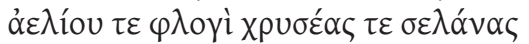

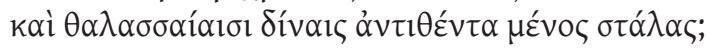

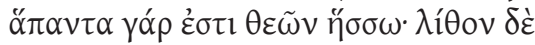

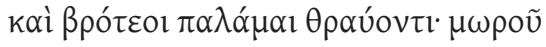

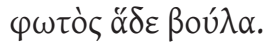

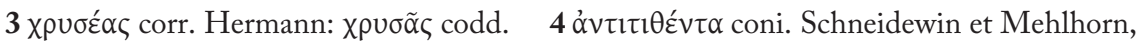

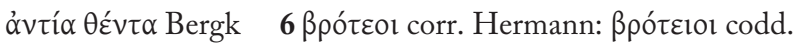

Cleobulo compôs cantos e enigmas, no total de três mil hexâmetros. Alguns dizem que foi ele próprio quem compôs o epigrama sobre Midas: 'Sou uma donzela de bronze, sobre o túmulo de Midas repouso./ Até que a água corra e as altas árvores dêem flor,/ se mostre o sol a brilhar e a lua cintilante,/ fluam os rios e o mar ondule,/ ficarei neste lugar sobre a sua tumba tão chorada,/ e anuncio aos que passam por perto que Midas está aqui sepultado.' Evocam como testemunho um canto de Simónides, onde diz:

Quem, confiado no seu juízo, louvaria o habitante de Lindos, Cleobulo, que aos rios eternos e às flores primaveris,

à chama do sol e da áurea lua,

e aos turbilhões do mar opôs a força de uma estela?

Pois tudo é inferior aos deuses. Até a pedra

a quebram mãos mortais. Louco

é o homem que profere tal sentença. 
Bem diverso do fragmento anterior é o tom destes versos citados por Diógenes Laércio, que os comentadores modernos supõem constituir um poema completo (Gerber 1970: 328, Campbell 1982: 393). O alvo da censura de Simónides é Cleobulo de Lindos, que governou esta cidade da ilha de Rodes como tirano c. 600 e foi, como Pítaco de Mitilene, considerado um dos Sete Sábios ${ }^{77}$.

Apesar das semelhanças entre as figuras visadas, este poema distinguese pela veemência da invectiva (cf. vv. 1, 6-7), que se estrutura a partir de uma longa oração interrogativa directa, procedimento retórico que Simónides empregou noutros fragmentos, ainda que em contextos bem diversos (cf. frr. $506,584)$. Notável é o contraste entre a extensa oração inicial, por meio da qual o poeta exprime a sua indignação (vv. 1-4), e as concisas sentenças que encerram o poema (vv. 5-7). Em nossa opinião, os vv. 2-4 exemplificam a singular capacidade de síntese de Simónides ${ }^{78}$, que condensou em três versos os seis que constituem o epitáfio de Midas atribuído a Cleobulo ${ }^{79}$. No entanto, na evocação das forças da natureza afasta-se da formulação do tirano, substituindo as formas verbais por epítetos mais expressivos, que remontam à tradição épica (v. 2), ou pela metáfora (v. 3). As reminiscências épicas destes versos, nos

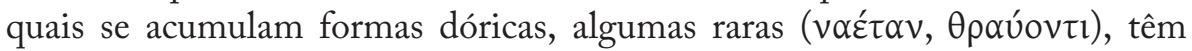
possivelmente a função de reforçar a crítica aos hexâmetros de Cleobulo ${ }^{80}$. Refira-se ainda o predomínio do polissíndeto no fragmento de Simónides.

${ }^{77} \mathrm{Na}$ opinião de A. H. Griffiths, o modo vigoroso como Simónides põe em causa as máximas de Pítaco, no fr. 542, e de Cleobulo, neste fragmento, indicia que o cânone estava a formar-se, se ainda não estava formado, no início do séc. V (OCD, s.v. Seven Sages). De acordo com Plutarco (de E apud Delphos 3.385d), os antigos sábios eram cinco: Quílon de Esparta, Tales de Mileto, Sólon de Atenas, Bias de Priene e Pítaco de Mitilene. Mais tarde, embora não sendo dignos desta distinção, observa-se, foram também incluídos Cleobulo de Lindos e Periandro de Corinto. Note-se, porém, que Cleobulo integra a lista de Platão (Prt. 343a) e a de Pausânias (10. 24. 1). Sobre esta lenda, vide Snell 1952; D. F. Leão, “Os 'Sete Sábios' como agentes de formação”, Biblos n.s. 1 (2003) 23-41, "A tradição dos Sete Sábios: o sapiens enquanto paradigma de uma identidade", in Leão, Ferreira \& Fialho 2010: 47-110.

${ }^{78}$ Bowra 1961:370 considera, no entanto, que esta formulação indicia que o poeta não conhecia os hexâmetros atribuídos a Cleobulo exactamente como foram transmitidos para a posteridade, uma vez que nada diz sobre uma estátua de bronze. Gerber 1970: 328, embora pondere esta leitura, privilegia a hipótese de o poeta ter incluído intencionalmente no termo $\lambda i ́ \theta$ ov tanto a figura de bronze como a base de pedra sobre a qual deve ter sido colocada, o que não parece provável.

${ }^{79}$ De acordo com Diógenes Laércio, algumas autoridades atribuíam a Cleobulo o epitáfio de Midas, que outras diziam ter sido composto por Homero. Vide Certamen 260-270 Allen = $15 \mathrm{~W}$ (cf. supra, p. 46) e $A P 7.153$.

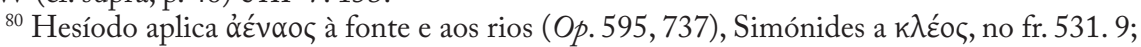

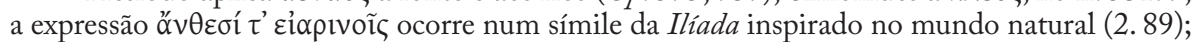
a metáfora do v. 3, atestada na tragédia (e.g. Aesch. Pers. 505), pode ser de inspiração épica (cf.

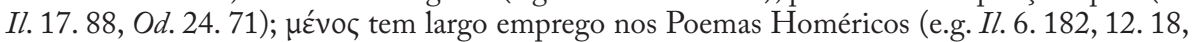
$O d$. 10. 160), mas a presença na composição de Simónides é claramente irónica e depreciativa (Gerber 1970: 328, Campbell 1982: 393-394). 
À 'sentença de um homem louco's1, que proclamou a perenidade de um monumento, o poeta contrapõe a afirmação do v. 5: 'tudo é inferior aos deuses'. Esta reivindicação, todavia, não apela ao sentimento religioso, mas antes à capacidade cognitiva do homem (cf. v. 1 vów ríouvos). O sujeito poético é alguém que reflecte e sabe que, ao contrário da natureza, que está em permanente mudança e renovação, as realizações humanas estão sujeitas à deterioração e à caducidade. Só os deuses e as suas criações permanecem. Mas no poema que compôs em honra dos Espartanos que perderam a vida nas Termópilas, Simónides aparentemente afirma o contrário (cf. fr. 531. 4-5), o que parece corroborar a ideia, avançada no comentário ao fr. 579 , de que as afirmações de carácter gnómico poderiam ser, de algum modo, condicionadas pelo género da composição poética. Sobre este aspecto, o comentário de Diógenes Laércio não nos ajuda, pois o termo $\alpha \hat{\alpha} \sigma \mu \alpha$, como sugere a sua formação etimológica (derivado de $\tilde{\alpha} \hat{\alpha} \delta \omega$, 'cantar'), não parece indicar uma composição lírica específica ${ }^{82}$. Este poema é para nós um testemunho da feição satírica de Simónides e, supondo que não fosse o único, compreendemos por que motivo a tradição the atribuiu a autoria do dístico elegíaco composto contra Timocreonte (epigr. XXXVII, cit. supra).

Fr. 584 [79 P, 71 B, 57 D] Athen. 12. 512c

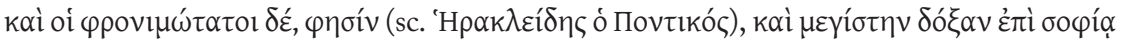

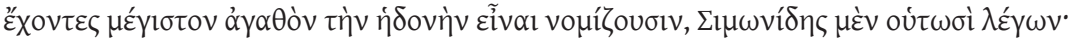

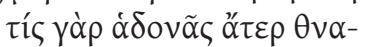

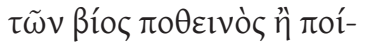

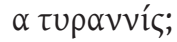

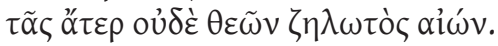

4 Kaibel: $\tau \tilde{\alpha} \varsigma \delta^{\prime}$ codd.

Até os homens mais prudentes, diz Heraclides Pôntico, os que têm a mais elevada reputação de sabedoria, consideram ser o prazer o maior bem, Simónides, por exemplo, que diz:

Pois, sem prazer, que vida

humana é desejável ou que

poder absoluto?

Sem ele, nem a existência dos deuses é invejável.

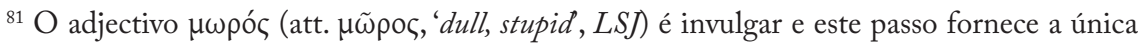
atestação lírica conhecida.

${ }^{82}$ É de considerar a possibilidade de este lexema ter designado, pelo menos nas fontes tardias, canções executadas por um coro, como foi referido na primeira parte deste estudo (cf. pp. 72, 75).
} 
O testemunho de Ateneu sugere, embora não seja muito claro (cf. 12 . 512a), que Simónides era citado no tratado Acerca do prazer, do filósofo Heraclides Pôntico, na qualidade de sábio. É natural que um poeta que reflectiu e compôs sobre as limitações do ser humano tenha também reconhecido as coisas boas da vida e fosse, por isso, admirado pela sua sabedoria. Até à publicação da última descoberta papirológica, no entanto, este era um dos poucos fragmentos a mostrar a faceta menos sombria e pessimista de Simónides ${ }^{83}$. O seu conteúdo, porém, como observam os comentadores modernos, não é inteiramente original. Mas, se contém reminiscências de Mimnermo (cf. fr. $1 \mathrm{~W}$ ), que antecedeu Simónides em

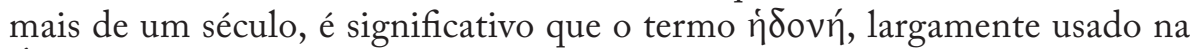
Época Clássica, encontre aqui a primeira atestação na literatura grega. Fica por esclarecer se esta noção reflecte uma visão pessoal do nosso lírico sobre a vida ou se é antes motivada pelas convenções literárias. Não podemos, de facto, saber se o poema prosseguia, como o fr. $1 \mathrm{~W}$ de Mimnermo, com uma reflexão lamentosa sobre a caducidade da existência humana, ou caminhava no sentido oposto à concepção do poeta de Cólofon, afirmando, por exemplo, a presença do prazer em todas as idades da vida.

Do ponto de vista formal, este fragmento evidencia o mesmo procedimento retórico que salientámos na análise anterior: o tema da reflexão é apresentado primeiro através da oração interrogativa directa, seguindo-se depois a resposta do poeta, que reforça a sua opinião com o exemplo divino. A formulação

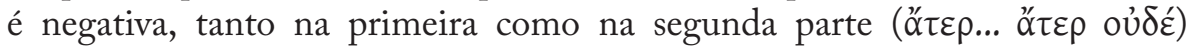
e dispensa as formas verbais. Rigorosa é a disposição dos termos na frase,

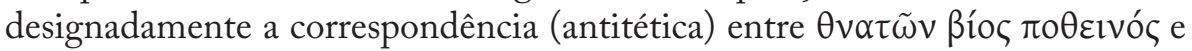
$\theta \varepsilon \tilde{\omega} v \zeta \eta \lambda \omega \tau$ ò $\alpha^{\prime} i \omega \omega v$. A escolha dos epítetos não parece ser casual: a vida dos homens pode ser desejável, se houver prazer, mas só a dos deuses merece ser invejada.

Fr. eleg. 19 Stob. 4. 34. 28 (cod. S)

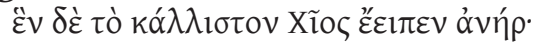

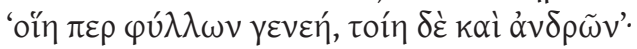

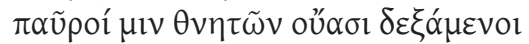

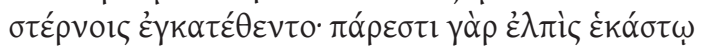

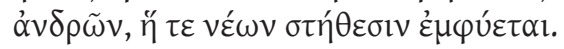

${ }^{83}$ Segundo o testemunho do retórico Élio Téon do séc. II d.C. (Progymnasmata 33 = fr. 646, 141 P, 192 B): 'Simónides, de modo prejudicial, recomenda que levemos a vida a brincar e que

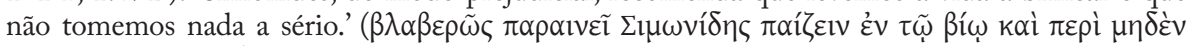

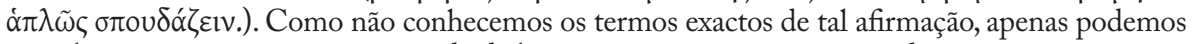
reconhecer que pressupõe uma atitude de leveza e optimismo perante a vida, que contrasta com a severidade e amargura dominante nos fragmentos analisados no início deste capítulo. 
Eis o que de mais belo disse o homem de Quios:

'Tal como a geração das folhas, assim é também a dos homens. ${ }^{94}$

Os poucos mortais que o ouviram

em seus peitos o guardaram, pois vive uma esperança em cada

homem, e ela floresce no coração dos jovens.

Uma das novidades da segunda edição do volume II de Iambi et Elegi Graeci ante Alexandrum Cantati, de West, foi a impressão, em separado, dos treze versos elegíacos transmitidos por Estobeu sob o nome de 'Simónides' (4. 34. 28), que alguns estudiosos defendiam pertencer a Semónides de Amorgos ${ }^{85}$. Com a atribuição a Simónides do P. Oxy. 3965, que contém oito desses treze versos (= fr. eleg. 20. 5-12, infra), esta polémica ainda não foi resolvida ${ }^{86}$. De facto, sabemos hoje que não há uma coincidência exacta entre o texto transmitido por Estobeu e o que se encontra no papiro, pois neste a secção que antecede os oito versos comuns (= fr. eleg. 20. 1-4, bastante mutilada e que, por essa razão, não tratamos) não corresponde, como seria de esperar, aos primeiros cinco versos transmitidos por aquele autor do séc. $\mathrm{V}$ da nossa era ${ }^{87}$. Uma vez que o papiro está datado do séc. II d.C. (Parsons 1992: 4), presume-se que esta versão esteja mais próxima do original. A descoberta papirológica veio, de resto, confirmar o que muitos estudiosos já sabiam: que a Estobeu apenas interessavam alguns passos gnómicos; por

${ }^{84}$ Il. 6. 146, trad. Rocha Pereira 2009: 39.

${ }^{85}$ G. Choeroboscus, gramático do séc. IV-V d.C., citado no Etymolog. Magnum (713. 17), explicita que o nome do iambógrafo de Amorgos se escrevia com $\eta$ e o do lírico de Ceos com 1 . Todavia, como nota Gerber 1999b: 7, as nossas fontes não fazem geralmente esta distinção. A confusão podia facilmente ser evitada com a menção da origem dos poetas, o que não acontece na antologia de Estobeu. Ezio Pellizer, "Bergk, Leopardi, Winterton e Semonide, fr. 29 Diehl: «Uno dei più sicuri resultati della ricerca filologica», QUCC 22 (1976) 15-21, defende que foi R. Winterton, em 1635, o primeiro a atribuir a citação de Estobeu a Semónides de Amorgos. Esta tese acolheu maior consenso desde que Wilamowitz a defendeu (cf. 1913: 273-275). Mais tarde aquele texto passou a ser também incluído nas antologias do iambógrafo como fr. 29 Diehl. Cf. Davison 1968: 70-77, Babut 1971: 23 e n. 36, West 1974: 179-180, Fränkel 1975: 207 n. 14, Lloyd-Jones 1975: 97, Hubbard 2001: 229-230.

${ }^{86}$ Para alguns estudiosos, a descoberta papirológica resolveu definitivamente a questão da autoria (cf. West 1993b: 1, 10 e n. 19; Burzacchini 1995: 34; Sider 2001b: 274-280), mas outros continuam a defender a atribuição do fr. 26 do P. Oxy. 3965 (fr. eleg. 20. 5-12) a Semónides de Amorgos, em grande parte por causa dos paralelos com o fr. $1 \mathrm{~W}$ deste poeta (cf. Hubbard 2001: 229-230). No entender de Parsons 1992: 43, o papiro apenas confirma que pertencem a Simónides os vv. 6-13 da citação de Estobeu. Nota, porém, que a citação seria um processo literário característico do nosso lírico (cf. frr. 542, 579, 581) e chama a atenção para o facto de uma das Vidas de Homero do Pseudo-Plutarco registar que Simónides havia chamado 'quiota' ao grande poeta épico $(2.2 \mathrm{~W})$.

${ }^{87}$ Note-se, porém, que dos três manuscritos que transmitem o fragmento apenas $\mathrm{S}$ continha a versão integral (Parsons 1992: 43). Para um exame da tradição manuscrita, vide Sider 2001b: 276-279. 
conseguinte, a composição elegíaca sobre 'o homem de Quios' pode ser o resultado da junção de extractos de poemas diferentes e, na pior das hipóteses, pertencentes a autores diversos (cf. Parsons 1992: 43). Portanto, no estado actual dos nossos conhecimentos, não é possível afirmar com segurança que o presente fragmento e o que comentaremos a seguir pertencem ao mesmo poema. Os estudiosos que defendem esta hipótese apoiam-se no testemunho da transmissão literária (West 1993b: 10), bem como na análise temática dos dois fragmentos (Hubbard 2001: 230-231, Gentili e Prato 2002: 202-203).

$\mathrm{Na}$ passagem do séc. VII para o VI, Mimnermo de Cólofon tomava o símile das folhas enunciado por Glauco na Ilíada (6. 146-149) ${ }^{88}$ como mote para uma reflexão sobre a brevidade do tempo da juventude (fr. $2 \mathrm{~W}$ ), atestando a celebridade do poema épico. Simónides torna mais explícita a reminiscência homérica ao incluir na sua composição o hexâmetro principal daquele símile, depois de evocar o poeta através de uma expressão que teria possivelmente grande difusão no seu tempo ${ }^{89}$, o que não faz, por exemplo, no fr. 579. Conciliou, portanto, o que parece ser uma das características da sua maneira de compor com um procedimento retórico típico, pois, como Campbell 1983: 232 observou, os Gregos apreciavam as listas do tipo 'a melhor coisa é..., depois..., a seguir... ${ }^{90}$.

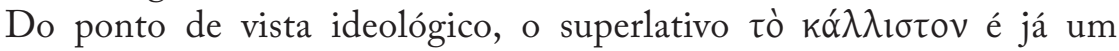
indício, quanto a nós, de um certo afastamento do negrume que domina os versos de Mimnermo e que não se encontra, de facto, no símile homérico. Interrogado sobre a sua linhagem, Glauco observa com uma certa amargura que as gerações humanas se sucedem sem interrupção, sugerindo que o homem não é mais do que uma folha, no meio de tantas. Julgamos, porém, que prevalece na reflexão do guerreiro a ideia de que esta substituição constante das gerações se integra perfeitamente no ciclo da natureza. $\mathrm{O}$ v. 1 confirma, por outro lado, a grande admiração que Simónides sentia pelo grande épico, tal como os vv. 3-4 são um testemunho da difusão oral do epos homérico. A apreciação deste facto cultural centra-se no seu efeito junto do

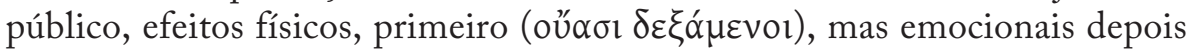

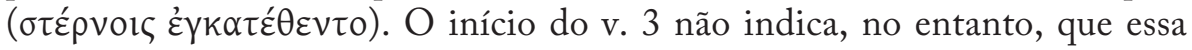
difusão não foi significativa, mas antes que o seu sentido profundo não foi percebido por todos os homens, o que pode conter uma alusão indirecta aos poetas que antes de Simónides compuseram sobre o mesmo símile ${ }^{91}$,

\footnotetext{
${ }^{88}$ Sobre a fortuna do símile das folhas, vide Sider 2001b: 274, 283-288.

${ }^{89}$ Cf. Davison 1968: 76-77 e supra, pp. 36-37.

${ }^{90}$ Um dos exemplos é o fr. 651 (= Carm. Conv. 890 PMG), atribuído por alguns autores a Simónides e, por outros, a Epicarmo.

${ }_{91}$ Designadamente Mimnermo, na opinião de Hubbard 2001: 230-231 e Sider 2001b: 279. Este investigador explora a possibilidade de Simónides ter citado o poeta de Cólofon
} 
o que já é mais do que um indício do afastamento ideológico que acima referimos. Aparentemente, pelo menos, o segundo hemistíquio do v. 4 e o v. 5 contêm uma apreciação da mensagem homérica mais positiva do que a que encontramos, por exemplo, em Mimnermo, mas já em Hesíodo o valor de $\varepsilon \lambda \pi$ đí é ambíguo, como demonstra o célebre mito de Pandora ( $O p$. 90-99). A continuação do poema (fr. eleg. 20) confirmará o valor ilusório da esperança, o que é uma forma subtil de falar da fraqueza humana. Pode ser casual a ausência de qualquer referência aos deuses nos dois fragmentos, mas a insistência na ideia de 'homem' (19. 1, 2, 3, 5; 20. 5, 11, [13]) sugere que a condição humana era o tema central deste poema. Do ponto de vista formal, o presente excerto evidencia processos retóricos típicos: os termos mais importantes ocupam posições de destaque em início e fim de verso e há um predomínio do enjambement. Ao mencionar a esperança, que alimenta os homens na primavera da vida, o poeta emprega um composto do verbo que ocorre no símile homérico a respeito daquela estação do ano (Il. 6. 148:

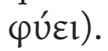

Fr. eleg. 20 P. Oxy. 3965 fr. 26. 5-17; Stob. ibid. (codd. SMA)

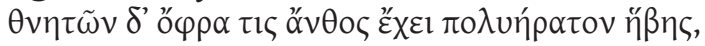

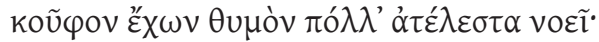

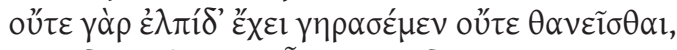

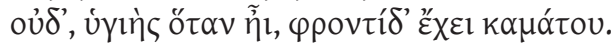

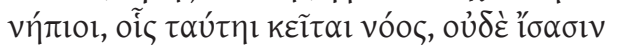

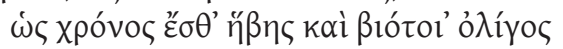

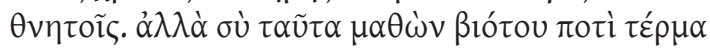

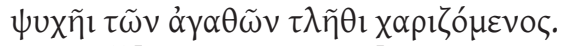

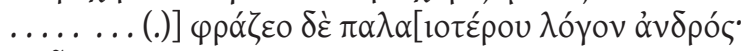

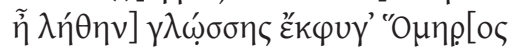

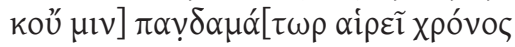

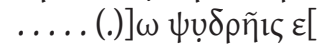

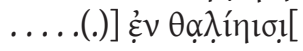

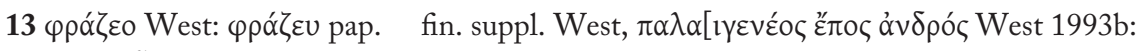

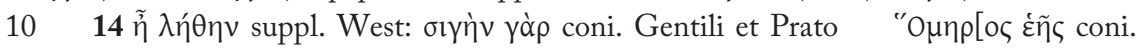

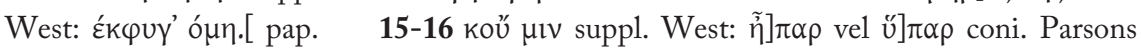
$\pi \alpha v \delta \alpha \mu \alpha \alpha[\tau \omega \rho$ suo arbitrio coni. West: fort. $\pi \alpha \rho-$ vel $\pi \alpha o-$ haud $\pi \alpha v$ - Parsons, Haslam,

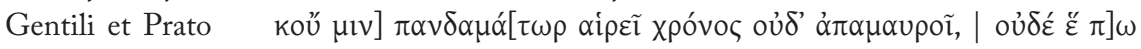

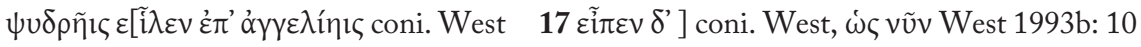

em confronto com Homero (cf. pp. 280-283, 286). Recorde-se que Sólon terá interpelado Mimnermo no fr. $20 \mathrm{~W}$, propondo-lhe a alteração de um dos seus versos sobre a velhice, frisando deste modo o seu distanciamento de uma perspectiva extremamente pessimista acerca da existência humana. Vide o comentário de Leão 2001: 438-439. 
Enquanto um mortal possui a flor muito amada da juventude, de ânimo leve planeia muitas coisas que ficam por cumprir, pois nem espera envelhecer nem morrer, nem, quando é saudável, cuida da doença.

Tolos os que assim pensam! E nem sabem como o tempo da juventude e da vida é breve

para os mortais. Mas tu, que aprendes isto no termo da vida, sê paciente, deleita a tua alma com o que é bom.

... aprecia [a palavra de um homem mais] velho.

[Ao esquecimento] escapou a voz de Homero (?)

[e não o agarra o tempo] que tudo vence (?) [nem o apaga,] [nem ainda o acusou] de falsidade... (?)

... em festas...

Das vinte linhas que constituem o fr. eleg. 20 citamos apenas as que se encontram em melhor estado de conservação ${ }^{92}$. Podemos distinguir neste passo dois momentos, sendo o primeiro o que se prolonga até à pausa do v. 11. A metáfora floral do v. 5 remete-nos de algum modo para o último verso do fr. eleg. 19, mas no estado actual dos nossos conhecimentos não temos nenhuma prova de que aqueles versos correspondiam ao início de uma composição elegíaca de Simónides ${ }^{93}$. A nossa leitura leva-nos a crer que esta hipótese pode ser uma via razoável, pois no presente fragmento surge também a ideia de que $\dot{\varepsilon} \lambda \pi$ rí é um apanágio dos jovens, esclarecendo-se agora o sentido, positivo ou negativo, que o poeta lhe atribui. A esperança é traiçoeira e a sua posse ( $\left.{ }^{\prime} \chi \chi \varepsilon l\right)$ corresponde, de facto, a um estado de cegueira mental (vv. 6, 8). A expressão dos vv. 7-8 é dominada pela formulação negativa e o emprego insistente do verbo है’ $\chi \omega$ (vv. 5, 6, 7, 8) traduz um confronto entre o que o homem possui - a juventude, o espírito ligeiro - e o

${ }^{92} \mathrm{Na}$ tradução destes fragmentos e dos que comentaremos a seguir incluímos as propostas de reconstituição de Parsons 1992 e West 1992a. Em relação aos vv. 1-4, vale a pena citar a

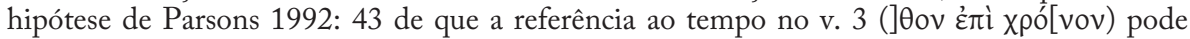
ser uma antecipação do tema do v. 10: a vida é curta, mas os jovens não vêem isso. Hubbard 2001: 231 supõe, com base na comparação com os fragmentos de Semónides e de Mimnermo, que os versos perdidos contivessem uma lista dos males que prejudicam os homens. Para a reconstituição dos vv. 17-19, vide West 1993b: 10-11. Ainda sobre este assunto, cf. Sider 2001b: 279-280.

${ }_{93}$ Sendo o primeiro verso do fr. eleg. 19 um pentâmetro, supõe-se que Estobeu tenha omitido o início do poema, o que fez por outras vezes (Sider 2001b: 275 e n. 4). Mas o facto de o verso principal do símile homérico ser um hexâmetro condicionou, certamente, a formulação de Simónides. Todavia, a confirmar-se a sugestão de West 1993b: 10-11 de que o fr. eleg. 19 não antecedia, mas antes se sucedia ao fr. eleg. 20, o pentâmetro inicial fica plenamente justificado. Para uma crítica à sugestão de West, vide Rutherford 2001a: 50, Sider 2001b: 279 e n. 14. 
que lhe falta - o bom senso, a capacidade de reflectir - quando a esperança ocupa o seu lugar (vv. 6-8).

O adjectivo vท́ $\pi$ los designa, em sentido literal, uma criança que ainda não é capaz de falar ('infante': e.g. Il. 2. 136, 9. 440). Quando aplicado a um jovem ou adulto funciona como uma censura, por alguém ter agido sem pensar (e.g. Il. 2. 38, 8. 177) ${ }^{94}$, sentido que está de acordo com o deste passo. É nos vv. 9-11 que a reflexão do poeta atinge o seu momento mais alto e a ideia mais importante deste primeiro momento - a brevidade do tempo de juventude

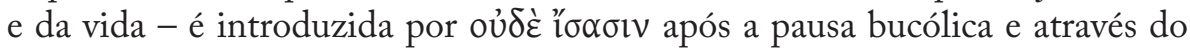
enjambement que se prolonga no verso seguinte. A insistência do poeta na falta de bom senso do homem jovem (vv. 6, 8 e, sobretudo, 9) traduz-se, ao nível do discurso poético, no predomínio de uma racionalidade cuja consequência mais evidente é a escassez de termos ornamentais. A excepção parece ser o epíteto

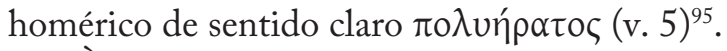

À reflexão pessimista acerca da brevidade da vida humana opõe-se o tom apologético e hedonista que parece distinguir o segundo momento do fragmento, cujo sentido, infelizmente, não nos é possível apreender com exactidão, dado o estado precário em que se encontra. A nível formal, $\dot{\alpha} \lambda \lambda \alpha_{\alpha}$, logo a seguir à pausa inicial do v. 11, assinala um contraste que é notório, pelo menos inicialmente. De facto, o poeta começa por salientar a capacidade de aprender do seu interlocutor $(\mu \alpha \theta \omega ́ v)$, porque é alguém que já atingiu a maturidade. O conselho que profere (v. 12, o último da citação de Estobeu), no entanto, já não apela tanto às capacidades intelectuais, mas antes às emoções. Esta diferença na orientação ideológica do poema sugere que nos versos seguintes, eventualmente, o poeta faria o elogio da poesia, retomando, por exemplo, o velho tema de Hesíodo (Th. 55) de que através dela os homens suportam mais facilmente as suas angústias e preocupações. Trata-se apenas de uma hipótese. $\mathrm{Na}$ verdade, o verbo $\varphi \rho \alpha ́ \zeta \omega$ (v. 13) tem aqui o sentido de 'pensar', 'reflectir', 'considerar' e inscreve-se, portanto, no domínio do intelectual. A descoberta papirológica revelou, como observa West 1992a: 123 no aparato crítico ao v. 12, que o poema de Simónides era mais extenso do que a citação de Estobeu permitia supor. No entanto, Parsons 1992: 6, tendo em consideração certamente o testemunho da tradição literária, põe a hipótese de os vv. 12-13 constituírem "talvez uma transição entre poemas" (cf. p. 44) ${ }^{96}$. Em nossa opinião, porém, a sucessão das formas de imperativo nos vv. 12 e 13

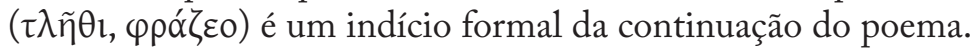

\footnotetext{
${ }^{94}$ Sobre o sentido de vท́ं $10 \varsigma$ nos Poemas Homéricos, vide Susan T. Edmunds, Homeric Nepios (New York-London 1990).

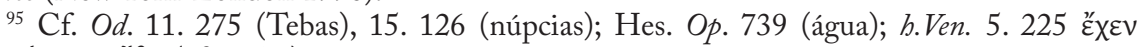

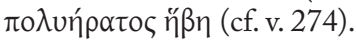

${ }^{96}$ Hubbard 2001: 230 pondera também esta hipótese.
} 
$\mathrm{Na}$ reconstituição do segundo hemistíquio do v. 13, West 1993b: 10

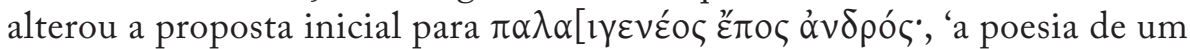
homem há muito tempo nascido'. Embora não muito divergente quanto ao sentido, $\pi \alpha \lambda \alpha$ lүعvń ć um epíteto homérico aplicado a Fénix (Il.17.561) e a Euricleia $(O d .22 .395)$. Esta conjectura vai ao encontro da reconstituição que o mesmo filólogo propõe para o verso seguinte e diminui as hipóteses de uma referência do sujeito poético no v. 13, o que podia ter importância para o estabelecimento do contexto de produção do poema. Por outro

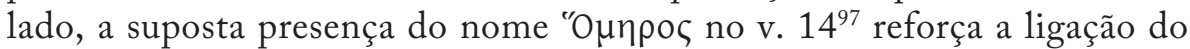
presente fragmento ao fr. eleg. $19^{98}$, e pode ser relevante no que respeita à problemática sobre a identificação do 'aedo de Quios' e a autoria do Hino Homérico a Apolo (cf. Burkert 2001: 217 e supra, pp. 36-37). De acordo com a reconstituição de West, ao evocar Homero no seu poema, Simónides desenvolvia possivelmente o tema, que terá longa fortuna (cf. Hor. Carm. 3. 30. 1), da pervivência da palavra poética (v. 15), apelando ao exemplo do grande épico do passado, que tem como objectivo último sublinhar a importância do seu ofício junto do seu patrono: só o canto permite a preservação da memória dos homens face à incombatível passagem do tempo. Mas a suposta reivindicação da veracidade da sua palavra (cf. v. 16) pode também ser uma réplica ao provérbio citado por Sólon $\pi 0 \lambda \lambda \dot{\alpha}$

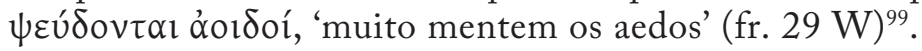

Tendo em consideração que West 1992a: 123 integra os frr. eleg. 19 e 20 na secção dos carmina convivalia, o contexto mais adequado à sua execução seria um banquete, eventualmente de um patrono. A apóstrofe

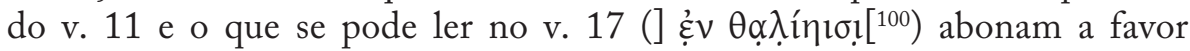
desta hipótese, bem como a temática tratada: não há referências divinas, mas apenas a condição humana no que ela tem de mais característico, o idealismo da juventude e a brevidade da vida. No entanto, como Sólon também havia notado (cf. fr. $18 \mathrm{~W}$ ), a idade não tem apenas aspectos negativos: é com ela que o homem adquire bom senso e desenvolve a sua capacidade de pensar. No comentário a um passo da Física, no qual Aristóteles afirma que 'alguns

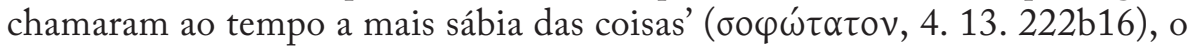
filósofo Simplício (séc. VI d.C.) informa que o autor de tal declaração fora

\footnotetext{
${ }^{97}$ Esta reconstituição é aceite por Burzacchini 1995: 34 e Sider 2001b: 274 n. 3. Cf. Parsons 1992: 44.

${ }^{98}$ De acordo com a análise de West 1993b: 10-11 (vide supra, n. 93), que não seguimos na nossa leitura, esta relação torna-se ainda mais evidente.

${ }^{99}$ Cf. Sider 2001b: 280. Embora não aceite totalmente a reconstituição de West, conjectura que Homero é evocado, no início do poema, pelas suas palavras acerca da efemeridade da vida humana e, no fim, como exemplo de algo que desafia esse facto.

${ }^{100}$ Geralmente empregue no plural, $\theta \alpha \lambda$ í $\alpha$ designa o banquete festivo em que não falta a execução de poesia (cf. Od. 11. 603; Hes. Th.64-65, Op. 115).
} 


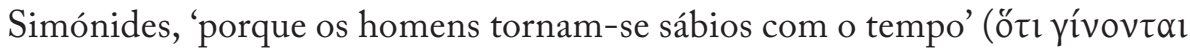

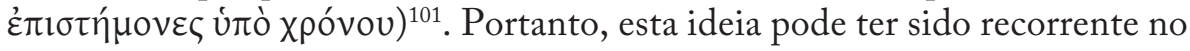
pensamento do poeta.

Em conclusão, embora tenhamos consciência de que nos movemos num espaço de grande incerteza, no estado actual dos nossos conhecimentos julgamos que os frr. eleg. 19 e 20 devem ser considerados um testemunho de que o poeta criou composições em dísticos elegíacos destinadas a serem executadas durante o banquete dos seus patronos ${ }^{102}$. Não obstante todas as dúvidas que persistem, estes dois fragmentos sugerem duas ideias sobre o carácter e a obra de Simónides: por um lado, que o poeta valorizou o conhecimento da épica homérica, a ponto de o proclamar nos fragmentos elegíacos e líricos (cf. fr. 564); por outro, que o pessimismo que predomina nas suas reflexões sobre a condição humana possa ser mais fruto dos incidentes da transmissão literária do que da sua maneira de pensar, como observou M. H. Rocha Pereira (1955: 63).

Fr. eleg. 21 P. Oxy. 2327 fr. $1+2$ (a) col. i. 3-9

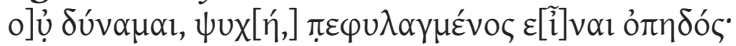

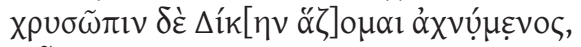

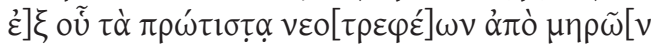

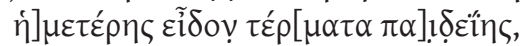

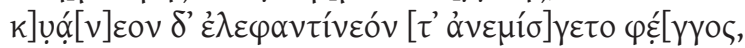

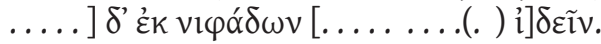

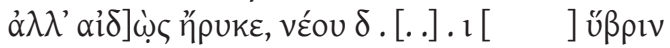

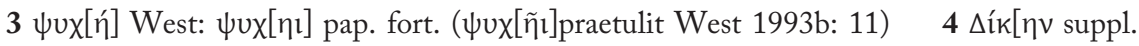

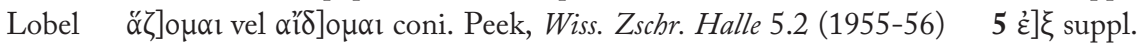

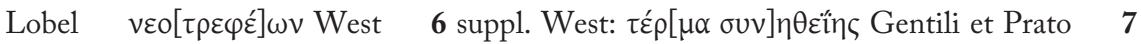

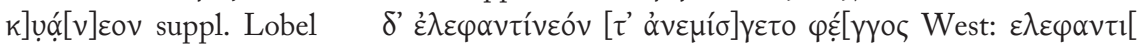

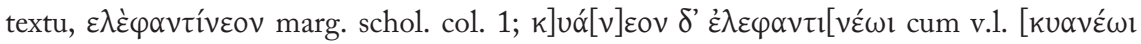

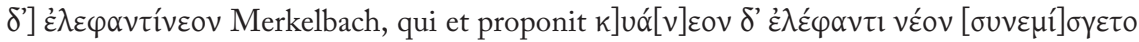

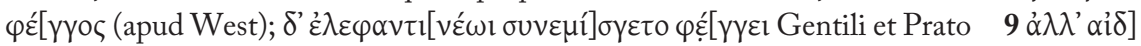

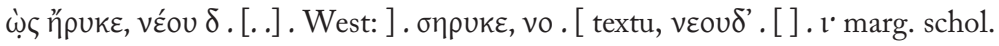

${ }^{101}$ Simp. in Ph. (Comm. in Arist. Graeca 9. 754 Diels = Simon. fr. 645, 140 P, 19 B). Uma das fontes deste comentário é Eudemo de Rodes, filósofo da segunda metade do séc. IV, do qual Simplício recolheu a informação de que 'em Olímpia Simónides louvara o tempo como a mais

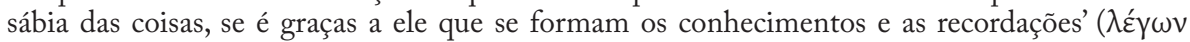

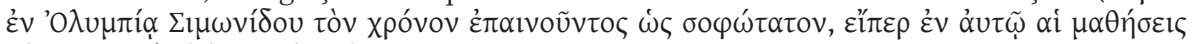

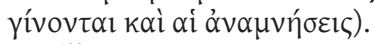

102 Para uma opinião divergente, vide Sider 2001b: 285-286. O investigador, embora não exclua completamente a possibilidade de uma execução simposíaca, analisa a hipótese de os frr. eleg. 19 e 20 pertencerem, como o fr. eleg. 11, ao poema sobre a batalha de Plateias, tendo em conta as semelhanças temáticas, designadamente a referência à imortalidade garantida por Homero aos guerreiros que perderam a vida em combate. Cf. Obbink 2001: 82-83, Rutherford 2001a: 50 e n. 81, Kowerski 2005: 109-145. 
Eu não posso, minha alma, ser o teu companheiro atento.

Mas a Justiça de olhos de ouro eu temo (?), com aflição, desde que nas minhas coxas juvenis

vi os primeiros limites da nossa meninice

e que o azul anil manchava o fulgor do marfim,

[e eu dizia] ver [a erva] por entre os flocos de neve...

[Mas o pudor] mantinha-me afastado, de um jovem... a insolência...

Desde a publicação em 1954, o presente fragmento, do qual citamos apenas sete das treze linhas que o compõem, tem suscitado as mais diversas leituras, o que se deve, antes de mais, ao estado precário em que se encontra, mas também à linguagem metafórica e ambígua que nele predomina, principalmente nos vv. 7-8. Actualmente, uma das leituras mais consensuais considera-o um exemplo único de paidikon ou poema erótico dirigido a um rapaz, destinado a ser executado num symposion ${ }^{103}$. Esta proposta de leitura é, de certo modo, surpreendente, tendo em conta a ausência de testemunhos sobre este tipo de composição e, a confirmar-se, como observa Catenacci 2000: 65, é mais uma prova da riqueza da personalidade poética de Simónides. A atribuição ao poeta, apenas sugerida por Lobel 1954: 67 (cf. Lobel 1981: 23), mas corroborada por Barigazzi 1963: 61, entre outros, tornou-se um dado definitivo com a publicação do P. Oxy. 3965, que revelou linhas comuns ao P. Oxy. 2327, como já foi dito (cf. West 1993b: 11).

Mais difícil de esclarecer é a relação entre este e o fr. eleg. 22, sugerida por razões paleográficas ${ }^{104}$, embora, como nota Barrigón 2002: 19, os filólogos prefiram fazer análises em separado. Esta questão relaciona-se, obviamente, com o sentido que cada investigador atribui ao texto preservado e um dos pontos que acolhe menos consenso é precisamente a identidade do sujeito poético do fr. eleg. $21^{105}$. Também não há unanimidade quanto à forma e

${ }^{103}$ Cf. West 1974: 167. 'It is evidently a love poem.' (West 1993b: 11), no qual o poeta desenvolve o tema 'estou apaixonado, mas contra a minha vontade' (cf. p. 12). Seguem esta linha de interpretação, com algumas divergências, Bartol 1999, Catenacci 2000, Barrigón 2002: 19-25.

104 Os frr. eleg. 21 e 22 integram linhas do mesmo papiro (P. Oxy. 2327) que se sucedem: P. Oxy. 2327 fr. 2 (a) col. i (fr. eleg. 21) e fr. 2 (a) col. ii + (b) (fr. eleg. 22). Parsons 1992: 33, 49 calculou uma lacuna com dez a vinte versos.

$105 \mathrm{Na}$ opinião de West 1993b: 11, identifica-se com o poeta. Assim também pensou Barigazzi 1963: 66. Para Bartol 1999: 27, o sujeito poético é um eromenos, o companheiro mais jovem numa relação pederástica, que perdeu o interesse pelo seu amante mais velho, o erastes. $\mathrm{Na}$ sua interpretação, o tema do fragmento é a relutância de um eromenos em cumprir os favores que o amante adulto the impõe. Catenacci 2000: 58, pelo contrário, considera que na poesia erótica deste teor a palavra poética pertence ao erastes, enquanto o eromenos é o destinatário do seu desejo e da sua paideia. 
ao sentido a atribuir a $\psi v \times \eta^{106}$, ainda que seja possível que o v. $3^{107}$ tenha como paralelo Thgn. 695, como West 1992a: 124 sugeriu inicialmente, com a diferença de que Simónides empregou, por motivos métricos, aquele termo em vez de $\theta u \mu \varepsilon ́$ (cf. Catenacci 2000: 61).

Se $\pi \varepsilon \varphi v \lambda \alpha \gamma \mu \varepsilon ́ v o \zeta$ tem aqui o sentido épico de 'prudente', 'atento' (Il. 23. 343; cf. LSJ), como observa Lobel 1954: 75, భvхท́ não parece designar 'vida' ou 'sopro da vida' (como nos Poemas Homéricos e no fr. 553. 2 de Simónides), mas antes a sede das emoções, dos desejos e dos afectos (cf. Anacr. fr. 360. 4 $P M G$, Simon. fr. eleg. 20. 12) ${ }^{108}$. Portanto, podemos surpreender nestes versos a expressão de um conflito pessoal entre o sujeito poético e a sua $\psi v \times \eta^{109}$, entre os seus desejos e o que, de facto, lhe é permitido fazer (o]ụ $\delta u ́ v \alpha \mu \alpha l)$, ainda que não seja muito claro que tipo de impedimento enfrenta. A obediência ao código social que regulamenta uma relação homoerótica é uma possibilidade, dada a

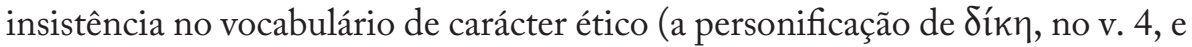

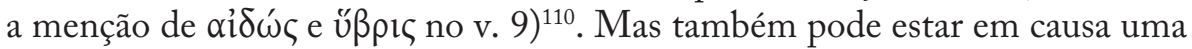
incapacidade física, designadamente a idade avançada do sujeito poético ${ }^{111}$, se

106 Quando publicou a nova edição dos fragmentos elegíacos, West propôs a forma de vocativo do singular, mas em 1993b: 11 n. 23 observou que, além de razões de ordem

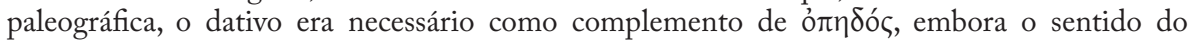
verso não fosse grandemente afectado com esta alteração. Para uma opinião divergente, vide Catenacci 2000: 61. Bartol 1999: 28 seguiu a sugestão de J. Danielewicz e optou pelo acusativo de relação dependente de $\pi \varepsilon \varphi u \lambda \alpha \gamma \mu \varepsilon ́ v o \zeta$. Catenacci 2000: 59 verificou, no entanto, que não é talvez exacta a existência de espaço no papiro para um dativo ou acusativo e, na ausência de certezas paleográficas, prefere o vocativo.

${ }^{107}$ West 1992a: 124 assinalou, com reservas, o início do poema neste verso (cf. West 1974: 167), baseando-se apenas no seu sentido. Nas palavras de Parsons 1992: 6, é tentador reconhecer um primeiro verso no v. 3, opinião de que também partilham Burzacchini 1995: 34 e Bartol 1999: 26. A conclusão diferente chegou Rutherford 2001a: 51, ao observar que no papiro não há nenhuma indicação de um espaço entre esta terceira linha e a anterior.

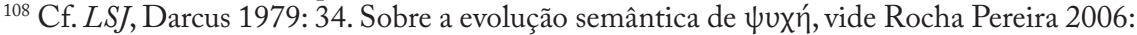
248-249.

${ }^{109}$ Sobre esta oposição, vide Darcus 1979: 36, 38-39, que aponta Pind. Pyth. 3.61 como possível paralelo desta passagem.

${ }^{110}$ Como observa N. R. E. Fisher, Hybris. A Study in the Values of Honour and Shame in Ancient Greece (Warminster 1992) 201, os participantes no banquete "were in constant danger of falling into bybris". Nas suas palavras, este é o termo "for a variety of damaging and insulting acts that it can be a general term for wickedness and the opposite of dike." Sobre o binómio bybris/ dike, o seu papel em contexto simposíaco e neste fragmento, vide Bartol 1999: 28, Catenacci 2000: 64, Barrigón 2002: 24-25.

${ }^{111}$ Esta linha de interpretação é explorada por Catenacci 2000: 59, que aponta entre as possíveis causas da "impossibilidade material da relação entre o poeta e o rapaz" a idade avançada do erastes, tema que Píndaro tratou no encómio para Teóxeno (fr. 123 Ma.), ou antes a idade adulta do eromenos. Por conseguinte, a hybris é a violação das normas da idade justa e dos papéis numa relação pederástica, o tema do fr. 25 W de Sólon, que Barrigón 2002: 23 considera "o antecedente mais directo do texto de Simónides". Sobre o fragmento do legislador ateniense, vide o comentário de Leão 2001: 441-442. 
lermos nos vv. 5-8 não apenas uma referência ao amadurecimento sexual, mas antes uma evocação nostálgica da primavera da vida, uma forma subtil de falar da brevidade da existência humana. O estado de conservação do fragmento e a sua curta dimensão não permitem grandes conjecturas.

O carácter metafórico da linguagem do fragmento é, no entanto, uma evidência, sobretudo nos vv. 7-8. O reconhecimento dos primeiros sinais de puberdade é sugerido inicialmente por meio de um jogo cromático entre o escuro (da pelugem do corpo) e o esplendor do branco (da pele) e, em seguida, ilustrado pela imagem de sentido equivalente, mas de horizontes mais vastos, da erva que se vislumbra por entre os flocos de neve nos primeiros dias de Primavera. Como bem notou Barrigón 2002: 24, o cromatismo do passo estende-se à "personificação divina" da Justiça, à qual é aplicado o raro epíteto

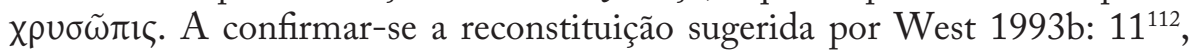
o presente fragmento é um belo exemplo do poder imagético da poesia de Simónides ${ }^{113}$.

Qualquer proposta de leitura, no estado actual dos nossos conhecimentos, é hipotética, como os estudiosos, em geral, têm o cuidado de sublinhar (cf. Bartol 1999: 26, Catenacci 2000: 57). Embora não seja a tendência mais seguida, não excluimos a hipótese de os frr. eleg. 21 e 22 estarem relacionados, questão a que voltaremos após a análise deste fragmento.

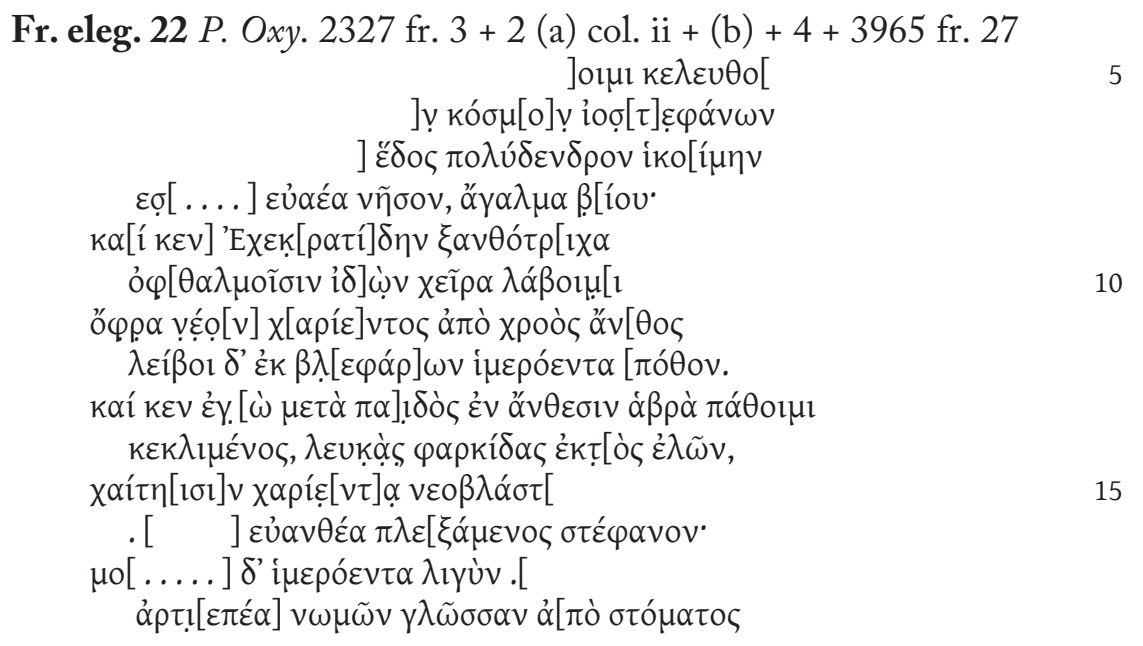

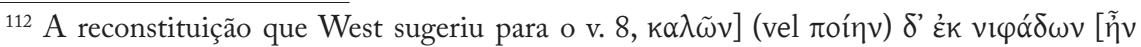

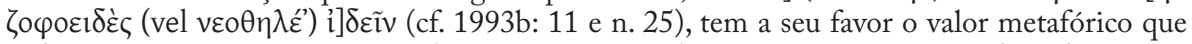

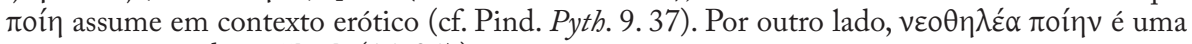
expressão atestada na Ilíada (14.347).

${ }^{113}$ Os vv. 7-8 são analisados com pormenor por Catenacci 2000: 62-64 e Barrigón 2002: 24. 


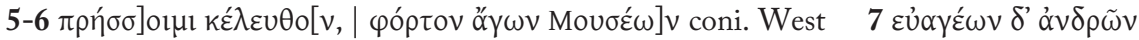

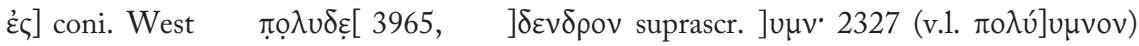

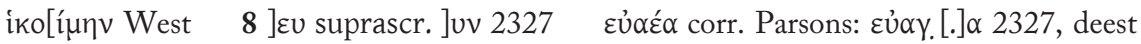

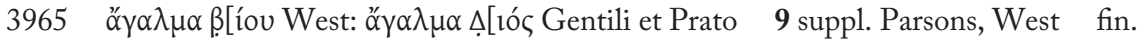

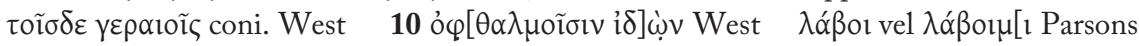

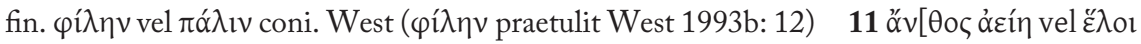

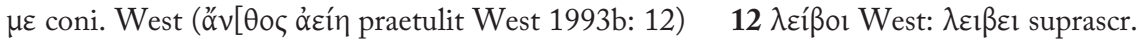

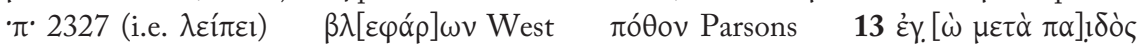

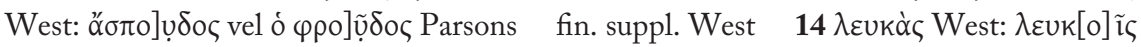

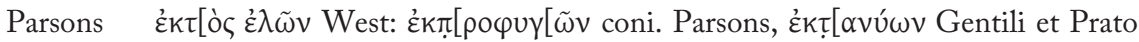

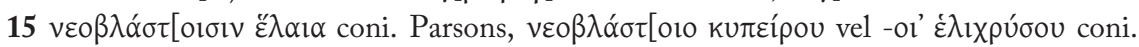

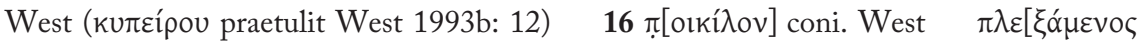

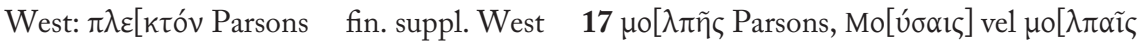

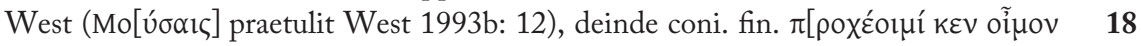
fin. suppl. West

...que eu possa fazer o caminho (?), [levando como fardo] um adorno [das Musas] de coroas de violeta,

e alcançar a morada [de homens íntegros], onde não faltam as árvores, ilha de bons ares (?)..., recompensa de uma vida (de Zeus?);

e quando virem Equecrátides de cabelos louros, [estes velhos] olhos, que eu possa dar-lhe a mão,

para que a tenra flor da graciosa pele

faça brotar dos seus olhos [o desejo] de sedução.

E oxalá eu [goze a ternura] de um jovem (?), entre flores reclinado, das brancas rugas despojado (?), com a graciosa [coroa] nos meus cabelos, entrançada de muitas flores da fresca [galanga?]

$\mathrm{E}$ hei-de [entoar um canto]... harmonioso e sedutor, adestrando a facunda voz [que de minha boca se solta...]

Transcrevemos catorze das vinte e uma linhas que formam o fr. eleg. 22, fruto da sobreposição dos P. Oxy. 2327 e 3965. Por este motivo, embora mais extenso do que o anterior, suscita igualmente muitas dúvidas e interpretações divergentes. Se as propostas de reconstituição de Parsons 1992: 7, 45-49 e de West 1993b: 12-14, nas quais se baseia essencialmente a nossa leitura, fundaram uma linha de análise que toma o presente fragmento como exemplo de composição adequada à execução num symposion ${ }^{114}$, a leitura singular de

${ }^{114}$ Parsons 1992: 49, "The extreme view would be this: The aged Simonides longs to escape (now, or after death), carrying his poetry, across the sea to the place of many trees, the Island of the Blest (Elysium), there to meet again the dead Echecratidas in all his desirable youth; they will join in the symposium; the wrinkled Simonides too will recover his youth." Na sequência desta interpretação, West 1993b: 13 sugere que o fragmento pertence a um propemptikon, dirigido a 
Yatromanolakis 2001, ainda que posta em causa por alguns estudiosos e severamente rejeitada por outros ${ }^{115}$, é uma prova da diversidade de sentidos a que o estado de conservação deste texto pode conduzir.

No âmbito do nosso estudo, o fr. eleg. 22 tem um interesse particular pela suposta menção no v. 9 do nobre Equecrátides, reconstituição que a comunidade científica em geral considera válida (cf. Parsons 1992: 47). Assim, independentemente do tema e do contexto em que foi executado, constitui um testemunho directo de que o poeta conviveu com membros das famílias reais da Tessália (cf. supra, pp. 160-161). Com estas palavras, não queremos dizer que interpretamos a referência onomástica como interpelação directa do poeta ao seu patrono. Não parece ser este, na verdade, o sentido que podemos depreender do fragmento, no estado actual dos nossos conhecimentos (cf. infra).

Nos versos transcritos distinguem-se quatro momentos, articulados por polissíndeto, evidente, pelo menos, no v. 13 (cf. v. 9). O emprego supostamente dominante do modo optativo, na primeira pessoa do singular

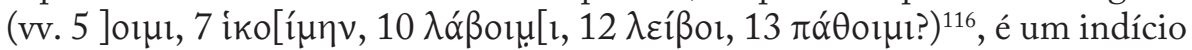
da possível natureza das acções descritas pelo sujeito poético: a expressão de uma intenção a cumprir num futuro próximo ou de um desejo que apenas se concretiza através da imaginação. A organização deste passo pode esquematizar-se do seguinte modo: vv. 5-8, intenção/desejo de realizar uma viagem a uma ilha paradisíaca, levando na bagagem a arte das Musas ${ }^{117}$; vv.

alguém da família de Equecrátides, e que na parte preservada o poeta se centra na descrição da viagem que ele pessoalmente gostaria de fazer: à ilha da felicidade, para ver Equecrátides de novo. A tese do propemptikon é explorada por Hunter 1993. Brillante 2000: 30-31 sublinha a inspiração erótica do fragmento, considerando tratar-se de um encómio composto para um jovem aristocrata, à semelhança do elogio que Íbico dirigiu a Polícrates (fr. 282 (a) $P M G$ ) e Píndaro a Teóxeno (fr. 123 Ma.). Na linha desta leitura, vide Mace 2001: 194-195, Gentili e Prato 2002: 205, García Romero 2004: 30-39.

115 Yatromanolakis 2001: 212 defende que o fr. eleg. 22 "may be part of a threnodic song sung by a woman or quoted by Simonides in the context of a broader threnodic composition" $\mathrm{e}$ considera não haver provas seguras de que o sujeito poético seja um homem (p. 211). A presença do nome Equecrátides no v. 9 sugere que essa mulher seja Díseris. Nas pp. 220-225 responde à crítica de Mace 2001: 203-207. Para uma revisão das duas leituras, vide A. Aloni, "A proposito di Simon. fr. 22 W. e Ael. Aristid. 31,2 K.”, Eikasmos 17 (2006) 69-73.

${ }^{116}$ A presença marcante do modo optativo resulta, em parte, das suposições dos editores, que nem todos os estudiosos aceitam. Parsons 1992: 46 observou que 5 ]ol $\mu$ pressupõe "um verbo optativo, e na primeira pessoa do singular", que é provavelmente essa a forma presente

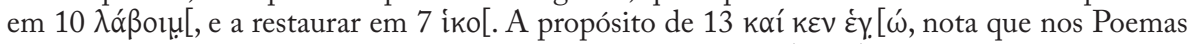
Homéricos esta expressão introduz normalmente o optativo (p. 48). Na p. 49 observa que a reconstituição proposta para os vv. 9 e 13 torna os optativos potenciais.

${ }^{117}$ Sentido que se baseia na proposta de West (que cita como paralelos Simon. fr. eleg. 11.23,

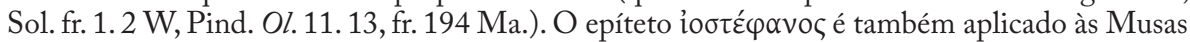
em Thgn. 250 e Bacch. 5.3. Cf. h.Ven. 6. 18, Sol. fr. 19. 4 W, Pind. fr. 76 Ma. Para a análise destas e de outras ocorrências, vide Jesus 2009: 45-51. 
9-12, intenção/desejo de aí encontrar Equecrátides e as delícias da sedução; vv. 13-16, intenção/desejo de amor e de rejuvenescimento (?) ${ }^{118}$; vv. 17-18, intenção/desejo de executar a poesia adequada ao ambiente de harmonia e sedução. Este último momento, incompleto, dado que é apenas constituído por dois versos e não quatro, como nos anteriores, denuncia um regresso ao tema da poesia mencionado no primeiro momento (tomando como plausível a reconstituição dos editores). Esta estrutura circular sugere, em nossa opinião, que a temática amorosa de teor homoerótico, que em geral os estudiosos tendem a valorizar, pode não ter sido o aspecto central da composição, uma vez que nos últimos versos citados a sedução do canto parece ocupar um lugar de maior relevo. É também nestes últimos versos que se revela a identidade do sujeito poético na identificação com o próprio

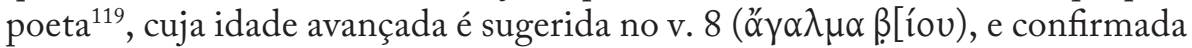

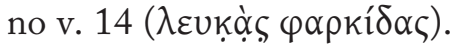

Se, por enquanto, não é unânime o sentido a atribuir à suposta viagem mencionada na abertura do passo transcrito (v. 5), com a qual se relacionam possivelmente as referências anteriores a $\theta \alpha \dot{\alpha} \lambda \alpha \sigma \sigma \alpha$, 'mar' (v. 1) e a Tópoc,'travessia' (v. 2) ${ }^{120}$, o lugar de chegada revela-se, de acordo com a reconstituição de West, uma 'morada [de homens íntegros] rica em árvores ${ }^{121}$ '

Parsons 1992: 45, perante a dificuldade em definir o sentido exacto de кó 'governo'; 'ornamento', fig. 'ornamento do discurso'; 'honra', cf. LSJ, Rocha Pereira 2006: 249252), embora não rejeite a reconstituição de West, propôs outras hipóteses: "Of a place, in this journeying context? - the sea, the glory of the Nereids, or the island, the glory of the Nymphs? somewhere glorified by the Muses (...)?”. Sobre este ponto, vide Mace 2001: 188-189.

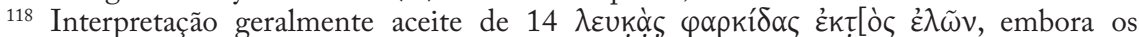
estudiosos apresentem diversas propostas para o final do verso (cf. Sider 2001a: 27). Se Parsons 1992: 49 nota, com razão, que não há provas de que os Bem-aventurados alcançavam o rejuvenescimento, embora reconheça que a ideia não é despropositada, Mace 2001: 194-195 observa que a imunidade à velhice é um dos topoi da tradição utópica, desde a 'Idade do Ouro' de Hesíodo aos Hiperbóreos de Píndaro (Pyth. 10. 41-42). D’Alfonso 2003 propõe um exame

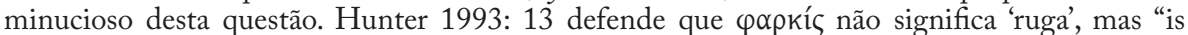
an otherwise unattested word for food of some kind". Para uma crítica a esta opinião, vide Burzacchini 1995: 35 e Poltera 1997: 272 e n. 43.

119 Parsons 1992: 46 começa por admitir, hipoteticamente, esta possibilidade: "the speaker (the poet?) is to meet someone...", mas na p. 49 é mais directo: a confirmar-se a referência no v. 9 ao chefe tessálio Equecrátides, a identificação entre a persona loquens e Simónides é mais plausível. Esta hipótese é aceite, com maior ou menor conviç̧ão, pela maioria dos filólogos. Cf. West 1993b: 12, Hunter 1993: 14, Brillante 2000: 30, Mace 2001: 189, Barrigón 2002: 26

${ }^{120}$ Cf. West 1993b: 13. Na interpretação de Parsons 1992: 46, esta viagem pode ser (a) real, (b) de evasão, ou (c) post mortem. Ainda que reconheça as dificuldades de uma escolha entre estas alternativas, privilegia as duas últimas. Nesta linha de análise se situa a tese de Mace 2001. Dela se distancia Brillante 2000: 35-37. Com base no estudo de W. J. Slater, "Symposium at Sea", HSPh 80 (1976) 161-170, sublinha a invulgar associação pontual entre uma temática familiar na poesia destinada ao banquete, a viagem (com a chegada a uma ilha remota), e o louvor (de natureza amorosa) de um jovem.

${ }^{121}$ Ainda que a sugestão de West seja verosímil, o epíteto عủă $ү$ ń , 'puro, sagrado', não está 


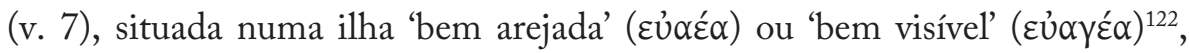
que é uma 'recompensa de uma vida' (v. 8). A conjugação destes elementos incentiva a ler neste passo uma possível crença numa existência feliz post mortem $^{123}$ ou, pelo menos, uma referência poética a um lugar ideal, como as

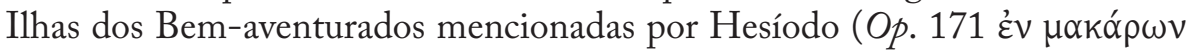

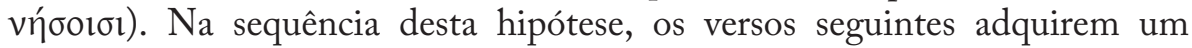
sentido muito particular. Equecrátides, provavelmente o pai de Antíoco e marido de Díseris ${ }^{124}$, beneficiou de um privilégio até então apenas reservado aos heróis ${ }^{125}$. Esta conjectura implica, no que diz respeito às circunstâncias de produção do poema, que a sua composição possa ter ocorrido muito depois da morte do aristocrata, inclusive quando o poeta já não se encontrava na corte tessália e teria, talvez, cerca de cinquenta anos. Vale a pena notar a raridade do

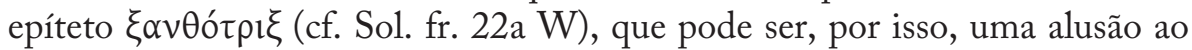
aspecto físico de Equecrátides. Mas a referência onomástica não pressupõe, em nosso entender, como pensam alguns investigadores, que este poema tivesse sido interpretado na presença da família do chefe tessálio ${ }^{126}$. Cremos que o contexto da sua execução, por enquanto, é uma incógnita ${ }^{127}$.

atestado na Época Arcaica (cf. LSJ). Cf. Eur. Ba. 1008.

${ }^{122} \mathrm{O}$ primeiro epíteto ocorre em Hesíodo (Op.599), o segundo em Píndaro (Pae. $7 \mathrm{~b} .47$ = fr. $52 \mathrm{~h} \mathrm{Ma}$.), aplicado à ilha de Delos ('far-seen or conspicuous', LSJ). As edições mais recentes dos

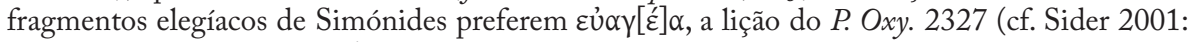
26, Gentili e Prato 2002: 11).

${ }^{123}$ Esta possibilidade é admitida por A. S. Brown, "From the Golden Age to the Isles of the Blest", Mnemosyne 51 (1998) 407, "It is unquestionably the case that the island evoked by the poet is a place of eschatological felicity, and that he can imagine one of his deceased contemporaries inhabiting such a region.", com uma importante ressalva: "There is no suggestion of esoteric doctrine here (...)". Barrigón 2002: 25, 30, sublinha no fr. eleg. 22 o "tema del recuerdo del amigo proyectado hacia un paisaje utópico o quizás escatológico", embora não desenvolva este aspecto.

${ }^{124}$ Esta é a opinião de West 1993b: 12, aceite por Rutherford 2001a: 51-52, mas não é consensual a identificação da personagem evocada no fragmento. Cf. Parsons 1992: 47, Mace 2001: 201, Brillante 2000: 32-33.

${ }^{125}$ A confirmar-se esta hipótese, poderíamos supor que desde Simónides se alterara a concepção de um Além feliz e tranquilo, apenas confinado aos heróis do mito. Parsons 1992: 49 chama a atenção para a canção de mesa (Carm. Conv. 894 PMG), que celebrava a sobrevivência de Harmódio nas Ilhas dos Bem-aventurados, junto de Aquiles e de Diomedes. Na mesma linha de pensamento, West 1993b: 12 afirma que o lugar evocado nos vv. 7-8 tem de ser "a Ilha (ou uma das ilhas) dos Bem-aventurados”. No entanto, Rocha Pereira 1955: 141 observa que o número daquelas ilhas foi sempre plural "como convém ao carácter vago desse lugar". Por outro lado, sendo vários os mitos de "terras longínquas" (ibidem, pp. 23-43), parece-nos preferível não avançar qualquer conjectura sobre a identificação da ilha paradisíaca referida neste fragmento.

${ }^{126}$ West 1993b: 13, pelo contrário, defende que o poema elegíaco foi seguramente dirigido ao filho de Equecrátides, Antíoco, ou a outro membro da família real de Larissa, e a sua composição teria ocorrido por volta de 490. Cf. Brillante 2000: 34, que aponta c. 500.

${ }^{127}$ Suscita-nos igualmente algumas dúvidas a identificação de Equecrátides, ao qual dizem respeito os vv. 9-12, com um suposto $\pi \alpha \tilde{i} \varsigma$ mencionado no v. 13 , bem como o sentido erótico 
Os vv. 10-16 encerram um núcleo temático característico da elegia amorosa, recorrendo o poeta a processos expressivos típicos, como a linguagem metafórica inspirada nas flores (v. 11), mas também a referência explícita ao desejo de sedução (vv. 12,17) e de rejuvenescimento (v. 14). Ao mesmo tempo, o poeta recria o ambiente característico de um banquete (cf. Xenoph. fr. 1 D-K), a ocasião adequada à execução deste tipo de poesia, com a evocação da companhia do eromenos (v. 13, uma suposição de West), da coroa de flores sobre a cabeça do conviva reclinado (vv. 14-16) e, principalmente, da presença da poesia ${ }^{128}$.

Tal como observou Barrigón 2002: 24, a propósito da linguagem do fr. eleg. 21, podemos dizer que na acumulação de epítetos do fr. eleg. 22 é evidente o equilíbrio entre tradição e inovação. Sendo particularmente descritivo, não é surpreendente a abundância de termos ornamentais. Notável é a combinação de formas épicas ${ }^{129}$ com outras novas, atestadas na elegia e na

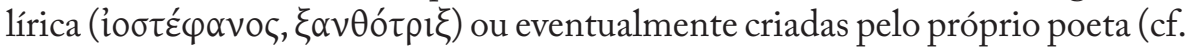

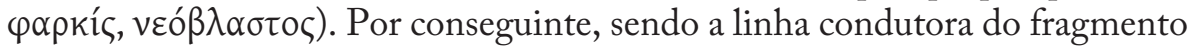
a evocação de uma viagem a um espaço de delícias, o desejo expresso nos vv. 17-18 concretiza-se, de facto, ao longo do texto preservado na descrição de um ambiente de harmonia e tranquilidade, propício à execução do ofício poético.

No que diz respeito a uma possível ligação dos frr. eleg. 21 e 22 aos restantes versos elegíacos revelados pelos P. Oxy. 2327 e 3965, as hipóteses de se chegar a alguma ideia definitiva são remotas, pelo menos por enquanto ${ }^{130}$. Todavia, Rutherford 2001a: 50 e n. 81 observa que há uma leve possibilidade de o fr. eleg. 21 pertencer ao poema sobre a batalha de Plateias (sublinhando que talvez o tema da justiça tenha ecos do fr. eleg. 11. 12). Pela nossa parte, suspeitamos de que o fr. eleg. 22 preserva apenas um momento (uma digressão do poeta?) de um poema mais extenso, cujo assunto poderia ser bastante

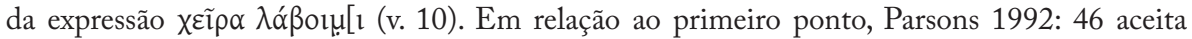
essa identificação (cf. Brillante 2000: 29-30). West 1993b: 13 inclina-se para a existência de

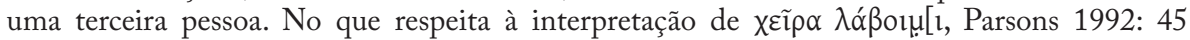
observou que a expressão pode significar: "A gesture of pledge (Il.6.233, 21. 286), reassurance (24. 671-672), welcome (Od. 3. 37), courtship (b.Ven. 5. 155) etc." De um modo geral, os investigadores consideram que é o último significado que está presente no fragmento de Simónides. Cf. Hunter 1993: 14 e n. 12, Brillante 2000: 30 e n. 4, Mace 2001: 193. Contra esta tendência, cf. Yatromanolakis 2001: 209 e n. 6.

${ }^{128}$ Nas palavras de Rocha Pereira 1955:144, as coroas de flores são "um símbolo característico da concepção helénica de felicidade”. Sobre o significado das referências ao ofício poético, vide a apreciação de Mace 2001: 196.

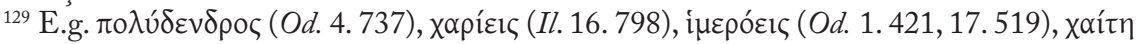

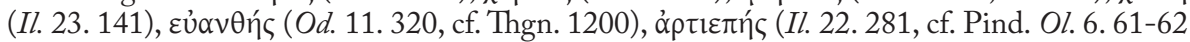

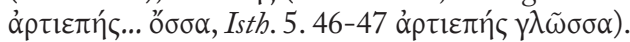

${ }^{130}$ Cf. Parsons 1992: 46, 49; Obbink 2001: 81- 85. A questão aqui enunciada é fundamental para o estudo de Kowerski 2005. 
diverso daquele que nos revela a parte preservada ${ }^{131}$. Por outro lado, a ligação ao fr. eleg. 21, que alguns especialistas ponderam como possibilidade ${ }^{132}$, não deve ser menosprezada, ainda que não passe de uma conjectura. Em ambos nos deparamos com a expressão, na primeira pessoa, do desejo de amor (homoerótico, provavelmente), e com o tema da idade avançada do sujeito poético (cf. Hunter 2001). A confirmação desta hipótese afectaria, por

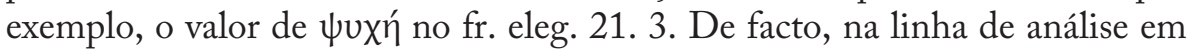
que se inscreve a nossa leitura do fr. eleg. 22, poderíamos supor que aquele termo é usado com o valor que tem nos Poemas Homéricos e que o sujeito poético não se dirige à sua $\psi v x \eta ́$, mas a alguém querido que se encontra agora num espaço distante e ideal. Trata-se, porém, de uma mera hipótese, como tantas outras que apresentámos nestas páginas.

${ }^{131}$ Esta ideia está bem presente na interpretação de West 1993b: 13. Vide supra, n. 114.

132 Cf. Catenacci 2000: 65 n. 28. Parsons 1992: 49, com base em West 1974: 167-168, admite, hipoteticamente, uma relação entre os frr. eleg. 21 e 22 . Todavia, posteriormente, West alteraria a sua posição. Em 1993b: 12, embora reconheça a proximidade paleográfica entre os dois fragmentos (vide supra, n. 104), considera que deverão pertencer a poemas diferentes. Esta é também a opinião da maior parte dos investigadores. Cf. Brillante 2000: 31 n. 5, Mace 2001: 186 n. 4. 
(Página deixada propositadamente em branco) 


\section{I.2. O ELOGIO DE UM ESFORÇO INDIVIDUAL: A GLÓRIA NAS COMPETIÇÕES DESPORTIVAS}

A dificuldade em organizarmos o nosso comentário a partir de critérios cronológicos levou-nos a seguir, à semelhança do capítulo anterior, a ordenação dos fragmentos estabelecida nas edições de Page 1962 e Campbell 1991. Do mesmo modo, os dados do aparato crítico foram recolhidos principalmente destas obras, bem como as citações em grego.

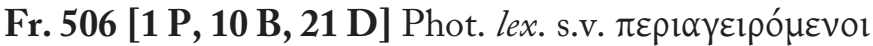

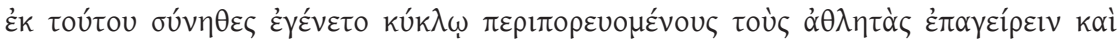

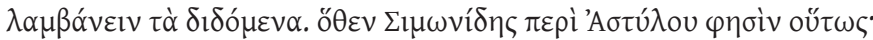

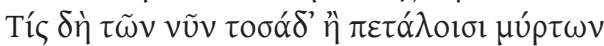

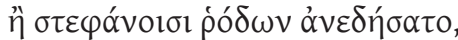

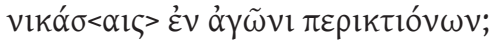

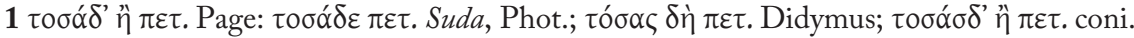

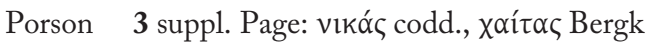

Por isso, surgiu o costume de os atletas andarem à volta, recolherem e aceitarem o que lhes era dado. É por essa razão que Simónides, a propósito de Astilo, diz assim:

Quem, de entre os homens de agora, tantas vezes se cingiu com folhas de mirto ou grinaldas de rosas, ao vencer numa competição das redondezas?

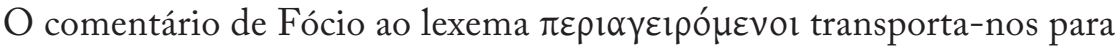
o ambiente festivo que se segue a uma competição desportiva, com a oferta de presentes ao vencedor. É esse momento do culminar da glória do atleta que o poeta parece evocar, possivelmente no início da sua ode. É natural que os versos seguintes contivessem a resposta ao pronome tíc e à oração interrogativa ou que essa informação fosse adiada, à semelhança do que acontece, por exemplo, na $I^{a}$ Olímpica de Píndaro, que apenas menciona Hierão no v. 11. Se Fócio nos transmitiu o incipit da ode, por meio da oração interrogativa e da conjunção coordenativa disjuntiva o poeta começava por sublinhar a rápida ascensão da carreira de Astilo, prova evidente da sua superioridade em relação aos demais atletas do seu tempo ${ }^{1}$. A ausência de

${ }^{1}$ Não parece haver dúvidas quanto à identificação do homenageado, que é confirmada por outras fontes que citam o fragmento. Cf. Page 1962: 238. 
adjectivação confere a estes versos uma certa austeridade, atenuada, todavia,

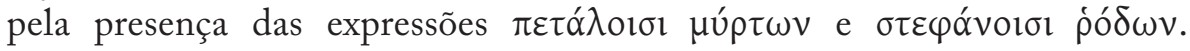
Recorde-se que Estesícoro mencionava as 'muitas folhas de mirto e grinaldas

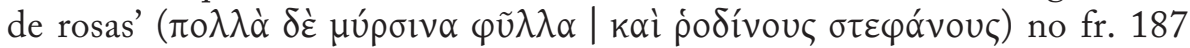
$P M G$, que pertencia talvez à descrição de um cortejo de casamento num poema sobre Helena (cf. Bowra 1961: 108), pelo que é natural que as duas plantas surgissem associadas a ambientes festivos (cf. Irwin 1984: 161-162). Embora as coroas de mirto fossem oferecidas em diversas competições

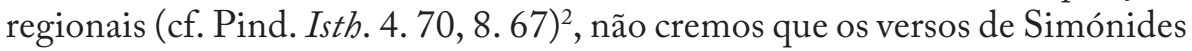
se refiram a uma ocasião precisa, mas apenas ao costume de os espectadores lançarem sobre o atleta vencedor coroas de folhas e flores ${ }^{3}$.

No comentário a este fragmento, Bowra 1961: 314-315 começa por sublinhar a jovialidade que parece ter iluminado os epinícios de Simónides, tão própria ao ambiente excitante da vitória, mas estranha à solenidade sentenciosa que domina as odes de Píndaro. Seguindo a lição de Diehl, segundo a qual

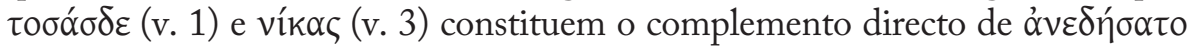
(v. 2), aquele helenista considerou o fragmento uma saudação, ligeiramente exagerada em seu entender, e uma homenagem elegante às vitórias de Astilo nas competições regionais (cf. $\pi \varepsilon p ı \kappa \tau \imath o ́ v \omega v)^{4}$. Depreende-se desta interpretação que o fragmento pertencia a um poema composto antes dos seus triunfos em Olímpia. Não cremos, porém, que estes versos permitam uma leitura tão definitiva. Simónides podia ter recordado as glórias alcançadas nas competições regionais e celebrar, na mesma ode, a ascensão de Astilo a atleta pan-helénico.

Ao mencionar a sua estátua em Olímpia, obra de Pitágoras de Régio, Pausânias informa que era natural de Crotona e havia obtido três vitórias consecutivas nas provas da corrida do estádio e duplo estádio (diaulos). Não dá indicações sobre as datas, mas observa que nas duas últimas competições Astilo se apresentou em Olímpia como siracusano, 'para cair nas boas graças de

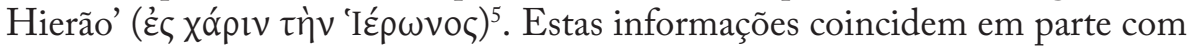

${ }^{2}$ Sobre os prémios dos Jogos, vide supra, pp. 141-142 n. 59. No comentário ao passo citado da $I V^{a}$ Ístmica, o escoliasta informa que os vencedores nos Iolaia eram coroados de mirto (apud Race 1997b: 171).

${ }^{3} \mathrm{O}$ costume da phyllobolia ou 'lançamento de folhas (ou pétalas)' aos vencedores é evocado num epinício de Píndaro datado de 474 (Pyth. 9. 124-125) e descrito num fragmento de Eratóstenes de Cirene (FGrHist 241 F 14). Cf. Finley and Pleket 1976: 30, Molyneux 1992: 216-217, Rausa 1994: 87.

${ }^{4}$ É esta a interpretação de West 1993a: 160 ('Which of the men of today has bound on his brows/ in myrtle leaves or wreaths of rose/ so many victories in regional competition?').

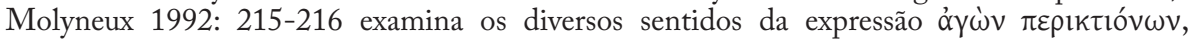
concluindo: "But the meaning which we have accepted, viz. local championships, remains the only probable one for this phrase when used without further definition." (p. 216).

${ }_{5}^{5}$ Paus. 6. 13. 1. Alguns comentadores julgam que Pausânias trocou o nome de Hierão, que só se tornou tirano em 478, pelo de Gélon (cf. Moretti 1957: 85), mas o Periegeta não 
os testemunhos de autores mais antigos. Dionísio de Halicarnasso menciona duas vitórias consecutivas no estádio, na $73^{\mathrm{a}}$ Olimpíada $(=488)$ e na $74^{\mathrm{a}}(=$ 484), em 8. 1.1 e 8. 77. 1, respectivamente. No primeiro passo é referido como crotoniata, no segundo como siracusano. Diodoro Sículo (11. 1. 2) situa na olimpíada seguinte outra vitória na mesma prova. Neste testemunho o atleta figura também como 'Astilo de Siracusa'. Supõe-se que seja esta a expressão que ocorre em duas linhas do P. Oxy. 222, que cobre os anos 480-

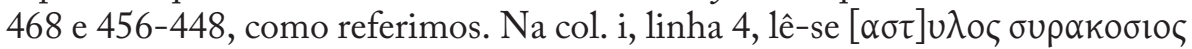

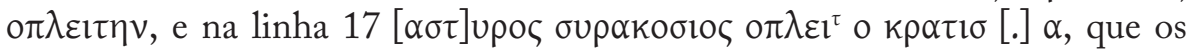

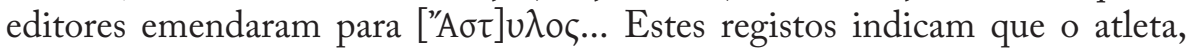
competindo como siracusano, venceu respectivamente em 480 e 476 a corrida de hoplitas.

O confronto dos testemunhos literários com os papirológicos não acolheu opiniões unânimes, mas parece indicar, pelo menos, que a carreira olímpica de Astilo se desenrolou entre os anos 488 e 476, um período que coincide com o da ascensão política de Hierão ${ }^{6}$. Se Simónides foi viver para a corte de Siracusa naquele ano de 476, como diz a tradição, certamente teria ouvido falar das proezas desportivas de Astilo. Mas também podia já conhecer a fama do atleta e até ter sido convidado a celebrar uma das vitórias anteriores.

\author{
Fr. 507 [2 P, 13 B, 22 D] Ar. Nu. 1355-1358 \\ $\Sigma \tau \rho \varepsilon \psi \iota \alpha ́ \delta\rceil \varsigma^{\circ}$

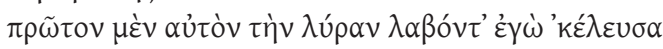

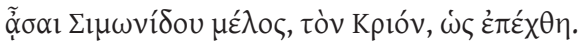

afirma explicitamente que Astilo pretendeu agradar ao tirano. Pausânias acrescenta que os habitantes de Crotona não apreciaram a atitude do atleta e vingaram-se, transformando

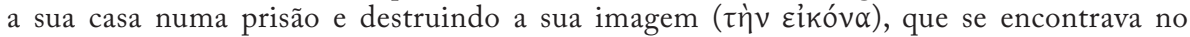
santuário de Hera Lacínia. Sobre esta história, em parte tratada por Calímaco (fr. 666 Pf.), cf. Podlecki 1979: 10-11, que suspeita da sua autenticidade. No entanto, a ser verdade, significa que Astilo, por volta de 480, já era honrado na sua terra natal, com direito a ter a sua imagem num santuário. Sobre o estatuto social deste atleta, vide Bernardini 1980: 94, Barrigón 1994b: 484-486.

${ }^{6}$ Como já referimos (p. 144 n. 64), Hierão foi regente em Gela entre 485-478 e tirano de Siracusa desde 478, vindo a falecer em 467/6. Segundo a interpretação dos editores do $P$. Oxy.

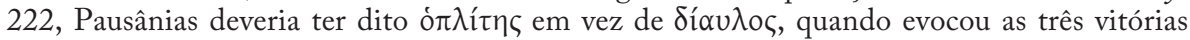
consecutivas alcançadas por Astilo em Olímpia (cf. supra). Por conseguinte, defendem que o atleta triunfou na corrida do estádio em 488, 484 e 480 e na prova de hoplitas em 484, 480 e 476 (Grenfell and Hunt 1899: 90). Moretti 1957: 90 discorda da emenda da linha 17, acima referida, e considera apenas uma vitória na corrida com armas. Outros estudiosos, em nosso entender com mais razão, acreditam na validade de todos os testemunhos. Assim, Astilo teria triunfado no stadion e no diaulos em 488, 484 e 480. Neste ano e na olimpíada seguinte (476) obteve ainda a vitória na corrida de hoplitas. Esta é a posição de Campbell 1991: 369, Barrigón 1994b: 484. Para a análise das fontes, cf. Podlecki 1979: 11-12, que se distancia desta interpretação, e em especial Molyneux 1992: 118-220, que trata o assunto com grande detalhe. 


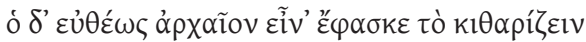

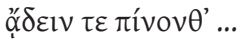

Estrepsíades:

eis que eu the pedi que pegasse na lira e cantasse uma ária de Simónides, aquela em que Crio, o Carneiro, era... «tosquiado». Ele, porém, veio-me logo com o argumento de que já tinha passado de moda essa coisa de tocar cítara e cantar enquanto se bebia... ${ }^{7}$

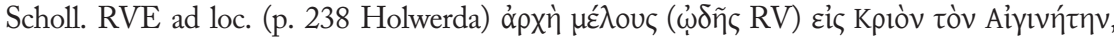

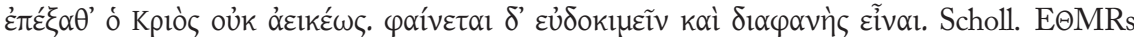

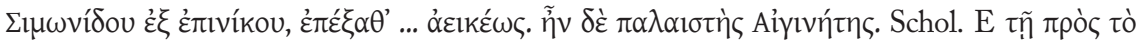

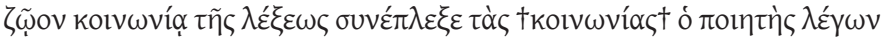

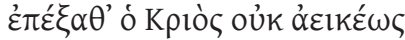

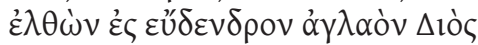

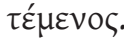

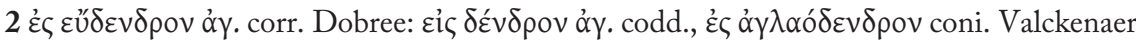
(apud Poltera 1997: 372)

Scholl. RVE: Início de uma canção sobre Crio de Egina, 'Tosquiou-se Crio não sem decoro'. Parece ter grande fama e ser notável. Scholl. E⿶MRs: De um epinício de Simónides, 'Tosquiou-se... sem decoro'; era um lutador de Egina. Schol. E: O poeta combinou a associação do nome com a associação ao animal, dizendo

Tosquiou-se Crio não sem decoro, quando se dirigiu ao bem arborizado esplêndido santuário de Zeus.

Depreendemos das palavras de Estrepsíades que o poema lírico de Simónides sobre Crio de Egina ficara na memória dos Gregos e era ainda conhecido nos finais do séc. $V$, pelo menos em Atenas. Este passo da comédia aristofânica testemunha também que, após a morte de Simónides, as suas composições corais continuavam a ser entoadas nos symposia, como canções de mesa, com acompanhamento musical.

Os escólios informam que os versos preservados constituem o incipit de um epinício ${ }^{8}$ e que Crio era um lutador de Egina, mas não esclarecem se a ode foi composta em sua honra. É evidente, como observa um dos escoliastas, que o poeta criou um jogo de palavras entre o verbo $\pi \varepsilon ́ \kappa \omega$, 'pentear, cardar',

${ }^{7}$ Tradução de Custódio Magueijo, in Silva e Magueijo 2006: 441.

${ }^{8}$ A validade desta informação não é contestada pelos estudiosos. Embora a aceite, Molyneux 1992: 62 n. 99 levanta a hipótese de o fr. 507 ter pertencido a um poema satírico, de género indeterminado, que abriria com uma referência à derrota atlética de Crio, escrito para um patrono ou público ateniense. Esta hipótese não é apoiada nem pelo texto de Aristófanes nem

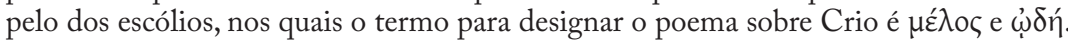


'tosquiar', e o nome do atleta ('Carneiro'), introduzindo no poema uma nota humorística que confirma a observação de Bowra sobre o carácter prazenteiro dos epinícios de Simónides (cf. supra, p. 240) ${ }^{9}$.

A definição do papel exacto que Crio terá ocupado neste poema suscitou em particular a atenção dos comentadores. Nas suas análises predominam duas perspectivas: uma que privilegia a exegese literária, designadamente o estilo que o poeta revela nos epinícios; uma outra que alarga este estudo às circunstâncias históricas e políticas em que o poema pode ter sido composto.

De um modo geral, os investigadores admitem que Crio de Egina é o político resistente de que fala Heródoto no Livro $\mathrm{VI}^{10}$. No início do séc. V, os Eginetas, entre outros ilhéus, forneciam terra e água a Dario, seguindo uma estratégia política que visava provavelmente salvaguardar as relações comerciais. Com o pretexto de que o povo de Egina, ao agir desta forma, traía a Grécia, os Atenienses instigaram Cleómenes a prender os principais responsáveis por esta política (§ 49). Quando o rei de Esparta enfrentou os Eginetas, deparou-se principalmente com a resistência de Crio, filho de Polícrito. 'Ao retirar-se de Egina, Cleómenes perguntou a Crio como se chamava. Quando este lhe respondeu, Cleómenes avisou: «Reveste desde já, carneiro, os teus chifres com bronze, pois terás de afrontar um grande perigo.» $(\S 50.3)^{11}$. Quando mais tarde os reis de Esparta marcharam de novo contra os Eginetas, estes decidiram não resistir. Escolheram os dez homens mais notáveis, entre os quais se encontrava Crio, e enviaram-nos como reféns a Atenas (§ 73). $\mathrm{Na}$ sequência da morte de Cleómenes, no final do ano 491 ou um pouco mais tarde, os Eginetas tentaram recuperar em vão os compatriotas retidos na Ática, e a recusa de Atenas suscitou novas hostilidades entre as duas cidades ( $\$ 85$ sqq.). Heródoto não volta a mencionar Crio, mas o seu filho distinguiu-se na batalha de Salamina (cf. 8. 92-93) $)^{12}$.

${ }^{9}$ A expressão દi̧ K Klóv pode ser entendida no sentido de 'em honra de Crio' ou, simplesmente, 'sobre, acerca de Crio'. Não há referência a uma vitória. Molyneux 1992: 48 e n. 80 menciona o comentário do gramático bizantino Tzetzes, segundo o qual Crio era um famoso lutador de Egina, cuja vitória em Olímpia foi celebrada numa ode de Simónides (Schol. in Aristoph. 4. 2,

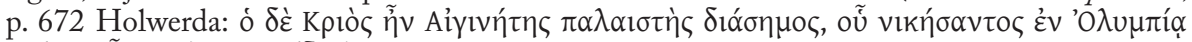

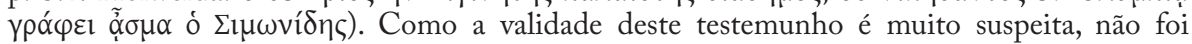
sequer considerado na edição de Page 1962. Para uma apreciação das variantes da tradição manuscrita, vide W. J. W. Koster, "Simonidis fr. 2 (507) Page in scholio Leidensi ad Ar. Nub. 1356”, Mnemosyne 19 (1966) 395-396.

${ }^{10}$ Cf. Page 1951: 142, Bowra 1961: 313, Molyneux 1992: 51. A faceta política de Crio de Egina não é mencionada nos escólios. Molyneux 1992: 62 n. 101 cita o testemunho de Eustátio,

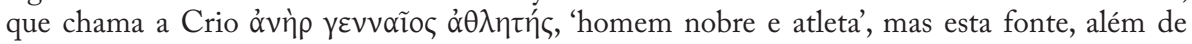
muito tardia, pode basear-se no texto de Heródoto.

${ }^{11}$ Tradução de Delfim F. Leão (2000: 83). Molyneux 1992: 49-50 observa que a réplica de Cleómenes é um indício de que os Gregos costumavam fazer trocadilhos com este nome, mas é possível que Heródoto tenha conhecido uma tradição que, eventualmente, remontava a Simónides.

${ }^{12}$ Não é consensual a datação dos acontecimentos relatados por Heródoto. Alguns 
De acordo com o relato de Heródoto, por volta de 491/490 Crio era considerado um inimigo político de Atenas. A ideia de prender os principais responsáveis pela política pró-persa partiu dos Atenienses, talvez de Milcíades, que então estava no centro das atenções, ou de Temístocles, que pode ter sido um dos estrategos eleitos em $490^{13}$. Portanto, se este é o Crio visado no fr. 507, é de supor que o epinício tenha sido composto em honra de um outro atleta, talvez de Atenas ${ }^{14}$. A fama de que gozava nesta cidade a 'canção sobre como Crio foi tosquiado' abona a favor desta hipótese ${ }^{15}$, bem como o facto de os atletas de Egina serem habitualmente celebrados por Píndaro e Baquílides ${ }^{16}$. A atender a estes dados, o poema de Simónides teria sido composto provavelmente entre a batalha de Maratona (ou um pouco antes deste conflito) e a de Salamina ${ }^{17}$. Mas as circunstâncias históricas e políticas têm de ser conciliadas com a análise literária, pois não está completamente posta de parte a hipótese de Simónides ter composto um epínicio em honra de Crio antes do virar do século, quando o poeta era convidado dos tiranos de Atenas ${ }^{18}$.

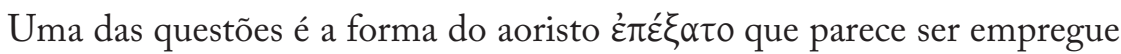
na voz média e daí a nossa tradução, 'tosquiou-se'. Alguns estudiosos chamam a atenção para o facto de no texto de Aristófanes o verbo ocorrer na voz passiva $(\varepsilon \dot{\varepsilon} \varepsilon \dot{\chi} \chi \emptyset \eta, \text { v. 1356 })^{19}$. Em nossa opinião, não é um argumento válido para

estudiosos defendem que ocorreram antes da batalha de Maratona (cf. Molyneux 1992: 52 e n. 105). N. G. L. Hammond, "The Expedition of Datis and Artaphernes", in J. Boardman et alii (edd.), The Cambridge Ancient History. Vol. IV (Cambridge 1988) 498, situa a morte de Cleómenes em Novembro de 491. Macan 1973 [1895]: I 342 considera que terá ocorrido após a batalha de Maratona. Para Molyneux 1992: 52 e n.106, a série de eventos relatados nos caps. 85 sqq. deve ser posterior a esta batalha, i.e., c. 487.

${ }^{13}$ Cf. Macan 1973 [1895]: I 308, Leão 2000: 83 n. 121.

${ }^{14}$ Molyneux 1992: 51, "We may therefore reasonably assume that his patron was an Athenian.”

${ }^{15}$ Huxley 1978: 240. Para Molyneux 1992: 51, este é um argumento importante a favor da tese de que a ode de Simónides era hostil a Crio. Na sua opinião, o motivo foi certamente a rivalidade entre Egina e Atenas, mais do que uma animosidade particular entre os dois homens.

${ }^{16}$ Cf. Pind. Ol. 8, Pyth. 8, Nem. 3, 4, 5, 6, 7, 8, Isth. 5 e 6; Bacch. 12 e 13.

${ }^{17} \mathrm{O}$ facto de Heródoto apenas mencionar Crio em 8.92 como pai de Polícrito e de nem sequer o referir no capítulo seguinte pode significar que já tivesse falecido. Wilamowitz defendeu que o epinício pertence ainda ao séc. VI. Bowra 1961: 312 sugeriu como data de composição o início do séc. V. Page 1951: 142 o período entre c. 491 e o transporte dos reféns para Atenas. Huxley 1978: 239-240 situa a composição do poema c. 490, observando ainda que o seu tom trocista se refere a um tempo em que o Egineta já não era prisioneiro na Ática, mas podia participar livremente em concursos atléticos. No entanto, segundo o relato de Heródoto, em 480 o seu filho comandava uma das trirremes no estreito de Salamina. Neste sentido, são pertinentes as observações de Molyneux 1992: 53 sobre as capacidades físicas de Crio nesta fase da sua vida, pois já não seria um homem muito jovem. Vide a sua discussão das datas possíveis do epinício, interpretado como hostil a esta figura, pp. 51-54.

${ }^{18}$ Crio estaria então na força da sua juventude.

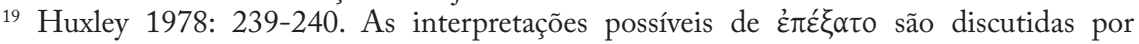


considerar que a forma verbal transmitida pelos escólios tem valor passivo. O sentido do verbo também não acolhe unanimidade. Em nossa opinião, a nota humorística que resulta do emprego de $\dot{\pi} \pi \dot{\xi} \xi \alpha \tau o$ seria inofensiva se Crio fosse o destinatário da ode, mas podia ser considerada um insulto, caso ele tivesse sido o atleta derrotado. Portanto, a aceitação da voz média mantém em aberto a identidade de $\mathrm{Crio}^{20}$. $\mathrm{O}$ valor passivo confere à forma verbal um sentido bastante diferente. A tradução mais correcta seria 'foi tosado', já que 'tosar' tem, mais do que 'tosquiar', o duplo sentido de 'cortar rente' e 'sovar'. Os defensores desta leitura consideram que o poeta não se refere à preparação do atleta, mas comenta o que aconteceu durante a sua exibição, a sua derrota, por exemplo ${ }^{21}$.

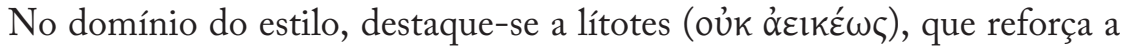
graça contida no emprego do verbo $\pi \varepsilon ́ k o \mu \alpha 1$, e a adjectivação dupla na perífrase pela qual se nomeia o local da prova, Olímpia ou Nemeia ${ }^{22}$. Surpreendente é a passagem repentina da nota cómica da primeira oração à solenidade religiosa que predomina na segunda. Mas talvez fosse esse o tom dos restantes versos do poema.

Em conclusão, a análise literária não permite esclarecer a natureza das relações entre o poeta e Crio. Parece evidente, no entanto, dada a dificuldade em se chegar a um consenso, que se confirma, pelo menos, o gosto de Simónides pelos equívocos verbais, pela ambiguidade e pelos jogos de palavras.

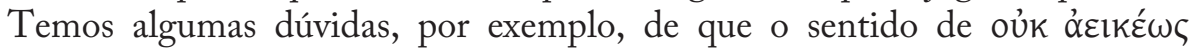
seja ironicamente ofensivo ${ }^{23}$. O facto de não podermos datar a ode e a curta dimensão do fragmento impedem-nos de chegar a uma conclusão definitiva. Mas não nos parece válida a recusa de alguns helenistas em aceitarem que $o$

\footnotetext{
Molyneux 1992: 48-50.

${ }^{20}$ Podlecki 1984: 184-185 reconhece que os comentários antigos não são explícitos, mas defende que há uma forte possibilidade de o epinício ter sido composto em honra de Crio. Embora não rejeitemos esta hipótese, não nos parece existirem provas de que o Egineta fosse patrono do poeta. Barrigón 1994a: 78, 1994b: 488, considera também que o fr. 507 pertence a um elogio de Crio.

${ }^{21}$ Com base no relato de Heródoto, Page 1951: 142 defende que Crio era o atleta derrotado pelo destinatário da ode de Simónides. Seguem esta leitura Bowra 1961: 313-314, Lesky 1995 [1971]: 216-217, Huxley 1978: 240, Molyneux 1992 (cf. supra n. 17), bem como West 1993a: 208. Para uma opinião divergente, vide o comentário ao fragmento por Fearn 2011: 204-211.

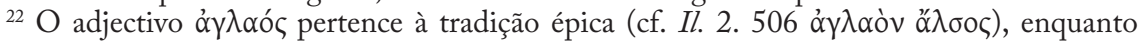

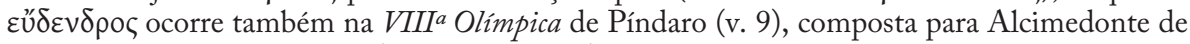
Egina provavelmente em 460 (Race 1997a: 134). Page 1951: 141, à semelhança de Wilamowitz, não parece ter dúvidas de que se trata do santuário de Nemeia. Sobre este assunto, vide Barrigón 1994a: 78, que supõe tratar-se do santuário de Zeus em Olímpia, como também defendeu Podlecki 1984: 185 .

${ }^{23} \mathrm{Na}$ opinião de Bowra 1961: 314, que considera o v. 1 do fr. 507 "a joke, 'the Ram was

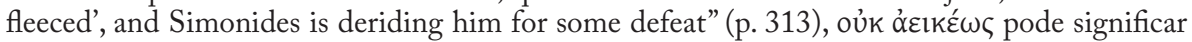
'not unnaturally', ou seja, que Crio teve exactamente o que mereceu.
} 
poeta não podia ter dirigido um cumprimento jocoso ao destinatário da ode. Todavia, se o epinício foi composto em honra do político de Egina retratado por Heródoto, julgamos que isso só poderia ter acontecido antes de a influência persa ter começado a minar as relações entre Atenas e Egina, portanto antes do findar do séc. VI, como pensava Wilamowitz.

\section{Fr. 509 [4 P, 8 B, 23 D] Lucian. pro imag. 19}

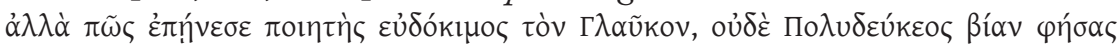

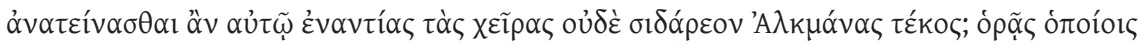

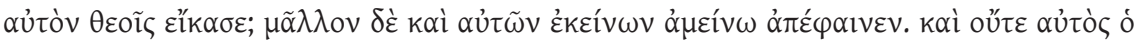

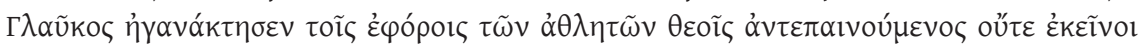

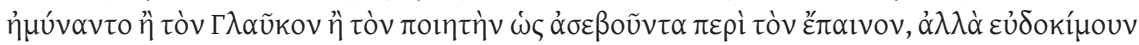

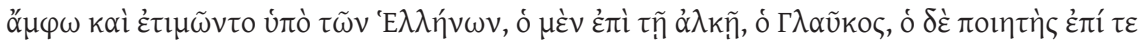

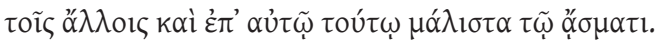

Poeta verba ita fere restituunt edd.:

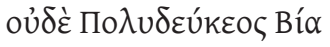

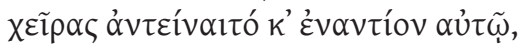

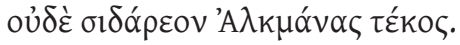

Mas como é que um poeta de renome celebrou Glauco, dizendo que nem a força de Polideuces podia ter levantado as mãos contra ele nem mesmo o férreo descendente de Alcmena? Sabes com que deuses o comparou? Aliás, ele mostrava-o melhor do que aqueles. E o próprio Glauco nem se irritou por ser louvado em confronto com os deuses que olham pelos atletas nem aqueles castigaram Glauco nem o poeta, por impiedade, por causa do elogio, mas ambos eram estimados e honrados pelos Gregos, Glauco pela sua força, o poeta por outros motivos e, em particular, por esta composição.

Os editores reconstituem as palavras do poeta da seguinte forma:

Nem a força de Polideuces

as mãos podia erguer contra ele

nem o férreo descendente de Alcmena.

Luciano, a escrever no séc. II da nossa era, conhecia provavelmente o reputado poeta que celebrou Glauco, mas não o nomeia ${ }^{24}$ e talvez nem tenha tido acesso directo à composição. Quanto à sua classificação genérica, os

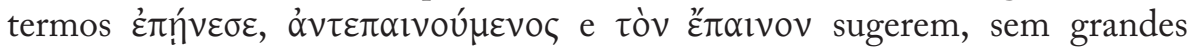
dúvidas, tratar-se de um epinício, composto em honra de um lutador (cf. ßíav, $\tau \tilde{\eta} \dot{\alpha} \lambda \kappa \tilde{n})$ que, não obstante o descomedido exagero do poeta, apreciou o seu trabalho, sublinha Luciano. O episódio que evoca, como exemplo de um elogio que recorre a uma comparação singular, pode remontar a uma tradição que

${ }^{24}$ Molyneux 1992: 34 considera que Luciano esperava que os seus leitores identificassem o poeta em causa. Na sua opinião, é mais razoável pensar-se em Simónides do que em Píndaro ou Baquílides. 
conhecemos graças a autores latinos, segundo a qual Simónides beneficiava de uma atenção especial por parte dos Dioscuros ${ }^{25}$. Como vimos na segunda parte, Quintiliano, que viveu no século anterior ao de Luciano, sublinha a grande incerteza quanto à identidade de um pugilista para quem Simónides havia composto um epinício, no qual havia dirigido grandes louvores a Castor e Polideuces/Pólux (Inst. 11. 2. 14 = fr. 510, supra pp. 162-163). Entre as hipóteses avançadas, figura à cabeça Glauco de Caristo. Apesar dos aspectos em comum (epinício para um pugilista, evocação dos Dioscuros e menção do nome Glauco), não se trata da mesma composição, pois a questão central da história recordada por Quintiliano é que o atleta celebrado não apreciou o trabalho e se recusou a pagar a soma acordada ${ }^{26}$. Todavia, o testemunho do autor latino atesta a existência de uma tradição - não muito sólida, sublinhe-se - que atribuía a Simónides a composição de um epinício em honra de Glauco de Caristo ${ }^{27}$.

As questões que se colocam dizem basicamente respeito às circunstâncias de produção do poema e ao universo axiológico e literário de Simónides: há alguma possibilidade de o poeta ter celebrado este atleta em alguma altura da sua vida? Qual era, de facto, o papel de Polideuces/Pólux e de Héracles neste elogio?

De um modo geral, aceita-se que o testemunho de Luciano diz respeito a uma vitória obtida pelo atleta na $65^{\text {a }}$ Olimpíada $(=520)^{28}$, na prova de boxe

${ }^{25}$ Esta hipótese foi equacionada por van Groningen 1948: 7 n. 14.

${ }^{26}$ Cf. Rose 1933: 166. Bowra 1961: 312 aponta um outro argumento, pouco sólido na nossa opinião: "A poem whose subject was so disputed cannot be the same as that which Lucian knew as praising Glaucus." Não nos parece válida a hipótese de Molyneux 1992: 38 e 41, que deduz do diferente tratamento do mito dos Dioscuros, a que aludem os testemunhos de Quintiliano e de Luciano, a existência de dois epinícios de Simónides dedicados a Glauco (de Caristo?). Cf. Fontenrose 1968: 101-102.

${ }^{27}$ Os filólogos dividem-se na exegese deste testemunho: Quintiliano diz que existia uma ode, na qual Simónides elogiava os Dioscuros, e a dúvida residia na identificação do destinatário, ou quatro odes, para diferentes patronos (Glauco, Leócrates, Agatarco e Escopas), todas contendo o elogio daqueles heróis, e o desentendimento dos autores antigos residia em saber qual delas havia suscitado o gesto de gratidão que salvara o poeta. Para uma defesa desta segunda leitura, na sequência de Schneidewin 1835 e de Bergk 1882, vide Rose 1933: 166, Molyneux 1992: 33 n. 2. Cremos que a interpretação literal do passo não indicia a existência de quatro odes. Todavia, também não faz sentido defender a validade da primeira interpretação, porque do confronto entre os testemunhos de Quintiliano e de Luciano, aceitando a identificação do 'poeta de renome' com Simónides, depreendemos que lhe eram atribuídas, pelo menos, duas odes em que os Dioscuros eram referidos.

${ }^{28}$ Cf. Suda $\Gamma 280$ e Anecd. Graec. I. 232 Bekker. A data que indicam, a 25a Olimpíada (= $680)$, foi emendada para 65a $(=520)$ por H. Brunn, Geschichte der griechischen Künstler. Vol. I (Braunschweig 1853) 83, que os estudiosos aceitam em geral. O testemunho mais relevante sobre a carreira de Glauco de Caristo é o de Pausânias (6. 10.1-3). Para uma análise das fontes, vide Fontenrose 1968: 99-103 e Molyneux 1992: 33-42. Sobre o estatuto social do atleta, vide Bernardini 1980: 93-94; B. Bilinski, "Un pescivendolo olimpionico: (Aristoteles, Rhet. I 71365 a - Ps. Simonides fr. 110 D.)”, Nikephoros 3 (1990) 158-159; Barrigón 1994b: 488-490. 
para paides $^{29}$. H. J. Rose, um dos primeiros investigadores a analisar este fragmento, considerou válidos tanto o testemunho do autor grego como o do autor latino, mas recusou-se a aceitar que as palavras preservadas pelo primeiro dissessem respeito a uma ode composta para a vitória de 520. Na sua opinião, nenhum poeta de bom gosto ('good taste') teria dito aquelas palavras a respeito de um atleta tão jovem, e com tanto exagero, o que não agradaria certamente a uma assistência grega (1933: 166). Mas Luciano era grego e o seu relato sublinha, com alguma perplexidade, que nem Glauco nem Simónides haviam sido castigados por impiedade. A explicação pode residir precisamente no facto de o destinatário da ode ser um jovem atleta, com uma prestação física que anunciava um futuro promissor e cuja ambição de vencer mereceu por parte do poeta um elogio tão descomedido que se aproximou do anedótico, mas obviamente sem implicações religiosas ${ }^{30}$. O elogio exagerado pode ter sido um traço característico do epinício, mas talvez não fosse muito bem visto dizer de um homem (adulto) que a sua força suplantava a dos heróis patronos dos atletas ${ }^{31}$.

Partindo do princípio de que estes dados estão próximos da verdade, em 520 Simónides teria cerca de trinta e seis anos, idade por certo adequada ao retrato que Luciano traça do autor do epinício, um poeta já com fama reconhecida e muito apreciado pelos Gregos. A crer na tradição, neste período conviveu em particular com os tiranos de Atenas (cf. supra, pp. 136 sqq.). Caristo é uma cidade situada no sul da Eubeia, a cerca de $50 \mathrm{Km}$ a norte da ilha de Ceos. O fr. 509 pode, portanto, levar a supor que nesta época o

${ }^{29}$ Esta hipótese baseia-se no relato de Pausânias sobre a primeira vitória de Glauco, obtida em Olímpia (6. 10. 2) Moretti 1957: 75, considerando que o Periegeta não explicita se o atleta venceu na categoria de paides ou na de andres, defende a segunda, mas não nos parece que tenha razão. Nos Jogos Olímpicos e Píticos não havia o escalão intermédio dos 'imberbes' (å̛vévelol), como nos Ístmicos e Nemeus (cf. Pind. Nem. 5, Bacch. 13). No entanto, na distribuição dos atletas pelos dois grupos etários, os Helanódices davam especial importância à compleição. Cf. Xen. HG 4. 1. 40, Plu. Ages. 13. 4, Paus. 6. 14. 1. Segundo N. B. Crowther, "The Age-Category of Boys at Olympia”, Phoenix 42 (1988) 304-308, em Olímpia a categoria de paides podia admitir participantes a partir dos doze anos (pelo menos desde o séc. IV), mas até à idade limite de dezassete. Apoia-se em especial em Paus. 6. 2. 10-11 e 6. 14. 2, respectivamente. Cf. M. Golden, Sport and Society in Ancient Greece (Oxford 1998) 104-116.

${ }^{30}$ Stella 1946: 10 n. 1 corrobora a opinião de Rose. Contra esta tese, Bowra 1961: 312 observa que o poeta não esperava talvez que fosse levado muito a sério. Huxley 1978: 234 não considera ímpias as palavras dirigidas ao precoce atleta. Molyneux 1992, embora aceite a tese de Bowra de que a ode foi composta para um jovem, rejeita a hipótese de o testemunho de Luciano dizer respeito à esforçada primeira vitória olímpica referida por Pausânias (pp. 36, 40).

${ }^{31} \mathrm{Na}$ opinião de Austin 1967: 13, o fr. 509 constitui 'a dangerously secular precedent' para o desenvolvimento do epinício. Barrigón 1994a: 78 n. 7 observa que a liberdade de expressão do poeta ao falar de Glauco, designadamente o tom humorístico, encontra justificação na natureza do komos festivo. 
espaço de mobilidade de Simónides estava especialmente confinado às regiões próximas da sua terra natal e da Ática.

A principal conjectura deste fr. 509 é o seu conteúdo, reconstituído pelos editores modernos a partir do texto de Luciano. A ênfase na formulação

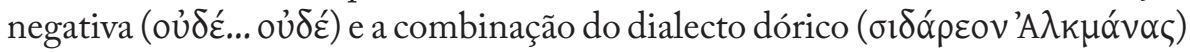
com epicismos (o genitivo По $\lambda \cup \delta \varepsilon u ́ k \varepsilon o \varsigma)$ aproximam estes versos de outros fragmentos de Simónides. As referências mitológicas, por outro lado, são adequadas a um epinício composto em honra de um lutador ${ }^{32}$. Ov. 2 suscita-nos uma dúvida que poderia abalar o testemunho de Luciano se tivéssemos dados mais concretos. O sentido da expressão no fr. 509 é claramente ofensivo, por

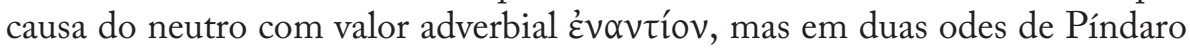

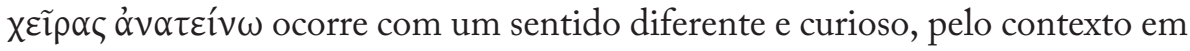
que é empregue. Na VIIa Olimpica, dedicada ao mais famoso pugilista grego,

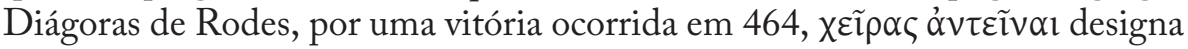
o acto de erguer as mãos que acompanha um juramento solene (v. 65). Na $V I^{a}$ Ístmica, celebrada em honra de Filácides de Egina, vencedor na prova do

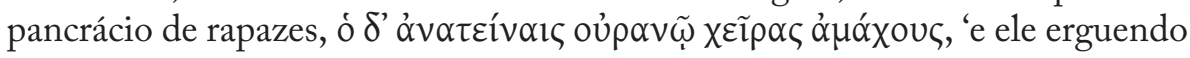
ao céu as mãos invencíveis', refere-se a Héracles, que ergue as suas mãos para suplicar a Zeus (v. 41). Nas duas odes, a expressão ocorre na secção do mito. Como o fr. 509 é muito pequeno, será legítimo supor que Luciano ou a sua fonte tenham interpretado erradamente o passo que nos transmitiram? Esta dúvida confirma que o estado precário dos poemas de Simónides é o obstáculo mais difícil de contornar.

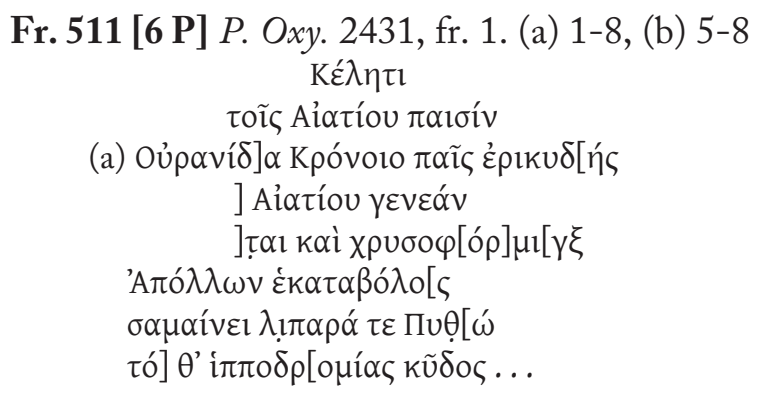

(b) $\beta \alpha \sigma \imath \lambda \tilde{\eta} \alpha[\tau] \varepsilon \lambda \varepsilon \sigma \varphi o ́ \rho o v$

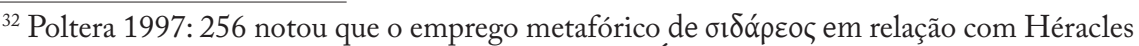
já se encontra num fragmento papiráceo atribuído a Íbico, que alguns estudiosos supõem pertencer a um epinício (fr. 11. 5-6 do P. Oxy. $2735=176 S L G$, cit. p. 91 n. 75). A aplicação deste adjectivo ao carácter de um homem, 'duro como ferro', 'inflexível', tem antecedentes épicos,

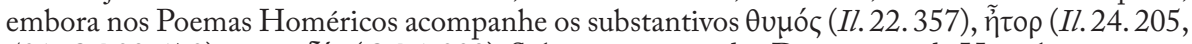

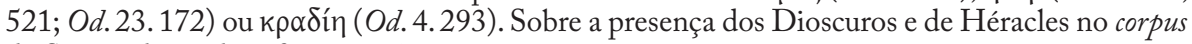
de Simónides, vide infra, pp. 317, 329-330. 


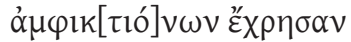

$\Pi] \cup \rho p i ́ \delta \alpha v \cdot \stackrel{\alpha}{\mu} \mu \alpha \delta \varepsilon \gamma \varepsilon v$. . o oùv ö $\lambda \beta \omega[1$

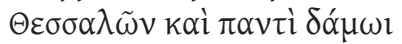

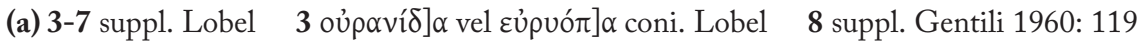
(b) 5 suppl. Lobel $\mathbf{6}$ suppl. Gentili, Page 7 init. suppl. Gentili (iam coni. Lobel) “ ' $\alpha \alpha$ $\delta \grave{\varepsilon}$ үर́voııo exspectas, legere uix possis' scripsit Page

\section{Para uma vitória na corrida de cavalos} dos filhos de Eácio

(a) Do descendente de Urano, de Cronos filho glorioso, [protege (?), honra (?) $]^{33}$ a raça de Eácio

... e o da lira de ouro,

Apolo que atira de longe,

dá o sinal, e a brilhante Delfos

e a [glória] da corrida de cavalos...

(b) Como rei supremo,

dos que habitam nas redondezas, receberam

o descendente de Pirro; ao mesmo tempo ... com prosperidade

também para todo o povo tessálio

Os versos citados pertencem ao fragmento mais bem preservado dos cinco que nos foram transmitidos pelo P. Oxy. 2431. Como referimos na segunda parte, tem a particularidade de ser legível a indicação da prova e do destinatário ${ }^{34}$. É plausível que o fr. 1 contenha o início da ode e um passo da mesma coluna (cf. Lobel 1959: 88, Page 1962: 245). Se assim era, verifica-se que o poeta começou por sublinhar a dimensão religiosa do evento desportivo. Todavia, o estado do fragmento não permite saber se esta composição comemorava uma vitória em Olímpia, em Nemeia ((a) 3) ou em Delfos ((a) 5-7), ou se evocava os sucessos atléticos desta família. Quanto à sua identificação, Gentili 1960: 118 observou que Aiótıoৎ é um nome nobre tessálio, que se relaciona com a própria origem do povo, pois era esse o nome do herói lendário da estirpe dos Heraclidas, filho de Fidipo e pai de Téssalo, o primeiro rei da Tessália ${ }^{35}$. O

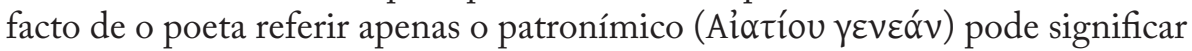

${ }_{33}$ Propostas de Gentili 1960: 118 e de West 1993a: 160, respectivamente.

${ }^{34}$ A ordenação das palavras do título, que indica primeiro a prova atlética e só depois o destinatário da ode, claramente diversa da dos epinícios de Píndaro e de Baquílides, sugeriu a

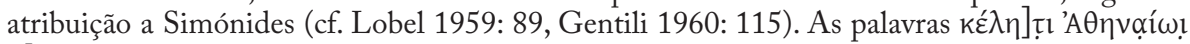
$\lambda$ [ do fr. 120 (b) 3 do P. Oxy. 2430 (fr. 519) corroboram esta suposição.

${ }^{35}$ Gentili baseia-se na obra Strategemata 8. 44, de Polieno da Macedónia (séc. II d.C.), e no estudo de Sordi 1958: 7-8. Cf. Lobel 1959: 89, que notou nas cinco ocorrências do nome Aió $\tau 10 \varsigma$ "a Thessalian ambience”. 
que foi Eácio quem encomendou a ode. Abona a favor desta hipótese a referência de carácter político em (b) 5-7, que pode ser um cumprimento laudatório do poeta ao seu patrono. Finalmente, a menção da prova desportiva ((a) 8) corrobora estas suposições, uma vez que as competições equestres eram geralmente mais acessíveis aos atletas com recursos.

Na opinião de Gentili 1960: 120-121, o contexto do fr. 1(b) não é fácil de reconstituir, nem é possível determinar com exactidão se neste passo o poeta se estava a referir ao mito ou à história da Tessália dos sécs. VII e

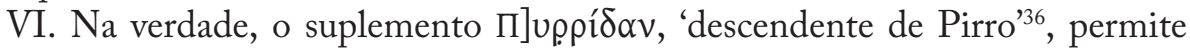
essas duas leituras, embora aquele helenista prefira a segunda ${ }^{37}$. As palavras dos vv. 7-8 levam a supor que o poema foi composto para uma assistência de Tessálios. A hipótese, discutida por Gentili (ibidem), de que Eácio seria parente dos Alévadas da Tessália não esclarece por completo a identidade do(s) destinatário(s) da ode, pois também não é claro o sentido do próprio fr. 1(b). Não obstante estas dúvidas, que nos impedem de estabelecer uma data para o epinício, este fragmento confirma que Simónides compôs para diversas famílias nobres da Tessália.

No domínio do estilo, evidencia-se o recurso à perífrase para designar o deus ((a) 3), tal como acontece em fragmentos anteriores (cf. frr. 507. 2-3, 509. 3). Um aspecto importante é a escolha dos epítetos, principalmente os que dizem respeito a Apolo: se $\chi \rho \cup \sigma o \varphi o ́ \rho \mu \imath ү \xi$ apenas está presente em

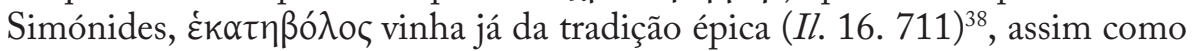

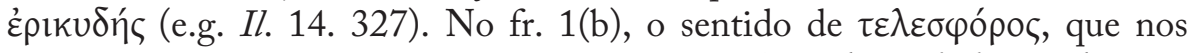

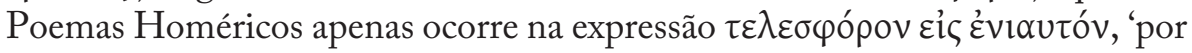
um ano completo' (e.g. Il. 19. 32, Od. 4. 86), parece ser 'capaz de cumprir, de realizar', 'poderoso', de que encontramos outros exemplos em obras posteriores $^{39}$. Tudo indica, portanto, que na selecção dos termos ornamentais o poeta não se afasta da tradição, mas revela a sua veia criativa na invenção de novas palavras $(\chi \rho \cup \sigma o \varphi o ́ \rho \mu l y \xi)^{40}$ ou na atribuição de outros sentidos às

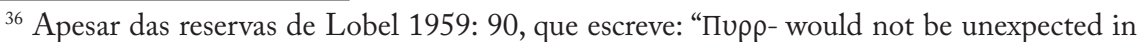
Thessaly, but I find nothing suitable on record and I am not sure that $\pi$ could be accepted as a reading."

37 Sobre a possível reconstituição dos aspectos histórico-políticos a que o epinício eventualmente fazia alusão, vide Gentili 1960: 120-122, Podlecki 1984: 184. Molyneux 1992: 130 observa, com razão, que mesmo se o assunto destes versos fosse um evento mítico, o seu uso mais apropriado seria como paradigma de uma situação contemporânea.

38 Note-se que não é exacto o sentido deste epíteto e a tradução 'que atira de longe' (tal como 'que acerta no alvo'), embora possível, não é segura. A mesma dúvida se põe em relação a

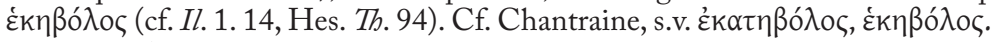

${ }^{39}$ E.g. Aesch. Pr. 511, Soph. Aj. 1390, h.Hom. 23.2.

40 A composição deste epíteto, como notaram Lobel 1959: 89 e Gentili 1960: 119, não remonta, como é frequente em Simónides, ao modelo homérico ou épico, mas evoca Pind. Pyth.

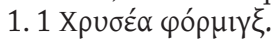


existentes ( $\tau \varepsilon \lambda \varepsilon \sigma \varphi o ́ \rho \circ \zeta)$. Saliente-se ainda a combinação do dialecto dórico

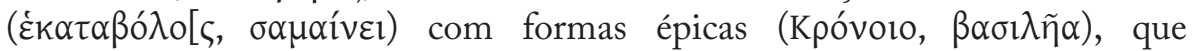
caracteriza a língua das composições corais.

\section{Fr. 515 [10 P, 7 B, 19 D] Arist. Rh. 3. 2. 1405b 23}

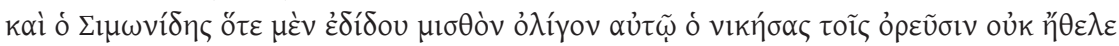

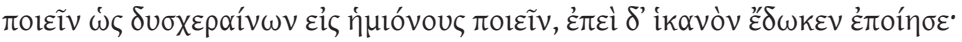

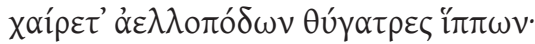

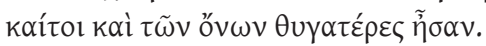

E Simónides, enquanto o vencedor na corrida de mulas lhe oferecia um magro salário, não queria fazer um poema, porque não lhe dava gosto compor em honra de mulas, mas quando lhe deu o suficiente, compôs:

Salve, ó filhas de cavalos rápidos como vendavais!

$\mathrm{E}$, todavia, eram também filhas de asnos.

O testemunho de Aristóteles, não obstante a sua validade, faz parte das histórias que retratam Simónides como amigo do dinheiro ${ }^{41}$ e confirma que no séc. IV, pelo menos, estava bem estabelecida a ideia de que o poeta exigia somas elevadas pelo seu trabalho. Contudo, parece-nos que o filósofo não sublinha tanto esse aspecto, mas antes a habilidade para obter, de um tema à partida sem interesse (ou mesmo desprezível: cf. $\delta v \sigma x \varepsilon \rho \alpha i ́ v \omega v)$, resultados poéticos singulares e de grande efeito junto do público, ainda que essa destreza pudesse fugir um pouco à realidade.

O verso que preservou tem todo o aspecto de ser o primeiro do epinício, com a forma imperativa de saudação, não endereçada, como seria habitual, ao proprietário dos animais, que pagara bem para ser cantado, mas às protagonistas da vitória, invocadas por meio de uma pomposa perífrase que tem claras reminiscências épicas ${ }^{42}$. Marzullo 1984: 148 sublinha a entoação solene instaurada pelo ritmo dáctilo-epítrito, característico da lírica de Píndaro (cf. Gerber 1970: 312), do que resulta um contraste irónico com o conteúdo do verso. É por certo um indício de uma atitude literária de desafio e de

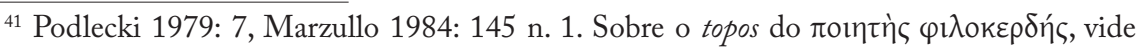
supra, pp. 174 sqq.

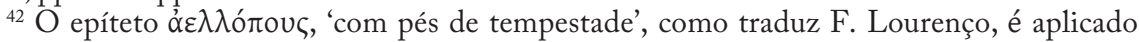
à mensageira dos deuses na Ilíada (8. 409) e aos cavalos de Trós no Hino a Afrodite (5. 217). A presença na $I^{a}$ Nemeia de Píndaro (v. 6), dedicada a Crómio do Etna (posterior a 476), confirma a sua apropriação por parte dos cultores do epinício. Como notam os estudiosos, a originalidade de Simónides reside na aplicação de um epíteto especificamente divino na tradição homérica a animais menos nobres (cf. Marzullo 1984: 148-150, Poltera 1997: 339-340, Henderson 1998: 15). A variação ou paródia de um verso da Ilíada, que visa obter um efeito cómico surpreendente, encontra outro exemplo no fr. eleg. 26, tratado na segunda parte, p. 166. 
afirmação, que pode ter sido inovadora entre os compositores de epinícios ${ }^{43}$. Sobre esta história chegou-nos um outro testemunho do séc. IV, o de Heraclides Pôntico (Politeiai 25. 5, in C. Müller, FHG II. 219):

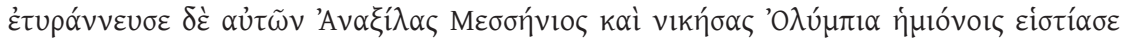

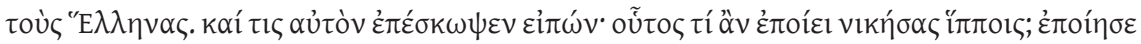

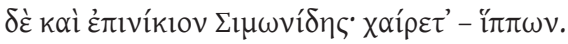

Governou-os como tirano Anaxilas da Messénia e, ao vencer os Jogos Olímpicos com as mulas, deu um banquete aos Helenos. E alguém troçou dele, dizendo: 'O que fazia este, se tivesse vencido com cavalos?' Simónides até compôs um epinício: 'Salve, ó filhas de cavalos rápidos como vendavais!'

Anaxilas, de ascendência messénia (Vallet 1958: 336 e n. 2), foi tirano de Régio desde 494 a $476^{44}$ e conquistou também Zancle em 490/489, que passou desde então a chamar-se Messana (actual Messina) ${ }^{45}$. Este testemunho fornece-nos um termo post quem para a composição do epinício, pois situa a vitória de Anaxilas num momento de auge político. Heraclides Pôntico informa ainda que a prova decorreu em Olímpia e que a excentricidade festiva do vencedor foi motivo de troça. Esta observação sugere que a corrida de carros de mulas ( $\alpha \dot{\pi} \eta \dot{v \eta})$ não era muito apreciada, como se depreende do testemunho de Pausânias (5. 9. 2) e explica, de certo modo, que também os poetas não se mostrassem particularmente motivados para celebrar os vencedores nesta modalidade ${ }^{46}$.

O testemunho de Heraclides Pôntico é confirmado pelo da numismática. Aristóteles, citado por Pólux 5.15 (= fr. 568 Rose), associou um novo tipo de moeda, comum a Régio e à nova Messana, com a vitória olímpica de Anaxilas:

${ }^{43}$ Tal não significa que o poeta pretendia ofender deliberadamente o destinatário da ode, como parece sugerir Marzullo 1984: 155 ("la caustica intenzione di Simonide"). Para uma análise detalhada do estilo e da linguagem do fr. 515, vide as pp. 146-148. Bowra 1961: 315 destaca, a propósito deste fragmento, "the playfulness of Simonides" como um traço de carácter que passou a fazer parte da sua lenda. Vale a pena citar a tese de Mosino 1978, segundo a qual o poeta se inspirou na cultura popular, mais precisamente na tradição fabulística em que Esopo também colheu o topos da mula vaidosa. Gabava-se o animal de ser filho de um cavalo veloz e aspirava a assemelhar-se a ele em tudo; quando, porém, foi obrigado a correr lembrou-se de que

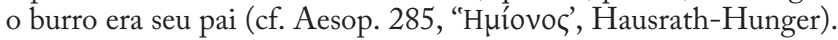

${ }^{44}$ Segundo D.S. 11. 48. 2, Anaxilas governou Régio como tirano durante dezoito anos e faleceu no primeiro ano da 76a Olimpíada (=476). Cf. Vallet 1958: 336, Podlecki 1979: 8.

${ }^{45}$ Mosino 1978: 93, Campbell 1991: 632.

${ }^{46}$ Registe-se que o P. Oxy. 222 não menciona a corrida de carros de mulas, mas duas odes olímpicas de Píndaro celebram vitórias neste concurso: a $V^{a}$, dedicada a Psâmis de Camarina,

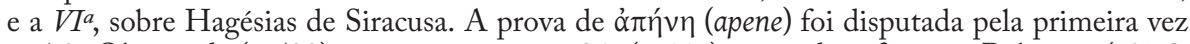
na $70^{\text {a }}$ Olimpíada $(=500)$ e manteve-se até à $84^{\mathrm{a}}(=444)$, segundo informam Pólemon $(F H G$, F 21) e Pausânias (5. 9. 1-2). Cf. Moretti 1957: 81, Christesen 2007: 480. 
para celebrar dignamente o seu triunfo, o tirano cunhou uma tetradracma com a figuração de um auriga a conduzir um carro puxado por uma parelha de mulas $^{47}$.

Na opinião de Vallet 1958: 366-367, esta vitória deve situar-se nas últimas três olimpíadas da tirania de Anaxilas (484, 480 ou 476), tendo em conta que o tipo de moeda precedente havia sido introduzido em Messana em 488 e está amplamente representado. O historiador concluiu que a data de 480 "parece a mais provável", opinião partilhada por outros estudiosos ${ }^{48}$.

Se a ode celebrava uma vitória olímpica conquistada em 480, este testemunhoconfirma que Simónides, numaépoca em que estava particularmente empenhado nas lutas da Hélade contra o invasor persa, continuava a compor para atletas de várias partes do mundo grego e partidários de regimes políticos diversos. Heraclides Pôntico parece também sugerir que o epinício foi escrito para ser executado durante o banquete oferecido a todos os Helenos, portanto em Olímpia. Por conseguinte, os testemunhos de que dispomos não indicam que o poeta teve de se deslocar à Magna Grécia para dar cumprimento ao convite do tirano de Régio ${ }^{49}$.

\footnotetext{
${ }^{47}$ No reverso, a moeda mostrava uma lebre. Para a análise deste testemunho, vide B. V. Head, Historia Numorum. A Manual of Greek Numismatics (Oxford 21911) 108-109, 153-154; Vallet 1958: 366 e n. 4, tav. XIX, no 8; R. R. Holloway, The Archaeology of Ancient Sicily (London and New York 1991) 127, fig. 160; Rocha Pereira 2000b: 26.

${ }^{48}$ Cf. Moretti 1957: 89, Mosino 1978: 93, Campbell 1991: 382. Podlecki 1979: 8, que considerou o testemunho de Diodoro Sículo (cf. supra, n. 44), mas não o da numismática, defende que a vitória de Anaxilas podia facilmente ter ocorrido mais cedo, i.e. desde 494, uma vez que "Simonides is known to have composed epinikia throughout his career." Molyneux 1992: 213-214 chegou à conclusão de que as datas possíveis são 484, 480 ou, menos provavelmente, 476. Vide, nestas mesmas pp., a sua análise da relação da mobilidade de Simónides com as diferentes datas propostas. Parece-nos, no entanto, que neste caso a prudência do investigador em não tomar partido prejudica a abordagem desta questão.

${ }^{49} \mathrm{O}$ detalhe sobre o banquete oferecido a toda a assistência pode ser autêntico, pois ocorre também no testemunho mais tardio de Ateneu (1. 3e) que, no entanto, nomeia, em vez de Anaxilas, o seu filho Leófron: 'Alcibíades, tendo vencido os Jogos Olímpicos... deu um banquete a toda a assistência. Isto fez também Leófron em Olímpia, tendo Simónides de Ceos escrito o epinício.' Huxley 1978: 247, com base neste testemunho e no de Aristóteles, concluiu que Anaxilas e Leófron foram patronos de Simónides, embora defenda sobretudo que "the sum of evidence for his connexions and for his stay in Sicily is meagre." Podlecki 1979: 8 equaciona também a hipótese de o epinício ter sido executado em Olímpia.
} 


\section{I.3. O ELOGIO DE UM ESFORÇO COLECTIVO: A GLÓRIA NAS LUTAS CONTRA OS PERSAS}

O número de epigramas incluídos no corpus de Simónides, por autores antigos ou pelos editores modernos, referentes a diversos conflitos bélicos, alguns posteriores à data tradicional da sua morte, é superior a trinta. Seleccionámos apenas os que dizem respeito às Guerras Medo-Persas, em particular os que são considerados mais bem feitos e podiam ter sido compostos pelo poeta ou no seu tempo.

A variedade formal das obras comentadas neste capítulo confirma, por um lado, a importância deste tema na poética de Simónides e, por outro, a sua reputação como cantor nacional da luta helénica. Na seriação dos poemas atendemos, em primeiro lugar e na medida do possível, à cronologia dos eventos a que respeitam. Dentro de cada subcapítulo, seguimos a numeração e o texto estabelecidos nas edições de Page (1962, 1975 e 1981) e Campbell 1991, para os fragmentos líricos e epigramas, e na de West 1992a para os fragmentos elegíacos. Recolhemos principalmente destas obras os dados que fornecemos no aparato crítico.

Um dos aspectos da nossa leitura é a determinação da autenticidade dos epigramas, questão difícil de resolver e muito pouco consensual.Comprovam-no as duas primeiras composições, que nos servem de introdução e ilustram, sobretudo, a pervivência de um tema que inspirou muitos poetas e artistas gregos. Apesar das nossas incertezas, os epigramas atribuídos a Simónides, tal como os Persas de Ésquilo e as Histórias de Heródoto, são um testemunho valioso sobre o significado histórico, político, social, cultural e ideológico das Guerras Medo-Persas no dealbar da Época Clássica.

\section{Epigr. XVIII [101 B, 119 D] $A P$ 7. 257, $A P l$

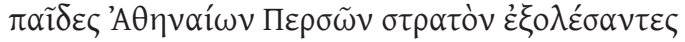

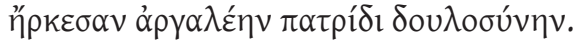 \\ Os filhos dos Atenienses aniquilaram o exército dos Persas e afastaram da pátria a dolorosa servidão.}

Transmitido pela Antologia Palatina e pela de Planudes como anónimo, este epigrama foi atribuído a Simónides pelo escoliasta de Élio Aristides. O facto de figurar no livro VII daquela antologia, que reúne os epigramas funerários, dá-nos alguns indícios sobre o seu género, mas o lemma $\mathrm{C}$ ( $\varepsilon i \zeta$

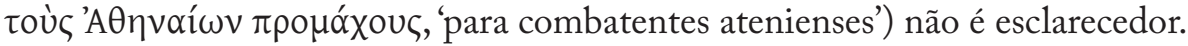




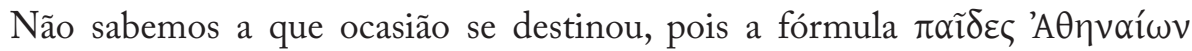
pode sugerir a batalha de Maratona, mas também outro combate ${ }^{1}$, e o termo

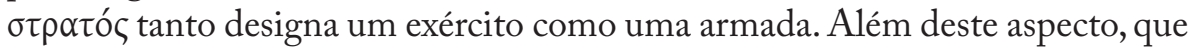
pode suscitar alguma suspeita sobre a autenticidade, a composição evidencia traços estilísticos característicos do epigrama arcaico: a concisão, a sobriedade (constituído apenas por nove palavras, das quais apenas uma é adjectivo), o tom impessoal e o anonimato (que a acompanhou até ao séc. II d.C., pelo menos).

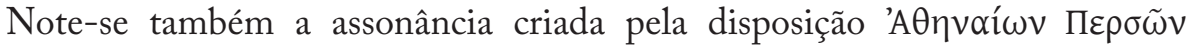

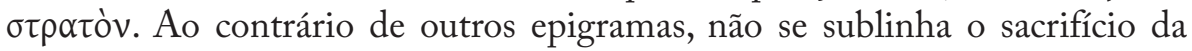
vida dos Atenienses, mas apenas o resultado da sua acção contra os Persas: o tema principal é a ideia de que o seu domínio significaria a subjugação do povo, portanto, a noção de liberdade (eleutheria), embora não extensiva à de pan-helenismo, que se encontra noutras composições ${ }^{2}$. Parece-nos justa a avaliação de Page 1981: 230, que acredita na sua antiguidade, embora não seja possível determinar o contexto histórico a que diz respeito 3 .

Um outro epigrama evidencia, do mesmo modo, a ausência de pormenores sobre o acontecimento que motivou a sua composição. Trata-se de um epigrama dedicatório pela consagração de despojos de guerra ao templo de Atena.

\section{Epigr. XIX [143 B, 144 D] $A P$ 6. 2, $A P l$

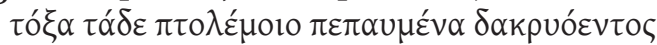

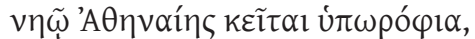

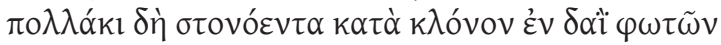

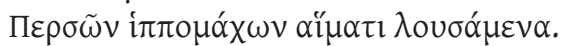

Estes arcos, que repousam da guerra causadora de lágrimas, estão dispostos sob o tecto do templo de Atena, pois muitas vezes, no tumulto lúgubre da batalha, se banharam no sangue de cavaleiros persas.

Embora não especificada, a ocasião diz respeito a uma batalha terrestre

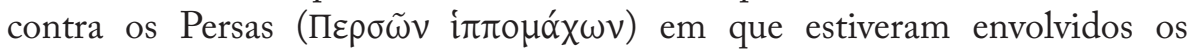

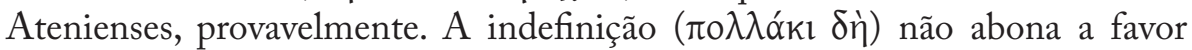

${ }^{1}$ Cf. epigr. III. 2 (que não comentamos) e XXIV. 2 (vide infra p. 274).

${ }^{2}$ Cf. infra epigr. XII, X, VIII, XV, XVI, XVII (b), XX (a). Segundo Podlecki 1973: 27, a luta pela liberdade ( $\dot{\lambda} \lambda \varepsilon \cup \theta \varepsilon \rho i ́ \alpha)$ era a palavra de ordem da resistência contra os invasores, como atestam outras fontes, e.g. Aesch. Pers. 401-405; Hdt. 7. 139. 5, 157. 2, 178. 2.

${ }^{3}$ Os comentadores da Antologia Palatina da colecção Budé puseram em causa que o dístico tenha sido composto para ser gravado sobre um monumento funerário (1938: 167). Page 1981: 217 n. 2 indica os estudiosos que o consideraram um exercício relativamente tardio e não uma cópia de uma inscrição antiga. Note-se, porém, que a ausência de dados sobre o local em que o epigrama era colocado (o da batalha, por exemplo) é típico das inscrições, mas não dos exercícios literários (Page 1981: 230). 
da sua autenticidade. Mas a característica principal deste epigrama é o tom patético e fortemente comovedor, mesmo quando não se trata de uma composição funerária e não se alude ao sacrifício da vida dos soldados gregos, mas à derrota dos Persas. O estilo é prolixo $(\varphi \omega \tau \tilde{\omega} v / \Pi \varepsilon \rho \sigma \tilde{\omega} v)$, enfático e pouco contido, ao insistir no pavor provocado pela crueldade da guerra, evocando as lágrimas, o tumulto da batalha e o sangue dos combatentes. Para

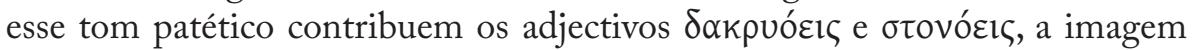
que encerra a composição, bem como alguns ecos de expressões homéricas ${ }^{4}$. Estas características formais permitem supor que não se trata provavelmente da cópia de uma inscrição e a atribuição a Simónides não tem assim qualquer valor. Na opinião de Page 1981: 218, o estilo sugere um exercício literário helenístico. Assim pensa também Campbell 1991: 537.

\subsection{Maratona (13 de Agosto de 490)}

A tradição associou Simónides às comemorações da vitória dos Atenienses em Maratona (cf. supra, pp. 143-144) e os estudiosos esforçaram-se por identificar o célebre dístico elegíaco que fez triunfar o lírico de Ceos sobre o grande trágico de Atenas. Esta história pode ter sido determinante na atribuição dos seguintes epigramas a Simónides.

\section{Epigr. V [133 B, 143 D] APl 232}

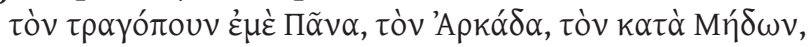

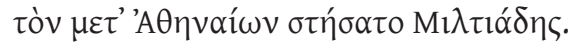

Pã de pés caprinos, o da Arcádia, o inimigo dos Medos, o amigo dos Atenienses: quem me erigiu foi Milcíades.

Trata-se de um epigrama dedicatório, possivelmente cópia da inscrição de uma estátua de Pã erigida por ordem do general ateniense Milcíades, na sequência da vitória em Maratona, no qual se recorda o apoio do deus 5 . Heródoto conta como Pã anunciou aos Atenienses que lhes seria favorável naquele confronto. Após a vitória, dedicaram ao deus uma gruta no flanco norte da Acrópole, mas o historiador não faz qualquer referência à consagração de uma estátua ${ }^{6}$.

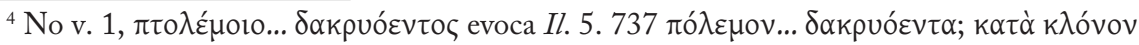

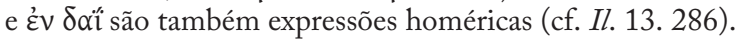

${ }^{5}$ Page 1981: 194 observa que há uma variação elaborada do mesmo tema em APl 233 (atribuído a Teeteto Escolástico), mas nenhum outro registo da dedicatória de uma estátua de Pã por Milcíades. Fontes tardias mencionam uma estátua de Pã em Constantinopla, dedicada após as Guerras Medo-Persas por Pausânias (Sozomenus, hist. eccles. 2. 5; Nicephorus 8. 33). Supõe-se, desde Bergk, que pode haver nestes testemunhos um lapso por Milcíades (cf. Page 1981: 194 n. 1, Campbell 1991: 525).

${ }^{6}$ Cf. Hdt. 6. 105; Ar. Lys. 721, 911; Paus. 1. 28. 4; Luc. BisAcc. 9, DDeor. 2 (22) 3.
} 
A construção do epigrama assenta na repetição do artigo đóv, que mantém

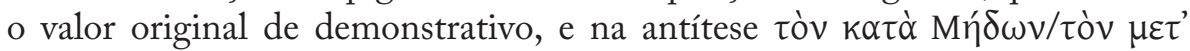

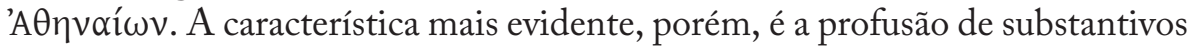
próprios. $\mathrm{O}$ estilo é sóbrio, mas não austero: há uma disposição rigorosa dos termos no verso, sobressaindo o epíteto de $\mathrm{Pa}^{7}$ a iniciar a composição e o nome do responsável pela dedicatória no seu fecho.

Se a atribuição a Simónides depende apenas do testemunho frágil de Planudes, o exame da possível autenticidade do epigrama também não é uma questão consensual. Page 1981: 195 discute as opiniões dos críticos mais antigos e, embora não chegue a uma conclusão definitiva ("The style of the epigram is consistent with any period from 490 B.C. onwards for hundreds of years"), considera que a especificidade do tema pode ser um indício de autenticidade. Por seu turno, Podlecki 1984: 187-188 tentou conciliar esta hipótese com o testemunho de Heródoto, segundo o qual os Atenienses construíram o santuário de Pã quando os conflitos já haviam cessado, o que implica um período de tempo que pode ir além de 480 . Em seu entender, a oferenda de Milcíades apenas podia ter acontecido logo após a batalha, dado que o general caiu em desgraça pouco tempo depois. Se se considerar a hipótese, avançada por outros estudiosos, de ter sido o seu filho, Címon, o responsável pela difusão do culto a Pã, nos seus esforços por proclamar o papel do pai no confronto de Maratona, dificilmente Simónides teria composto a inscrição. Nesta época, defende o investigador, o poeta estava firmemente ao lado de Temístocles. Embora concordemos, no seu conjunto, com estas conjecturas, parece-nos improvável que a convivência de Simónides com o herói de Salamina, que discutimos na segunda parte, ou com outros dirigentes políticos, tenha tido uma influência determinante nas suas relações profissionais.

À semelhança do que acontece com outras composições, nenhuma autoridade antiga atribui o epigrama seguinte ao poeta e a integração no seu corpus apenas se pode entender como conjectura dos editores modernos. Trata-se de uma das inscrições da base de um monumento votivo ateniense, possivelmente um memorial (Page 1981: 220), erigido após as naumaquias de 480. Ao lado destes dois dísticos elegíacos figuram os que formam o epigr. XX (a), comentado mais adiante, igualmente dedicado aos soldados atenienses que participaram nas lutas contra o invasor bárbaro ${ }^{8}$.

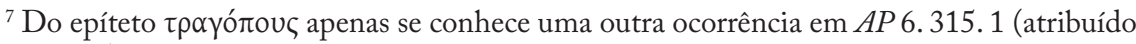
a Nicodemo).

${ }^{8}$ Para um resumo da história da descoberta arqueológica e dos principais problemas textuais, vide Hansen 1983: 1-4, Podlecki 1984: 186-187.
} 
Epigr. XX (b) [88b D] $S E G$ 10. 404 = 2 Hansen

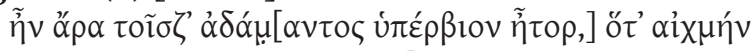

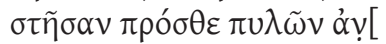

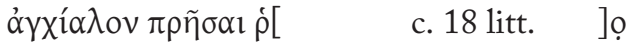

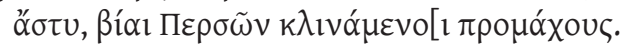

$\mathbf{1}$ suppl. Page post Wilhelm 4 suppl. Page

[Resistente coração de diam]ante o destes homens, quando a lança ergueram frente às portas...

incendiar à beira-mar...

a cidade, com bravura repeliram a vanguarda persa.

A presença do deíctico ( $\tau$ iõ $\left.\sigma \zeta^{\prime}\right)$, um dos traços característicos das inscrições funerárias arcaicas, pressupõe uma referência concreta: os nomes dos soldados mortos teriam sido gravados no monumento original ${ }^{9}$. A composição elogia o valor dos guerreiros que enfrentaram os Persas, provavelmente numa batalha terrestre, $\mathrm{e}$ parece aludir à defesa de uma cidade situada à beira-mar, embora o sentido não seja claro, dado o estado de conservação do monumento. No entanto, a crer na lição de Page 1981:224, vale a pena chamar a atenção para a metáfora (hiperbólica) do v. 1, pela qual se sublinha a capacidade de resistência dos soldados gregos. $\mathrm{O}$ adjectivo

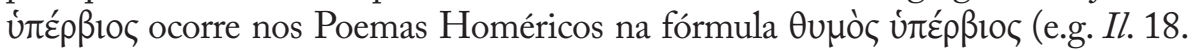
262 , Od. 15.212), mas o sentido mais próximo deste epigrama encontra-se nos epinícios de Píndaro (Ol.10.15, composto em 476) e de Baquílides (3.37, de 468), como qualificativo, respectivamente, de Héracles e de Zeus.

Supõe-se, em geral, que se trata de uma homenagem aos soldados de Maratona ${ }^{10}$, gravada a título póstumo, depois de em 480 os Persas terem destruído a pedra comemorativa da primeira grande batalha terrestre. A atribuição a Simónides ficaria definitivamente comprometida se se pudesse provar que o epigr. XX (b) é um acrescento muito posterior à campanha de 480/47911.

${ }^{9}$ Cf. Oliver 1933: 488, Campbell 1991: 539. Contra esta interpretação, cf. Meiggs and Lewis 1975: 57, Page 1981: 222-223.

${ }^{10}$ É também a opinião de Page 1981: 221 e Campbell 1991: 539. Page discute as objecções a esta hipótese, sublinhando que a única ocasião em que os Persas tentaram incendiar Atenas e foram derrotados aconteceu em 490, pois conseguiram fazê-lo com sucesso dez anos mais tarde (cf. Hdt. 6. 102, 8. 53).

${ }^{11}$ A suspeita de o epigr. XX (b) ter sido gravado na mesma pedra alguns anos após a primeira inscrição apoia-se na análise epigráfica, mas não há certezas quanto à reconstituição das circunstâncias históricas. Recorde-se que Oliver 1933: 492, influenciado pela história transmitida pela Vita Aeschyli ( $\$ 8$ = Simon. test. 15, cit. pp. 143-144), atribuiu o epigr. XX (b) a Ésquilo e o XX (a) a Simónides. Esta proposta foi retomada por Myres 1934. Na sequência das críticas de F. Hiller von Gaertringen (Hermes 69.2, 1934, 204-206) e de W. Peek (Hermes 69.3, 1934, 339-343), Oliver corrobou a sua tese com novos argumentos (1935). Sobre esta questão, vide Meiggs and Lewis 1975: 54-57, Podlecki 1973: 37-39, Page 1981: 144-145, Ferreira 1992: 
O último epigrama a considerar foi transmitido por Licurgo, orador ateniense do séc. IV.

\section{Epigr. XXI [90 B, 88 D] Lycurg. in Leocr. 109}

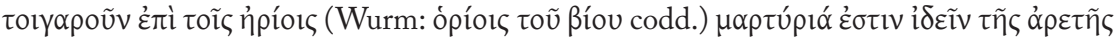

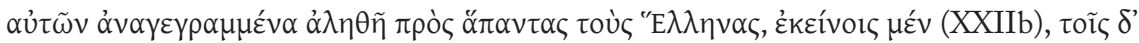

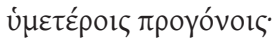

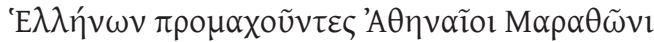

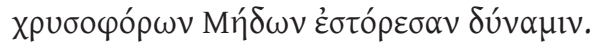

Portanto, †nos seus túmulos† está inscrito um testemunho verdadeiro da sua coragem para todos os Helenos verem, para eles [os Espartanos] (XXIIb), para os vossos antepassados:

Pelos Helenos lutando em Maratona, os Atenienses derrubaram o poderio dos Medos cobertos de ouro.

A concisão, a simplicidade, a clareza de expressão e a disposição cuidada dos termos no verso caracterizam o estilo deste dístico elegíaco. $\mathrm{O}$ acontecimento a que se refere é explicitado sem ambiguidade, ou seja, trata-se de uma homenagem aos soldados que combateram na batalha de Maratona. Do ponto de vista temático, a composição sublinha o alcance pan-helénico da empresa dos Atenienses ('E $\lambda \lambda \eta ́ v \omega v$, a iniciar o epigrama) e não se centra no sacrifício das suas vidas ${ }^{12}$, mas na derrota infligida ao inimigo. A colocação de

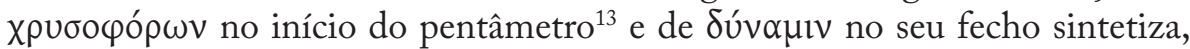
em poucas palavras, a imagem que os Gregos do período clássico fixaram do invasor bárbaro (e.g. Aesch. Pers. 1-9, Hdt. 9. 80), e enfatiza, de forma velada, a desproporção de forças e a singularidade da actuação do exército ateniense ${ }^{14}$. Como é característico das inscrições arcaicas, este dístico foi transmitido anonimamente e nenhuma autoridade antiga o atribui a Simónides. A sua inserção no corpus do poeta é uma suposição dos editores modernos.

Se alguns destes aspectos abonam a favor da autenticidade do epigrama, também não há razões legítimas para contestarmos o testemunho de Licurgo, cuja informação acerca do epitáfio dos soldados espartanos que

302-304, Molyneux 1992: 148-149.

12 Jacoby 1945: 160 encontrou nesta omissão um argumento contra a autenticidade do epigrama. Cf. Page 1981: 227-228. Para um exame do pan-helenismo nos epigramas atribuídos a Simónides, vide Ferreira 1992: 301-313.

${ }^{13}$ Trata-se da ocorrência mais antiga atestada (cf. LSJ). Page 1981: 225 n. 2 salienta a sua

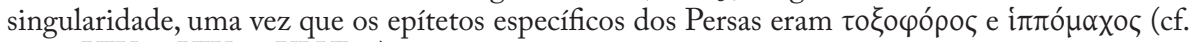
epigr. XIV. 3, XIX. 4, XLVI. 2).

${ }^{14}$ Fontes mais tardias transmitem versões diferentes do pentâmetro (de autenticidade questionável, defende Page 1981: 229), que sublinham o grande número de inimigos: 'Pelos Helenos lutando em Maratona, os Atenienses/ mataram noventa mil (ou 'duzentos mil')

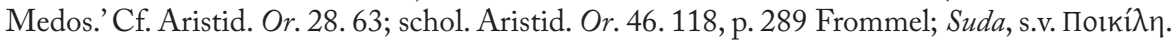


haviam tombado nas Termópilas coincide com o que diz Heródoto (7. 228. 2, vide infra p. 271). Supomos que estaria bem informado sobre Maratona e, aparentemente, o presente dístico assinalava o túmulo dos Atenienses que haviam sido enterrados, contra o que era costume, no local em que se deu a batalha (Thuc. 2. 34. 5, Paus. 1. 32. 3). Page 1981: 229 aceita a hipótese de se tratar de uma inscrição autêntica, embora a questão não seja consensual, como demonstra no extenso comentário que lhe dedica ${ }^{15}$. Na sua opinião, o epitáfio figurava no бopó ৎ de Maratona, designação que se aplica em particular a uma urna ou caixão para guardar os restos mortais (Hdt. 1. 68. 3, 2. 78, cf. $L S J)$ ). O texto de Licurgo não é claro quanto a este ponto. Campbell 1991: 540-541 segue a emenda de Wurm, que propôs a alteração

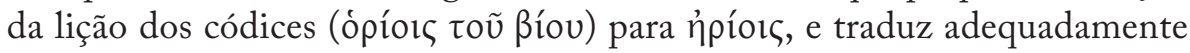
"So on their tombs...", sendo que ท̉píov designa 'túmulo' (cf. Il. 23. 126). Mas, de acordo com LSJ, o termo ópíov é sinónimo de ópoc, que pode ter o sentido de 'marco' ou 'pilar comemorativo' (cf. Hdt. 1. 93. 3). Parece, portanto, que não deve ser ignorada a possibilidade de este dístico elegíaco ser uma cópia de uma inscrição de um memorial e não de um epitáfio, que pode ter sido acompanhada de uma lista com os nomes dos soldados que haviam perdido a vida no conflito, como sugerem Page 1981: 228 e Campbell 1991: $541^{16}$. Esta hipótese justificaria a menção do local da batalha, que o próprio Page (ibidem) considera estranha, porque era contra a norma dos epitáfios. O mesmo helenista observa: "Moreover, the epitaph at Marathon (if there was one) was, so far as we know, the first public epitaph in Athenian history." (1981: 227). Se, de facto, foi isso que aconteceu, supomos que a sua composição seria confiada a um poeta de grande valor. A reputação do talento artístico de Simónides, com cerca de sessenta e seis anos, seria nesse momento amplamente reconhecida, o que faria dele um candidato com grandes possibilidades. Ainda que nem todos os pormenores da lenda preservada na Vida de Ésquilo tenham fundamento histórico, a sua existência não é apenas um testemunho da ligação de Simónides a Atenas, mas sublinha

${ }^{15}$ Cf. pp. 226-229. Na opinião de Bowra 1938: 188, o epigrama é uma criação do séc. IV.

${ }_{16}$ Oliver 1933: 489 já havia chamado a atenção para o testemunho de Pausânias (1.32.3), segundo o qual as estelas que assinalavam o túmulo dos Atenienses em Maratona continham apenas os nomes dos guerreiros mortos, distribuídos por tribos. Na opinião de Podlecki 1984: 186, é improvável que o contexto de composição deste epigrama tenha sido fúnebre, uma vez que não há nele nem referências à morte nem ao funeral. A entrada da Suda sobre o 'Pórtico pintado' de Atenas (s.v. Пoıkí $\eta$ ) levou alguns estudiosos do séc. XIX a defenderem que o epigr. XXI estava gravado nesse edifício (cf. Oliver, ibidem). Como bem observa Page 1981: 226, que rejeita esta possibilidade, este testemunho apenas indica que a batalha de Maratona era um dos episódios tratados e que existia um epigrama composto para os que haviam lutado naquele conflito. Não explicita que a inscrição acompanhava a representação pictórica. Sobre esta questão, cf. E. D. Francis and M. Vickers, "The Marathon Epigram in the Stoa Poikile", Mnemosyne 38 (1985) 390-393. 
especialmente a capacidade do poeta em compreender a importância da luta travada em Maratona, como dissemos na segunda parte (p. 144).

\subsection{Termópilas (20 de Agosto de 480)}

Uma das provas mais convincentes de que Simónides foi convidado a compor em homenagem aos guerreiros que perderam a vida neste episódio memorável da luta contra os Persas é o fragmento lírico transmitido por Diodoro Sículo, relativo a Leónidas e aos Espartanos.

Fr. 531 [26 P, 4 B, 5 D] D.S. 11. 11.6

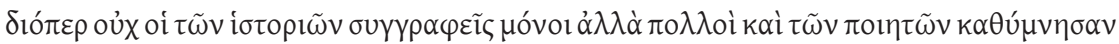

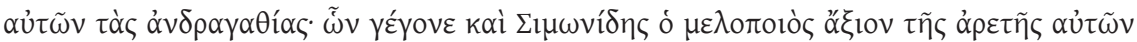
$\pi 0 ı ́ \sigma \alpha \varsigma \dot{\varepsilon} \gamma \kappa \omega \dot{\mu l o v}, \dot{\varepsilon} \nu \tilde{\omega} \lambda \lambda \dot{\varepsilon} \gamma \varepsilon l^{\circ}$

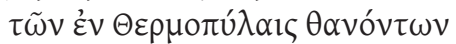

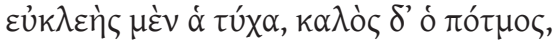

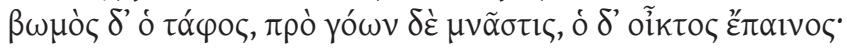

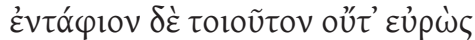

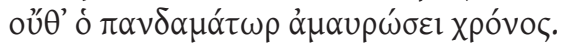

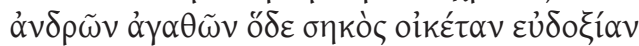

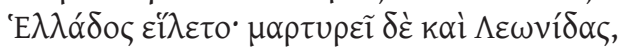

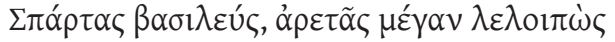

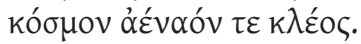

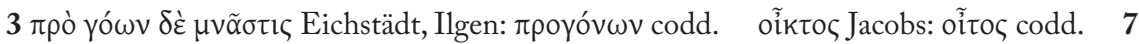

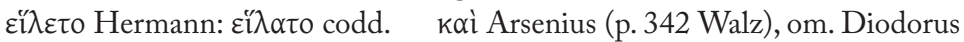

Por isso, não só os historiadores, mas também muitos poetas celebraram os feitos valorosos destes homens, entre os quais o poeta lírico Simónides, que compôs um encómio digno da virtude deles, no qual diz:

Dos que morreram nas Termópilas

glorioso é o destino, bela a morte,

um altar é seu túmulo; em vez de gemidos, lembrança; o lamento é louvor.

Um memorial assim nem o bolor tornará obscuro nem o tempo que tudo doma.

Este santuário de homens valorosos como guardião tomou

o bom nome da Hélade. Testemunha-o Leónidas, rei de Esparta, que de bravura deixou um grandioso ornamento e uma glória imperecível.

De todos os versos de Simónides que o tempo não conseguiu apagar estes são, provavelmente, os que desde há muito ilustram o seu estilo lapidar e explicam por que foi distinguido como cantor das lutas contra os Persas. Constituem um dos passos mais belos do corpus preservado de poesia grega 
arcaica, não obstante as diversas dificuldades que nos coloca. Essas começam logo com a sua caracterização genérica, pois Diodoro Sículo diz que é um

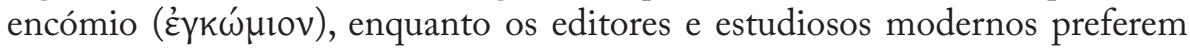
integrá-lo no grupo dos trenos ${ }^{17}$. A incapacidade de se chegar a um consenso neste domínio é a prova da ambiguidade que Simónides conseguiu instaurar

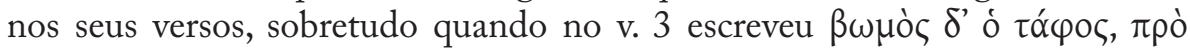

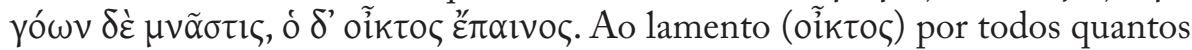

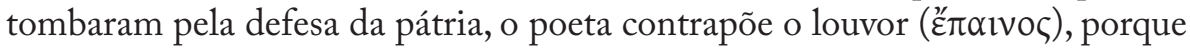
com a sua morte, bela aos olhos de quem compreendeu o seu significado (cf. epigr. VIII. 1, infra), estes homens alcançaram a recompensa de serem admirados e lembrados para sempre ${ }^{18}$. Não sendo imortais, ganharam o direito ao respeito e à veneração devidos aos deuses e aos heróis, pelo que o poeta pode dizer que o espaço que assinala a sua sepultura é agora local de culto ( $\beta \omega \mu$ ò

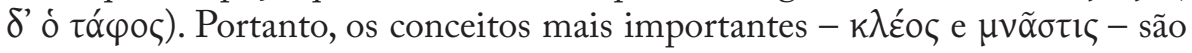
adequados aos epitáfios e aos trenos, e inspiraram outras composições sobre as Guerras Medo-Persas. Se o v. 1 não pertencesse ao poema, como defendeu West ${ }^{19}$, aquela primeira noção abria e encerrava o fragmento ( $\varepsilon \dot{u} k \lambda \varepsilon \dot{\zeta} \varsigma \mu \dot{\varepsilon} v . . . \tau \varepsilon$

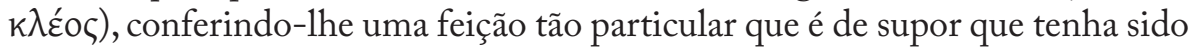
considerado um poema completo, pelo menos num dos diversos momentos em que foi posteriormente interpretado ${ }^{20}$. Mais singular do que estas noções, que já remontam, como é sabido, à mais antiga poesia heróica, é o modo como o

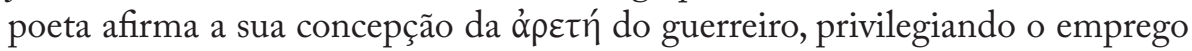
da frase nominal e a disposição simétrica e antitética dos termos nos vv. 2-3,

${ }^{17}$ Alguns estudiosos notam, provavelmente com razão, que no texto de Diodoro Sículo

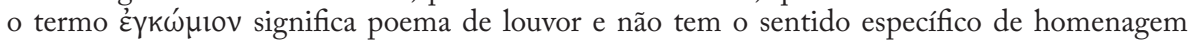
pessoal a um cidadão, que aquela palavra teria no séc. V. Cf. Harvey 1955: 163 n. 6, Bowra 1961: 345, Gerber 1970: 314-315, Campbell 1982: 388.

${ }^{18}$ Este passo pode conter a mais antiga ocorrência conhecida da palavra Ě́taıvoৎ (que surge também em Pind. fr. 181 Ma.). Para uma leitura diferente da nossa, vide Bowra 1961: 347-348.

${ }^{19}$ No artigo "Prose in Simonides", $C R 17$ (1967) 133, West escreveu sobre o v. 1 "It is a

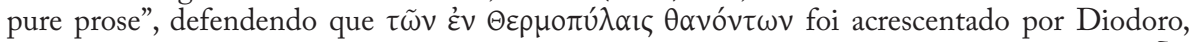
ao fazer a citação, ou por algum escriba. $O$ original, na sua opinião, poderia ter apenas $\tau \tilde{\omega} v \delta \varepsilon$. Retomaria esta tese, com novos argumentos, em 1970 (pp. 210 sqq.) e em 1975 ("Some lyric fragments reconsidered”, $C Q$ 25: 307-309, esp. 308-309), para responder às críticas que Page havia apresentado em 1971 ("Poetry and Prose: Simonides, P.M.G. 531, Ibycus 298", CR 21: 317-318). Na sequência deste artigo, H. Lloyd-Jones, "Simonides, P.M.G. 531", CR 24 (1974)

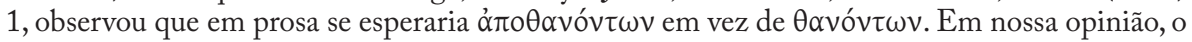
v. 1 deve pertencer ao poema de Simónides, o que não significa que antecedesse imediatamente

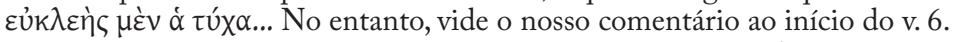

20 Segundo Molyneux 1992: 205 n. 44, apenas F. Cipolla (Atti del Reale Instituto Veneto 60, 1900-1901, 513-514) defendeu a hipótese de o fr. 531 constituir um poema completo. Por seu turno, Burzacchini 1977, na sequência de Kegel 1962: 29-30, propôs que o fr. 594, formado por um único verso, pertença ao mesmo poema. 
o que do ponto de vista formal se traduz num contraste evidente com o resto do fragmento.

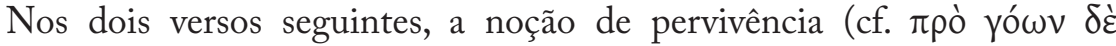
$\left.\mu \nu \tilde{\alpha} \sigma \tau \iota \varsigma^{21}\right)$ é corroborada pelo oxímoro que resulta do emprego de $\pi \alpha v \delta \alpha \mu \alpha \tau^{\tau} \omega \rho$ junto de oú $\theta^{\prime}$... $\alpha \mu \alpha \nu \rho \omega ́ \sigma \varepsilon \varepsilon$. Num fragmento elegíaco transmitido por Estobeu, Simónides afirmara 'o Tempo tem o dente afiado/ e corrói todas

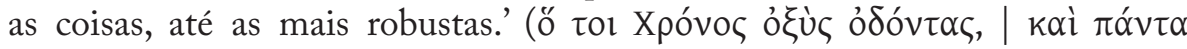

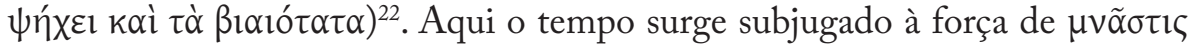
e de $k \lambda \varepsilon ́$ ç. Não é inteiramente clara a interpretação deste passo, tal como

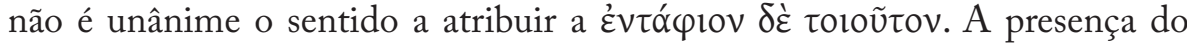
pronome demonstrativo e a referência ao bolor indicam um objecto sujeito às

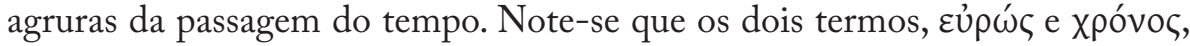
ocupam posições simétricas em final de verso. Quando no v. 3 o poeta diz 'um altar é seu túmulo', referia-se, possivelmente, embora não seja uma opinião consensual, à sepultura comum que nas Termópilas acolheu os corpos dos soldados que tombaram na batalha e se tornou num espaço sagrado (cf. Hdt.

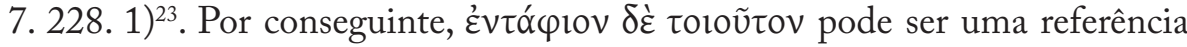
a um cenotáfio edificado em Esparta, um 'túmulo vazio' que funcionava como uma sepultura verdadeira e junto do qual eram prestadas honras fúnebres ${ }^{24}$, ou a algo relacionado com esse culto ${ }^{25}$. Permitimo-nos, por isso, uma outra

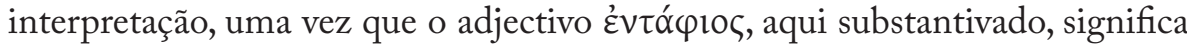
algo tão geral como 'relativo a ou usado no funeral' (cf. LSJ, s.v.). Julgamos, como pensa Podlecki 1968: 261, que o poeta se refere de modo figurado às suas palavras, que constituem o 'louvor' mencionado no v. 3, e formam o poema composto para ser executado junto do monumento fúnebre ${ }^{26}$. A confirmar-se

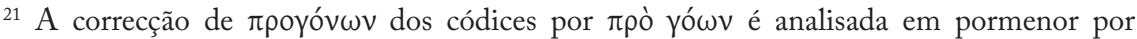
Palmisciano 1996: 39-48.

${ }^{22}$ Stob. 1. 8. 22 = fr. eleg. 88, epigr. LXXXIX. O epíteto $\pi \alpha \nu \delta \alpha \mu \alpha ́ \tau \omega \rho$, que nos Poemas Homéricos caracteriza o sono (Il. 24.5, Od.9.373), é aplicado ao tempo no fr. eleg. 20.15 e em Baquílides (13. 205-206). Sobre a pervivência da metáfora "o dente do tempo", vide o estudo de F. Pontani, "The Tooth of Time. A Poetic Metaphor from Simonides to Shakespeare - and beyond”, $C$ \& $M 52$ (2001) 5-36.

${ }^{23}$ Esta é, por exemplo, a opinião de Podlecki 1968: 260, que interpreta o poema como um

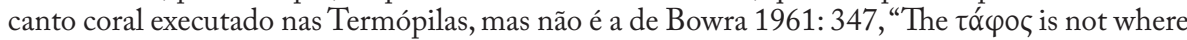
they are buried at Thermopylae, but somewhere else, presumably at Sparta, where their memory is held in honour."

${ }^{24}$ Estes rituais em nada diferiam dos que eram praticados junto das sepulturas verdadeiras. Cf. Kurtz and Boardman 1971: 99-100.

${ }^{25}$ Segundo informa Pausânias (3. 14. 1), um memorial ( $\left.\mu v \tilde{\eta} \mu \alpha\right)$ erguido em Esparta viria a acolher os restos mortais de Leónidas, trasladados em 440. Todos os anos se realizavam cerimónias, com discursos e competições atléticas, nas quais participavam apenas espartanos, e os nomes dos combatentes das Termópilas haviam sido inscritos numa estela. Dos jogos fúnebres chegaram-nos testemunhos epigráficos da Época Romana (e.g. IG V,1.18. A 8; 19.15, 658.12).

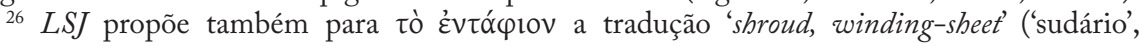


esta hipótese, Simónides sublinha a relação de dependência entre a concessão de $\kappa \lambda$ Éoৎ e o ofício poético, motivo que há-de desenvolver na 'Elegia de Plateias' (cf. fr. eleg. 11.24-28), supostamente composta mais tarde, e que Íbico já havia tratado na 'Ode a Polícrates' (cf. fr. 282 (a). 47-48 PMG).

Os últimos quatro versos funcionam como uma espécie de confirmação pública do que o poeta declarou nos versos precedentes. De facto, se a morte destes homens é uma prova da sua ảpetŕ, só os nomes da Hélade e de Leónidas, dispostos de forma quiástica e ocupando as posições extremas do v. 7, podem resgatá-los do anonimato. $\mathrm{O}$ fragmento adquire um estilo particularmente elevado nos vv. 6-7, nos quais o poeta sublinha a dimensão nacional do sacrifício dos combatentes das Termópilas, que beneficiou a Hélade inteira e não apenas Esparta. Os dois nomes, note-se, figuram em posição simétrica em início de verso. Tal como no fr. 579 diviniza a arete, nos vv. 6-7 Simónides personifica a

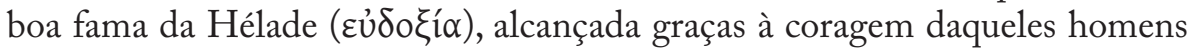
e parece querer dizer que, doravante, ela velará pelo seu santuário como serva dedicada (oỉkétav) ${ }^{27}$.

Se $\alpha v \delta \rho \tilde{\omega} v \alpha ̉ \gamma \alpha \theta \tilde{\omega} v$ lembra, em particular, o início do fr. 542 (cf. frr. 520, 521 e epigr. XX (a)), o genitivo plural, pelo paralelismo que sugere com o v. 1, abala de certo modo a opinião dos que defendem a excisão deste verso (vide supra). A atenção dada a Leónidas no período final, em nossa opinião, não significa necessariamente que todo o poema lhe fosse dedicado, como foi proposto $^{28}$. O poeta começou por falar em termos gerais e nos últimos versos centra-se na figura que simboliza por excelência o sacrifício das Termópilas. Através da linguagem metafórica e do processo de composição em anel, reafirma exactamente as ideias que focou ao longo do fragmento: o valor excepcional

'mortalha'), citando, entre outros, este passo de Simónides, que atesta a ocorrência mais antiga da palavra (Campbell 1982: 384). Mesmo que seja aquele o objecto referido, como o poeta diz que não sofrerá a erosão do tempo, supõe-se que esteja a falar em sentido figurado. Bowra 1933: 280 (cf. 1961: 348), que analisa o termo com algum detalhe, julga tratar-se de uma oferenda ou rito fúnebre, opinião partilhada por Campbell (ibidem), que sugere 'shroud' como tradução alternativa (cf. 1991: 425). Podlecki 1968: 261, que contesta a tese de Bowra, observa que não

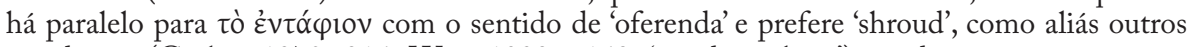
estudiosos (Gerber 1970: 316, West 1993a: 163, 'winding-sheet'), ainda que empregue em sentido figurado. A aceitação de que o poeta se refere a uma mortalha pressupõe, em nossa opinião, uma execução nas Termópilas, junto das sepulturas dos guerreiros. Sobre este ponto, vide ainda Steiner 1999, esp. p. 387, onde apoia o argumento de Podlecki.

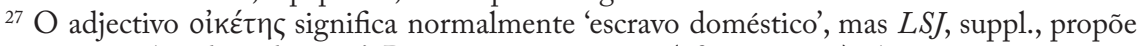
para este passo 'residing divinity'. Bowra 1933: 280-281 (cf. 1961: 349) observou que o termo tem um significado religioso em Esparta, sugerindo o sentido de 'protecting divinity' que vela pelo recinto sagrado. Cf. Gerber 1970: 317, Campbell 1982: 384.

${ }^{28}$ Esta tese foi defendida em particular por Kegel, que rejeitou a variante introduzida por Arsénio (vide aparato), pois a manutenção de koì no v. 7 coloca Leónidas numa posição de subordinação relativamente aos outros guerreiros. Cf. Podlecki 1968: 261, Palmisciano 1996: 48-50. 


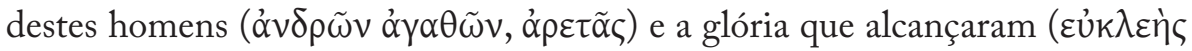

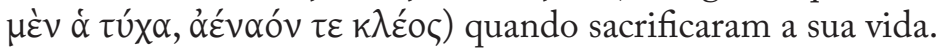

Simónides pode ter sido, de facto, convidado a compor um treno, mas o que nos legou é um poema celebrativo da coragem dos homens que preferiram morrer a desertar e alcançaram um estado de glória que tem um lugar garantido na memória colectiva. Como notou Diodoro Sículo, este misto de encómio e de treno é a composição adequada a uma cerimónia pública em honra de guerreiros que, como se diz no epigr. IX (talvez composto em honra de Espartanos, vide infra), oủdè $\tau \varepsilon \theta v \tilde{\alpha} \sigma l$ $\theta \alpha v o ́ v \tau \varepsilon \varsigma$, 'morreram, mas não estão mortos' (v. 3).

A dificuldade em identificarmos o subgénero do poema decorre também da nossa ignorância sobre as circunstâncias de composição e execução, que os versos preservados não permitem esclarecer, apesar das diversas conjecturas apresentadas $^{29}$. Crêem alguns helenistas que o v. 1 mostra que o poema foi cantado em Esparta, porque não faria sentido se a cerimónia se realizasse nas Termópilas ${ }^{30}$. Essa é a regra das composições epigráficas, mas não sabemos se seria observada num canto coral. Além disso, podíamos evocar o mesmo argumento a propósito do aposto de Leónidas, $\Sigma \pi \alpha ́ \rho \tau \alpha \varsigma \beta \alpha \sigma \imath \lambda \varepsilon u ́ \varsigma$, que faria mais sentido se o poema fosse apresentado fora de Esparta ${ }^{31}$. Este tipo de raciocínio acaba por ser muito falível, porque não só é subjectivo como exclui a possibilidade de o poema ter sido interpretado nos dois lugares, em momentos diferentes, mas com a mesma intenção de evocar o sacrifício e a coragem dos valorosos combatentes. As palavras do poeta, que não são mais esclarecedoras, não confirmam nem negam esta hipótese. Não podemos saber, por exemplo, se

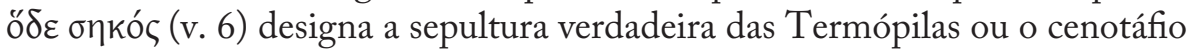
de Esparta $^{32}$. Julgamos, no entanto, que o poeta se está a referir a algo concreto

${ }^{29}$ Contra a possibilidade de o fr. 531 ser um treno, Bowra 1933: 277 (cf. 1961: 345) observou que este canto coral era normalmente executado sobre o corpo do defunto logo após a sua morte. $\mathrm{Na}$ opinião de Bowra, nas palavras de Simónides não há lamentação, o que constitui um dos argumentos a favor da tese de que o poema foi cantado em Esparta e não nas Termópilas, região que foi ocupada pelos Persas a seguir à batalha. Cf. Podlecki 1968: 258-261, Gerber 1970: 315, Palmisciano 1996: 51-52.

${ }^{30}$ Cf. Bowra 1961:345-349, Campbell 1982: 384. Molyneux 1992: 186 discorda, observando "if the lines are intended as a permanent tribute to the dead, the site of the battle would naturally be specified, even if the poem was originally performed there."

${ }^{31}$ Para Bowra 1933: 281 (cf. 1961: 349), a referência em separado ao general é uma prova de que o poema foi executado em Esparta, no santuário erguido em homenagem aos guerreiros das Termópilas, junto do qual se encontrava o memorial de Leónidas (cf. supra, n. 25). A sua hipótese toma como paralelo um passo da $I X^{a}$ Olímpica de Píndaro, composta em 468, na qual, ao aludir à vitória do atleta Efarmosto nos jogos de Tebas, o poeta evoca o túmulo de Iolau como testemunho dessa proeza (v. 98).

${ }^{32}$ Nos Poemas Homéricos, onkó designa um espaço destinado aos animais ('redil', 'curral'). LSJ propõe para este passo a tradução 'sepulchre, burial place, enclosed and consecrated', embora também contemple 'sacred enclosure, precinct'. Na opinião de Bowra 1933: 279 (cf. 1961: 347), 
(ao contrário do que acontece nos vv. 4-5, vide supra), opinião que não é partilhada por todos os estudiosos ${ }^{33}$.

Uma vez que navegamos num mar de conjecturas, a data de composição do poema também não pode ir além de uma mera suposição, como demonstrou Molyneux 1992: 187. O historiador pensa que se o poema foi apresentado em Esparta, isso teria acontecido pouco tempo depois do desastre, o suficiente para a construção do memorial. Mas se foi composto para uma cerimónia nas Termópilas, só pode ter sido apresentado depois da batalha de Plateias, uma vez que a zona de combate ficou sob controlo persa. Portanto, apenas podemos supor uma data vaga, entre o Outono de 480 e o de 479.

Molyneux (ibidem) aborda levemente a questão da mobilidade de Simónides ("the performance of the poem, which may or may not have involved a visit of Simonides to Sparta,...”), e na verdade não podemos avançar muito mais. Antes da publicação da 'Elegia de Plateias', o fr. 531 era a prova mais importante de que o poeta havia dedicado parte do seu talento e do seu tempo aos Espartanos que haviam combatido o invasor persa. Além disso, é legítimo pensar que o seu canto poderá ter influenciado a imagem mítica que o episódio das Termópilas ocupa na história da Grécia antiga. Vêm a propósito as palavras de Paola A. Bernardini, "La eroicizzazione dei morti alle Termopili, il particolare rilievo che assume al v. 8 il nome di Leonida con la significativa apposizione $\Sigma \pi \alpha ́ \rho \tau \alpha \varsigma \beta \alpha \sigma \imath \lambda \varepsilon v ́ \varsigma$, l'arete intensa convenzionalmente come valore in battaglia rivelerebbero già una mitizzazione dell'episodio." (1969: 149). Mais difícil é saber se esta elevação dos guerreiros das Termópilas a heróis corresponde a um culto oficial prestado junto dos monumentos funerários ou se apenas existiu nas palavras de Simónides.

Epigr. VI [94 B, 83 D] Hdt. 7. 228. 3-4

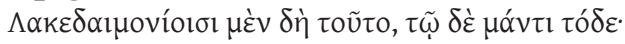

esta palavra designa qualquer recinto sagrado, um termo apropriado a um lugar de culto, mesmo sem os corpos. G. Perrotta e B. Gentili, Polimnia (Messina-Firenze 1953) 292 identificaram aqui uma referência ao túmulo das Termópilas, observando que segundo Hesíquio ơkós é sinónimo

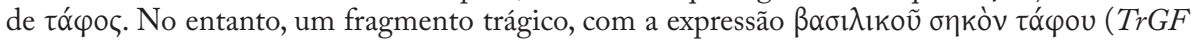
II, fr. adespota 166), leva a pensar que é propriamente o 'recinto' do túmulo. Parece claro que o termo designa um espaço consagrado às honras fúnebres, quer se trate de um cemitério ou de um memorial.

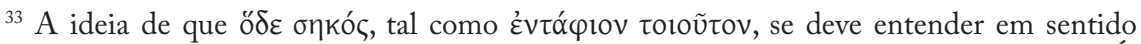
figurado, é defendida por Podlecki 1968: 260-261, West 1970: 210-211, Gerber 1970: 317. É, por certo, com base nesta interpretação que Podlecki escreve "We may perhaps conjecture that the work was composed by Simonides not for official use at a hypothetical state festival, but for more private singing, possibly in the men's messes at Sparta, where Simonides'verses would have been sung in much the same way, and probably for the same purposes, as were Tyrtaeus'stirring lines." (p. 262). Cf. Palmisciano 1996: 51-52. 


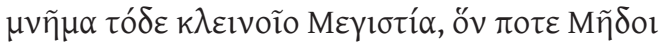

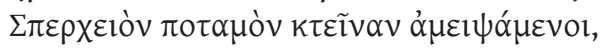

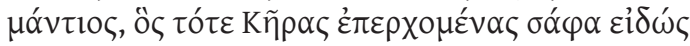

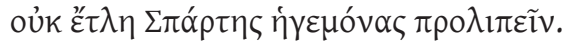

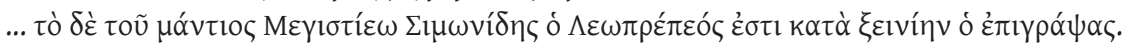

Esta é a inscrição dos Lacedemónios (epigr. XXII (b), infra), e a dedicada ao profeta é a seguinte:

Este é o túmulo do ilustre Megístias que outrora os Medos

mataram, ao transporem o rio Esperqueu,

um profeta que sabia já próximas as deusas da Morte

e não suportou abandonar os chefes de Esparta.

... mas a inscrição do profeta Megístias gravou-a Simónides, filho de Leóprepes, em atenção aos laços de hospitalidade.

Como referimos na segunda parte, a autenticidade desta composição, assegurada em princípio pelas palavras de Heródoto, constitui uma excepção no corpus epigramático de Simónides. São evidentes os traços formais que distinguem o epitáfio arcaico, como a identificação clara do falecido e o motivo da sua morte, a concisão linguística e a presença de $\pi 0 \tau \varepsilon$, frequente nestas inscrições que visam especialmente a preservação da memória $(\mu v \tilde{\eta} \mu \alpha)$ do defunto entre as gerações posteriores ${ }^{34}$. $\mathrm{O}$ tom despojado revela-se na quase total ausência de ornamentos, pelo que $\kappa \lambda \varepsilon$ เvoĩo adquire um valor singular. Megístias era, de facto, famoso antes da sua morte, mas sê-lo-á muito mais depois.

Talvez não seja tão surpreendente a profusão de substantivos próprios, cuja presença destacámos, por exemplo, na análise do epigr. V. No v. 1, o primeiro nome identifica o sujeito do epitáfio e o segundo o acontecimento histórico a que diz respeito. Essa informação é pormenorizada no verso seguinte, através da menção do rio Esperqueu, forma indirecta de nomear o confronto nas Termópilas, mas que é já uma antecipação do sentido do segundo dístico. É que a transposição do rio tessálio situado a norte daquele desfiladeiro significou, em termos militares e políticos, a condenação dos homens que tentaram travar o avanço do exército persa. Por isso, a capacidade de prever ( $\left.\mu \alpha v^{\prime} \tau i o \zeta\right)$ e de conhecer o futuro ( $\varepsilon i \delta \omega \varsigma$, reforçado por $\sigma \alpha ́(\varphi \alpha)$ ocupa as posições privilegiadas do v. 3, ladeando a morte que surge

${ }^{34}$ Cf. infra epigr.XXII (a),XXIV,XI,XV.Na opinião de Campbell 1982: 395, é mais razoável considerar que $\pi$ to $\varepsilon$ é empregue "with posterity in mind", uso antigo que está atestado na Ilíada (7. 87-91). Opinião diferente defendeu Wade-Gery 1933: 71-82, que analisou a presença de

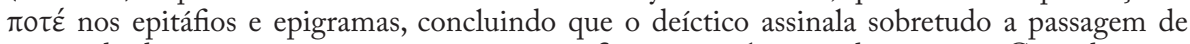
tempo desde o momento em que ocorreu o conflito até à colocação da inscrição. Considera que no epigr. VI o emprego de $\pi 0 \tau \varepsilon ́$ é excepcional, porque se refere às circunstâncias da morte. 
divinizada $(\mathrm{K} \tilde{\eta} \rho \propto \varsigma)^{35}$.É no v. 4 que culmina o sentido da homenagem fúnebre a Megístias, enfatizado pelo emprego da lítotes e de uma forma verbal que pode significar 'tolerou', 'suportou', 'ousou', 'resistiu' (oủk É $\tilde{\tau} \lambda \eta$ ). Sublinha-se, por um lado, a entrega de um homem ao seu dever, à semelhança de Aquiles ou Sarpédon, mas, por outro, é a camaradagem e lealdade que surgem em evidência, pela colocação de $\pi \rho \lambda_{\imath} \imath \varepsilon \varepsilon \tilde{\imath} v$ no final do epigrama. A atitude de Megístias adquire um sentido ainda mais profundo quando sabemos que era um aliado da Acarnânia, ideia que, quanto a nós, está latente no último verso $^{36}$. Destaque-se ainda a organização geral do epigrama, que assenta em duas orações relativas, e na disposição meticulosa das palavras, um traço característico do estilo de Simónides, mas que aqui é em parte determinado pela natureza da composição.

Parece certo que não estamos perante um epitáfio típico, que habitualmente indicava o nome do defunto, da sua cidade, da sua família e a sua idade, principalmente. Destes aspectos, Simónides menciona apenas o nome e o ofício, mas o adjectivo $\kappa \lambda \varepsilon \imath v o ́ \varsigma$ explica, de certo modo, as omissões: Megístias dispensava, de facto, uma apresentação formal. No seu epitáfio, o poeta cunhou para sempre o que as gerações posteriores deviam saber sobre este homem: que foi um exemplo de firmeza militar e de solidariedade humana.

A autenticidade deste epigrama não é assunto polémico. De facto, Heródoto não diz que a composição é de Simónides, mas que o poeta assumiu a responsabilidade de colocar a inscrição. Subentende-se, naturalmente, que teria sido o seu autor ${ }^{37}$. Esse acto, informa o historiador, foi motivado pelos laços de xenia que uniam os dois homens, laços que exigiam o cumprimento

${ }^{35}$ Heródoto menciona por duas vezes que Megístias previu a sua morte e a dos seus companheiros nas vésperas da batalha das Termópilas, mas o vidente recusou-se a abandonar Leónidas, tendo mandado regressar a casa o único filho que possuía e que o havia acompanhado na campanha militar $(7.219,221)$.

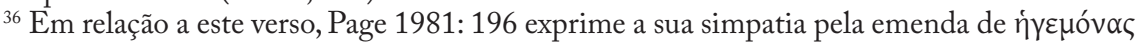

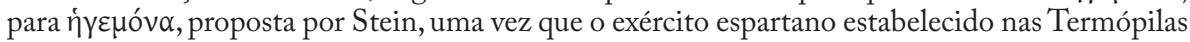
foi liderado apenas por Leónidas.

${ }^{37}$ Não é, porém, consensual a interpretação das palavras de Hdt. 7. 228. 4 (vide infra, epigr. XXII (b)). Num primeiro momento, o historiador observa que os heróis foram homenageados com inscrições e estelas por iniciativa dos Anfictíones. Num segundo momento, especifica que da homenagem a Megístias se ocupou Simónides pelos laços de hospitalidade que os uniam. Em nossa opinião, a antítese ( $\mu \varepsilon \dot{v} . . . \delta \varepsilon ́$ ) diz respeito ao carácter destas homenagens, a primeira é oficial e segue um costume cívico, a segunda é de ordem particular. É interessante a interpretação de Wade-Gery 1933: 73, que, ao contrário de Page, acredita que Simónides compôs também os epigr. XXII (a) e (b): "It looks as if the poet who inscribed the two public monuments took

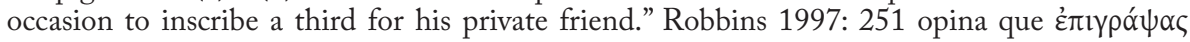
significa apenas que o poeta foi responsável pela inscrição e pagou-a, mas é mais razoável considerar, como Gerber 1970: 330, que também chamou a si a tarefa de a compor, sobretudo se se tratava de um tributo particular. Esta é também a opinião de Campbell 1982: 395. Sobre esta questão, vide infra n. 41 . 
de determinados rituais, inclusive o de prestar honras fúnebres ${ }^{38}$. As palavras de Heródoto são importantes por outra razão. É que esta breve referência aos deveres de hospitalidade de Simónides é um dos raros testemunhos sobre as suas relações sociais e dá-nos uma ideia da diversidade humana que teria feito parte do seu espaço de mobilidade.

O epitáfio sobre Megístias figura como anónimo na Antologia Palatina (7. 677), o que é um dado curioso, sobretudo quando o mesmo livro atribui a Simónides o epigrama seguinte.

\section{Epigr. VII [95 B, 120 D] $A P$ 7. 301, $A P l$

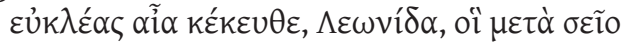

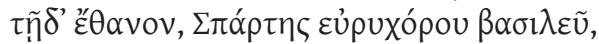

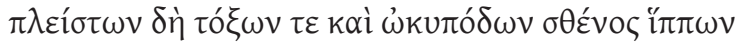

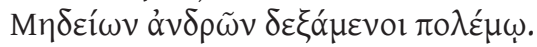 \\ Gloriosos os que a terra cobre, Leónidas, que contigo aqui pereceram, rei da vasta Esparta: a força de muitos arcos e dos céleres cavalos dos Medos, na guerra, enfrentaram.}

Aparentemente trata-se do epitáfio composto para os homens que perderam a vida nas Termópilas sob o comando de Leónidas. O primeiro dístico sublinha a noção de bela morte ( $\varepsilon \cup ̉ k \lambda \varepsilon ́ \alpha \varsigma)$ associada a um sacrifício colectivo.

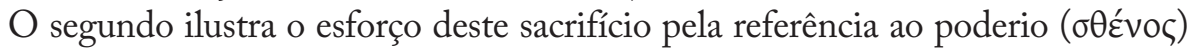

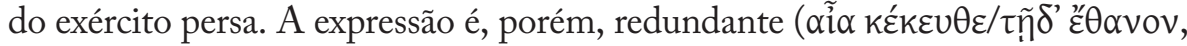

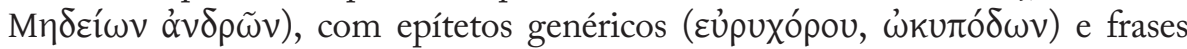
feitas (cf. Page 1981: 197), o que não abona a favor da sua autenticidade. Alguns estudiosos defendem que se trata, provavelmente, de um exercício literário do período helenístico. O argumento estilístico é corroborado pelo testemunho dos Antigos, uma vez que, a crer em Heródoto (7. 228. 2) e Licurgo (in Leocr. 109, cf. supra), o epitáfio dos heróis espartanos das Termópilas é o epigr. XXII (b), que comentaremos a seguir. Registe-se, no entanto, que Molyneux 1992: 181, embora considere pertinente o argumento estilístico, discorda da observação de Page, ibidem, de que o epigr. VII não podia ter figurado no polyandrion (sepultura comum) das Termópilas, ideia que, todavia, não desenvolve.

\section{Epigr. XXII (a) et (b) [91-92 B et D] Hdt. 7. 227-228}

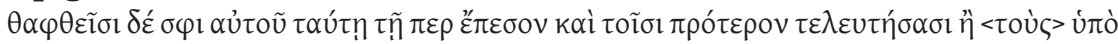

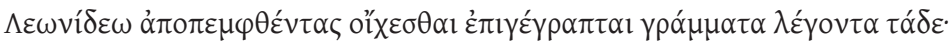

${ }^{38}$ Esta questão é tratada por G. Herman, Ritualised Friendship and the Greek City (Cambridge 1987) 26. Cf. as reservas de Page 1981: 196. 


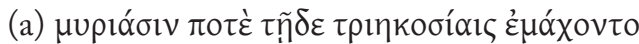

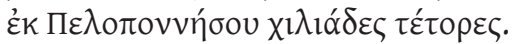

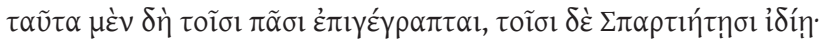

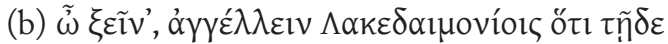

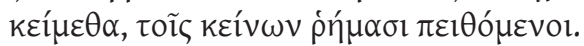

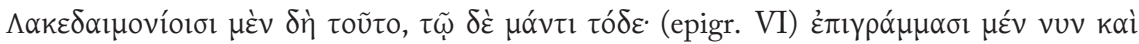

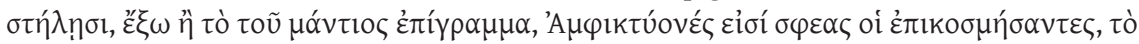

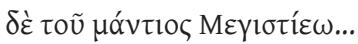

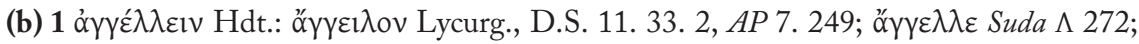

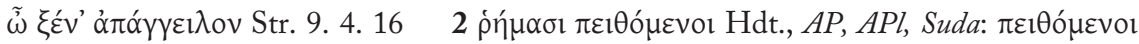
vouíuoıc Lycurg., D.S., Str.

Para os que haviam sido sepultados precisamente no lugar em que tombaram, e para os que haviam morrido antes de partirem os que Leónidas mandou embora, foram gravadas as inscrições que dizem o seguinte:

(a) Contra três milhões outrora aqui lutaram, vindos do Peloponeso, quatro mil.

Esta é a inscrição gravada para todo o exército, mas a dos Espartanos é:

(b) Estrangeiro, anuncia aos Lacedemónios que aqui jazemos, obedientes às suas ordens.

Esta é a inscrição dos Lacedemónios, e a dedicada ao profeta é a seguinte: (epigr. VI, supra). Os epigramas, bem como as estelas, à excepção do epigrama do profeta, é a homenagem dos Anfictíones, mas a inscrição do profeta Megístias...

As palavras de Heródoto e o estilo das composições, marcado pela concisão, singeleza, ausência de ornamentos e de referências ao local da batalha, desnecessárias uma vez que figuravam na sepultura comum das Termópilas, confirmam a autenticidade destes dísticos elegíacos. Se Heródoto chegou a ver as inscrições não sabemos. Page 1981: 233 tem dúvidas (cf. Petrovic 2007: 50-53).

A primeira louva o espírito de resistência das tropas gregas que, face à desproporção das forças em combate, não desistiram de tentar travar o avanço do poderoso exército persa. Se há algum exagero quanto ao número dos inimigos, a hipérbole é compreensível num epigrama que não apela ao pranto, mas à admiração das gerações futuras (cf. $\pi 0 \tau \varepsilon)^{39}$. Como esta

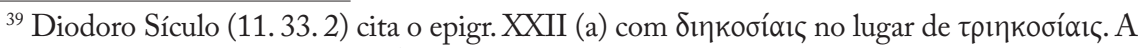
inscrição é da responsabilidade dos Anfictíones, pelo que os números nela mencionados deveriam reflectir a versão oficial. Mas o número de três milhões de inimigos não se afasta muito do total de combatentes indicado por Heródoto: 2.641 .610 (7.185. 3). Hignett 1963: 345-355 discute as fontes e as estimativas modernas. As forças do Peloponeso indicadas por Heródoto ascendiam a 3100 homens (7.202), mas ao lado dos trezentos espartanos combatiam também hilotas e periecos (cf. 7. 229, 8. 25). Cf. Hignett 1963: 116, Lazenby 1993: 134-135. Vide ainda Vannicelli 2007. 
formulação se afasta da do epitáfio tradicional, Page 1981: 232-233 contestou esta classificação, observando ainda que o relato de Heródoto é pouco exacto. Também Wade-Gery 1933: 72 havia afirmado que o epigrama não é um epitáfio, porque apenas marca o campo de batalha.

O segundo dístico é um dos mais célebres do corpus. Uma das características particulares é a feição dialogante, que prende a atenção do viajante ao confiar-lhe uma missão ingrata, revelando-lhe deste modo a razão de ser do epitáfio: sublinhar o orgulho dos guerreiros que na morte se mantêm fiéis aos valores da sua pólis (cf. Hdt. 7. 104. 4-5). Estes homens não morreram em vão, mas no cumprimento do seu dever e, por isso, têm de ser lembrados, sobretudo pelo seu povo. É um exemplo perfeito de concisão e austeridade, talvez mais do que o anterior. Ao empregar o tempo presente e uma forma verbal ambígua, o poeta estabeleceu para sempre a imortalidade destes soldados ${ }^{40}$.

No que diz respeito à paternidade das inscrições, não nos parece que tenha razão Page 1981: 231 quando afirma que as palavras de Heródoto não admitem a atribuição a Simónides ${ }^{41}$. Esta hipótese não é contestada pelo estilo das inscrições nem pelo dialecto (o iónico). O testemunho da Antologia Palatina $(7.248,249)$ não é, de facto, decisivo, mas vale a pena sublinhar que Cícero atribuiu o epigr. XXII (b) a Simónides e, como escreveu M. H. Rocha Pereira, "é difícil supor que qualquer outro poeta da época fosse capaz desta concisão e força." ${ }^{42}$. Não sabemos se existiram compositores de epigramas com o seu talento, mas é provável que ele tenha feito outros poemas sobre o desastre

${ }^{40}$ Vide a análise literária deste epigrama por Bowra 1938: 193-195, que defende, como

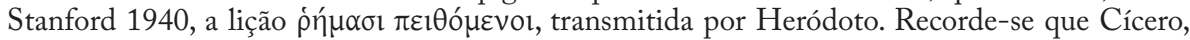
que o traduziu em Tusc. 1.42 (dic, hospes, Spartae nos te hic uidisse iacentes/dum sanctis patriae legibus obsequimur), se baseou, ao que parece, na versão de Licurgo, Diodoro Sículo e Estrabão. Contra esta opinião, Mcdermott 1944 propôs a hipótese de o orador romano ter tratado o grego de modo livre e considerado a análise do carácter espartano por Heródoto (7. 104. 4-5). Para uma discussão das duas lições, vide Page 1981: 233-234, Campbell 1982: 399-400.

${ }^{41}$ Nas palavras de Page, a possibilidade de Simónides ter sido o autor dos dois epigramas "is quite ruled out by the context." Podlecki 1968: 258, embora reconheça que possa ser excessivo negar que Simónides tenha composto também os epigr. XXII (a) e (b), sublinha que a atribuição decorre somente da associação com o episódio de Megístias (cf. 1973: 34, 35; 1984: 190). Já Campbell 1982: 395 considera que, além do epigr. VI, é provável que o poeta tenha também composto os outros dois (cf. pp. 398-399). Na opinião de Gerber 1970: 330, esta possibilidade está implícita no relato de Heródoto, como Bowra 1938: 192 também defendeu: "Herodotus does not state to be the work of Simonides but quotes in the same context as the lines of Megistias as if they were." A questão é tratada por Molyneux 1992: 176-179, que discorda de Page. Na sua opinião, é virtualmente certo que Simónides tenha composto a inscrição de Megístias. Embora Heródoto não o explicite, é uma hipótese razoável que os Anfictíones lhe tenham solicitado os outros dois epigramas.

42 "Poetas Gregos em Augusto Gil”, Humanitas 21-22 (1971) 388. Sobre o testemunho de Cícero, vide supra, n. 40. 
das Termópilas, além do epigr. VI e do fr. 531. Não nos surpreende, por isso, que o epitáfio dos Lócrios tenha sido integrado no seu corpus.

Epigr. XXIII [93 B et D] Str. 9. 4.2

ó $\delta^{\prime}$ 'О

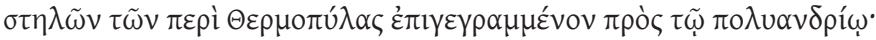

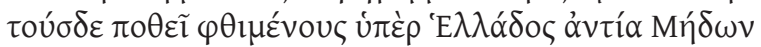

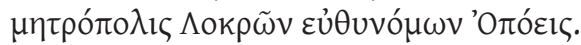

Opunte é a (sua) metrópole, como também mostra a inscrição gravada na primeira das cinco estelas das Termópilas, perto da sepultura comum dos combatentes:

Chora estes homens mortos pela Hélade contra os Medos

Opunte, cidade-mãe dos Lócrios de leis justas.

Dos epigramas analisados sobre a batalha nas Termópilas, este é o único que contém a noção de que o confronto implicou um esforço conjunto em benefício de todos os Helenos, que pode ter mais significado por se encontrar numa inscrição de um exército aliado do contingente de Esparta. A ênfase dada a Opunte explica-se, provavelmente, por se tratar de um epitáfio colocado a expensas da pólis.

A crer no relato de Heródoto, parece que a actuação dos Lócrios ficou aquém do que o seu epitáfio reflecte, embora tudo indique que apenas se submeteram aos Persas após o confronto nas Termópilas (cf. 7. 203, 207; 8.66. $2 ; 9.31 .5)$. É uma questão complexa, porque aparentemente a autenticidade é assegurada pelas palavras de Estrabão - que suscitam dúvidas a Page 1981: 235, sublinhe-se - e corroborada pelo estilo, marcado pelo hipérbato de

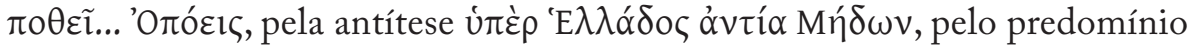
dos substantivos próprios em detrimento do vocabulário ornamental e pela omissão de referências ao sítio das Termópilas (desnecessárias num epitáfio ${ }^{43}$. Por si só estes aspectos não asseguram a atribuição do dístico elegíaco a Simónides, cuja inserção no seu corpus remonta, pelo menos, a F. W. Schneidewin e Th. Bergk. Mas também não há razões concretas para rejeitar esta proposta ${ }^{44}$. A confirmar-se esta hipótese e o testemunho de Estrabão sobre as estelas das Termópilas, Simónides poderia ter composto os epigramas de Megístias, das forças do Peloponeso, dos Espartanos e dos

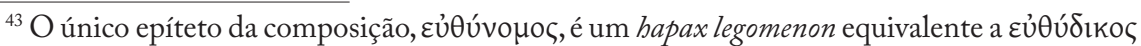
(cf. Bacch. 5. 6), segundo LSJ. No que respeita à actuação dos Lócrios no conflito, cf. Hignett 1963: 196 e n. 6, Lazenby 1993: 106, 134.

${ }^{44}$ Page 1981: 236 não exclui a hipótese de o epigrama datar do período helenístico. Se for autêntico, Molyneux 1992: 183 considera provável que o seu autor tenha sido Simónides, "in view of his composition of the Megistias epigram and (very possibly) of the other two epigrams quoted by Herodotus." 
Lócrios (VI, XXII (a), XXII (b) e XXIII) e Filíades de Mégara o dos Téspios (vide infra, pp. 276-277). Ou seja, embora com reservas, não há nenhum fundamento objectivo para negarmos a autoria de Simónides de, pelo menos, quatro inscrições das Termópilas.

\subsection{Artemísio (23 de Agosto de 480)}

Mais uma vez, a atribuição a Simónides do epigrama seguinte, que Plutarco cita como anónimo em Vida de Temistocles e De Herodoti malignitate 34. $867 \mathrm{f}^{45}$, parece basear-se apenas nas suposições dos editores modernos.

\section{Epigr. XXIV [135 B, 109 D] Plu. Them. 8. 4-5}

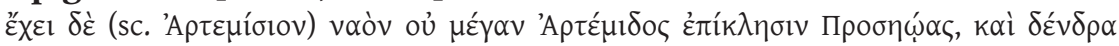

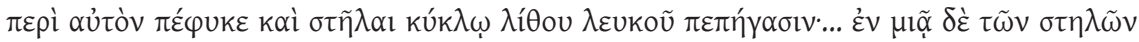

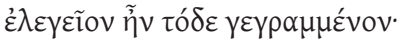

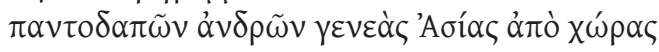

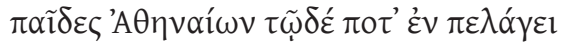

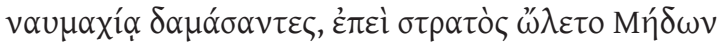

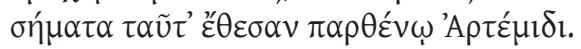

[O cabo Artemísio] tem um pequeno templo dedicado a Ártemis voltada para o Oriente; à sua volta crescem árvores e estelas de pedra branca foram dispostas em círculo; (...) numa das estelas estão gravados estes dísticos elegíacos:

Povos de todas as raças da terra da Ásia os filhos dos Atenienses outrora neste pélago

subjugaram numa naumaquia; destruída a armada dos Medos, estas insígnias dedicaram à virgem Ártemis.

Ao colocar em posição simétrica, no início do verso, $\pi \alpha \nu \tau o \delta \alpha \pi \tilde{\omega} v$

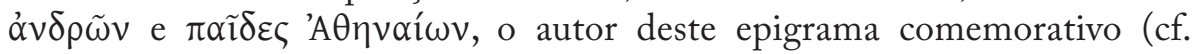
Wade-Gery 1933: 73, Manfredini 1991: 561) quis sublinhar o confronto entre a diversidade dos povos que constituíam a armada persa e uma frota uniforme, a fim de destacar o papel dos Atenienses e o falhanço do adversário, ideia a que dedica todo o v. 3. O resultado pode ser surpreendente e, como observam os estudiosos (cf. Page 1981: 236-237), não totalmente fiel à veracidade histórica, mas o exagero não nos parece invulgar, sobretudo numa dedicatória (cf. epigr. XX (a), XXIII).

${ }^{45}$ Se muitas vezes os estudiosos puseram em causa a autenticidade deste tratado, a crítica actual considera a questão ultrapassada. Cf. Hauvette 1896: 32 n. 2; J. Romilly, La douceur dans la pensée grecque (Paris 1979) 301; G. Lachenaud, Plutarque. Oeuvres Morales XII'P(Paris 1981) 114-117; Bowen 1992: 2-3; Sven-Tage Teodorsson, "Ethical Historiography. Plutarch's Attitude to Historical Criticism”, in C. Schrader et alii (edd.), Plutarco y la Historia (Zaragoza 1997) 439 e n. 1. 
As palavras de Plutarco não esclarecem se os dísticos elegíacos ainda eram visíveis no seu tempo. Aparentemente, sugerem que cita uma cópia dessa inscrição, mas a opinião dos estudiosos não é unânime ${ }^{46}$. Se são evidentes algumas das características das inscrições autênticas (o anonimato, presença de $\pi 0 \tau \dot{\varepsilon}$, ausência de referências explícitas à batalha), é certo que a concisão não é um dos seus atributos principais, nem o estilo prima pela sobriedade

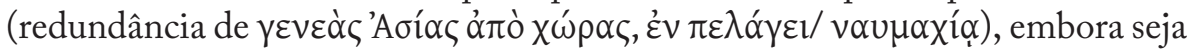
evidente a parcimónia dos termos ornamentais $(\pi \alpha \nu \tau o \delta \alpha \pi \tilde{\omega} \nu)$. Estes processos explicam-se pelo propósito geral da composição, que é o de sobrevalorizar a actuação dos soldados atenienses.

Os aspectos estilísticos referidos, em nossa opinião, ainda que não sejam fortes objecções à sua autenticidade, não favorecem a atribuição do epigrama a Simónides, que se baseia, como já referimos, nas suposições de F. W. Schneidewin e de Th. Bergk. A crítica moderna encontra um argumento de peso nos fragmentos que é possível atribuir ao poeta. Podlecki 1968: 266 acredita na autenticidade dos dísticos elegíacos e não exclui que sejam da autoria de Simónides, argumentando que era o epigramatista mais importante do seu tempo e já havia concebido um poema lírico sobre a naumaquia junto do cabo Artemísio. Molyneux 1992: 157 defende sensivelmente a mesma opinião. A possibilidade de ter existido uma obra elegíaca sobre a mesma matéria (cf. supra, pp. 144-145) pode reforçar este argumento. Em nossa opinião, porém, não devemos pôr de parte a hipótese de a dedicatória dos Atenienses ao templo de Ártemis ter sido colocada alguns anos depois da batalha, quando a Eubeia já era membro da Simaquia de Delos, ou só por volta de 445, quando Atenas teve de conter uma revolta que se revelou particularmente resistente na região norte da ilha, como observou Bowen 1992: $136^{47}$.

\subsection{Salamina ( 28 de Setembro de 480 )}

As inscrições do corpus de Simónides respeitantes à batalha travada no estreito de Salamina foram todas citadas no tratado De Herodoti malignitate, como provas de que Heródoto não avaliou correctamente a actuação de alguns contingentes gregos. Apenas em duas ocasiões Plutarco menciona a autoria de Simónides.

${ }^{46} \mathrm{Na}$ opinião de Podlecki 1973: 35, o modo como Plutarco descreve o templo de Ártemis sugere que terá visitado o local e provavelmente registado aí o epigrama. Manfredini 1991: 562 considera que o texto de Plutarco não confirma que a inscrição era visível e julga mais plausível a derivação directa de uma fonte literária, de um historiador, mas não necessariamente Eforo (cf. Boas 1905: 88). Menos céptica é a posição de Bowen 1992: 136, para quem o passo acima citado da Vida de Temistocles atesta que Plutarco viu a inscrição in situ.

${ }^{47}$ Para uma análise das objecções históricas à autoria de Simónides, vide Manfredini 1991: 564-568. 
Epigr. XIX (a) [136 B, 65 D] Plu. de Herod. malign. 36. 869c

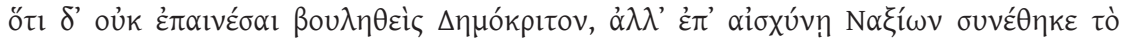

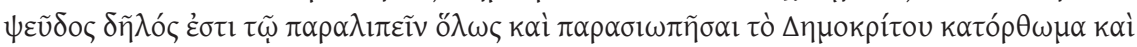

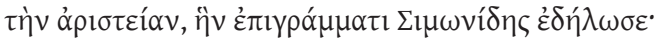

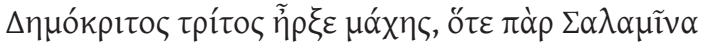

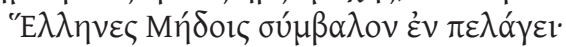

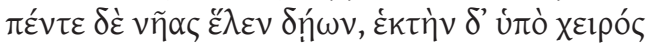

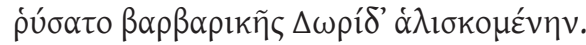

É evidente que [Heródoto] inventou a sua mentira não por desejar louvar Demócrito, mas antes para cobrir de vergonha os Náxios, ao deixar completamente de parte e guardar silêncio sobre o sucesso e a valentia de Demócrito, que Simónides mostrou num epigrama:

Demócrito foi o terceiro a iniciar o combate, quando junto a Salamina os Helenos atacaram os Medos no mar:

cinco barcos tomou ao inimigo e um sexto, dórico, salvou de cair em mãos bárbaras.

Plutarco acusa Heródoto de faltar à verdade por afirmar que os cidadãos de Naxos enviaram quatro embarcações em auxílio dos Persas, que passaram para o lado dos Helenos por incentivo de Demócrito (8.46.3). Os estudiosos discutem não só a atribuição a Simónides destes versos elegíacos, bem como a sua classificação como epigrama, dados que Plutarco recolheu decerto nas suas fontes. As composições que analisaremos a seguir, dedicadas aos Coríntios, são todas anónimas, o que é geralmente considerado um indício da sua natureza epigráfica. Neste caso, não se trata, de facto, nem de uma composição funerária nem votiva. Evoca-se primeiro o momento em que Demócrito, um dos capitães da frota de Naxos, entrou em acção no estreito de Salamina (após a frota de Atenas e Egina, segundo Hdt. 8. 84. 2), e, no segundo dístico, os sucessos alcançados. O estilo, no entanto, marcado pela concisão, simplicidade, e sem ornamentos, é próprio dos epigramas arcaicos. A construção formal do primeiro dístico encontra um paralelo no epigr. XX (b). 1-2: a oração temporal inicia-se na cesura heftemímere e prolonga-se em enjambement.

Como celebra apenas os feitos de Demócrito, Page 1981: 219, embora reconhecendo o estilo epigramático, sugeriu que o seu autor fosse um poeta de Naxos, argumento pouco válido quando sabemos que Simónides celebrou patronos de diversas partes do mundo grego. $\mathrm{O}$ mesmo investigador, no comentário ao epigr. XIV (p. 214), observa que, segundo Estêvão de Bizâncio (s.v. $\Theta \varepsilon ́ \sigma \pi \varepsilon l \alpha)$, os Téspios solicitaram os serviços de Filíades de Mégara para 
compor um epitáfio pelos seus mortos nas Termópilas ${ }^{48}$. E não parece muito razoável supor que os poetas apenas aceitavam celebrar feitos colectivos, embora seja essa a concepção dominante nos epigramas sobre as Guerras Medo-Persas. Como observa Molyneux 1992: 196, Page (ibidem) pode ter tido razão em sugerir que estes versos eram um skolion, uma pequena composição destinada a ser recitada num banquete, mas esta conjectura não exclui que tenham originalmente pertencido a um poema mais extenso ${ }^{49}$. Apesar das suas objecções e embora não haja certezas, não nos parece razoável negar a autoria de Simónides ${ }^{50}$. Molyneux (ibidem), que considera esta hipótese, nota ainda que não é possível apurar se, no caso de estes versos pertencerem a uma composição elegíaca, o poeta se teria deslocado à ilha de Naxos para a executar.

\author{
Epigr. XI [96 B, 90 D] Plu. de Herod. malign. 39. 870e + IG I'2. $927=131$ \\ Hansen

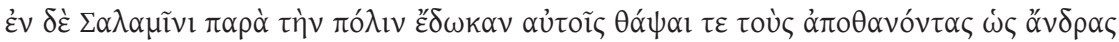

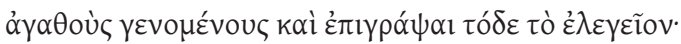

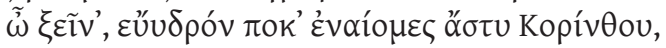

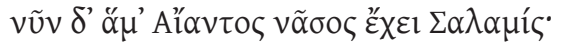

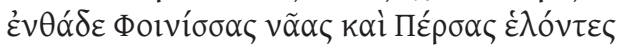

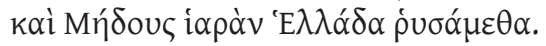

concederam-lhes [os Atenienses aos Coríntios] que sepultassem os seus mortos em Salamina, perto da cidade, como homens de grande coragem que haviam sido, e a gravar estes dísticos elegíacos:

Estrangeiro, outrora habitámos a cidade de boas águas, Corinto,

${ }^{48}$ Cf. 'Philiadas I' in Page 1981. Bowra 1938: 187 acredita na veracidade do testemunho de Estêvão de Bizâncio, notando com razão que ninguém atribuiria um epigrama com algum interesse a um poeta pouco conhecido, se ele não o tivesse escrito. Para uma opinião divergente, cf. Molyneux 1992: 183-184, que argumenta tratar-se de um autor tardio.

${ }^{49}$ A tese de Page encontra apoio nas palavras de Bowra 1938: 183. Este helenista observa que alguns versos elegíacos eram escritos em memória de homens já falecidos para serem entoados durante os brindes nos banquetes e não para serem gravados no túmulo. Cita como exemplo os de Cédon, que costumavam ser cantados em Atenas no séc. VI. Na sequência de Wilamowitz 1913: 144 n. 2 e de Diehl, Barigazzi 1963: 68 sugeriu que o epigr. XIX (a) era um fragmento de um poema elegíaco sobre a batalha de Salamina. A confirmar-se esta possibilidade, observa Podlecki 1968: 271, Simónides demorou-se na descrição das façanhas dos chefes gregos e dos diversos contingentes. Molyneux 1992: 196, cremos que com mais razão, supõe antes que a matéria desse poema seria a actuação dos guerreiros de Naxos nas Guerras Medo-Persas e não especificamente na batalha de Salamina. Por seu turno, Manfredini 1991: 570 não considera excepcional a forma deste epigrama e rejeita a hipótese de se tratar de um fragmento elegíaco.

${ }^{50} \mathrm{~A}$ atribuição do epigrama a Simónides, que se relaciona, em parte, com o problema das fontes de Plutarco, é tratada por Manfredini 1991: 571-573. No que respeita às fontes do autor de Queroneia, vide Bravi 2006: 72-73. 
agora detém-nos a ilha de Ájax, Salamina.

Neste lugar, ao vencermos as naus fenícias, os Persas

e os Medos, a sagrada Hélade salvámos.

O carácter epigráfico da composição é atestado por Plutarco e as descobertas arqueológicas confirmaram que a pedra original conserva parte do primeiro dístico e exibiu provavelmente o segundo. Nem todos os estudiosos aceitam esta última hipótese ${ }^{51}$. Em nossa opinião, a análise formal e temática do epitáfio sugere que toda a composição é autêntica. Evidencia aspectos convencionais, como a apóstrofe inicial (cf. epigr. XXII (b)), a feição dialogante

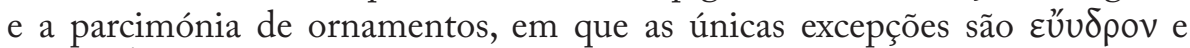
iapóv . É, no entanto, singular o facto de a referência à morte, habitual num epitáfio ( $\kappa \varepsilon i ́ \mu \varepsilon \theta \alpha$, por exemplo), ser substituída por um eufemismo (v. 2). Mas revela-se no contraste, que dá forma ao primeiro dístico, entre o tempo ( $\pi \circ \alpha \alpha)$

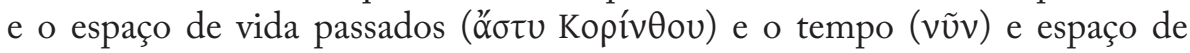
morte $(\Sigma \alpha \lambda \alpha \mu i ́ \varsigma)$ presentes. Corinto e Salamina ocupam, por isso, posições de destaque em fim de verso. O tom do segundo dístico é menos sóbrio: é o momento em que se afirma a razão de ser do sacrifício da vida, que tem um alcance pan-helénico. E a firmeza desta reivindicação é reforçada pelo polissíndeto e pela identificação detalhada das diferentes facções do inimigo.

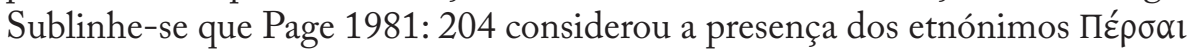
e Mñסor uma prova da antiguidade do epitáfio. De facto, como Boegehold 1965: 186 já havia notado, essas designações ocorrem nos vv. 8-9 do fr. 27 (col. ii) do P. Oxy. 2327 (fr. eleg. 13. 8-9, vide infra), confirmando que no tempo de Simónides os Gregos faziam bem a distinção entre os dois povos. Julgamos, portanto, que o segundo dístico completa o sentido do primeiro, pelo que nos parece improvável que não pertença à composição original. Por conseguinte, esta inscrição atesta que os argumentos pan-helénicos não foram reivindicados apenas por Atenas e Esparta.

${ }^{51}$ A inscrição em alfabeto coríntio arcaico foi encontrada em 1895 em Ambelaki, perto das ruínas da cidade antiga de Salamina, numa placa de mármore proveniente da acrópole, e publicada em 1897 por S. N. Dragoumis. Cf. Boegehold 1965: 180, Meiggs and Lewis 1975: 52-53, Manfredini 1991: 575 nn. 69 e 70 (com referências bibliográficas), Molyneux 1992: 192. No que diz respeito à autenticidade do segundo dístico, Campbell 1982: 398 parece seguir Bowra 1938: 189, para quem esses versos devem ter sido acrescentados quando o gosto "demanded something more colored and more emphatic." No entanto, a análise epigráfica levou Boegehold 1965: 185 a concluir que o exame da pedra não prova que a inscrição original era formada por um único dístico. Na opinião de Podlecki 1973: 28, o segundo é uma expansão literária e a atribuição do epigrama a Simónides pode ser fruto também dessa versão posterior. Cf. os argumentos de Page 1981: 202-203, a favor da autenticidade do segundo dístico elegíaco. Manfredini 1991: 577-579 contesta a autoria de Simónides por o epigrama ter sido composto em dialecto coríntio. Nas palavras de Page 1981: 204, note-se, trata-se de "coríntio poético, não vernáculo". 
A atribuição a Simónides apenas se encontra expressa em Favorino (ps. D.Chr. or. 37.18) $)^{52}$, o que não é significativo, como sabemos. A qualidade literária da composição reforça este testemunho, mas não é um argumento decisivo.

Epigr. XII [97 B, 95 D] Plu. de Herod. malign. 39. 870e + Aristid. Or. 28. 66

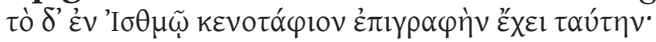

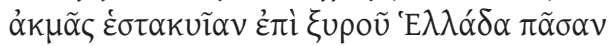

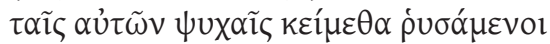

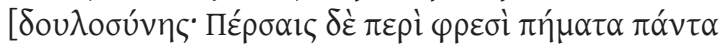

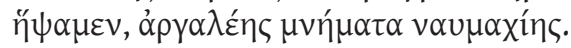

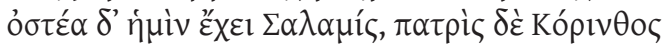

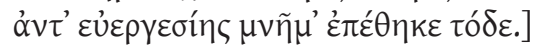

O cenotáfio no Istmo ostenta esta inscrição:

Sob a ameaça da lâmina estava toda a Hélade: jazemos aqui por a salvarmos com as nossas vidas

[da servidão. Os corações persas cingimos de todas as desgraças, em memória de uma penosa batalha naval.

Os nossos ossos acolhe-os Salamina, mas a pátria, Corinto, por esta boa acção, sobre nós ergueu este memorial.]

O problema da autenticidade desta composição, para a qual dependemos apenas da transmissão literária, assume contornos particulares. Plutarco citou o primeiro dístico elegíaco, que figura também na Antologia Palatina (7. 250), na de Planudes e num escólio de Aristides (III. 136 Dindorf). Este retórico do séc. II d.C. transmitiu-nos uma versão de seis versos, que prolonga o primeiro dístico. É provável que estes quatro versos não sejam originais, como notou F. W. Schneidewin (cf. Page 1981: 204 n. 1). Todavia, a questão é mais complexa, pois é notório que o primeiro dístico, do ponto de vista da sua funcionalidade, pelo menos, também não está completo.

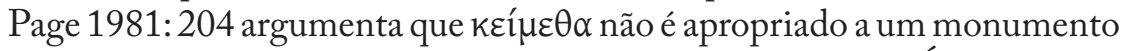
de vitória. Plutarco, que possivelmente se baseia no historiador Éforo do séc. IV (Page, ibidem), observa que a inscrição se encontrava num cenotáfio que, no santuário de Poséidon do Istmo de Corinto, homenageava os que haviam perdido a vida a combater, provavelmente contra os Persas, o que se deduz da referência à salvação da Hélade. $O$ primeiro dístico retoma a concepção pan-helénica de que se cumpriu um sacrifício colectivo em benefício de todos os Helenos, mas os mortos não são identificados. Podemos supor que as inscrições dos cenotáfios (na realidade, memoriais) eram compostas como

${ }^{52}$ Manfredini 1991: 576-577 procede à análise comparada dos textos de Plutarco e de Favorino, estabelecendo as afinidades e discrepâncias existentes entre eles. 
epitáfios autênticos, mas mesmo assim seria essencial a indicação de que a verdadeira sepultura se encontrava noutro local.

Esse e outros dados figuram nos vv. 4-6. É no segundo dístico que surge o tema da liberdade da Hélade (cf. supra, epigr. XVIII). Algum vocabulário

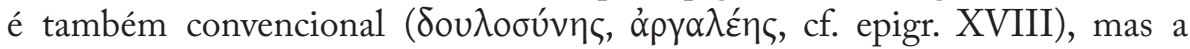
repetição do termo $\mu \nu \tilde{\eta} \mu \alpha$ nos vv. 4 e 6 prejudica a concisão característica da

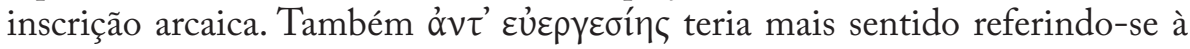
salvação da Hélade (vv. 1-2) que ao conteúdo dos vv. 3-4. Ou seja, os vv. 3-6 não tornam a composição mais coerente.

Note-se que o primeiro e o último dístico evidenciam semelhanças formais e temáticas com o epigrama anterior, embora se distingam na forma explícita como a morte é referenciada e no dialecto usado. No entanto, a semelhança temática e vocabular não significa necessariamente que estejamos perante exercícios literários. É natural que um conflito tão ameaçador tenha levado à constituição de um imaginário e de um fundo temático e linguístico comum, que terá sido partilhado por diversos poetas e inspirado, possivelmente, pelas ideias ou palavras de ordem que circulavam entre os principais intervenientes no conflito.

Finalmente, vale a pena lembrar a observação de Th. Preger ${ }^{53}$ de que $\kappa \varepsilon i ́ \mu \varepsilon \theta \alpha$, no v. 2, pressupõe que a indicação do local de sepultura dos soldados figurava num segundo dístico, que se perdeu, uma vez que os versos que Aristides nos legou são certamente um acrescento posterior. Um argumento a favor desta tese, além dos aspectos acima considerados, é o facto de apenas o primeiro dístico ser atribuído a Simónides pela Antologia Palatina, o que pode ser uma indicação da sua antiguidade, embora não signifique que tenha sido, de facto, por ele composto ${ }^{54}$.

\section{Epigr. XIII [134 B, 108 D] Plu. de Herod. malign. 39. $870 \mathrm{f}$}

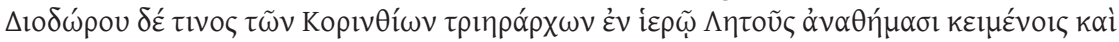

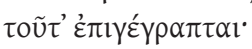

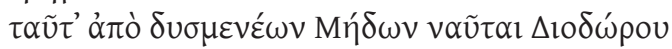

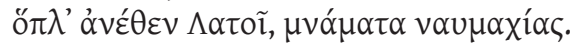

${ }^{53}$ Inscriptiones Graecae metricae ex scriptoribus praeter Anthologiam collectae (Leipzig 1891) 5-6, apud Page 1981: 204.

${ }_{54}$ Podlecki 1973: 28-29 trata com algum pormenor a questão da transmissão literária, mas chega, talvez, a uma conclusão demasiado céptica, aceitando a tese de B. Keil, editor de Aristides, de que todo o epigrama é uma ficção literária ("totum epigramma ficticium"). Na sua opinião, se houve, de facto, um cenotáfio no Istmo para assinalar o sacrifício dos Coríntios que foram sepultados em Salamina, o epigrama não teria sobrevivido, pelo que não temos forma de saber se Simónides foi o seu autor. Manfredini 1991: 580 põe em dúvida que o monumento fosse um cenotáfio e supõe que se tratasse antes do polyandrion de todos os outros coríntios que haviam falecido na luta contra os Persas. 
Esta é a inscrição gravada nas oferendas depositadas no templo de Leto por Diodoro, um dos capitães coríntios:

Estas armas, tomadas aos Medos hostis pelos nautas de Diodoro, a Leto foram dedicadas em memória da batalha naval.

O que sabemos de Diodoro resume-se a este testemunho. É possível, portanto, que se trate efectivamente de uma inscrição que acompanhava a consagração de despojos, da qual Plutarco teve conhecimento através da mesma fonte que lhe transmitiu outras inscrições respeitantes aos Coríntios e às Guerras Medo-Persas. Esta conjectura é corroborada pelo estilo da composição, que obedece às convenções das inscrições votivas. $\mathrm{O}$ hipérbato chama a atenção para os objectos consagrados e, por meio de uma forma simples, mencionamse os responsáveis pela oferenda na segunda parte do hexâmetro. $\mathrm{O}$ cuidado na disposição das palavras de acordo com o ritmo do verso é evidente também no pentâmetro: primeiro nomeia-se a divindade homenageada, em seguida

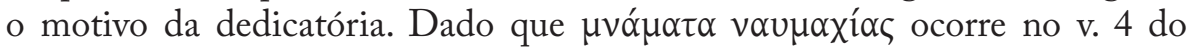
epigr. XII, trata-se possivelmente de uma expressão votiva convencional. No entanto, embora o epigrama possa ser autêntico, como se pensa (cf. Manfredini 1991: 580), a atribuição a Simónides pela Antologia Palatina (6.215) é fruto, certamente, da transmissão helenística. Podlecki 1968: 272 tem dúvidas de que mereça crédito.

Epigr. X [98 B, 94 D] Plu. de Herod. malign. 39. $870 f$

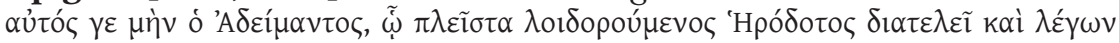

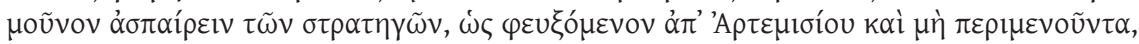

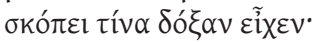

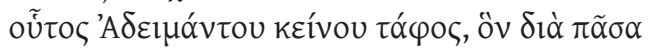

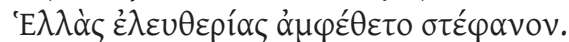

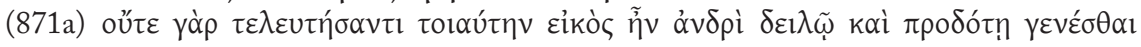

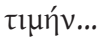

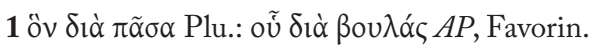

Quanto ao próprio Adimanto, a quem Heródoto lança a todo o momento numerosos insultos, chegando a dizer que era o único dos generais a protestar, que queria fugir de Artemísio e não esperar, veja-se que reputação tinha:

Este é o túmulo do ilustre Adimanto, graças a quem toda

a Hélade se cingiu com a coroa da liberdade.

De facto, não seria provável que, depois de falecer, um homem vil e traidor recebesse tal honra, (...)

Trata-se do epitáfio do comandante dos Coríntios nas batalhas travadas junto do cabo Artemísio e da ilha de Salamina. Segundo Heródoto, Adimanto 
apenas participou na primeira naumaquia, porque foi subornado por Temístocles $(8.5$, cf. 59, 61). No entanto, o historiador observa que a sua versão sobre o comportamento pouco heróico de Adimanto em Salamina (8. 94.1-3) era de origem ateniense, e nota que esta versão era contestada com veemência pelos Coríntios, que tinham a seu favor o testemunho de todo o resto da Grécia (8. 94. 4). Este desencontro de opiniões sobre o empenho dos diversos contingentes na luta contra o invasor bárbaro radica certamente na rivalidade que passa a caracterizar as relações entre Atenas e Corinto a partir de 459-458, por causa da aliança ateniense com Mégara. No tempo de Simónides não seria esta, por certo, a opinião que corria sobre a participação do exército coríntio nas batalhas navais.

É evidente uma certa semelhança formal entre este epitáfio e o que foi composto para o profeta Megístias (epigr. VI). Ambos se iniciam

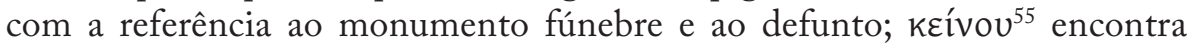
correspondência em $k \lambda \varepsilon$ เvoĩo, os únicos ornamentos da composição; com a pausa bucólica coincide o início da oração relativa, que se prolonga por enjambement. A concisão e simplicidade são também atributos do epitáfio de Adimanto. Diferem, no entanto, do ponto de vista temático. Neste caso, o tema da liberdade alcançada para toda a Grécia é articulado, através da metáfora e da personificação, com o tema da coroa da vitória, que se encontra também nos epigramas sobre atletas ${ }^{56}$. Estas considerações não pretendem justificar a atribuição a Simónides, que apenas se encontra expressa em Favorino (ps. D.Chr. or. 37.19) ${ }^{57}$. É natural que os compositores de epigramas cultivassem os mesmos processos retóricos e os mesmos temas. Por isso, como observa Page 1981: 201, é de supor que se trate de um epitáfio autêntico, o que parece ser corroborado pela Antologia Palatina, que o transmitiu como anónimo (7. 347). Pertinente é a observação de Molyneux 1992: 193 de que não foi composto para a sepultura de um guerreiro que perdera a vida em combate, porque, como Page também havia notado, Adimanto teve três filhas e um filho, a quem deu nomes que reflectem a glória alcançada em Salamina (cf. Plu. de Herod. malign. 39. 871a). Este facto reduz fortemente as hipóteses de Simónides ter sido o seu autor.

55 Page 1981: 202 observa que o pronome demonstrativo é desnecessário e contrário ao costume, pondo a hipótese de no original ter figurado $\kappa \lambda \varepsilon ı v o \tilde{v}$ ( $\kappa \lambda \varepsilon ı v o ́ \varsigma$, 'glorioso, ilustre'). Mas o pronome demonstrativo grego pode expressar também essa noção. Cf. Bravi 2009, que discute a construção formal e temática do epigr. X, o tratamento da figura de Adimanto em Heródoto e a utilização do epitáfio por Plutarco.

${ }^{56}$ Cf. epigr. XXX. 4, referido supra p. 153, e epigr. VIII. 3, infra p. 285.

${ }^{57}$ Boas 1905: 53 sqq. defendeu que a fonte literária do epigr. X seria o historiador Éforo. A confirmar-se esta opinião, observa Page 1981: 201, trata-se de um epitáfio genuíno, uma vez que os pseudo-epitáfios como propaganda são posteriores ao tempo de Éforo. 


\section{Epigr. XIV [137 B, 104 D] Schol. Pind. Ol. 13. 32b (I. 364-365 Dr.)}

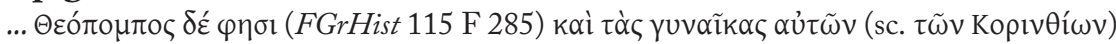

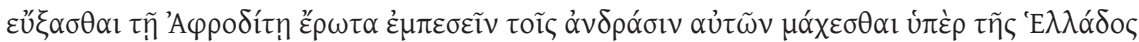

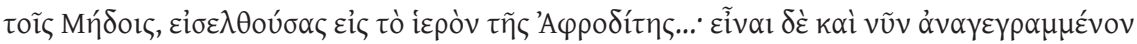

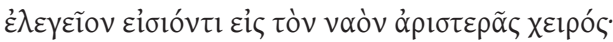

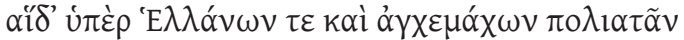

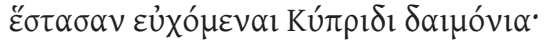

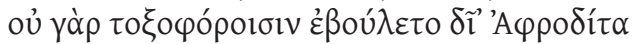

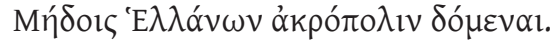

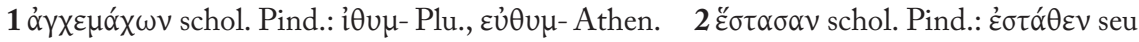

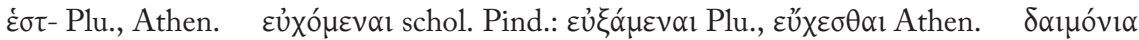

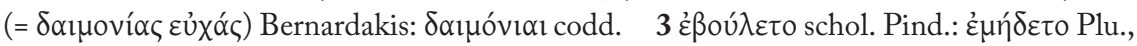

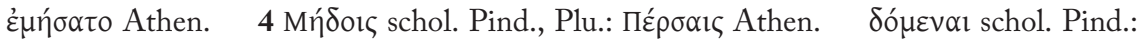

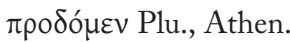

... Teopompo diz que as mulheres deles [dos Coríntios] também foram ao templo de Afrodite e suplicaram à deusa que se abatesse sobre os seus homens a paixão de combater os Medos pela salvação da Hélade (...); [diz] também que ainda agora há uma inscrição em dísticos elegíacos gravada no lado esquerdo de quem entra no templo:

Estas mulheres, pelos Helenos e cidadãos aliados,

apelam a Cípris em devota súplica, pois não era da vontade da deusa Afrodite

aos Medos armados de arcos dar a acrópole dos Helenos.

Como nota Boas 1905: 51 n. 19, o templo de Afrodite foi destruído apenas em 146, mas o comentador da ode composta para Xenofonte de Corinto baseia-se apenas no testemunho do historiador do séc. IV Teopompo

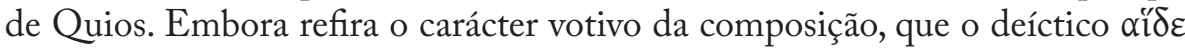
pressupõe, não esclarece a natureza da dedicatória, informação que vamos encontrar em Plutarco e Ateneu.

Em de Herod. malign. 39. 871a-b, esta história e o epigrama são evocados como argumento final contra uma visão depreciativa da actuação dos Coríntios na luta contra os Persas. Plutarco sugere que Heródoto ignorou intencionalmente uma história que 'andava nas bocas do mundo', e acrescenta que Simónides compôs o epigrama para a dedicatória de estátuas de bronze

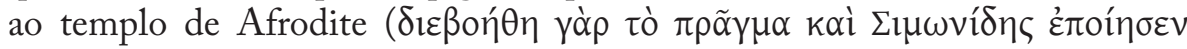

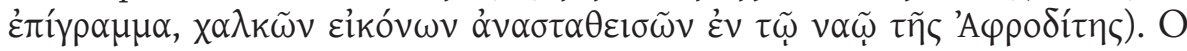
epigrama é também atribuído a Simónides por Ateneu (13.573c-e), mas na sua versão as mulheres são hetairai e a dedicatória é uma pintura ${ }^{58}$.

${ }^{58}$ Além destas divergências, tanto Plutarco como Ateneu citam versões diferentes da inscrição transmitida pelo escoliasta de Píndaro (vide o aparato, supra), o que significa que seguiram 
Não temos certezas quanto ao grau de veracidade destas versões, mas julgamos importante a observação de Plutarco de que a história era muito conhecida. Embora os estudiosos modernos não valorizem a atribuição a Simónides $^{59}$, não parece haver dúvidas de que o presente epigrama era uma inscrição votiva. A análise formal e temática confirma esta classificação. A sobriedade é evidente na parcimónia de epítetos ${ }^{60}$. É surpreendente que não ocorra uma referência explícita aos Coríntios, como se estas mulheres fossem motivadas por um ideal pan-helénico e não por preocupações familiares e cívicas. De facto, a queda de Corinto teria sido fatal para as forças gregas. A cidade é evocada apenas no último verso, mas através de uma perífrase, e a composição em anel leva à repetição de 'E $\mathrm{\lambda} \lambda \alpha{ }^{\prime} v \omega v$. No primeiro dístico revela-se a razão de ser da dedicatória e a divindade a que é consagrada. Como também acontece nos epigr. VI e XX (a), o segundo dístico é dominado pela

outras fontes. Embora Plutarco não mencione as suas, depreende-se que conhecesse também, ainda que indirectamente, a versão de Teopompo (cf. Page 1981: 208). O passo de Ateneu deixa algumas dúvidas, porque começa por citar o tratado Acerca de Píndaro, de Cameleonte, quanto ao costume de as hetairai de Corinto serem convidadas a rezar no templo de Afrodite em momentos de crise (13.573c) e, quando dá o exemplo do que sucedeu durante a invasão de Xerxes (13.573d-e), menciona também Teopompo e o livro VII do historiador Timeu de Tauroménio (séc. IV-III). Como neste testemunho as suplicantes são heteras, supõe-se que a fonte principal tenha sido Cameleonte (ou Timeu), embora o texto não seja claro. Na análise desta questão, van Groningen 1956 defende que Ateneu deriva principalmente de Cameleonte, e que a tradição que se baseia em Teopompo tem mais probabilidade de ser autêntica (cf. p. 21). Page 1981:207-210 discute em detalhe a transmissão literária do epigrama e conclui: "it appears highly probable that Theopompus' version of the epigram is both older and better authenticated than that of 'Plutarch' and Athenaeus; and that the object dedicated was a painting, not statuary. It remains uncertain whether the women portrayed were Corinthian matrons or hetaerae or (as we are strongly inclined to believe) temple-slaves.” Em nossa opinião, vale a pena considerar a hipótese de van Groningen 1956: 15 de a dedicatória ao templo ter incluído as estátuas de bronze e a pintura. $\mathrm{Na}$ análise deste ponto, Palumbo Stracca 1985 defende que as opiniões de Plutarco e de Ateneu não devem ser lidas em alternativa, porque o primeiro podia estar a referir-se à dedicatória e o segundo à tabula que continha a inscrição e os nomes das mulheres (p. 61).

${ }_{59}$ Page 1981: 208, que não atende ao comentário de Plutarco sobre a divulgação da história, observa que a atribuição de uma inscrição a um autor em particular não tem paralelo nos autores gregos antes do período helenístico. Na sua opinião, os testemunhos de Plutarco e de Ateneu podem ser uma indicação de que na última parte do séc. IV foi publicada uma colecção de inscrições sob a autoria de Simónides, colecção essa que foi sendo alargada ao longo dos séc. III e II (p. 210). Para Manfredini 1991: 584-585, porém, o facto de a atribuição a Simónides não figurar no escólio de Píndaro não significa que essa informação não se encontrava em Teopompo, embora também considere o historiador do séc. IV a fonte principal desse escólio e de Plutarco.

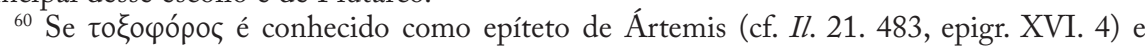

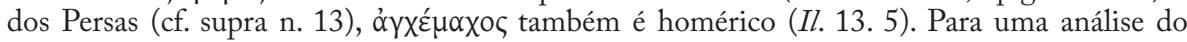
emprego deste epíteto (e da sua possível ocorrência no v. 14 do fr. eleg. 11, infra), vide Rawles 2008: 462-463, esp. O investigador considera, provavelmente com razão, que a escolha dos dois epítetos não é meramente ornamental, mas visa salientar o contraste entre o modo de combater dos Coríntios e o dos Medos que, ao usarem o arco, não se aproximavam do inimigo. 
formulação negativa, que imprime mais força à afirmação final. Todavia, não se alude ao conteúdo da prece (que era, por certo, do conhecimento geral), mas às intenções da deusa. A ideia sugerida por esta composição é que as mulheres de Corinto foram motivadas, por devoção ou inspiração divina $(\delta \alpha \iota \mu o ́ v ı \alpha)^{61}$, a dirigirem-se ao templo, como se a deusa esperasse que uma súplica formal legitimasse a sua vontade de intervir na luta contra os Persas. Estes aspectos formais e o testemunho de Plutarco levam-nos a considerar plausível a atribuição a Simónides.

\subsection{Plateias (fins de Agosto de 479) \\ Epigr. VIII [100 B, 118 D] $A P$ 7.253, $A P l$

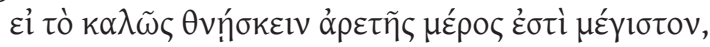

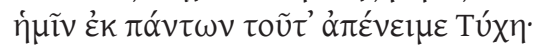

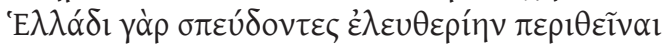

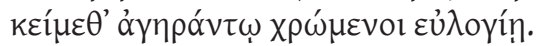

Se a bela morte é da bravura a parte maior, a nós, entre todos, no-la concedeu a Fortuna:

na luta por dar à Hélade a coroa da liberdade jazemos aqui, na posse de um louvor sem idade.

O presente epigrama e o que se segue distinguem-se tanto do ponto de vista formal, como conceptual. Como foram imitados, depreende-se que tiveram uma grande fama ${ }^{62}$. É plausível, por isso, que sejam criações de Simónides, como alguns estudiosos supõem, e que formem um par. O facto de não identificarem os homenageados nem o local da batalha indica que eram

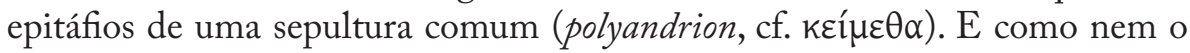
inimigo é mencionado, supõe-se que seja o exército persa, que no espírito dos

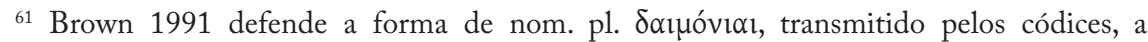

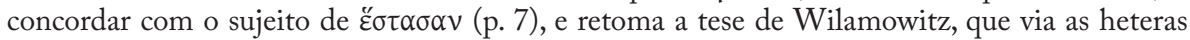
mencionadas por Ateneu como as hierodouloi que serviam no templo de Afrodite (p. 8). Não nos

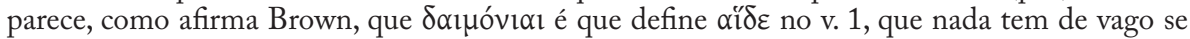
figurar na inscrição de uma dedicatória. Julgamos que tem mais razão Palumbo Stracca 1985: 63, que considera indispensável a emenda de Bernardakis, porque a inscrição devia aludir ao carácter extraordinário e quase divino da prece das mulheres. Por esta razão, parece-nos mais plausível a tradição do escoliasta de Píndaro e de Plutarco, que identificava as suplicantes com as esposas dos combatentes. Para uma análise mais detalhada do nosso argumento, vide Ferreira 2007/2008. Vide ainda Bravi 2006: 60-63, para um exame dos vários problemas suscitados pela transmissão literária da inscrição.

${ }^{62}$ Este facto permitiu estabelecer uma data ante quem para a sua composição. Page 1981: 198 observa que o epigr. VIII é seguramente anterior ao período helenístico, porque foi imitado num epitáfio do Cerâmico que data de c. 317/316 ou um pouco antes. O epigr. IX foi imitado num epitáfio de Cnossos que data do séc. II. Cf. W. Peek, Griechische Vers-Inschriften I (Berlin 1955), $\mathrm{n}^{\circ} 1689$ e 1513 , respectivamente (apud Page). 
Gregos que viveram este conflito havia constituído uma verdadeira ameaça à liberdade da Hélade (v. 3). Entre os aspectos mais singulares desta composição salientamos, além da feição dialogante (ท́ $\mu \tilde{v} v, \kappa \varepsilon i ́ \mu \varepsilon \theta \alpha)$ e da precisão do estilo, que não é invulgar nos epitáfios, a oração condicional que a inicia, que põe a ênfase na noção de 'bela morte'. Esta surge como passo determinante para a consagração do guerreiro, que é alcançada na luta por um objectivo comum. Ao contrário do que acontece noutros epitáfios, a morte não é aqui lamentada. Ela é sinal de um destino distinto e, por conseguinte, o seu lamento tem de ser substituído pelo elogio que perdurará. Este é, como sabemos, um tema tratado na elegia guerreira mais antiga (e.g. Tyrt. fr. 10.1-2 W) e que Simónides desenvolveu no fr. 531 (vide supra).

De acordo com os lemmata, este epigrama e o seguinte foram compostos em homenagem aos soldados que perderam a vida nas Termópilas. Os estudiosos contestam esta informação, uma vez que conhecemos com razoável segurança os epitáfios que dizem respeito a esta batalha (Page 1981: 197). Th. Bergk, tendo em consideração o testemunho de Pausânias, segundo o qual os túmulos dos Espartanos e dos Atenienses em Plateias exibiam epitáfios de Simónides (9.2.5), sugeriu que o poeta tenha composto o presente epigrama em homenagem aos Atenienses e o seguinte para os Espartanos ${ }^{63}$.

\author{
Epigr. IX [99 B, 121 D] $A P$ 7.251, $A P l$

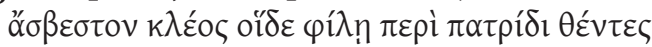

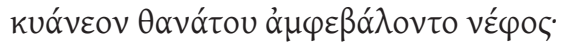

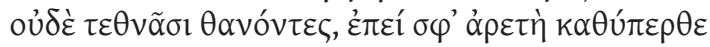

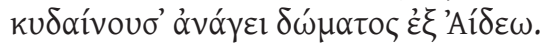 \\ Estes homens, cingindo a pátria amada de uma glória imortal, \\ envolveram-se na sombria nuvem da morte; \\ morreram, mas não estão mortos: sobre eles se derrama a fama \\ do seu valor, que os trará da morada de Hades.
}

Th. Bergk baseou-se na suposição de que o pan-helenismo que caracteriza

\footnotetext{
${ }^{63}$ Apud Page 1981: 198, que aceita a sua teoria, refutada por Jacoby 1945: 159 n. 11. Page destaca a qualidade literária das composições e considera que a atribuição a Simónides, embora se encontre na Antologia Palatina, pode ser verdadeira. Esta hipótese foi também aceite por Bowra 1938: 192-193 e Molyneux 1992: 197, embora este historiador invoque um argumento pouco sólido: "in view of his composition of other Persian war poems for both the cities." A autoria de Simónides é considerada duvidosa, mas não impossível, por Gerber 1970: 330. Campbell 1982: 401 aceita a tese de Bergk, mas discorda da atribuição dos epigramas ao poeta, considerando que datam provavelmente do séc. IV. Saliente-se ainda que os editores da Antologia Palatina da colecção Budé divergem destas posições na interpretação das circunstâncias de composição dos epigramas (1938: 165).
} 
em particular o epigr. VIII era mais adequado a um epitáfio para os Atenienses, que se consideravam defensores de toda Hélade, enquanto a defesa da pátria era especialmente importante para os Espartanos (apud Page 1981: 198-199). Se esta hipótese pudesse ser confirmada, bem como a atribuição a Simónides, teríamos aqui a prova de uma capacidade extraordinária para apreender os valores e os sentimentos mais caros a cada pólis ${ }^{64}$. Esta qualidade não seria de estranhar, no entanto, num ancião que havia passado grande parte da sua vida a viajar e a contactar com diversas gentes do mundo grego.

O presente epigrama é ainda mais omisso do que o anterior relativamente às circunstâncias da sua composição. No v. 1 , a referência explícita à guerra é substituída por uma metáfora alusiva à coroação dos vencedores e à glória que se estendia à sua terra natal; no v. 2, a morte é referida de forma eufemística e metafórica (cf. Il. 20.417-418), para ser negada logo a seguir através de um oxímoro (v.3). Este epigrama exprime, do mesmo modo, a noção de que morrer no campo de batalha é um estado transitório para a glorificação permanente,

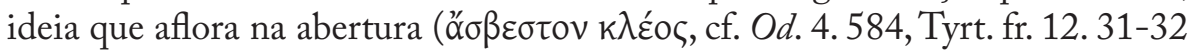
$\mathrm{W})$ e se concretiza no último verso ( $\kappa v \delta \alpha i ́ v o v \sigma \alpha)$.

\section{Epigr. XV [140 B, 107 D] Plu. Arist. 19.7}

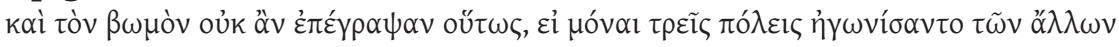

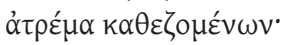

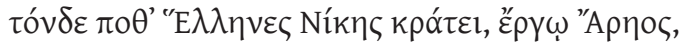

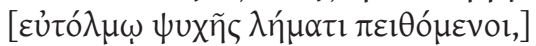

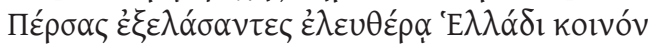

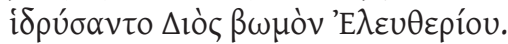

E não teriam gravado no altar a seguinte inscrição, se apenas três cidades tivessem combatido, enquanto as restantes ficassem tranquilamente paradas:

Outrora os Helenos, com a força da Vitória e o trabalho de Ares, [obedecendo à vontade audaciosa do seu espírito,]

os Persas repeliram e à Hélade livre edificaram este altar comum de Zeus Libertador.

A fim de desmentir Heródoto, por este afirmar que nos confrontos decisivos de Plateias apenas participaram Espartanos, Atenienses e Tegeatas (9. 59 sqq., cf. 9. 85), Plutarco cita, neste passo e em de Herod. malign. 42. $873 \mathrm{~b}$, a inscrição que teria sido gravada pelos 'Helenos' num altar erguido em Plateias em honra de Zeus Libertador, que viria a ser o centro do festival

${ }^{64}$ Esta ideia é sugerida por Bowra 1938: 196, que propõe uma análise comparada bastante interessante dos dois epigramas. 
Eleutheria ${ }^{65}$. A Antologia Palatina (6.50), que a atribui a Simónides, acrescenta um pentâmetro (v. 2), provavelmente espúrio (cf. Page 1981: 212). Tendo em conta o estilo epigráfico e a presença dos deícticos ( $\tau o ́ v \delta \varepsilon \pi 0 \theta$ ' 'Е $\lambda \lambda \eta v \varepsilon \varsigma$ ), é provável que os outros três versos constituam a inscrição autêntica. O emprego

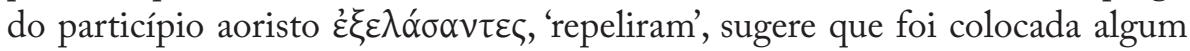
tempo (ou bastante) depois do conflito ${ }^{66}$, numa altura em que estava enraizada a ideia de que a vitória contra os Persas havia resultado do esforço conjunto de todos os Helenos pela liberdade da Hélade. Este aspecto é sublinhado com a repetição dos conceitos de Helenos/Hélade (vv. 1, 3) e de liberdade (vv. 3, 4).

A invulgar estrutura métrica do epigrama (dois hexâmetros e um pentâmetro) é argumento suficiente para alguns classicistas rejeitarem a atribuição a Simónides, que depende inteiramente do testemunho pouco seguro da Antologia Palatina. Mas se Wilamowitz 1913: 198 considerou original aquela forma, parece-nos que tem mais razão Page 1981: 212 e n.1, que suspeita da qualidade literária da composição, embora aceite que possa ser cópia de uma inscrição genuína (anónima ${ }^{67}$.

Epigr. XVI [107 B, 96 D] $I G$ VII. 53 = SEG 13.312

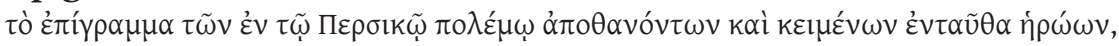

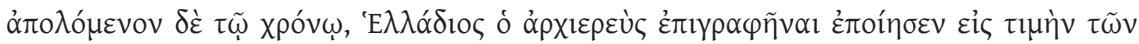

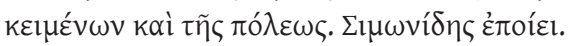

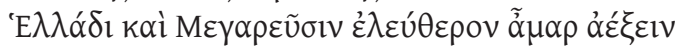

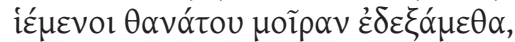

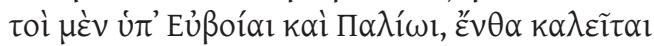

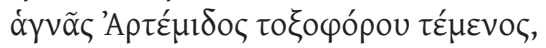

${ }^{65}$ Segundo Tucídides (2.71. 2), Pausânias e outros Helenos que com ele haviam combatido promoveu cerimónias em honra de Zeus Eleutherios na ágora de Plateias. Num outro passo, informa que anualmente os túmulos dos guerreiros eram honrados com oferendas (3. 58. 4; cf. Plu. Arist. 19. 7-8). De acordo com o Periegeta, o altar não se encontrava muito afastado dos monumentos fúnebres (9.2. 5). Estrabão observa que o festival Eleutheria compreendia um concurso atlético que tinha como prémio uma coroa, mas não fornece mais detalhes $(9.2$. 31). A tradição, transmitida por Diodoro Sículo (11. 29. 1) e Plutarco (Arist. 21. 1-2), de que se realizavam agones em Plateias desde 479, de quatro em quatro anos, foi discutida e refutada por R. Étienne et M. Piérart, "Un décret du Koinon des Hellènes à Platées en l'honneur de Glaucon, fils d'Étéoclès, d'Athènes”, BCH 99 (1975) 51-75, esp. 63-68. Segundo este estudo, a instituição do festival com esta forma, que ainda se realizava no tempo de Pausânias (9.2.6), data talvez do tempo de Filipe e Alexandre da Macedónia. Outros estudiosos têm chamado a atenção para a ausência de fontes da Época Clássica sobre o festival. Cf. Boedeker 1995: 222, Schachter 1998: 26, Rutherford 2001a: 40-41. As inscrições sobre o festival são discutidas por L. Robert, "Épigrammes satiriques de Lucillius", L'épigramme grecque. Entretiens Hardt XIV (Genève 1968) 187-190.

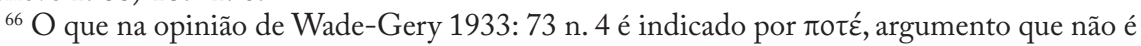
suficiente, em nossa opinião (vide supra, epigr. VI).

${ }^{67}$ Menos válido nos parece o argumento de Molyneux 1992: 197, que considera plausível a atribuição a Simónides, caso tenha também composto os epigr. VIII e IX. 


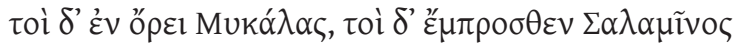

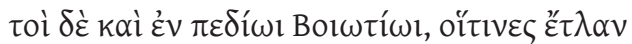

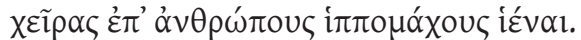

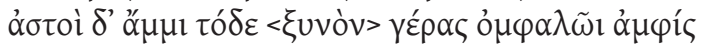

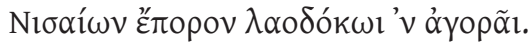

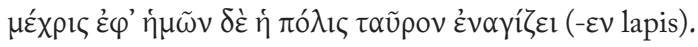

9 suppl. Wade-Gery $\mathbf{1 0}$ Wade-Gery: $\lambda \alpha o \delta$ ok $\omega \nu$ lapis

Visto que o epigrama dos heróis que morreram na guerra persa e aqui repousam foi destruído pelo tempo, Heládio, o grande sacerdote, fez por que fosse gravado em honra dos mortos e da cidade. Simónides era o seu autor.

Da Hélade e dos Megarenses o dia da liberdade

procurámos engrandecer e um destino fatal recebemos,

uns na Eubeia e no Pélion, onde se ergue

o santuário da pura Ártemis, a archeira,

outros na montanha de Mícale, outros frente a Salamina

outros ainda na planície beócia, aqueles que ousaram

lançar as mãos aos soldados de cavalaria.

A nós concederam os cidadãos esta honra comum, no coração

da ágora que acolhe o povo dos Niseus.

Até aos nossos dias, a pólis tem sacrificado um touro.

A forma das letras desta inscriçãa ${ }^{69}$ sugere que o monumento colocado por ordem de Heládio data do séc. IV d.C. ou é posterior (Page 1981: 213, Campbell 1991: 533). Não obstante as palavras do preâmbulo, pode ter sido antes um memorial, como julga Page (ibidem), edificado na ágora de Mégara (v. 10), em homenagem a todos os cidadãos que haviam perdido a vida nas lutas contra os Persas (vv. 3-8). Pausânias informa que os Megarenses tinham túmulos dentro da cidade e um deles fora construído para aqueles homens (1. 43. 3), mas segundo os historiadores da Época Clássica os soldados de Mégara haviam sido sepultados no campo de batalha, inclusive os que foram dizimados em Plateias pela cavalaria tebana (Hdt. 9. 85, Thuc. 3. 58.4).

A noção de que com o sacrifício da vida, mencionado de forma eufemística no v. 2, os Megarenses alcançaram a liberdade para todos os Helenos ocupa o primeiro dístico da composição. O tema da liberdade é aqui retomado de forma

\footnotetext{
${ }^{68} \mathrm{O}$ canteiro omitiu um pentâmetro e uma palavra do v. 9. Cf. Wade-Gery 1933: 96, Page 1981: 213, Campbell 1991: 535.

${ }^{69} \mathrm{~A}$ inscrição foi descoberta por M. Fourmont e publicada por A. Boeckh em 1818. O primeiro comentário e edição de referência são de Von A. Wilhelm, "Simonideische Gedichte", Jahr. des Öst. Arch. Inst. Wien 2 (1899) 221-244 (in Pfohl 1972: 290-322, esp. 311-322).
} 
mais elaborada, mas o coração do epigrama é preenchido com a menção das batalhas, terrestres e navais, em que os soldados de Mégara participaram (vv.

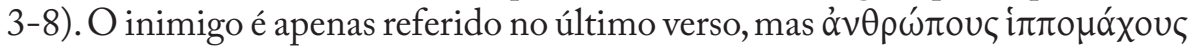
tanto pode designar os Persas como a cavalaria dos Tebanos, que foram seus aliados (cf. Hdt. 9.69). Característica particular é a articulação da enumeração simples com as duas digressões em enjambement (vv. 3-4, 7-8), cuja intenção, provavelmente, pode não ir além do mero ornamento ${ }^{70}$, à semelhança do que ocorre na poesia épica em catálogo (cf. Hes. Th. 252-255). O último dístico diz apenas respeito ao memorial, dedicado a expensas do povo de Mégara, mencionado através de uma perífrase que evoca o seu rei mítico, Niso (cf. infra fr. eleg. 11. 37). A feição dialogante, que é introduzida no epigrama por $\varepsilon \delta \varepsilon \xi \alpha^{\prime} \mu \varepsilon \theta \alpha$ no v. 2, culmina agora no pronome pessoal $\alpha \mu \mu \nu$ e confere a toda a composição um tom menos impessoal e mais intimista.

O preâmbulo atribui a Simónides a autoria do epigrama e não cremos que haja objecções do ponto de vista histórico e cronológico. Informa um escólio de Theoc. 12. 27-33b-c (pp. 255-256 Wendel = fr. 629, 124 P, 199 B)

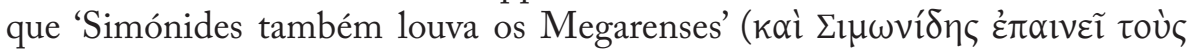

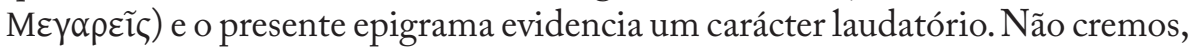
no entanto, que o seu estilo apoie a atribuição ao poeta, que provavelmente tem origem na transmissão literária do período helenístico ${ }^{71}$. A sua dimensão, que contrasta com a brevidade das inscrições arcaicas, e a construção formal, que se

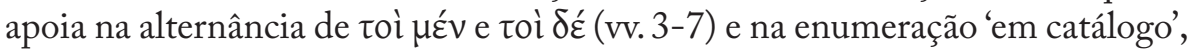
fazem lembrar o epigr. XLIII, composto em honra do corredor Nicoladas de Corinto, também incluído no corpus de Simónides (cf. supra, p. 155).

\section{Epigr. XVII (a) et (b) [138 B, 105 D]}

(a) Thuc. 1.132.2

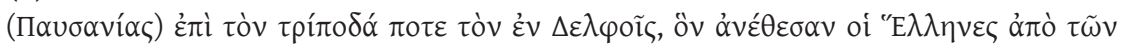

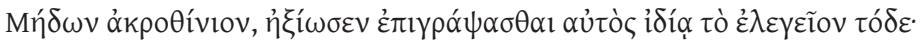

${ }^{70}$ Os epítetos de Ártemis são ambos homéricos. Em Od. 5.123 emprega-se, como no

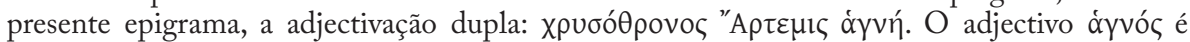

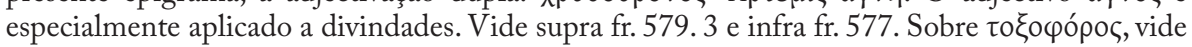
supra, n. 60.

${ }^{71}$ Cf. Page 1981: 214, que pensa tratar-se de uma inscrição genuína, composta por um poeta de Mégara (p. 215). Na opinião de Wade-Gery 1933: 96, Heládio copiou o epigrama de um livro, bem como a atribuição a Simónides. Para Molyneux 1992: 200, as palavras do sacerdote esclarecem que a inscrição, não a pedra, foi desgastada pelo tempo e, embora reconheça que a autoria de Simónides não é segura, não a rejeita totalmente. Esta possibilidade foi também equacionada por Podlecki 1973: 27. Este investigador sugeriu que o epigrama pode ter sido na origem destinado a assinalar a dedicatória do santuário mencionado por Pausânias (1. 43. 3, cf. supra). Notou também que a atribuição a Simónides constitui, além do Marm. Par. Ep. 54, o único registo epigráfico do nome do poeta (p. 25). Para uma análise do epigr. XVI, vide Bravi 2006: 65-68. 


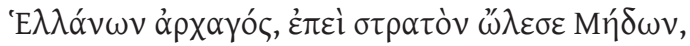

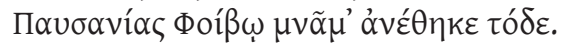

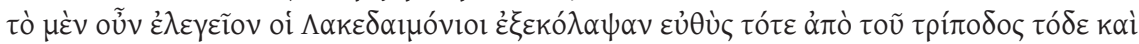

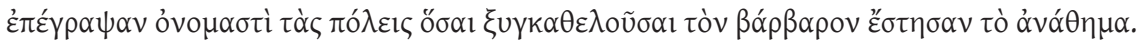

[Pausânias] considerou que devia inscrever, a título pessoal, sobre a trípode que, primícias do espólio dos Medos, os Helenos dedicaram outrora em Delfos, o seguinte dístico elegíaco:

Ao destruir o exército dos Medos, o comandante dos Helenos,

Pausânias, a Febo dedicou este memorial.

Logo então os Lacedemónios rasparam este dístico da trípode e nela inscreveram os nomes de todas as cidades que consagraram a dedicatória, por terem derrotado em conjunto os bárbaros.

(b) D.S. 11. 33. 2

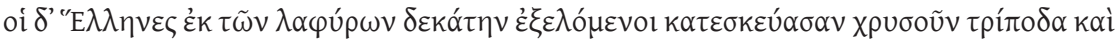

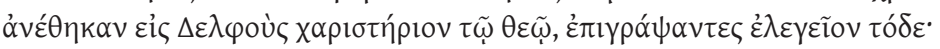

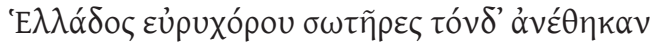

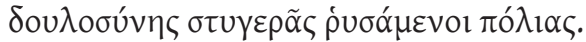

Os Helenos, com a décima parte dos despojos, construíram uma trípode de ouro, que dedicaram em Delfos como acção de graças ao deus, tendo nela inscrito o seguinte dístico elegíaco:

Da vasta Hélade salvadores fizeram esta dedicatória, quando da servidão odiosa libertaram suas cidades.

É notório o estilo epigráfico das duas composições. Ambas especificam o seu carácter votivo, os responsáveis pela dedicatória e o motivo. A primeira, mais directa e concisa, indica também a divindade a que é consagrada e distinguese pelo protagonismo que atribui a Pausânias (na batalha de Plateias). A

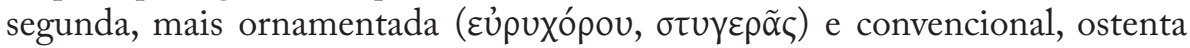
a qualificação dos Helenos como $\sigma \omega \tau \tilde{\eta} \rho \varepsilon \varsigma$ e o tema da liberdade da Hélade, que a identificam como respeitante às Guerras Medo-Persas. Note-se que os conceitos de Helenos e Hélade ocorrem, respectivamente, no início da primeira e da segunda composição.

Do ponto de vista formal, não há razões para contestarmos a validade destes testemunhos, segundo os quais estas são as inscrições da trípode consagrada ao santuário de Delfos pelas vitórias de $479^{72}$. Todavia, só a primeira é atestada por

${ }^{72}$ Segundo Heródoto, após a vitória de Plateias, de uma parte dos despojos foram feitas oferendas a Apolo em Delfos, a Zeus em Olímpia e a Poséidon no Istmo (9.81.1). A dedicatória consagrada a Delfos era uma trípode de ouro sobre uma coluna de bronze de seis a oito metros, que tinha a forma de três serpentes entrelaçadas. Nessa coluna foram inscritos os nomes das trinta e uma cidades gregas que combateram os Persas (Plu. Them. 20.3), figurando à cabeça os Lacedemónios, os Atenienses e os Coríntios. Quando os Fócios ocuparam Delfos na $3^{\text {a }}$ Guerra 
outras fontes ${ }^{73} \mathrm{e}$, como dissemos na segunda parte, o Periegeta atribui a autoria a Simónides (3. 8. 2). Page 1981: 217, que considera as duas composições autênticas, desvaloriza este testemunho com base em Boas 1905: 113, segundo o qual Pausânias usou uma antologia. Mas alguns estudiosos aceitaram-na, invocando como argumento a tradição anedótica que relacionava Simónides e o general de Plateias ${ }^{74}$. A publicação do P. Oxy. 3965 (vide infra, fr. eleg. 11. 33-34) veio confirmar que os dois homens se conheciam de facto, pelo que o testemunho do Periegeta, em nossa opinião, merece ser considerado.

Epigr. XX (a) [88a D] SEG 10. 404 + Meritt 1956: 268 sqq. = 2 Hansen

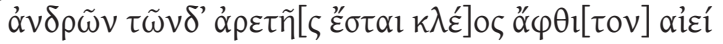

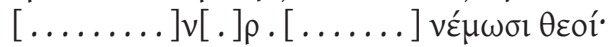

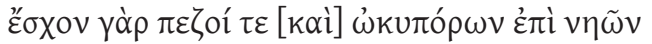

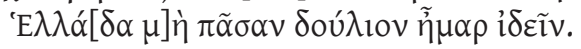

A glória do valor destes homens será sempre imortal concedam os deuses.

Pois não permitiram, a pé ou em céleres naus, que a Hélade toda visse o dia da servidão.

A presença do deíctico $(\tau \tilde{\omega} \vee \delta \varepsilon)$, como no epigr. $X X(b)$, sugere que os nomes dos soldados que perderam a vida em combate figuravam no memorial. $\mathrm{Na}$ parte conservada, pelo menos, não surge qualquer referência à morte. Sublinha-se, pelo contrário, a imortalidade da fama do mérito que caracterizou a actuação destes homens. As palavras conservadas do v. 2 sugerem a ideia geral, presente em alguns passos gnómicos de Simónides, de que a arete depende também da benevolência dos deuses. $\mathrm{O}$ v. 3 indicia que o epigrama foi composto após a batalha de Salamina ${ }^{75}$, mas, como observa Page 1981: 220221, pode dizer respeito a toda a guerra e não a um confronto em particular.

Sagrada (356-346) fundiram o ouro (Paus. 10.13.9). A coluna seria levada para Constantinopla por ordem do imperador Constantino e instalada no Hipódromo, onde se encontram ainda 5,5 metros do monumento original. Sobre a inscrição que nele figurava, vide Meiggs and Lewis 1975: 57-60.

${ }^{73}$ Cf. Ps. Dem. in Neaer. 59. 97; Aristodem., FGrHist 104 F 4; Nep. Paus. 1. 3; Plu. de Herod.

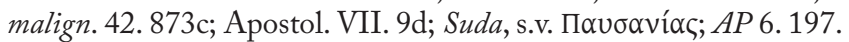

${ }^{74}$ Cf. Stella 1946: 7, Bowra 1961: 345, Podlecki 1973: 37, Molyneux 1992: 198. A autoria de Simónides é reiterada na Antologia Palatina. Huxley 1978: 246 considera difícil aceitá-la, dado o tom arrogante das palavras, mas a arrogância do comandante espartano parece ser um topos (cf. Thuc. 1. 130; epigr. XXXIX, citado em Athen. 12.536a-b).

${ }^{75}$ A reconstituição do segundo hemistíquio do v. 3 que apoia esta interpretação depende de um fragmento de uma cópia do séc. IV do epigr. XX (a), publicado por B. D. Meritt, The Aegean and the Near East (New York 1956) 268-280. Como já referimos, durante muito tempo alguns filólogos pensaram que os epigr. XX (a) e (b) diziam ambos respeito à batalha de Maratona. Sobre esta questão, cf. p. 144 e epigr. XX (b), pp. 259-260 e n. 11. 
É o que sugere o verso seguinte, no qual está presente o mesmo tema do epigr. $\mathrm{XVIII}^{76}$, mas se distingue pela noção de pan-helenismo: o que está agora em causa não é a liberdade de uma cidade, mas a de uma nação, ideia enfatizada pelo emprego da formulação negativa e pela personificação do conceito de Hélade. Se algum dia se confirmar a tese, dominante na primeira metade do séc. XX, de que o epigrama dizia respeito a Maratona, teríamos aqui uma prova de que a preocupação com a liberdade dos Gregos e a consciência da união pan-helénica eram ideias mais antigas do que as composições epigráficas permitem supor ${ }^{77}$.

O estilo desta inscrição, pelo menos na parte conservada, evidencia sobriedade e cuidado na disposição das palavras (por exemplo, a colocação de termos importantes no início dos vv. 1 e 4). Além do epíteto ornamental do

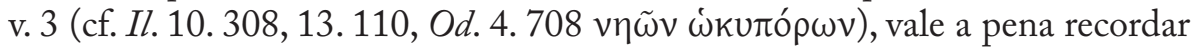

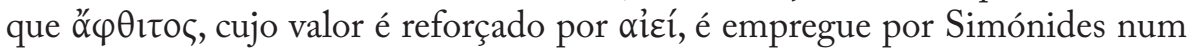
passo gnómico para qualificar os deuses (fr. 523.3). Isto não significa de modo algum que estamos perante uma prova da sua autoria. A atribuição ao poeta é uma suposição dos editores modernos e baseia-se, quanto a nós, em critérios cronológicos e não tanto estilísticos. Diga-se, a propósito, que Page 1981: 223 sublinhou o estilo convencional desta composição ("lucid and dignified, perfectly suited to its purpose"), considerando que o epigr. XX (b) era "more interesting and original".

Na segunda edição do volume II de Iambi et Elegi Graeci ante Alexandrum Cantati, Martin West atribuiu à 'Elegia de Plateias' os frr. eleg. 10-17 e, com algumas reservas, também o fr. eleg. 18 (formado por sete linhas extremamente mutiladas). À excepção dos frr. eleg. 15 e 16, os restantes não contêm uma única linha completa. É larga, portanto, a margem da incerteza. E ainda que seja muito significativo o conjunto de trabalhos publicados sobre esta matéria, o essencial, a palavra e o pensamento do poeta, em grande parte, apenas nos é acessível através das reconstituições e conjecturas dos editores e críticos modernos. Por esta razão, decidimos não comentar os frr. eleg. 12, 17 e 18, cujo sentido não é possível determinar, dado o estado precário em que se encontram. As propostas de reconstituição, citadas no texto e no aparato,

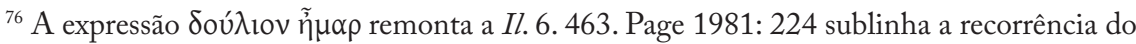
tema nos epigramas sobre as Guerras Medo-Persas. Cf. supra, n. 2.

77 Sobre esta questão, vide W. C. West, "Saviors of Greece", GRBS 11 (1970) 271-282. Como não há certezas de que o epigr. XXI (vide supra) seja autêntico, este investigador chega à conclusão de que "there is no evidence from unequivocal fifth-century sources that the Athenians emphasized Panhellenism in their early propaganda concerning Marathon. It is readily evident that such an attitude was associated with Salamis.” (p. 278).
} 
recolhidas principalmente das edições de Parsons 1992 e de West 1992a ${ }^{78}$, foram incluídas na nossa tradução.

Fr. eleg. 10 P. Oxy. 3965 fr. 22. 2-5

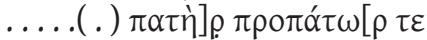

$$
\begin{aligned}
& \text {........... (.)]. } \theta \omega \omega \eta \eta v \sigma[
\end{aligned}
$$

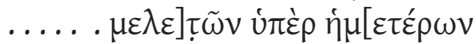

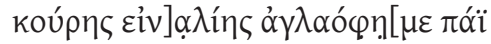

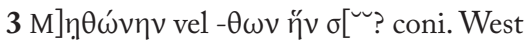

... [pai] e antepassado ... [Metona?]... em benefício da minha dedicação... [ó filho] glorioso da marinha donzela...

Formado por seis linhas, das quais citamos apenas quatro, o fr. 22 do P. Oxy. 3965 foi identificado como pertencente ao 'proémio de Aquiles', suposição que se baseia no v. 4, possível referência do poeta ao seu trabalho ${ }^{79}$ e, em particular, na apóstrofe perifrástica ao filho de Tétis, que preenche o v. 5 e é uma suposição de West. Aceitando-a, é de salientar a aliteração do v. 2 e a disposição quiástica dos termos no v. 5 . O primeiro epíteto deste verso, que no fr. eleg. 11.20 é aplicado a Nereu, é usado na Odisseia (4. 443), mas a respeito de um animal. O segundo pode ser uma criação do poeta ${ }^{80}$, que ocorre também no fr. 20.13 do P. Oxy. 3965 (fr. eleg. 3).

Este fragmento sugere que Simónides iniciava (?) o seu poema com a evocação de um dos heróis mais célebres do mito e da epopeia, o que nos pode levar a suspeitar de que estabelecia uma comparação entre os seus feitos militares e os que foram alcançados pelos guerreiros que enfrentaram os Persas em Plateias, mas também que terá dado ao seu poema contornos épicos. A intenção do poeta não é, porém, fácil de apreender e as muitas propostas de interpretação da função deste 'proémio' e do que constitui a 'parte mítica' do poema (fr. eleg. 11. 1-20) primam pela diversidade e pela falta de consenso (vide infra).

${ }^{78} \mathrm{Na}$ edição e tradução dos frr. eleg. 10-18, Sider 2001a: 17-24 fornece um aparato crítico mais completo que o de West, no qual compila as propostas de outros helenistas. É também de grande utilidade a edição de Gentili e Prato 2002: 193-201. Merece destaque o estudo de Kowerski 2005, que desenvolve algumas das propostas de interpretação do 'Novo Simónides' apresentadas por D. Obbink, I. Rutherford e D. Sider, e procura demonstrar que é metodologicamente errado pressupor que estes fragmentos papirológicos, em especial o fr. eleg. 11, transmitem um poema exclusivamente dedicado à batalha de Plateias.

${ }^{79}$ West 1993a: 168, ‘... for m[y compos]ition...'. O editor evoca como paralelo Emp. B 131. 2 D-K. Cf. o comentário de Pavese 1995: 8, que corrobora esta leitura.

80 Trata-se de uma suposição de West, que Parsons 1992: 42 não aprova totalmente, observando " $\eta[$ not in itself an obvious reading of the traces." Vide o comentário ao epíteto

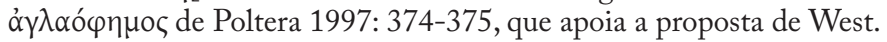


Transcrevemos a seguir o fragmento mais importante da que ficou conhecida por 'Elegia de Plateias', que resulta da junção dos P. Oxy. 2327 e 3965 (à semelhança do fr. eleg. 22, já comentado).

Fr. eleg. 11 P. Oxy. 2327 fr. $5+6+27$ col. i +3965 fr. $1+2$ (vv. 1-42)

$$
\begin{aligned}
& \pi \underset{1}{\alpha}[[.] \sigma] \text {. [ }
\end{aligned}
$$

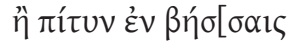

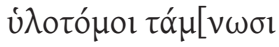

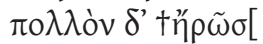

$$
\begin{aligned}
& \text { ]ọ } \lambda \alpha o ̀ y[
\end{aligned}
$$

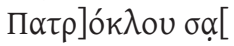

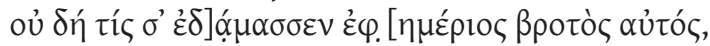

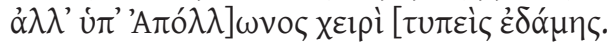

] $\sigma \varepsilon 0 v \sigma \alpha \pi .[\ldots . . . .($. $)] \sigma \tau[$

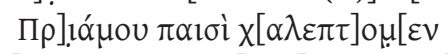

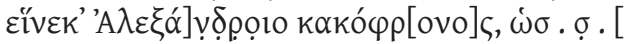

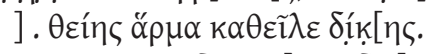

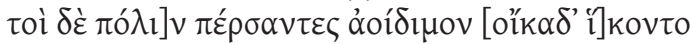

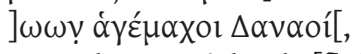

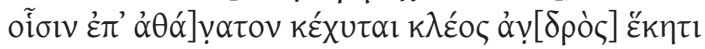

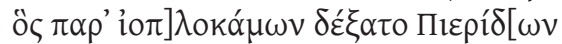

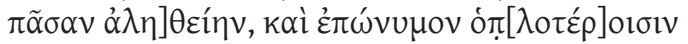

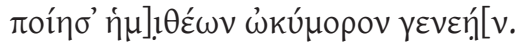

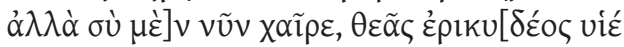

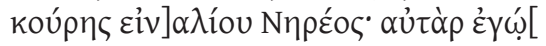

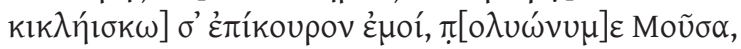

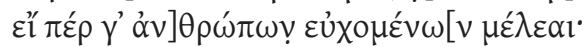

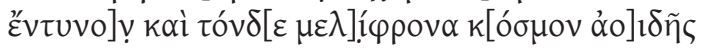

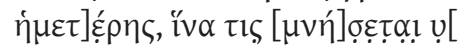

$\dot{\alpha} v \delta \rho \tilde{\omega}] v$, oî $\Sigma \pi \alpha \dot{\alpha} \rho \tau[\eta 1$

.....] $\alpha \mu u v v[] . .[$

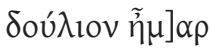

]$\omega[$

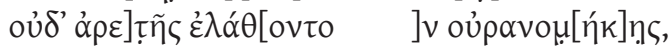

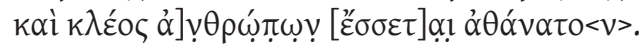

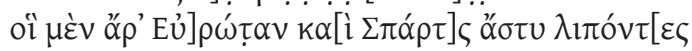

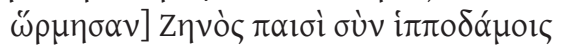

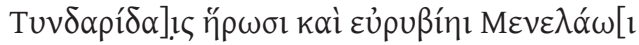

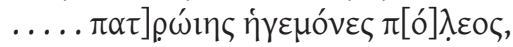

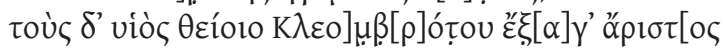

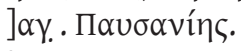

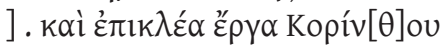

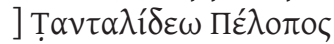

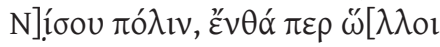

] $\varphi . \tilde{v} \lambda \alpha \pi \varepsilon \rho ı \kappa \tau l o ́ v \omega v$

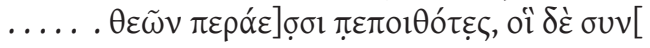




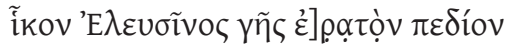

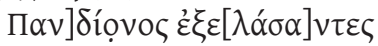

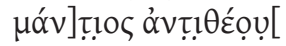

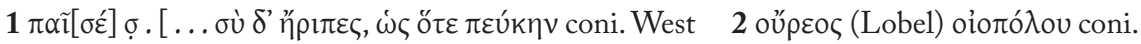

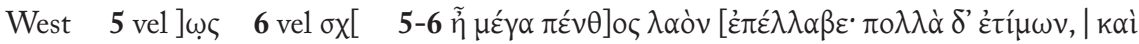

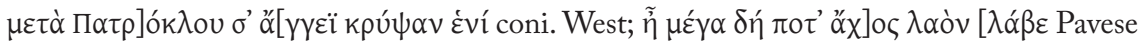

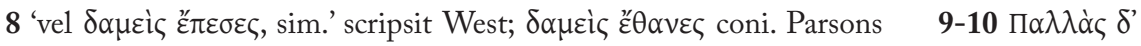

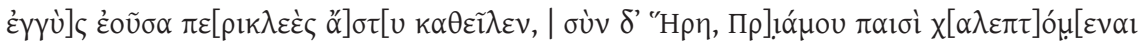

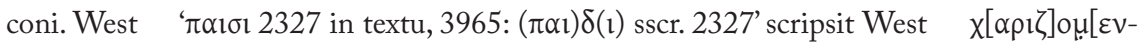
tentaverat Parsons 11 fort. $\omega \sigma \tau \underline{\varepsilon}$, vel țọ. coni. West $\dot{\omega} \varsigma$ țọ̀ [ạ $[\dot{\alpha} \imath \tau \rho o ́ v$ coni. West 12

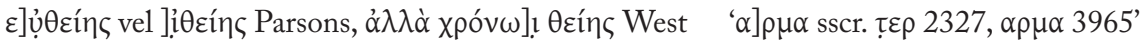

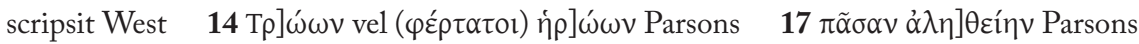

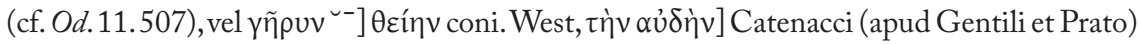

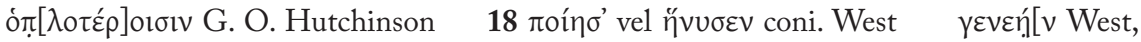

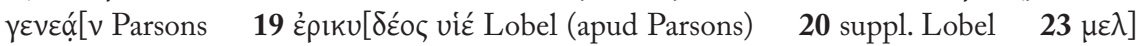

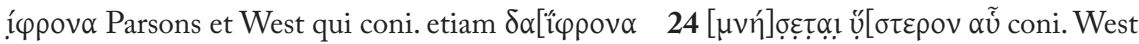

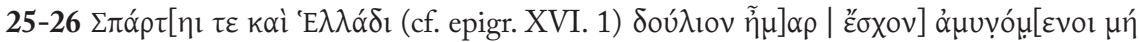

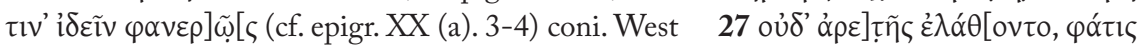
$\delta$ Parsons ËXz]v coni. West oủpavou[ [ńk]ņ I. Rutherford 28 suppl. Lobel 31

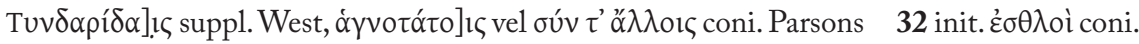

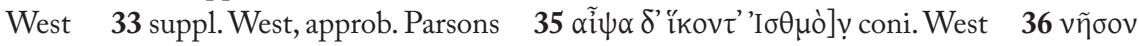

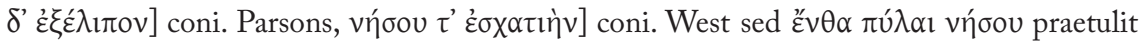

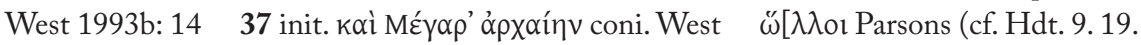

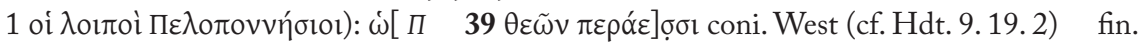

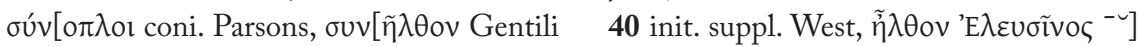

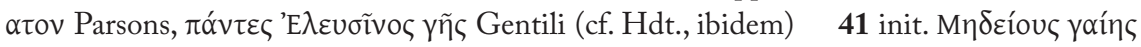

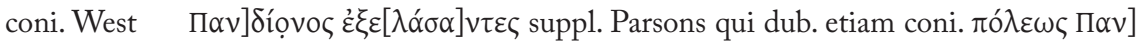

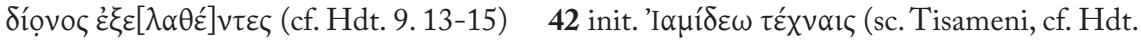

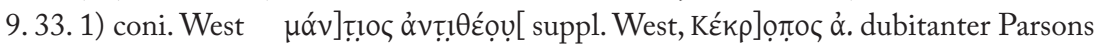

atingiram-te (?) [e tu tombaste, como quando um cedro ou um pinheiro nos vales profundos [de uma montanha solitária... os lenhadores abatem... e muito...

uma grande dor tomou] o exército; [muitas honras foram prestadas e no mesmo vaso guardaram as tuas cinzas e as de Pátr]oclo.

Não te] dominou [nenhum efémero mortal, mas caíste ferido] pela mão de Apolo.

Palas] estava (?) [por perto e destruiu, com Hera, uma cidade muito ilustre,] irritadas (?) com os filhos de Príamo, por causa de Alexa]ndre de maus pensamentos,... ... o carro da justiça recta (?) derrubou [o culpado (?)

$\mathrm{E}$ depois de saquearem a [cidade] muito cantada [a casa] tornaram os mais bravos dos heróis (?),] os Dânaos que conduzem o combate,... 
sobre eles] se derramou uma glória imortal, pelo querer de um homem

que] recebeu das Piérides de tranças violáceas (?)

toda] a verdade (?), e aos homens vindouros

deu a conhecer a raça passageira dos semideuses.

Mas tu,] agora, salve, [ó filho] de uma deusa gloriosa (?), a filha] do marinho (?) Nereu, enquanto eu...

invoco]-te como minha aliada, ó Musa [famosa], se cuidas, na verdade,] das súplicas dos homens.

Apresta] também o doce (?) [arranjo] do nosso (?)

canto (?), para que alguém [mais tarde] se lembre (?) [de novo (?)

dos varões] que por (?) Esparta [e pela Hélade resistiram],

[não deixando que ninguém visse o dia da servidão],

não] se esqueceram da coragem(?), [a fama] chega até ao céu

e a glória] dos homens [será] imortal.

Do Eurotas e da cidade [de Esparta] apartados,

marcharam] com os filhos de Zeus, domadores de cavalos,

os heróis [Tindáridas], e com o forte Menelau

os chefes [nobres] da cidade paterna,

que o filho] excelso [do divino] Cleômbroto comandava

... Pausânias.

Depressa chegaram ao Istmo] e aos famosos domínios de Corinto,

limite extremo da ínsula] do Tantálida Pélops,

e a Mégara, antiga] cidade de Niso, onde os restantes (?)...

a eles se reuniram (?)], tropas das regiões vizinhas...

...... confiantes nos presságios (?) [divinos], e os aliados (?)

chegavam] à agradável (?) planície [da região de Elêusis,

os Medos] expulsaram [da terra de] Pandíon,

pelas artes do Iâmida,] o vidente (?) que iguala os deuses...

A crer nas propostas dos editores, Simónides acolheu no seu poema um dos processos literários mais característicos dos Poemas Homéricos, o símile que ocupa os vv. $1-3^{81}$, por meio do qual se compara a morte de um guerreiro, supostamente Aquiles, ao abate de uma árvore de grande porte ${ }^{82} \mathrm{Na}$ Iliada, este tipo de símile surge, pelo menos, quatro vezes, mas o modelo mais próximo, em nossa opinião, é o que o poeta emprega para ilustrar a morte de Ásio por Idomeneu (13. 389-393) e de Sarpédon às mãos de Pátroclo (16. 482-486) ${ }^{83}$.

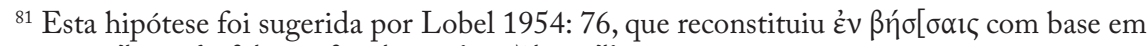

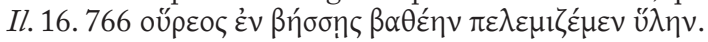

${ }^{82}$ Trata-se da interpretação de West do fr. 5 do P. Oxy. 2327, com a qual concordam Barchiesi 1995: 33 e Burzacchini 1995: 26. Na opinião de Parsons 1992: 28, “others contexts could be thought of, even within this poem: the fall of Masistius, or Mardonius?”. Assim pensa também Lloyd-Jones 1994: 1. Cf. Capra e Curti 1995: 27 n. 2, Pavese 1995: 9.

${ }_{83}$ Nos outros dois símiles da Ilíada, o guerreiro que tomba é comparado à árvore arrancada por uma força da natureza (cf. 4. 482-489, 17. 53-60). 
Diz o poeta que o guerreiro tomba como tomba um carvalho, um álamo ou um pinheiro, que nas montanhas os lenhadores abatem com os seus machados para construírem uma embarcação. Apenas é seguro referir que o texto de Simónides tem em comum com o da Ilíada o início do v. 2 (cf. 13. 390, 16.

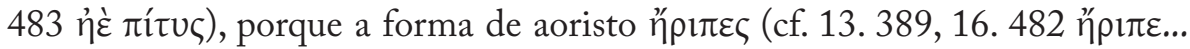
ท̆ editores, que podem ter considerado o símile homérico como paralelo. Mas o início do v. 3 preservado pelo papiro favorece esta hipótese, pois também o

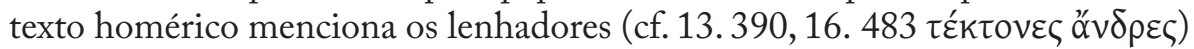

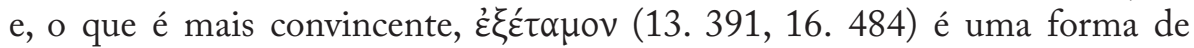
aoristo de um verbo composto do que ocorre no poema de Simónides.

De acordo com esta interpretação, a morte de Aquiles era evocada à maneira homérica. Em princípio, Simónides centrava-se em seguida nas honras fúnebres que lhe foram prestadas pelo exército (vv.5-6), mas esta ideia depende inteiramente das conjecturas dos editores. Mesmo a palavra mais legível é uma suposição, legítima uma vez que Pátroclo era o companheiro fiel de Aquiles e só a sua morte instigou o herói a regressar ao campo de batalha. Não obstante o estado mutilado do papiro (2327 fr. 6), é provável que Simónides lembrasse que Aquiles apenas foi dominado ( $\dot{\varepsilon} \delta$ ạ́ $\mu \alpha \sigma \sigma \varepsilon v)$ pela intervenção de Apolo

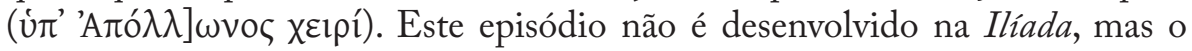
herói tem conhecimento de que perecerá às mãos de Páris ajudado pelo deus (19. 416-417, 22. 359-360). Na Odisseia, a psyche de Agamémnon descreve as cerimónias fúnebres realizadas em sua honra e sublinha que a mesma urna acolheu as cinzas de Aquiles e as de Pátroclo (24. 36-97, cf. Il. 23. 83-84). Das diversas versões que os poemas do Ciclo Épico difundiram sobre a forma como morrera o maior guerreiro aqueu, parece que Simónides retomou a que alcançou mais fama e era mais digna do perfil heróico de Aquiles, ou seja, que Apolo fora o principal responsável ${ }^{84}$. Se as conjecturas dos editores estão $\operatorname{certas}^{85}$, do ponto de vista formal, a expressão negativa do início do v. 7 confere

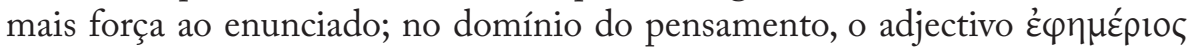
vai ao encontro do que o poeta afirma nos fragmentos gnómicos sobre as limitações do ser humano.

Os quatro versos que se seguem (9-12) não dizem propriamente respeito a Aquiles, mas antes aos motivos da Guerra de Tróia e ao seu desenlace. O contexto troiano do mito é uma suposição de West, da qual Parsons 1992: 28 não discorda. As palavras que podemos ler nos papiros sugerem que o poeta

\footnotetext{
${ }^{84}$ Sobre esta questão e as diferentes versões da morte de Aquiles, vide Aloni 2001: 86-87, Pavese 1995: 10-11.

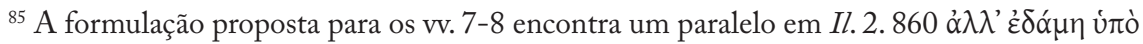

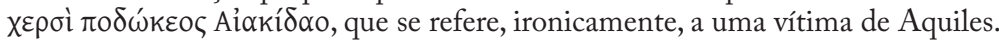


entendeu o desfecho do conflito como um acto de justiça (v. 12), que castigou o comportamento insensato de Alexandre (v.11) ${ }^{86}$. Se atendermos às conjecturas dos editores, o louvor da actuação do exército aqueu é reforçado, porque a aç̧ão militar contra Tróia passa a ter como adjuvantes as deusas que também na Ilíada apoiam o lado grego, Palas Atena e Hera (vv. 9-10) ${ }^{87}$.

A evocação do feito que o exército aqueu, conduzido pelos senhores de Esparta e Micenas, alcançou em Tróia pode ser lida como o primeiro momento da comparação que Simónides estabelece entre esse episódio mítico e épico e a história contemporânea. $\mathrm{O}$ segundo momento ocupa os vv. 13-18, nos quais se desenvolve o tema da imortalidade concedida pela poesia, que atinge tanto

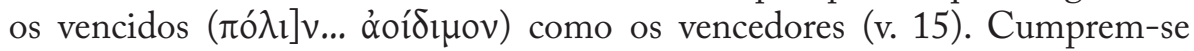
assim as palavras de Helena na Ilíada (6.357-358), quando se lamentava a Heitor de que os seus males eram enviados por Zeus e seriam matéria de canto

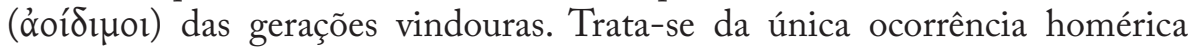
daquele adjectivo e não deixa de ser curioso que Simónides o empregue no momento em que fala da destruição de Tróia ${ }^{88}$.

Distinguem-se claramente nestes versos dois aspectos: o retrato dos heróis (vv. 13-15) e o de Homero (vv. 15-18). Se o superlativo do início do

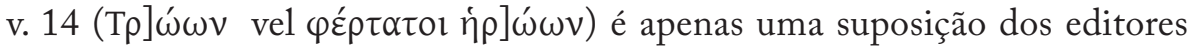

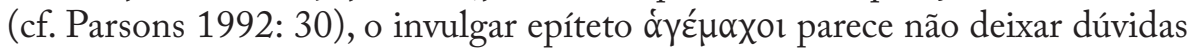
de que neste passo Simónides elogiava a capacidade militar dos Dânaos e o regresso vitorioso à pátria (cf. Rawles 2008). A sua intenção vai mais além deste simples elogio, porque logo a seguir sublinha o papel essencial do poeta no estabelecimento do renome imortal daqueles heróis. Simónides não nomeia

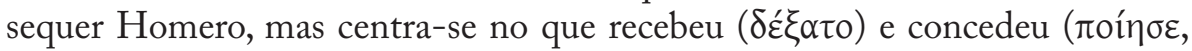
suposição de West; cf. Parsons 1992: 31). Perante a primeira afirmação, lembramo-nos dos vv. 22-28 do proémio da Teogonia de Hesíodo. O poeta da Beócia conta como foi instruído no canto pelas Moṽ $\sigma \alpha \mathrm{l}$ 'O $\lambda \cup \mu \pi \imath$ ó $\delta \varepsilon \varsigma$ e recorda as palavras que elas the dirigiram (vv. 27-28) ${ }^{89}$. Simónides, se podemos confiar

${ }^{86}$ Se o poeta empregou, de facto, o epíteto kakó $\varphi \rho \omega v$, é possível que se trate da ocorrência mais antiga, embora apareça em Píndaro (fr. $211 \mathrm{Ma}$.) e se torne vulgar na tragédia. Lobel (apud Parsons 1992: 28) propôs $\kappa \alpha \kappa o \varphi \rho \alpha \delta \varepsilon ́ c$, que ocorre em Il. 23. 483. Sobre a imagem do carro da justiça, vide Parsons 1992: 29, Pavese 1995: 11, Poltera 1997: 112-113, Rutherford 2001a: 44.

${ }^{87}$ Uma outra interpretação resulta da aceitação de $\chi \alpha \lambda \varepsilon \pi \tau$ tó $\mu \varepsilon v o \varsigma$ no v. 10 . O sujeito seria Apolo que ao matar Aquiles vinga Heitor, fazendo um favor a seus irmãos, os filhos de Príamo. Cf. Parsons 1992: 28, Luppe 1993: 2-3, Capra e Curti 1995: 28, Pavese 1995: 11.

${ }^{88}$ Esta referência não passou despercebida aos estudiosos, que chamam a atenção para o mesmo procedimento "simbólico" no emprego de outros adjectivos de tradição homérica (vide infra). Sobre o emprego de ỏoí́iıo neste passo, cf. Lloyd-Jones 1994: 1, Poltera 1997: 199-200.

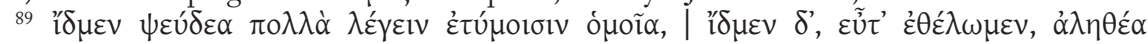

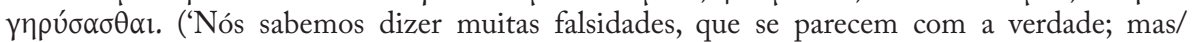
também, quando queremos, proclamamos verdades.'Trad. Rocha Pereira 2009: 107). Suárez da la Torre 1998b: 30 n. 10 observa que Simónides assume uma postura mais 'homérica' que 
no suplemento de Parsons, afirma que o dom das Musas ao poeta é 'toda a verdade' (v. 17). Mas estes versos também nos trazem à memória o célebre fragmento de Safo, no qual ela proclama que a imortalidade apenas pertence aos que partilham das rosas da Piéria (fr. 55 L-P). Não é exactamente a ideia aqui presente, porque Simónides não alude à glória do poeta, mas à que o seu canto concede, o que nos leva à segunda afirmação, que ocupa o segundo hemistíquio do v. 17 e todo o v. 18. Cremos que estes versos são reveladores da intenção de Simónides: o seu poema toma como modelo um canto épico que celebrou a verdade e que coroou os seus heróis de um renome imortal. Supomos que sejam esses os atributos que o nosso poeta reivindica para o seu trabalho: proclamar a verdade e fazer dos guerreiros espartanos modelos das gerações vindouras ${ }^{90}$.

Vale a pena chamar a atenção para alguns lexemas dos vv. 16-18. De acordo com as propostas de reconstituição de ] $\lambda$ okó $\mu \omega v$, o epíteto das Piérides oscila entre 'de tranças violáceas' (io $\pi \lambda$ ók $\alpha \mu \circ$, , West) e de 'tranças

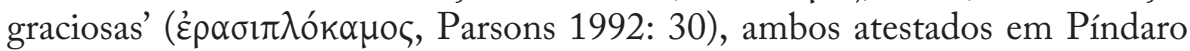
(respectivamente, Pyth. 1. 1 e 4. 136). Na primeira destas ocorrências,

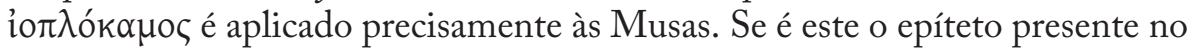
poema de Simónides, que num fragmento lírico qualifica as 'Pelêiades'(fr. 555. 3 , infra), pode ter sido por ele criado ${ }^{91}$. Assim, mais uma vez, surpreendemos a técnica de combinar formações originais com outras transmitidas pela tradição

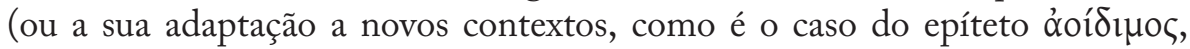
acima comentado), pois os restantes lexemas dos vv. 17-18 já se encontram nos Poemas Homéricos e receberam grande atenção da crítica moderna ${ }^{92}$.

‘hesiódica'. Na opinião de Lauriola 1998: 1139-1144, as alusões do poeta a Hesíodo não são puramente formais. Revelam o empenho de Simónides na reflexão acerca dos meios e modos de fazer poesia e sobre as suas funções.

${ }_{90}$ Partilhamos da opinião, defendida por Lauriola 1998: 1149-1150, de que Simónides reivindica o seu papel na concessão do kleos eterno através da poesia (fr. eleg. 11.28), residindo neste aspecto também a identificação com Homero. Para Stehle 2001: 114-119, o objectivo do poeta é celebrar os que tombaram em Plateias como seres 'heroizados'. A glória a que têm direito não é concedida pelo poeta, mas liga-se a um culto da comunidade. A investigadora exclui qualquer analogia funcional entre Homero e Simónides, no que diz respeito à poesia como meio de 'eternizar'. O canto poético pode contribuir para preservar a glória, mas não a cria. Cf. Kyriakou 2004, Bremmer 2006.

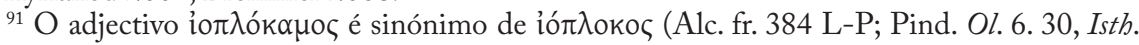
7. 23; Bacch. 9. 72). Quanto à sua formação, pertence ao grupo de adjectivos épico-líricos,

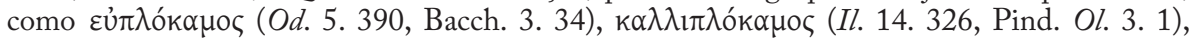

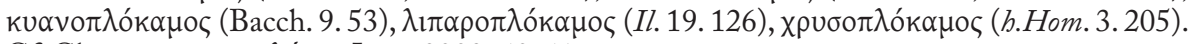

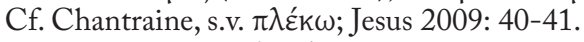

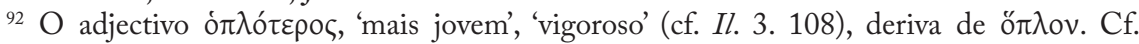
Chantraine, s.v. Foi proposto por Hutchinson (apud Parsons 1992: 31), que notou a influência deste passo de Simónides em Theoc. 16.34 sqq., onde o adjectivo ocorre com o sentido 'de uma geração mais recente' (v. 46, cf. supra p. 158). 
Se o fr. eleg. 10 pertence, como pensam os editores, a um proémio em que se desenvolve o tema de Aquiles, os vv. 19-20 correspondem certamente ao seu remate, uma vez que o poeta emprega as fórmulas de conclusão de alguns dos Hinos Homéricos ${ }^{93}$. No início do v. 19 , a suposta conjunção adversativa

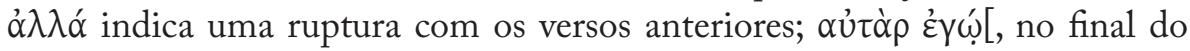
v. 20, assinala a passagem para o assunto principal do poema, a celebração dos heróis contemporâneos. A oposição entre o pronome oú (que é apenas uma

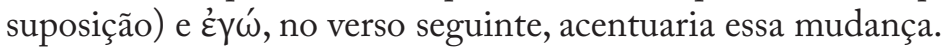

Anuncia-se, portanto, uma transição de tema (cf. Parsons 1992: 32), mas são ainda as convenções da poesia heróica que surpreendemos nos vv. 21-28, nos quais distinguimos a 'invocação à Musa' (vv. 21-24) 94 $^{4}$ e 'proposição' (vv. 24-28). A crer na reconstituição que os editores propõem para os vv. $23-24^{95}$, se

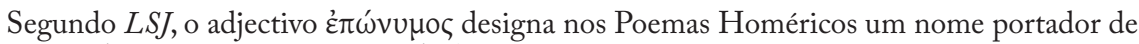
significado (e.g. Il. 9.562, Od.19.409). A estrutura sintáctica dos vv. 17-18 leva-nos a preferir a interpretação de Parsons, segundo a qual Teócrito, no passo acima referido, entendeu દ̇đúvvuo

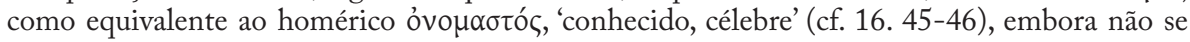
conheça nenhum paralelo deste emprego. Poltera 1997: 344 aceita esta interpretação, que foi

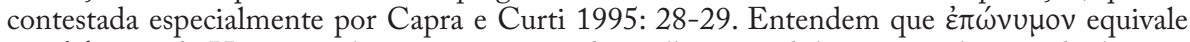

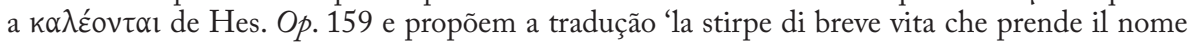
dai (di) semidei'. Na sequência das críticas de Burzacchini 1995: 31 e de Suárez de la Torre 1998b: 30, A. Capra reafirmou aquela interpretação (2001). Por seu turno, Giangrande 2002 corroborou a argumentação de Suárez de la Torre com um passo de Nonn. D. 24. 43-45, no qual દ̇ $\tilde{\omega} v u \mu o \zeta$ ocorre com o sentido de 'famoso, célebre', e que pode ser um eco dos versos de Simónides. Também Bremmer 2006: 23 e Brillante 2007: 105-109 defendem o significado de 'famoso' ('famous'). Merece atenção a proposta de Arrighetti 2007, que valoriza o sentido que o termo tinha já nos Poemas Homéricos (aspecto que tem sido negligenciado pelos estudiosos, como bem notou), discute os comentários de Eustátio e o testemunho de Nono acima referido, e defende que "the exact meaning of that word cannot be but "bearing a significant name".

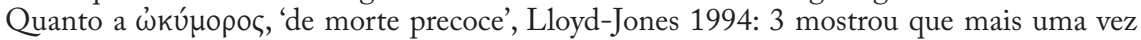
Simónides escolheu uma palavra homérica adequada ao seu texto. Aplicado em geral às armas (que provocam uma morte rápida: e.g. Il.15. 441, Od.22. 75), o epíteto ocorre cinco vezes na Ilíada e em quatro $(1.417,505 ; 18.95,458)$ é usado por Tétis a propósito do filho. Na Odisseia, caracteriza os pretendentes. Cf. Poltera 1997: 354-355.

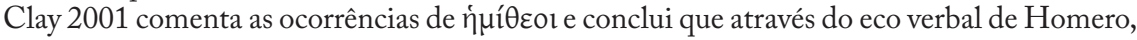
Simónides estabelece um elo com o poeta épico, mas ao mesmo tempo assinala também que se separa dele e do seu tema. Cf. Parsons 1992: 31, Capra e Curti 1995: 29, Poltera 1997: 466-467, Bremmer 2006: 24-25, e supra fr. 523.

${ }^{93}$ E.g. h.Hom. 3. 545-546, 4. 579-580. Capra e Curti 1995: 30 observam que a fórmula de transição do hino para a narração conheceu um amplo emprego (cf. Hes. Th. 963-965, Pind. Isth. 1. 32), pelo que a sua presença nestes versos não implica a existência de um hino em sentido restrito, com os traços constitutivos dos Hinos Homéricos, como defendeu Aloni 1994: 14. Cf. Parsons 1992: 28, 32.

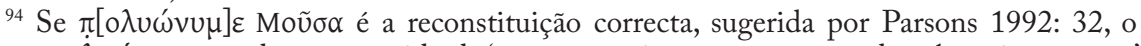

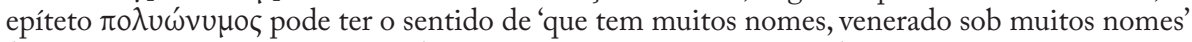
(e.g. h.Hom. 2. 18, Pl. Phdr. 238a) ou 'de grande renome, famoso' (Hes. Th. 785, h.Hom. 3. 82, Pind. Pyth. 1. 17). Cf. Poltera 1997: 351-352.

${ }_{95} \mathrm{O}$ sentido destes versos pode variar ligeiramente consoante as diferentes propostas de

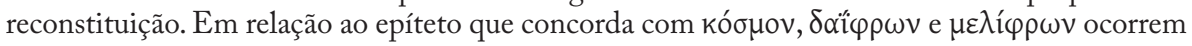


o poeta pretende chamar a atenção para a importância do assunto que vai tratar a seguir, talvez valha a pena notar que o seu pedido especifica que o auxílio da

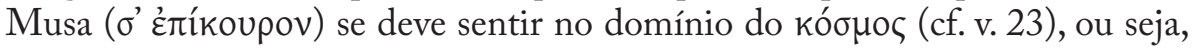
da organização geral do poema ${ }^{96}$, o que pode significar um contraste com os vv. 16-17, nos quais afirmara que Homero recebeu das Piérides 'toda a verdade ${ }^{97}$. Esta diferença pode ser um indício de que Simónides tinha consciência de estar a adoptar um modelo épico que devia adaptar às circunstâncias particulares do seu poema, uma vez que o assunto a tratar era recente e sobre ele dispunha certamente de informação, enquanto Homero, que celebrou os feitos dos heróis do passado, dependia especialmente das Musas.

Apesar do estado precário dos versos que constituem a 'proposição', o que é possível restaurar sugere que Simónides chama a atenção para uma função essencial da poesia, a de preservar a memória (v. 24), apresenta agora a sua matéria de canto (v. 25) e reafirma a fama imortal concedida aos que são celebrados através da poesia (v. 28). Na reconstituição dos vv. 25-26, os editores baseiam-se nos epigramas sobre as Guerras Medo-Persas integrados no corpus do poeta. A confirmar-se a proposta de West, que se apoia nos epigr. XVI.1 e XX (a). 3-4, os Espartanos lutaram pela liberdade da sua pátria e

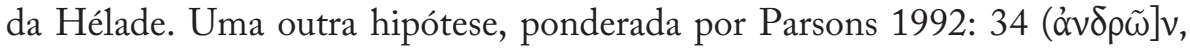

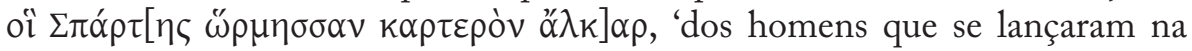
defesa poderosa de Esparta'), reduziria o alcance pan-helénico do seu combate a um benefício regional, ideia que não traduz com exactidão a importância de uma batalha que foi considerada decisiva na derrota dos Persas. Além disso, o paralelo que o poeta estabelece entre a campanha de Tróia e a de Plateias parece residir precisamente no seu carácter pan-helénico, embora os versos preservados nos possam levar a pensar que Simónides sublinhou a hegemonia de Esparta nos dois conflitos (cf. 11. 14, 25, 33-34). Voltaremos a este ponto, uma vez que a orientação ideológica do poema suscitou teorias diversas sobre as circunstâncias da sua composição. Se os editores tiverem razão, nos vv. 2728, fazendo uso do processo de 'composição em anel', o poeta regressava ao tema do v. 15, propondo a heroização dos guerreiros que combateram em

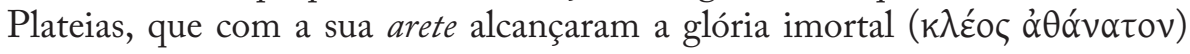

nos Poemas Homéricos e o último é aplicado por Píndaro ao canto (fr. 52i. 78 Ma.). Mas talvez a proposta com mais consequências seja a reconstituição do início do v. 24. Seguimos na

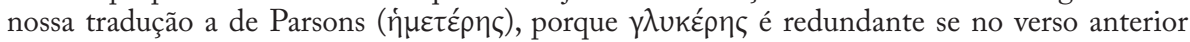
se encontrar $\mu \varepsilon \lambda i ́ \varphi \rho o v \alpha$ e $\mu \alpha \kappa \rho o \tau \varepsilon ́ p \eta \varsigma$ não nos parece fazer muito sentido: 'mais longo' em comparação com a secção anterior?

${ }_{96}$ Cf. Sol. fr. 1.2 W, Parm. fr. 8. 52 D-K, Pind. fr. 194. 3 Ma. Sobre a integração no fr. eleg.

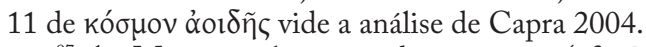

97 As Musas conhecem todas as coisas (cf. Il. 2. 485, Pind. fr. 52f. 54-55 Ma.). Sobre a

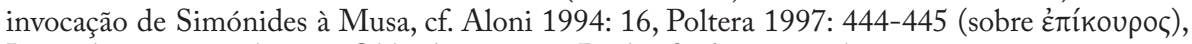
Lauriola 1998: 1125-1136, Obbink 2001: 71, Rutherford 2001a: 45-46. 
que Homero outorgou aos seus heróis.

$\mathrm{Na}$ reconstituição do início do v. 29, Luppe 1993: 9 propôs $\beta \tilde{\eta} \sigma \alpha v$ ' Eủ] $\rho \omega ́ \tau \alpha v$, mas esta sugestão implica que há continuidade entre os vv. 28 e 29. Parece-nos mais credível a proposta de West (oî $\mu \dot{\varepsilon} v$ óp $\rho$ ), que confere mais ênfase ao início da narrativa sobre a batalha de Plateias.

As linhas preservadas do papiro permitem saber que, num primeiro momento da narrativa, o poeta evoca a partida do exército de Esparta (v. 29) e a marcha até ao campo de batalha. Não é claro se a referência aos Dioscuros e a Menelau nos vv. 30-31 é uma alusão ao costume de o exército espartano marchar com as imagens daqueles heróis, que eram venerados como protectores (cf. Hdt. 5.75.2), ou se deve ser antes entendida como prova de que Simónides conferiu à sua obra contornos épicos, introduzindo, por exemplo, as epifanias. A primeira hipótese parece-nos mais plausível, o que não quer dizer que o poeta nos ofereça uma descrição exacta das manobras militares dos Espartanos ${ }^{98}$. O tom destes versos é claramente épico, como também mostra a apresentação de Pausânias (vv. 33-34). Em nossa opinião, é inegável a ênfase dada neste passo ao comandante do contingente espartano em Plateias, o que não significa que outras figuras não tenham sido louvadas no resto do poema.

Depreendemos dos vestígios preservados que no momento seguinte eram mencionadas as regiões que o exército atravessou, o Istmo de Corinto e Mégara, pelo menos, detendo-se o poeta em pormenores de natureza mitológica (vv. 35-37). Das diversas propostas de reconstituição do início do v. 36, vท́бov $\tau$ '

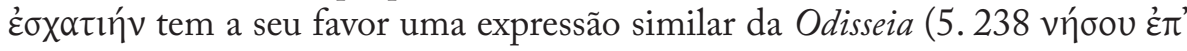
$\dot{\varepsilon} \sigma \chi \alpha \tau ı \tilde{\eta} \varsigma)^{99}$. Na pausa bucólica do v. 37, o poeta parece transitar da descrição geográfica para a evocação das tropas que se aliaram ao contingente de Esparta, à medida que este avançava para o campo de Plateias, matéria que Heródoto tratou em 9. 19.1-2, inclusive a referência aos presságios divinos (v. 39).

O fr. eleg. 11 tem quarenta e cinco linhas, das quais excluímos as três últimas, que estão muito mutiladas. A aceitarmos a reconstituição de West, Simónides afirmava que o exército de Esparta havia expulso os Persas da Ática (v. 41), o que diverge da narração de Heródoto ${ }^{100}$, e detinha-se em seguida na figura de

${ }^{98}$ A segunda interpretação é explorada por Hornblower 2001: 140-145, esp. Como notou Parsons 1992: 35, a prática militar retratada nos vv. 30-31 diverge do que afirma Heródoto (5. 75. 2), segundo o qual normalmente apenas um dos Dioscuros acompanhava o exército de Esparta. Para uma análise deste ponto, cf. Asheri 2004: 70-71. Note-se que na Ilíada o

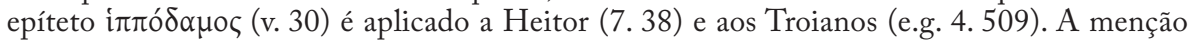
de Menelau é discutida por Hornblower 2001: 146-147. Sobre esta questão, vide ainda Pavese 1995: 15-16.

${ }_{99}$ Recorde-se que West alterou esta primeira proposta para ह̌v $\theta \alpha \pi u ́ \lambda \alpha l$ vท́бov (1993b: 14)

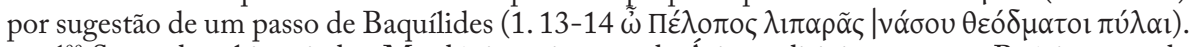

${ }^{100}$ Segundo o historiador, Mardónio retirou-se da Ática e dirigiu-se para a Beócia antes da chegada das tropas gregas, quando descobriu que estavam em marcha para o Istmo (9.13). No 
Tisâmeno (v. 42), o vidente de Eleia, da família dos Iâmidas ${ }^{101}$, que adquiriu a cidadania espartana ${ }^{102}$. O historiador dedica-lhe alguns capítulos (9. 33-36), mas é no último que se refere ao seu papel em Plateias. O descendente de Íamo leu nas entranhas das vítimas que os Gregos alcançariam a vitória se actuassem na defensiva, mas perderiam a batalha se tomassem a iniciativa de atacar. De acordo com a disposição dos fragmentos sugerida por West, a revelação dessa profecia ocorre apenas quando os exércitos estão prestes a iniciar o combate ou se avistam na planície beócia, momento do poema a que pode pertencer o fragmento que analisaremos a seguir.

Fr. eleg. 13 P. Oxy. 2327 fr. 27 col. ii. 8-12

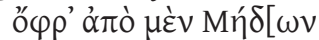

$\kappa \alpha \grave{~} \Pi \varepsilon \rho \sigma \tilde{\omega} v, \Delta \tilde{\omega} \rho \circ v \delta[\dot{\varepsilon}$

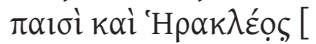

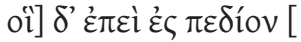

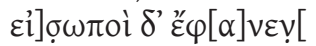

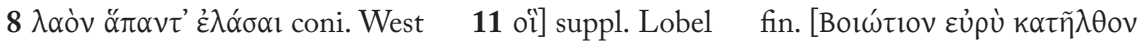
coni. West (cf. epigr. XVI. 7)

... a fim de [expulsar o exército inteiro] dos Medos e dos Persas, e... os filhos de Doro e de Héracles... E quando à planície [vasta da Beócia chegaram (?)]... tornaram-se visíveis...

Embora não seja possível avançar qualquer comentário, este fragmento de um pedaço de papiro com treze linhas muito mutiladas confirma que uma das características do poema era a introdução constante de referências mitológicas (vide supra, fr. eleg. 11. 35-37). Tem o interesse de apresentar

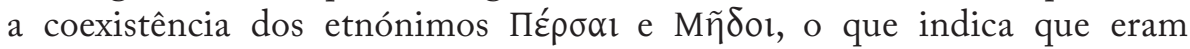
considerados povos distintos no tempo de Simónides. A presença destes

estado actual dos nossos conhecimentos, apenas podemos fazer suposições sobre o modo como Simónides teria tratado esta matéria. No entanto, como notou Pavese 1995: 17-18, dizer que os Persas foram expulsos da Ática quando os diversos contingentes chegaram a Elêusis é mais conforme ao tom panegírico de todo o poema, pelo que o suplemento de West para o início do v. 41 merece ser considerado.

${ }^{101}$ Os Iâmidas, como foi referido (p. 53 n. 80), constituíam uma estirpe de videntes que residiam em Olímpia (cf. Pind. Ol. 6. 5). Cf. H.W. Parke, The Oracles of Zeus (Cambridge, Mass. 1967) $173-178$.

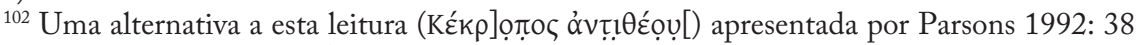
"as part of a paraphrase for 'Athenians", introduziria no poema uma referência a uma figura do mito ateniense. Todavia, o estado do papiro não é esclarecedor ("But once again, ]o is not an obvious, though it is a possible, interpretation of the first trace”, observa), pelo que não é possível saber se o poeta mencionava nesta parte do poema os Atenienses (que vieram de Salamina reunir-se ao exército, cf. Hdt. 9. 19. 2) ou se nomeava apenas os Espartanos. 
nomes, a menção dos Espartanos (os filhos de Doro, antepassado lendário dos Dórios, e de Héracles), e a possibilidade de os vv. 11-12 se referirem ao momento em que os exércitos se avistam no campo de batalha são indícios de que este fragmento pertence provavelmente à 'Elegia de Plateias' (cf. Parsons 1992: 32). Na opinião de alguns estudiosos, designadamente Aloni 1994: 20-21, confirma que Simónides privilegiou a actuação do exército de Esparta ou compôs o poema a pedido desta pólis. Um dos aspectos que pode abonar a favor desta tese é o relevo que parece ser dado à profecia do adivinho Tisâmeno, evocada no fragmento seguinte. Opinião diferente expressou Boedeker 1995: 224, observando que o fr. eleg. 13 pode pertencer a um catálogo, no qual se enumerava a disposição dos diferentes contingentes ao longo da linha de batalha.

Fr. eleg. 14 P. Oxy. 3965 fr. 21. 2-8

$$
\begin{aligned}
& \text { ] } \alpha \delta \text { ov } \beta \alpha \lambda \lambda \text { o } \mu \varepsilon[v
\end{aligned}
$$

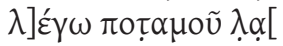

$$
\begin{aligned}
& ] \rho \psi \alpha 1 \pi \rho \tilde{\omega} \tau \alpha \beta[1] \eta[
\end{aligned}
$$

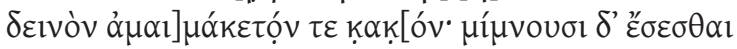

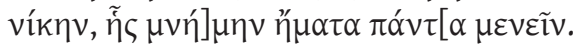

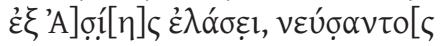

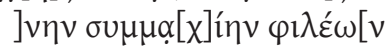

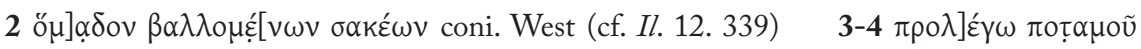

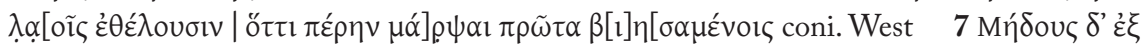

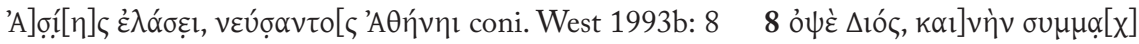
ínv $\tau \varepsilon \lambda \varepsilon^{\prime} \omega[v$ coni. West, ibidem

... o fragor (?) do embate [dos escudos (?)...

eu declaro à armada que, na sua violência (?),

[anseia por] atingir (?) primeiro [a outra parte] do rio,

[é uma terrível] e indómita desgraça; [se esperarem, hão-de alcançar uma vitória que será] lembrada todos os dias.

[Os Medos] fará sair [Ares?] da Ásia (?), com a anuência [de Atena e de Zeus?], uma nova (?) aliança desejando (cumprindo?)...

Das dezassete linhas que formam o fr. 21 do P. Oxy. 3965 citamos apenas sete. $\mathrm{Na}$ sequência da proposta de interpretação do v. 42 do fr. eleg.

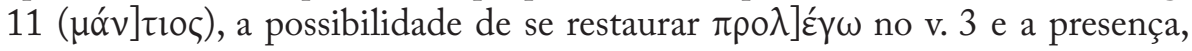

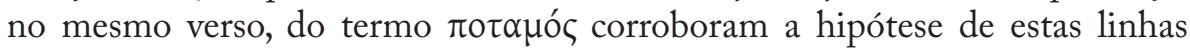
conterem a profecia de Tisâmeno, que Heródoto também refere (9. 36, vide supra). Sendo assim, este fragmento sugere que no poema de Simónides o adivinho dos Espartanos tomava a palavra e declarava o que havia lido nas entranhas (vv. 3-6), provavelmente no momento em que os exércitos estavam 
prestes a defrontar-se, já que a reconstituição do v. 2 indicia uma referência à confusão do combate ${ }^{103}$. Este fragmento mostra também que as formas verbais de primeira pessoa do singular podem induzir em erro. Neste caso, é quase certo que o sujeito de $\pi \rho \circ \lambda] \varepsilon ́ \gamma \omega$ não é o poeta.

O sentido dos vv. 7-8 é mais difícil de decifrar, mas talvez possamos avançar a hipótese de o desfecho vitorioso do confronto ser entendido como cumprimento da vontade de Zeus, tal como no fr. eleg. 11.12 a conquista de Tróia é considerada um acto de justiça ${ }^{104}$.

Antes do aparecimento do P. Oxy. 3965, os nossos conhecimentos acerca de um poema elegíaco de Simónides sobre a batalha de Plateias limitavam-se a duas citações não seguidas no tratado De Herodoti malignitate. A coincidência de algumas letras da segunda citação com o fr. 5 do novo papiro (cf. Parsons 1992: 38) foi decisiva para a sua identificação.

\section{Fr. eleg. 15 Plu. de Herod. malign. 42. 872d-e}

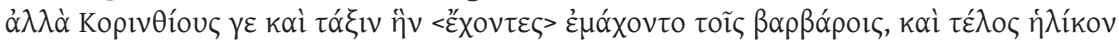

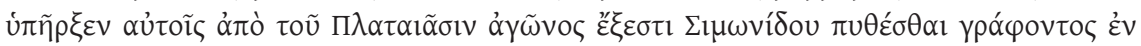

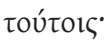

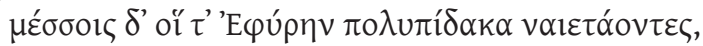

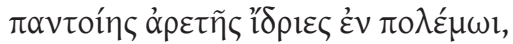

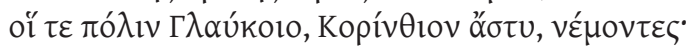

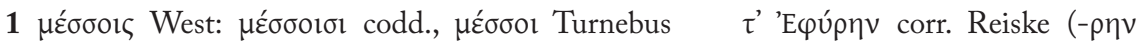

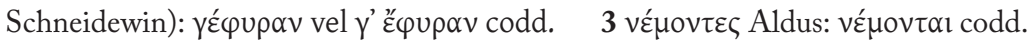

Todavia, no que respeita aos Coríntios, é possível saber em que posição lutaram contra os bárbaros e as consequências que teve para eles a batalha de Plateias graças a Simónides que escreveu nestes versos:

e no centro, tanto os que habitam Éfira rica em nascentes, artífices exímios nas astúcias da guerra, como os que ocupam a pólis de Glauco, a cidade de Corinto.

${ }^{103}$ A reconstituição proposta por West faz todo o sentido. O termo ö $\mu \alpha \delta$ os, 'tumulto',

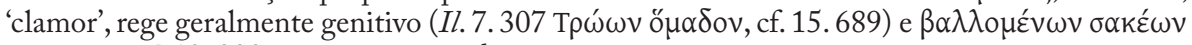
ocorre em Il.12.339, como notou o editor.

${ }^{104} \mathrm{~A}$ atribuição do presente fragmento à profecia de Tisâmeno foi proposta por West 1992a: 121, que Parsons 1992: 42 considerou “very attractive possibility.”É menos plausível a interpretação dos vv. 6-13 como uma referência à fundação da Simaquia de Delos, em 477 (cf. West 1993b: 8-9). Aloni 1994: 21 n. 38 observou, com mais razão, que seria estranho que Tisâmeno, o vidente dos Espartanos, profetizasse a instituição do principal instrumento da política anti-espartana de Atenas. Por outro lado, como notaram outros estudiosos (cf. Pavese 1995: 18) supõe-se que este poema tenha sido composto antes de 477 (vide infra, p. 311). 
Estes três versos apenas dizem respeito à posição ( $\tau$ ó́łı) que os Coríntios ocupavam no combate (cf. Hdt. 9. 28. 3, 9. 31.3) e podem ser importantes para os estudiosos interessados na reconstituição da batalha. Do ponto de vista formal, além da disposição simétrica das formas verbais em final de verso e do uso do epíteto homérico ( $\pi 0 \lambda \cup \pi \tilde{\imath} \delta \alpha \xi$, e.g. Il. 8. 47, 14. 157, referente ao monte Ida), o aspecto mais interessante é o carácter perifrástico do passo, cuja intenção é salientar a experiência militar do contingente coríntio. Em nossa opinião, a avaliar por estes versos, Simónides foi provavelmente minucioso na construção do poema, tendo o cuidado de enumerar os exércitos envolvidos, talvez recorrendo à técnica de composição em catálogo (atente-se na repetição de ol $\tau \varepsilon$ ) e introduzindo, a pouco e pouco, notas de carácter mitológico, como a referência a Glauco $^{105}$. Esta hipótese levanta a questão da extensão do poema e da sua execução, aspectos sobre os quais a citação seguinte pode fornecer algumas pistas.

Fr. eleg. 16 Plu. pergens; P. Oxy. 3965 fr. 5 oí

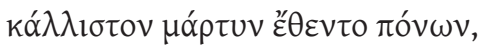

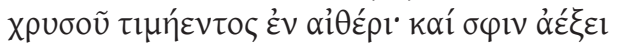

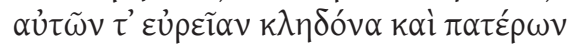
]$\pi, 0 \lambda \underline{u}[$

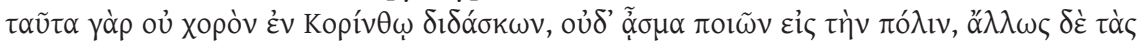

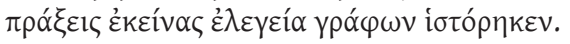

os que

estabeleceram o mais belo testemunho dos seus esforços, o do ouro precioso que habita no céu. E engrandece uma fama vasta, a deles e a de seus pais ...muito...

Estas informações não as dá ao treinar um coro em Corinto nem ao compor um canto em honra da cidade, mas, pelo contrário, quando escreve os dísticos elegíacos sobre aquelas façanhas.

Se atendermos às palavras de Plutarco (cf. supra fr. eleg. 15), este fragmento pode pertencer à parte do poema em que Simónides reflectia sobre as consequências da batalha de Plateias para os Coríntios, provavelmente a heroização dos combatentes ( $\varepsilon \dot{\rho} \rho \varepsilon \tilde{\imath} \alpha \nu \kappa \lambda \eta \delta o ́ v \alpha)$. E a fim de corroborar as

${ }^{105} \mathrm{O}$ significado da referência a Glauco e a razão do emprego de dois topónimos relativos, aparentemente, ao mesmo espaço, são discutidos, entre outras questões, por Catenacci 2001: 121-126. A existência do catálogo no poema é uma hipótese aceite por vários estudiosos (cf. supra fr. eleg. 13). Cf. Aloni 1994: 18, Obbink 2001: 69, Rutherford 2001a: 48, Asheri 2004: 69. 
suas palavras, evoca o testemunho de Hélios, cujo valor enfatiza através do superlativo e da metáfor ${ }^{106}$. O procedimento literário é, portanto, o mesmo que adoptou no fr. 531, no qual o testemunho de Leónidas funciona como uma autoridade exterior que reforça a opinião do poeta sobre os ${ }^{\prime} v \delta \rho \varepsilon \varsigma \alpha \beta \gamma \alpha \theta$ oí $^{107}$.

As palavras elogiosas sobre os feitos do exército coríntio, no estado actual dos nossos conhecimentos, são apenas um indício de que Simónides não se limitou a celebrar a actuação do contingente de Esparta. Não invalidam a hipótese, defendida por vários estudiosos, de ter dedicado ao exército de Pausânias uma atenção especial, como já dissemos no comentário aos fragmentos anteriores. As últimas palavras de Plutarco, que se prestam a diversas interpretações, vão ao encontro do que os papiros revelaram: que o assunto mais importante do poema era possivelmente o confronto dos exércitos grego e persa em Plateias. Mas Simónides tratou também os antecedentes da batalha, a marcha do exército e as profecias, pelo menos, além de ter começado (?) por evocar, como paradigma mitológico, o destino de Aquiles e a Guerra de Tróia.

A referência à morte do filho de Peleu através de um símile de sabor homérico (vv. 1-3), a evocação dos seus funerais (vv. 5-6), o sentido dos vv. 17-18, nos quais o poeta usa lexemas que na Ilíada se aplicam especificamente

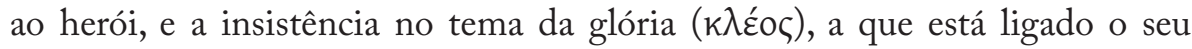
destino, sugerem que Aquiles é basicamente evocado na qualidade de herói da epopeia, ainda que isso cause estranheza, uma vez que, por norma, os hinos eram dirigidos a divindades. Por esta razão, alguns helenistas preferiram relacionar o poema de Simónides com os cultos em que Aquiles era venerado como divindade (vide infra).

Em nossa opinião, não é apenas pela sua arete que o poeta o evoca, mas também pelo destino de morte, que ele escolheu, como Megístias, porque valorizou a glória em detrimento de uma longa vida obscura. E precisamente essa glória que se derramará sobre os guerreiros que caminharam até Plateias e aí deram a vida em sacrifício. Mas não é só a eles que Simónides dedica o seu poema, porque evoca também os Dânaos que regressaram a casa sãos e salvos (cf. fr. eleg. 11.13). Supomos, portanto, que um dos temas centrais do poema seria o elogio da vitória alcançada pelos contingentes gregos na campanha de Plateias.

Uma vez que os versos preservados dizem respeito, quanto é possível saber, aos antecedentes da batalha, presume-se que a composição seria longa

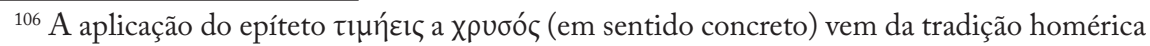

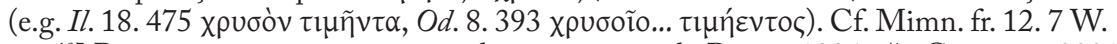

${ }^{107}$ Para uma outra interpretação destes versos, vide Pavese 1996: 57, Catenacci 2001: 127, Rutherford 2001a: 49. 
e apresentaria uma estrutura tripartida, pelo menos: o mito (frr. eleg. 10, 11. 1-20), a transição (fr. eleg. 11. 20-28) e a narrativa principal (frr. eleg. 11.29 sqq., 12-18) ${ }^{108}$. Sabemos que tinha mais de 123 versos, que é o número das linhas detectadas nos papiros, segundo a reconstituição de West. Portanto, um poema longo, mas que não ocuparia um rolo de papiro inteiro, pensa este helenista (cf. 1993b: 4).

Por conseguinte, a 'Elegia de Plateias' constitui mais um exemplo notável de influência homérica (cf. Brillante 2007). Não podemos saber, no entanto, se a escolha de um modelo épico influenciou a adopção do verso mais próximo do hexâmetro e, porventura, de uma modalidade de execução que estava igualmente mais próxima da dos aedos. A única referência neste âmbito encontra-se no

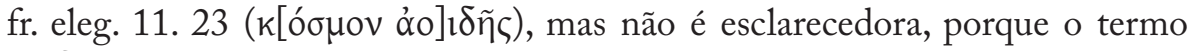
óoı $\delta$ ń nos Poemas Homéricos designa especificamente o canto do aedo e nos versos de Simónides pode ter apenas a função de reforçar a ligação do poema ao modelo homérico. Registe-se, no entanto, que Capra e Curti 1995: 31 propuseram a reconstituição $\kappa[$ ó $\lambda \lambda \circ \pi \alpha \chi 0] \rho \delta \tilde{\eta} \varsigma$, 'cravelha da corda' (cf. Od. 21.407), que constitui uma referência mais forte ao acompanhamento musical, embora possa não passar de uma simples conjectura ou ser empregue em sentido figurado. De facto, nas suas palavras, "Simonide inviterebbe la Musa a regolare la chiave della corda, in concomitanza con il passagio del registro epico a quello storico.” (pp.31-32).

$\mathrm{O}$ assunto centrado num acontecimento contemporâneo, a extensão e o metro escolhido integram a 'Elegia de Plateias' num subgénero com antecedentes literários, ao qual E. L. Bowie dedicou um estudo importante em $1986^{109}$. Na sua opinião, este tipo de poema, uma narrativa histórica composta em dísticos elegíacos, destinava-se em particular a ser interpretado numa cerimónia pública de carácter comemorativo. Como os fragmentos não nos dão indicações sobre as circunstâncias de composição e de execução, multiplicam-se as conjecturas dos estudiosos. West 1993b: 5 sugeriu que a ênfase inicial dada a Aquiles se explica talvez por o poema ter sido composto por ocasião de algum festival ou ritual em sua honra. Não é o único investigador a sublinhar uma possível ligação entre a evocação do

${ }^{108}$ Pavese 1995: 24 considera que o poeta provavelmente tratou na parte precedente ao mito a batalha das Termópilas e a morte de Leónidas. Na sua interpretação, a vitória de Plateias é vista como uma vingança pelo desastre de 480. Em nossa opinião, esta leitura não encontra nenhum apoio nos versos preservados. Baseia-se apenas na convicção de que o motivo da vingança estava bem difundido no séc. V (cf. Hdt. 8.114; 9. 64, 78-79).

${ }^{109}$ Sobre esta questão, vide West 1993b: 5, Aloni 1994: 12 (cf. 2001: 104), Boedeker 1995: 219. Cf. Sider 2006, que discute a validade da designação "elegia histórica" ("historical elegy") como subgénero literário. A discussão mais minuciosa do estudo de Bowie é proposta por Kowerski 2005: 63-74, esp. 
herói maior da Ilíada e as circunstâncias de execução ${ }^{110}$, embora a tendência da crítica seja a de relacionar esta escolha com a orientação ideológica do poema, como também preferimos (vide supra) ${ }^{111}$.

Julgamos que as últimas palavras de Plutarco (cf. fr. eleg. 16) sublinham o rigor e imparcialidade de Simónides no tratamento das façanhas dos Coríntios (cf. Aloni 1994: 18-19), e indiciam, embora nem todos os estudiosos pensem assim (cf. Shaw 2001: 178 sqq.), que o poema não foi apresentado em Corinto (ou no Istmo) $)^{112}$.

Os soldados que morreram em Plateias foram sepultados no local da batalha (Hdt. 9. 85, Thuc. 3. 58.4) e esse espaço viria a acolher cerimónias de carácter fúnebre e, eventualmente, heróico. Sabemos que foi aí erguido um altar dedicado a Zeus Libertador e, a partir de uma data que tem sido objecto de discussão, as cerimónias de homenagem evoluíram para competições atléticas, o festival Eleutheria (cf. supra epigr. XV). Em nossa opinião, não se deve excluir a hipótese de o poema de Simónides ter sido apresentado pela primeira vez nesse lugar sagrado. Quer tenha sido aí ou num outro local ${ }^{113}, \mathrm{o}$

110 Por exemplo, Sbardella 2000 defende que os versos preservados não dão indícios suficientes de uma concepção pan-helénica da vitória de Plateias. Em seu entender, o poeta valoriza claramente o papel dos Espartanos e, como o proémio é dedicado a Aquiles, o poema teria sido apresentado em Esparta, porque a Lacónia era uma das poucas regiões da Grécia Continental que conservava um culto a Aquiles na qualidade de deus. Sobre os cultos prestados ao herói, vide Farnell 1921: 285-289, West 1993b: 5, Pavese 1995: 20-21, Shaw 2001:165-178.

${ }^{111}$ As posições dos estudiosos em relação a este ponto são, como seria de esperar, muito diversas. West 1993b: 6 n. 15 pôs em dúvida a existência de um possível paralelo entre Aquiles e Pausânias, como sugeriram Parsons 1992: 32 e Lloyd-Jones 1994: 1. Para este último investigador, o poeta evoca Aquiles na qualidade de herói, pois pretende fazer por Pausânias e pelos outros soldados de Plateias o que Homero fez pelos heróis da Guerra de Tróia. Contra esta interpretação, Aloni 1994: 20 n. 34 (cf. 2001: 98) considera que o filho de Peleu é o modelo heróico dos que perderam a vida, cuja glória era celebrada no próprio sítio da batalha. Singular é a opinião de Pavese 1995: 21 (cf. 1996: 57), que, de acordo com a sua leitura dos fragmentos, vê em Aquiles o paradigma mitológico de Leónidas.

${ }^{112}$ Não nos parece, como pensa Boedeker 1995: 225 (cf. 220 e n. 12), que se possa concluir que "Plutarch himself argues that the elegy was not biased in favor of one city" ou que estabelece um confronto entre as funções do poema lírico e as do elegíaco ("Plutarch's point here is obviously that an elegy, as opposed to a choral song performed for local consumption, is designed for a broad audience and hence presents an objective account."). De facto, as palavras de Plutarco colocam-nos a mesma dúvida que os versos preservados de Simónides: na 'Elegia de Plateias' pode ter celebrado um contingente em especial (o de Esparta) ou todos os guerreiros que combateram na batalha.

${ }^{113}$ No entanto, parece-nos pouco prudente supor, como Aloni 1994: 19-21, que o poema tenha sido composto a pedido de Esparta ou de Pausânias, a fim de ser executado por ocasião da instituição do festival Eleutheria, em particular da consagração do altar pan-helénico de Zeus Libertador, numa cerimónia em que a celebração da vitória não excluía o lamento dos que haviam perdido a vida. Nem os versos preservados nem o testemunho de Plutarco (cf. fr. eleg. 16) apoiam essa suposição. Por outro lado, como já dissemos, é discutível que o referido festival tenha sido instituído imediatamente a seguir aos confrontos (cf. supra epigr. XV). Para uma discussão da tese de Aloni, vide Boedeker 1995: 221 sqq. Tal como esta investigadora, Suárez 
momento deve ter sido solene, adequado ao tom sublime do poema (cf. West 1993b: 9), não necessariamente fúnebre, mas que, de algum modo, pusesse em relevo a heroização que Simónides reivindica para os guerreiros que celebra ${ }^{114}$.

Ao contrário do que acontece habitualmente, neste caso é possível propor uma cronologia aproximada, porque o modo como o poeta evoca Pausânias

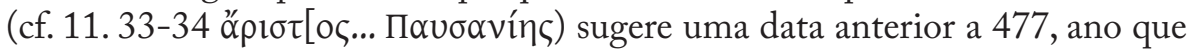
assinala o declínio político do general (Thuc. 1.94-95, 128-134) ${ }^{115}$.

Finalmente, as palavras acima citadas de Plutarco (fr. eleg. 16) confirmam que das actividades de um poeta dos finais da Época Arcaica faziam parte o treino de coros e a composição 'de cantos em honra da cidade'. Indirectamente, constituem também um testemunho da sua mobilidade. Em relação a este aspecto, a 'Elegia de Plateias' não nos trouxe nada de novo, uma vez que não conhecemos bem as circunstâncias em que foi composta. Confirma, no entanto, que Pausânias deve ser contado entre os ilustres que foram celebrados por Simónides e, neste sentido, vale a pena comentar neste momento duas teorias.

$\mathrm{Na}$ opinião de Aloni 1994: 21-22, não obstante o que designa de "equilíbrio diplomático", Simónides não conseguiu deixar de elogiar o comitente do poema (Pausânias, segundo a sua tese). O investigador relaciona esta conjectura com a tradição de que o poeta terminou os seus dias longe de Atenas, concluindo que a perseguição movida contra o general espartano esteve na origem da sua partida. Observa ainda que não há traços nem memória do seu poema nas principais fontes sobre os acontecimentos (e.g. Heródoto), ou seja, a 'Elegia de Plateias' pode ter sido alvo de uma espécie de censura ${ }^{116}$. A tese de Aloni encontra apoio na cronologia tradicional, que situa a ida de Simónides para a Magna Grécia em 476. Em nossa opinião, é possível que a mudança de fortuna de Pausânias possa ter condicionado as tradições orais sobre Plateias e a memória desses acontecimentos, mas parece-nos exagerado supor que motivou a fuga de um poeta que era um dos mais admirados na Grécia Continental.

de la Torre 1998a: 90 considera também que o poema de Simónides revela "una orientación indudablemente panhelénica”. Com base neste argumento, Rutherford 2001a: 41 sugeriu a sua execução em Delfos, por ocasião da cerimónia de consagração da coluna serpentina (cf. supra epigr. XVII (a) et (b)). Para uma resenha das diferentes teses sobre a ocasião e o lugar de apresentação do poema, vide García Romero 2004: 27-30.

${ }_{114}$ Aloni viria a reformular a sua tese, sublinhando que o poema se destinava a uma cerimónia de edificação dos túmulos de Plateias, presidida por Pausânias: "What we have here is a narrative elegy on a historical subject, destined to serve as a threnody for public performance." (2001: 104). Em nossa opinião, apenas o proémio do poema sugere esta ideia, uma vez que os restantes versos preservados dizem respeito à glória dos guerreiros e aos antecedentes da batalha.

${ }_{115}$ Cf. Aloni 1994: 16-18, 21; Boedeker 1995: 225; Pavese 1995: 24.

116 Para uma crítica a esta leitura, cf. Boedeker 1995: 225. Sobre a relação entre o poema de Simónides e a narração de Heródoto no que respeita à batalha de Plateias, vide Boedeker 2001a, Asheri 2004: 70 sqq., García Romero 2004: 26-27. Cf. infra, n. 118. 
Julgamos ainda menos credível a tese de Schachter 1998: 29, que avançou a hipótese de o poema composto por Simónides ter sido apresentado pela primeira vez no Achilleion situado perto do Sigeu, à entrada do Helesponto, no decurso da expedição espartana contra Chipre e Bizâncio (478/477, cf. Thuc. 1. 94). De acordo com a sua leitura dos fragmentos, Schachter propôs que a 'Elegia de Plateias' teria sido encomendada pelo general espartano para ser executada naquele templo, local tradicional do túmulo comum do grande herói e de Pátroclo (cf. Od.24. 76-84), a fim de impressionar os Gregos da Ásia com a grandeza do feito alcançado na Beócia, esperando, deste modo, convencê-los a escolher Esparta como líder militar em vez de Atenas (pp. 29-30). Esta tese, embora tenha interesse, suscita-nos duas objecções. $\mathrm{O}$ investigador não se pronuncia sobre as condições de composição do poema nem toma em consideração as possibilidades físicas de Simónides, que teria então cerca de setenta e oito ou setenta e nove anos. Rutherford 2001a: 41, embora reconheça que o Achilleion seria o espaço mais adequado à execução de um hino a Aquiles, aponta bem uma das nossas dúvidas: "but how likely is it that Simonides remained in the retinue of Pausanias through the winter of 478/477?". Por outro lado, esta interpretação, bem como a de outros estudiosos ${ }^{117}$, pressupõe que a 'Elegia de Plateias' não foi mais do que uma peça de propaganda política ao serviço das intenções imperialistas de Esparta, o que nos parece pouco congruente com a leitura que os versos preservados permitem.

Estes fragmentos elegíacos não revelaram uma faceta nova do talento poético de Simónides. Confirmaram esse talento e engrandeceram a sua versatilidade, a extraordinária capacidade de retomar e renovar a tradição poética, quer no domínio da estrutura da língua quer no das convenções literárias e, podemos conjecturar, das modalidades de execução. Em nossa opinião, o estado precário dos fragmentos não permite esclarecer a orientação ideológica do poema. Mesmo a ideia mais consensual - a expedição dos Dânaos contra Tróia surge como paradigma mitológico da vitória alcançada em Plateias contra os 'Bárbaros'118 - permite partir para leituras diversas: o poeta sublinhou a hegemonia do exército de Esparta ou a participação dos restantes contingentes gregos? Os versos preservados parecem apoiar a primeira hipótese, mas as palavras de Plutarco (cf. fr. eleg. 16) sugerem que

${ }^{117}$ Cf. e.g. Bearzot 1997. Segundo este estudo, a 'Elegia de Plateias' foi encomendada por Temístocles, no âmbito da sua amizade com Simónides e no clima de exaltação da unidade pan-helénica que se seguiu imediatamente à vitória. Para uma crítica desta leitura, cf. Salvato 1998: 111, esp.

${ }^{118}$ Como notou Barchiesi 1995: 37 n. 18, a 'Elegia de Plateias'é um testemunho do processo de 'barbarização dos Troianos', que se afirma durante o séc. V. A Guerra de Tróia torna-se num precedente paradigmático das Guerras Medo-Persas no âmbito da oposição Europa/Ásia. Na opinião de Asheri 2004: 70, este paralelo "e presente in Erodoto in tutta la sua maturità" e foi estabelecido pela primeira vez por Simónides. 
Simónides não deixou de elogiar a actuação das outras cidades. A orientação pan-helénica do poema é uma possibilidade, mas não uma certeza. No entanto, parece-nos seguro que o poeta retomou um procedimento literário que já se encontra em Íbico, na 'Ode a Polícrates' (fr. 1 P): o kleos que Homero concedeu aos Dânaos que conquistaram Tróia é o paradigma do kleos que é objecto de canto do poeta. A 'Elegia de Plateias' veio confirmar que a celebração da glória do guerreiro foi um dos temas privilegiados na poesia de Simónides. 
(Página deixada propositadamente em branco) 


\section{O MITO: DEUSES E HERÓIS NA obRA DE Simónides}


(Página deixada propositadamente em branco) 
O actual corpus de Simónides confirma que o mito ocupou na sua obra uma parte fundamental, como seria de esperar de um poeta lírico que se especializou, como cremos, na composição de epinícios, peanes e ditirambos. A célebre história, transmitida por Cícero e Quintiliano, sobre o malogrado banquete de Escopas (vide supra, pp. 162-163, 180-181) pode ser considerada apenas no âmbito da tradição pseudo-biográfica, mas um dos dados verosímeis é o destaque concedido pelo poeta na sua ode aos Dioscuros, que são, como se sabe, uma presença regular na lírica do período arcaico e em particular nos epinícios de Píndaro ${ }^{1}$. No entanto, da obra preservada de Simónides apenas podemos citar a evocação de Pólux no fr. 509, que integrava um epinício composto para Glauco de Caristo. A reconstituição dos fragmentos da 'Elegia de Plateias' sugere, porém, que as referências a Castor e Pólux não são exclusivas dos metros líricos (cf. fr. eleg. 11. 30-31)2. Tocamos, assim, num dos aspectos delicados desta questão, pois raramente sabemos a que subgénero pertencem os fragmentos de carácter especificamente mitológico. Esta dúvida não se coloca tanto em relação ao corpus revelado pelas descobertas papirológicas, mas para os versos transmitidos indirectamente, visto que poucos elementos fornecidos pelo contexto da citação se referem à composição original. Assim se justifica que esta matéria seja tratada num capítulo à parte. Convém esclarecer, antes de mais, que o nosso estudo não é exaustivo, uma vez que privilegiamos os fragmentos que incluem citações e analisaremos de modo muito breve os que são propriamente comentários sobre os mitos tratados por Simónides.

Nos fragmentos líricos comentados nos capítulos anteriores não encontrámos muitas referências às divindades mais importantes do panteão grego: é ao 'santuário de Zeus' que se dirige Crio de Egina para competir (cf. fr. 507); ao pai dos deuses e a Apolo aludia o poeta na ode composta para os filhos de Eácio (cf. fr. 511). Os fragmentos elegíacos mais recentes contêm apenas vestígios de nomes como 'Apolo' (fr. eleg. 11. 8), 'Zeus' (fr. eleg. 11. 30), 'Deméter', (fr. eleg. 17. 1), 'Diónisos' (frr. eleg. 24, 30. 5) e 'Cípris' (fr. eleg. 33. 14). No entanto, Zeus é mencionado nos frr. 508 e 543, que analisaremos mais adiante. Em nossa opinião, vale a pena referir ainda um conjunto de

\footnotetext{
${ }^{1}$ Cf. Stesich. fr. 178 PMG; Ibyc. fr. 282A Campbell (fr. 1.15 sqq.); Pind. Pyth. 2. 69, 5. 9, 11.61-62; Nem. 10; Isth. 1. 16, 5.33; Bacch. fr. 21 Ma. Recorde-se igualmente o que foi dito na segunda parte sobre a 'Canção de Castor', p. 127 n. 26.

${ }^{2}$ Cf. a reconstituição de West do fr. eleg. 70.2 (= P. Oxy. 3965 fr. 32.2), integrado na rubrica

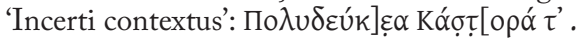


testemunhos, muito breves, sobre o modo como Simónides abordou alguns temas mitológicos.

De acordo com um escólio de Teócrito, o poeta tratou a disputa de Hefestos e Deméter pela posse da Sicília, na qual Etna interveio como árbitro ${ }^{3}$. A crer no escoliasta da Ilíada, Zeus e Apolo tinham um papel importante na versão que Simónides compôs da história de Idas e Marpessa, também tratada por Baquílides (Dith. 20, fr. 20A Ma.). Com o deus de Delfos se relaciona igualmente a lenda dos Hiperbóreos, que o poeta terá evocado na sua obra, segundo informa Estrabão ${ }^{4}$. No entanto, Simónides podia ter abordado este mito ao tratar a lenda de Perseu, como fez Píndaro, que relata a viagem do herói àquele reino mítico (cf. Pyth. 10.27-44). Recorde-se ainda o testemunho do imperador Juliano, mencionado na segunda parte, a propósito da composição e execução de hinos (p. 124), sobre um canto lírico centrado possivelmente na destruição da serpente Píton. Um outro testemunho do séc. IV da nossa era fala da desenvoltura juvenil com que Simónides (ou Píndaro) teria composto hinos a Diónisos e a Apolo5.

O testemunho mais significativo sobre os deuses olímpicos é um escólio de Apolónio de Rodes, que preservou dois versos sobre a genealogia de Eros.

Fr. 575 [70 P, 43 B, 24 D] Schol. A.R. 3.26 (p. 216 Wendel)

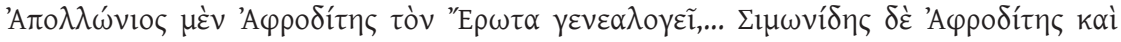
"A $\rho \varepsilon \omega \varsigma^{\circ}$

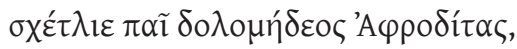

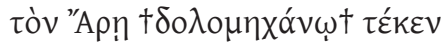

${ }^{3}$ Schol. Theoc. 1. 65-66, p. 56 Wendel $=$ fr. 552, 47 P, 200 B B. Diz também respeito a

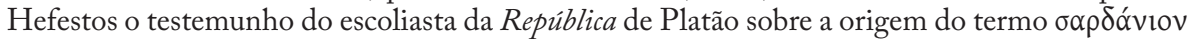
(schol. P1. R. 337a, p. 192 Greene = fr. 568, 63 P, 202A B): 'De acordo com Simónides, tem origem no Talos de bronze, que Hefestos fabricou para Minos, a fim de o pôr como sentinela da ilha. Diz ele que tinha vida e destruía os que se aproximavam, queimando-os. Daqui a expressão

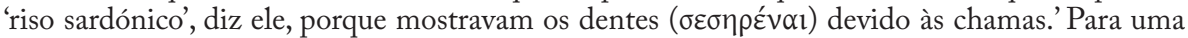
discussão deste testemunho, vide Poltera 1997: 574, 586; Schneider 1997: 84-87. Sobre o mito de Talos, vide John K. Papadopoulos, LIMC VII. 1, s.v. Talos 1 (München 1994) 834-837, VII. 2: 583-584. Este investigador observa que o tema principal do mito, e o mais representado na arte, é a chegada dos Argonautas a Creta e a morte do homem de bronze causada pelos poderes mágicos de Medeia (pp. 834-835). Coloca-se, pois, a hipótese de Simónides ter falado de Talos ao tratar a saga dos Argonautas (vide infra, pp. 339 sqq.).

${ }^{4}$ Schol. BT Hom. Il. 9. 557-558 (II. 518-519 Erbse) = fr. 563, 58 P, 216 B; Str. 15.1. 57 = fr. 570, 65 P, 197 B. Registe-se que B. Snell, “Bakchylides'Marpessa - Gedicht (Fr. 20A)”, Hermes 80.2 (1952) 156-163 (= Gesammelte Schriften, Göttingen, 1966, 105-111), pôs em dúvida que este testemunho dissesse respeito a Simónides (cf. p. 157/106). Sobre o mito de Marpessa, vide Linda J. Roccos, LIMC VI. 1, s.v. Marpessa (München 1992) 364-366, VI. 2:182-183, e o nosso estudo "Io e Marpessa - Uma análise dos ditirambos XIX e XX de Baquílides", Humanitas 60 (2008) 57-73, esp. 67-73.

${ }^{5}$ Him. Or. 47. 1, pp. 189-190 Colonna = fr. 574, 69 P, $210^{\mathrm{A}}$ B. 


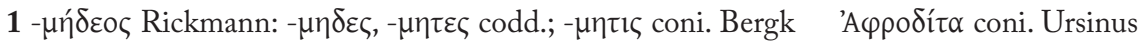

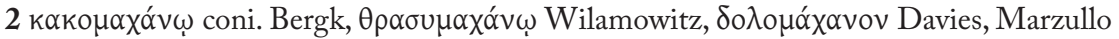

Apolónio faz descender Eros de Afrodite, (...) mas Simónides de Afrodite e de Ares: ó filho terrível da ardilosa Afrodite, que para Ares, to urdidor de ardis†, ela gerou

Na Teogonia de Hesíodo, Eros é gerado a partir do Caos primitivo. É o mais belo dos deuses e uma força dominadora e invencível quer para os imortais quer para os humanos (vv. 120-122). Se este atributo se mantém na tradição mitológica, os poetas posteriores atribuem diferentes genealogias a Eros, cujos traços fisionómicos se definem ao longo da Época Arcaica, e os mitógrafos tardios acrescentaram pormenores mais complexos. $\mathrm{O}$ escólio de Apolónio acima citado informa que para Safo era filho de Geia e de Urano. Segundo o escoliasta de Teócrito (13.1-2c, p. 258 Wendel), que corrobora a informação sobre Simónides, em Alceu era filho de Íris e de Zéfiro (fr. 327 L-P). A genealogia do deus do amor era, portanto, um tema mitológico que permitia alguma liberdade, embora os líricos associassem habitualmente Eros a Afrodite 6 .

Não podemos saber até que ponto a concepção de Simónides é original ${ }^{7}$. Do ponto de vista estilístico, este pequeno fragmento, que suscita dúvidas de crítica textual, é marcado pela disposição simétrica dos epítetos (pelo menos na lição aceite por Page), sendo que no v. 1 o qualificativo antecede o nome e no

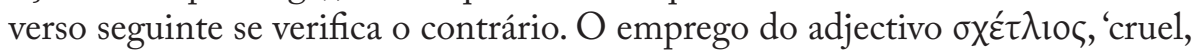
terrível, obstinado', que ocorre várias vezes nos Poemas Homéricos ${ }^{8}$, sugere que

${ }^{6}$ Cf. Alcm. fr. 59 (a) P; Ibyc. fr. 287 PMG; Anacr. frr. 346 (fr. 1), 357 PMG. Sobre o mito do nascimento de Eros, vide Graves 1960: I. 15. Para uma análise dos dois escólios, vide Pontani 2007: 119-121.

${ }^{7}$ Sobre esta questão, vide Pontani 2007, que nota: "A nostra scienza, la prima occorrenza letteraria sicura di Eros come divinità olimpia è invece proprio PMG 575 di Simonide, dove egli è detto figlio di Ares e Afrodite.” (p. 122). Recorde-se que a ligação legítima entre Ares e Afrodite estava bem estabelecida na tradição a partir de Hesíodo (cf. Th. 933-935, Pind. Pyth. 4. 87-88), enquanto a história do seu adultério, cantada por Demódoco na Odisseia (8. 266-366), parece constituir um episódio isolado, que viria também a ter seguidores e marcou a mitologia posterior (e.g. Ov. Ars 2. 561-592, Met. 4. 171-189). Cf. W. Burkert, "Das Lied von Ares und Aphrodite. Zum Verhältnis von Odysee und Ilias”, RhM 103 (1960) 130-144 (= Kleine Schriften I: Homerica, Göttingen, 2001, 105-116); West 1966: 415; Bruce K. Braswell, "The Song of Ares and Aphrodite: Theme and Relevance to Odyssey 8”, Hermes 110.2 (1982) 129-139; Hainsworth 1988: 363-364.

${ }^{8}$ E.g. Il. 5. 403, 10. 164; Od. 9. 351, 12. 279. Para uma análise do termo, vide Barrigón 2002: 14-15. Acosta-Hughes 2010: 203-204 defende, com base no vocativo $\pi \alpha \tilde{\imath}$, interpretado normalmente como 'filho', que Simónides inovou na caracterização de Eros ao apresentá-lo como criança. Além de nos parecer uma leitura forçada do fragmento, a concepção do deus do amor como uma figura infantil, imagem que se cristaliza na Época Helenística, pode estar já presente nos líricos mais antigos (cf. Alcm. fr. 58 P; Anacr. frr. 357. 1-4, 358. 1-4, 398 PMG). 
Eros é representado convencionalmente como uma figura que causa dissabores tanto aos seres divinos como aos humanos. No mesmo sentido aponta o epíteto de Afrodite, 'expediente em enganos', que não está atestado em nenhum outro

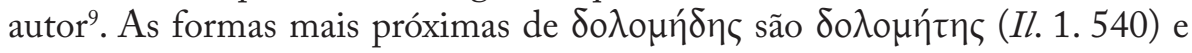

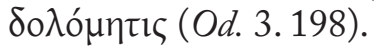

A crer na tradição manuscrita, o poeta empregou dois epítetos formados a

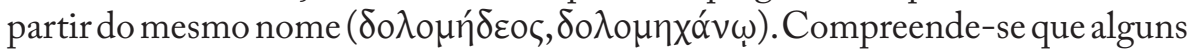
estudiosos tenham feito propostas no sentido de alterar esta estranha simetria.

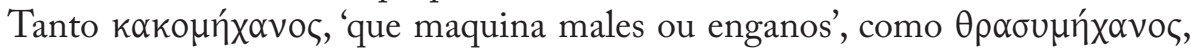
'que trama audácias, ousado', se encontram atestados, o primeiro nos Poemas Homéricos (Il.6.344, Od.16. 418), o segundo em Píndaro (Ol. 6. 67). Por sua

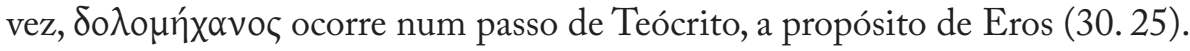

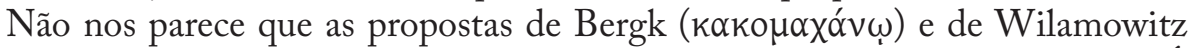
$(\theta \rho \alpha \sigma u \mu \alpha \chi \alpha ́ v \omega)$ suplantem a lição dos códices, embora esta não seja segura. É possível, porém, que o presente fragmento contenha a atestação mais antiga de $\delta \circ \lambda o \mu \eta ́ x \propto v o \zeta$, ainda que não tenhamos certezas se qualifica, como parece, Ares, ou antes Eros, como defendem Davies e Marzullo ${ }^{10}$.

De grande interesse nos parecem os fragmentos líricos revelados pelas descobertas papirológicas, que nos propomos tratar de modo muito breve, tendo em consideração o estado precário em que se encontram.

O P. Oxy. 2430, como referimos na segunda parte, foi editado em 1959 por Lobel e data provavelmente de c. 100 d.C. Contém 166 fragmentos, seleccionados a partir de uma quantidade maior, que o editor considerou "Choral lyric in the doric dialect (?Simonides)". Neles detectou "the remnants of at least five unrelated texts", entre os quais epinícios e peanes (1959: 45). A escrita aparentava ser obra de um único copista, mas com grandes variações no seu aspecto geral, diferenças no tamanho das letras e no espaçamento das

Sobre a construção da imagem do deus do amor, vide V. Jabouille, "Materializações de Eros na mitologia grega", in Aires A. Nascimento, V. Jabouille, F. Lourenço (edd.), Eros e Philia na Cultura Grega. Actas (Lisboa 1996) 39-50.

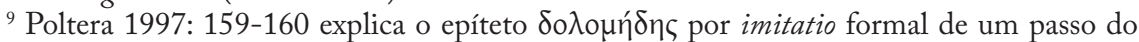
Hino Homérico a Hermes (v. 319), mas vide a nossa observação infra, n. 31. Cf. Pontani 2007:

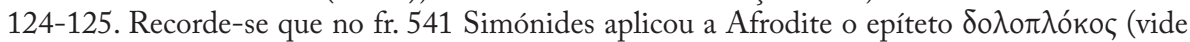
supra, p. 202 e n. 31). Os dois qualificativos sublinham as astúcias e sortilégios da deusa, tema

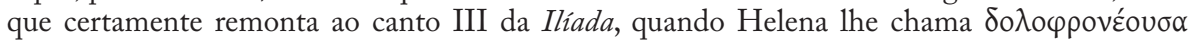
(v. 405). Cf. G. A. Privitera, "La rete di Afrodite. Richerche sulla prima ode di Saffo", QUCC 4 (1967) 7-58.

${ }_{10}$ M. Davies, "Simonides and Eros", Prometheus 10 (1984) 114-116; B. Marzullo, "Simon. fr. 575 P.”, MCr 19/20 (1984-1985) 15. Menos plausível nos parece a tese de G. Giangrande,

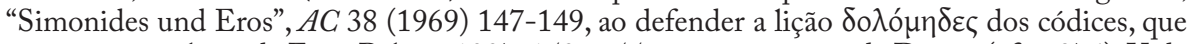
seria assim atributo de Eros. Poltera 1997: 159 n. 55 apoia a proposta de Davies (cf.p. 376). Vide Pontani 2007: 126-127. 
linhas. Lobel teve o cuidado de frisar que o estado deteriorado do material não permitia determinar se todos os fragmentos de lírica coral pertenciam ao mesmo corpus. Notou ainda que este papiro contribuía pouco para o conhecimento do trabalho de Simónides (p. 46). Em nosso entender, a análise de Rutherford 1990, centrada nos fragmentos que têm mais hipóteses de pertencerem a peanes, modificou um pouco esta percepção ${ }^{11}$.

A atribuição a Simónides do P. Oxy. 2430, que Page considerou na sua edição (= fr. 519), foi definitivamente confirmada por Lobel 1981: 21-22, que detectou coincidências entre os vv. 1-3 do fr. 520 e o fr. 14 do P. Oxy. 2623 (=519A Campbell), como já dissemos, e entre este papiro e o que agora nos interess $\mathrm{a}^{12}$. A determinação do subgénero dos fragmentos apoia-se na ocorrência

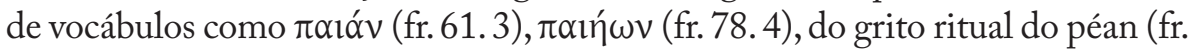

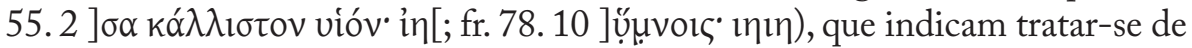

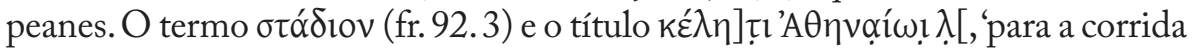
de cavalos, para Ateneu de...' (fr. 120 (b) 3) sugerem, naturalmente, o epinício. Mas esta análise tem também em conta as diversas ocorrências de nomes de deuses e de lugares sagrados que habitualmente associamos àqueles subgéneros líricos, como Zeus, Apolo, Ártemis, Pisa, Delfos, Delos... Infelizmente, alguns destes nomes não são mais do que meras referências e podem até ser fruto das reconstituições dos editores modernos ${ }^{13}$. Há, no entanto, alguns fragmentos mais significativos, embora nenhum apresente um verso completo ${ }^{14}$.

O P. Oxy. 2623 (= 319-386 SLG, 519A Campbell) já foi referido na segunda parte, a propósito dos Oligétidas de Corinto (vide p. 155). Num artigo publicado em 1988, Ma Carmen Barrigón defendeu que este papiro preserva fragmentos de um poema em que se evoca a mitologia de Héracles, composto para os reis de Esparta. Não pretendemos comentar a validade desta tese, mas devemos referir que alguns fragmentos contêm, de facto, como notou Lobel 1967: 66, referências a Esparta (fr. 1), enquanto outros remetem, provavelmente, para o tema de Héracles (frr. 41. 5, 45, 46. 6, 57. 3). Há, todavia, também referências a divindades como 'Zeus Ceneu', venerado no

${ }^{11}$ Rutherford apresentou um estudo de crítica textual e comentário interpretativo focado na questão do género. Trata também, em apêndice, a relação entre os conteúdos do P. Oxy. 2430 e a edição helenística de Simónides, os 'Poemas délicos' (fr. 539, cf. supra, p. 133) e a organização dos peanes de Simónides, e o metro dos fragmentos deste papiro.

${ }_{12}$ Sobre este ponto, cf. Rutherford 1990: 169 n. 5.

${ }^{13}$ Zeus: frr. 9. col. ii. 2, 41. 4, 94. 2; Apolo: frr. 9. col. ii. 5, 23. 2, 35 (b) 2, 41. 2-3?, 55. 1, 61. 4, 84. 8-9; Ártemis: frr. 31. 2?, 35 (b) 7-8, 41. 1; Atena: 35 (b) 3, 62. 4?; Leto: fr. 32?; Poséidon: fr. 77. 6; Olímpia: frr. 53. 8?, 131. 6; Pisa: fr. 1. col. ii. 6; Alfeu: fr. 131. 4; Delfos: frr. 9. col. ii. 4?, 35 (b) 11; Delos: schol. 35 (e) 4, frr. 47.2?, 70.1; monte Parnes: 35 (b) 1.

${ }^{14}$ Referimo-nos aos frr. 32, 35 (b), 41, 55, 77, 79, 92. Estes dois últimos pertencem, provavelmente, a odes de vitória. Dos restantes, há alguns indícios de que os frr. 32, 35 (b) e 55 tenham feito parte de peanes. No capítulo seguinte destacamos as referências à natureza neles presentes, bem como no fr. 77 (pp. 360-361). 
promontório da cidade situada a noroeste da Eubeia (fr. 2.12 Knvoíou $\Delta[$ iòs), 'Diónisos' (fr. 10. $1 \Delta \mathrm{\Delta l}$ ]ọ́vvợ[o]ৎ) e 'Acestor', epíteto de Apolo em Eur. Andr.

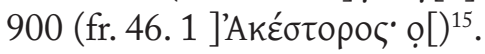

Campbell inclui também na sua edição da lírica de Simónides o P. Oxy. 2624 (= 519B, 387-442 SLG), observando que a atribuição ao poeta "is likely enough but not certain" (1991: 411). Lobel, que não chegou a uma conclusão definitiva sobre esta questão, notou a ocorrência de muitos vocábulos até então não atestados em nenhum autor antigo (1967: 91). Este papiro do séc. II d.C. contém igualmente diversas referências de carácter mitológico, embora o estado de conservação dos fragmentos não permita uma análise temática. Registe-se somente que o fr. 1, cujos vv. 11-12 remetem para o contexto de um sacrifício,

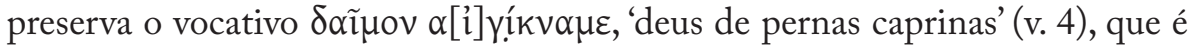
um epíteto do deus Pã (cf. $A P$ 6.167.1). Ocorrem também referências a Palas

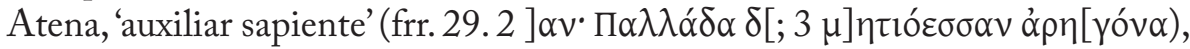
e às Musas (fr. $32.6 \mathrm{Mo}[\mathrm{l} \sigma] \tilde{\alpha}[\mathrm{v}) . \mathrm{O}$ fr. 56 remete para os atributos e centros de

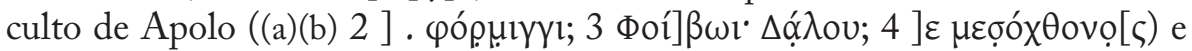
de Poséidon, 'senhor que abala a terra' ((c) 4-6).

Já comentámos neste trabalho outros fragmentos que contêm a invocação da Musa ${ }^{16}$. Recorde-se que West propõe a leitura $\pi[0 \lambda \nu \omega ́ v v \mu] \varepsilon$ Moṽ $\sigma \alpha$ para o final do v. 21 do fr. eleg. 11 da 'Elegia de Plateias'. Refere-se provavelmente àquela deusa a apóstrofe $\theta u ́ \gamma \alpha \tau \varepsilon \rho ~ \Delta$ ló do v. 1 do fr. eleg. 86 (vide supra, p. 149). A invocação da patrona da poesia é segura no fr. eleg. 92 (vide supra, p. 148).

Os fragmentos conhecidos pela tradição directa, embora não tão ricos a este respeito, conservam vestígios da menção das Musas na obra de Simónides. O fr. 22 do P. Oxy. 2430 (= fr. 519) atesta os termos Moloõv, 'das Musas' (v. 3), e $\Pi] \eta v \varepsilon \varepsilon$ ṽ[, 'de Peneu' (v. 4), nome do rio que corria junto da Piéria, berço das deusas. $\mathrm{O}$ fr. 41, mais bem conservado, parece aludir ao início de um concerto de Apolo com as Musas, na morada de Zeus (vv. 4-5, cf. Campbell 1991: 391). Estes fragmentos sugerem, embora possa ser casual, que a patrona do

${ }^{15}$ A ligação entre Zeus Ceneu e o mito de Dejanira é atestada por Baquílides (Dith. 16. 17-18) e Sófocles (Tr. 237-238, 752-754, 993-995). Sublinhe-se que Barrigón 1988: 52-53, 58-60, esp., discute devidamente a relação entre o tema de Héracles e as referências a Zeus Ceneu e Apolo Acestor.

${ }_{16}^{16}$ Não consideramos, porém, o fr. 947 PMG (29 P, Simon. 60 + 46 B, Stesich. 25 D), citado por Élio Aristides (Or. 28. 66), que Page incluiu nos fragmenta adespota, embora vários helenistas defendam a atribuição a Simónides, designadamente Bowra 1961: 362 n. 3 . O fragmento figura no vol. V da edição de Campbell (1993: 368-369) com a nota "Ascribed to Stesichorus or, with more probability, to Simonides." Para uma discussão da sua autenticidade, vide U. Albini, “Frammenti di un' ode di Simonide?", PP 18 (1963) 456-462, Poltera 1997: 22 e o seu artigo “Simonidea”, SIFC 96 (2003) 207-211. 
poeta é invocada sobretudo na forma de singular, sendo o plural empregue nas referências mais gerais. É o que se verifica no fragmento mais importante sobre este tema, que nos foi transmitido por Plutarco.

Fr. 577 [72 P, 44-45 B, 26-25 D] Plu. De Pythiae oraculis 17. 402c-d

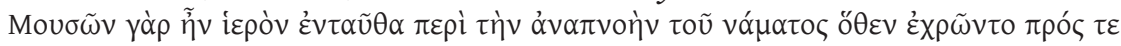

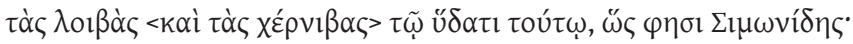

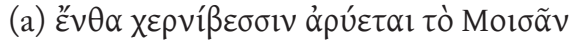

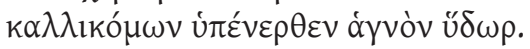

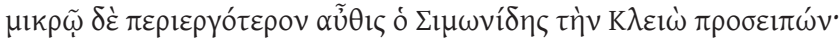

(b) $\dot{\alpha} \gamma v \tilde{\alpha} v \varepsilon \dot{\pi} \pi i ́ \sigma \kappa o \pi \varepsilon \chi \varepsilon \rho v i ́ \beta \omega v$,

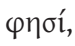

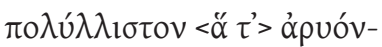

$$
\begin{aligned}
& \tau \varepsilon \sigma \sigma \mathrm{l}, \chi \rho \cup \sigma o ́ \pi \varepsilon \pi \lambda \varepsilon<\mathrm{K} \lambda \varepsilon 10 \tilde{\text {, }} \\
& \pi \alpha \rho \varepsilon ́ \chi \varepsilon 1 \zeta>\varepsilon \dot{u} \tilde{\omega} \delta \varepsilon \varsigma \dot{\alpha} \mu \beta \rho \circ \sigma i ́ \omega v
\end{aligned}
$$

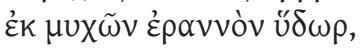

$$
\begin{aligned}
& \lambda_{0 ı} \beta \tilde{\alpha} v \text {... }
\end{aligned}
$$

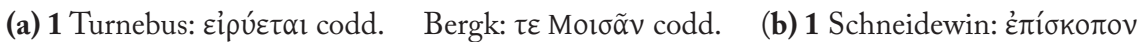

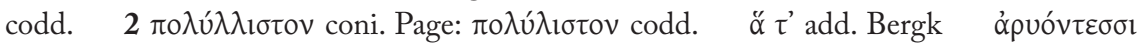

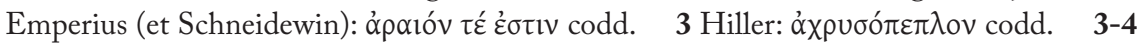

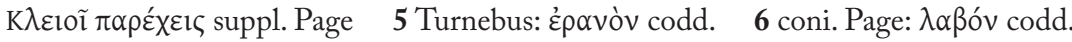

Pois ali mesmo estava um santuário das Musas, junto da nascente do rio cuja água usavam para libações e lustrações, como diz Simónides:

(a) aí, para as lustrações, se recolhe das profundezas a água pura das Musas de belos cabelos.

Com um pouco mais de elaboração, diz de novo Simónides, dirigindo-se a Clio:

(b) guardiã das puras águas lustrais, Clio de ouro vestida, que dás, aos que a recolhem das divinas profundezas, a agradável água olorosa, invocada por muitas preces, das libações...

Não vamos discutir aqui a utilização destes versos como testemunho da existência, no santuário de Delfos, de um culto às Musas anterior ao de Apolo ${ }^{17}$. As palavras de Plutarco não são esclarecedoras, mas a temática dos

${ }^{17}$ Tese defendida por H. W. Parke, "Apollo and the Muses, or Prophecy in Greek Verse", Hermathena 130-131 (1981) 99-112. Sobre esta questão, vide Rutherford 1990: 197-198, Barrigón 1996: 450-453 e, em particular, da mesma investigadora, o artigo "Sobre el culto de las Musas en Delfos", CFC 6 (1996) 237-250. 
dois fragmentos sugere, em princípio, que pertençam ao mesmo poema ${ }^{18}$. Não nos parece plausível, porém, que se sucedessem imediatamente, dada a presença,

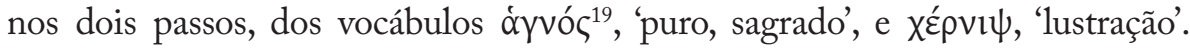

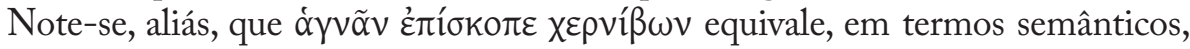
ao primeiro fragmento, o que transparece na nossa tradução. Por outro lado, está também presente no segundo fragmento a noção de que a água lustral é

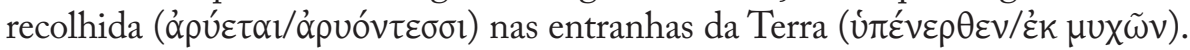
Por conseguinte, como notara Plutarco, o segundo fragmento não se distingue do primeiro pelo conteúdo, mas pela formulação mais elaborada. Por tudo isto, parece-nos mais provável que estes versos pertençam a composições distintas ${ }^{20}$.

A formulação mais elaborada do segundo fragmento assenta em três aspectos. Em primeiro lugar, do conjunto das Musas o poeta elege Clio, a primeira a ser nomeada por Hesíodo (Th.77) e cujo nome evoca imediatamente a glória (kleos) concedida pelo canto ${ }^{21}$. A distinção é corroborada pelo epíteto, pois $\chi \rho \cup \sigma o ́ \pi \varepsilon \pi \lambda$ ○ é de emprego mais raro que $\kappa \alpha \lambda \lambda \hat{i ́ k o \mu o \zeta ~ e ~ n a ̃ o ~ e s t a ́ ~ a t e s t a d o ~}$ na tradição épica ${ }^{22}$. Em segundo lugar, a simplicidade do advérbio úrévep $\theta \varepsilon v$

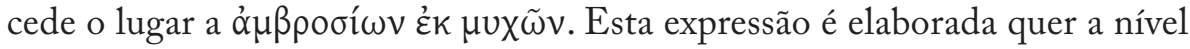
sintáctico (enjambement, anástrofe) quer semântico: a nascente situada no interior da Terra é agora da mesma natureza das Musas, divina e imortal.

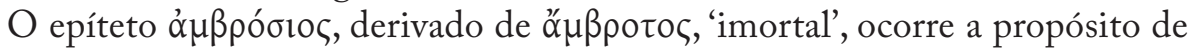
uma ninfa no Hino Homérico a Hermes (4. 230), mas qualifica habitualmente coisas, como os cabelos de Zeus (Il.1.529), o sono (Il.2.19), a noite (Od. 4. 429) e o canto das Musas (Hes. Th. 69). Finalmente, o segundo fragmento

${ }^{18}$ Esta é a opinião de Barrigón, ibidem, p. 240: "Actualmente basándonos en la similitud que presenta el contenido creemos que formaban parte de un único peán para Delfos.”

19 Sobre este epíteto, vide Barrigón 1996: 450 n. 16. Note-se que Píndaro emprega a

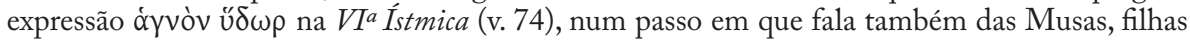

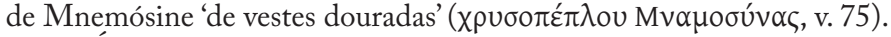

${ }^{20}$ É o que defende também Rutherford 1990: 197, que considera plausível que as composições fossem peanes.

${ }_{21}$ No proémio da Teogonia o poeta nomeou em catálogo as nove filhas de Zeus e de Mnemósine (vv. 77-79), inspirando-se nas ideias sobre música, canto e poesia presentes nos versos anteriores. Esta interpretação terá sido apresentada pela primeira vez por R. H. Klausen (RhM 1835, 443-444, apud West 1966: 180). Nas palavras de B. Snell, o passo de Hesíodo proporciona "o que se poderia chamar uma poética em forma teológica" (1992 [1975]: 68). Píndaro evoca Clio na $I I I^{a}$ Nemeia (v. 83). Baquílides escreveu três odes de vitória sob o seu patrocínio $(3.3,12.2,13.9,228)$.

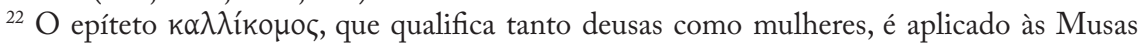
por Safo (fr. 128 L-P) e talvez por Anacreonte (fr. 390 PMG). Cf. Il. 9. 449 (mulher); Od. 15. 58 (Helena); Hes. Th. 915 (Mnemósine), Op. 75 (Horas); Stesich. fr. 212. 1 PMG (Graças);

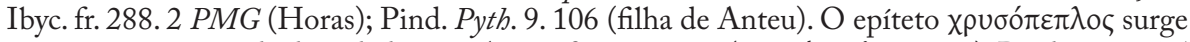

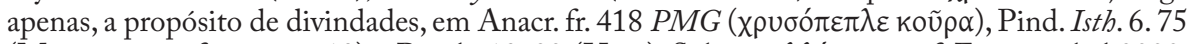

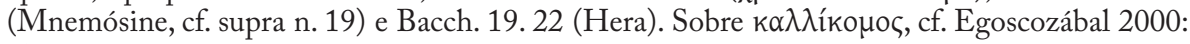
17-18. 
é dominado pelos epítetos da água, enquanto no primeiro apenas ocorre áyvòv. Esta interpretação, sublinhe-se, não é segura, dada a corrupção destes versos, mas a aceitar-se a reconstituição dos editores modernos ${ }^{23}$ são três

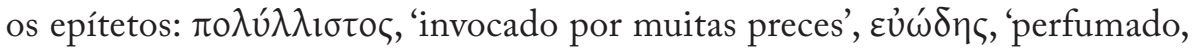
oloroso', e દ’pavvós, 'agradável, amável'. O primeiro surge nas palavras que Ulisses dirige ao rio que o há-de salvar, antes de chegar junto de Nausícaa (Od.5. 445) e é particularmente adequado a templos (b.Hom.2.28, 3.347) e altares (Bacch. 11. 41-42). Tem, de certo modo, o mesmo valor que áyvóv no primeiro fragmento. Os restantes epítetos pertencem igualmente à tradição épica, ainda que tenham outras aplicações. Todavia, se nestes versos $\varepsilon \dot{u} \tilde{\omega} \delta \varepsilon \varsigma$ sublinha a natureza excepcional desta água que, no estado normal, não teria odor, દ̇pavvóv tem sobretudo uma função ornamental, como acontece nos Poemas Homéricos ${ }^{24}$.

Supondo que estes versos pertencem a duas composições distintas, é de notar que há um vocabulário comum e que a variação é, sobretudo, de natureza formal. Neste sentido, a citação de Plutarco pode conter um exemplo do modo como Simónides realizava o seu trabalho, quando era solicitado a compor sobre matérias já tratadas noutros poemas. Outro aspecto a destacar é que nestes versos a água das Musas não é uma alegoria da poesia, como na $V I^{a}$ Ístmica de Píndaro (vv. 74-75)25. As filhas de Zeus são evocadas como guardiãs da água sagrada de Delfos destinada às purificações e este tipo de referência seria adequado num péan. Não cremos, porém, que se possa concluir que o poeta privilegiou esta concepção das Musas, nem nos parece que estes versos atestem que no seu tempo estavam principalmente associadas às purificações, como escreveu Rutherford 1990: 198. De facto, Simónides terá composto outros cantos líricos em honra das patronas da poesia, de acordo com um testemunho de Himério (Or. 62. 54-60 = fr. 578, 73 P, 201 B):

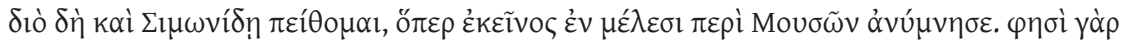

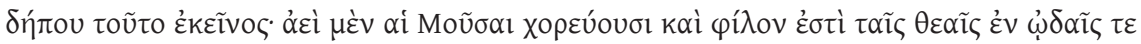

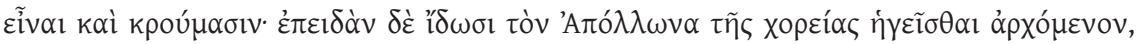

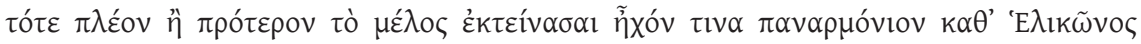

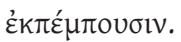

Por isso é que eu confio em Simónides, no que disse nos seus cantos em louvor das Musas. Pois diz seguramente isto: as Musas dançam sempre e é-lhes caro estar entre os cantos e os

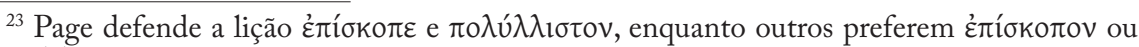
$\pi \circ \lambda \hat{u} \lambda(\lambda)$ เ $\sigma \tau \varepsilon$. A aceitar-se esta lição, o epíteto diria respeito a Clio. Cf. Poltera 1997: 90 n. 258.

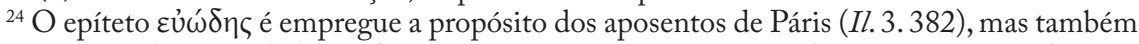
de um cipreste (Od. 5. 64); દ́pavvó qualifica habitualmente cidades (Il. 9. 577, Od. 7. 18).

${ }_{25}$ No entender de Poltera 1997: 185, a menção repetida de $\chi \varepsilon \rho v i ́ \beta \varepsilon \varsigma$ obscurece a relação água-poesia, mas crê tratar-se do mesmo topos presente na ode de Píndaro. 
sons. Mas quando vêem Apolo a dirigir a dança, então, elevando o canto muito mais do que antes, fazem sair do Hélicon um som todo harmonioso.

A crer neste testemunho, como notou Campbell 1983: 270, Simónides também retratou as Musas de um modo convencional, seguindo de perto, como parece, Hesíodo, quando celebra as divindades do Hélicon e as suas actividades preferidas na abertura da Teogonia ${ }^{26}$. O santuário de Delfos, morada de Apolo e cenário do tratado de Plutarco, teria sido adequado à execução destes cantos em louvor das Musas. No entanto, como não é exacto o valor morfológico de Év $\theta \alpha$, não é prudente conjecturar que o fr. 577 (a) pertença a uma composição executada naquele lugar sagrado ${ }^{27}$.

A fim de confirmar que Simónides havia também usado o termo $\Pi \varepsilon \lambda \varepsilon \iota_{\alpha} \delta \varepsilon \varsigma$ (por $\Pi \lambda \varepsilon \iota_{\alpha} \delta \varepsilon \varsigma$ ), Ateneu cita a seguinte referência a Hermes, que pode ter figurado num epinício:

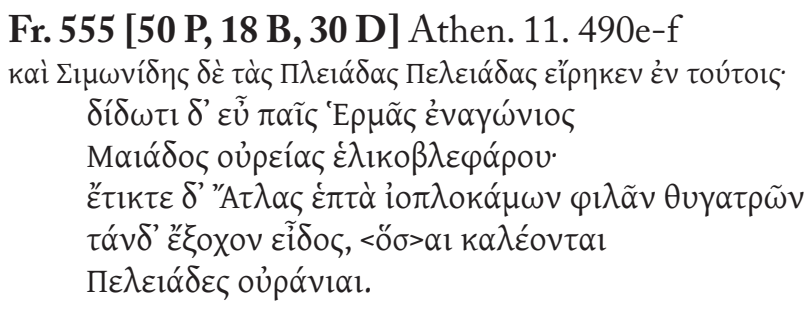

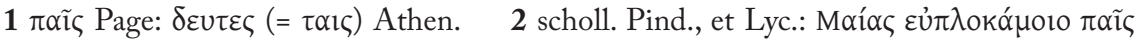

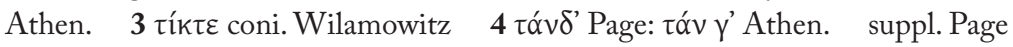

E Simónides também chama às Plêiades 'Pelêiades' nestes versos: ... bem merecido é o dom de Hermes, senhor dos jogos, filho da alpestre Maia de olhos vivos; gerou-a Atlas e das sete queridas filhas de tranças violáceas é a primeira em beleza, as quais são chamadas Pelêiades celestes.

A possibilidade de o poema original ter sido um epinício apoia-se, por um lado, na forma verbal inicial $\delta i ́ \delta \omega \tau \imath$ (dórica por $\delta i ́ \delta \omega \sigma l)$, que pressupõe a

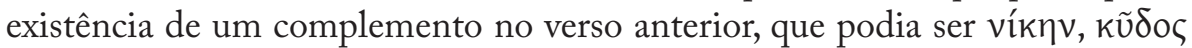

\footnotetext{
${ }^{26} \mathrm{Na}$ opinião de Rutherford 1990: 183, a ideia de que as Musas cantam mais alto quando vêem Apolo, que Himério atribui a Simónides, pode dizer respeito ao fr. 41 do P. Oxy. 2430 (= fr. 519). Vide supra, pp. 322-323.

${ }^{27} \mathrm{O}$ advérbio é empregue com a função de conjunção relativa, a mais bem atestada em Píndaro, defende Poltera 1997: 313.
} 


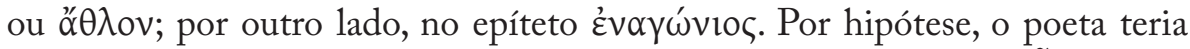
afirmado que 'Hermes, o senhor dos jogos, concede a merecida ( $\varepsilon \tilde{u})$ vitória/ glória' a um atleta ${ }^{28}$. Tais conjecturas são corroboradas pelos versos de Píndaro, que usa por duas vezes, pelo menos, o mesmo epíteto: na expressão ' $\pi \alpha \tilde{i} \varsigma$

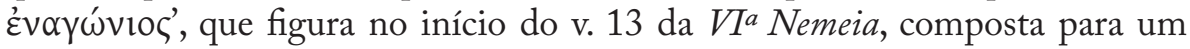

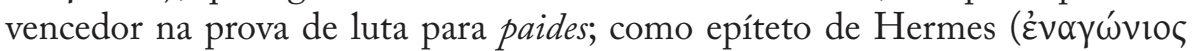
'E $\rho \mu \tilde{\alpha} \varsigma$ ), surge na $I I^{a}$ Pítica (v. 10). Mas o lírico de Tebas também evocou o arauto dos deuses em outras ocasiões, ora sublinhando este atributo ora o de protector dos festivais atléticos ${ }^{29}$.

Como habitualmente acontece na poesia grega arcaica, Simónides complementa a referência mitológica inicial a Hermes pela evocação da sua genealogia, pelo que os vv. 2-5 são dedicados à sua progenitora. Este laço de parentesco já figura na Odisseia (14. 435) e na Teogonia de Hesíodo encontram-se os dados essenciais do mito (v. 938): 'E para Zeus, a filha de

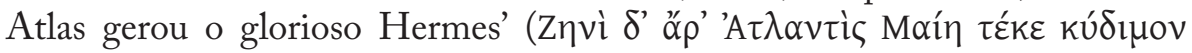

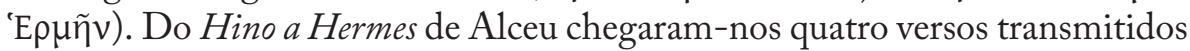
por Heféstion, nos quais se preserva a apóstrofe ao filho de Maia (fr. 308 L-P). É, no entanto, o Hino Homérico a Hermes que nos oferece o relato mais completo sobre a concepção e o nascimento do arauto dos deuses (b.Hom. 4. 1-19). Simónides mostra conhecer o mito ao empregar o epíteto oủpeía, 'montanhesca, alpestre', pois foi nas cadeias montanhosas do monte Cilene (da Arcádia) que Maia, inicialmente uma ninfa (cf. Hes. fr. 169 M-W), se uniu a Zeus e gerou Hermes (h.Hom. 4. 1-5). Esta é a explicação dada pelo escoliasta

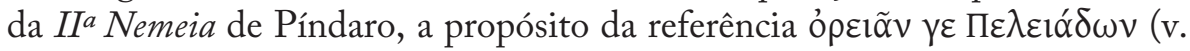
$11)^{30}$. Em nosso entender, não é de excluir a hipótese de Simónides ter criado

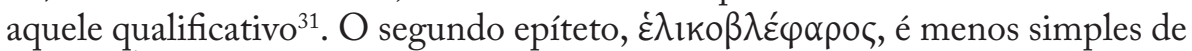
definir. À letra parece significar 'de pálpebras em forma de espiral ou voluta', portanto 'de pálpebras arqueadas', para designar uns olhos de belos contornos

${ }^{28}$ Esta conjectura, proposta também por Campbell 1991: 447 (n. 2 ad loc.), apoia-se em construções que se encontram já na Ilíada (e.g. 8.216, 17. 596; cf. Od. 3. 380).

${ }^{29}$ Cf. Ol.6. 79, 8. 81; Pyth. 4. 178, 9. 59; Nem. 10.53; Isth. 1. 60; Dith. 4.37 (= fr. 70d Ma.). Baquílides evoca Hermes no Dith. 19.25-26.

${ }_{30}$ Schol. Pind. Nem. 2. 17c, III. 34-35 Dr. (= Hes. fr. 170 M-W). O escoliasta observa:

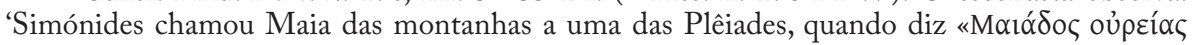

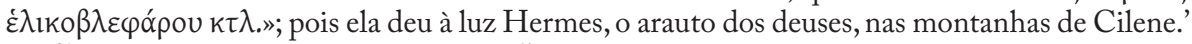

${ }^{31} \mathrm{Na}$ opinião de Poltera 1997: 527, oúpeloৎ ocorre pela primeira vez como epíteto de Maia no Hino Homérico a Hermes (v. 244), que teria fornecido o modelo do passo de Simónides. O epíteto tem, de facto, um emprego limitado (cf. Aesch. $A g$. 497, Soph. Ph. 937). Note-se, porém, que a cronologia daquela composição é bastante problemática, como demonstra Càssola 1975: 173-174, que é, de resto, considerada a mais tardia dos hinos maiores e mais antigos. Na melhor das hipóteses, data do fim do séc. VI (cf. Janko 1982: 143), mas West 2003: 14 não exclui a possibilidade de pertencer ao séc. $V$. 
e sedutores. Outra interpretação destaca a vivacidade deste olhar ${ }^{32}$. As duas interpretações são plausíveis, uma vez que o vocábulo é epíteto distintivo de Afrodite no proémio da Teogonia de Hesíodo (v. 16) e no VIo Hino Homérico (v. 19). Píndaro aplica-o à deusa do amor no encómio para Teóxeno de Ténedos (fr. 123 Ma.), mas também a Alcmena (Pyth. 4. 172). Dado que esta ode foi composta em 462, já depois da morte de Simónides, é possível que

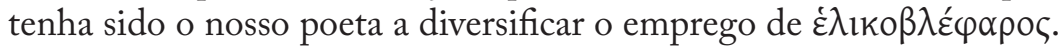

Tal como no v. 1, a ênfase no v. 3 recai sobre a forma verbal हैं $\imath \kappa \tau \varepsilon$, já não respeitante ao nascimento de Hermes, mas à filiação paterna de Maia. $\mathrm{Na}$ Odisseia, o gigante Atlas é mencionado como pai da ninfa Calipso (1. 52, 7. 245). Na Teogonia, Hesíodo evoca primeiro o seu nascimento (v. 509) e, em seguida, a luta em que participou com outros Titãs contra os deuses, pela qual foi condenado por Zeus a sustentar a abóbada celeste sobre os ombros (vv. 517-520). Este mito terá sido também evocado por Simónides, de acordo com um passo de Filodemo, filósofo e poeta do séc. ${ }^{33}$. É só no v. 938, acima citado, que Hesíodo recorda brevemente a paternidade de Maia. Mais frequentes são as referências às restantes filhas de Atlas, que Simónides evoca também, para afirmar que a mãe de Hermes lhes era superior pelo seu aspecto ( $\tilde{\tilde{i} \delta} \delta \varsigma)$. Perseguidas por Oríon, as sete ninfas foram divinizadas e convertidas nas sete estrelas da constelação das Plêiades. Figuram já, com as suas irmãs Híades, no escudo de Aquiles descrito no canto XVIII da Ilíada (v. 486). Na Odisseia, é com os olhos nelas que Ulisses empreende a sua viagem de libertação, ao deixar a ilha de Calipso (5. 272). Nos Trabalhos e Dias, Hesíodo recorda a filiação paterna (v. 383), as épocas do ano em que são visíveis (do início ou meados de Maio até Novembro, vv. 383-387), e a perseguição incessante de Oríon (vv. 619-620), motivo a que alude Píndaro na II Nemeia (vv. 10-12).

O v. 3 do presente fragmento de Simónides é, como o anterior, fortemente marcado pela adjectivação. Além de $\varphi \imath \lambda \tilde{\alpha} v$, destaca-se o raro epíteto io $\lambda \lambda o ́ k \alpha \mu \circ$, , 'de tranças violáceas', que não se encontra atestado antes do nosso poeta e na 'Elegia de Plateias' seria aplicado às Piérides, segundo propõem os editores (fr. eleg. 11. 16). Já oủpóvioৎ, que ocorre na tragédia (Aesch. Pr.164, Soph. OT 301), é bem mais antigo ${ }^{34}$.

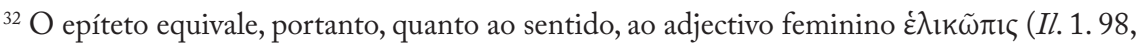
Hes. Th. 298, Pind. Pyth. 6. 1) e a $\dot{\varepsilon} \lambda i ́ k \omega \psi(I l .1 .389)$, aplicado aos Aqueus, ambos geralmente traduzidos por 'de olhos vivos' ou 'de olhos negros'. Cf. Càssola 1975: 561.

${ }^{33}$ Philodem. Piet., p. 37 Gomperz = fr. 556, 51 P, $202^{\text {B }}$ B. O conhecimento do mito está subjacente no v. 289 da IVa Pítica de Píndaro.

${ }^{34} \mathrm{Na}$ Teogonia de Hesíodo, Oủpavín é nome de uma Musa (v. 78) e de uma Oceânide (v. 350). No Hino a Deméter (v. 55) é epíteto dos deuses. Sobre o adjectivo io $\pi \lambda o ́ k \alpha \mu \circ$, vide supra, p. 300 e n. 91 . 
O último verso do fragmento encerra o motivo principal da citação de

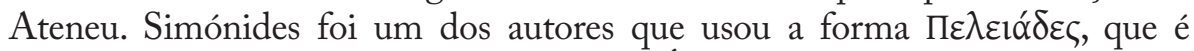
distinta das que ocorrem na grande épica ${ }^{35}$. É nos fragmentos de Hesíodo (288, 289, $290 \mathrm{M}-\mathrm{W}$ ) que o nome das Plêiades ocorre com esta forma e no passo acima referido da $I I^{a}$ Nemeia de Píndaro (v. 11). Se esta escolha não foi ditada

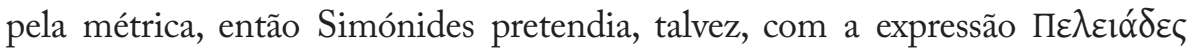
oủpóvial, 'pombas do céu', aludir à versão do mito segundo a qual as ninfas, antes de serem transformadas em estrelas por piedade de Zeus, haviam sido convertidas em pombas ${ }^{36}$. Tratando-se de uma lenda da Arcádia, observa Bowra 1961: 317, teria agradado, por certo, a um vencedor desta região do mundo grego.

A figura mais popular da mitologia clássica, herói e deus ao mesmo tempo, como afirma Píndaro na $I I I^{a}$ Nemeia (v. 22), Héracles está relativamente pouco representado no corpus de Simónides. Esta constatação não significa que não tenha sido uma referência significativa na sua obra, como sugerem alguns fragmentos (fr. 509, frr. eleg. 13. 10, 92) e os vestígios de um poema maior patentes no P. Oxy. 2623 (vide supra, pp.321-322). Além deste material, restam-nos alguns testemunhos sobre temas mitológicos tratados pelo poeta, que se relacionam eventualmente com o ciclo de Héracles (cf. infra fr. 551A Campbell, p. 346).

Quando Píndaro evoca, na VII a Olimpica (v. 24), a ascendência materna de Tlepólemo, filho de Héracles e fundador da ilha de Rodes, o escoliasta informa (Ol. 7. 42b, I. 210-211 Dr. = fr. 554, 49 P, 219 B): 'Astidamia: (...) era filha de Filas. (...) Neste ponto diz Píndaro que era filha de Amintor, enquanto Hesíodo e Simónides dizem ser filha de Órmeno.' O valor deste testemunho reside sobretudo no facto de nomear Hesíodo (fr. $232 \mathrm{M}-\mathrm{W}$ ) como uma das fontes mitológicas de Simónides. A genealogia seguida pelo nosso lírico foi retomada por Diodoro Sículo (4.37. 4).

A segunda fonte é uma glosa de Hesíquio, que regista um patronímico usado (criado?) por Simónides (O 248, II. 740 Latte = fr. 566, 61 P, 245 B):

Oikióonৎ

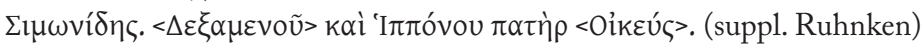

Ecíada

Simónides. Eceu foi pai de Dexâmeno e de Hipónoo.

A possibilidade de este patronímico ter figurado num poema em que Simónides tratava um tema do ciclo de Héracles é apenas sugerida por se

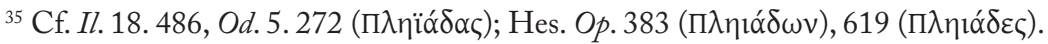

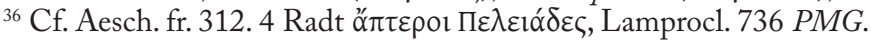


referir, talvez, a Dexâmeno, rei da cidade de Óleno, situada na Acaia, que acolheu o herói e lhe concedeu a mão de sua filha Mnesímaque, quando Augias o expulsou da Élide ${ }^{37}$.

Registe-se ainda a existência de dois testemunhos sobre a Hidra de Lerna, a serpente terrível que Héracles teve de matar. O número de cabeças do monstro era variável na Antiguidade e nem os gramáticos mostram certezas nesta matéria. Segundo informa o escoliasta da Teogonia de Hesíodo, em Alceu tinha nove (fr. $443 \mathrm{~L}-\mathrm{P}$ ), enquanto Simónides falou em cinquenta ${ }^{38}$. Este número é corroborado por Sérvio in Verg. Aen. 6.575 (II. 80 Thilo-Hagen), embora num passo posterior (v. 7.658, II. 177 T.-H.) indique o número cem.

Não obstante a sua brevidade, estes testemunhos permitem supor que Simónides terá tratado o tema dos trabalhos de Héracles e, por conseguinte, deixam-nos a suspeita de que a nossa perda neste domínio é muito maior do que os versos preservados sugerem.

Ao analisar as relações entre prosa e poesia, que ocupa a última parte da Composição estilística, Dionísio de Halicarnasso citou como exemplo lírico um passo singular de uma peça coral de Simónides. Legou-nos igualmente uma das problemáticas maiores do seu corpus, pois os esforços de editores e estudiosos, no sentido de reconstituírem a colometria e o texto do fragmento centrado no sofrimento de Dânae, estão longe de chegar a um consenso. Conseguiu, como pretendia, mostrar que uma composição poética também podia parecer prosa, sem nada ter de prosaico, se não conhecermos o esquema estrófico empregue pelo poeta ${ }^{39}$.

Os dados principais do mito de Dânae eram bem conhecidos nos inícios do séc. V, como se depreende da sua influência nas pinturas de vasos ${ }^{40}$. Quando um oráculo revelou a Acrísio, rei de Argos, que encontraria a morte às mãos de um neto, o monarca reagiu brutalmente, mandando aprisionar a filha numa câmara de bronze subterrânea. Segundo a versão mais célebre, Zeus

${ }^{37}$ Cf. D.S. 4. 33. 1, Apollod. 2. 5. 5, Paus. 7.18.1.

${ }^{38}$ Schol. Hes. Th. 313 (pp. 60-61 Di Gregorio) = fr. 569, 64 P, 203 B.

${ }^{39}$ Estes esforços têm sido em vão provavelmente porque, como notaram Page 1951: 133-135 e Bowra 1961: 337, as três partes da ode não estão completas no fragmento. Embora Dionísio de Halicarnasso sugira que o poema tinha estrutura triádica, não é possível detectar nele as correspondências métricas e a identificação da colometria exacta torna-se muito difícil. $\mathrm{Na}$ opinião de Page, Dionísio citou a última parte da antístrofe, todo o epodo e a primeira parte da estrofe seguinte (p. 135). Sobre esta problemática, vide J. A. Davison, "Simonides fr. 13 Diehl”, CQ 29 (1935) 85-95 (= 1968: 257-275); Page 1951: 133-140; Perrotta 1951; Gerber 1970: 323; R. Führer, “Text und Kolometrie von Simonides'Danae”, Gött. Nachr. 4 (1976) 111-164; M. L. West, "Simonides'Danae Fragment: A metrical Analysis", BICS 28 (1981) 30-38; Robbins 1997: 248, Hutchinson 2001: 308-309.

${ }^{40}$ Cf.Jean-Jacques Maffre, LIMCI. 1. s.v. Akrisios (München 1981) 449-452,II.2: 342-344; LIMC III. 1. s.v. Danae (München 1986) 331-337, III. 2: 247-248. 
penetrou na cela sob a forma de chuva de ouro e uniu-se a Dânae (cf. Pind. Pyth.12.17-18). Acrísio, porém, não acreditou na concepção divina de Perseu e ordenou que mãe e filho fossem encerrados numa arca e lançados ao mar. Como geralmente sucede nos mitos de exposição, a arca deu à costa na ilha de Serifos e foi resgatada por marinheiros ${ }^{41}$. $\mathrm{O}$ essencial da lenda figura já no catálogo das amantes de Zeus do canto XIV da Iliada (vv. 319-320): '... a filha de Acrísio, Dânae de belos tornozelos, / que gerou Perseu, notável entre todos

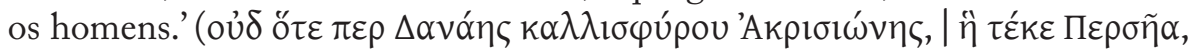

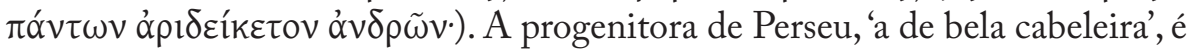
evocada no Catálogo das heroinas ou Ehoiai, atribuído a Hesíodo (fr. 129 M-W;

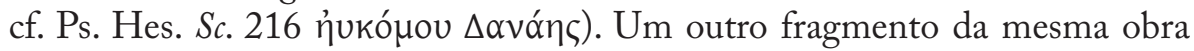
indica que eram também aí tratados, pelo menos, a visita de Zeus sob a forma de chuva de ouro e a clausura na arca (fr. $135 \mathrm{M}-\mathrm{W}$ ).

O presente fragmento de Simónides centra-se neste último episódio, sendo de destacar dois momentos: numa parte introdutória, iniciada com uma oração temporal, o poeta convoca os elementos essenciais que permitem recriar o ambiente adverso em que se encontram mãe e filho (vv. 1-5), sublinhando em particular o estado psicológico da princesa (vv. 5-6); a reprodução do seu lamento constitui a parte fundamental do fragmento e é possível que Dionísio de Halicarnasso o tenha citado na íntegra (vv. 7 sqq. $)^{42}$.

\section{Fr. 543 [38 P, 37 B, 13 D] D.H. Comp. 26. 14-15}

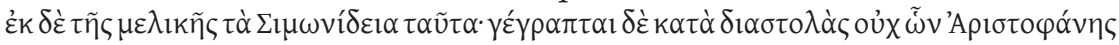

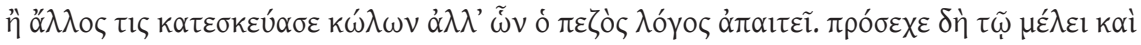

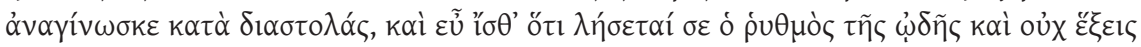

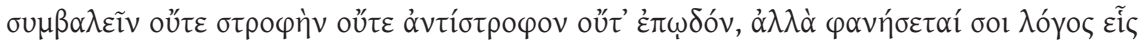

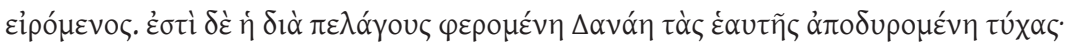

$\dot{\varepsilon} \nu \delta \alpha 1 \delta \alpha \lambda \varepsilon^{\prime} \alpha$

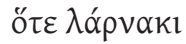

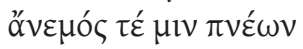

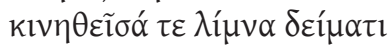

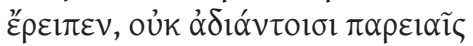

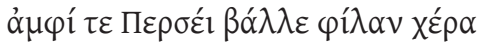

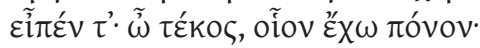

$\sigma \dot{~} \delta^{\prime} \alpha \dot{\alpha} \omega \tau \varepsilon \bar{\imath} \zeta, \gamma \alpha \lambda \alpha \theta \eta v \tilde{\omega}$

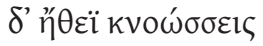

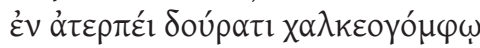

10

$<\tau \tilde{\omega} \imath>\delta \varepsilon v v \kappa \tau \imath \lambda \alpha \mu \pi \varepsilon \tilde{\imath}$,

${ }^{41}$ Cf. W. Burkert, "Mythos und Mythologie", in Propyläen Geschichte der Literatur, I (Berlin 1981) 11-35. Trad. port. M. H. Rocha Pereira (Lisboa 1991) 26.

${ }^{42} \mathrm{O}$ aparato que apresentamos baseia-se, como nos outros fragmentos, em Page 1962: 284285 e Campbell 1991: 439, mas também em Hutchinson 2001: 48-49. 


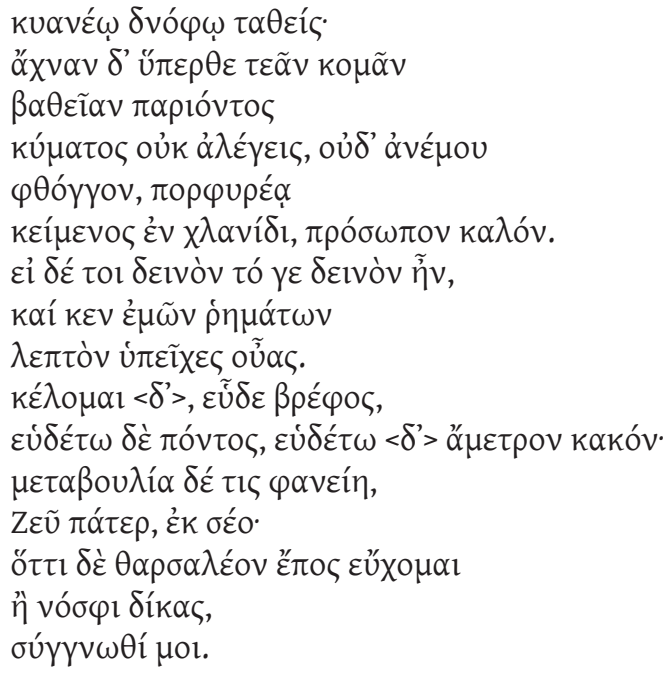

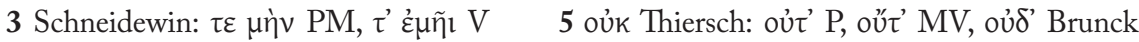

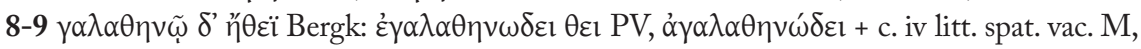

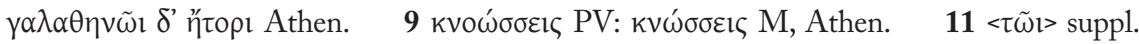

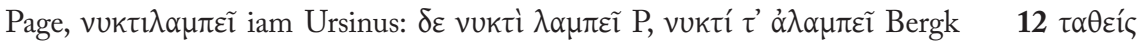

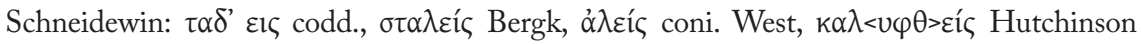

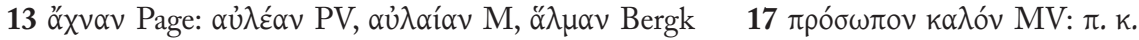

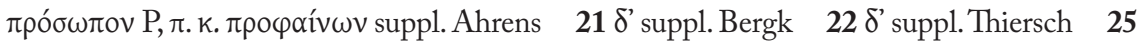

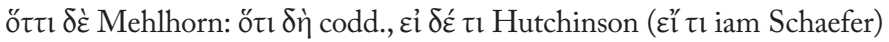

Da poesia mélica, os seguintes versos de Simónides: estão aqui escritos não de acordo com as divisões métricas que Aristófanes ou algum outro estabeleceu, mas segundo as que a prosa exige. Presta atenção ao poema e faz a sua leitura de acordo com as divisões, e fica bem ciente de que te vai escapar o ritmo da ode e não conseguirás reconhecer nem a estrofe nem a antístrofe nem o epodo, mas vai parecer-te um discurso em prosa. Trata-se de Dânae levada através do pélago, lamentando a sua sorte:

Quando na arca

elaborada com arte, o sopro do vento

e a agitação da água no terror

a lançavam, com as faces não enxutas,

em volta de Perseu pôs o seu braço

e disse: "Ó filho, quantos trabalhos eu tenho!

Mas tu dormes, pequenino

que és, e entregas-te ao sono

neste miserável lenho de cavilhas de bronze,

que na noite resplandece,

na treva negra estendido.

A espuma no teu cabelo, 
espessa da onda que passa,

não te aflige, nem do vento

a voz, na purpúrea

manta deitado, um rosto belo.

Se o que é terrível fosse terrível para ti,

as minhas palavras

chegariam aos teus ouvidos ternos.

Eu te ordeno: dorme, meu menino,

dorme, ó mar, dorme, ó desmedida desgraça.

E que algum sinal de mudança,

Zeus pai, venha de ti.

Se é ousada a minha prece

ou se afasta da justiça,

perdoa-me."

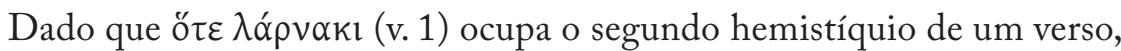
é de supor que o sofrimento de Dânae fosse evocado como paralelo mítico de uma situação histórica. Observa Suárez de la Torre 1988b: 211 que parece evidente a apresentação in medias res e, talvez, a interrupção brusca, que se encontram igualmente em Baquílides. A identificação do episódio é desde o início clara pela referência à célebre arca, na qual Dânae e Perseu, nomeado no v. 6, são encerrados e lançados ao mar. O poeta centra-se, portanto, nos momentos terríveis que antecedem a chegada à ilha de Serifos e o salvamento de mãe e filho por Díctis, matéria que Ésquilo tratou no drama satírico perdido Diktyoylkoi ${ }^{43}$. Vale a pena lembrar que o tema da arca flutuante, que se encontra noutros mitos gregos e nos de outros povos ${ }^{44}$, alcançou elevada projecção nas pinturas de vasos desde os inícios do séc. $\mathrm{V}^{45}$. Um aspecto que, em geral, os artistas procuram mostrar é a decoração elaborada da arca. Trata-se, provavelmente, de um motivo tradicional, já que não está ausente dos versos de Simónides $\left(\delta \alpha 1 \delta \alpha \lambda \varepsilon_{\varepsilon} \alpha\right)^{46}$. O poeta, no entanto, não se limitou

${ }^{43}$ Cf. TrGF III, F 46a-47c; J. Diggle, Tragicorum Graecorum Fragmenta Selecta (Oxford 1998) 5-9.

${ }^{44}$ Sobre o tema da arca flutuante, vide N. M. Holley, “The Floating Chest”, JHS 69 (1949) 39-47; Burkert 1983: 209-210.

45 Jean-Jacques Maffre, cit. (n. 40), p. 336, não exclui a possível influência da ode de Simónides, especialmente no lécito ático de Providence (Museum of Art, Rhode Island School of Design 25.084; LIMC, s.v. Danae no 53), datado de c. 480, que mostra mãe e filho na arca, em pleno alto mar. A diferença mais significativa, e reside talvez aqui um dos aspectos singulares da peça lírica, é que Perseu não é uma criança de colo. Este era, porém, um dos temas do mito, como atestam representações iconográficas mais antigas, nas quais surge nos braços de uma ama ou de Dânae. Vide http://www.perseus.tufts.edu/hopper/artifact?name=RISD+25.084\&object $=$ Vase [acedido em 27/06/2012].

${ }^{46} \mathrm{O}$ adjectivo $\delta \alpha 1 \delta \alpha ́ \lambda \varepsilon \circ \varsigma$ é frequente nos Poemas Homéricos como qualificativo de diversos

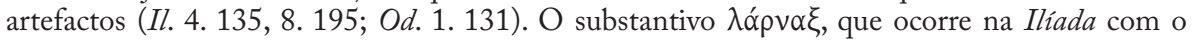


a seguir a tradição, porque é evidente o contraste entre a referência inicial à arca e o modo realista como é descrita por Dânae: não mais do que uma triste e simples embarcação de madeira (v. 10). O contraste é ainda mais forte pelo emprego de $\alpha \_\varepsilon \rho \pi n ́ \varsigma$, adjectivo formado $\operatorname{com} \alpha$ - privativo a partir

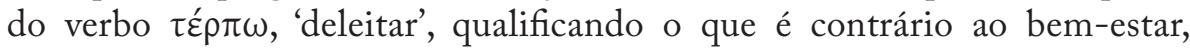
como a fome (Il. 19. 354), e provoca angústia (Od.11. 94, cf. 7. 279). O

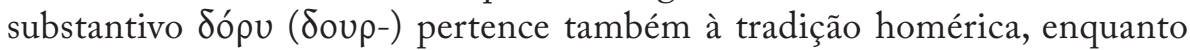
$\chi \alpha \lambda \kappa \varepsilon o ́ \gamma о \mu \varphi о \varsigma$, 'de pregos de bronze', pode ser considerado um hápax. Se $\alpha \tau \varepsilon \rho \pi \varepsilon ́ 1$ expressa a ausência de conforto da arca e, indirectamente, a amargura da princesa, $\chi \propto \lambda \kappa \varepsilon о \gamma o ́ \mu \varphi \omega$ introduz a nota pictórica, que é um dos traços notáveis deste fragmento. $\mathrm{O}$ poeta sublinha deste modo a funesta situação em que se encontram Dânae e Perseu, mas acentua também o contraste entre a consciência do perigo que atormenta a princesa e o sossego do filho que, apesar do ambiente hostil, não desperta do doce sono ${ }^{47}$. Esta oposição é um dos aspectos fundamentais destes versos e talvez o mais inovador do tratamento de Simónides, pois nas pinturas de vasos da Época Clássica Perseu é retratado sempre acordado.

Para muitos filólogos, o fr. 543 exemplifica na perfeição a máxima atribuída a Simónides de que a poesia é uma pintura que fala (test. 47 (b), supra p. 184). De facto, é singular o modo como o poeta consegue sugerir, com uma clareza surpreendente, não obstante a concisão vocabular, a fúria dos elementos da natureza - o sopro sonoro do vento (vv. 3, 15-16) e a agitação das águas (vv. 4,14-15) - que põem em perigo a integridade física das personagens. Mas o traço impressionista revela-se também nas 'faces não enxutas de Dânae' (v. 5), no seu gesto de ternura, quando põe o braço em volta do filho, antes de começar a falar (v. 6), nos pregos de bronze da arca (v. 10), na manta de púrpura em que descansa Perseu e na beleza do seu rosto, que se torna visível no seio da escuridão (vv. 16-17). É notável, por outro lado, como parte da descrição do geral para o particular, conseguindo neste movimento chamar a atenção para o rosto da criança. Do ponto de vista formal, o uso reiterado de $\tau \varepsilon$ confere aos versos de abertura um aparente tom linear, que não está livre de dificuldades sintácticas (cf. v. 3). Atente-se

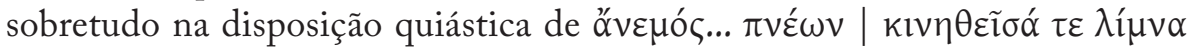
(vv. 3-4), na lítotes no início do v. 5, no uso de um adjectivo raro, formado

significado de 'arca, baú' para guardar mantimentos ou armas (cf. 18. 413), e designa também a arca funerária em que são depositados os ossos de Heitor (24.795), viria a adquirir mais tarde o

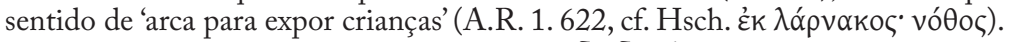

${ }^{47}$ Hutchinson 2001: 310 considera que $\delta \alpha 1 \delta \alpha \lambda \varepsilon \alpha_{1}$ permite expressar o contraste entre o luxo civilizacional associado ao objecto real e as rudes forças da natureza, no meio das quais se encontram agora mãe e filho. O mesmo investigador observa, com razão, que enquanto o poeta descreve o exterior da arca, Dânae diz o que pensa acerca do seu interior (pp. 312-313). 


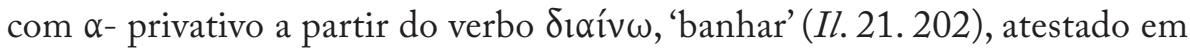
Píndaro (Nem. 7. 73) e Baquílides (17.122), e no emprego metafórico de

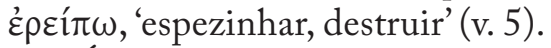

É num cenário aterrador que Dânae dá voz ao seu sofrimento, comovida com o sossego do filho. Mais singular ainda que a presença do solilóquio numa ode coral, de que encontramos exemplos notáveis em Píndaro e Baquílides ${ }^{48}$, é a insistência no contraste profundo entre o sofrimento que atormenta Dânae (v. 7) e o estado de quietude de Perseu (vv. 8-9), que não pode ter consciência da situação adversa em que se encontra (vv. 13-16). Em termos formais, esse contraste surge primeiro nos vv. 8-9, com o emprego enfático do pronome pessoal ( $\left.\sigma \dot{\nu} \delta^{\prime}\right)$ e a sucessão de dois verbos raros que significam 'dormir' ( $\alpha \omega \tau \varepsilon \tilde{\iota} \varsigma$,

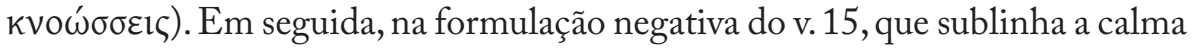
de Perseu, e culmina na afirmação paradoxal do v. 18.

A interpretação do fragmento enfrenta dificuldades de ordem linguística, que têm suscitado opiniões muito divergentes, sobretudo a respeito dos vv. 8-18. Este problema relaciona-se, de certo modo, com a faceta criativa do poeta. O adjectivo $\gamma \alpha \lambda \alpha \theta \eta$ vós, à letra 'lactante', ocorre também no fr. 553 (sobre o pequeno Ofeltes), citado num passo de Deipnosophistae em que se evoca o uso original que Simónides fez daquele vocábulo. De facto, na Odisseia (4.336) e em Anacreonte (fr. 408 PMG) designa as crias da cerva" ${ }^{49}$

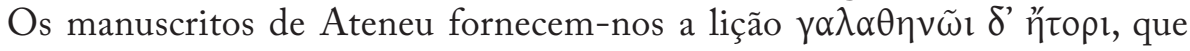
alguns filólogos defendem como sendo mais adequada do que a proposta de Bergk ${ }^{50}$, mas note-se que $\tilde{\eta} \theta$ os é empregue por Píndaro, numa ode que data de 476 (Ol.11.20), com o sentido de 'carácter, qualidade inata'. Outra dificuldade lexical diz respeito aos vv.11-13. Se a lição adoptada por Page for a correcta, este passo preserva o único emprego conhecido de $v \cup \kappa \tau \imath \lambda \alpha \mu \pi \eta ́ \varsigma$, 'resplandecente na noite' ${ }^{51}$, e o mais antigo de $\delta$ vó $\varphi \circ \varsigma$, 'obscuridade, treva',

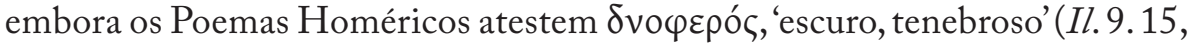
Od.13.269). Quanto ao início do v. 13, a sugestão de Page, óx $\chi v \alpha v$, parece-nos mais poética do que a de Bergk ( $\propto \lambda \mu \alpha v)$, ainda que os dois termos pertençam

${ }^{48}$ Os mais célebres são talvez os da I ${ }^{a}$ Olímpica (vv. 75-85) e da IVa Pítica (vv. 13-56, 87-92, 97-119, 138-167, 229-231), mas encontramos muitos outros exemplos no corpus dos dois poetas (e.g. Bacch. 3. 37-47, 78-84; 5. 79-92; 24. 1-13).

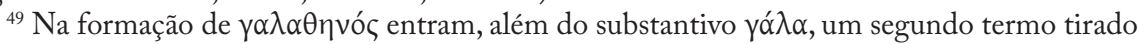
de $\theta \tilde{\eta} \sigma \theta \alpha l$, 'mamar' (Il.24. 58, h.Hom. 2. 236), e o sufixo -vó (Chantraine, s.v. үó $\lambda \alpha$ ). Cf. Poltera 1997: 449-450.

${ }^{50}$ Cf. Perrotta 1951: 82, Bowra 1961: 338 n. 1, Campbell 1991: 438-439, Poltera 1997: 145, Hutchinson 2001: 312. Gerber 1970: 324 prefere

${ }^{51}$ Para uma discussão das diversas propostas de emenda do v. 11, vide Bernardini 1969:

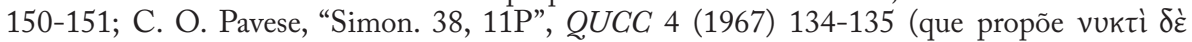

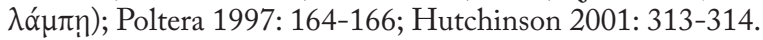


à tradição homérica ${ }^{52}$. Finalmente, no que respeita ao final do v. 17, alguns filólogos preferem adoptar a sugestão de Ahrens, considerando $\pi \rho o ́ \sigma \omega \pi o v$ $\kappa \alpha \lambda o ́ v$ insuficiente, hipótese que não tem em conta a concisão vocabular que, em nosso entender, caracteriza todo o fragmento ${ }^{53}$. A proposta de Page resulta num homoteleuto expressivo, que é reiterado nos versos seguintes.

A primeira parte do solilóquio é, naturalmente, dominada pela parataxe. A oração condicional do v. 18 marca, por conseguinte, uma mudança de tom, que traduz o ponto culminante da angústia de Dânae. A princesa desabafa com o único ser humano que a pode ouvir, mas a pequena criatura não tem a mesma percepção da realidade cruel. Não ouve a voz do vento, mas também não ouve a da sua mãe. É a face visível da ausência de comunicação e da solidão de Dânae ${ }^{54}$. A inquietação da princesa não decorre, assim, apenas do medo, mas também da consciência terrível de que as suas palavras, neste momento, não terão qualquer efeito.

É talvez o sossego do filho que desperta em Dânae a esperança de que o mar se acalme e a sorte de ambos mude (vv. 21-22). Este passo, no qual se acumulam as figuras de retórica, ilustra bem o trabalho poético de Simónides.

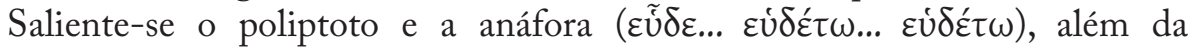

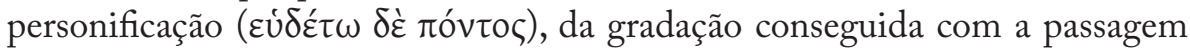

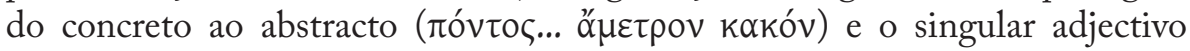

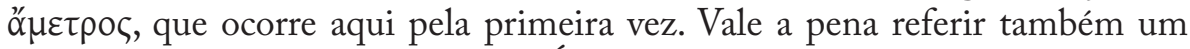
aspecto notado por vários filólogos. É que a formulação adoptada é claramente a das canções de embalar ${ }^{55}$, o que não deixa de ser curioso, porque Perseu há

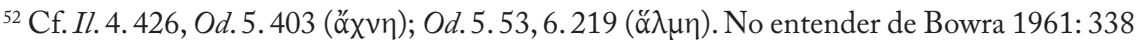
n. 1 , a proposta de Bergk é adequada à cena, enquanto a de Page "seems a little too precise and precious.” Os filólogos que preferem ő $\lambda \mu \alpha v$ (cf. Poltera 1997: 101-102, Hutchinson 2001: 315)

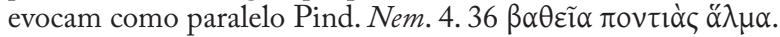

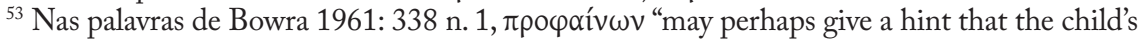
face shines in the darkness." A interpretação sintáctica da expressão não acolhe unanimidade. Em resposta a Davison, Page 1951: 136 observou tratar-se de um "vocative in apposition, and in apposition not merely to some single word, but rather to the whole of the preceding picture.". Cf. J. A. Davison, "Professor Page's Simonidea. A Note", JHS 72 (1952) 120 (= 1968: 275-276). Por

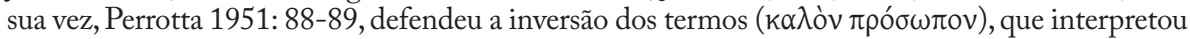
como acusativo de relação. Para uma análise destas posições, vide Hutchinson 2001: 316.

${ }^{54}$ Para uma interpretação do fragmento centrada neste aspecto, vide Rosenmeyer 1991, que afirma "The poet sings here about Danae singing about not being listened to." (p. 11).

${ }^{55}$ R. Merkelbach, "Bettelgedichte (Theokrit, Simonides und Walther von der Vogelweide)", RhM 95 (1952) 312-327, conjecturou que Simónides adaptou aos seus poemas líricos canções populares como a Eiresione, 'o canto do ramo envolto em lã' (cf. Ar. Eq. 729, Plu. Thes. 22. 6-7), e a Chelidonismos, 'o canto da andorinha' (cf. Athen. 8.360c e infra, p. 363 n. 23). A influência da canção de embalar na poesia grega culta, bem como neste fragmento de Simónides, foi tratada por Ingrid Wærn, “Greek Lullabies”, Eranos 58 (1960) 1-8, esp. 3-4. Silk 1974: 164 aceita esta interpretação dos vv. 21-22, mas supõe que possam ter sido influenciados pelo fr. $89 \mathrm{P}$ de Álcman (p. 167 n. 15). A evocação das canções de embalar é reconhecida por outros estudiosos (cf. Rosenmeyer 1991: 23-24, Hutchinson 2001: 317). Sobre a influência da poesia popular no 
muito que dorme, para espanto de sua mãe. É um sinal, quanto a nós, de que Dânae atingiu o cume do seu desespero.

É plausível que os vv. 22 sqq. do nosso fragmento correspondam ao final do solilóquio. É num tom pleno de esperança comedida que a princesa se volta agora para Zeus, deus dos fenómenos atmosféricos, pai dos deuses e dos homens. Se o desejo de mudança está bem presente (o hápax $\mu \varepsilon \tau \alpha \beta$ ou $\lambda i ́ \alpha$ surge em posição enfática, no início do verso), as palavras finais são a expressão do terror de alguém que se inquieta com a possibilidade de piorar a sua situação. Escapa-nos, porém, o seu valor exacto, uma vez que desconhecemos a orientação que Simónides teria dado ao mito (saberá Dânae que dirige uma prece ao próprio progenitor do seu filho? $)^{56}$. Cremos que pode ter razão G. Perrotta ao afirmar que a súplica da princesa constitui o ponto mais alto do episódio mítico e, depois dele, dificilmente seria dado relevo ao salvamento ${ }^{57}$. Portanto, visto que não temos qualquer ideia sobre o desfecho do poema e as intenções de Simónides, não nos parece que seja de grande interesse discutir o possível subgénero da composição original ${ }^{58}$.

Não obstante as nossas incertezas quanto ao texto, metro e tratamento do mito, o fr. 543 preserva uma das imagens mais memoráveis da maternidade de toda a literatura grega e uma das mais antigas da literatura ocidenta ${ }^{59}$. Como salientam muitos helenistas, apenas na tragédia grega os sentimentos maternos (e paternos) voltam a cativar a atenção do poeta com esta intensidade ${ }^{60}$. É evidente, por outro lado, que Simónides tem o cuidado de dar ao seu poema uma estrutura formal próxima das palavras plenas de ternura que uma mãe dirige a um filho pequeno, fluente e marcada pela simplicidade. No entanto, os diversos recursos poéticos que emprega fazem deste fragmento uma obraprima da poesia lírica grega.

trabalho poético de Simónides, cf. supra, p. 253 n. 43. Sobre a Eiresione, vide o nosso estudo "O canto popular da Eiresione”, Boletim de Estudos Clássicos 48 (2007) 15-18.

${ }^{56}$ Será, por isso, talvez excessivo considerar que as palavras finais da princesa são reveladoras de sentimentos de culpa, por ter tido um filho contra as indicações do oráculo, como defende Barrigón 1994a: 79, citando B. Gentili, Polimnia (Florencia ${ }^{2}$ 1965) 334. Para uma interpretação diversa da nossa, vide Hutchinson 2001: 318-320.

${ }^{57}$ Perrotta 1951: 116.

${ }^{58}$ As hipóteses dos estudiosos sobre este ponto são muito diversas. Esta falta de consenso leva-nos a concluir que talvez seja mais correcto pressupor que o lamento de Dânae podia integrar qualquer composição de lírica coral. Cf. Bowra 1961: 336, Gerber 1970: 324, Campbell 1983: 179, Suárez de la Torre 1988b: 211, Robbins 1997: 449.

59 Cf. Perrotta 1951: 117, Kegel 1962: 92, Robbins 1997: 249, Hutchinson 2001: 308, Parsons 2001: 64. As imagens da infância na poesia grega arcaica podem, todavia, não ter sido tão raras, como habitualmente se depreende dos poucos exemplos conhecidos.

${ }^{60} \mathrm{Em}$ Ájax, Sófocles retratou uma criança que não tem consciência do perigo (vv. 552-559). Eurípides deu maior relevo à emoção da mãe abraçada ao filho (cf. HF 70-79, 462-475, Tr. 757-762). 
Filho de Licurgo, rei lendário de Nemeia, e de Eurídice, Ofeltes foi entregue aos cuidados de uma cativa de Lemnos, Hipsípile. Um oráculo revelara que a criança não devia ser colocada no chão enquanto não conseguisse caminhar. Quando os Sete Chefes que integraram a expedição contra Tebas passaram por Nemeia, pediram a Hipsípile que lhes indicasse uma fonte. A ama interrompeu por momentos a sua vigilância e o pequeno príncipe foi sufocado por uma serpente. Os heróis instituíram então jogos fúnebres em sua honra e Ofeltes passou a chamar-se Arquémoro, nome premonitório que significa 'começo do destino'. Uma vez que, segundo o mito, as cerimónias fúnebres deram mais tarde origem aos Jogos Nemeus, é legítimo supor que pertença a um epinício o fragmento de Simónides citado por Ateneu, ao qual nos referimos já no comentário ao fr. $543^{61}$. Vale a pena lembrar que tanto o significado do nome de Arquémoro como a instituição dos jogos em sua honra são evocados por Baquílides, num epinício composto em data desconhecida para Automedes de Fliunte, pela vitória no pentatlo dos Jogos Nemeus (9. 10-14).

Fr. 553 [48 P, 52 B, 29 D] Athen. 9. 396e

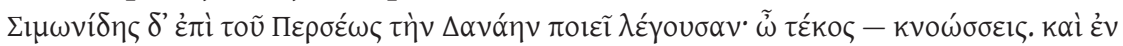

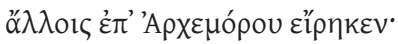

$<$ Eủpudíkaৎ>

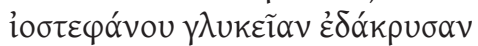

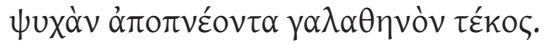

Simónides põe Dânae a dizer sobre Perseu: "ó filho... entregas-te ao sono" (fr. 543). E, noutros versos, diz sobre Arquémoro:

por ele choraram, quando o doce

alento exalou, o filho terno [de Eurídice] coroada de violetas.

Estes versos e o referido passo de Baquílides constituem as referências literárias mais antigas ao destino de Ofeltes, que Eurípides tratou mais tarde na tragédia perdida Hipsípile ${ }^{62}$. Como já foi dito, esta citação é motivada pela aplicação do singular adjectivo $\gamma \alpha \lambda \alpha \theta \eta$ vó a uma criança. $O$ passo é, de resto, fortemente marcado pela adjectivação. De notar que não está atestada antes de Simónides a aplicação do epíteto ioøté $\varphi$ avos, ‘de coroa de violetas' ou 'de

${ }^{61}$ Esta hipótese é ponderada por Poltera 1997: 349 n. 41, apoiado em H. v. Geisau, KlPauly IV, s.v. Opheltes (München 1972) 311. Segal 1985: 183 supõe tratar-se antes de um fragmento de um treno, dado o seu tom patético.

${ }^{62} \mathrm{Cf}$. L. Séchan, Études sur la tragédie grecque dans ses rapports avec la céramique (Paris ${ }^{2} 1967$ ) 341-366; G. W. Bond, Euripides. Hypsipyle (Oxford 1963) 147-149, cita as fontes principais do mito; W. Pülhorn, LIMC II. 1. s.v. Archemoros (München 1984) 472-475, II. 2: 355-358. 
coroa de cor violeta', a uma mortal ${ }^{63}$. Por outro lado, o emprego original de $\gamma \lambda \cup \kappa \varepsilon \tilde{\alpha} \alpha$ como qualificativo de $\psi u x \eta ́$ é ainda sublinhado pela ênfase nos sons nasais, que contribuem para o tom suave e, ao mesmo tempo, lamentoso, perfeitamente adequado ao tema. Do ponto de vista sintáctico, note-se que o

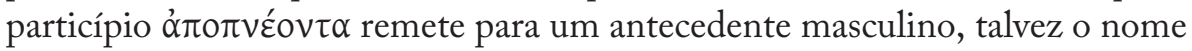
do menino (Poltera 1997: 485), pelo que a ênfase do fragmento recai em

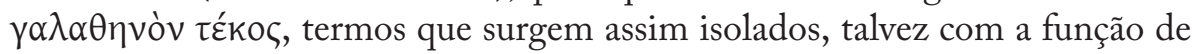
'aposição explicativa', como propõe o mesmo especialista (p. 450). Finalmente, este fragmento confirma que Simónides empregou o termo $\psi u x \eta ́$ com o sentido de 'sopro vital' (cf. supra, pp. 230, 237) ${ }^{64}$.

À saga dos Argonautas em demanda do velo de ouro dedicou Píndaro a IVa Pítica, a ode mais longa da colecção. O tema era caro ao destinatário, Arcésilas de Cirene, vencedor na corrida de carros em 462, uma vez que pertencia à dinastia dos Bátidas, que se proclamava descendente de um dos Argonautas (Race 1997a: 258).

Vários testemunhos, provenientes de escólios na sua maioria (da referida ode de Píndaro, da Medeia de Eurípides, de Apolónio de Rodes), bem como comentários de Tzetzes atestam que a lenda de Jasão e Medeia foi também tratada por Simónides, pelo menos num hino a Poséidon. Dada a sua brevidade, as informações que nos fornecem não nos permitem formar uma ideia global do modo como o poeta terá cultivado este tema.

Segundo o escoliasta de Apolónio de Rodes, Simónides afirmou em Vários ou Escritos mistos (Ẻv $\Sigma u \mu \mu i ́ k \tau o l \varsigma)$ que o povo antigo dos Mínias habitava Iolco, a cidade tessália donde partira a nau dos Argonautas ${ }^{65}$. Uma série de testemunhos refere-se ao célebre talismã que motivou a expedição, o velo da Cólquida. Simónides terá usado o termo vókn, que ocorre em Od.14. 530,

${ }^{63}$ Cf. supra fr. eleg. 22.6 (p. 233 n. 117). Poltera 1997: 347-348 traduz o epíteto por à la couronne de la couleur des violettes', observando que é sinónimo do equivalente métrico

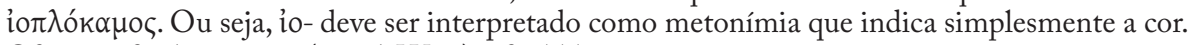
Cf. supra fr. eleg. 11.16 (suppl. West) e fr. 555.3.

Eủpudíkas é um suplemento de Bergk, que tanto Page como Campbell aceitam. No

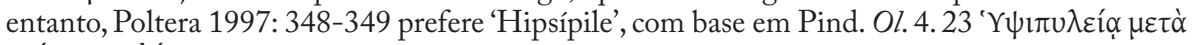

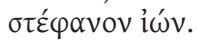

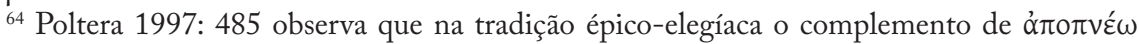

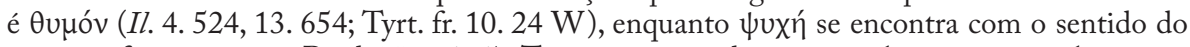
presente fragmento em Pind. Nem. 1. 47. Trata-se, supõe, de uma simples variante estilística.

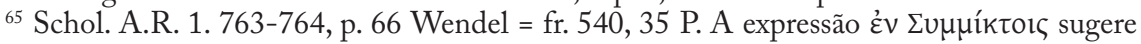
uma edição mista, mas não nos chegou qualquer outra informação. Leva a supor, como notou Robbins 1997: 244, que os críticos alexandrinos tiveram dificuldades em classificar algumas obras de Simónides. Para uma análise de conjunto dos fragmentos de Simónides transmitidos por Apolónio e pelos escoliastas da sua obra, vide Acosta-Hughes 2010: 198-206. 
ou vákos, como Píndaro na $I V^{a}$ Pítica (v. 68) ${ }^{66}$, e afirmado que era da cor da púrpura. Esta informação é surpreendente, pois na versão mais conhecida aquele objecto mágico é de ouro (cf. Eur. Med. 5). Esta inovação pode ter sido ditada por o mito ser evocado num hino dedicado ao deus do $\operatorname{mar}^{67}$.

Informa um escólio da Medeia de Eurípides (v. 2, II. 141 Schw. = fr. 546, 41 P, 22 B) que Simónides chamou aos rochedos móveis do Bósforo

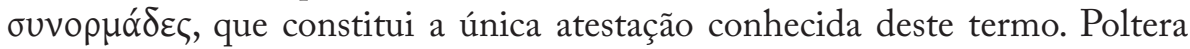
1997: 280 destaca que este composto e o que Píndaro emprega em Pyth. 4. 208-209 ( $\sigma u ́ v \delta \rho o \mu \circ \varsigma)$ põem a ênfase no movimento ameaçador, enquanto o

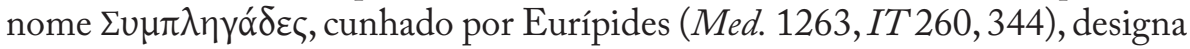
propriamente o embate das rochas uma contra a outra.

No comentário ao v. 253 da $I V^{a}$ Pítica, no qual Píndaro recorda que os Argonautas participaram nos jogos fundados por Hipsípile em Lemnos, competindo por uma peça de roupa, observa-se que '... a história também

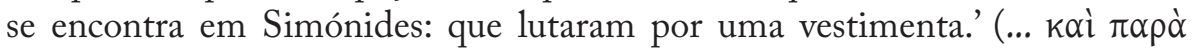

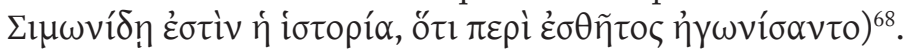

Destes testemunhos sobre o velo da Cólquida, a designação das perigosas rochas situadas à entrada do Ponto Euxino e a competição por uma vestimenta em Lemnos depreendemos que o nosso lírico tratou diversos episódios da expedição dos Argonautas. Outro dado é fornecido pelo escoliasta da Medeia de Eurípides (Argum., II. 137 Schw. = fr. 548, 43 P, 204 B), segundo o qual em Ferecides, genealogista ateniense do séc. V, e em Simónides, Medeia rejuvenesce Jasão pela cozedura. Ou seja, aplica no amado o acto mágico a que submeteu Pélias, embora com intenções benévolas. Este testemunho confirma, portanto, que o nosso poeta manteve um dado tradicional do mito da princesa da Cólquida: os elementos de magia.

Refere-se também a esta heroína o único fragmento que podemos atribuir com segurança a este tema mitológico.

Fr. 545 [40 P, 48 B, 31 D] Schol. Eur. Med. 19, II. 144 Schw. (cod. B)

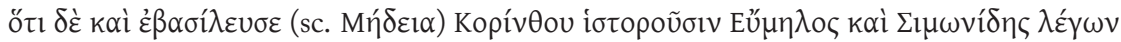

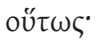

${ }^{66}$ Etymologicum Genuinum (p. 38 Calame) = Etymologicum Magnum 597.14 = fr. 544, 39 P, 21 adnot. B.

${ }^{67}$ Schol. Eur. Med. 5 (II. 142 Schw.) = fr. 576, 71 P, $21+200^{A}$ B. Segundo esta fonte, 'Simónides, no hino em honra de Poséidon, diz que [a pele do animal] foi tratada com a

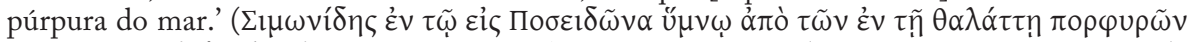

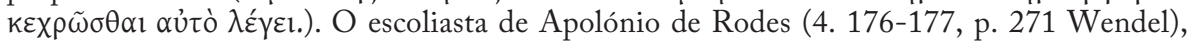
corrobora esta informação, acrescentando que o poeta teria dito, por vezes, que o velo era

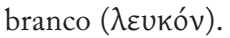

${ }^{68}$ Schol. Pind. Pyth. 4.451 (II. 160 Dr.) = fr. 547, 42 P, 205 B. 


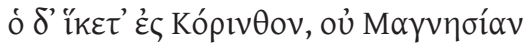

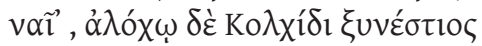

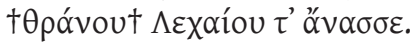

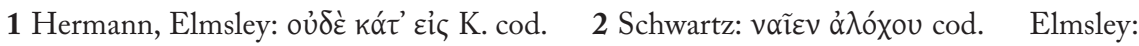

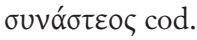

Que (Medeia) também reinava em Corinto é referido por Eumelo e Simónides, ao dizer assim:

E ele (Jasão) chegou a Corinto, na Magnésia

não habitava, e partilhando o seu lar com a sua esposa da Cólquida reinava sobre... e o Lequeu.

Tendo em conta a informação do escólio, parece-nos mais lógico aceitar a emenda de Hermann e de Elmsley do v. 1, sendo as restantes menos relevantes. Poltera 1997: 25-26, no entanto, reconstitui o fragmento de modo diferente. Defende, em primeiro lugar, que pertencem apenas a Simónides os vv. 2-3 (a partir de $\alpha \lambda o_{\chi}(\omega)$, enquanto a primeira oração deve ser atribuída a Eumelo, o outro autor citado no escólio. Em segundo lugar, propõe a correcção łuv'

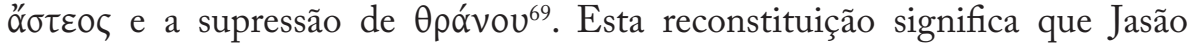
reinava sobre a cidade e o porto, ou seja, o seu poder abarcava toda a terra de Corinto (cf. Poltera 1997: 207 n. 13).

Apesar de não haver certezas quanto ao texto, parece seguro que Simónides também valorizou a origem bárbara de $\mathrm{Medeia}^{70} \mathrm{O}$ v. 2 sugere, porém, que o poeta não tratava, pelo menos neste poema, a traição de Jasão, tema que será difundido pela tragédia de Eurípides.

$\mathrm{Na}$ opinião de alguns helenistas, é possível que pertença a um poema dedicado à expedição dos Argonautas um fragmento sobre Orfeu transmitido por Tzetzes.

Fr. 567 [62 P, 40 B, 27 D] Tz. H. 1.312 sqq.

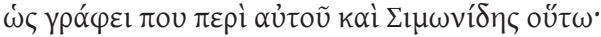

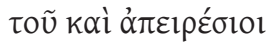

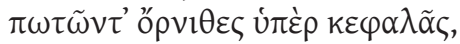

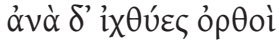

69 "Le mot $\theta$ póvou ne donne non seulement aucun sens intelligible, mais il semble lui même le produit d'une corruption; aussi convient' il de l'athétiser, puisqu'il s'agit très vraisemblablement d'une glose maladroite." (Poltera 1997: 25). O A. discutiu os seus argumentos com mais detalhe no artigo "Simonide, Eumelos et la Korinthiaka (Simon. 545 PMG): un fragment irrecuperable?", Emerita 65.2 (1997) 311-319.

${ }^{70}$ Registe-se que Lobel reconstituiu o topónimo 'Cólquida' no fr. 54.3 do P. Oxy. 2623 (= $372 S L G, 519$ A Campbell). 


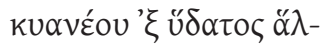

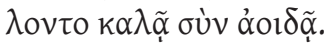

... como também Simónides escreve sobre ele, em qualquer parte, assim:

$\mathrm{E}$, inumeráveis, as aves voavam sobre a sua cabeça, e os peixes saltavam, a direito, das aniladas águas ao som do seu belo canto.

O passo centra-se no poder encantatório que a melodia de Orfeu exercia sobre os seres da natureza e constitui a referência literária mais antiga a este tema ${ }^{71}$. O poeta põe a ênfase nesse fascínio com o emprego dos adjectivos

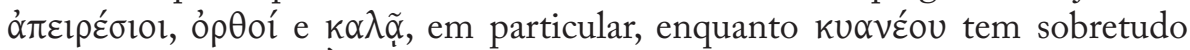
valor ornamental ${ }^{72}$. À semelhança do fragmento sobre Dânae, confirma o poder evocativo e descritivo de Simónides. O célebre cantor é, possivelmente, um dos tripulantes da nau Argo, como sugere a presença, à sua volta, de aves, peixes e águas.

Dada a natureza do tema, a evocação de Orfeu podia provavelmente figurar em qualquer composição de lírica coral, como confirmam os versos de Píndaro e de Baquílides. O primeiro menciona o distinto cantor na referida $I V^{a}$ Pitica (v. 177) e num treno (fr. 128c. 11-12 Ma.). O segundo num ditirambro (Dith. 28 = P. Oxy. 2364 fr. 1b).

Com o tema de Orfeu devem talvez relacionar-se, como supõem alguns helenistas ${ }^{73}$, estes versos citados por Plutarco, ao falar das condições atmosféricas que influenciam a difusão do som:

Fr. 595 [90 P, 41 B, 40 D] Plu. Quaestionum Convivalium 8. 3. 4, 722c

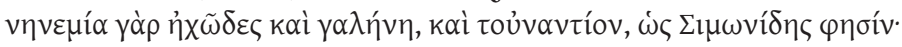

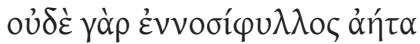

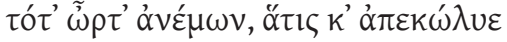

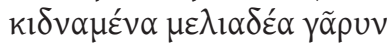

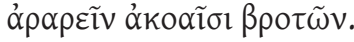

2 corr. Page: $\kappa \alpha \tau \varepsilon \kappa \omega ́ \lambda \cup \varepsilon$ codd. 3 corr. Wyttenbach (et Schneidewin): $\sigma \kappa ı \delta v \alpha \mu \varepsilon ́ v \alpha$ codd.

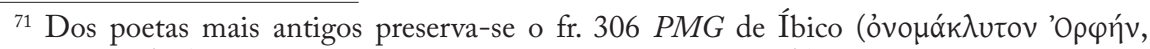
'famoso Orfeu'). As outras referências encontram-se na tragédia (Aesch. Ag. 1629-1630; Eur. Alc. 357-362, Ba.560-564, IA 1211-1212) e em Apolónio de Rodes (1.26-31).

${ }^{72}$ Irwin 1974: 103 observa que Simónides parece ter sido o primeiro a descrever o mar como kuóveos: "As the adjective continues to be considered suitable for the sea, Simonides may well have associated it with blueness, although he obviously felt a strong element of darkness." Cf. infra fr. 597, p. 363 e n. 22.

${ }^{73}$ Cf. Bowra 1961: 365, Gerber 1970: 326, Rocha Pereira 2009: 179. 
Pois o som ecoa quando não se levanta o vento e está calmo o mar, e o contrário também se verifica, como diz Simónides:

Pois nem o sopro dos ventos, que as folhas

agita, então se ergueu, pois não deixaria,

se surgisse, que a doce voz de mel

se prendesse aos ouvidos dos mortais.

A ligação destes versos a um passo anterior sobre o tema do canto é

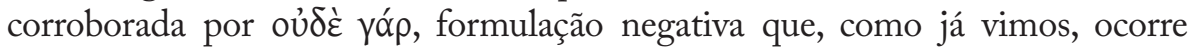
também em dois fragmentos que Estobeu atribui aos 'Trenos' de Simónides (cf. frr. 521. 3, 523. 1). Do ponto de vista formal, destacam-se os epítetos

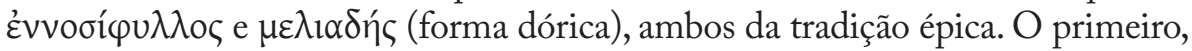

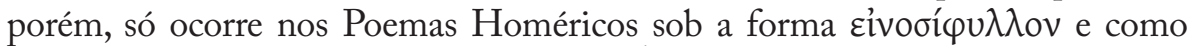
qualificativo de montes, como o Nérito de Ítaca (Il.2.632, Od.9.22) ou o Pélion da Tessália $(O d .11 .316)^{74}$. O segundo é de emprego frequente na poesia épica e

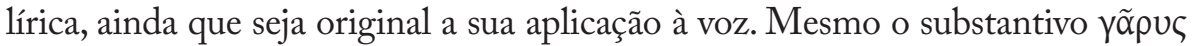

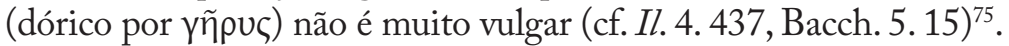

A execução musical ao ar livre e o poder de uma 'voz doce como mel', que acalma as forças da natureza e 'adere' aos ouvidos dos mortais ${ }^{76}$, sugerem imediatamente o tema de Orfeu. Trata-se, porém, de uma conjectura. Assim, o valor deste fragmento reside em particular no facto de ser um dos poucos do corpus de Simónides a aludir às condições de execução musical (cf. supra, fr. eleg. 22).

Tendo posto termo à submissão a Creta, Teseu tornou-se no arquétipo por excelência do heroísmo ateniense. É talvez esse facto que explica a sua ausência do actual corpus de Píndaro. Baquílides, porém, dedicou-lhe, pelo menos, dois ditirambos (17 e 18).

De acordo com os testemunhos, das muitas peripécias que preenchem a sua lenda, Simónides tratou dois episódios: o regresso a casa, depois de ter

${ }^{74}$ Manieri 1990: 89 chama a atenção para o paralelo com os epítetos homéricos de Poséidon

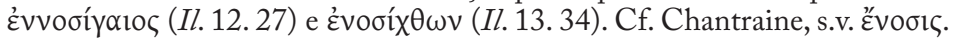

${ }^{75}$ Nos Poemas Homéricos, $\mu \varepsilon \lambda ı n \delta$ ‘́ qualifica realidades concretas, como o vinho (Il.4.346) e o fruto de lótus (Od.9.94), mas também abstractas, como a vida (Il.10.495), o regresso à pátria (Od.11. 100) e o sono (Od.19. 551). Nos fragmentos de Alceu designa o vinho (367.2, 369. 1

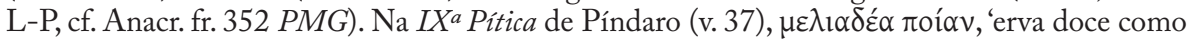

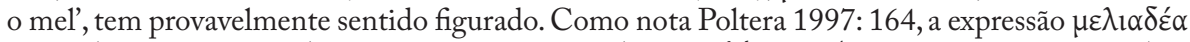

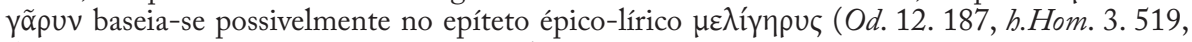
Alcm. fr. 26. 1 P; Pind. Ol.11. 4, Nem. 3. 4).

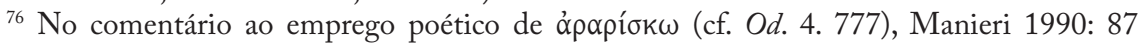
nota que a ideia aqui presente é mais uma sugestão táctil do que sonora, criando um efeito de sinestesia. 
vencido o Minotauro, e a luta contra as Amazonas. Segundo a versão mais conhecida do primeiro tema, no momento da partida Teseu recebeu do pai duas velas para o navio: uma branca, para assinalar o bom êxito da empresa, e uma negra, para revelar o seu fracasso. Ao regressar a casa, o herói esqueceu-se de içar a vela branca. Egeu, que o aguardava ansiosamente na costa, ao avistar a vela negra julgou que o filho havia perecido e lançou-se ao mar. Ao tratar este ponto na Vida de Teseu, a fonte mais completa sobre a sua lenda, Plutarco cita dois passos de um poema de Simónides, registando o afastamento da versão tradicional do mito.

Fr. 550 [45 P (a) = 54 B, 33 D; (b) = 56 B] Plu. Thes. 17.5

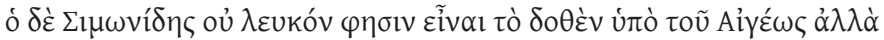

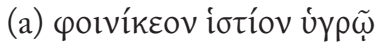

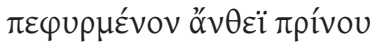

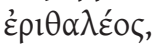

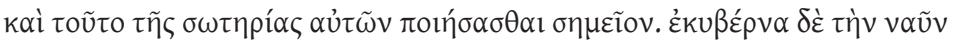

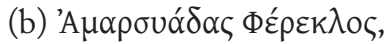

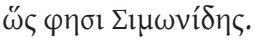

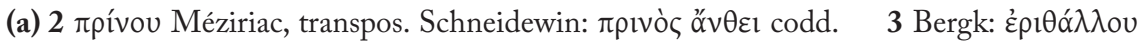
codd.

Mas Simónides diz que a oferta de Egeu não era branca, mas

(a) uma vela escarlate, tinta da húmida flor do carvalho viçoso,

E era este o sinal da sua salvação. Pilotava o navio

(b) Féreclo, filho de Amársias, como diz Simónides.

Uma vez que o primeiro passo se centra precisamente na descrição da vela da vitória, supomos que tenha sido extraído da parte em que o poeta recordava os preliminares da partida. Viria a seguir, talvez, a identificação do piloto do navio, que segundo a versão de Filócoro, citado também no texto de Plutarco, se chamava Nausítoo e era natural de Salamina ${ }^{77}$.

${ }^{77}$ Cf. FGrHist 328 F 111. Sobre este ponto, vide C. Ampolo e M. Manfredini, Plutarco. Le Vite di Teseo e di Romolo (Milano 1988) 219-220. Podlecki levantou a hipótese de o nome dado por Simónides ao piloto ter tido algum significado político contemporâneo. No artigo “Theseus and Themistocles", RSA 5 (1975) 1-24, analisa a apropriação política do herói em Atenas, após as Guerras Medo-Persas, e supõe que o poeta tenha sido convidado a compor uma ode, à qual pertence o presente fragmento, para celebrar a renovação das Oscofórias, promovida por Temístocles. Este festival celebrava a libertação de Atenas do tributo anual devido ao Minotauro. Como o próprio investigador reconheceu, embora plausível, esta conjectura não 
É evidente que o poeta deu especial atenção ao pormenor da cor da vela, explicitando o modo como a tinta escarlate podia ser obtida. A presença do adjectivo úypós, que nos Poemas Homéricos apenas qualifica líquidos ${ }^{78}$, indicia que ớv $\theta$ o ৎ não significa propriamente 'flor', mas talvez antes 'esplendor, cor viva', como em Teógnis (v. 452) e Platão (R. 557c). A partir da Época Clássica, aquele termo ocorre com o sentido de 'púrpura' (cf. P1. R. 429d, Arist. $H A$ 5. 15. 547a7), que não se aplica aqui, em nosso entender, uma vez que no verso anterior surge polvíkeov iotíov. Assim, ainda que as propostas de reconstituição sejam discutíveis, julgamos que o presente fragmento contém uma das primeiras referências atestadas à tinta vermelha obtida a partir do $\pi \rho \tilde{v}$ o $\varsigma^{79}$. Portanto, este passo confirma, mais uma vez, a originalidade de Simónides no tratamento mitológico, pela introdução de pequenos detalhes

pode ser comprovada, no estado actual dos nossos conhecimentos. Sobre as Oschophoria, vide Parke 1977: 77-80, esp.

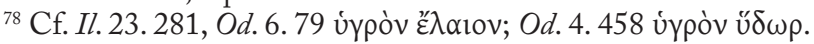

${ }^{79} \mathrm{O} \pi \rho \tilde{i} v o \varsigma$ é a Quercus coccifera, conhecida vulgarmente por 'Carrasco' e 'Carrasqueiro', um

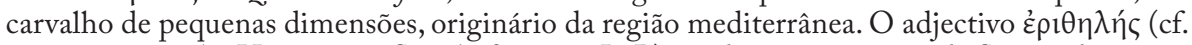
Il. 10. 467, 17.53; Hes. Th.30; Sapph. fr. 98a. 9 L-P), ainda que no poema de Simónides possa ter apenas função ornamental, é particularmente adequado a esta árvore de folhas persistentes e sempre verdes, que floresce entre Abril e Maio. A designação científica (fr. 'Chêne kermès', ingl. 'Kermes-oak') corresponde ao que escreve Teofrasto acerca do $\pi \rho \tilde{i} v o \varsigma$ (HP 3. 7. 3): 'O carrasco produz a sua baga escarlate', informação que repete quando descreve a árvore (cf. 3. 16. 1). Não é claro se conhecia exactamente a origem da tinta. Esta dúvida coloca-se também em relação a Plínio, o Antigo, que menciona a sua utilização na confecção das capas dos generais romanos (Nat. 22. 3), mas julgava que o coccum era uma baga de origem vegetal (cf. 9. 134, 141; 16. 32). Na verdade, as pequenas excrescências vermelhas e redondas que se formam nas folhas da árvore são compostas pelos corpos mortos e ressequidos das fêmeas do insecto 'quermes' (Chermes ilicis). Secas e pulverizadas, serviam para fazer uma matéria corante escarlate, que é considerada a mais antiga conhecida e é também designada por 'quermes' (cf. Paus. 10. 36. 1). Cf. H. Baumann, Le bouquet d'Athéna. Les plantes dans la mythologie et l'art grecs. Trad. fr. R. Barbier (Paris 1984) 159 e fig. 318; S. Amigues, Théophraste. Recherches sur les plantes. Tome II. Livres III-IV (Paris 1989) 139 n. 9, 179-180, nn. 1-5; J. W. Humphrey, J. P. Oleson and A. N. Sherwood, Greek and Roman Technology: a Sourcebook (London 1998) 358359; J. Franco, s.v. Carrasco, in Enciclopédia Verbo Luso-Brasileira de Cultura. Edição Século XXI. Vol. 6 (Lisboa 1998) 73.

Em vez da reconstituição, Poltera 1997: 189-190 propôs a eliminação dos termos $\pi$ pıvó

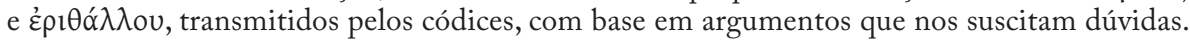
Traduz זрĩvos por 'yeuse' ('azinheira', Quercus ilex), observando que é este o significado do termo nos autores arcaicos e clássicos, mas baseia-se numa única ocorrência (Hes. Op. 436). Com esta emenda, o fragmento alcança uma "coerência métrica-sintáctica perfeita" (p. 190) e o sentido será 'uma vela escarlate, tingida com a húmida púrpura (őv $\theta$ os)'. Segundo esta interpretação, o poeta refere-se à púrpura do mar extraída do múrice. Poltera não explica por que razão Simónides não podia ter referido a Quercus coccifera e não parece ter em conta

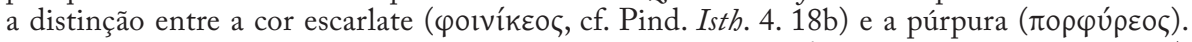

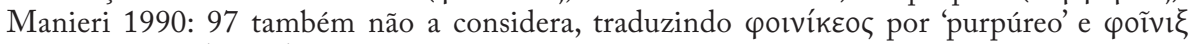
por 'vermelho' ('rosso'). Mas cf. Xenoph. fr. 32 D-K. Sobre este ponto, vide P. Chantraine, "À propos du nom des Phéniciens et des noms de la pourpre”, StudClas 14 (1972) 7-12; J. P. Wild, OCD, s.v. dyeing; Ferreira 2007: 39-44. 
em que se afasta da versão mais divulgada, mas também o seu interesse pela cor, como sugerem outros fragmentos.

Pertence provavelmente ao mesmo poema um outro fragmento constituído apenas por um verso, citado pelo escoliasta de Sófocles.

Fr. 551 [46 P, 55 B, 34 D] Schol. Soph. $A j .740$ (p. 64 Papageorgiu)

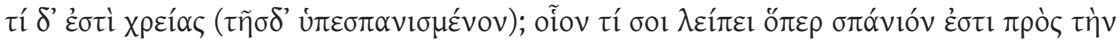

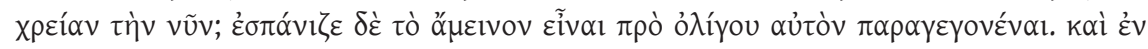

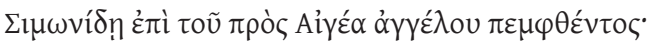

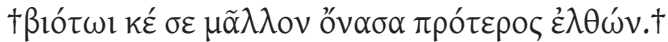

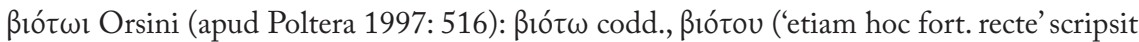

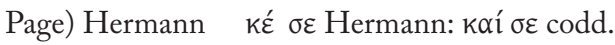

'E o que é que nessa missão fica por fazer? ${ }^{80}$ Ou seja, o que é que foi deixado que está a

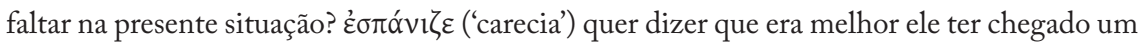
pouco antes. E em Simónides, sobre o mensageiro enviado a Egeu:

à tua vida muito mais útil teria eu sido, se tivesse vindo primeiro.

Este pequeno fragmento, cujo texto não suscita unanimidade ${ }^{81}$, permite supor que o suicídio de Egeu era um dos temas tratados por Simónides. Aspecto relevante é que se trata possivelmente de uma fala do mensageiro a Egeu, proferida demasiado tarde, o que significa que a secção mitológica integrava discurso directo.

Finalmente, a possibilidade de Simónides ter tratado a luta de Teseu com as Amazonas apoia-se somente num passo do terceiro livro da Biblioteca atribuída a Apolodoro, que não foi considerado na edição dos fragmentos líricos de Page, embora se encontre na de Campbell (= fr. 551A $)^{82}$ :

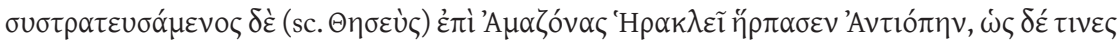

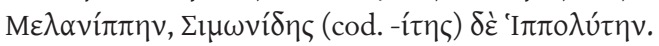

(Teseu), integrando uma expedição militar com Héracles contra as Amazonas, raptou Antíope, que segundo alguns é Melanipe, mas Simónides chama-lhe Hipólita.

${ }^{80}$ Tradução de M. H. Rocha Pereira, in Rocha Pereira et alii 2003: 63.

${ }^{81}$ Poltera 1997: 516-517 propõe a correcção de ßı́́ $\omega$, o genitivo dórico indicado nos códices,

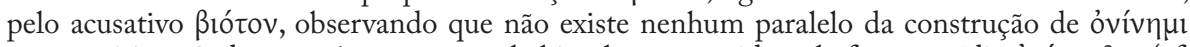
com genitivo, ainda que seja esse o caso habitualmente regido pela forma média óvív $\alpha \sigma \theta \alpha \mathrm{l}$ (cf.

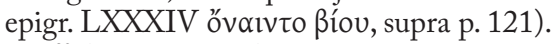

${ }^{82}$ A edição é de A.Papadopulos-Kerameus, "Apollodori Bibliothecae Fragmenta Sabbaitica”, RhM 46 (1891) 184. Cf. A. Lorenzoni, "Simon. Cei Fragm. Novum”, MCr 15-17 (1980/82) 5152 . 
Além das últimas recuperações papirológicas, os temas do ciclo troiano estão representados no corpus de Simónides por quatro versos líricos pertencentes, talvez, a um mesmo poema, por vários testemunhos, que provêm, na sua maioria, de escólios dos Poemas Homéricos, e por um fragmento muito deteriorado de um comentário descoberto num papiro de Oxirrinco, datado de finais do séc. II d.C. Ainda que pouco significativo, este material mostra, porém, que o poeta tratou ou evocou, como era prática dos cultores de lírica coral, vários episódios relacionados com a guerra de Tróia ${ }^{83}$.

Um dos fragmentos diz respeito ao número de filhos que Hécuba deu a Príamo.

Fr. 559 [54 P, 49 B, 35 D] Schol. B Hom. Il. 10. 252 (III. 436 Dindorf)

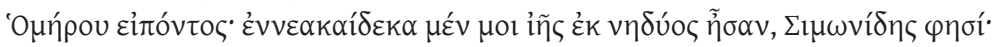

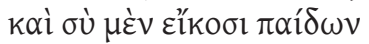

$\mu \tilde{\alpha} \tau \varepsilon \rho \tilde{c}^{\prime} \lambda \lambda \alpha \theta \mathrm{l}$.

Homero diz 'dezanove filhos eu tive do mesmo ventre' (Il. 24. 496), mas Simónides diz:

Mas tu, de vinte filhos

mãe, sê propícia.

O número de filhos que Hécuba deu a Príamo varia consoante a tradição ${ }^{84}$. São catorze, de acordo com Apolodoro (3. 12. 5), mas Eurípides refere cinquenta (cf. Hec. 421). É natural, portanto, que também os líricos tenham introduzido variações neste tema. Este fragmento atesta, mais uma vez, a presença do discurso directo na secção mitológica, neste caso inspirada possivelmente no destino dos Troianos ou na figura de Hécuba.

Um outro fragmento de dois versos indicia que o poeta se pode ter demorado na descrição dos contingentes que participaram no conflito ou na genealogia dos seus heróis. Foi transmitido pelos escoliastas de Píndaro ( $\mathrm{Ol}$. 13. 78, I. 374 Dr.) e de Aristóteles, e também evocado por Plutarco (Dion 1. 958).

Fr. 572 [67 P, 50 B, 36 D] Arist. Rh. 1. 6. 1363a

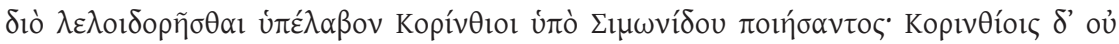
$\mu \varepsilon \dot{\mu} \mu \varepsilon \varepsilon \tau \alpha$ t

Schol. ad loc. (Comm. in Ar. graec. 21. 2, p. 294-295 Rabe = Anecd. Par. I. 284-285 Cramer):

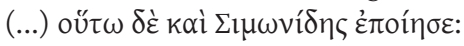

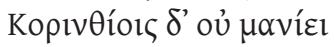

\footnotetext{
${ }^{83}$ Por exemplo, no ditirambo Mémnon (fr. 539), cf. supra, pp. 133-134 e n. 37.

${ }^{84}$ A informação do escólio homérico é corroborada por outras fontes. Cf. Porph. ad Il. (Od.) I. 148 Schrader, schol. Theoc. 15.139.
} 


\section{oủ ' $\alpha \tilde{u} \Delta \alpha v \alpha o i ́$,} $\tau$ tò "I $\lambda \operatorname{lov}^{85} \delta \eta \lambda \alpha \delta \eta$.

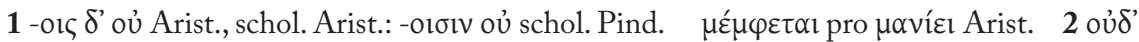

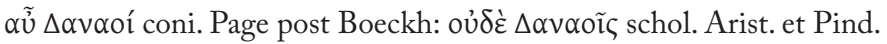

Por esta razão, os Coríntios pensaram que eram insultados com as palavras de Simónides 'Ílion não censura os Coríntios'. Schol. ad loc.: ... Do mesmo modo, também Simónides escreveu, certamente a propósito de Ílion:

e nos Coríntios não derrama a sua cólera nem tão pouco os Dânaos

Não obstante a brevidade do fragmento, é de notar o uso da formulação negativa. $\mathrm{O}$ texto apresenta dificuldades, mas as emendas propostas por Boeckh e Page, que seguimos na tradução, estão de acordo com a explicação dada pelo escoliasta de Aristóteles (que não citamos na íntegra), pois os Troianos tiveram a combater a seu lado Glauco da Lícia, que remontava a sua linhagem a Belerofonte de Corinto.

A hipótese, acima apresentada, de Simónides ter evocado no seu poema as forças que combateram em Ílion, em particular os aliados dos Troianos, é corroborada por um outro escólio homérico referente a um dos últimos versos do canto II da Ilíada (schol. A Hom. Il. 2. 872a, I. 351 Erbse = fr. 565, 60 P, 214 B). Ao comentar a descrição dos chefes cários, Nastes e Anfímaco, em particular a afirmação contida no v. 872 de que este último avançara para a guerra 'coberto de ouro', o escoliasta informa que este detalhe figurava num poema de Simónides, embora aplicado ao outro chefe cário. Acrescenta ainda: ‘... (Homero) também não diz que ele envergava uma armadura de ouro,

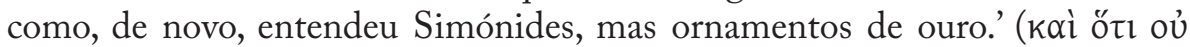

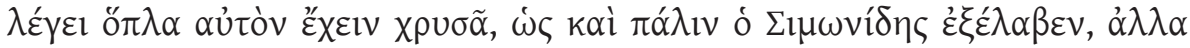
kó $\tilde{\mu}$ ov $\chi \rho \cup \sigma o \tilde{v}$.). Portanto, este testemunho corrobora que o poeta tinha o cuidado de introduzir pequenas variações, para assim se distanciar da tradição mitológica ${ }^{86}$.

Um outro escólio sugere que, mesmo quando tratava temas homéricos, Simónides podia seguir outros poetas. Ao comentar o ataque de Deífobo a Idomeneu (Il. 13. 516-517), o escoliasta anotou (T Hom. Il. 13. 516, III. 500 Erbse = fr. 561, 56 P, 208 B): ' ...já que era seu rival no amor a Helena,

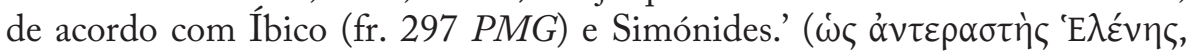

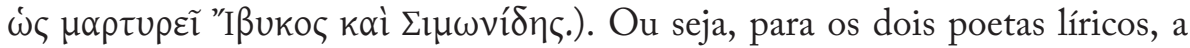

\footnotetext{
${ }^{85} \mathrm{O}$ género do topónimo (a forma épica e lírica é $\mathfrak{\eta}$ ”I $\lambda$ 1oc) é discutido por Poltera 1997: 589.

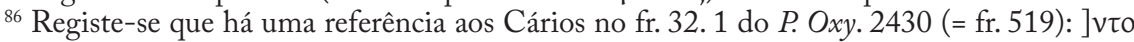

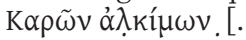


actuação de Deífobo tinha uma motivação passional, ideia que está ausente da Ilíada.

A possibilidade de Simónides ter seguido Íbico no tratamento deste e de outros temas mitológicos encontra apoio numa outra fonte. Segundo um escólio de Apolónio de Rodes (4. 814-815a, p. 293 Wendel = fr. 558, 53 P, 213 B): 'Íbico (fr. $291 P M G$ ) foi o primeiro a dizer que Aquiles casou com Medeia

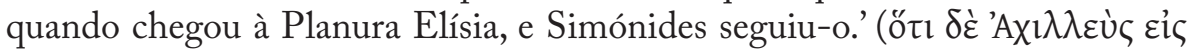

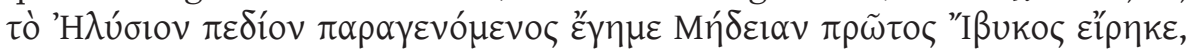
$\mu \varepsilon \theta^{\prime}$ òv $\Sigma \imath \mu \omega v i ́ \delta \eta$ s.).

Não deixa de ser curioso que o poeta seja associado a Íbico a propósito do tratamento de dois temas de carácter amoroso. Sublinhe-se que é apenas uma suposição dos editores modernos que as informações contidas nestes escólios digam respeito a obras líricas ${ }^{87}$. Do mesmo modo, é célebre o testemunho do autor do tratado Do Sublime sobre a impressão causada por Simónides ao tratar a aparição da sombra de Aquiles sobre o seu túmulo (15.7 = fr. 557, 52 P, 209 B):

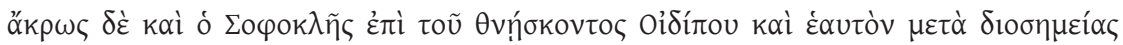

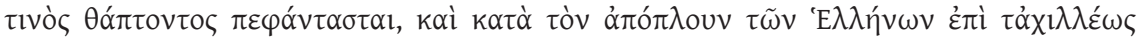

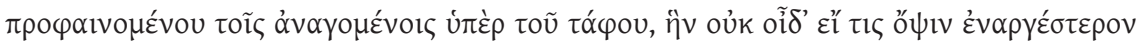

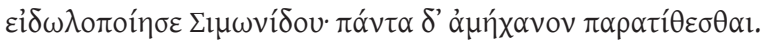

Também com perfeição Sófocles apresentou a morte de Édipo e a cerimónia fúnebre realizada em sua honra com o sinal de Zeus, e a aparição de Aquiles aos que embarcavam, na altura da partida dos Helenos, sobre o seu túmulo, visão que não sei se alguém descreveu mais claramente do que Simónides. Mas é impossível ilustrar tudo.

Se estas palavras são suficientemente claras quanto ao talento pictórico de Simónides, como notam os estudiosos (cf. Bowra 1961: 363-364, Lesky 1995

${ }^{87}$ O escólio de Apolónio de Rodes, como observa Poltera 1997: 238, não permite saber se

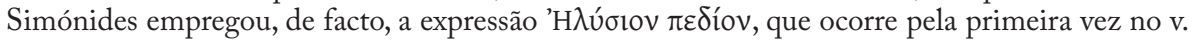
563 do canto IV da Odisseia e só volta a aparecer no passo de Apolónio (4. 811). Como se sabe, o destino profetizado por Proteu a Menelau é uma excepção, por ser marido de Helena e genro de Zeus (v. 569), visto que as psychai dos restantes heróis vão para o Hades (11. 387sqq., 24. 15 sqq.). O passo de Apolónio e o respectivo escólio sugerem que com Íbico e Simónides o maior herói dos Aqueus também foi admitido após a morte num lugar situado no 'extremo da terra', onde a vida é fácil e o clima ameno (Od.4. 564-568). Como já referimos, uma canção de mesa dos fins do séc. VI proclamava a sobrevivência de Aquiles nas Ilhas dos Bem-aventurados (vide supra, p. 235 n. 125). Segundo fontes tardias, foi nesse lugar que desposou Medeia (Apollod. Epit. 5. 5, schol. Lyc. 172). A descrição homérica da Planura Elísia aproxima-se da que nos oferece Hesíodo das Ilhas dos Bem-aventurados (Op. 171-173), mas as duas concepções de um Além feliz pertenciam provavelmente a tradições independentes, pelo menos no princípio. Cf. Rocha Pereira 1955: 29 e Martínez 2002: 523. Sobre a variedade de destinos atribuídos a Aquiles, vide pp. 31-36 e 524-526, respectivamente. Sobre as duas concepções referidas, vide ainda West 1978: 193-194, S. West 1988: 227. 
[1971]: 220), elas não nos dão qualquer pista sobre o subgénero da composição e esta dúvida torna-se mais legítima desde a publicação da 'Elegia de Plateias'. A sombra de Aquiles exigia o sacrifício de Políxena, para ser apaziguada ou como garantia de um regresso seguro dos heróis gregos. Sófocles terá tratado o mito, ausente dos Poemas Homéricos, na tragédia perdida Polixena e Eurípides segue esta versão na Hécuba (vv. 35-41, 107-143, 218 sqq.; cf. Tr. 622-623). Segundo um escólio ao v. 41, o sacrifício de Políxena foi também tratado por Íbico (I. 17 Schw. = fr. 307 PMG). Assim, mais uma vez o lírico de Régio surge como possível fonte de inspiração.

Há alguns indícios de que Simónides tratou também a história de Agamémnon. Informa o escoliasta do Orestes de Eurípides (Or. 46, I. 102 Schw. = fr. 549, 44 P, 207 B): 'É evidente que o cenário do drama se situa em Argos. Mas Homero coloca o palácio de Agamémnon em Micenas, Estesícoro

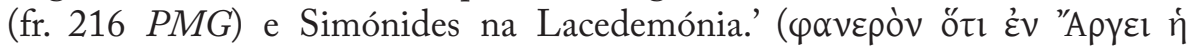

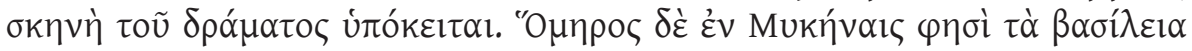

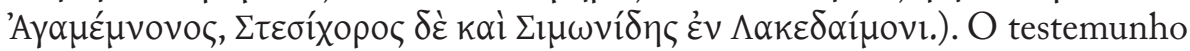
é muito vago e não é prudente concluir que Simónides tratou no seu poema a matéria da tragédia de Eurípides. A sua validade reside, sobretudo, no facto de corroborar o distanciamento da tradição homérica e o apreço por um dos seus antecessores líricos.

A referência ao sacrifício de uma mulher e à dor de uma mãe, bem como

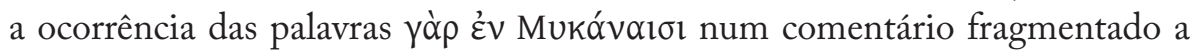
uma obra de Simónides, transmitido pelo P. Oxy. 2434 (= fr. 608, 103 P), são dados mais relevantes, permitindo supor que um dos assuntos tratados tenha sido o sacrifício de Ifigénia ${ }^{88}$.

Recordada por Fénix num momento crucial do canto IX da Ilíada (vv. 529-599), a 'Embaixada a Aquiles', a fim de aplacar a obstinação cega do herói, a história desventurada de Meleagro inspirou naturalmente os cultores de lírica coral $^{89}$. A fonte mais importante sobre o nosso poeta é um passo dos Deipnosophistae, em que Seleuco, gramático alexandrino do séc. I d.C., se pronuncia sobre a autoria da composição centrada no tema dos jogos fúnebres em honra de Pélias.

Fr. 564 [59 P, 53 B, 32 D] Athen. 4. 172e

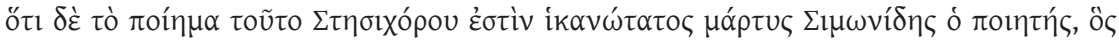

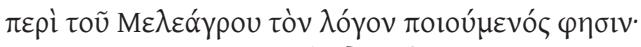

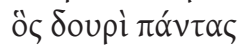

${ }^{88}$ Cf. Poltera 1997: 62 e n. 129, 345 n. 24,590, que aceita esta interpretação, embora com reservas.

${ }^{89}$ Cf. Stesich. frr. 179, 221, 222 e 222B Campbell; Ibyc. fr. 290; Pind. Isth. 7. 32; Bacch. 5. 68 sqq., 25. 


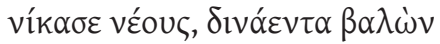

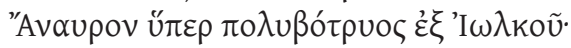

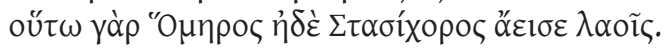

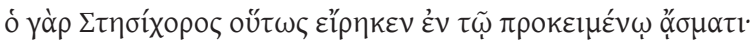

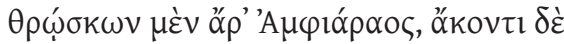

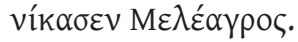

A testemunha mais convincente de que este poema é de Estesícoro é o poeta Simónides, que diz na sua composição sobre Meleagro:

todos os jovens, lançando-a sobre

... aquele que venceu, com a sua lança,

a voragem do Anauro, desde Iolco, rica em vides.

Pois assim cantaram aos povos Homero e Estesícoro.

Pois Estesícoro (fr. 179b $P M G$ ) dizia assim no citado poema:

No salto venceu Anfiarau, com a lança Meleagro.

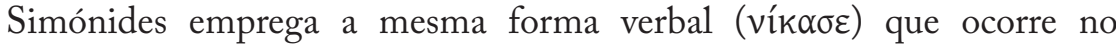
fragmento de Estesícoro, o que pode ser uma mera coincidência. O primeiro

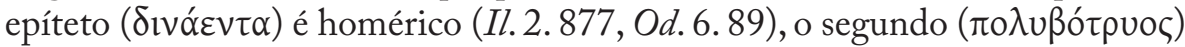
ocorre num fragmento de Hesíodo (59. $3 \mathrm{M}-\mathrm{W})^{90}$. Portanto, embora a linguagem seja marcadamente épica, como Poltera 1997: 360 notou, estes versos contêm a referência mais antiga ao lírico de Hímera e confirmam que Simónides o considerava uma autoridade no domínio da narrativa mitológica. Terá sido, por ventura, um dos líricos antigos mais influentes na sua obra (cf. supra fr. 549). Se há alguma relação temática entre os dois fragmentos citados por Seleuco, então a excelência de Meleagro no manejo da lança, que o nosso poeta evoca de modo hiperbólico, refere-se à prestação do herói nos jogos fúnebres em honra de Pélias e não num campo de batalha. Por conseguinte, este passo seria adequado a um epinício composto para um vencedor no pentatlo.

\footnotetext{
${ }^{90}$ Os dois epítetos são analisados por Poltera 1997: 294 e 360, respectivamente.
} 
(Página deixada propositadamente em branco) 


\section{A PRESENÇA DA NATUREZA}


(Página deixada propositadamente em branco) 
A observação dos fenómenos astronómicos e atmosféricos, das particularidades do mundo animal e vegetal, no que tem de belo e horrível, é um dos elementos presentes na literatura grega desde os seus primórdios. Constitui uma das fontes mais ricas dos símiles dos Poemas Homéricos, principalmente dos da Ilíada ${ }^{1}$, e inspirou, como é sabido, epítetos pitorescos e

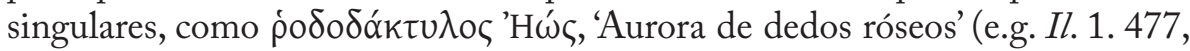

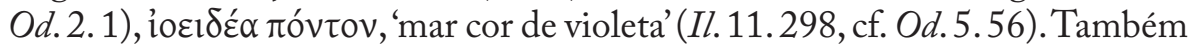
não podemos esquecer grandes momentos descritivos da poesia épica, como o nocturno que encerra o canto VIII da Ilíada (vv. 553-565), o cenário pleno de sensualidade em que culmina o 'dolo de Zeus' (14.347-351), o 'escudo de Aquiles' (18. 478-608), a gruta maravilhosa de Calipso (Od. 5. 63-74), a luta dos ventos (5.291-296) e a terrível tempestade que quase arrasta Ulisses para a morte (5.313-332), os invulgares jardins de Alcínoo (7.112-132), o Verão na terra natal de Hesíodo (Op. 582-596).

A natureza em todas as suas manifestações despertou igualmente a sensibilidade dos poetas arcaicos, em particular dos líricos, estando presente em todos os géneros. Atente-se no modo como Arquíloco traça o perfil da ilha de Tasos (fr. $21 \mathrm{~W}$ ), descreve uma mulher (fr. $30 \mathrm{~W}$ ), recorda um eclipse do sol (fr. $122 \mathrm{~W}$ ). O fr. $7 \mathrm{~W}$ de Semónides de Amorgos, o fragmento mais longo do período arcaico composto em ritmos iâmbicos, parte da observação do mundo natural e animal para descrever dez tipos de mulher (casada). Em Álcman, a natureza é um tema privilegiado, como bem ilustram o 'Grande Partenéion' (fr. 1 P), a descrição do adormecimento da vida animal e vegetal (fr. $89 \mathrm{P}$ ) ou as muitas referências ao mundo das aves, no qual o poeta reencontra a essência da sua arte (cf. frr. 26, 39, 40 P). Nos versos pessimistas de Mimnermo de Cólofon, o esplendor da Primavera é recordado para sublinhar a brevidade da vida humana (fr. 2. 1-4 W). Em Safo, belos e velozes são os pardais que puxam o carro de Afrodite (fr. 1.9-12 L-P) e é um jardim de macieiras, águas frescas e rosas que acolhe a deusa (fr. $2 \mathrm{~L}-\mathrm{P}$ ). Os seus versos falam do fulgor da lua (fr. 34 L-P), da chegada da estrela da tarde (fr. 104 L-P), da beleza da Aurora (fr. 123 L-P), do canto maravilhoso do rouxinol (fr. 136 L-P)... Tópico fundamental da sua poética, o elogio da natureza é também ponto de partida para a exaltação da beleza humana (cf. frr. 94, 96, 105, 115, 122 L-P). Nos versos de Alceu encontramos a mesma observação atenta da diversidade

\footnotetext{
${ }^{1}$ Cf. J. Duchemin, "Aspects pastoraux de la poésie homérique: les comparaisons dans l'Iliade", REG 73 (1960) 362-415; Edwards 1991: 34-37.
} 
do mundo natural (frr. 345, 359 L-P) e das estações do ano, com as suas particularidades, como o calor do Verão (fr. 347 L-P, cf. frr. 367, 397, 399 L-P). Em dois fragmentos de Sólon, a evocação de fenómenos meteorológicos, como a queda de neve e de granizo, o ribombar do trovão e o encrespamento do mar (frr. 9. 1-2, $12 \mathrm{~W}$ ), tem um carácter funcional, dado que o Estadista ateniense os apresenta como paradigmas da organização social da pólis ${ }^{2}$. Os líricos da Magna Grécia não deixaram também de evocar as 'maçãs cidónias', designação poética dos marmeleiros, as folhas de mirto, as grinaldas de rosas, as andorinhas, os rouxinóis e outras aves, a Primavera... De Anacreonte lembramos, em particular, a alegoria da poldra da Trácia (fr. $417 P M G)^{3}$.

Quando Simónides compôs a sua obra não pôde fugir a este legado ${ }^{4}$. Assim, não é de surpreender que também ele mencione as 'folhas de mirto' e as 'grinaldas de rosas', oferecidas aos vencedores dos Jogos (fr. 506. 1-2), o 'bem arborizado' santuário de Zeus (fr. 507. 2), o 'volver da mosca de longas asas' (fr. 521. 3), a 'flor do carvalho viçoso' (fr. 550 (a). 2-3), Eurídice 'coroada de violetas' (fr. 553. 2), Iolco 'rica em vides' (fr. 564. 3), os 'rios eternos' e as 'flores primaveris', a 'chama do sol e da áurea lua', os 'turbilhões do mar' (fr. 581. 2-4), os 'flocos de neve' (fr. eleg. 21. 8). No fr. 543, o sopro do vento e a agitação das águas acentuam o sofrimento de Dânae. No fr. 567, é a própria natureza seduzida pelo talento de Orfeu que se torna matéria de canto, e no fr. 595 o poeta celebra o tempo sereno, que favorece a execução musical. Quando Simónides falou do bom tempo num outro poema, evocou a alcíone, ave lendária, bela e melancólica, já referida nos Poemas Homéricos (Il. 9. 562563) e na poesia lírica mais antiga ${ }^{5}$ :

\section{Fr. 508 [3 P, 12 B, 20 D] Arist. HA 5. 8. 542b}

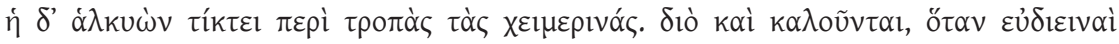

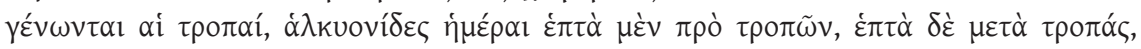

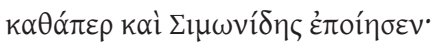

ஸ́s ómótav

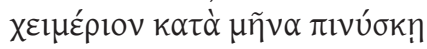

${ }^{2}$ Para um comentário, vide Leão 2001: 421-423.

${ }^{3}$ Cf. Stesich. frr. 187, 211, 235, 262 PMG; Ibyc. frr. 286, 287, 288, 303 (b), 315, $317 P M G$; Anacr. frr. 346 (fr. 1. 7-9), 394 (a), 408, 437, 443, 453, 456 PMG.

${ }^{4}$ Sobre a presença da natureza na poesia grega, vide G. Soutar, Nature in Greek Poetry: Studies Partly Comparative (Oxford 1939), cap. 1-2; A. Parry, "Landscape in Greek Poetry", YCIS 25 (1957) 3-29; Fowler 1984: 119-149, Irwin 1984, Lourenço 1993; Marcos Martínez, "Descripciones de jardines y paisajes en la literatura griega antigua", $C F C(G) 18$ (2008) 279318; Jesus 2009.

${ }_{5}$ Cf. Alcm. fr. 26 P, Sapph. fr. 195 L-P, Stesich. fr. 248 PMG, Ibyc. fr. 317 (a) PMG. Encontram-se outras imagens famosas de alcíones nos vv. 1089 sqq. de Ifigénia em Táuride, de Eurípides, e no $V I I^{\circ}$ Idílio de Teócrito (vv. 52-60). Para uma análise deste passo, vide Lourenço 1993: 103-105. 


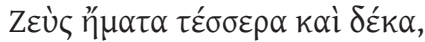

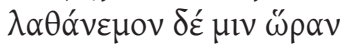

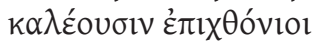

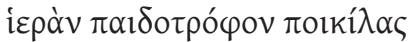

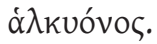

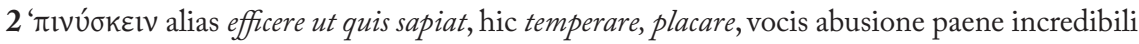
interpretantur' scripsit Page $4 \delta$ ć corr. Schneidewin: $\tau \varepsilon ́$ codd.

A alcíone procria por volta do solstício de Inverno. Por isso é que, quando são tranquilos os solstícios, se chamam alcióneos os sete dias anteriores ao solstício e os sete posteriores, como também disse Simónides na sua composição:

no mês das tempestades, ... como quando,

Zeus faz serenar catorze dias, estação do vento esquecida

lhe chamam os que vivem na terra, sagrada ama da variegada alcíone.

Transmitido por Aristóteles, no âmbito da sua exposição sobre as épocas de reprodução das espécies, este fragmento é o mais extenso dos que evocam um tema da natureza e integrava um epinício composto para um vencedor no

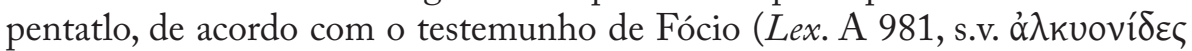

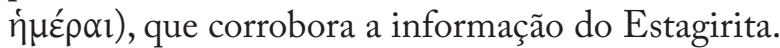

A presença de $\omega \varsigma \zeta$ órótav indicia que este passo fazia parte de um símile e se o poeta pretendia, como supomos, aludir ao poder de Zeus sobre as forças da natureza, é possível que esta referência surgisse na sequência de um elogio ao modo como determinado atleta havia dominado o adversário. Trata-se apenas de uma mera conjectura, pois não é claro o sentido que Simónides atribui

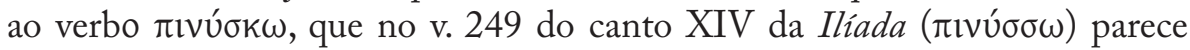
significar 'instruir', 'aconselhar', referindo-se a uma ordem dada ao Sono por Hera (cf. Janko 1992: 190-191). Não obstante as nuances semânticas do verbo, parece claro que está aqui presente a ideia de que o soberano dos céus exerce o seu poder pacificador sobre os ventos e faz abrandar o mar ${ }^{6}$. A alusão à

${ }^{6}$ As traduções de Campbell 1991: 373 ('Zeus admonishes fourteen days') e de West 1993a: 160 ('Zeus chastens fourteen days') vão ao encontro desta interpretação. Atente-se, contudo, na nota de Page ad loc., que aceitou $\pi ı v u ́ \sigma k \omega$, embora notando tratar-se de um 'abuso quase inacreditável do vocábulo'. Cremos que é de todo o interesse a discussão do problema por M. Clarke, " $\pi ı v u ́ \kappa \omega$ and its Cognates: a Note on Simonides, fr. 508 Page", Glotta 74 (199798) 135-142, que discorda da interpretação tradicional. No seu artigo defende que $\pi ı v u ́ \sigma k \omega$ se relaciona estreitamente com $\pi v \varepsilon \varepsilon \omega$, 'soprar, respirar', e que ambos respondem a uma subtil unidade semântica, baseada na crença de que a respiração participa do processo de pensamento. 
serenidade do tempo reflecte-se no plano fónico, visto que o predomínio das nasais (especialmente nos vv. 2 e 4 ) confere uma sonoridade muito suave a estes versos.

Este fragmento é também ilustrativo da arte de compor de Simónides, no sentido em que, não se referindo explicitamente aos 'dias alcióneos ${ }^{7}$, como as palavras de Aristóteles poderiam levar a pensar, expressa a mesma ideia de

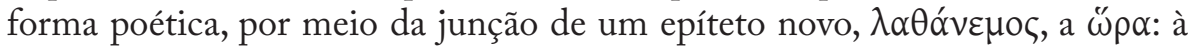
letra, 'estação do vento esquecida' (v. 4). Paradoxalmente, no verso seguinte, o

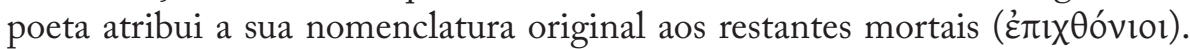
As suas palavras adquirem deste modo o tom épico apropriado à solenidade inerente à evocação do fenómeno divino. O vocábulo ĖđıxӨóvioৎ ocorre, de facto, com alguma frequência nos Poemas Homéricos, mas acompanha

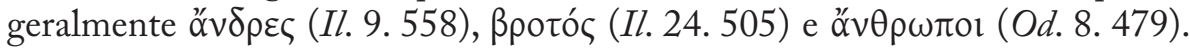
Não podemos deixar de notar que nos versos de Simónides está provavelmente subjacente uma oposição entre a figura única e poderosa de Zeus e os muitos 'terrenos' que apenas podem testemunhar as suas acções. A formulação do v. 5 significa também que o poeta está aqui a tratar uma lenda conhecida no seu tempo, que poderia ter sido introduzida no poema no âmbito de uma referência à paz e tranquilidade, que é preciso aproveitar por serem breves. Portanto, não é prudente excluir a hipótese de este passo ter feito parte de uma secção gnómica da ode ${ }^{8}$.

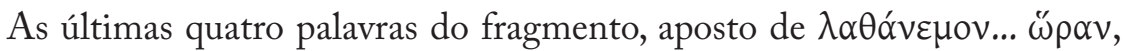
confirmam que Simónides conhecia as crenças sobre os hábitos de nidificação da alcíone, identificada habitualmente com o martim-pescador, maçarico ou pica-peixe (Alcedo ispida). Segundo a tradição grega, que Aristóteles cita na sua exposição (cf. 5. 8.542b12, 5.9.542b22), a semana que antecede o solstício de Inverno e a que se lhe segue são propícias à reprodução das alcíones, uma vez que a acalmia do mar permite que elas façam os ninhos sobre as águas. Ainda

Depois de analisar as ocorrências do verbo $\pi \imath v u ́ \sigma \kappa \omega / \pi \imath v u ́ \sigma \sigma \omega$ e da forma homérica negativa

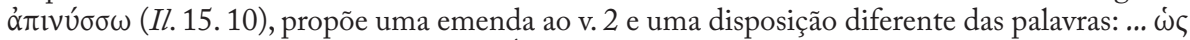

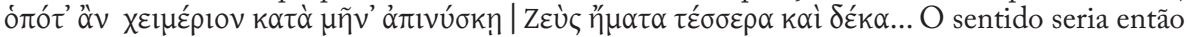
que Zeus 'perde o seu fôlego', deixando de soprar os ventos durante catorze dias. Clarke nota que esta concepção do pai dos deuses como senhor dos ventos é invulgar, embora esteja atestada (cf. Eur. $I A$ 1323-1325; AP 12. 53. 7-8). Se esta emenda estiver certa, o sentido geral do poema não se altera, mas torna-se mais claro e a imagem sugerida mais nítida.

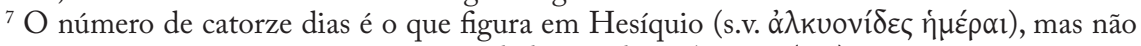
há consenso quanto a este ponto nas autoridades citadas pela $S u d a$ (s.v.).

${ }^{8}$ As ocorrências de ótótav (sem $\omega ́$ ) na obra de Píndaro apoiam esta possibilidade. Cf. especialmente Pyth. 8. 8, frr. 94b. 17, 225. 1 Ma. Ao pronunciar-se sobre o possível contexto original deste fragmento, Bowra 1961: 316 escreveu "This is a simile, and though we do not know its context, it must refer in some way to a sudden glory in a dark season." Por seu lado, depois de notar a relevância destes versos, Campbell 1983: 61 avançou a hipótese de Simónides ter falado do momento de relaxamento que se seguiu à vitória do atleta. 
que meramente alusivas, as palavras de Simónides constituem a referência mais antiga a este fenómeno, que não parece ter fundamento científico, embora possa ter sido tratado pelos líricos mais antigos ${ }^{9}$.

A escolha do vocabulário revela, de novo, o cuidado do poeta em combinar o legado épico e lírico com o que é fruto da sua criatividade. Se nos versos

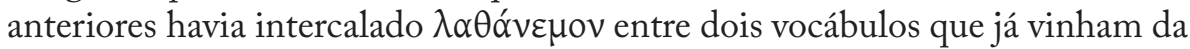
tradição épica, no v. 6 o processo repete-se: este passo preserva a ocorrência mais antiga de $\pi \alpha 1 \delta o \tau \rho o ́ \varphi o \zeta^{10}$, que surge entre dois adjectivos mais conhecidos. Esta estação é 'sagrada' (îع óv $)^{11}$, porque é obra dos desígnios de Zeus, e é 'nutrice, ama' ( $\pi \alpha 1 \delta o \tau \rho o ́ \varphi o v)$ ao permitir a procriação da raça das alcíones. Finalmente, o epíteto пoıkílos, já presente nos Poemas Homéricos (no v. 30 do canto $\mathrm{X}$ da Ilíada qualifica a pele com que se cobre Menelau, ao sair da tenda durante a noite), era caro aos líricos, mas este é o único passo do corpus de poesia grega arcaica em que é aplicado à alcíone ${ }^{12}$. A associação dos dois termos seria provavelmente evocativa para um auditório familiarizado com a poesia lírica. É significativo que a última palavra do fragmento seja ả $\lambda$ kvóvo५. A menção da mítica ave seria, por certo, a palavra mais esperada numa digressão sobre os dias de acalmia do solstício de Inverno. A acumulação de epítetos permite ao poeta adiar essa expectativa e deste modo obter um efeito mais impressionante.

Aristóteles observa na sua exposição que os 'dias alcióneos' se verificavam sobretudo nas águas da Sicília (5.8.542b16). Supomos que foi esta informação que sugeriu a alguns estudiosos a ideia de que o destinatário da ode seria de origem siciliana (cf. Bernardini 1980: 95-96, Barrigón 1994a: 78). Em nosso entender, depreende-se das palavras de Simónides (cf. v. 5) e do Estagirita (cf. 5. 8. 542b12: $\Lambda \varepsilon ́ \gamma \varepsilon \tau \alpha 1 . .$.$) que o fenómeno dos 'dias alcióneos' era proverbial,$ pelo que o poeta não precisava de o ter visto para o mencionar na sua obra.

${ }^{9}$ Não cremos, porém, que se possa concluir das afirmações de Aristóteles em $H A$ 5. 9. 542b24 que Estesícoro o tratou, como pensa Poltera 1997: 130, embora aquele testemunho sugira que tenha sido um dos líricos a mencionar a ave fabulosa na sua poesia (fr. 248 PMG). Aludem também aos 'dias alcióneos' Aristófanes (Av. 1594, cf. 251) e Luciano (Halc. 2). Para um elenco completo das fontes, vide Thompson 1936: 48-49. A génese desta tradição é discutida nas pp. 49-50. Sobre o mesmo assunto, cf. Gow 1965b: 146-147; Pollard 1977: 96-98.

A breve referência na Ilíada (9. 562-563) à 'muito amargurada alcíone' (ả $\lambda$ kvóvos

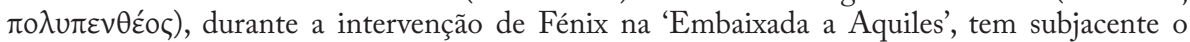
conhecimento do mito de Alcíone e Ceíce. Cf. schol. Il. 9. 562, Apollod. 1. 7. 4, Luc. Halc. 2, Hyg. Fab. 65, Ov. Met. 11. 410-750. Para uma análise da lenda, vide Graves 1960: I. 45.

${ }^{10}$ Cf. Aesch. fr. 47a. 806 Radt, Soph. OC 701, Eur. HF 901. Sobre a formação e interpretação do epíteto, vide Poltera 1997: 437-438.

${ }^{11}$ Simónides evoca talvez o poema de Álcman a que pertence o fr. $26 \mathrm{P}$, no qual chamava à alcíone 'i $\alpha \rho o ̀$ s őpvic' (v. 4).

${ }^{12}$ Cf. Alcm. frr. 1. 66, 93. 1 P; Sapph. fr. 39. 2 L-P; Ibyc. fr. 317 (a). 2 PMG; Thgn. 602;

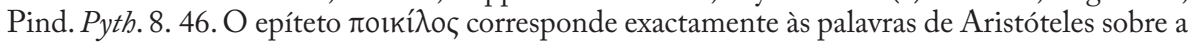
plumagem da alcíone (cf. HA 5. 9.616a14-15). Sobre este ponto, cf. Fowler 1984: 126. 
Evocado indirectamente no v. 4 ( $\lambda \alpha \theta \alpha$ óverov), o vento teria sido tema de uma ode composta por ocasião de uma batalha naval, segundo informa Himério (Or. 47. 14 = fr. 535, 30 P, 25 B). E de acordo com um escólio da Ilíada ${ }^{13}$, Simónides tentou representar (no mesmo poema?) o principiar de um

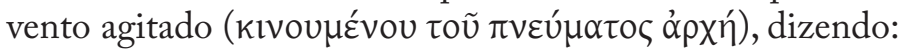

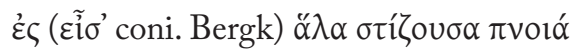

... sobre o mar as marcas do sopro do vento...

Não obstante a brevidade, este fragmento é um bom exemplo da linguagem figurativa e da capacidade pictórica de Simónides, que associou um substantivo já conhecido dos Poemas Homéricos ( $\pi v o$ ıń) a um verbo que significa à letra 'assinalar com uma marca', 'tatuar' (especialmente escravos e prisioneiros), atestado sobretudo na literatura da Época Clássica (cf. Hdt. 7. 35. 1, Ar. Ra. 1511). Criou, assim, a imagem exacta do efeito de relevo que caracteriza o encrespamento da superfície do mar, quando sopra a brisa. Mas o verso não apela apenas à visão, dado que o predomínio das sibilantes ( $\left.\varepsilon_{\zeta} . . . \sigma \tau i ́ \zeta o v \sigma \alpha\right)$ é claramente evocativo do som produzido pelo vento.

A natureza parece ter sido um elemento importante nos poemas a que pertencem os fragmentos do P. Oxy. 2430 (= 519). O fr. 32 preserva seis versos mutilados de um péan (Lobel 1959: 45 n. 1, Campbell 1991: 387). Apesar do estado deteriorado em que se encontra, parece claro que se fala aqui de uma

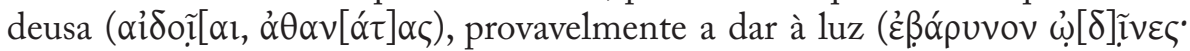
ớ ]$\lambda \hat{\varepsilon} \varepsilon \downarrow \mu \tilde{\omega} v \alpha \varsigma)$. A hipótese de se tratar da descrição do nascimento de Apolo e de Ártemis, gerados por Leto, merece ser considerada ${ }^{14}$.

A Primavera é evocada em dois fragmentos de peanes do mesmo papiro (35 (b) 5,55.7). Embora não nos seja possível reconstituir totalmente o sentido destas referências, supomos que permitiam ao poeta situar a época em que se realizava a festa religiosa durante a qual era executado o péan, como o festival de Apolo em Delos, que ocorria na Primavera. De facto, a expressão $\Delta \alpha \lambda i ́ \omega v$ $\theta u ́ \gamma \alpha \tau[\rho \varepsilon \varsigma$, 'as filhas dos Délios', do fr. 55.3, relembra, imediatamente, o passo

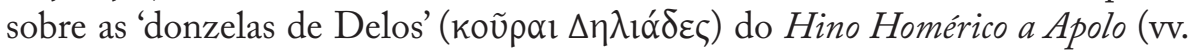
156-164), evocado no capítulo de introdução (p. 34) ${ }^{15}$.

${ }^{13}$ Schol. B Hom. Il.21.126 (V.149 Erbse), s.v. $\varphi$ píł, 'encrespamento' = fr. 600, 95 P, 78 B, 41 D.

${ }^{14}$ Cf. Lobel 1959: 54-55, Lloyd-Jones 1961: 18, Rutherford 1990: 180-183, Campbell 1991: 389 .

${ }^{15}$ Cf. Rutherford 1990: 176 (fr. 35), 178-179 (fr. 55). 
Finalmente, o fr. 77 preserva um passo de um poema em que Simónides

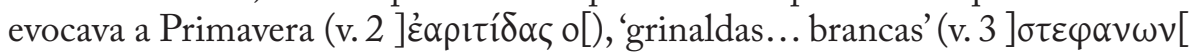
] $\lambda \varepsilon \cup \kappa \omega[$ [), 'germinando em abundância e trazendo as folhas da região' (v. 5 ]

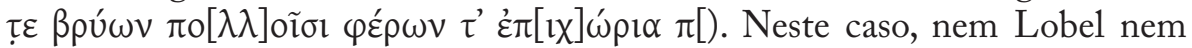
Campbell se pronunciaram sobre o subgénero do poema. Se era um epinício, como a referência às grinaldas parece sugerir, a hipótese mais plausível seria uma prova nos Jogos Ístmicos, que se realizavam na Primavera, de dois em dois anos, em honra de Poséidon. Esta hipótese faz algum sentido, pois é precisamente esta a divindade mencionada nos vv. 6 e 7 do mesmo fragmento

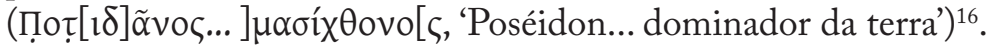

À semelhança do que acontece com outros líricos, o corpus de Simónides integra ainda pequenos fragmentos sobre aves e insectos vulgares na Grécia. Os contextos em que figuravam são hoje difíceis de reconstituir, embora valha a pena explorar algumas hipóteses. De acordo com um passo de Ateneu (9. $374 \mathrm{~d}=$ fr. $\left.583,78 \mathrm{P}, 80^{\mathrm{B}} \mathrm{B}, 47 \mathrm{D}\right)$, o poeta empregou a apóstrofe i $\mu \varepsilon \rho o ́ \varphi \omega v^{\prime}$

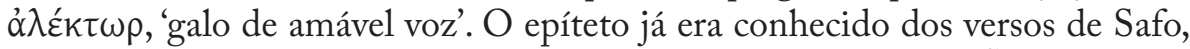
que o aplicou ao rouxinol 'mensageiro da Primavera' (fr. $136 \mathrm{~L}-\mathrm{P}$ : ทे

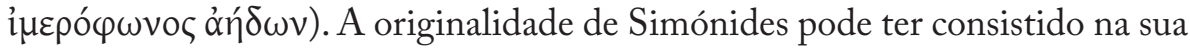

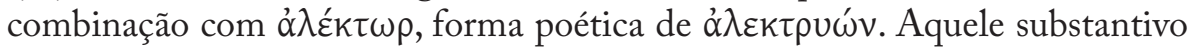
ocorre no v. 192 do poema herói-cómico Batrachomyomachia, que a tradição atribuiu a Homero e a outros nomes, como Pigres de Halicarnasso (cf. Suda,

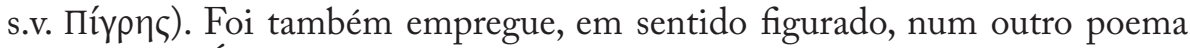
do início da Época Clássica. No epinício composto para Hierão de Siracusa em 470, pela vitória na corrida de carros dos Jogos Píticos (4. 7-8), Baquílides

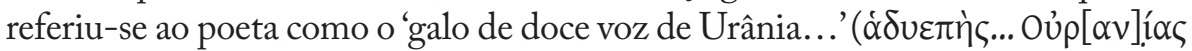
$\dot{\alpha} \lambda \varepsilon \dot{\varepsilon}[\kappa \tau \omega \rho)$, certamente porque lhe cabia enumerar, com o seu canto, o triunfo do atleta ${ }^{17}$. Portanto, a natureza pode também ter sido para Simónides uma fonte de inspiração da linguagem figurativa.

A julgar pelos versos preservados, a menção do rouxinol e da andorinha, símbolos do canto suave e do tempo primaveril, é um topos frequente nos líricos mais antigos ${ }^{18}$. Simónides filia-se ainda nesta tradição, como atestam

${ }^{16}$ Sobre a referência a Poséidon, cf. Poltera 1997:532-533 (que defende o epíteto $\left.\delta \alpha\right] \mu \alpha \sigma i ́ x \theta o v o[\varsigma)$.

${ }^{17}$ Cf. Campbell 1992: 137 n. 3; C. Catenacci e M. Di Marzio, "Il gallo di Urania (Bacchilide, Epinicio 4)”, QUCC 76.1 (2004) 71-89, especialmente p. 73. Poltera 1997: 364

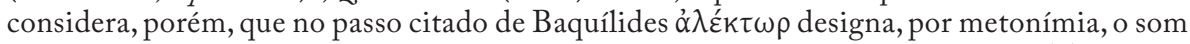
de um instrumento musical. Sobre o galo no imaginário da Grécia antiga, vide Thompson 1936: 33-34, Pollard 1977: 88-89, e o artigo de C. Catenacci e M. Di Marzio, pp. 81-84 em particular. Para uma discussão da datação e autoria do poema Batracomiomaquia, vide Rodolfo Lopes, Pseudo-Homero, Batracomiomaquia. A guerra das rãs e dos ratos (Coimbra 2008) 20-27.

${ }^{18}$ Cf. supra Sapph. fr. 136 L-P; Alc. fr. 399 L-P; Stesich. fr. 211 PMG; Ibyc. fr. 303 (b) 
dois fragmentos. Um foi citado no comentário do Etymologicum Magnum a

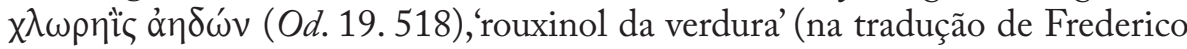
Lourenço) ou 'rouxinol verde pálido' $(L S J)$, aparentemente como referência poética à cor da plumagem da ave $(813.5=$ fr. $586,81 \mathrm{P}, 73 \mathrm{~B}, 45 \mathrm{D})$ :

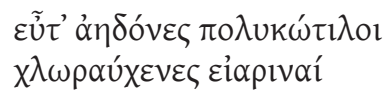

quando os gárrulos rouxinóis

de colo esverdeado, aves da Primavera...

A acumulação de epítetos é uma das características das referências à

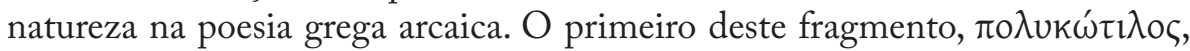
é um hápax, mas pode ter sido inspirado pelos versos de Anacreonte, que chamou à andorinha $\kappa \omega \tau i ́ \lambda \eta$, 'tagarela, parladora' (fr. $453 P M G)$. O significado do epíteto é fornecido por Tzetzes (ad Hes. Op. 372 = fr. 606, 101 P, 243 B): 'A

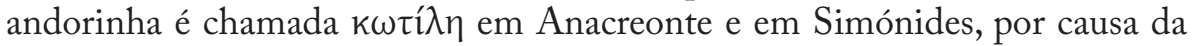

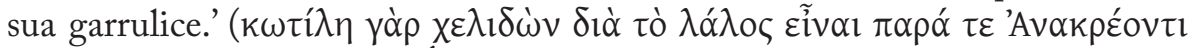
$\kappa \alpha i ̀ ~ \Sigma \imath \mu \omega v i ́ \delta \eta n ~ \kappa \alpha \lambda \varepsilon \tilde{\imath} \tau \alpha$ l.). É possível que esta informação diga respeito ao presente fragmento de Simónides, embora não seja exacta. Note-se, porém, que

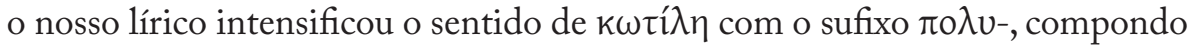
uma forma nova. No segundo verso combinou uma possível criação pessoal ( $\chi \lambda \omega \rho \alpha u ́ x \eta v)$ com um epíteto que na Ilíada é aplicado às flores (2. 89: غ̇ं

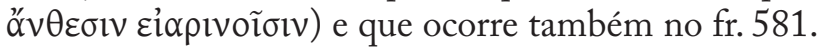

Julgamos que $\chi \lambda \omega \rho \alpha u ́ \chi \eta \nu$, formado a partir de $\chi \lambda \omega \rho o ́ s$, diz respeito à plumagem do colo do rouxinol. Dado o sentido amplo e ambíguo deste termo cromático, é possível que Simónides tenha pensado numa matiz verde (ou amarela) acastanhada, que estaria próxima da que caracteriza a plumagem do pescoço do rouxinol, predominantemente castanha ${ }^{19}$.

PMG; Anacr. frr. 394 (a), 453 PMG. As duas aves surgem associadas no mito etiológico de Aédon/Procne e Quélidon/Filomela. Cf. Evi Touloupa, LIMC VII. 1, s.v. Prokne et Philomela (München 1994) 527-529, VII. 2: 418-420; Burkert 1983: 179-185. Sobre o rouxinol e a andorinha na cultura e literatura gregas, cf. Thompson 1936: 16-22, 314-325, Pollard 1977: 30-33, 42-43.

${ }^{19} \mathrm{Cf}$. Svensson \& Grant 2003: 258-259. Segundo alguns filólogos, $\chi \lambda \omega \rho \alpha u ́ \chi \eta \nu$ refere-se ao chilreio vibrante e fresco (sinestesia) do rouxinol, porque Baquílides aplica este epíteto a Dejanira, 'colo de verdura', sublinhando a sua juventude (5. 172; cf. LSJ: 'with the bloom of youth on her neck'). Cf. G. E. Marindin, "The Word $\chi \lambda \omega \rho \alpha u ́ x \eta \nu$ in Simonides and Bacchylides", CR 12 (1898) 37; R. Resinski, "Deianeira's Neck in Bacchylides, Ode 5", Helios 27.1 (2000) 3-14. O termo $\chi \lambda$ $\lambda$ pó o 'verde' (Od. 16. 47, h.Ap. 223), 'verde amarelo' ou 'amarelo' (Il. 11. 631, Soph. Aj. 1064, Zopyr. ap. Orib. 14. 61. 1), 'verde pálido' ou 'pálido', como epíteto do terror (Il. 7. 479, h.Cer.

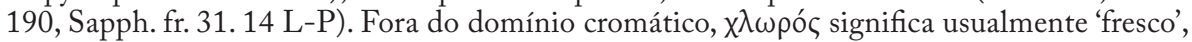
'verdejante' (cf. Hes. Op. 743, Pind. Nem. 8. 40, Ar. Ra. 559). A interpretação de uma palavra 
O segundo fragmento foi citado, juntamente com o fr. 345 L-P de Alceu, num escólio de As Aves, com a observação de que Aristófanes os teria parodiado na primeira fala do Sicofanta ${ }^{20}$ (schol. Av. 1410, p. 256 White = fr. 597, 92 P, $74 \mathrm{~B}, 46 \mathrm{D})$ :

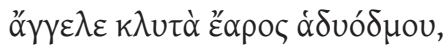

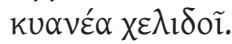

mensageiro famoso da Primavera de doces aromas, preta andorinha!

Em rigor, destes versos o comediógrafo ateniense reteve apenas o nome da andorinha, que não aparece no fragmento de Alceu. $\mathrm{O}$ ponto comum aos três passos é a acumulação de epítetos. Também aqui se verifica que Simónides

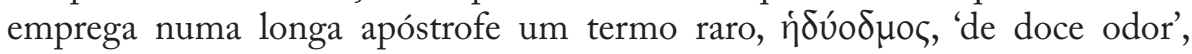
que tem neste passo a atestação mais antiga ${ }^{21}$, junto de dois adjectivos que ocorrem com frequência nos Poemas Homéricos e na poesia lírica, $k \lambda u \tau o ́ s$ e Kuáveo $\varsigma^{22}$. O efeito que se obtém é original, como notou Henderson 1998: 15 , mas os dois temas aqui evocados, o regresso do bom tempo e a plumagem predominantemente negra da ave, já estão presentes na abertura da canção ródia da andorinha (fr. 848.1-5 $P M G$ ), que pode remontar ao séc. VII ou VI²3.

Estes dois fragmentos são também uma prova do talento pictórico de Simónides, que se detém em particular nas notações de cor ( $\chi \lambda \omega \rho \alpha u ́ x \varepsilon v \varepsilon \zeta$,

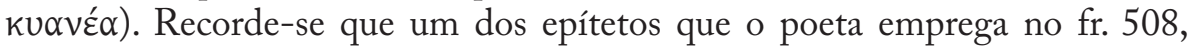

com um horizonte de sentidos tão vasto suscita, naturalmente, dificuldades e interpretações divergentes. Cf. Chantraine, s.v. $\chi \lambda \omega \rho o ́ \varsigma$, 'se dit d'un vert ou d'un jaune clair' (cf. Hsch. s.v.

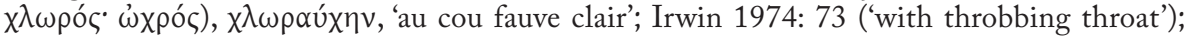

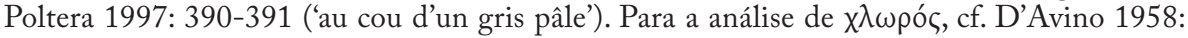

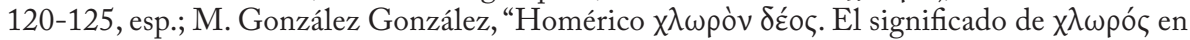
la poesía griega arcaica”, Minerva 18 (2005) 11-23.

${ }^{20}$ Ar. Av. 1410-1411: 'Que aves são estas - tesas que nem carapau -, de asas matizadas, ó andorinha de longas asas coloridas?' (trad. Maria de Fátima Silva, in Silva e Jesus 2010: 484).

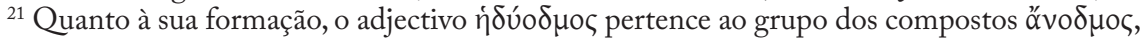

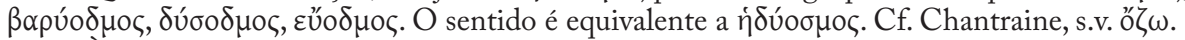

22 À excepção do fr. 567.4 (cf. supra), em Simónides (cf. frr 543. 12, fr. eleg. 21. 7), bem como em Íbico (fr. 287.1 PMG), Teógnis (v. 709), Píndaro (Ol.6. 40, fr. 33c. 6 Ma.) e Baquílides (13.64), o valor cromático predominante de kuáveos é negro (mais do que azul escuro), sendo, porém, mais poético do que $\mu \varepsilon ́ \lambda \alpha c$. Para um exame do sentido deste termo na poesia lírica grega e nos fragmentos de Simónides, cf. Irwin 1974: 99-109, Manieri 1990: 91, Ferreira 2007: 36-39.

${ }^{23}$ Cf. G. Murray et alii, The Oxford Book of Greek Verse (Oxford 1951) 166. Segundo informa Ateneu (8. 360b-d), o canto popular da ilha de Rodes era entoado por crianças às portas das casas, enquanto aguardavam pelos presentes dos moradores. Cf. F. Rodríguez Adrados, "La canción ródia de la golondrina y la cerámica de Tera", in El mundo de la lírica griega antigua (Madrid 1981) 311-331, e o nosso estudo "A canção ródia da andorinha (Carmina popularia, fr. 848 PMG)”, Boletim de Estudos Clássicos 46 (2006) 17-21. 


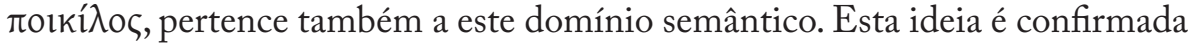
por um último fragmento a considerar neste capítulo, que nos foi transmitido por Plutarco (De profectibus in virtute 8. 79c = fr. 593, $88 \mathrm{P}, 47 \mathrm{~B}, 43 \mathrm{D})^{24}$ :

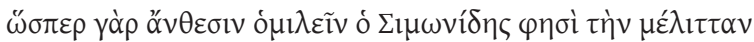

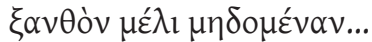

Pois como Simónides diz que a abelha se une às flores o louro mel preparando...

O primeiro aspecto a salientar é a sonoridade suave que emana da

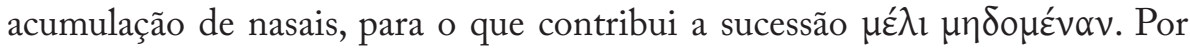

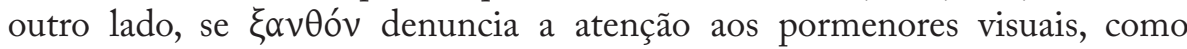
dissemos, pode ser também uma prova da criatividade do poeta, que se pode ter apoiado numa expressão homérica (Il. 11.631, Od.10. 234: $\mu$ ć $\left.\lambda_{1} \chi \lambda \omega \rho o ́ v\right)$, fazendo uso de um epíteto que era sobretudo atributo do cabelo ou da crina do cavalo ${ }^{25}$. Um passo da colectânea Anecdota Oxoniensia (III. 173.13 Cramer)

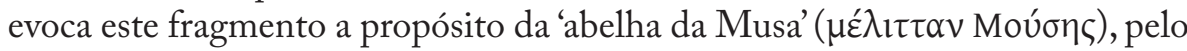
que alguns helenistas supõem que Simónides comparou o poeta (ou a Musa) com aquele insecto, procurando provavelmente sublinhar a doçura e distinção da sua $\operatorname{arte}^{26}$.

A palavra final é para a cigarra, que tem igualmente presença assídua na poesia grega desde os Poemas Homéricos. Referida no célebre símile do canto III da Ilíada, como termo comparativo do modo de falar dos anciãos (vv. 150-152) ${ }^{27}$, símbolo do canto melodioso e incansável nas longas tardes de Verão (cf. Hes. Op. 582-584, Alc. fr. 347. 2-3 L-P), não surpreende, por isso, que Simónides a tenha evocado nos seus poemas. Não chegou até nós nenhum fragmento, mas somente o testemunho de Estêvão de Bizâncio que,

${ }^{24} \mathrm{O}$ fragmento é também citado, sem indicação de autor, em P1. Ion 534a-b e Plu. De recta ratione audiendi $8.41 \mathrm{f}$, De amore prolis $2.494 \mathrm{a}$.

${ }^{25}$ Cf. D’Avino 1958: 118, para quem o sentido de $\xi \alpha v \theta o ́ \varsigma$ no fragmento de Simónides é “sicuramente giallo" (p. 119). Manieri 1990: 94 considera, mais do que o valor cromático, a ideia de luminosidade e brilho. Além dos fragmentos comentados, atestam a importância das referências cromáticas na poética de Simónides os frr. 517, 571 e 585. Para um estudo mais detalhado desta matéria, vide Ferreira 2007.

${ }^{26}$ Cf. Bergk ad loc., Bowra 1961: 362-363, Campbell 1991: 473, Henderson 1999: 98. Na opinião de W. J. Oates, The Influence of Simonides of Ceos upon Horace (Princeton 1932) 98-100, que tratou esta questão com algum detalhe, Simónides pode ter sido um dos primeiros poetas a estabelecer esta comparação, que também se encontra em Píndaro (Pyth. 4. 60, 10. 54, fr. 152 Ma.) e Baquílides (10.10). Cf. Ar. Av. 749, Ec. 973. Vide o elenco completo das fontes em Oates, ibidem, p. 99 n. 204. Além desta comparação, há outras referências à abelha na poesia grega arcaica. Cf. Alcm. fr. 89. 4 P; Semon. 7. 83-93 W; Sapph. 146 L-P; Pind. Ol. 6. 47, Pyth. 6. 54, frr. 123. $11 \mathrm{Ma}$.

${ }^{27}$ Cf. W. B. Stanford, “The Lily Voice of the Cicadas (Iliad 3. 152)”, Phoenix 23 (1969) 3-7. 


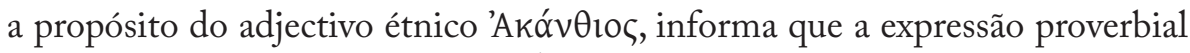

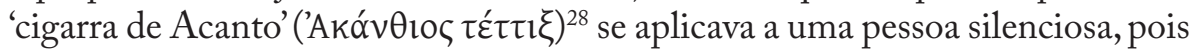
segundo Simónides as cigarras daquela região não cantavam ${ }^{29}$.

${ }^{28}$ Cf. Hdn.Gr. I. 119 Lentz; Diogenian. I. 22 L-S; Apostol. I. 100a, XVI. 32 L-S.

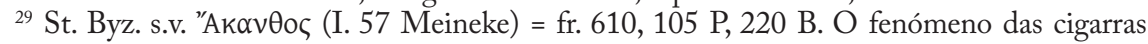
silenciosas é referido por Aristóteles (HA 4.7.532b14-17, 5.30.556a14-20) e Pausânias (6.6. 4). 
(Página deixada propositadamente em branco) 
Conclusões 
(Página deixada propositadamente em branco) 
Percorrido o itinerário que escolhemos, chegou o momento de apresentarmos as linhas fundamentais da nossa investigação. O estudo do corpus de um poeta arcaico na perspectiva da sua mobilidade implicava, em nosso entender, recuar até aos primórdios da literatura grega. $\mathrm{O}$ episódio de Tâmiris no canto II da Ilíada, as palavras de Eumeu a Antínoo no canto XVII da Odisseia e os vv. 650-662 de Trabalhos e Dias constituem os testemunhos literários mais antigos sobre a existência de poetas itinerantes no mundo grego. Os Poemas Homéricos associam esta realidade ao valor singular destes profissionais, mas podemos afirmar que desde o princípio, além do peso da tradição, a mobilidade decorre principalmente do carácter oral do ofício poético, que apenas se concretiza pela execução, no ambiente íntimo dos palácios ou em festas públicas.

São tardios e pouco seguros os testemunhos que nos permitem reconstituir a actuação dos líricos da Época Arcaica. A evolução política, económica e cultural deste longo período influenciou, naturalmente, as condições de produção e de execução poética. Diversificam-se as temáticas, surgem novas formas literárias, como o epinício, que exige do cantor uma atitude cada vez mais profissional. No entanto, não se alteraram significativamente os motivos que o incentivam a viajar: a participação em festivais ou competições musicais, cada vez mais organizados e numerosos, o desejo de alcançar maiores lucros, de que a lenda de Aríon é um bom exemplo, e a protecção oferecida por tiranos ou outros homens de poder, que é um fenómeno mais recente.

Assim, apesar dos riscos e dificuldades que sempre acompanharam os viajantes, no tempo de Simónides a mobilidade era um hábito enraizado na tradição, que continuava a justificar-se: tal como no passado, cabia ao poeta a tarefa de compor a letra e a música, de apresentar a obra e, tratando-se de uma peça coral, de preparar os executantes. Sobre estes assuntos sabemos muito pouco.

O carácter pan-helénico da obra de Píndaro e de Baquílides levou-nos a considerar, de modo muito breve, a possibilidade de terem enviado algumas das suas composições, quando não se podiam deslocar (principalmente à Sicília). Em nossa opinião, os exemplos discutidos confirmam essa hipótese, que a obra de Simónides não reflecte. A razão pode dever-se apenas ao estado muito mais fragmentado do seu corpus. No entanto, é plausível que esta prática se tenha divulgado nos últimos anos da sua vida, visto que a data mais antiga das odes em causa é o ano de 476. 


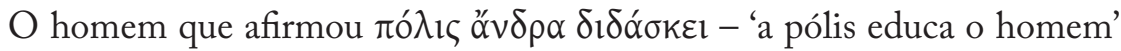
(fr. eleg. 90) - partilhou o seu talento e saber por toda a Hélade e alcançou uma fama perene, como cidadão e como poeta. Os traços de carácter que a tradição biográfica elegeu - a avareza, a criatividade, a sabedoria pragmática, que se fixou em máximas de alcance universal - reflectem a opinião dos Gregos do fim da Época Clássica, para quem Simónides havia sido, mais do que um exímio cultor das Musas, um Sábio. Mas para nós foi um homem atento aos acontecimentos históricos e políticos do seu tempo, que soube gerir com habilidade e sentido de oportunidade as suas relações.

Os testemunhos e fragmentos de que dispomos hoje não permitem reconstituir com segurança o percurso profissional de Simónides, mas sugerem, pelo menos, que conviveu com os poetas mais ilustres do seu tempo - Anacreonte, Xenófanes, Laso de Hermíone, Píndaro, Baquílides e Ésquilo - e que teve como patronos figuras de destaque da área política e militar. É plausível, por isso, que alguns acontecimentos históricos tenham condicionado esse percurso, especialmente a sua ida para a Tessália após a morte de Hiparco e a expulsão de Hípias de Atenas. É provável também que tenha regressado por altura das Guerras Medo-Persas.

Mas, à semelhança do que aconteceu com outros líricos, julgamos que a mobilidade de Simónides foi determinada sobretudo pela reputação que o seu talento consolidou e pela própria natureza do seu ofício. As breves informações de que compôs peanes, prosodia, um hino a Poséidon, um canto lírico no qual versava sobre a luta de Apolo contra Píton, bem como referências dispersas no seu corpus aos principais lugares sagrados do mundo grego, deixam supor que a deslocação a esses santuários tenha sido frequente. $\mathrm{Na}$ segunda parte notámos que o fr. 35 do P. Oxy. 2430 (= fr. 519) indicia que um dos seus peanes foi apresentado por Atenienses em Delos e um outro por cidadãos de Andros em Delfos. Pensamos que o poeta acompanhava as deslocações destes coros, mas não temos provas de que assim acontecia. Também não nos chegaram muitas informações sobre a composição de epinícios e, ao que parece, o seu papel foi determinante para a consolidação desta forma poética. Os cinco fragmentos que comentámos na terceira parte perfazem apenas um total de vinte e poucos versos e não podem ser, por isso, representativos da sua arte. Mesmo assim, vale a pena notar que dizem respeito a atletas da Eubeia, da Tessália, da Magna Grécia, talvez até de Egina, e que pertencem a odes compostas entre 520 e 476, ou seja, já numa fase madura da vida do poeta. Devemos, portanto, considerar a hipótese de a ida de Simónides para a Sicília, a convite de Hierão, não ter sido o início de uma carreira ocidental, mas antes a confirmação de contactos mais antigos. Os restantes fragmentos analisados na terceira parte corroboram a convivência do poeta com as famílias de Escopas e de Equecrátides, e a sua eleição como cantor da luta helénica contra os Persas. 
A maior parte dos fragmentos, porém, não nos fornece qualquer elemento sobre o tema central do nosso estudo, mas uma leitura da obra de Simónides não podia deixar de os incluir.

O comentário literário de um corpus fragmentado inscreve-se sempre no domínio do hipotético e as interpretações possíveis multiplicam-se. Os fragmentos que os editores integram habitualmente na secção dos trenos atestam a pervivência na poesia grega arcaica da reflexão de teor pessimista e moralista sobre as limitações do ser humano, sujeito à supremacia dos deuses, à instabilidade da fortuna e à inevitabilidade da morte. Não cremos que estas ideias sejam reveladoras do pensamento de Simónides. No entanto, noutros fragmentos deixou transparecer preocupações de natureza ética e política, designadamente quando versou sobre a dificuldade do homem em alcançar e manter a excelência ( $\alpha \rho \varepsilon \tau \eta ́)$ ao longo da sua vida, ou formulou o conceito de úүı̀̀ ơv ńp, ou seja, alguém que não é perfeito, mas actua em conformidade com as leis da sua pólis.

Assim, temos de supor que o tom sombrio de alguns dos seus versos mais célebres pode ser sobretudo fruto dos incidentes da transmissão literária, que apenas nos revela fragmentos do pensamento do poeta. Esta ideia é especialmente sugerida pelas últimas recuperações papirológicas, em particular pelo fr. eleg. 20, no qual se reflecte sobre o idealismo da juventude e a brevidade da vida, não com o pessimismo de Mimnermo, mas antes com a sabedoria de Sólon: com o tempo, os homens tornam-se mais sábios.

A celebração do sacrifício da vida pela defesa do interesse colectivo, da pátria ou de toda a Hélade, é um dos temas principais das composições relativas às Guerras Medo-Persas, bem como a noção de que esse gesto - é bela a morte

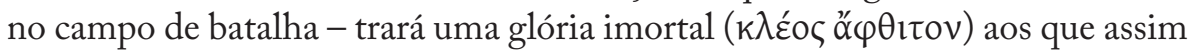
perderam a vida. Outro tema recorrente é a proclamação de que a derrota dos Persas significou a preservação da liberdade helénica. A publicação da 'Elegia de Plateias' confirmou o estatuto de Simónides como arauto da causa grega, mas também a sua versatilidade poética, dado que compôs sobre os principais confrontos deste conflito em metros líricos e elegíacos.

No segundo capítulo do nosso comentário reunimos os testimonia e fragmenta que contêm referências a deuses e a heróis. Apesar do estado deteriorado em que se encontra esta parte do corpus, que não permite conhecer a fundo o modo como Simónides teria tratado o legado mitológico, podemos traçar algumas linhas gerais.

São muito breves, em geral, as referências às divindades mais importantes do panteão grego e, a avaliar pelos versos que nos chegaram, até poderíamos pensar que os deuses constituíam um tema menor na poética de Simónides. Esta ideia é desmentida principalmente pelos $P$. Oxy. 2430, 2623 e 2624, cuja extensão e fragmentação nos impedem de apreciar estas composições, que se 
destinavam, supomos, a festas públicas, mas confirmam que a nossa perda é imensa.

A análise de outros fragmentos leva-nos a concluir que Simónides não se distanciou dos seus predecessores na selecção da matéria mitológica, mas acolheu essa herança com ousadia e liberdade poéticas. No fragmento mais extenso deste capítulo, detém-se num momento da infância de um herói, Perseu, dá voz à sua jovem mãe e compõe um dos passos mais comoventes da poesia grega. O contraste entre o sofrimento de Dânae e o sossego do filho, uma criança de colo, poderá ter sido um dos aspectos singulares do poema. O fr. 567 contém a referência literária mais antiga ao fascínio que Orfeu exercia sobre os seres da natureza e podia ter figurado em qualquer obra lírica. Simónides também alterou alguns dados do mito tradicional, como a afirmação de que o velo da Cólquida, habitualmente de ouro, era da cor da púrpura ou branco, e que Medeia havia rejuvenescido Jasão pela cozedura. Quando tratou a expedição de Teseu a Creta, introduziu outro pormenor cromático inovador: a vela que assinalava o êxito do príncipe ateniense não era branca, mas escarlate.

Os testemunhos e fragmentos actualmente disponíveis sugerem que os poetas mais influentes nesta área foram os épicos mais antigos e os líricos da Magna Grécia. Segundo o escoliasta da VIa Olimpica de Píndaro, Simónides seguiu Hesíodo ao falar da ascendência paterna de Astidamia. A influência de Íbico é especialmente notada nos testemunhos sobre temas passionais: a rivalidade entre Deífobo e Idomeneu por causa de Helena, a união de Aquiles com Medeia, quando chegou à Planura Elísia, e talvez também o sacrifício de Políxena sobre o túmulo do Pelida. Podíamos supor que Simónides teria preferido as versões dos líricos mais antigos, designadamente Estesícoro. Todavia, o fr. 564 testemunha que tanto o poeta de Hímera como Homero eram referências fundamentais na sua obra. Esta última ideia viria a ser confirmada pela 'Elegia de Plateias'.

$\mathrm{Na}$ breve introdução ao último capítulo do nosso comentário procurámos mostrar que a evocação da natureza está amplamente representada quer nos Poemas Homéricos quer na poesia da Época Arcaica. Muitas vezes fonte da linguagem figurativa, só raramente surge como tema principal. Simónides mantém-se fiel a esta tradição poética: adopta uma linguagem semelhante à dos seus antecessores e não parece demorar-se na descrição do mundo natural, ainda que esta ideia seja especialmente sugerida pelo estado fragmentado do seu corpus. As notas são breves e simples, mas profundamente evocativas da paisagem grega: o mar, os rios, o sopro dos ventos, os prados, as flores (mirto, rosas, violetas...), o carvalho viçoso, as aves e insectos vulgares (o rouxinol, a andorinha, o galo, a abelha, a cigarra...). Testemunham uma sensibilidade penetrante e um olhar atento à diversidade dos seres da natureza. Supomos 
que estas referências teriam várias motivações, além do seu valor estético: comparar a condição humana com a dos outros seres, recriar um ambiente ou fornecer indícios temporais, sublinhar o poder dos deuses...

Um dos aspectos que procurámos valorizar no nosso comentário foi o estilo. Não queremos, portanto, terminar este trabalho sem antes confrontarmos as nossas conclusões neste domínio com os testemunhos dos autores antigos.

Dionísio de Halicarnasso, em De Compositione Verborum, integra Simónides no grupo de poetas que praticaram com excelência o 'estilo polido' ( $ү \lambda \alpha \varphi$ pós), ao lado de Hesíodo, Safo e Anacreonte (23. 9). Num outro ensaio (Imit. 2. 420), destaca de Simónides a 'selecção dos nomes, o rigor da sua

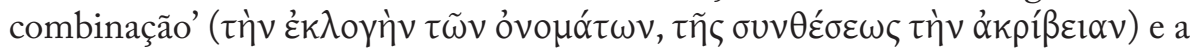
capacidade de 'suscitar a compaixão, não por meio de um estilo grandíloquo,

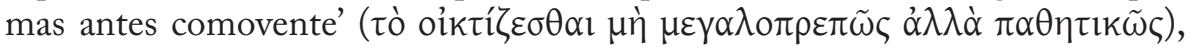
aspecto em que era considerado superior a Píndaro. Esta apreciação foi também registada por Quintiliano (Inst. 10.1.64) e se outros autores latinos, como Catulo (38. 7-8) e Horácio (Carm. 2. 1. 37-38), sublinharam a tristeza do canto de Simónides, os epigramas anónimos sobre os nove maiores líricos põem a ênfase na sua doçura e no deleite que despertava ( $A P$ 9. 184. 5, 571. 1-2).

Em nossa opinião, o fragmento que melhor ilustra estas ideias é precisamente o que Dionísio de Halicarnasso nos transmitiu sobre Dânae. Impressiona-nos, em especial, o modo como o poeta conseguiu criar um canto pleno de beleza e tristeza, aparentemente tão simples, como são as canções de embalar ou as preces dirigidas aos deuses, mas que é, na verdade, fruto de um aturado trabalho poético. Se a concisão vocabular domina todo o fragmento, o seu encanto resulta da selecção cuidada dos nomes, alguns deles pouco comuns, do rigor da sua combinação, do emprego de diversas figuras de retórica e do apelo constante às emoções, pela evocação de sensações visuais e auditivas. Como dissemos no comentário, ilustra na perfeição o talento pictórico do poeta, a capacidade de pôr em relevo, de um modo sucinto e claro, todos os pormenores que nos permitem sentir profundamente o desespero da mãe de Perseu.

Os aspectos que acabámos de enumerar encontram-se noutras composições, independentemente do seu subgénero. $\mathrm{O}$ fragmento sobre Arquémoro, apenas com dois versos, evidencia do mesmo modo o tom patético, o uso inovador dos epítetos, e a ênfase nos sons nasais é apropriada à evocação da morte do príncipe. Quando Simónides celebrou os espartanos que haviam tombado nas Termópilas (fr. 531), a ocasião exigia-lhe, talvez, um estilo grandíloquo, mas o poeta privilegiou a sobriedade, a expressão lapidar, a disposição rigorosa das palavras no verso, criando um jogo de simetria e de antíteses. Este tom austero e sentencioso predomina, naturalmente, nos versos de carácter gnómico, nos 
quais se destacam a expressão negativa, o aoristo gnómico e a presença de үó $\rho$ a anunciar a reflexão final. Como sabemos, estes aspectos não constituem traços particulares do estilo de Simónides, mas antes marcas do legado poético, que assimilou de um modo coerente e inovador.

É provável que a tradição literária tenha condicionado a sua técnica de composição. Os poetas arcaicos, em especial os líricos, dão grande relevo aos epítetos, à musicalidade do verso, à correspondência estreita entre o sentido e a forma, às referências cromáticas. A influência da cultura popular, que notámos no comentário aos frr. 508, 514, 515 e 543, é ainda uma marca da tradição poética. É também um processo literário tradicional a inclusão do discurso directo na narrativa mitológica, bem como a elaboração do poema a partir da evocação das palavras proferidas por uma figura célebre, um dos Sete Sábios ou poeta ilustre, para as corroborar ou refutar, que denuncia o pendor racionalista da poesia de Simónides. Podíamos ainda referir a

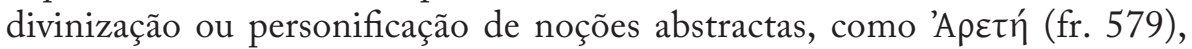

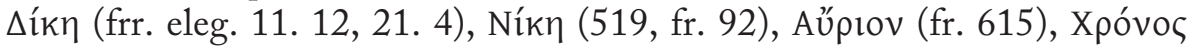
(fr. eleg. 88).

No domínio linguístico, um dos traços característicos da técnica de composição de Simónides é a busca constante de variedade, em particular no tratamento dos epítetos. A todo o momento, o poeta procura conciliar o legado poético (especialmente a linguagem épica) com a sua vontade de inovar, ora combinando termos da tradição com os que ele próprio inventava, ora atribuindo novos sentidos aos já existentes, ora diversificando o seu emprego. Por conseguinte, os fragmentos líricos confirmam o testemunho da Suda de que Simónides compusera em dialecto dórico, mas no qual estão quase sempre presentes formas épicas.

O seu talento criativo revela-se também no gosto pelos equívocos verbais e pela ambiguidade (cf. fr. 531). Os escólios de Aristófanes que transmitiram o fragmento sobre Crio de Egina informam que o poeta fez um jogo de palavras com o nome do atleta, conferindo ao incipit da ode um tom humorístico cujo alcance não podemos apreciar por inteiro. $\mathrm{O}$ relevo dado às palavras

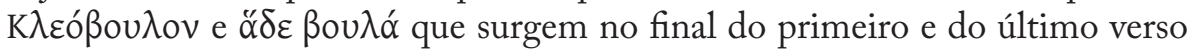
do fr. 581, oferece-nos outro exemplo de um jogo de palavras com o nome de uma figura (cf. Anacr. fr. 357. 9-10 $P M G$ ), num fragmento que ilustra em particular a faceta satírica de Simónides. A habilidade para obter grandes efeitos poéticos com humor e ironia depreende-se também do fr. 515, que exemplifica ainda o emprego da perífrase, recorrente nos epinícios.

Vale a pena recordar ainda outros recursos retóricos. No comentário ao fr. 521, chamámos a atenção para a comparação singular entre uma realidade visível e familiar, o volver da mosca, e uma noção abstracta elevada, a mudança de fortuna. Vários fragmentos ilustram o emprego da metáfora e há, pelo 
menos, dois exemplos de símile, que integravam epinícios (cf. fr. 508; 519, fr. 92).

Finalmente, cremos que a qualidade principal do trabalho poético de Simónides é a versatilidade, no modo singular como acolheu e renovou a herança poética e, especialmente, no tratamento exímio quer dos ritmos líricos quer dos elegíacos. Como bem notou Hutchinson 2001: 289, neste último ponto Simónides não teve mestres nem discípulos. 
(Página deixada propositadamente em branco) 
Bibliografia 
(Página deixada propositadamente em branco) 


\section{Edições, traduções E COMENTÁRIOS}

\section{Antologia Grega}

Gow, A. S. F., Page, D. L. 1965. The Greek Anthology: Hellenistic Epigrams. 2 Vol. Cambridge.

Page, D. L. 1975. Epigrammata Graeca. Oxonii. 1981. Further Greek Epigrams. Cambridge. [FGE]

Paton, W. R. 1916-1918. The Greek Anthology. 5 vols. Cambridge, Mass.

Waltz, P., Desrousseaux, A.-M., Dain, A., Camelot, P., des Places, E. 1938. Anthologie Grecque. $1^{e}$ partie. Anthologie Palatine. Tome IV. Paris.

Waltz, P., des Places, E., Dumitrescu, M., Le Maitre, H., Soury, G. 1960. Anthologie Grecque. $1^{e}$ partie. Anthologie Palatine. Tome V. Paris.

Beckby, H. ${ }^{2}$ 1965-1968. Anthologia Graeca. 4 vols. München.

\section{Aristófanes}

Coulon, V., Van Daele, H. 22002 [1923-1930]. Aristophane. Comédies. 5 vols. Paris.

Silva, M. F., Magueijo, C. 2006. Aristófanes. Comédias I. Lisboa.

Silva, M. F., Jesus, C. A. M. 2010. Aristófanes. Comédias II. Lisboa.

\section{Ateneu}

Gulick, C. B. 1927-1941. Athenaeus: Deipnosophistae. 7 vols. Cambridge, Mass.

\section{Calímaco}

Pfeiffer, R. ${ }^{2}$ 1965. Callimachus. 2 vols. Oxonii. [Pf.]

\section{Diodoro Sículo}

Oldfather, C. H. et alii. 1933-1967. Diodorus of Sicily. 12 vols. Cambridge, Mass.

\section{Dionísio de Halicarnasso}

Aujac, G., Lebel, M. 1981. Denys d'Halicarnasse. Opuscules rhétoriques. Tome III: La composition stylistique. Paris. 
Mobilidade poética na Grécia antiga: uma leitura da obra de Simónides

\section{Ésquilo}

Fraenkel, E. ${ }^{2}$ 1962. Aeschylos. Agamemnon. 2 vols. Oxford.

Radt, S. 1985. Tragicorum Graecorum Fragmenta (TrGF). Vol. 3: Aeschylus. Göttingen. [Radt]

\section{Eurípides}

Diggle, J. 1981-1994. Euripidis Fabulae. 3 vols. Oxonii.

\section{Heródoto}

Leão, D. F. 2000. Heródoto. Histórias. Livro 6º. Lisboa.

Macan, R. W. 1973 [1895]. Herodotus. The Fourth, Fifth, and Sixth Books. Vols. I and II. New York.

Rocha Pereira, M. H., Ferreira, J. R., Silva, M. F. 1994. Heródoto. Histórias. Livro $1^{0}$. Lisboa.

Rosén, H. B. 1987. Herodoti Historiae. Vol I. Leipzig. 1997. Herodoti Historiae. Vol II. Stutgardiae et Lipsiae.

Strassler, R. B. 2007. The Landmark Herodotus. The Histories. New York.

\section{Hesíodo}

Mazon, P. ${ }^{16} 2002$ [1928], Hésiode. Théogonie, Les Travaux et les Jours, Bouclier. Paris.

Merkelbach, R., West, M. L. 1967. Fragmenta Hesiodea. Oxford. [M-W]

Pinheiro, A. P. E., Ferreira, J. R. 2005. Hesiodo. Teogonia. Trabalhos e Dias. Lisboa.

West, M. L. 1966. Hesiod. Theogony. Oxford. 1978. Hesiod. Works \& Days. Oxford.

\section{Homerica}

Allen, T. W., Halliday, W. R., Sikes, E. E. ${ }^{2}$ 1936. The Homeric Hymns. Oxford. Allen. T. W. ${ }^{2}$ 1917-1919. Homeri Opera III-IV. Oxonii.

21946. Homeri Opera V. Oxonii.

Càssola, F. 1975. Inni Omerici. Milano.

Dawe, R. D. 1993. The Odyssey: Translation and Analysis. Lewes. 
Edwards, M. W. 1991. The Iliad: A Commentary. Vol. V. Cambridge.

Hainsworth, B. 1993. The Iliad: A Commentary. Vol. III. Cambridge.

Heubeck, A., West, S., Hainsworth, J. B. 1988. A Commentary on Homer's Odyssey. Vol. I. Oxford. [Heubeck 1988, S. West 1988, Hainsworth 1988]

Heubeck, A., Hoekstra, A. 1989. A Commentary on Homer's Odyssey. Vol. II. Oxford.

Janko, R. 1992. The Iliad: A Commentary. Vol. IV. Cambridge.

Kirk, G. S. 1985. The Iliad: A Commentary. Vol. I. Cambridge.

1990. The Iliad: A Commentary. Vol. II. Cambridge.

Lourenço, F. 2003. Homero. Odisseia. Lisboa.

2005. Homero. Ilíada. Lisboa.

MacLeod, C. W. 1982. Homer. Iliad. Book XXIV. Cambridge.

Richardson, N. J. 1993. The Iliad: A Commentary. Vol. VI. Cambridge.

Russo,J., Fernández-Galiano, M.,Heubeck, A. 1992. A Commentary on Homer's Odyssey. Vol. III. Books XVII-XXIV. Oxford.

Van Thiel, H. 1991. Homeri Odyssea. Hildesheim. 1996. Homeri Ilias. Hildesheim.

Von der Mühll, P. ${ }^{3} 1962$. Homeri Odyssea. Stuttgart.

West, M. L. 1998. Homerus Ilias (I-XII). Stutgardiae et Lipsiae.

- 2000. Homerus Ilias (XIII-XXIV). Monachii et Lipsiae.

2003a. Greek Epic Fragments from the Seventh to the Fifth Centuries BC. Cambridge, Mass.

2003b. Homeric Hymns, Homeric Apocrypha, Lives of Homer. Cambridge, Mass.

Willcock, M. M. 1978. The Iliad of Homer (I-XII). London. 1984. The Iliad of Homer (XIII-XXIV). London.

\section{Inscrições}

$I G=$ Inscriptiones Graecae (Berlin 1902-).

SEG $=$ Supplementum Epigraphicum Graecum (Leiden 1923-).

Dittenberger, W. 1982. Sylloge Inscriptionum Graecarum. 4 vols. Hildesheim. [SIG] 
Hansen, P. A. 1983. Carmina Epigraphica Graeca. Berlin and New York.

Meiggs, R., Lewis, D. 1975. A Selection of Greek Historical Inscriptions to the End of the Fifth Century B.C. Oxford.

\section{Líricos, elegíacos e iambógrafos}

Bergk, Th. ${ }^{4}$ 1882. Poetae Lyrici Graeci. Pars III: Poetae Melici. Leipzig. [B]

Campbell, D. A. ${ }^{2}$ 1982. Greek Lyric Poetry: A Selection of Early Greek Lyric, Elegiac and Iambic Poetry. Bristol.

Campbell, D. A. ${ }^{21990-1993 . ~ G r e e k ~ L y r i c . ~} 5$ vols. Cambridge, Mass. [Campbell] 1988. Vol.II: Anacreon, Anacreontea, Choral Lyric from Olympus to Alcman; 1991. Vol. III: Stesichorus, Ibycus, Simonides, and Others; 1992. Vol. IV: Bacchylides, Corinna, and Others;

1993. Vol. V: The New School of Poetry and Anonymous Songs and Hymns.

Davies, M. 1991. Poetarum Melicorum Graecorum Fragmenta I. Oxford.

Diehl, E. ${ }^{21942 . ~ A n t h o l o g i a ~ L y r i c a ~ G r a e c a . ~ V o l . ~ I I . ~ L e i p z i g . ~[D] ~}$

Gentili, B., Prato, C. 2002. Poetae Elegiaci II. Editio altera Novis Simonidis fragmentis aucta. München-Leipzig.

Gerber, D. E. 1970. Euterpe: An Anthology of Early Greek Lyric, Elegiac, and Iambic Poetry. Amsterdam.

__ 1999a. Greek Elegiac Poetry. Cambridge, Mass. 1999b. Greek Iambic Poetry. Cambridge, Mass.

Hutchinson, G. O. 2001. Greek Lyric Poetry: A Commentary on Selected Larger Pieces. Oxford.

Jesus, C. A. M. 2008. Arquíloco. Fragmentos poéticos. Lisboa.

Lobel, E., Page, D. L. 1963. Poetarum Lesbiorum Fragmenta. Oxford. [L-P]

Lourenço, F. 2006a. Poesia Grega de Álcman a Teócrito. Lisboa.

Maehler, H. ${ }^{11}$ 2003. Bacchylides. Carmina cum fragmentis. Leipzig. [Ma.]

Page, D. L. 1962. Poetae Melici Graeci. Oxford. [P (numeração individual de cada poeta) e $P M G$ (numeração contínua)] 1974. Supplementum Lyricis Graecis. Oxford. [SLG]

Rocha Pereira, M. H. ${ }^{10} 2009$. Hélade. Antologia da Cultura Grega. Lisboa.

Schneidewin, F. G. 1835. Simonidis Cei carminum reliquiae. Brunsvigae.

Sider, D. 2001a. "Fragments 1-22 W²: Text, Apparatus Criticus, and Translation", in Boedeker and Sider 2001: 13-29. 
West, M. L. ${ }^{2} 1989$. Iambi et Elegi Graeci ante Alexandrum Cantati. Vol. I. Oxford. [W]

21992a. Iambi et Elegi Graeci ante Alexandrum Cantati. Vol. II. Oxford. [W]

1993a. Greek Lyric Poetry. The poems and fragments of the Greek iambic, elegiac, and melic poets (excluding Pindar and Bacchylides) down to 450 BC. Oxford.

\section{Logógrafos}

Jacoby, F. 1926-1958. Die Fragmente der griechischen Historiker. Leiden. [FGrHist

Müller, K. 1828-1883. Fragmenta Historicorum Graecorum. Paris. [FHG]

\section{Papiros $^{1}$}

Grenfell, B. P., Hunt, A. S. 1899. "List of Olympian Victors", The Oxyrhynchus Papyri 2. London: 85-95.

__ 1922. "Miscellaneous Biographies", The Oxyrhynchus Papyri 15. London: 137-150.

Lobel, E., Roberts, C. H. 1954. “2327. Early Elegiacs”, The Oxyrhynchus Papyri 22. London: 67-76.

Lobel, E., Turner, E. G., Winnington-Ingram, R. P. 1959. The Oxyrbynchus Papyri 25. London.

Lobel, E., West, M. L., Turner, E. G. 1967. The Oxyrhynchus Papyri 32. London.

Lobel, E. 1981. "Simonides", in Papyri Greek and Egyptian Edited by Various Hands in Honour of Eric Gardner. London: 21-23.

Parsons, P. J. 1992. “3965. Simonides, Elegies”, in Handley, E. W. et alii. The Oxyrhynchus Papyri 59. London: 4-50.

\section{Pausânias}

Rocha Pereira, M. H. ${ }^{2}$ 1989-1990. Pausaniae Graeciae Descriptio. 3 vols. Lipsiae. Musti, D., Torelli, M. ${ }^{3}$ 1997a. Pausania. Guida della Grecia. Libro II. Milano. 31997b. Pausania. Guida della Grecia. Libro IV. Milano.

\footnotetext{
${ }^{1}$ A digitalização dos papiros de Oxirrinco está disponível online no site http://www. papyrology.ox.ac.uk/POxy/ [acedido em 26/07/2012].
} 
Mobilidade poética na Grécia antiga: uma leitura da obra de Simónides

\section{Píndaro}

Gentili, B. et alii. 1995. Pindaro. Le Pitiche. Milano.

Maehler, H. 1989. Pindarus. Pars II: Fragmenta, Indices. Leipzig. [Ma.]

Privitera, G. A. 1982. Pindaro. Le Istmiche. Milano.

Race, W. H. 1997a. Pindar: Olympian Odes, Pythian Odes. Cambridge, Mass. 1997b. Pindar: Nemean Odes, Isthmian Odes, Fragments. Cambridge, Mass.

Rocha Pereira, M. H. 2003. Sete Odes de Pindaro. Porto.

Snell, B., Maehler, H. ${ }^{81987 . ~ P i n d a r u s . ~ P a r s ~ I: ~ E p i n i c i a . ~ L e i p z i g . ~}$

Suárez de la Torre, E. 1988a. Pindaro: Obra completa. Madrid.

Willcock, M. M. 1995. Pindar. Victory Odes (Ol. 2, 7, 11; Nem. 4; Isth. 3, 4, 7). Cambridge.

\section{Platão}

Burnet, J. 1967-1968 [1900-1907]. Platonis Opera. 5 vols. Oxonii. Jabouille, V. 1999. Platão. Ín. Mem Martins.

Murray, P. 1996. Plato on Poetry: Ion; Republic 376e-39869; Republic 595608610. Cambridge.

Pinheiro, A. P. E. 1999. Platão. Protágoras. Lisboa.

\section{Plutarco}

Babbitt, F. C. et alii. 1927-1969. Plutarch: Moralia. 16 vols. Cambridge, Mass. Bowen, A. 1992. The Malice of Herodotus (de Malignitate Herodoti). Warminster. Lasserre, F. 1954. Plutarque. De la musique. Olten-Lausanne.

Leão, D. F. 1999. Plutarco. Vida de Sólon. Lisboa.

Perrin, B. 1914-1926. Plutarch: The Parallel Lives. 11 vols. Cambridge, Mass.

Soares, C., Rocha, R. 2010. Plutarco. Obras Morais - Sobre o Afecto aos Filhos, Sobre a Música. Coimbra. Disponível online: https://bdigital.sib.uc.pt/ jspui/handle/123456789/43 [acedido em 26/07/2012].

\section{Pré-Socráticos}

Diels, H., Kranz, W. 1951-1952. Die Fragmente der Vorsokratiker. 3 vols. Berlin. $[\mathrm{D}-\mathrm{K}]$ 


\section{Sófocles}

Lloyd-Jones, H., Wilson, N. G. ${ }^{2} 1992$. Sophoclis Fabulae. Oxonii.

Rocha Pereira, M. H., Ferreira, J. R., Fialho, M. C. 2003. Sófocles. Tragédias. Coimbra.

\section{Teócrito}

Gow, A. S. F. ${ }^{2} 1965$ a. Theocritus. Vol. I: Introduction, Text, and Translation. Cambridge.

—_ ${ }^{2}$ 1965b. Theocritus. Vol. II: Commentary, Appendix, Indexes, and Plates. Cambridge.

\section{Terpandro}

Gostoli, A. 1990. Terpander. Veterum testimonia collegit fragmenta edidit. Roma.

\section{Tucídides}

Jones, H. S., Powell, J. E. ${ }^{2}$ 1942. Thucydidis Historiae. 2 vols. Oxonii.

Strassler, R. B. 1998. The Landmark Thucydides. A Comprehensive Guide to the Peloponnesian War. New York.

\section{Xenofonte}

Marchant, E. C. ${ }^{2}$ 1921. Xenophontis opera omnia. Oxonii. 
(Página deixada propositadamente em branco) 


\section{Estudos}

Acosta-Hughes, B. 2010. "Simonides Recalled: Imitations of a Poikilos Original", in Arion's Lyre. Archaic Lyric into Hellenistic Poetry. Princeton and Oxford: 171-213.

Adkins, A. W. H. 1960. Merit and Responsibility: A Study in Greek Values. Oxford.

1972. Moral Values and Political Behaviour in Ancient Greece: From Homer to the End of the Fifth Century. London.

Aloni, A. 1994. "L'elegia di Simonide dedicata alla bataglia di Platea (Sim. Frr. 10-18 $\mathrm{W}^{2}$ ) e l'occasione della sua performance", ZPE 102: 9-22.

_ 2001. "The Proem of Simonides'Plataea Elegy and the Circumstances of Its Performance", in Boedeker and Sider 2001: 86-105.

_ 2009. "Elegy. Forms, functions and communication", in Budelmann 2009: 168-188.

Anderson, W. D. 1994. Music and Musicians in Ancient Greece. Ithaca and London.

André, J.-M., Baslez, M.-F. 1993. Voyager dans l'Antiquité. Paris.

Andrewes, A. 1956. The Greek Tyrants. London.

Araújo, L. M., Rodrigues, N. S. 2006. As comunicações na Antiguidade. Lisboa.

Arrighetti, G. 1994. "Stesicoro e il suo pubblico", MD 32: 9-30.

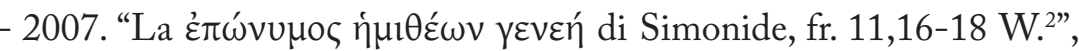
Eikasmos 18: 89-98.

Asheri, D. 2004. "Simonide, Achille e Pausania figlio di Cleombroto", QUCC 77.2: 67-73.

Austin, N. 1967. "Idyll 16: Theocritus and Simonides", TAPhA 98: 1-21.

Babut, D. 1971. “Sémonide et Mimnerme”, REG 84: 17-43.

1975. "Simonide moraliste", REG 88: 20-62.

Bagordo, A. 1999. “Eine Bemerkung zum Epinikion”, Hermes 127: 118-120.

Balasch, M. 1967. “Sófocles y Simónides”, BIEH 1: 45-63.

Barchiesi, A. 1995. "Simonide e Orazio sulla morte di Achille", ZPE 107: 33-38.

1996. "Poetry, Praise, and Patronage: Simonides in Book 4 of Horace's 
Odes", CA 15: 5-47.

Barigazzi, A. 1963. "Nuovi frammenti delle elegie di Simonide (Ox. Pap. 2327)", $M H$ 20, fasc. 2: 61-76.

Barrett, W. S. 1978. "The Oligaithidai and their victories (Pindar, Olympian 13; SLG 339, 340”, in Dawe, R. D., Diggle, J., Easterling, P. E. edd. 1978. Dionysiaca. Nine Studies in Greek Poetry by former Pupils presented to Sir Denys Page on his seventieth Birthday. Cambridge: $1-20$.

Barrigón, Ma C. 1988. "Reflexiones sobre el P. Oxy. 2623”, Minerva 2: 47-63. 1994a. "Los dioses en Simónides de Ceos", Actas del VIII Congreso Español de Estudios Clásicos, vol. III. Madrid: 77-84.

1994b. "La condición social del atleta en la Grecia arcaica y los epinicios de Simónides de Ceos", H. Ant. 18: 477-492.

1996. "Plutarco y Simónides de Ceos”, in Fernández Delgado, J. A., Pordomingo Pardo, F. edd. 1996. Estudios sobre Plutarco: Aspectos formales. Madrid: 447-458.

1998. "Observaciones sobre Sim. fr. 22 West"”, in Gil, L., Martínez Pastor, M. R., Aguilar, Ma . edd. 1998. Corolla Complutensis. Homenaje al Profesor José S. Lasso de la Vega. Madrid: 139-146.

- 2000. "La désignation des héros et hérö̈nes dans la poesie lyrique grecque", in Pirenne-Delforge, V., Suárez de la Torre, E. edd. 2000. Héros et héroines dans les mythes et les cultes grecs. Liège (Kernos, suppl. 10): 1-14.

2002. "La expresión del sentimiento amoroso en Simónides", Humanitas 54: 9-33.

Barron, J. P. 1964. “The Sixth-Century Tyranny at Samos”, CQ 14: 210-229. 1984. "Ibycus: Gorgias and other Poems”, BICS 31.1: 13-24.

Bartol, K. 1999. "Between Loyalty and Treachery. P. Oxy. 2327 fr. 1 + 2(a) col. 1 = Simonides 21 West - Some Reconsiderations", ZPE 126: 26-28.

Baslez, M.-F. 1984. L'Étranger dans la Grèce Antique. Paris.

Bearzot, C. 1997. "P. Oxy. 3965: Considerazioni sulla data e sull'ispirazione dell'elegia di Simonide per la battaglia di Platea", in Kramer, B. et al. edd. 1997. Akten des 21. Internationalen Papyrologenkongresses I. Stuttgart: 71-79.

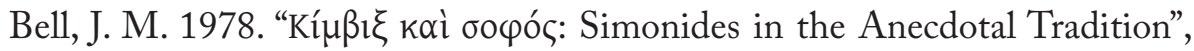
QUCC 28: 29-86.

Bernardini, P. A. 1969. “Simonide: rassegna critica delle edizioni, traduzioni e 
studi dal 1949 al 1968 (1969)”, QUCC 8: 140-168.

1980. "Esaltazione e critica dell'atletismo nella poesia greca dal VII al V sec. a. C. Storia di un'ideologia”, Stadion 6: 81-111.

Bing, P., Bruss, J. S. edd. 2007. Brill's Companion to Hellenistic Epigram. LeidenBoston.

Boas, M. 1905. De Epigrammatis Simonideis. Groningen. Disponível online: http://archive.org/details/deepigrammatiss00boasgoog [acedido em 26/07/2012].

Boedeker, D. 1995. "Simonide on Plataea: narrative elegy, mythodic history", ZPE 107: 217-229.

2001a. "Heroic Historiography: Simonides and Herodotus on Plataea", in Boedeker and Sider 2001: 120-134 = Arethusa 29.2 (1996) 223-242.

2001b. "Paths to Heroization at Plataea", in Boedeker and Sider 2001: 148-163 = Fisher, N., Van Wees, H. edd. 1998. Archaic Greece: Nerw Approaches and New Evidence. Cardiff: 231-249.

Boedeker, D., Sider, D. edd. 2001. The New Simonides. Contexts of Praise and Desire. Oxford.

Boegehold, A. 1965. “The Salamis Epigram”, GRBS 6.3: 179-186.

Bowie, E. L. 1986. "Early Greek Elegy, Symposium and Public Festival”, JHS 106: 13-35.

2009. "Wandering poets, archaic style", in Hunter and Rutherford 2009: 105-136.

Bowra, C. M. 1933. "Simonides on the Fallen of Thermopylae", CPh 28.4: 277-281.

—_ 1938, repr. 1969. Early Greek Elegists. New York. ${ }^{2}$ 1961. Greek Lyric Poetry from Alcman to Simonides. Oxford.

1963. “Two Lines of Eumelus”, CQ 13.2: 145-153 = On Greek Margins (Oxford 1970) 46-58.

1964. Pindar. Oxford.

Bravi, L. 2006. Gli epigrammi di Simonide e le vie della tradizione. Roma.

2009. “Tre corone: Simonide ep. X; Erodoto 8, 59 e 123 s.”, QUCC 92.2: 73-83.

Bremer, J. M. 1991. "Poets and their Patrons", in von Hofman, H. ed. 1991. Fragmenta Dramatica. Beiträge zur Interpretation der griechischen Tragikerfragmente un ibrer Wirkungsgeschichte. Göttingen: 39-60.

Bremmer, J. N. 2006. "The Rise of the Hero Cult and the New Simonides", 
ZPE 158: 15-26.

Brillante, C. 2000. "Simonide, fr. eleg. 22 West", QUCC 64.1: 29-38. 2007. "Omero, Simonide e l'elegia di Platea", Eikasmos 18: 99-118.

Brown, C. G. 1991. "The Prayers of the Corinthian Women: (Simonides, Ep. 14 Page, FGE)”, GRBS 32: 5-14.

Buck, C. A. 1955. The Greek Dialects. Chicago.

Budelmann, F. ed. 2009. The Cambridge Companion to Greek Lyric. Cambridge.

Buongiovanni, A. M. 1998. "Ou min ego momsomai: la rilevanza encomiastica di Simonide, $P M G$ 542”, SCO 46.3: 1033-1047.

Burkert, W. 1979. "Kynaithos, Polycrates, and the Homeric Hymn to Apollo", in Bowersock, G. W., Burkert, W., Putnam, M. C. J.edd.1979. Arktouros. Berlin-New York: 53-62 = Kleine Schriften I: Homerica (Göttingen 2001) 189-197.

1983. Homo Necans. The Anthropology of Ancient Greek Sacrificial Ritual and Myth. Berkeley.

1993 [31977]. Religião grega na época clássica e arcaica. Trad. M. J. Simões Loureiro. Lisboa.

_ 2001. "The Making of Homer in the Sixth Century B.C.: rhapsodes uersus Stesichorus", in Kleine Schriften I: Homerica, pp. 198-217 (= Papers on the Amasis Painter and his World. Malibu. 1987: 43-62).

Burnett, A. P. 2005. Pindar's Songs for Young Athletes of Aigina. Oxford.

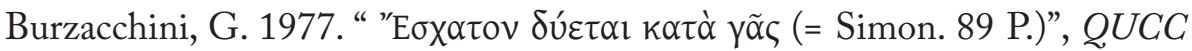
25: 31-41.

1995. "Note al nuovo Simonide", Eikasmos 11.3: 21-38.

Campbell, D. A. 1983. The Golden Lyre: The Themes of the Greek Lyric Poets. London.

Capra, A. 2001. "«Addio, Achille», o il commiato dall' epos (Simon. fr. 11, 13$\left.21 \mathrm{~W} .^{2}\right)$ ", Eikasmos 12: 43-54.

2004. "Simonide e le corone di Omero (Simon. 47k Campbell = 10,2 Lanata e fr. 11 West $^{2}$ )", in Zanetto 2004: 101-126.

Capra, A., Curti, M. 1995. "Semidei Simonidei: note sull'elegia di Simonide per la battaglia di Platea”, ZPE 107: 27-32.

1996. "Corrigenda", ZPE 113: 248.

Carey, C. 2007. "Pindar, Place, and Performance", in Hornblower and Morgan 2007: 199-210. 
Carson, A. 1992a. "How not to read a poem: unmixing Simonides from Protagoras”, CPh 87: 110-130.

1992b. "Simonides painter", in Hexter, R., Selden, D. edd. 1992. Innovations of Antiquity. New York-London: 51-64.

Casson, L. 1994 [1974]. Travel in the Ancient World. Baltimore-London.

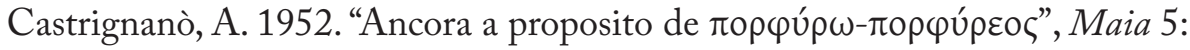
$118-121$.

Catenacci, C. 2000. "L'eros impossibile e ruoli omoerotici (Simonide fr. 21 West²)", QUCC 66.3: 57-67.

2001. "Simonide e i Corinzi nella battaglia di Platea (Plut. De Herodt. malign. 872d-e = Simon. frr. 15-16 West²)", QUCC 67.1: 117-131.

Christesen, P. 2007. Olympic Victor Lists and Ancient Greek History. Cambridge.

Cingano, E. 1990. "L'opera di Ibico e di Stesicoro nella classificazione degli antichi e dei moderni", AION 12: 189-224.

1993. "Indizi di esecuzione corale in Stesicoro", in Pretagostini 1993: 347-361.

___ 2003. "Entre skolion et enkomion: Réflexions sur le «genre» et la performance de la lyrique chorale grecque", in Jouanna, J., Leclant, J. edd. 2003. La poésie grecque antique. Paris: 17-45.

Citti, V. 1987. "Il lenzuolo funebre della tirannide. A proposito di Simon. 89 P.", Prometheus 13.1: 11-12.

Clay, J. S. 1997. “The Homeric Hymns”, in Morris and Powell 1997: 489-507. 2001. “The New Simonides and Homer's Hemitheoi”, in Boedeker and Sider 2001: 182-184 = Arethusa 29.2 (1996) 243-245.

Crotty, K. 1982. Song and Action. The Victory Odes of Pindar. Baltimore.

D'Alessio, G. B. 2009. "Defining local identities in Greek lyric poetry", in Hunter and Rutherford 2009: 137-167.

D'Alfonso, F. 1994. Stesicoro e la performance. Studio sulle modalità esecutive dei carmi stesicorei. Roma. 2003. "Il ringiovanimento nelle terre dell'utopia. (Simonides $22 \mathrm{~W}^{2}=$ P.Oxy. 2327 fr. 3 + 2a col.ii + b + 4 + P.Oxy. 3965 fr. 27)", RCCM 15.1: 7-32.

D’Angour, A. 1997. "How the Dithyramb Got its Shape”, CQ 47.2: 331-351.

D’Avino, R. 1958. "La visione del colore nella terminologia greca”, RicLing 4: 99-134.

Darcus, S. M. 1979. “A Person's Relation to భuxń in Homer, Hesiod, and the 
Greek Lyric Poets", Glotta 57: 30-39.

Davies, M.1988. "Monody, Choral Lyric, and the Tyranny of the Hand-book", CQ 38.1: 52-64.

Davison, J. A. 1968. From Archilochus to Pindar. London.

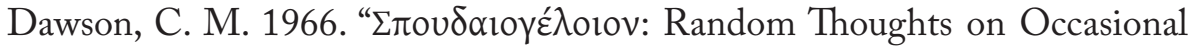
Poems”, YCIS 19: 39-76.

De Martino, F., Vox, O. 1996. "Eumelo", in Lirica Greca. Vol. 1: Prontuarie e lirica dorica. Bari: 112-117.

Des Places, É. 1969. “Simonide et Socrate dans le «Protagoras» de Platon”, LEC 37: 236-244.

Detienne, M.1964. “Simonide de Céos ou la sécularisation de la poésie”, $R E G$ 77: 405-419.

Dickie, M. 1978. "The Argument and Form of Simonides $542 P M G$ ", HSPh 82: 21-33.

Dillon, M., Garland, L. 1994. Ancient Greece. Social and Historical Documents from Archaic Times to the Death of Socrates (c. 800-399 BC). LondonNew York.

Dodds, E. R. 1951. The Greeks and the Irrational. Berkeley (trad. port. de Leonor Santos B. de Carvalho: Lisboa 1988).

Donlan, W. 1969. “Simonides, Fr. 4 D and P. Oxy. 2432”, TAPhA 100: 71-95.

Drees, L. 1968. Olympia. Gods, Artists and Athletes. London.

Dunbabin, T.J. 1948. “The Early History of Corinth”, JHS 68: 59-69.

Easterling, P. E. 1974. “Alcman 58 and Simonides 37”, PCPhS 20: 37-43.

Easterling, P. E., Knox, B. M. edd. 1985. The Cambridge History of Classical Literature. Vol I. Part I. Cambridge.

Egoscozábal, C. 2000. "Epítetos épicos compuestos más imitados por los líricos arcaicos”, Faventia 22.2: 13-26. Disponível online: http://ddd.uab.cat/ pub/faventia/02107570v22n2/02107570v22n2p13.pdf [acedido em 3/2/2011].

Ehrenberg, V. 1964. Society and Civilization in Greece and Rome. Harvard.

Fantuzzi, M. 2001. "Heroes, Descendents of Hemitheoi: The Proemium of Theocritus and Simonides 11 W" $^{2}$, in Boedeker and Sider 2001: 232241 = Prometheus 24.1 (1998) 97-110.

Farnell,L.R.1921. Greek Hero Cults and Ideas of Immortality. Oxford.Disponível online: http://archive.org/details/greekherocultsid00farnuoft [acedido em 26/07/2012]. 
Fearn, D. 2011. Aegina. Contexts for Choral Lyric Poetry. Myth, History, E Identity in the Fifth Century BC. Oxford.

Ferreira, J. R. 1990. A democracia na Grécia Antiga. Coimbra. 1992. Hélade e Helenos. I. Génese e evolução de um conceito. Coimbra.

Ferreira, L. N. 2007. "Referências cromáticas nos fragmentos de Simónides", Humanitas 59: 29-48.

2007/2008. "Iniciativa feminina em tempos de guerra. O epigrama XIV Page atribuído a Simónides e o testemunho de Plutarco", Ploutarchos 5: 33-42.

2011. “La transmisión de Simónides de Ceos por Plutarco",in Candau Morón, J. M., González Ponce, F. J., Chávez Reino, A. L. edd. 2011. Plutarco transmissor. Sevilla: 59-67.

Finley, M. I., Pleket, H. W. 1976. The Olympic Games: The First Thousand Years. London.

Flower, M. A. 1998. "Simonides, Ephorus, and Herodotus on the Battle of Thermopylae”, CQ 48: 365-379.

__ 2000. "From Simonides to Isocrates: The Fifth-Century Origins of Fourth-Century Panhellenism", CA 19: 65-101.

Fontenrose, J. 1968. "The Hero as Athlete”, CSCA 1: 73-104.

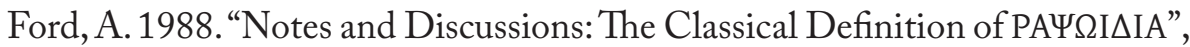
CPh 83.4: 300-307.

Fowler, B. H. 1984. "The Archaic Aesthetic”, AJPh 105: 119-149.

Fowler, R. L. 1987. The Nature of Early Greek Lyric: Three Preliminary Studies. Toronto.

Fränkel, H. 1975. Early Greek Poetry and Philosophy. A history of Greek epic, lyric, and prose to the middle of the fifth century. Trans. by M. Hadas and J. Willis. Oxford.

García Romero, F. 2004. “El «Nuevo» Simónides, una década después”, EClás 125: $17-44$.

Garulli, V. 2007. “Callimaco e Simonide: ancora sul fr. 64 Pf.”, Eikasmos 18: 251-263.

Gentili, B. 1960. "Studi su Simonide. I. I nuovi frammenti papiracei (P. Oxy. 2431)”, RCCM 2: 113-123.

1961. Rec. Lobel 1959, Gnomon 33.4: 331-343.

1964. "Studi su Simonide II: Simonide e Platone”, Maia 16: 278-306. 1996 [1984]. Poesía y público en la Grecia antigua. Trad. esp. Xavier Riu. 
Barcelona.

Gentili, B., Pretagostini, R. edd. 1988. La Musica in Grecia. Roma-Bari.

Gerber, D. E. 1994. "Greek Lyric Poetry Since 1920. Part II: From Alcman to Fragmenta Adespota”, Lustrum 36: 7-188.

ed. 1997. A Companion to the Greek Lyric Poets. Leiden-New YorkKöln.

Giangrande, G. 2002. “Simónides y Teócrito”, Habis 33: 39-41.

Giuliano, F. M. 1991. "Esegesi letteraria in Platone: la discussione sul carme simonideo nel Protagora", SCO 41: 105-190.

Goldhill, S. 1988. "A Footnote in the History of Greek Epitaphs: Simonides 146 Bergk", Phoenix 42.3: 189-197.

Gómez Espelosín, F. J. 2000. El descubrimiento del mundo. Geografía y viajeros en la antigua Grecia. Madrid.

Graves, R. 1960. The Greek Myths. 2 vols. Harmondsworth.

Graziosi, B., Haubold, J. 2009. "Greek lyric and early Greek literary history", in Budelmann 2009: 95-113.

Gzella, S. 1971. "Problem of the Fee in Greek Choral Lyric", Eos 59: 189-202.

Hamilton, R. 1974. Epinikion. General Form in the Odes of Pindar. The Hague.

Harmatta, J. ed. 1984. Actes du VIIe Congrès de la Fédération Internationale des Associations d'Études Classiques I. Budapest.

Harrell, S. E. 2002. "King or Private Citizen: Fifth-Century Sicilian Tyrants at Olympia and Delphi”, Mnemosyne 64.4: 439-464.

Harrison, S. 2001. “Simonides and Horace”, in Boedeker and Sider 2001: 261271.

Harvey, A. E. 1955. “The Classification of Greek Lyric Poetry”, CQ 5: 157175.

1957. "Homeric Epithets in Greek Lyric Poetry”, CQ 7: 206-223.

Hauvette, A.1896. De l'authenticité des épigrammes de Simonide. Paris.

Helly, B. 1995. L'état thessalien. Alevas Le Roux, les tétrades et les tagoi. Lyon.

Henderson, W. J. 1989. "Criteria in the Greek Lyric Contests” Mnemosyne 42: 2-40.

1998. "Received Responses: Ancient Testimony on Greek Lyric Imagery", AClass 41: 5-27.

1999. "Imagery in Simonides", AClass 42: 95-103. 
Henry, W. B. 1998. “Simonides, PMG 541”, ZPE 121: 303-304. 1999. “Simonides, PMG 542.1-3”, CQ 49: 621.

Herington, J. 1985. Poetry into Drama. Early Tragedy and the Greek Poetic Tradition. Berkeley.

Hignett, C. 1963. Xerxes' Invasion of Greece. Oxford.

Holloway, R. R. 1966. "Music at the Panathenaic festival", Archaeology 19: 112-119.

Hooker, J. T. 1980. The Ancient Spartans. London.

Hornblower, S. 2001. "Epic and Epiphanies: Herodotus and the New Simonides", in Boedeker and Sider 2001: 135-147.

Hornblower, S., Morgan, C. edd. 2007. Pindar's Poetry, Patrons, and Festivals. From Archaic Greece to the Roman Empire. Oxford.

Hubbard, T. K. 2001. “New Simonides' or Old Semonides? Second Thoughts on P.Oxy. 3965, fr. 26", in Boedeker and Sider 2001: 226-231 = Arethusa 29.2 (1996) 255-262.

Hunter, R. 1993. "One party or two?: Simonides 22 West"”, ZPE 99: 11-14. 1996. Theocritus and the Archaeology of Greek Poetry. Cambridge. 2001. "The Poet Unleaved: Simonides and Callimachus", in Boedeker and Sider 2001: 242-254.

Hunter, R., Rutherford, I. edd. 2009. Wandering Poets in Ancient Greek Culture. Travel, Locality and Pan-Hellenism. Cambridge.

Huxley, G. L. 1966. The Early Ionians. New York. 1978. "Simonides and his World", PRIA, section C, 78: 231-247.

Ieranò, G. 1997. Il ditirambo di Dioniso. Le testimonianze antiche. Pisa-Roma. Irwin, E. 1974. Colour Terms in Greek Poetry. Toronto.

1984. "The Crocus and the Rose: A Study of the Interrelationship Between the Natural and the Divine World in Early Greek Poetry", in Gerber, D. E. ed. 1984. Greek Poetry and Philosophy. Chico, California: 147-168.

Jacoby, F. 1945. “Some Athenians Epigrams from the Persians Wars”, Hesperia 14: 157-211.

Janko, R. 1982. Homer, Hesiod and the Hymns. Diachronic Development in Epic Diction. Cambridge.

Jenner, E. A. B. 1986. "Further Speculations on Ibycus and the Epinician Ode: S 220, S 176, and the 'Bellerophon' Ode”, BICS 33.1: 59-66. 
Jesus, C. A. M. 2009. "Grinaldas de violetas. Epítetos derivados de ion e suas valências na poesia grega", Humanitas 61: 31-57.

Kegel, W. J. H. F. 1962. Simonides. Groningen.

Kemp, J. A. 1966. "Professional Musicians in Ancient Greece”, $G \in \mathcal{E} R$ 13: 213-222.

Kirk, G. S. 1962. The Songs of Homer. Cambridge.

1981. "Orality and Structure in the Homeric «Hymn to Apollo»", in Brillante, C. et alii. edd. 1981. I poemi epici rapsodici non omerici e la tradizione orale. Padova: 163-182.

Kowerski, L. M. 2005. Simonides on the Persian Wars. A Study of the Elegiac Verses of the "New Simonides". New York \& London.

2008. "A Competition in Praise: An Allusion to Simon. fr. $11 \mathrm{~W}^{2}$ in Theoc. Id. 22.214-23”, Mnemosyne 61: 568-585.

Krummen, E. 2009. "Alcman, Stesichorus and Ibycus", in Budelmann 2009: 189-203.

Kurke, L. 1991. The Traffic in Praise. Pindar and the Poetics of Social Economy. Ithaca and London.

Kurtz, D. C., Boardman, J. 1971. Greek Burial Customs. London.

Kyriakou, P. 2004. "K $\lambda$ Éoৎ and Poetry in Simonides fr. $11 \mathrm{~W}^{2}$ and Theocritus, Idyll 16”, RhM 147: 221-246.

Lambin, G. 1992. La chanson grecque dans l'Antiquité. Paris.

Lauriola, R. 1998. "Richerche sul nuovo Simonide”, SCO 46.3: 1111-1164.

Lazenby, J. F. 1993. The Defense of Greece, 490-479 BC. Warminster.

Leão, D. F. 2001. Sólon. Ética e Politica. Lisboa.

Leão, D. F., Ferreira, J. R., Fialho, M. C. ${ }^{22010 . ~ C i d a d a n i a ~ e ~ P a i d e i a ~ n a ~ G r e ́ c i a ~}$ antiga. Coimbra. Disponível online: https://bdigital.sib.uc.pt/jspui/ handle/123456789/33 [acedido em 26/07/2012].

Lefkowitz, M. R. 1981. The Lives of the Greek Poets. London. 1991. First-Person Fictions: Pindar's Poetic 'I'. Oxford.

Lesky, A. 1995 [31971]. História da Literatura Grega. Trad. Manuel Losa. Lisboa.

Lidov, J. B. 1989. "Alterning rhythm in archaic Greek poetry", TAPhA 119: 63-85.

Lloyd-Jones, H. 1961. Rec. Lobel 1959, CR 11: 17-21. 1975. Females of the Species. Semonides on Women. London. 
1994. "Notes on the New Simonides", ZPE 101: 1-3.

López Férez,J. A. ed. 2002. Mitos en la literatura griega arcaica y clásica. Madrid.

Lorenzoni, A. 1980/82. "Simon. Cei fragm. novum”, $M C r$ 15-17: 51-52.

Lourenço, F. 1993. "Imagens e expressões de deleite estético na poesia grega: elementos para a definição de uma problemática", Humanitas 45: 95111.

—_ 2004. Grécia Revisitada. Ensaios sobre Cultura Grega. Lisboa.

—_ org. 2006b. Ensaios sobre Pindaro. Lisboa.

—_ 2009. "Lírica coral e monódica: uma problemática revisitada", Humanitas 61: 19-29.

Luppe, W. 1993. “Zum Neuesten Simonides: P. Oxy. 3965 Fr. 1 / 2327 Fr. 6”, ZPE 99: 1-9.

Mace, S. 2001. "Utopian and Erotic Fusion in a New Elegy by Simonides", in Boedeker and Sider 2001: 185-207 = ZPE 113 (1996) 233-247.

MacLachlan, B. C. 1997. "Personal Poetry: 'Alcaeus', 'Sappho', 'Ibycus', 'Anacreon', 'Corinna”, in Gerber 1997: 133-220.

Manfredini, M. 1991. "Gli epigrammi del De Herodoti malignitate”, ASNP 21: 559-590.

Manieri, A. 1990. “La terminologia 'mimetica' in Simonide”, Rudiae 2: 77-102.

Marasco, G. 1978. I viaggi nella Grecia antica. Roma.

Marincola, J. ed. 2007. A Companion to Greek and Roman Historiography. 2 vols. Malden.

Martínez, M. 2002. "Las Islas de los Bienaventurados/Afortunadas: historia de um mito en la literatura griega arcaica y clásica", in López Férez 2002: 515-544.

Marzullo, B. 1984. “Simonides fr. 515 Page”, Philologus 128: 145-156.

Mathiesen, T. J. 1999. Apollo's Lyre. Greek Music and Music Theory in Antiquity and the Middle Ages. Lincoln and London.

Mcdermott, W. C. 1944. "Simonides, Fragm. 92”, CJ 40.3: 168-170.

Meritt, B. D. 1936. “Greek Inscriptions”, Hesperia 5: 355-441.

Molyneux, J. H. 1992. Simonides. A Historical Study. Wauconda, Illinois.

Moretti, L. 1957. "Olympionikai, i vincitori negli antichi agoni olimpici”, Atti della Accademia Nazionale dei Lincei, 8ª s., vol. 8, fasc. 2: 55-198.

Morgan, C. 1990. Athletes and Oracles. The Transformation of Olympia and Delphi in the eight century $B C$. Cambridge. 
Morris, I., Powell, B. edd. 1997. A New Companion to Homer. Leiden.

Morrison, J. S. 1942. "Meno of Pharsalus, Polycrates, and Ismenias. Sect. 2: Thessaly down to 400 B. C.”, CQ 36: 57-78.

Mosino, F. 1978. “Simonide, Esopo e le mule”, QUCC 28: 93-96.

Mossé, C. 1969. La Tyrannie dans la Grèce Antique. Paris.

Most, G. W. 1994. "Simonides'Ode to Scopas in Contexts”, in De Jong, I. J. F., Sullivan, J. P. edd. 1994. Modern Critical Theory and Classical Literature. Leiden: $127-152$.

Moulinier, L. 1965. “Socrate devant Protagoras”, AFLA 39: 101-125.

Murray, O. ed. 1990. Sympotica. A Symposium on the Symposium. Oxford.

Nagy, G. 1989. "Early Greek Views of Poets and Poetry”, in Kennedy, G. A. ed. 1989. The Cambridge History of Literary Criticism. Vol. I: Classical Criticism. Cambridge: 1-77.

Myres, J. L. 1934. "Simonides, Aeschylus, and the Battle of Marathon", Antiquity 8: $176-178$ = Pfohl 1972: 323-326.

Obbink, D. 2001. "The Genre of Plataea: Generic Unity in the New Simonides", in Boedeker and Sider 2001: 65-85 = Arethusa 29.2 (1996) 193-203.

Oliveira, F. ed. 2000. O Espirito Olimpico no novo Milénio. Coimbra.

Oliver, J. H. 1933. "Selected Greek Inscriptions”, Hesperia 2: 480-513. 1935. “The Marathon epigrams”, AJPh 53.1: 193-201.

Osborne, R. 1996. Greece in the Making 1200-479 BC. London-New York.

O'Sullivan, N.1992. Alcidamas, Aristophanes and the Beginnings of Greek Stylistic Theory. Stuttgart.

Page, D. L. 1951. "Simonidea”, JHS 71: 133-142.

Palmisciano, R. 1996. "Simonide 531 P. Testo, dedicatario e genere letterario", QUCC 54.3: 39-53.

Palumbo Stracca, B. M.1985 ."Lettura critica di epigrammi greci (I)", BollClass 6: $58-75$.

Parke, H. W. 1977. Festivals of the Athenians. London.

Parry, H. 1965. "An Interpretation of Simonides 4 (Diehl)", TAPhA 96: 297320.

Parsons, P. J. 2001. “These Fragments We Have Shored against Our Ruin”, in Boedeker and Sider 2001: 55-64.

Pavese, C. O. 1967. “Simon. 38, 11P”, QUCC 4: 134-135. 
- - 1974. Studi sulla Tradizione Epica Rapsodica. Roma.

1995. "Elegia di Simonide agli Spartiati per Platea”, ZPE 107: 1-26.

1996. "Addenda et corrigenda a «Elegia di Simonide agli Spartiati per

Platea», ZPE 107 (1995) 1-26”, ZPE 112: 56-58.

Pédech, P. 1976. La géographie des Grecs. Paris.

Pereira, A. M. R. R. 2001. A Mousiké: das origens ao drama de Eurípides. Lisboa.

Pérez Jiménez A., Cruz Andreotti, G. edd. 1997. Los limites de la tierra: el espacio geográfico en las culturas mediterráneas. Madrid.

Perrotta, G. 1951. "Il lamento di Danae", Maia 4: 81-117.

1952. "Simonidea", Maia 5: 242-270.

Petrovic, A. 2007. "Inscribed Epigram in Pre-Hellenistic Literary Sources", in Bing and Bruss 2007: 49-68.

Pettersson, M. 1992. Cults of Apollo at Sparta. The Hyakinthia, the Gymnopaidiai and the Karneia. Stockholm.

Pfeiffer, R. 1968. History of Classical Scholarship. I: From the Beginnings to the End of the Hellenistic Age. Oxford.

Pfohl, G. ed. 1972. Die Griechische Elegie. Darmstadt.

Pickard-Cambridge, A. ${ }^{2}$ 1962. Dithyramb, Tragedy and Comedy. Revised by T. B. L. Webster. Oxford.

${ }^{2}$ 1968. The Dramatic Festivals of Athens. Revised by John Gould and D. M. Lewis. Oxford.

Pizzocaro, M. 1999. "Il canto nuovo di Femio. Le origini dell'epos storico", QUCC 61.1: 7-33.

Podlecki, A.J. 1966. "The Political Significance of the Athenian 'Tyrannicide-' Cult”, Historia 15: 129-141.

—_ 1968. "Simonides: 480", Historia 17: 257-275.

1969. "Simonides and Themistocles: Supplementary notes", Historia 18: 251.

—_ 1973. "Epigraphica Simonidea”, Epigraphica 35: 24-39.

1979. "Simonides in Sicily”, PP 34: 5-16.

-1980. "Festivals and Flattery: the early Greek Tyrants as Patrons of Poetry", Athenaeum 68: 371-395.

—_ 1984. The Early Greek Poets and Their Times. Vancouver.

Pollard, J. 1977. Birds in Greek Life and Myth. London. 
Poltera, O. 1997. Le langage de Simonide. Étude sur la tradition poétique et son renouvellement. Bern.

Pontani, F. 2007. "Simonide e Amore (a proposito di PMG 575), Eikasmos 18: 119-142.

Pretagostini, R. ed. 1993. Tradizione e innovazione nella cultura greca da Omero all'Età Ellenistica. Vol. I. Roma.

Privitera, G. A. 1957. "Archiloco e il ditirambo letterario pre-simonideo", Maia 9: 95-110.

- 1965. Laso di Ermione nella cultura ateniense e nella tradizione storiografica. Roma.

1988. "Il ditirambo come spettacolo musicale. Il ruolo di Archiloco e di Arione", in Gentili e Pretagostini 1988: 123-131.

Rausa, F. 1994. L'immagine del vincitore. L'atleta nella statuaria greca dall'età arcaica all'ellenismo. Roma.

Rawles, R. 2005. "Simonides and a New Papyrus in Princeton", ZPE 153: 59-67.

2008. "Simonides fr. 11.14 W: 'Close-fighting Danaans”, Mnemosyne 61: 459-466.

Richardson, N. J. 1981. “The Contest of Homer and Hesiod and Alcidamas' Mouseion", CQ 31: 1-10.

Richter, G. M. A. ${ }^{4} 1970$. The Sculpture and Sculptors of the Greeks. New HavenLondon.

—_ ${ }^{2}$ 1984. The Portraits of the Greeks. Abridged and revised by R. R. R. Smyth. Oxford.

Robbins, E. 1997. "Public Poetry: 'Alcman', 'Stesichorus' 'Simonides' ,'Pindar', 'Bacchylides", in Gerber 1997: 221-287.

Rocha Pereira, M.H.1955. Concepçôes Helénicas de Felicidade no Além. Coimbra. 1997a. "Les Fondements Classiques de l'Idée Européenne”, Humanitas 49: 25-39.

1997b. "O estatuto social dos artistas gregos", Revista Critica de Ciências Sociais 47: 23-37.

_ 2000a. "Entre o Epos e o Logos: Xenófanes de Cólofon”, Humanitas 52: 77-89.

__ 2000b. “Os vencedores dos Jogos: a glória na arte”, in Oliveira 2000: 23-43.

102006. Estudos de História da Cultura Clássica. Vol. I: Cultura Grega. 
Lisboa.

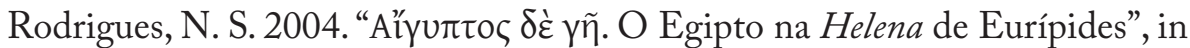
Ramos, J. A. et alii. edd. 2004. Percursos do Oriente Antigo. Homenagem a José Nunes Carreira. Lisboa: 481-496.

Rose, H. J. 1933. “Simonides and Glaukos”, CR 47: 165-167.

Rosenmeyer, P. A. 1991. “Simonides'Danae Fragment Reconsidered”, Arethusa 24.1: 5-29.

Rosenmeyer, T. G. 1968. "Elegiac and Elegos”, CSCA 1: 217-231.

Rougé, J. 1975. La marine dans l'Antiquité. Paris.

Roux, G. 1976. Delphes. Son oracle et ses dieux. Paris.

1984. “Politique et religion: Delphes et Délos à l'époque archaïque”, in Harmatta 1984: 97-105.

Rubio Tovar, J., Vallejo Girvés, M., Gómez Espelosín, F. J. edd. 2008. Viajes y visiones del mundo. Madrid-Málaga.

Rutherford, I. 1990. “Paeans by Simonides”, HSPh 93: 169-209.

2001a. "The New Simonides: Towards a Commentary", in Boedeker and Sider 2001: 33-54 = Arethusa 29.2 (1996) 167-192.

2001b. Pindar's Paeans. A Reading of the Fragments with a Survey of the Genre. Oxford.

Salvato, E. 1998. "Simonide, l'elegia per Platea”, $A \mathcal{E}^{2} R$ 43.3-4: 110-126.

Sbardella, L. 2000. "Achille e gli Eroi di Platea. Simonide, Frr. 10-11 W"2, ZPE 129: 1-11.

Schachter, A. 1998. "Simonides' elegy on Plataia: the occasion of its performance”, ZPE 123: 25-30.

Schneider, J. 1997. "Simonide et l'Occident grec et romain", in Billaut, A. ed. 1997. Héros et voyageurs grecs dans l'Occident Romain. Paris: 63-102.

Sealey, R. 1957. "From Phemios to Ion", REG 70: 312-355.

Segal, C. 1985. "Choral Lyric in the Fifth Century", in Easterling and Knox 1985: 181-203.

Shapiro, H. A. 1989. Art and Cult under the Tyrants in Athens. Mainz am Rhein.

1998. "Hipparchos and the Rhapsodes", in Dougherty, C., Kurke, L. edd. 1998. Cultural Poetics in Archaic Greece. Cult, Performance, Politics. New York: 92-107.

Shaw, P.-J. 2001. "Lords of Hellas, Old Men of the Sea: The Occasion of 
Simonides' Elegy on Plataea", in Boedeker and Sider 2001: 164-181.

Sider, D. 2001b. "As Is the Generation of Leaves' in Homer, Simonides, Horace, and Stobaeus", in Boedeker and Sider 2001:272-288 = Arethusa 29.2 (1996) 263-282.

— 2006. "The New Simonides and the Question of Historical Elegy", AJPh 127: 327-346.

2007. "Sylloge Simonidea", in Bing and Bruss 2007: 113-130.

Silk, M. S. 1974. Interaction in Poetic Imagery. With special reference to early Greek poetry. Cambridge.

Silva, M. F. 1997 [1987]. Crítica do teatro na comédia antiga. Lisboa.

Simon, E. 1983. Festivals of Attica. An Archaeology Commentary. Madison, Wisconsin.

Slater, W. J. 1972. “Simonides' house”, Phoenix 26: 232-240.

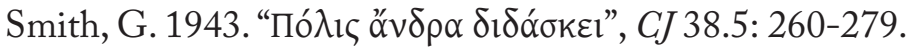

Smith, R. R. R. 2007. "Pindar, Athletes, and the Early Greek Statue Habit", in Hornblower and Morgan 2007: 83-139.

Snell, B. 1952. Leben und Meinungen der Sieben Weisen. München.

1961. Poetry and Society. The Role of Poetry in Ancient Greece. Bloomington.

1992 [1975]. A descoberta do espírito. Trad. Artur Morão. Lisboa.

Soares, C. L. 2003. A morte em Heródoto. Valores universais e particularismos étnicos. Lisboa.

Sordi, M. 1958. La lega tessala fino ad Alessandro Magno. Roma.

Stanford, W. B. 1940. "Epitaph on the Slain at Thermopylae", Hermathena 55: 99-101.

Stehle, E. 2001. "A Bard of the Iron Age and His Auxiliary Muse", in Boedeker and Sider 2001: 106-119 = Arethusa 29.2 (1996) 205-222.

Steiner, D. 1999. “To Praise, not to Bury: Simonides fr. 531P”, CQ 49.2: 383395.

Stella, L. A. 1946. “Studi Simonidei”, RFC: 1-24.

Stewart, A. 1990. Greek Sculpture. An Exploration. Vol. I: Text. Vol. II: Plates. New Haven \& London.

Suárez de la Torre, E. 1988b. "Capítulo VIII: Lírica coral”, in López Férez, J. A. ed. 1988. Historia de la Literatura Griega. Madrid: 206-242.

1998a. "La lírica griega”, in Estefanía, D., Domínguez, M., Amado, 
Ma. T. edd. 1988. Géneros literarios poéticos grecolatinos (Cuadernos de Literatura Griega y Latina II). Madrid-Santiago de Compostela: 63105.

1998b. "El adjectivo eponumos en la elegía por la batalla de Platea de Simónides (fr. 11.17 West²)”, Lexis 16: 29-32.

Svensson, L. \& Grant, P. J. 2003. Guia das aves. Guia de campo das aves de Portugal e da Europa. Trad. B. Ramos, G. Silva e M. M. Baptista. Coord. da ed. port. L. Costa. Lisboa.

Tedeschi, A. 1985. "L'invio del carme nella poesia lirica arcaica: Pindaro e Bacchilide", SIFC ser. 3.3: 29-54.

Thomas, R. 2007, "Fame, Memorial, and Choral Poetry: The Origins of Epinikian Poetry - an Historical Study", in Hornblower and Morgan 2007: 141-166.

Thompson, D’A. W. 1936. A Glossary of Greek Birds. London.

Vallet, G. 1958. Rhégion et Zancle. Histoire, commerce et civilisation des cités chalcidiennes du détroit de Messine. Paris.

Van Groningen, B. A. 1948. "Simonide et les Thessaliens", Mnemosyne 1: 1-7. 1956. "Théopompe ou Chamaeléon? À propos de Simonide 137B, 104D”, Mnemosyne 9: 11-22.

—_ 1960. La composition littéraire archaïque grecque. Amsterdam.

Vannicelli, P. 2007. “To Each His Own: Simonides and Herodotus on Thermopylae", in Marincola 2007: 315-321.

Velardi, R. 1982-1983. "Lo spettacolo del rapsodo nello Ione di Platone:

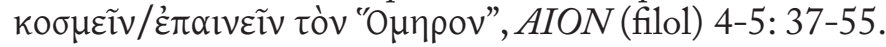

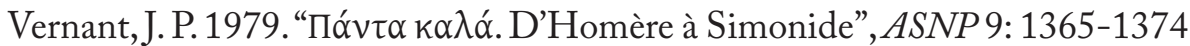
= Actes VIIe Congr. FIEC.I (1984) 167-173.

Visa-Ondarçuhu, V. 1997. "Milon de Crotone, personnage exemplaire", in Billaut, A. ed. 1997. Héros et voyageurs grecs dans l'Occident Romain. Paris: 33-62.

Wade-Gery, H. T. 1933. "Classical Epigrams and Epitaphs. A Study of the Kimonian Age”, JHS 53: 71-104.

___ 1936. "Kynaithos", Greek Poetry and Life. Essays Presented to G. Murray. Oxford: 56-78 = Essays in Greek History (Oxford 1958) 17-36.

Walcot, P. 1966. Hesiod and the Near East. Cardiff.

Wallace, M. B. 1970. "Notes on Early Greek Grave Epigrams", Phoenix 24: 95-105. 
1984. “The Metres of Early Greek Epigrams”, in Gerber, D. ed. 1984. Greek Poetry and Philosophy: Studies in Honour of Leonard Woodbury. Chico, California: 303-317.

Webster, T. B. L. 1970. The Greek Chorus. London.

West, M. L. 1967. “The Contest of Homer and Hesiod”, CQ 17: 433-450.

1970. "Melica", CQ 20: 205-215.

1971. “Stesichorus”, CQ 21: 302-314.

1974. Studies in Greek Elegy and Iambus. Berlin.

1975. “Cynaethus'Hymn to Apollo”, CQ 25: 161-170.

1981. "The Singing of Homer and the Modes of Early Greek Music", JHS 101: 113-129.

___ 1992b. Ancient Greek Music. Oxford.

1993b. "Simonides Redivivus", ZPE 98: 1-14.

1999. "The Invention of Homer", CQ 49.2: 364-382.

2002. "Eumelos: A Corinthian Epic Cycle?”, JHS 122: 109-133.

West, W. C. 1977. "Hellenic Homonoia and the New Decree from Plataea", GRBS 18: 307-319.

Wilamowitz-Moellendorff, U.von. 1913. Sappho und Simonides. Berlin.

Wilson, P. 2009. “Thamyris the Thracian: the archetypal wandering poet?", in Hunter and Rutherford 2009: 46-79.

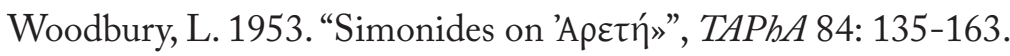

1968. "Pindar and the Mercenary Muse: Isthm. 2.1-13", TAPhA 99: 527-542.

1985. "Ibycus and Polycrates", Phoenix 39.3: 193-220 = Collected Writings (Atlanta 1991) 410-438.

Yatromanolakis, D. 2001. "To Sing or to Mourn? A Reappraisal of Simonides $22 \mathrm{~W}^{2 ”}$, in Boedeker and Sider 2001: 208-225 = ZPE 120 (1998) 1-11.

Zanetto, G. et alii. edd. 2004. Momenti della Ricezione Omerica: Poesia Arcaica e Teatro (Quaderni di Acme 67). Milano.

Zanker, P. 1995. The Mask of Socrates. The Image of the Intellectual in Antiquity. Berkeley.

Zimmermann, B. 1992. Dithyrambos. Geschichte einer Gattung. Göttingen. 2002. "Myth in Dithyrambic Poetry”, in López Férez 2002: 151-157. 
ÍNDICES 
(Página deixada propositadamente em branco) 


\section{ÍNDICE DE FONTES ANTIGAS}

\section{Acusilau de Argos}

FGrHist 2 F 2: 53 n. 80

Africanus, Iulius: 153 n. 87, 172 n. 138

Alceu: 75,78 n. 38, 81 e n. 45, 89 n.

69, 90

Frr. Lobel-Page

6: 100

42: 216 n. 71

73: 100

129: 78 n. 38

130: 78 n. 38

208: 100

305: 100

308: 327

327: 319

345: 355-356, 363

347: 356,364

359: $355-356$

367: 343 n. 75,356

369: 343 n. 75

384: 300 n. 91

397: 356

399: 356,361 n. 18

443: 330

Alcidamante: 41 e n. 56

Mouseion: 41 n. 56

Soph. 14: 51 n. 76
Álcman: 72, 74-75, 81 n. 45, 82 e n. 47, 89 n. 69,104

Frr. Page $(\mathrm{P}=P M G)$

1 ('Grande Partenéion'): 74 e n. 27, 83, 103 e n. 17,$355 ; 1.36: 216$ n. $71 ; 1.44: 103 ; 1.66: 359$ n. 12; $1.84: 103 ; 1.97: 57$ n. 87; 1 . 98-99: 103 n. 17

3: 74

13 (a): 74 n. 26

14 (a): 57 n. 87

16: 74 n. 26

26: 103,343 n. $75,355,356$ n. 5, 359 n. 11

27: $103 ; 27.3: 30$ n. 30

28: 103

37: 103

38: 103

39: 103,$355 ; 39.3: 74$ n. 26

40: 103,355

41: 103

52: 74

58: 319 n. 8

59 (a): 319 n. 6

87 (b): 103

89: 194 n. 10,336 n. 55, 355, 364 n. 26

93. 1: 359 n. 12 
Mobilidade poética na Grécia antiga: uma leitura da obra de Simónides

101: 103 e n. 19

145: 73

148: 74 n. 26

Amiano Marcelino

16. 5. 8: 180 e n. 156

Anacreonte: 89 nn. 69 e 70, 90 e n. 72 , 92-94, 119 n. $15,136,168,362,370$, 373

Frr. $P M G$

346 (1 P): 319 n. 6,356 n. 3

348 (3 P): 92, 93

343 (7 P): 311 n. 75

353 (8 P): 92,93

357 (12 P): 319 n. 6 ; 357. 1-3: 202;

357. 1-4: 319 n. 8; 357. 9-10: 374

358 (13 P): 92 n. 77; 358. 1-3: 202;

358. 1-4: 319 n. 8

360 (15 P): 230

373.3 (28. 3 P): 103

374 (29 P): 103

375 (30 P): 103

379 (34 P): 92 n. 77

386 (41 P): 103

390 (45 P): 324 n. 22

394 (a) (49a P): 356 n. 3, 362 n. 18

398 (53 P): 319 n. 8

408 (63 P): 335,356 n. 3

412 (67 P): 94

417 (72 P): 356

418 (73 P): 324 n. 22

437 (92 P): 356 n. 3

443 (98 P): 356 n. 3

453 (108 P): 356 n. 3, 362 e n. 18

456 (111 P): 356 n. 3

471 (126 P): 93 n. 81

483 (138 P): 93 e n. 81

491 (146 P): 92

495 (150 P): 94

505 (a) (160 P): 92 n. 78
Epigr. VII FGE: 94 n. 86, 160-161

Epigr. XIII FGE: 94 n. 86, 160-161

Anecdota Graeca (Bekker)

I. $232: 247$ n. 28

Anecdota Oxoniensia (Cramer)

III. 173. 13: 364

Antifonte (orador)

6. $11: 135$ n. 45

Antípatro de Sídon

Epigr. XV Gow-Page: 92 n. 76, 94 n. 87

Epigr.XIX Gow-Page: 25 n. 19, 102

Antípatro de Tessalonica: 74 n. 26

Antologia Palatina: 152 n. 86, 256 n. 3, 286 n. 63

6. $2: 256$

6. $50: 288$

6. 136: 94 n. 86, 160-161

6. 142: 94 n. 86, 160-161

6.167. 1: 322

6. 197: 292 nn. 73 e 74

6. 213: 133

6. $214: 165$ n. 120

6. 215: 281

6. 315. 1: 258 n. 7

7.18.5-6: 74 n. 26

7. $27: 92$ n. 76,94 n. 87

7.75: 81

7.77: 121

7. 153: 219 n. 79

7.248: 272

7.249: 272

7.250: 279,280

7. 251: 286-287

7. 253: 285-286

7.257: 255

7.301: 270

7.347: 282

7.348: 115 n. $3,147-148$ 
7. $511: 150$

7. 516: 121

7.677: 270

7.714: 93 n. 83

7. 745: 25 n. 19,102

9. 184. 5: 373

9.571.1-2: 373

9. 239. 3: 94 n. 87

9.599: 93 n. 85

9. 757: 156 n. 99

12. 53. 7-8: 358 n. 6

13. 14: 154-155

13. 19: 155

13. $26: 156$ e n. 100

13. $30: 148$

13. 31: 115 n. 4,148

Antologia Planudea ou de Planudes:

121, 147, 156 n. 99, 255, 256, 258,

$270,279,285,286$

2: 153

23: $153-154$ e n. 92

24: 172 e n. 139

232: 257

233: 257 n. 5

306: 92 n. 76,94 n. 87

307-309: 93 n. 85

Apolodoro: 163

1.3. 3: 18 n. 7,19 n. 9

1.7. $4: 359$ n. 9

2. 5. 5: 330 n. 37

3: 346

3. $9.2: 91$ n. 75

3. $12.5: 347$

Epit. 5. 5.: 349 n. 87

Apolónio de Rodes: 319, 339 e n. 65

1.26-31: 342 n. 71

1. $622: 334$ n. 46

4. $811: 349$ n. 87
Scholia (Wendel)

1. 211-215c, p. $26: 145$ n. 69

1. 763-764, p. 66: 333 e n. 65

3. 26, p. 216: 318-319

4. $176-177$, p. $271: 340$ n. 67

4. 814-815a, p. 293: 349 e n. 87

Apostolius (Leutsch-Schneidewin)

I. 100a, XVI. 32: 365 n. 28

VII. 9d: 292 n. 73

Aristides, Élio: 182, 255

Or. 28. 54: 74 n. 26

Or. 28. 59-60: 115, 179-180

Or. 28. 63: 260 n. 14

Or. 28. 66: 279-280 e n. 54, 322 n. 16

Or. 31. 2: 159-160

Schol. Aristid. Or. 46. 118, p. 289 Frommel: 260 n. 14

Schol. Aristid. III. 136 Dindorf: 279

Schol. Aristid. III. 533 Dindorf: 122 n. 16

\section{Aristodemo}

FGrHist 104 F 4: 292 n. 73

Aristófanes: 36, 101 e n. 13, 374

Av. 217: 87 e n. 63; 251: 359 n. 9; 575: 36 n. 42; 749: 364 n. 26; 904-952: 107 n. 29; 1403-1404: 135; 1410-1411: 363 n. 20; 1594: 359 n. 9

Ec. 973: 364 n. 26

Eq. 406: 129 n. $29 ; 729: 336$ n. 55

Lys. 721, 911: 257 n. 6

Nu.1355-1358: 241-242 e n. 8, 244

Pax 695-699: 174 e n. 141; 736738: 149 e n. 79; 797-798: 85 n. 59

Ra. 559: 362 n. 19; 1511: 360

Th. 159-163: 90

V. 1411-1412: 95, 131 e n. 33 
Mobilidade poética na Grécia antiga: uma leitura da obra de Simónides

Scholia

Av. 917-919, p. 174 White: 124 e n. 18

Av. 1403, p. 254 White: 76,94 n. 89

Av. 1410 , p. 256 White: 363

Eq. 405-406, p. 102 Jones: 128-129 n. 29

Nu. 1355-1358: 242 e n. 8

Pax 695-699, pp. 107-108 Holwerda: 174-177 e n. 151

Pax 736-738, p. 114 Holwerda: 149

Pax 797-798, p. 125 Holwerda: 85 n. 59

Aristófanes de Bizâncio: 332

Fr. 124 Slater: 134

Aristóteles: 74 n. 26, 129, 146, 147, 177, 178

Ath. 15. 4: 137

Ath. 18. 1: 93 e n. 84,136 e n. 48

Ath. 19. 6: 94

Ath. 60. 3: 142 n. 59

EN 4. 1: 177 n. 152

EN1149b15-16: 202 n. 31

HA 4. 7.532b14-17: 365 n. 29

HA 5. 8. 542b: 356-358; 5. 8. 542b12: 358, 359; 5. 8. 542b16: 359

HA 5. 9. 542b22: 358; 5. 9. 542b24: 359 n. 9; 5. 9. 616a14-15: 359 n. 12

HA 5. 15. 547a7: 345

HA 5. 30. 556a14-20: 365 n. 29

Metaph. N 3. 1091a.5: 184 n. 163

Ph. 4. 13. 222b16: 227-228

Po. 4. 1448b-1449a: 43 n. 59

Po. 26.1462a5-7: 51 n. 76

Pol. 8. 6.1341a37-1341b8: 86 n. 62

Pol. $1274 a 26$ sqq.: 70 n. 19

Pol. 1289b36-39: 29 n. 27

Rh. 1.6.1363a: 347-348

Rh. 1. 9. 20, 1367b: $140-141$ e n. 57
Rh.2.16.1391a8-12: 165-166, 177 n. 152

Rh. 2.20.1393b: 70 n. 19

Rh. 2.21.1394b-95a: 81

Rh. 3.2.1405b 23: 252, 254 n. 49

Rh. 1389b3-4: 210 n. 53

Rh. 1403b-1404a: 51 n. 76

Fr. 75 Rose: 146-147

Fr. 568 Rose: 253

Fr. 617 Rose: 170

Schol. ad. Rh. 1. 6. 1363a: 347-348

Eustratius in Arist. EN 6. 7: 43 n. 59

Arquíloco: 18, 42 n. 57, 52 e nn. 77, 78; 71,127

Frr. West

21: 355

24: 100

30: 355

105: 100

120: 76 e n. 32

121: 104 n. 20

122: 355

201: 43 n. 59

303: 43 n. 59

324: $126-127$ e nn. 24,25

Arsenius: 265 n. 28

Ateneu: 335

Deipnosophistae: 335

1 (epit.) 32b: 115 n. 4

1. $3 \mathrm{e}: 254$ n. 49

4. 141 e-f: 71 n. 21

4. 172e: 90 n. $71,350-351$

4. $184 \mathrm{~d}: 88$ n. 68

7. 318f: $129-130$

8.338b: 96 n. 94

8. 360 b-d: 363 n. $23 ; 8.360$ c: 336 n. 55

9. 374d: 361

9.396e: 338 
10. $415 f-10.416 a:$ 148; 10. 416a: 147

10. 438 c: 164 n. 119

10. 455 c-d: 95 e n. 92

10. $456 \mathrm{c}: 117$

10. $456 \mathrm{f}: 117$

11. 490e-f: 326,329

12. $512 \mathrm{a}: 221$

12. 512c: $220-221$

12. $536 \mathrm{a}-\mathrm{b}: 292$ n. 74

12. 540d-e: 93

13. 573 c-e: $283-284$ e nn. 58, 59; 285 n. 61

13. 596 c-d: 99 n. 3

13.599 c-d: 94 n. 87

14. $617 \mathrm{~b}-\mathrm{f}: 96$

14. 620 c-d: 51 n. 76,52 n. 78

14. $624 \mathrm{e}-\mathrm{f}: 95$

14. 634 f: 103 n. 19

14. 635 b: 103 n. 19

14. $635 \mathrm{~d}-\mathrm{e}: 68 \mathrm{n} .12$

14. 635 e-f: 69 n. 16

14. $656 \mathrm{c}: 166$

14. 656d-e: 166, 177-178, 183

15. 678 b-c: 72 e n. 23,75

\section{Aulo Gélio}

3. $11: 42$ n. 58

6. $8: 78$ n. 40

Baquílides: 30 n. 30, 77 n. 33, 91 n. 75, 105-107, 109-110, 116 e nn. 5 e 8 , $124,126,128,135,151$ n. 82,168 , 169 e n. 128,200 e n. $22,201,214$ e n. 66,215 n. $69,244,246$ n. 24,250 n. $34,333,369,370$

Epinicios

1: 106, 107; 1. 13-14: 303 n. 99

2: 106,107

3: 106,109 n. 33,$169 ; 3.3: 324$ n. 21; 3. 34: 300 n. 91; 3. 37: 259;

3. 37-47, 78-84: 335 n. 48; 3. 87: 201 n. 26
4: $106 ;$ 4. 7-8: 361 e n. 17

5: 106, 109, 110 n. 37; 5. 6: 273 n. 43; 5. 10-16: 109; 5. 15: 343; 5. 37-41: 108; 5. 49: 109; 5.68 sqq.: 350 n. $89 ; 5$. 79-92: 335 n. 48 ; 5.172 : 362 n. $19 ; 5.195-$ 200: 109

6: 106; 6. 14-15: 107

7: 106; 7. 2-3: 107

8: 106

9: 106; 9. 10-14: 338; 9. 53: $300 \mathrm{n}$. 91; $9.72: 300$ n. 91

10: 106; 10. 10: 364 n. 26

11: 106; 11. 41-42: 325; 11. 44: 201 n. 27

12: 106, 244 n. 16; 12. 2: 324 n. 21

13: 106, 244 n. 16,248 n. 29; 13. 9 : 324 n. $21 ; 13.64: 363$ n. $22 ; 13$. 199-209: 200; 13. 205-206: 264 n. 22 ; $13.224-226: 107$ n. 29 ; 13. $228: 324$ n. 21

14: 106

\section{Ditirambos}

15: 133 n. 37

16: $106 ; 16.17-18: 322$ n. 15

17: 106, 133 n. 37, 343; 17. 24: 201 n. $27 ; 17.122: 335 ; 17.130$ sqq.: 116 n. 9

18: 106,133 n. 37,343

19: 106, 133 n. 37 ; 19. 11: 116 n. 9; 19. 22: 324 n. $22 ; 19.25-26$ : 327 n. 29

20: 106,133 n. 37,318

23: 104 n. 21,133 n. 37

24. 1-13: 335 n. 48

25: 350 n. 89

28: 342

Frr. Maehler

1: 202 n. 30

3. $83: 203$ n. 33

4: 106

5. 3: 233 n. 117 
Mobilidade poética na Grécia antiga: uma leitura da obra de Simónides

14. $4: 201$ n. 27

20A: 318

20B. 1-4: 110 e n. 38

20C: 106; 20C. 2-7: 109-110 e n. 37

21: 317 n. 1

Calímaco: $163,171,172$ n. 134

Ap. 30-31, 71-87: 71 n. 21

Frr. Pfeiffer

26. $5: 57$ n. 88

64: 162 n. 114,$163 ; 64.3-4: 119$, 165; 64. 8-9: 115 n. 3; 64. 9: 182; 64. 10: 179-180; 64. 1114: 162

222: 115 e n. $4,175-176$ e n. 145 , 178

397: 43 n. 59

612: 165

666: 241 n. 5

\section{Calino}

Fr. 6 W: 46 n. 66

Cameleonte: 117 e n. 11, 164, 166, 167, $170,177-178,284$ n. 58

\section{Camões}

Elegia I: 182

\section{Carmina convivalia (PMG)}

890: 223 n. 90

893-896: 139 e n. 55; 894: 235 n.

125

\section{Carmina popularia (PMG)}

848: 363 e n. 23

880: 16 n. 3

\section{Catulo}

38. 7-8: 373

Certamen Homeri et Hesiodi: 37, 39, 41-48, 144 n. 64, 166, 168 n. 125

1-17 Allen (=1-2 W): 38 n. 46, 42

13-15 Allen (=2 W): 47, 53 n. 80

15-17 Allen (= 2 W): 43

19-22 Allen $(=3 \mathrm{~W}): 41$ n. 56

32-34 Allen (= 3 W): 41 n. 55
54-74 Allen (= 5-6 W): 42-43

54-239 Allen $(=5-14 \mathrm{~W}): 41$ n. 56

64 Allen $(=6 \mathrm{~W}): 29$ n. 27

74-177 Allen $(=7-12 \mathrm{~W}): 45$

78-79 Allen $(=7 \mathrm{~W}): 41$ n. 56

90-94 Allen (= 8 W): 42

177-205 Allen $(=12 \mathrm{~W}): 45$

205-210 Allen $(=13 \mathrm{~W}): 45$

213-214 Allen $(=13 \mathrm{~W}): 45$ e n. 65

215-254 Allen $(=13-14 \mathrm{~W}): 46$

239-240 Allen (= $14 \mathrm{~W}): 41$ n. 56

255-321 Allen (= 15-18 W): 46

260-270 Allen (= 15 W): 219 n. 79

275-321 Allen (= 16-18 W): $47 \mathrm{n}$.

67

276-321 Allen (= 16-18 W): 46

303-304 Allen $(=17 \mathrm{~W}): 47$

307-308 Allen (= $17 \mathrm{~W}): 38$ n. 46 , 47

309-310 Allen $(=17 \mathrm{~W}): 47$

321-338 Allen (= $18 \mathrm{~W}): 46$

Choeroboscus, Georgius: 222 n. 85

Cícero: 163, 272 e n. 42, 317

de Orat. 2. 46. 194: 22 n. 16

de Orat. 2. 74. 299: 182 n. 160

de Orat. 2. 86. 351-353: 162, 180182; 2. 86. 351: 115 n. 3; 2.86. 352: 212 n. 62

Div. 1.27.56, 2.66.135: 122 n. 16

Div. 1.37.80: 22 n. 16

Fin. 2. 32. 104: 145, 146, 182 n. 160

N.D. 1. 22. 60: 166-167 e n. 123, 184

Pro Archia 4: 112

Rep. 2. 20: 117 n. 12

Sen. 7. 23: 119 n. 15

Tusc. 1. 42: 272 n. 40

Tusc. 4. 71: 90, 92 n. 76

Clemente de Alexandria

Strom. 1. 18: 210 n. 53 
Strom.1.21.131: 68 n. 11

Strom.1.78: 92 n. 76

Strom. 4. 7. 48: 216

Corina: 144 n. 64

\section{Cornélio Nepos}

Paus. 1. 3: 292 n. 73

\section{Crates}

FGrHist 362 F 5: 53 n. 80

\section{Cratino}

Fr. 338 Kassel-Austin: 73

Fr. 368 Kassel-Austin: 43 n. 59

\section{Crinágoras}

Epigr. VII Gow-Page: 94 n. 87

\section{Cristodoro de Copto}

Ekphrasis 229: 152 n. 86

Crítias: 210 n. 53

\section{Demócrito}

Frr. Diels-Kranz

17, 18: 22 n. 16

249: 165 n. 121

\section{Demóstenes}

21. $17: 135$ n. 45

Pseudo-Demóstenes

in Neaer. 59. 97: 292 n. 73

Dídimo: 167, 210 n. 53

Diodoro Sículo: 263 e n. 19, 266, 272

n. 40

1.96. 2-3: 99 n. 4

4. $33.1: 330$ n. 37

4. 37. $4: 329$

11. 1. $2: 241$

11. 11. 6: $262-263$ e n. 17

11. $29.1: 288$ n. 65

11. 33. 2: 271 n. 39,291

11. $48.2: 253$ n. 44,254 n. 48

11. 48-49: 168 n. 125

11. 53. $1: 154$ n. 93

12. 9. $6: 172$ n. 138

14. 109. 1-6: 54-55, 102
Diógenes Laércio

1. 41, 63: 210 n. 53

1. 57: 49-50 n. 70

1. 89-90: $218-219$ e n. 79

1. 94-100: 95 n. 93

1. 109-115: 21 n. 15

2. $25: 163$ n. 116

2. $46: 146-47$

9. 18: 56

Diogeniano (Leutsch-Schneidewin)

Praef. paroem., I. 179: 130

I. $2: 365$ n. 28

Dionísio de Halicarnasso: 330 e n. 39

Antiquitates Romanae

4. 41. 1: 153 n. 87

8. 1. 1: 241

8. $77.1: 241$

9.37. 1: 154 n. 93

Comp. 19. 7: 85 n. 57

Comp. 23. 9: 373

Comp. 24. 5: 85 n. 57

Comp. 26. 14-15: 331-333

Imit. 2. 420: 373

Éforo: 71, 275 n. 46, 279, 282 n. 57

\section{Eliano}

NA 6. 10: 180 e n. 156

NA 12. $45: 75$ n. 28

VH 4. 15: 169

VH 9.4: 92

VH 12. 1: 163 n. 116

VH 13. 25: 144 n. 64

\section{Empédocles}

B 131. 2 Diels-Kranz: 294 n. 79

Epicarmo: 223 n. 90

Eratóstenes: 41, 163

FGrHist 241 F 14: 240 n. 3

\section{Esopo}

285, 'Huíovoc', Hausrath-Hunger: 253 n. 43 
Mobilidade poética na Grécia antiga: uma leitura da obra de Simónides

Ésquilo: 94, 96, 144 e n. 64,146 n. 72, 168,259 n. 11, 370

Ag. 497: 327 n. 31; 979: 177 n. 149; 1629-1630: 342 n. 71

Oresteia: 177 n. 149

Persas: 255; 1-9: 260; 401-405: 256 n. $2 ; 505: 219$ n. 80

Pr. 164: 328; 511: 251 n. 39

Supp. 815: 201 n. 27

$\operatorname{Tr} G F$ III

46a-47c (Diktyoylkoi): 333 e n. 43

47a. 806: 359 n. 10

312. 4: 329 n. 36

Vita Aesch., T 1. 8. 27-30: 143-144 e n. $64,149,168,259$ n. 11, 261

Vita Aesch., T 1.9.33-34 (Aetnaeae): 112 e n. 48

Schol. M. Pr. 128, p. 15 Dindorf: 94

Estesícoro: 39 n. 48, 69 e n. 14, 70 n. 19,75 e n. $30,78,80$ n. 44, 81-85, 89 e n. $69,91,102,104,110,116$, 117 e n. 12,119 n. 15,322 n. 16, 351, 359 n. 9, 372

Frr. $P M G$

178 (1 P): 317 n. 1

179 (2 P): 90 n. $71,350-351$ e n. 89

187 (10 P): 240, 356 e n. 3

192 (15 P): 83

211 (34 P): 356 e n. 3,361 n. 18

212 (35 P): 83,85 n. 59, 324 n. 22

213 (36 P): 82

214 (37 P): 82

216 (39 P): 81, 350

221 (44 P): 350 n. 89

222 (45 P): 350 n. 89

222A Campbell: 83

222B Campbell: 350 n. 89

225 (48 P): 79 n. 40

235 (58 P): 356 e n. 3

248 (71 P): 356 n. 5,359 n. 9

262 (85 P): 356 e n. 3
271 (94 P): 81 n. 45

7-16 SLG: 82-84

27 SLG: 82

Gerioneida: 82

Oresteia: 81 n. 46, 82, 85 n. 59

Palinódia a Helena: 54, 81-82 n. 46, 83

Estêvão de Bizâncio (Meineke)

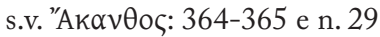

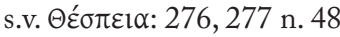

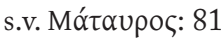

Estobeu: 194, 222 e nn. 85, 86; 225 n. $93,226,343$

1. $8.22: 264$ e n. 22

3.10.38: 177 n. 151

3. $29.70: 96$ n. 94

3. $33.12: 184$ n. 165

4. 34. 14: 196; 4. 34. 28: 221-222, 224-225

4. 41. 9: 162, 193-194; 4. 41. 62: 162,195 n. 13

4. 51. 5: 195; 4. 51. 7: 196

4. $52.22: 41$ n. 56

Estrabão: 272 n. 40

9.2. $31: 288$ n. 65

9. 3. $10: 86$ n. 60,88 n. 66

9. 4. $2: 273$

9.5.20: 158

10.1.10: $143 ; 10.1 .12: 29$ n. 28

10. $4.16: 71$

10. 5. 6: 115 n. 1,116 e n. 10

14. 1. 16: 92-93; 14.1. 28: 73; 14. 1 . 30: 92 n. $78 ; 14.1 .35: 53$ n. 80

14. 6. $3: 40$

15. $1.57: 318$ e n. 4

15. 3. 2: 133-134

Etymologicum Genuinum (Calame)

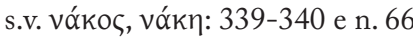

Etymologicum Magnum

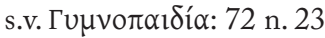


713. $17: 222$ n. 85

813. 5: 362

Eumelo: 34 n. 36, 65-68, 75, 103, 124

Frr. Campbell

1 (a): 65-68

1 (b): 66-67

1 (c): 66 n. 6

Fr. 3B Davies: 341

Eurípides: 341

Alc. 357-362: 342 n. 71

Andr. 900: 322

Autólito: 176 n. 146

Ba. 560-564: 342 n. 71; 1008: 235 n. 121

Hec. 35-41, 107-143, 218 sqq.: 350; 421: 347

Hel. $185: 87$ n. 63

HF 70-79, 462-475: 337 n. 60; 901: 359 n. 10

Hipp. 265: 210 n. 53; 1300: 203

Hipsípile: 338 e n. 62; Hyps. Iiii9: 87 n. 63

IA 1211-1212: 342 n. 71; 13231325: 358 n. 6

IT 146: 87 n. 63; 260, 344: 340; 1089 sqq.: 356 n. 5; 1091: 87 n. 63

Medeia: 339; 5: 340; 1263: 340

Rh. 921-925: 18 n. 7, 19 n. 9

Tr. 119: 87 n. 63; 622-623: 350; 757-762: 337 n. 60

Scholia (Schwartz)

Andr. 631, II. 293: 90

Hec. 41, I. 17: 350

Med. Argum., II. 137: 340

Med. 5, II. 142: 124, 340 e n. 67

Med. 2, II. 141: 340

Med. 19, II. 144, cod. B: 340-341

Hipp. 264: 210 n. 53

Or. 46, I. 102: 350

Or.235, I. 122: 201
Eusébio: 71 n. 21, 172 n. 138

Crónica

O1. 5. 1: 66 n. 4

O1. 9.1: 66 n. 4

O1.28.1: 72 n. 23

O1.34. 3/4: 68 n. 11

O1. $40.2: 75$ n. 29

O1. $42.2: 81$ n. 45

O1. 55.1: 81 n. 45

O1. 60: 118

O1. 61.1: 92 n. 77

O1. 73: 118

Eustátio: 243 ก. 10, 301 n. 92 in Od. 1821.37: 166

\section{Fânias de Éreso}

FGrHist 1012 F 3: 164 n. 119

Favorino: 161, 195 n. 13

Corinthiaca or. (ps. D.Chr. or. 37) 18: 279 e n. 52

Corinthiaca or. (ps. D.Chr. or. 37) 19: 282

Ferecides: 340

Filócoro de Atenas: 37, 38, 58

FGrHist 328 F 111: 344 e n. 77; F 212: 37

\section{Filodemo}

Mus. 1.30 .31 sqq.: 70 n. 19

Piet., p. 37 Gomperz: 328 e n. 33

\section{Filóstrato}

VA 1. 14: 180 e n. 156

Fócio: 172

Lexicon (Naber)

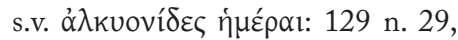
357

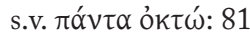

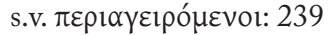

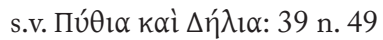

Bibl.320a33: 86 n. 60

Fragmenta adespota (PMG)

947: 322 n. 16 
Mobilidade poética na Grécia antiga: uma leitura da obra de Simónides

949: 202 n. 31

953 (35 P): 94 n. 87

Frínico, Fenícias: 149 n. 78

Glauco de Régio: 71, 83

\section{Harpocrácion}

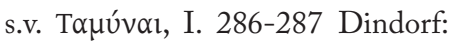
142

Heféstion: 327

4. 6, pp. 14-15 Consbruch: 138-139

Helânico de Lesbos: 41, 68 n. 11, 76

FGrHist 4 F 20: 53 n. 80; F 85-86: 69 e n. 16,75 n. 31

Heraclides Pôntico: 42 n. 58, 69, 73, 83, 220, 221

Politeiai 25. 5: 253-254

\section{Heraclito}

Fr. 42 Diels-Kranz: 52 n. 77

Heraclito, Allegoriae Homericae 5: 100

\section{Herodiano}

I. 119 Lentz: 365 n. 28

Heródoto: 89 n. 70, 99, 194 n. 12, 246, 258, 273 n. 44, 275, 281, 282 n. 55, 283, 311 e n. 116,312 n. 118

Histórias: 255

1. 23-24: 75; 1. 23. 1: 76-77

1. 24. 1: 77-78, 177 n. $149 ; 1.24 .5$ : 57 n. 87,$79 ; 1.24 .6-7: 78$ n. 39 ; 1.24. $7: 79 ; 1.24 .8: 75$ n. 28,77

1.29-33: 99 n. 4

1.68.3: 261

1. $82: 72$ n. 23

1. $90.1: 141$ n. 59

1. $93.3: 261$

1.145: 130

1. $168: 92$ n. 78

1.176. 1: 195 n. 14

2.53.2: 42 n. 58

2. $78: 261$

2.79: 16 n. 3

2.93.1: 203
2.135. 6: 141 n. 59

3. 39-43: 93 n. 82

3. 120-125: 93 n. 82

3. $121: 93$

3. $125: 21$ n. 15

3. 129-137: 21 n. 15

4. $32: 46$ n. 66

4. $35.4: 116$ n. 10

5. $44.2: 53$ n. 80

5.56: 94

5. $67.1: 49$ e n. 68,52 n. 77,57 n. 86

5.75.2: 303 e n. 98

5. 92. 3: 66 n. 4

5. $99: 29$ n. 28

5.102. 3: 115 n. $2,129,141-142$

6. $27: 162$ n. $112 ; 6.27 .2: 103$ n. 17

6. 49, 50, 73: 243 e nn. 10, 11, 12, 244,245 n. 21

6. 85 sqq.: 243-244 e n. 12

6. $102: 259$ n. 10

6. 103. 1-3: 138 ก. 50

6. $105: 257$ e n. 6

6. 106. 3: 71 n. 21

6. 120: 101

6. $127.4: 163$ n. 115

7.6. 2: 159; 7.6. 3: 95

7.35.1: 360

7. 104. 4-5: 272 e n. 40; 7. 104. 5: 52 n. 79

7.130. 3: 159

7.134. 1: 53 n. 80

7.139. 5: 256 n. 2

7. $157.2: 256$ n. 2

7. $158.3: 180$ n. 155

7.163-164: 118

7.173. 1-2: 157 n. 103

7. 178. 2: 256 n. 2

7. 185. 3: 271 n. 39

7.189: 145 n. 69 
7. 202: 271 n. 39

7. 203: 273

7. 206. $1: 71$ n. 21

7. 207: 273

7.219: 269 n. 35

7. $221: 53$ n. 80,269 n. 35

7. 227-228: 270-272; 7.228. 1: 264;

7. 228. 2: 261, 270; 7. 228. 3-4:

267-269 e n. 37,$270 ; 7.228 .4$ :

115 n. 3

7. 229: 271 n. 39

8. 5: 281-282

8. $25: 271$ n. 39

8. 46. 2: 115 n. 1

8. 46. 3: 276

8. $53: 259$ n. 10

8. $59: 282$

8. $61: 282$

8. $66.2: 273$

8. 79. 1: 142

8. 84. 2: 276

8. 92-93: 243,244 n. 17

8. 94. 1-4: 282

8. 114: 309 n. 108

8. 124. 3: 141 n. 59

8. $135: 34$ n. 37

9. $13: 303$ e n. 100

9. 19.1-2: 303; 9. 19. 2: 304 n. 102

9.28. 3: 307

9.31. 3: 307; 9. 31. 5: 273

9. 33-36: 304; 9. 33. 1: 53 n. 80;

9. $36: 305$

9. 40: 195 n. 14

9. 59 sqq.: 287

9. 64: 309 n. 108

9. $69: 290$

9. 78-79: 309 n. 108

9. $80: 260$

9. $81.1: 291$ n. 72

9. $85: 287,289,310$
Pseudo-Heródoto

Vita Herodotea: 38 n. 46, 44 e nn. 60, $62 ; 47$ n. 67

6, 7, 21-22 W: 44

32 W: 177 n. 149

Hesíodo: 10, 18, 27-31, 37, 38 e n. 44; 41 e nn. 55,$56 ; 42$ e n. $58,43,45$ e nn. 64,$65 ; 46,52$ e n. $78,55,56$, 78 n. 40, 87, 88, 116 e n. 7,119 n. 15,144 n. 64,165 n. $121,185,217$ e n. 76,234 n. 118,300 n. 89, 329, 372,373

Teogonia: 27, 29, 36 nn. 39 e 41, 326 1-115: 30

11: 30 n. 30

16: 328

22-23: 27; 22-28: 35-36, 299 e n. 89; 22-34: 18 e n. 6,30

30: 345 n. 79

33: 30 n. 30

37: 22,30 n. 30

48: 30 n. 30

51: 22,30 n. 30

55: 226

64-65: 227 n. 100

69: 324

70: 30 n. 30

77-79: 324 e n. 21

78: 328 n. 34

94: 251 n. $38 ; 94-97: 58$

101: 30 n. 30

120-122: 319

252-255: 290

298: 328 n. 32

337-345: 29 n. 23

350: 328 n. 34

509: 328

517-520: 328

785: 301 n. 94

915: 324 n. 22

933-935: 319 n. 7 
Mobilidade poética na Grécia antiga: uma leitura da obra de Simónides

938: 327,328

955: 198 n. 20

963-965: 301 n. 93

Trabalhos e Dias: 27, 28, 45 e n. 65

25-26: 28,174

75: 324 n. 22

90-99: 224

115: 227 n. 100

159: 301 n. $92 ; 159-173: 196$ n. 17

171: $235 ; 171-173: 349$ n. 87

225-237: 195 n. 14

289-292: 195 n. 14,216 e n. 71, 217

383: 329 n. 35 ; 383-387: 328; 383-

392: 45 n. 64

436: 345 n. 79

582-584: 364

582-596: 355

595: 219 n. 80

599: 235 n. 122

618-694: 99

619: 329 n. 35

619-620: 328

633-640: 27

639-649: 42

648-649: 28

650-651: 38

650-662: 27-31, 100, 369

654-659: 44-45, 67

657: 30, 87; 657-658: 45

662: 45

737: 219 n. 80

739: 226 n. 95

743: 362 n. 19

Frr. Merkelbach-West

59. 3: 351

65: 18 n. 7,19 n. 8

129: 331

135: 331

169: 327
170: 327 n. 30

232: 329

288: 329

289: 329

290: 329

302: 177 n. 149

305: 16 n. 3

Fr. dub. 357 M-W: 37-38, 45 nn. 64 e $65,58,144$ n. 64

Pseudo-Hesíodo

Sc. 216: 331

Scholia

Schol. Th. 313, pp. 60-61 Di Gregorio: 330 e n. 38

Schol. Op. 654: 29 n. 27

Schol. Op. 657: 45 n. 65

\section{Hesíquio}

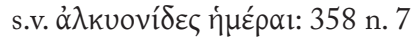

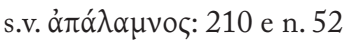

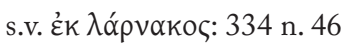

s.v. $\Lambda \alpha \sigma i ́ \sigma \mu \alpha \tau \alpha: 96$ n. 94

s.v. Oikıódฤ५: 329

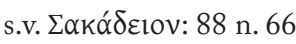

s.v. ఠฤкóc: 267 n. 32

s.v. $\chi \lambda$ $\lambda \omega$ مós: 363 n. 19

\section{Higino}

Fab. 65: 359 n. 9

Himério: 89 n. 70

Or. 12. 32-33: 145 n. 69

Or. 28. 2: 93 n. 81

Or. 29. 22: 92 e n. 80

Or. 31. 5: 115 n. 3, 170

Or.39.1: 125

Or. 47. 1: 318 e n. 5; 47. 14: 145 n. 69,360

Or. 62. 54-60: $325-326$ e n. 26

Or. 69. 35: 102

Hinos Homéricos: 30, 33 e n. 33, 35 e n. 38, 37 n. 43, 301 e n. 93 
$A$ Deméter (II)

18: 301 n. 94

28: 325

55: 328 n. 34

190: 362 n. 19

236: 335 n. 49

495: 35 n. 38

A Apolo (III): $33,37,39$ e n. 50, 227

1-178: 33 e n. 34

82: 301 n. 94

114: 36 n. 42

146: 36; 146-150: 36; 146-155: 33;

146-164: 34

149-150: 33,35

150: 36

151-155: 34 n. 37

153: $36 ; 153-154: 36$

156: $36 ; 156-164: 68,360$

158: 37

160: 35

161: 30 n. $30,36,37$

162-164: 34 e n. $37 ; 164: 37$

165-172: 36, 37; 165-176: 33-40

177-178: 35 n. 38

179-546: 33 e n. 34

205: 300 n. 91

223: 362 n. 19

347: 325

519: 343 n. 75

545-546: 301 n. 93 ; 546: 35 n. 38

A Hermes (IV)

1-19: 327

230: 324

244: 327 n. 31

319: 320 n. 9

579-580: 301 n. 93

A Afrodite (V)

155: 236 n. 127

217: 252 n. 42
225: 226 n. 95

274: 226 n. 95

293: 30 n. 30

$A$ Afrodite (VI)

2-3: 40

18: 233 n. 117

19-20: 40

19: 328

b.Hom. 7. 53: 78 n. 40

h.Hom. 11. 5: 40 n. 53

h.Hom. 15. 9: 40 n. 53

h.Hom. 23. 2: 251 n. 39

h.Hom. 24. 5: 40 n. 53

h.Hom. 25. 2-5: 58; 25. 6: 40 n. 53

h.Hom. 26. 12-13: 40

Hipóstrato: $38-39,50$

FGrHist 568 F 5: 38-39

Homero: 19, 36-38 e n. 47, 39 e nn. 51, 52; 41 e n. 55,42 e nn. 57,$58 ; 43$ e n. 59,44 e nn. 61,$62 ; 45$ e nn. 64 , 65; 46 e n. 66,47 e n. $67,49-52$ e n. $77,53-56,59,69$ e n. $14,82,83$, 116 e n. 7,117 n. 12,119 n. 15,137 , 144 n. 64,165 n. $121,185,219$ n. 79, 222 n. 86, 224 n. 91, 225, 227 e n. 99, 228 n. 102, 299, 300 n. 90, 301 n. 92, 302, 303, 310 n. 111, 313, 348, 350, 351, 361, 372

Poemas Homéricos: 10, 27, 28, 33, 42 n. $57,52,57$ e n. $86,65,124$, 137, 165 n. 121, 226 n. 94, 230, 233 n. 116, 237, 249 n. 32, 297, 301 n. 92, 302 n. 95, 309, 347, 350, 355, 360, 363, 364, 369, 372

Ilíada: 15 e n. 1, 17, 18, 19, 36, 46, 52 e n. 77,54 n. 82,211 n. 57 , 252 n. 42, 298, 299, 310, 349, 355

1. $14: 251$ n. 38

1. $93: 20$ n. 14

1. $98: 328$ n. 32

1. 384-385: 20 n. 14 
Mobilidade poética na Grécia antiga: uma leitura da obra de Simónides

\begin{tabular}{|c|c|}
\hline 1.389: 328 n. 32 & 5. 403: 319 n. 8 \\
\hline 1. 417: 301 n. 92 & 5.597: 210 \\
\hline 1. $472-474: 15$ & 5.737: 257 n. 4 \\
\hline 1. $474: 22$ & $6.130-140: 18$ n. 6 \\
\hline 1. $477: 355$ & $6.142: 209$ n. 45 \\
\hline 1. 505: 301 n. 92 & $6.146-149: 223$ e n. 88,224 \\
\hline 1.529: 324 & $6.146: 222$ e n. 84 \\
\hline 1. $540: 320$ & 6. $182: 219$ n. 80 \\
\hline $2: 369$ & $6.200-202: 18$ n. 6 \\
\hline $2.19: 324$ & 6. 233: 236 n. 127 \\
\hline 2.23: 29 n. 26 & 6.313-315: 21 n. 14 \\
\hline $2.38: 226$ & $6.344: 320$ \\
\hline 2. 89: 219 n. 80,362 & 6. 357-358: 16 n. 4,299 \\
\hline 2.136: 226 & 6. $358: 19$ n. 10 \\
\hline 2. 303-304: 29 & $6.463: 293$ n. 76 \\
\hline 2. $485: 302$ n. 97 & 6. 488-489: 192 n. 2 \\
\hline 2. $506: 245$ n. 22 & 7.38: 303 n. 98 \\
\hline 2. 591-600: 17-19; 2. 597: 40; 2. & 7. 87-91: 268 n. 34 \\
\hline 599-600: 21 & 7.307: 306 n. 103 \\
\hline 2.632: 343 & 7. 479: 362 n. 19 \\
\hline 2. $730-732: 21$ n. 14 & $8.47: 307$ \\
\hline 2.730: 19 & $8.177: 226$ \\
\hline 2. $860: 298$ n. 85 & 8. 195: 333 n. 46 \\
\hline 2. $872: 348$ & $8.216: 327$ n. 28 \\
\hline $2.877: 351$ & 8. 409: 252 n. 42 \\
\hline 3. $108: 300$ n. 92 & $8.524: 209$ \\
\hline 3. $150-152: 364$ e n. 27 & $8.553-565: 355$ \\
\hline $3.382: 325$ n. 24 & $9.15: 335$ \\
\hline 3. $405: 320$ n. 9 & 9.185-191: 16 \\
\hline 4. $135: 333$ n. 46 & $9.186: 22$ \\
\hline 4.189-219: 21 n. 14 & $9.189: 22$ \\
\hline 4. $346: 343$ n. 75 & $9.319-320: 192$ n. 2 \\
\hline 4. $426: 336$ n. 52 & $9.440: 226$ \\
\hline 4. $437: 343$ & 9. 449: 324 n. 22 \\
\hline 4. 482-489: 297 n. 83 & $9.529-599: 350$ \\
\hline 4. 509: 303 n. 98 & $9.558: 358$ \\
\hline 4. $524: 339$ n. 64 & 9. 562: 301 n. 92 \\
\hline 5.9: 132 n. 35 & $9.562-563: 356,359$ n. 9 \\
\hline 5. 61-63: 21 n. 14 & 9. $577: 325$ n. 24 \\
\hline
\end{tabular}


10. $30: 359$

10. $164: 319$ n. 8

10. 308: 293

10. $467: 345$ n. 79

10. $495: 343$ n. 75

11. 298: 355

11. $482: 29$ n. 26

11. 511-518: 21 n. 14

11. 514: 21 n. 14

11. $631: 362$ n. 19,364

11. 833: 21 n. 14

12. $18: 219$ n. 80

12. $23: 196$ n. 17

12. $27: 343$ n. 74

12. 237: 194 n. 9

12. 339: 306 n. 103

13. $5: 284$ n. 60

13. $34: 343$ n. 74

13. $70: 20$ n. 14

13. 110: 293

13. 126-133: 45 n. 64

13. $286: 257$ n. 4

13. 339-344: 45 n. 64

13. 389-393: 297-298

13. 516-517: 348

13. $654: 339$ n. 64

13. $663: 20$ n. 14

13. 731: 19 n. 10

14. 33-34: 166 e n. 122

14. 157: 307

14. 249: 357

14. 319-320: 331

14. 326: 300 n. 91

14. $327: 251$

14. $347: 231$ n. 112

14. 347-351: 355

15. $10: 358$ n. 6

15. $441: 301$ n. 92

15. 641-643: 206
15. 689: 306 n. 103

16. $28: 21$ n. 14

16. 234: 99 n. 1

16. 482-486: 297-298

16. 711: 251

16. $766: 297$ n. 81

16. $798: 236$ n. 129

17. 53: 345 n. 79

17. 53-60: 297 n. 83

17. $88: 219$ n. 80

17. 561: 227

17. 596: 327 n. 28

18. 95: 301 n. 92

18. $262: 259$

18. 413: 333- 334 n. 46

18. $458: 301$ n. 92

18. 475: 308 n. 106

18. 478-608: 15, 355

18. 486: 328,329 n. 35

18. 491-496: 15

18. 495-496: 15, 22

18. 526: 16,22

18. 569-572: 16

18. 590-606: 16

18. $604: 22$

19. $32: 251$

19. $126: 300$ n. 91

19. 350: 194 n. 9

19. $354: 334$

19. 416-417: 298

20. 417-418: 287

21. 202: 335

21. 286: 236 n. 127

21. 483: 284 n. 60

22. 73: 210 n. 55

22. 281: 236 n. 129

22. 357: 249 n. 32

22. 359-360: 298

22.391-392: 15 
Mobilidade poética na Grécia antiga: uma leitura da obra de Simónides

23. 83-84: 298

23. $126: 261$

23. $141: 236$ n. 129

23. 257-897: 30 n. 31

23. $281: 345$ e n. 78

23. $343: 230$

23. $483: 299$ n. 86

23. $513: 30$

23. 629-642: 30 n. 31

23. 677-680: 30 n. 31

24. $5: 264$ n. 22

24. $58: 335$ n. 49

24. $205: 249$ n. 32

24. $496: 347$

24. 505: 358

24. $521: 249$ n. 32

24. 525-533: 199

24. 602-609: 18 n. 6

24. 671-672: 236 n. 127

24. 719-722: 17,31

24. $795: 334$ n. 46

Odisseia: 15, 16, 17, 19, 20 e n. 11, 24-26, 46, 47, 52 e n. 77,54 n.

$82,89,100,211$ n. 57,301 n. 92

1. $52: 328$

1. $131: 333$ n. 46

1. 153-154: 25-26

1. $154: 25,211$

1. 325-326: 23,24

1. 325-327: 26

1. 326-327: 16 n. 4

1. $328: 21$

1. 337, 339-340: 23

1. $338: 16 \mathrm{n} .4$

1. 340-342: 24

1. 346-347: 22,24

1. 351-352: 23

1.368: 23

1.371: 24
1. 421: 236 n. 129

2. 1: 355

3. $37: 236$ n. 217

3. 71-74: 100

3. 198: 320

3. 262-272: $24-25$ e n. 19

3. $380: 327$ n. 28

4. $17: 23$

4. $86: 251$

4. 293: 249 n. 32

4. $336: 335$

4. 429: 324

4. 443: 294

4. $458: 345$ n. 78

4. 563-569: 349 n. 87

4. 584: 287

4. $708: 293$

4. 737: 236 n. 129

4. $777: 343$ n. 76

5. 53: 336 n. 52

5. $56: 355$

5.63-74: 355

5. 64: 325 n. 24

5. 123: 290 n. 70

5. 238: 303

5. 249-250: 21 n. 14

5. 272: 328,329 n. 35

5. 291-296: 355

5.313-332: 355

5.390: 300 n. 91

5. 403: 336 n. 52

5. $445: 325$

6. $79: 345$ e n. 78

6. $89: 351$

6. 162-167: 36 n. 40

6. 219: 336 n. 52

7. 18: 325 n. 24

7. 112-132: 355

7. 245: 328 
7.279: 334

8. 43-45: 21

8. 43-47: 26

8. $62: 24,26$

8. 63-64: 22,26

8. $73: 16,22$

8. 75-83: 16 n. 4

8. 86-92: 24

8. 105-108: 26

8. $185: 216$ n. 72

8. 222: 209 n. 45

8. 258-366: 37,82

8. 266-366: 16 n. $4,26,319$ n. 7

8. 393: 308 n. 106

8. $429: 30$

8. $472: 24$

8. 474-481: 177 n. 149

8. $479: 358$

8. 479-481: 22,24

8. 485-498: 25

8. 487-490: 22

8. 492-521: 16 n. 4

8. 496-499: 22

8. $498: 21$

8. 499-520: 26

8. 536-543: 25

9. 1-11: 24

9. $4: 24$

9. 6-11: 41-42

9. $22: 343$

9. $94: 343$ n. 75

9. $351: 319$ n. 8

9.373: 264 n. 22

10. $160: 219$ n. 80

10. $234: 364$

10. 492-495: 20 n. 14

11. $90-151: 20$ n. 14

11. $94: 334$

11. 100: 343 n. 75
11. 275: 226 n. 95

11.316: 343

11.320: 236 n. 129

11.368-369: 22

11. 387 sqq.: 349 n. 87

11. 603: 227 n. 100

12. 104, 106: 195

12. $187: 343$ n. 75

12. $279: 319$ n. 8

13. $27: 23$

13. $28: 24$

13. $269: 335$

13. 280: 180 n. 155

14. 327-330: 99 n. 1

14. $435: 327$

14. 530: 339

15. 58: 324 n. 22

15. 126: 226 n. 95

15. 212: 259

15. 234: 195

16. $47: 362$ n. 19

16. $252: 25$

16. $418: 320$

17: 70,369

17. 340-341: 21 n. 14

17. 358-360: 24

17. 380-387: 19-20

17. 385-386: 21, 24

17. 518-521: 22-23

17. 519: 236 n. 129

19. 55-57: 21 n. 14

19. 109-114: 195 n. 14

19. 135: 20

19. 282: 198 n. 20

19. 409: 301 n. 92

19. 518: 362

19. 551: 343 n. 75

20. $287: 210$ n. 54

20. 365-366: 206 
Mobilidade poética na Grécia antiga: uma leitura da obra de Simónides

21. $407: 309$

22. $75: 301$ n. 92

22. $330: 24$

22. $331: 25$

22. 344-349: 23,40

22. $347: 23$ e n. 17,57 n. 86

22. $350-353: 25,211$

22. $354-360: 23$

22. $376: 23$

22. $395: 227$

23. $172: 249$ n. 32

23. $327: 195$

24. 15 sqq.: 349 n. 87

24. 36-97: 298

24. 60-61: 17 n. 5

24. $71: 219$ n. 80

24. 76-84: 312

24. $85-92: 30$ n. 31

Batrachomyomachia: 361 e n. 17

Epigonos: 46 e n. 66

Margites: 43 e n. 59

Tebaida: 46 e n. 66

Scholia

A Hom. Il. 2. 872a (I. 351 Erbse): 348

B Hom. Il. 10. 252 (III. 436 Dindorf): 347 e n. 84

B Hom. Il. 18. 570 (IV. 558 Erbse): 16 n. 3

B Hom. Il.21.126 (V.149 Erbse): 360 e n. 13

BT Hom. Il. 9. 557-558 (II. 518519 Erbse): 318 e n. 4

Hom. Il. 7.76: 194 n. 9

Hom. Il. 9. 562: 359 n. 9

T Hom. Il.13. 516 (III. 500 Erbse): 348

T Hom. Il. 24. 228b: 177 n. 151

Horácio: 181 n. 158

Carm. 2.1.37-38: 115 n. 4, 373
Carm. 3. 30. 1: 227

Íbico: 25 n. 19, 78, 80 n. 44, 89-93 e n. $83,94,102,103,116,127,349$ e n. 87,372

Frr. $P M G$

282 (a) ('Ode a Polícrates', 1 P): 89 e n. 70,215 n. 70,233 n. 114 , 313; 282 (a). 47-48: 265

282A Campbell: 90 e n. 71, 91 n. 75, 104, 249 n. 32 ; fr. 1.15 sqq.: 317 n. 1

282B Campbell: 91 n. 75

286 (5 P): 90, 356 e n. 3

287 (6 P): 90, 319 n. 6, 356 e n. 3, 363 n. 22

288 (7 P): 324 n. 22,356 e n. 3

289 (8 P): 90

290 (9 P): 350 n. 89

291 (10 P): 349

296 (15 P): 90

297 (16 P): 90, 349

303 (b) (22b P): 356 e n. 3, 361 n. 18

306 (25 P): 342 n. 71

307 (26 P): 350

315 (34 P): 356 e n. 3

317 (36 P): 356 e n. 3

317 (a) (36a P): 356 n. 5, 359 n. 12

343 (62 P): 102

169. 1 SLG: 216 n. 72

\section{Inscrições ${ }^{1}$}

$I G \mathrm{I}^{2} .115 .17,34: 211$

$I G \mathrm{I}^{2} .485: 138$

$I G \mathrm{I}^{2} .761: 141$

$I G \mathrm{I}^{2} .927: 277-278$

$I G \mathrm{II}^{2} .2318: 132$

$I G \mathrm{~V}, 1.18$. A 8; 19.15, 658.12: 264 n. 25
1 Corpus disponível online no site http://epigraphy.packhum.org/ inscriptions/ [acedido em 3/07/2012]. 
$I G$ VII. $53=S E G$ 13.312: 288-290

$I G$ XII. 5. 1. 593: 116 n. 10

$I G$ XII. 5. 608: 116 n. 8

$I G$ XII. 5. 609. 102-103, 637: 115

n. 2

SEG 10. 320: 137

SEG 10. 352. 6: 141

SEG 10. 404: 259, 292-293

SEG 15. 517, col. II: 18 n. 6

Isócrates: 41 n. 56

Hel. 64: 85 n. 57

Hel. 65: 54

Panath. 17-18: 52 n. 78; 18: 56-57

Julianus Imperator: 318

Ep. 24: 124

\section{Lâmprocles}

$736 P M G: 329$ n. 36

Laso de Hermíone: 76, 94-96, 104, 131

e n. 33,135 e n. $43,136,370$

Frr. $P M G$

702 (1 P): 95

704 (3 P): 95 n. 92

\section{Leónidas de Tarento}

Epigr. XXXI Gow-Page: 92 n. 76, 94 n. 87

\section{Pseudo-Libânio}

Narr. 13: 122 n. 16

\section{Lícofron}

Schol. Lyc. 172: 349 n. 87

Licurgo: 272 n. 40

In Leocr. 102: 46

In Leocr. 109: 260-261, 270

\section{Lísias}

21.1-4: 94 n. 88

\section{Longino}

Rh. 718 : 180 n. 157

Pseudo-Longino

De subl. 13. 3: 82

De subl. 15. 7:349
Luciano

BisAcc. 9: 257 n. 6

DDeor. 2 (22) 3: 257 n. 6

Halc. 2: 359 n. 9

Ind. 8-9: 80 n. 43

Pro imag. 19: 246-249

Pseudo-Luciano

Macr. 26: 92 n. 77, 119 n. 15

\section{Marmor Parium}

Ep. 34: 68 n. 11

Ep. $36: 78$ n. 38

Ep. 46: 94, 135

Ep. 47: 135

Ep. $50: 85$ n. 57

Ep. 54: 132, 138, 180 e n. 156, 290

$$
\text { n. } 71
$$

Ep. 57: 118

\section{Máximo de Tiro}

21. $7: 92$ n. 79

37. $5: 93$ n. 81

\section{Menandro Retor}

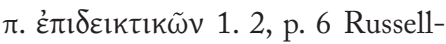
Wilson: 194 n. 8

Menecmo de Sícion

FGrHist $131 \mathrm{~F}$ 9: 57-58 n. 89

Mimnermo: 223 e n. 91, 224, 225 n. 92,371

Frr. West

1: 221

2: $223 ; 2.1-4: 355$

5. 3: 192 n. 3,193 n. 5

12. 7: 308 n. 106

Nicephorus

8. $33: 257$ n. 5

Nicodemo: 258 n. 7

Nono de Panópolis

Dionysiaca 24. 43-45: 301 n. 92

Novum Testamentum

Act. 2. 3-11: 34 n. 37 
Mobilidade poética na Grécia antiga: uma leitura da obra de Simónides

\section{Ovídio}

Ars 2. 561-592: 319 n. 7

Met. 4. 171-189: 319 n. 7

Met. $11.410-750: 359$ n. 9

\section{Papiros}

Flinders Petrie Papyrus: 41 n. 56

Michigan Papyrus 2754: 41 n. 56

Papiro de Lille: 83

P. Berol. 13875: 137

P. Hibeh 17: 166, 183 e n. 161

P. Oxy. (Oxyrhynchus Papyri): 12

P. Oxy. 7: 100 n. 6

P. Oxy. 222: 50 n. 71, 153 e n. 90,

154,241 e n. 6,253 n. 46

P. Oxy. 1087, col. i 30, viii 102-103:

194 n. 9

P. Oxy. 1800

fr. $1: 99$ n. 3

fr. 1, col. 2.36-40: 115 n. 1

fr. 1 , col. 2.40 sqq.: 180 e n. 156

P. Oxy. 2289. 6: 100 n. 6

P. Oxy. 2310, fr. 1 col. i. 22-39: 100

P. Oxy. 2327: 143 n. 63, 229 e n.

104, 232, 235 n. 122, 236, 295

fr. 1: $228-229$

fr. 2 (a) col. i.: 228-229, 229 n. 104

fr. 2 (a) col. ii.: 229 n. 104, 231234

fr. 2 (b): 229 n. 104, 231-234

frr. 3-4: 231-232

fr. 5: 295-297 e n. 82

fr. 6: 295-298

fr. 27 col. i: $295-297$

fr. 27 col. ii: 278, 304-305

P. Oxy. 2364, fr. 1. b: 342

P. Oxy. 2387: 74

P. Oxy. 2389, fr. 9, col. 1.5 sq.: 74

n. 26

P. Oxy. 2430: 125, 128, 320-321,
321 n. 11,371

fr. 1. col. ii. $6: 321$ n. 13

fr. 9. col. ii. 2 , 4, 5: 321 n. 13

fr. 22. 3-4: 322

fr. 23: 321 n. 13

fr. $31: 321$ n. 13

fr. 32: 321 nn. 13 e14, 348 n. 86, 360 e n. 14

fr. $35: 125-126$ e n. 21,370

fr. 35 (b): 321 e nn. 13, 14; 360 e n. 15

fr. 41: 321 nn. 13 e14; 322, 326 n. 26

frr. 47, 53: 321 n. 13

fr. 55: 321 e nn. 13, 14; 360 e n. 15

fr. $61: 321$ e n. 13

frr. 62, 70: 321 n. 13

fr. 77: 321 nn. 13 e 14, 361

fr. $78: 321$

fr. 79: 321 n. 14

fr. 84: 321 n. 13

fr. $92: 321$ e n. 14

fr. $94: 321$ n. 13

fr. 120 (b) 3: 250 n. 34, 321

fr. $131.4,6: 321$ n. 13

schol. 35 (e) 4: 321 n. 13

P. Oxy. 2431, fr. 1: 164

fr. 1. (a) 1-8, (b) 5-8: 249-252

P. Oxy. 2432: 199

P. Oxy. 2434: 350

P. Oxy. 2438, col. 1, linhas 9-10: 135

P. Oxy. 2506, fr. 1 col. ii: 104 e n. 23

P. Oxy. 2617, fr. 7: 82

P. Oxy. 2623: 155 n. 96, 321, 329, 371

fr. 1: 321

fr. $2: 128,321-322$

fr. 10: 322

fr. 14: 193,321 
frr. 21, 22: 155 e n. 96,156 e n. 98, 193

frr. 41, 45: 321

fr. $46: 321,322$

fr. $54: 341$ n. 70

fr. $57: 321$

P. Oxy. 2624: 322, 371

fr. 1. 4, 11-12: 322

fr. 9 (b): 209 n. 45

fr. $29: 322$

fr. $32: 322$

fr. $48: 142$

fr. $56: 322$

P. Oxy. 2637, fr. 1-42: 91 n. 75

P. Oxy. 2735: 90 e n. 71, 91-92 n. 75

fr. 1. 5: 104

fr. 11: 91 n. 75,249 n. 32

P. Oxy. 3965: 9, 143 n. 63, 145 e n.

69, 222, 229, 232, 236, 292, 295,

306

fr. 1: 295-297

fr. 2. 1-42: 295-297

fr. 5: 306,307

fr. $7: 158$ n. 105

fr. 20: 145 n. 69,294

fr. 21: 305

fr. 22: 294

fr. $26: 222$ n. $86,224-225$

fr. 27: 231-232

fr. $32: 317$ n. 2

P. Princeton inv. AM87-59: $162 \mathrm{n}$. 114

\section{Parménides}

Fr. 8. 52 Diels-Kranz: 302 n. 96

Pausânias: 34 n. 36, 103, 171

1.2. 3: 93 n. 81,168

1.8. 5: 138

1. $14.4: 70$ e n. 18

1.25.1: 92 n. 76,93 n. 85

1. $28.4: 257$ n. 6
1. 32. 3: 261 e n. 16

1. 43. 3: 289,290 n. 71

1. $44.6: 102$ n. 14

2. 1. $1: 66$ n. 4

2. 11. 3: 102 n. 14

2. $15.2: 102$ n. 14

2. 22. 8: 87

2. $35.1: 95$ n. 91

3. 8. 2: 149,292

3. 11. 9: 72 n. 23

3. $14.1: 264$ n. 25

3. 15. 2: 74

3. $25.7: 75$ n. 28

4. 4. $1: 66-67 ; 4.4 .4: 67$

4. $13.7: 67$

4. $27.7: 88$

4. 33. 2: 65-68; 4. 33. 3: 18 n. $7 ; 4$. 33. $7: 44$ n. 62

5. 9. 1-2: 253 e n. 46

5. 17. $11: 91 \mathrm{n} .75$

5. 19. $10: 66$ n. 6

5. 25. 2-4: 102-103, 104

5. 27. 8: 102 n. 16

6. 2. 10-11: 248 n. 29

6. $6.4: 365$ n. 29

6. $9.1: 153$

6. 9. 6-7: 161-162 n. 111; 6. 9. 6: 152 n. 85 ; 6. 9. 9: 115 n. 3, 151152

6. 10. 1-3: 247 n. 28,248 nn. 29 e 30; 6. 10. 3: 152 n. 83

6. 13. 1: 240-241 e nn. 5, 6

6. 14. 1: 248 n. 29; 6. 14. 2: 248 n. 29; 6. 14. 5: 152, 172; 6. 14. 6-8: 172 n. 138 ; 6. 14. 9-10: 86 n. 61 , 87; 6. 14. 13: 152 e nn. 84,85

7. 18. 1: 330 n. 37

7. $27.4: 130$ n. 30

8. 48. 2: 141 n. 59

9. 2. 5: $151,286,288$ n. $65 ; 9.2 .6$ : 288 n. 65 
Mobilidade poética na Grécia antiga: uma leitura da obra de Simónides

9.9. 5: 46 n. 66

9.12. 5-6: 88 n. 68

9.16.1: 109

9.22.3: 144 n. 64

9. 29.6-7: 16 n. 3

9.30. $2: 88$ e n. 67

9.31. $3: 30$ n. 32

10. 5. 5: 102 n. 14

10. 7. $2: 19$ n. $9 ; 10.7 .4-5: 86 ; 10.7$. 4-6: $30 ; 10.7 .5-6: 86-87 ; 10.7$. 7: 86 n. 60

10. 13. 9: 291-292 n. 72

10. $24.1: 95$ n. 93,210 e n. 53,219 n. 77

10. 32. 8: 102 n. 14

10. 36. 1: 345 n. 79

Píndaro: 30 n. 30, 53 n. 80, 77 n. 33, 88, 93 n. 85, 95, 104-111, 118, 119 e n. $15,124-127$ e n. $27,128,135,137$, 138 e n. 51,144 n. 64,151 n. 82,153 n. 91,156 e n. $97,160,165$ n. 120 , 168-171, 175 e nn. 144,$145 ; 200$ n. 22,214 e n. 66,215 n. $69,240,244$, 246 n. 24,250 n. $34,252,318,326$ n. $27,343,369,370,372,373$

Olimpicas

1: 106, 109; 1. 11: 239; 1. 75-85: 335 n. 48; 1. 103-105: 107 n. 29; $1.115-116: 106$ e n. 28,110 2: 106; 2. 49-51: 170-171; 2. 86-89: $168-169,200$ n. 24

3: 106; 3. 1: 300 n. 91

4. 14-16: 107 n. $29 ; 4.23: 339$ n. 63 5: 253 n. $46 ; 5.15: 105$ e n. $26 ; 5.23$ :

210; 5. 23-24: 194 n. 12

6: 253 n. 46; 6. 5: 304 n. 101; 6. 22-

28: 130 n. $31 ; 6.30: 300$ n. $91 ; 6$. 40: 363 n. $22 ; 6.47: 364$ n. $26 ; 6$. 61-62: 236 n. 129; 6. 67:320; 6. 71: 53 n. 80; 6. 77-78: 107-108; 6. 79: 327 n. 29; 6. 87-98: 108; 6. 88: $110-111$ e n. 43 ; $6.103-$ 105: 108
7: 105 n. 27; 7. 24: 329; 7. 65: 249; 7. 81-87: 155 n. $95 ; 7.83: 142$ n. 59; 7. 94-95: 194 n. 12

8: 244 n. $16 ; 8.9: 245$ n. $22 ; 8.19$ sqq: 153 n. $91 ; 8.81: 327$ n. 29; 8. $87: 198$ n. 20

9.1-4: 126-127; 9. 89-90: 142 n. 59; 9. $97-98: 130$ n. $30 ; 9.98: 266$ n. 31

10: 106; 10.15: 259; 10.73-77: 106; 10. 78 sqq.: 127 n. $26 ; 10.99-$ 102: 106

11: 106; 11. 4: 343 n. 75; 11. 13: 233 n. $117 ; 11.20: 335$

13: 105 n. $27 ; 13.1-8: 107$ n. 29; 13. 1: 155; 13.17-19: 76; 13.18-19: 134; 13. 24-48: 155, 156; 13. 93-113: 155; 13. 106-113: 130 n. $32 ; 13.106-113: 155$ n. 95

Piticas

1: 107; 1. 1: 251 n. 40, 300; 1. 3: 57 n. $87 ; 1.17: 301$ n. 94

2: 108 e nn. 31, 33; 2. 1-4: 108 e n. 31, 110; 2. 10: 327; 2. 68: 108, 110; 2. 69: 127 n. 26,317 n. 1; 2. 70-71: 108

3: 108 n. 33; 3. 61: 230 n. 109; 3. 6876: 108; 3.80 sqq.: 193

4: 339; 4. 13-56: 335 n. 48; 4. 16: 99 n. $1 ; 4.60: 364$ n. $26 ; 4.68: 340$; 4. 87-88: 319 n. 7; 4. 87-92, 97119: 335 n. 48; 4. 136: 300; 4. 138-167: 335 n. 48; 4. 172: 328; 4. 177: 342; $4.178: 327$ n. $29 ; 4$. 208-209: 340; 4. 229-231: 335 n. 48 ; 4. 253: 340; 4. 289: 328 n. 33

5. 9: 317 n. 1; 5. 23-53: 130 n. 31; 5. 68-69: 217 n. 73; 5. 106-107: 105 e n. 26

6: $170 ; 6.1: 328$ n. $32 ; 6.54: 364$ n. 26

8: 244 n. 16 ; 8. 8: 358 n. 8; 8. 35-37: 153 e n. 89; 8. 46: 359 n. 12; 8. 88-94: 194 n. 12 ; 8. 95-97: 193 
9. 37: 231 n. 112,343 n. 75; 9. 59: 327 n. 29; $9.106: 324$ n. $22 ; 9$. 124-125: 240 n. 3

10: 214 n. 67; 10. 27-44: 318; 10. 41-42: 234 n. $118 ; 10.54: 364$ n. $26 ; 10.64$ : $159 ; 10.64-66$ : 107 n. 29

11. $61-62: 317$ n. 1

12: 87; 12.17-18: 331

\section{Nemeias}

1. 6: 252 n. 42; 1. 24-25: 200 n. 24;

1. $47: 339$ n. 64

2: 50 e n. $71 ; 2.1-5: 50,53 ; 2.2: 50$, 57 n. 87; 2. 10-12: 328; 2. 11: 329; 2. 13: 50 n. 71

3: 109 e n. 34, 111 n. 45, 244 n. 16;

3. 3-5: 109; 3. 4: 343 n. 75; 3. 22: 329; 3. 66, 76-80: 109; 3. 83: 324 n. 21

4: 244 n. 16 ; $4.36: 336$ n. 52; 4. 62 : 201 n. 27

5: 244 n. 16,248 n. 29

6: 105 n. 27,244 n. 16; 6. 13:327; 6 . 23-24: 217 n. 76

7: 244 n. $16 ; 7.17-20: 195$ n. 16; 7. 61-63: 107 n. 29; 7.73: 335

8: 244 n. 16; 8. 40: 362 n. 19; 8. 5051: 127 n. 26

9. 6: 216 n. 71

10: 317 n. 1; 10. 43: 142 n. 59; 10. 44: 130 n. $30 ; 10.53: 327$ n. 29

Istmicas

1: 130 n. $31 ; 1.10-11: 106 ; 1.16$ : 127 n. 26, 317 n. 1; 1. 32: 301 n. $96 ; 1.42: 105$ e n. $26 ; 1.60$ : 327 n. 29

2: 108 n. $33,170,171$ n. $133 ; 2.1$ : 109; $2.6: 175$ e n. $145 ; 2.12-17$ : 109; 2. 13: 109 n. 35; 2. 31: 109; 2. 36-42, 47-48: 109

4. 18 b: 345 n. 79 ; 4. 38-39: 57 n. 88; 4. $70: 240$

5: 244 n. $16 ; 5.12-16: 194$ n. $12 ; 5$. 33: 317 n. 1; 5. 46-47: 236 n.
129; 5. 57: 105 e n. 26

6: 244 n. $16 ; 6.10: 105$ e n. $26 ; 6.41$ : 249; 6. 74-75: 324 nn. 19 e 22, 325 e n. 25

7. 23: 300 n. $91 ; 7.32: 350$ n. 89

8. $67: 240$

Frr. Maehler

2-3: 153

33c. $6: 363$ n. 22

35b: 210 n. 53

36: 99 n. 1

52c. $94: 104$ n. 20

52d. 21-24: 106, 116 n. 9

52e: 126

52f. 54-55: 302 n. 97

52g. 11: 104 n. 20, 126

52h: 126, 235 n. 122

52i: 126; 52i. 78: 302 n. 95

52p: 126

52s: 126

70 b: 95 n. 92,133 n. 37,201 n. 27

70d: 327 n. 29

75. $18: 104$ n. 21

76: 233 n. 117

94b. $17: 358$ n. 8

123: 230 n. 111, 233 n. 114, 328; 123. $11: 364$ n. 26

124ab. 1-2: 109

125: 68 n. $12 ; 125.3: 103$ n. 19

128c: 16 n. 3 ; 128c. 11-12: 342

140b. $15-17: 78$ n. 40

152: 364 n. 26

181: 263 n. 18

188: 73

194: 233 n. $117 ; 194.3: 302$ n. 96

211: 299 n. 86

222: 201 n. 26

225. $1: 358$ n. 8

226: 210 n. 51

269: 88 e n. 67 
Mobilidade poética na Grécia antiga: uma leitura da obra de Simónides

272: 119

339: 137

Scholia (Drachmann)

Ol. 2. 29d, I. 68-69: 45, 167

Ol. 2.86 sqq. $157 \mathrm{a}, 158 \mathrm{~d}$, I. $99: 168-$ 169, 176 n. 145

Ol. 6. $148 \mathrm{a}, 149 \mathrm{a}: 108$

Ol. 7. 42b, I. 210-211: 329

Ol. 9. 1-4, I. 268. 5-10 + 12-14: 127

Ol. 9.74 b, I. $285: 144$ n. 64,169 n. 129,176 n. 145

Ol. 13. 26b, I. 361-362: 94 n. 89

Ol. 13.32 b, I. $364-365: 283$ e n. 58 , 284 e n. 59,285 n. 61

Ol. 13. 78, I. 374: 347

Pyth. hypothesis, II. 2: 86 n. 60, 88 n. 66

Pyth. 1. 152b, II. 26: 165 n. 120

Pyth. 2. 127: 73 e n. 22

Pyth. 4. 451, II. 160: 340 e n. 68

Nem. 2. 1c, III. 29: 38 e n. 47, 50, 53 n. 80

Nem. 2. 1d, III. 31: $37-38$ e n. 44, 57 e n. 89

Nem. 2. 17c, III. 34-35: 327 e n. 30

Nem. 4. 60b: 176 n. 145

Isth. 2. argum., III. 212: 170-171

Isth. 2. 1b, III. 213: 92 n. 76

Isth. $4.63: 58$ n. 89

Isth. 4. 70: 240 n. 2

Eust. prooem. Pind. 27, III. 299-300: 95 n. 90,104 e n. 24

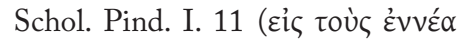

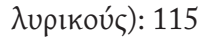

Vita Ambrosiana, I. 2-3: 118-119, 145

Vita Thomana, I. 4: 95 n. 90

Platão: 10, 55, 57, 69, 119 n. 15, 176 e n. 148, 205 nn. 34 e 35, 207 n. 41, 213 n. 63

Ap. 19e-20a: 176 n. 148,185
Chrm. 157e: 94

Hp.Mi. 363c-d: 185; 364d: 176 n. 148

Ion

530a: 51; 530b: 51, 80 n. 43; 530d: 51, 52, 53

531a-b: 52

532a: $52 ; 532 \mathrm{c}-\mathrm{d}: 51$

533b-c: 26; 533c: 51, 55

534a-b: 364 n. 24; 534c: 96 n. 95; 534e: 51

535a: 51; 535b: 51; 535b-c: 51; 535d: 51 e n. 75,80 n. 43; 535e: 51

536a: 51; 536e: 51

538e: 53 n. 80

539e: 51

541a: 52; 541b: 51, 55; 541c: 80 n. 43

Lg. 1.633 c: 72 n. 23

Lg. 2. 658b-d: 52 nn. 77 e 78; 54 n. 82

Lg. 6. 764d-e: 80 n. 44

Phdr.238a: 301 n. 94

Phdr. 243a: 83, 85 n. 57

Phdr.245a: 22 n. 16

Phdr. 252b: 54

Protágoras: 183, 185

315a-b: 185

316d: 185

326a-b: 105

339a-346d: 158, 173, 203-205; 339a: 212; 339b: 158; 339bc: 207,213 n. 63; 339c-d: 207; 339e sqq.: 207; 343a: 95 n. 93, 207 n. 43, 219 n. 77; 343b: 153 n. 91, 210 e n. 53

R. 331e: 183

R. 335e: 183

R. $337 \mathrm{~b}: 52$ n. 79

R. 373b: 58 n. 93 
R. 394c: 134 n. 39

R. 395a: 51 n. 76 ; 395 e: 200 n. 24

R. 429d: 345

R. $489 \mathrm{~b}-\mathrm{c}: 165$

R. $557 \mathrm{c}: 345$

R. 599e: 54

R. 600d: 55

Smp. 173d: 200 n. 24

Ti. 21b: 52 n. 78

Pseudo-Platão

Ep. 2.311a: 149, 168

Hipparch. 228b-c: 49, 52 n. 77, 93 e n. 84,136 e n. $46,137,177$

Schol. Ion 530a: 52 n. 79, 58 n. 89

Schol. Lg. 1. 633a-c: 72 n. 23

Schol. R. 337a, p. 192 Grene: 318 n. 3

Schol. R. 394c: 134

\section{Plínio, o Antigo}

Nat. 2. 54: 81 n. 45

Nat. 7. 89: 180 n. 157

Nat. 9. 20-33: 78 n. 40

Nat. 9. $134: 345$ n. 79

Nat. 9. 141: 345 n. 79

Nat. 16. 32: 345 n. 79

Nat. 22. 3: 345 n. 79

Nat. 35. 58: 86 n. 60

Plutarco: 147 n. 74, 151, 194 n. 12, 275, 277 n. 50,282 n. 55,310 n. 112

Moralia

Amatorius 760e-f: 29 n. 28

An seni sit ger. 3. $785 \mathrm{a}: 119$ n. 15, 132 e n. 36

An seni sit ger. $5.786 \mathrm{~b}: 178$ n. 153

Apothegmata Laconica 238a-b: 72 n. 23

Cons. Apoll. 6. 105a: 149

Cons. Apoll. 11. 107a-b: 191-193 n. 7

De adulatore 15.58 b: 184 n. 164
De amore prolis 2. 494a: 364 n. 24

De audiendis poetis 3. 17f-18a: 184 n. 164

De cupiditate div. 527c: 164 n. 118

De curios. 10. 520a: 177 n. 151

De E... 3. 385d: 207 n. 43, 219 n. 77

De E... 9. 388e, 389b-c: 134 n. 40

De exilio 13. 604f: 144 n. 64, 168

De garrulitate 23. 514f-515a: 184185

De gloria Atheniensium 3. 346f: 184

De Herodoti malignitate: 274 e n. 45, 275

34. $867 f: 274$

36. 869 c: 276

39. 870 e: $277-279$ e n. $52 ; 39$. 870f: $280-282$

39. 871a: 282; 39. 871a-b: 283285

42. 872d-e: 306-307

42. 873b: 287; 42. 873c: 292 n. 73

De profect. virt. 8. 79c: 364

De Pythiae oraculis $17.402 \mathrm{c}-\mathrm{d}$ : 323326

De recta ratione aud. 8. 41f: $364 \mathrm{n}$. 24

De ser. num. vind. 11. 555f: $177 \mathrm{n}$. 151

De soll. anim. 36. 984e-985b: 79 n. 40

De vitioso pudore 5: 96 n. 94

De vitioso pudore 534e: 146 n. 70

Instituta Laconica 17. 238c: 69 n. 13

Praecepta ger. reipubl. 807b: 146 n. 70

Quaest. conv. 3.644e-f: 184 n. 165

Quaest. conv. 5. 2. 674f-675a: $41 \mathrm{n}$. 55

Quaest. conv. 8. 3. 4, 722c: 342-343

Quaest. conv. 9.748a: 184 n. 164 
Mobilidade poética na Grécia antiga: uma leitura da obra de Simónides

Sept. sap. conv. 10.153f: 29 e n. 27;

10. 153f-154a: 41 n. 55

Sept. sap. conv. 18. 160e-19. 162b: 78 n. 39

Sept. sap. conv. 19. 162c-20. 163d: 78 n. 40

Vitae

Ages. 13. 4: 248 n. 29

Ages. 29. 2-3: 72 n. 23

Arist. 19. 7: 287; 19. 7-8: 288 n. 65

Arist. 21. 1-2: 288 n. 65

Cato Maior 18. 5: 164 n. 118

Cimon 10. 5: 164 n. 118

Dion 1. 958: 347

Lyc. 4. 1: 70, 71; 4. 2-3: 70, 74 n. 23

Per. 13. 6: 86 n. 62

Sol. 2. 1: 99

Sol. 12. 7-12: 21 n. 15

Sol. 21. 5: 100-101 e n. 9

Sol. 25. 6: 99 n. 4

Sol. 26: 99 n. 4

Sol. 27-28: 99 n. 4

Them. 1. 4: 146

Them. 5. 5: 149 n. 78; 5. 6: 115 n. 3; 5. 6-7: $145-146$ e n. 70; 5. 7: 156

Them. 8. 4-5: 274-275 e n. 46

Them. 15. 4: 145 n. 67

Them. 20. 3: 291 n. 72

Them. 21: 147

Thes. 17. 5: 344

Thes. 22. 6-7:336 n. 55

Fr. 84 Sandbach: 29 n. 27

Pseudo-Plutarco

De Musica: 72 n. 23

3. 1132 b: 19 n. 9; 3. 1132b-c: 26, 83; 3. 1132 c: 69 e n. 14,73

4. 1132d: 73; 4. 1132e: 69

5. 1132 f: 69 n. 14

5. 1133b: 73

6. 1133 c: 69 n. 13
7. $1133 \mathrm{e}-\mathrm{f}: 83$

8. 1134a: 86 n. 62,88 ; 8. 1134ab: 88 n. 65,88

9. 1134 b-c: $70-71$ e n. 20,87 , 89; 9. 1134c: 72-73

10. 1134d: 73; 10. 1134d-e: 71; 10. 1134 e: 73 e n. 24,134 n. 39

12. 1135 c: 88

17. 1136f: $124-125$

26. 1140c: 127 n. 26

28. $1140 f: 79$ e n. 41

29.1141c: 96

31. 1142b: 96

42. 1146b: 70 e n. 18

Regum et imperat. apoph. 185c-d: 146 n. 70

Vit. Hom. 2. 2 W: 222 n. 86

\section{Pólemon de Ílion}

FHG, F 21, 3. 122 Müller: 253 n. 46

\section{Políbio}

4. 20. 4-12: 73 n. 25

\section{Polieno}

Strategemata 8. 44: 250 n. 35

\section{Pólux}

4. $78: 88$ n. 66

5. $15: 253$

\section{Porfírio}

Ad Il. (Od.) I. 148 Schrader: 347 n. 84

Pratinas de Fliunte: 70 n. 18, 96

$708 P M G(1 \mathrm{P}): 96$ e n. 95

\section{Prisciano}

de metr. Terent. 24: 145 e n. 68

\section{Proclo}

Chr. 312a18-20 Bekker: 66 n. 5

Quintiliano: 317

Inst. 10. 1. 62: 82, 83 e n. 51; 10. 1. 64: 373

Inst. 11. 2.11-16: 162, 181 e n. 158; 11. 2. 14: 153, 247 e nn. 26, 27; 
11. $2.14-16: 163$ e n. $115 ; 11.2$. 16: 180,181

Safo: 75,78 e n. 38,81 e n. 45, 90 n. 72, 99 n. $3,319,373$

Frr. Lobel-Page

1. 2: 202 n. $31 ; 1.9-12: 355$

2: 355

5: 99 ก. 3,100 n. 6

16: 215 n. 70

22. $11: 103$ n. 19

31: 362 n. 19

34: 355

39: 359 n. 12

44. 24-25: 104

55: 300

94: 355

96: 355

98a. 9: 345 n. 79

104: 355

105: 355

106: 57 n. 87

115: 355

122: 355

123: 355

128: 324 n. 22

136: 355,361 n. 18

140 (b): 16 n. 3

146: 364 n. 26

156: 103 n. 19

195: 356 n. 5

202: 99 n. 3

Semónides de Amorgos: 222 e nn. 85, $86 ; 225$ n. 92

Frr. West

1: 222 n. 86

3: 193 n. 5

7: $355 ; 7.83-93: 364$ n. 26

\section{Sérvio}

In Verg. Aen. 6. 575, II. 80; 7. 658, II. 177 Thilo-Hagen: 330

\section{Simónides}

Frr. $P M G$

506: 128, 129, 172, 219, 239-241, 356

507: 128, 129, 153 n. 91, 241-246, $251,317,356$

508: 129 e n. $29,317,356-359,363$, 374,375

509: $128,129,142,152$ n. $83,246-$ $249,251,317,329$

510: 115 n. $3,128,129,153,162-$ $163,180-183,212$ n. 62,247

511: 128, 129, 164, 201 n. 26, 241252,317

512: 128 e n. 29

513: $170-171$

514: 129-130, 148, 374

515: 128, 129, 172, 177, 252-254, 374

517: 364 n. 25

518: 115 n. $3,129,141-142$

519: $125,128,250$ n. 34, 321 e nn. 13,$14 ; 322,326$ n. 26,348 n. 86 , 360-361, 370; 519, fr. 35: 125126 e n. $21 ; 519$, fr. $78: 30$ n. 30 ; 519, fr. 92: 374, 375

520: 191-198, 208, 265; 520. 1-3: 321

521: $162,193-197$ n. 19, 198, 265, $343,356,374$

522: 195-196

523: 196-197, 293, 301 n. 92, 343

524: 196

526: 197-198, 201, 208, 217

527: 198-199

528: 159-160

529: 159 n. 106,160

530: 142

531: 150, 180 n. 155, 182, 219 n. $80,220,262-267,273,286,308$, 373,374

533: 145 e n. 68 
Mobilidade poética na Grécia antiga: uma leitura da obra de Simónides

534: 145 e n. 69

535: 145 e n. 69,360

539: 77 n. 33, 133-134, 321 n. 11, 347 n. 83

540: 339 e n. 65

541: 199-203, 206, 208, 209 e n. 46, 211, $212-214$ n. 65,215 n. 70, 320 n. 9

542: 148, 158, 164, 173, 183, 185, 200 nn. 21-23, 201, 202 e n. 29, 203-217, 219 n. 77, 222 n. 86, 265

543-579: 128

543: 317, 330-338, 356, 363 n. 22, 372-374

544: $339-340$ e n. 66

545: $340-341$

546: 340

547: 340 e n. 68

548: 340

549: $81,350,351$

550: 344-346; 550 (a). 2-3: 356

551: 346

552: 318 e n. 3

553: 230, 335, 338-339, 356, 373

554: 329

555: 300, 326-329, 339 n. 63

556: 328 e n. 33

557: $349-350$

558: 116 n. 7,349

559: 347

561: 116 n. 7,348

562: 134

563: 318 e n. 4

564: 81 n. $45,82,116$ n. 7,117 n. 12 , $227,350-351,356,372$

565: 348

566: $329-330$

567: 341-342, 356, 363 n. 22, 372

568: 318 n. 3

569: 330 e n. 38
570: 318 e n. 4

571: 364 n. 25

572: $347-348$

573: 124

574: 318 e n. 4

575: 202 n. $31,318-320$

576: 124,340 e n. 67

577: 290 n. 70, 323-326

578: $325-326$

579: 116 n. $7,183,185,195$ n. 14 , 207, 216-218, 220, 222 n. 86, 223, 265, 290 n. 70,374

580: 115 n. 3,170

581: 46, 148, 183, 185, 207, 218220,222 n. 86, 356, 362, 374

583: 361

584: $219,220-221$

585: 364 n. 25

586: 362

589: 125

593: 364

594: 263 n. 20

595: 342-343, 356

597: 342 n. 72,363

598: 201, 202

600: 360 e n. 13

602: 144 n. 64,169 n. 129

606: 362

607: $137-138$ e nn. 49,50

608: 350 e n. 88

610: $364-365$ e n. 29

615: 194 n. 8, 374

623: 177 n. 151

627: 146 e n. 73

629: 290

632: 158

642 (a): 183

645: 227-228 e n. 101

646: 221 n. 83

651: 223 n. 90 
653: 184 n. 163

519A Campbell: 128, 155, 193, 321-322, 341 n. 70

519B Campbell: 322

Fr. 9 (b): 209 n. 45

Fr. 48: 142

551A Campbell: 329, 346 e n. 82

Frr. eleg. West

1-9: 145 e n. 69

3: 145 n. 69,294

5: 145 n. 67

10-18: 293-294 e n. 78

10: 294, 301, 309

11: 228 n. 102, 294 n. 78, 295-304, 280; 11.1-20: 294, 308, 309; 11. 8: 317; 11. 12: 236, 306, 374; 11. $14: 284$ n. $60 ; 11.16: 328$, 339 n. $63 ; 11.18: 196$ n. $17 ; 11$. 20: 294; 11.21: 322; 11. 23: 233 n. 117,$309 ; 11.24-28: 265 ; 11$. 30-31: 317; 11.33-34: 149, 292, 311; 11.35-37: 304; 11.37: 290; 11. $42: 305$

13: 304-305, 307 n. 105; 13. 8-9: 278; 13. 10: 329

14: 305-306

15: 151, 156, 293, 306-307

16: $151,156,293,310$ e n. 113,311 , 312; 16. 2 : 201 n. 26

17. $1: 317$

19: 116 n. 7, 183, 185, 207, 216, 221-224, 225 e n. 93, 227 e n. 98, 228 e n. 102; 19. 1-2: 36

20: 224-228, 230, 371; 20. 1-4: 222; 20. 5-12: 222 e n. 86 ; 20. 12: 230; 20. 15: 264 n. 22

21: 228-231, 236, 237 e n. 132, 356, 363 n. 22; 21. 4: 201 n. 26, 374

22: 229 e n. 104, 229, 231-237, 295 , $343 ; 22.6: 339$ n. $63 ; 22.9: 161$

24: 115 n. 4,317

26: $165,166,252$ n. 42

29: 158 n. 105
30. $5: 317$

33. $14: 317$

70. $2: 317$ n. 2

86: $149-150$ e n. $80 ; 86.1: 322$

88: 263 e n. 22,374

89: $115,179-180$

90: 370

91: $149-150$ e n. 81

92: 148 e n. $76,322,329$

Epigr. $F G E$

I: $138-140$

III: 256 n. 1

$\mathrm{V}: 257-258,268$

VI: 115 n. 3, 141 n. 57, 142, 180 n. 155, 267-272 n. 41, 273, 274, 282, 284, 288 n. 66

VII: 270

VIII: 151, 256 n. 2, 263, 282 n. 56, 285 e n. $62,286-288$ n. 67

IX: 151, 266, 285 n. 62, 286-288 n. 67

X: 256 n. 2, 281-282

XI: 268 n. 34, 277-279

XII: 256 n. 2, 279-281

XIII: 280-281

XIV: 156, 260 n. 13, 276, 283-285

XV: 256 n. 2, 268 n. 34, 287-288, 310 e n. 113

XVI: 256 n. 2, 284 n. 60, 288-290, 302

XVII (a): 149, 290-292, 311 n. 113

XVII (b): 256 n. 2, 290-292, 311 n. 113

XVIII: 255-256, 280, 293

XIX: 256-257, 260 n. 13

XIX (a): 276-277

XX (a): 144 e n. 65, 256 n. 2, 258 e n. 8, 259 n. $11,265,274,284$, 292-293, 302

XX (b): 144 e n. 65,258 e n. 8, 259, 276, 292 e n. 75,293 
Mobilidade poética na Grécia antiga: uma leitura da obra de Simónides

XXI: 260-262, 293 n. 77

XXII (a): 268 n. 34,269 n. 37, 270,

271 e n. 39,272 e n. 41,274

XXII (b): $260,268,269$ n. 37,270 ,

271, 272 e nn. 40-42, 274, 278

XXIII: $273-274$

XXIV: 256 n. 1, 268 n. 34, 274-275

XXV: 172 n. 139

XXVI (a): 140-141

XXVI (b): 141

XXVII: 133-134

XXVIII: 105, 119, 131-133, 164, 179

XXIX: 115 n. 3, 151-152 e n. 86, 153 n. 91,154

XXX: 153 e n. 91,282 n. 56

XXXI: 153-154 e n. 92

XXXII (a) e (b): 156 e n. 99

XXXIII (b): 156 n. 99

XXXIV: 165 n. 120

XXXV: 154-155

XXXVI: 156 e n. 100

XXXVII: 115 n. 3, 147-148, 220

XXXIX: 292 n. 74

XLIII: 130 n. 30, 155 e n. 95, 290

XLV-LVIII: 118

XLVI. 2: 260 n. 13

LXXV: 150

LXXXIV: 102 n. 15, 121, 122 e n. 16,346 n. 81

LXXXV: 102 n. 15, 121-122 e n. 16, 162 n. 113

LXXXIX: 264 e n. 22

Testt. Campbell

1: 115 nn. 1 e 3,117 e n. 13, 118, $119,124-125$ e n. $19,144-145$

2: 116

3: 115 e n. $4,175-176$

5: 119

6: 118
7: 118

8: 118

10: 93 n. 84,136

12: 115 n. $3,145-146$

13: $115,158-159$

15: 143-144, 259 n. 11

16: $146-147$

17: 149,168

18: 168

19: $167-168$ e n. 125

20: 168-169

21: 115 n. $3,119,162,165$

22: $174-177$ e n. 151

23: 166, 177-178, 183

24: 180 n. 157

25: 145,182 n. 160

26: 180 n. 157

27: 145-146, 156

33: 124 e n. 18

34: 185

35: 183

38: 115 n. 4

44: 115

47 (b): 184 e n. 164,334

47 (c): 166-167 e n. 123,184

47 (d): 165,177 n. 152

47 (e): 178 n. 153

47 (f): 183 e n. 161

47 (h): $184-185$ e n. 165

47 (j): 45 n. 65,116 n. 7

47 (k): 45 n. 65,116 n. 7

\section{Simplício}

in Ph. (Comm. in Arist. Graeca 9. 754 Diels): 227-228 e n. 101

Siriano: $132,133,134$ n. 41, 171

in Hermog., I. 86 Rabe: 117, 131, 164

Sófocles: 18,119 n. 15, 144 n. 64, 174, 349

Aj. 552-559: 337 n. 60; 1064: 362 n. 
19; 1390: 251 n. 39

OC 701: 359 n. 10

OT: 102, 194 n. 12; 301: 328; 391:

57 n. 86; 715-716: 101 e n. 10;

800-812: 101

Ph. 937: 327 n. 31

Tr. 237-238, 752-754, 993-995:

322 n. 15

$\operatorname{Tr} G F$ IV

236-245 (Tâmiras): 18 e n. 7

Polixena: 350

Schol. Soph. Aj. 740, p. 64 Papageorgiu: 346

Sólon: 49-50 n. 70, 52 e n. 78, 99 e n. 4, 100 n. $9,184,194$ n. 12,210 n. 53 , 219 n. 77,371

Frr. West

1. 2: 233 n. 117,302 n. 96

9. 1-2: 356

12: 356

18: 227

19. $4: 233$ n. 117

20: 224 n. 91

22a: 235

24. 7-10: 195 n. 14

25: 230 n. 111

29: 227

\section{Sosíbio de Esparta: 72}

FGrHist 595 F 3: 69 e n. 16, 71 n. 21

\section{Sozomenus}

Hist. eccles., Praef. 5, p. 2 Bidez: 159 n. 107

Hist. eccles. 2. 5: 257 n. 5

Suda: 374

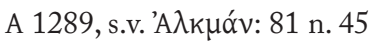

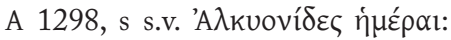
358 n. 7

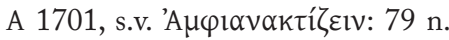
41

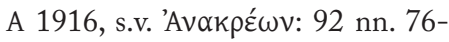
78
A 3886, s.v. 'Apí $\omega v$ : 75 e n. 29, 76, 77 n. 33,104

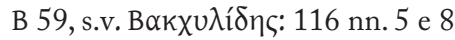

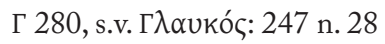

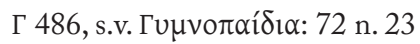

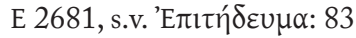

I 80, s.v. "Ißukoఢ: 89 e n. 70, 102

K 2087, s.v. Kópıvva: 144 n. 64

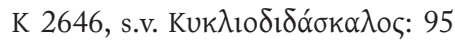
n. 92

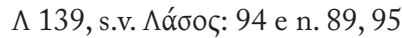

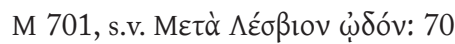
e n. 17

O 251, s.v. "Ouпрос: 38 n. 46

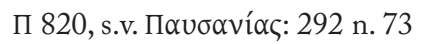

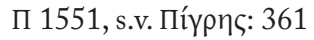

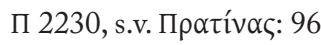

П 3079, s.v. Поเкíर ๆ: 260 n. 14, 261 n. 16

P 71, s.v. 'P $\alpha \psi \omega \delta$ oí: 52 n. 79, 57 n. 88

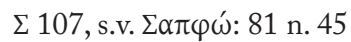

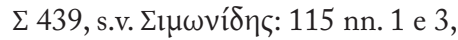
117 e n. $13,118,119,124-125$ e n. $19,144-145$ e n. 69,180 e n. 156, 182

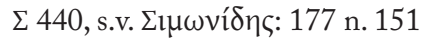

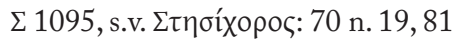
e n. $45,82-84,104$

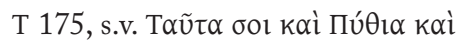
$\Delta \hat{\eta} \lambda_{\imath} \alpha: 39$ n. 49

T 319, s.v. Téw: 92 n. 78

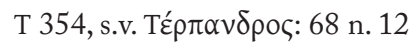

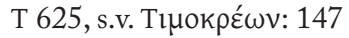

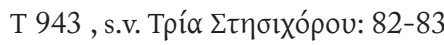

\section{Teágenes de Régio}

Fr. 8. 1 Diels-Kranz: 42 n. 57

Teeteto Escolástico: 257 n. 5

Teócrito: 93 n. 85, 159 n. 107

5. $83: 71$ n. 21 
Mobilidade poética na Grécia antiga: uma leitura da obra de Simónides

Idílios

7. $52-60: 356$ n. 5

16. 34 sqq.: $300-301$ n. $92 ; 16.34-$ 39: 158, 159; 16. 39: 164 n. 119; 16. 42-47: 158-159; 16. 44: 115 ; 16. 45-46: 300-301 n. 92; 16. 46-47: 160, 164

28. $23: 180$ n. 155

30. 25: 320

Scholia (Wendel)

1. 65-66, p. $56: 318$ e n. 3

Arg. Id. 4 c-d, p. 135: 172

5. 83, p. 170 sq.: 74

12. 27-33b-c, pp. 255-256: 290

13. 1-2c, p. 258: 319

15. $139: 347$ n. 84

Arg. Id. 16: 177 n. 151

16. $34-35$, p. $327: 159,161$ n. 110

16. 36-37, 44, pp. 327-328: 159 n. 106, 160

\section{Teófilo de Antioquia}

ad Autolycum 2. 8: 197

ad Autolycum 2. 37: 198

\section{Teofrasto}

HP 3. 7. 3: 345 n. 79

HP 3. 16. 1: 345 n. 79

\section{Teógnis: 215}

206: 192 n. 3

250: 233 n. 117

335: 210 n. 53

401: 210 n. 53

421-422: 200

452: 345

602: 359 n. 12

695: 230

709: 363 n. 22

725-728: 195 n. 14

798: 180 n. 155

1200: 236 n. 129

1386: 202 n. 31

\section{Téon}

Prog., Rhet. Gr. I. 215 Walz: 221 n. 83

\section{Teopompo de Quios}

FGrHist 115 F 285: 283, 284 nn. 58 e 59

Terpandro: 57 n. 87, 68-71, 79 e n. 41, 86, 167

Fr. 697 PMG: 79 n. 41

Timeu de Tauroménio: 167, 284 n. 58

Timocreonte: 130, 146-148, 220

Frr. $P M G$

727-730 (1-4 P): 147 e n. 74

734 (8 P): 130

Fr. 10 W: 115 n. 4,148 e n. 76

Tirteu: 176 n. 146,267 n. 33

Frr. West

5. 7: 67

10. 1-2: 286; 10. 24: 339 n. 64

12. 31-32: 287; 12. 43: 217 n. 76

Tragicorum Graecorum Fragmenta ( $\operatorname{Tr} G F$ II), fr. adespota 166: $267 \mathrm{n}$. 32

Tucídides: 36, 39

1. 5-8: 100

1.15. 3: 29 n. 28

1. $94: 312 ; 1.94-95: 311$

1. 111: 161 n. 110

1.128-134: 311

1. 130: 292 n. 74

1.132. 2: 149, 290-291

2.34. 5: 261

2. $44.4: 177$ n. 151

2. $71.2: 288$ n. 65

3. $58.4: 288$ n. $65,289,310$

3. 104. 2: 39 n. $49 ; 3.104 .3-6: 36$

5. $70: 127$ n. 26

6. 54-59: 139 n. 53; 6. 54. 6-7: 141

6.59.3: 140

7. $57: 115$ n. 1 
Schol. ad 3.104. 3-6: 36 n. 41

Tzetzes: 339

ad Hes. Op. 372: 362

H. 1.312 sqq.: $341-342$

H. 4.131. 235 sqq.: 92 n. 79

H. 8. 807-808: 177 n. 151

Schol. in Aristoph. IV. II, p. 672

Holwerda: 243 n. 9

Vida de Hesiodo: 41 n. 55

Schol. H. 1. 624, pp. 552-553

Leone: 132 n. 36

\section{Valério Máximo}

1. 7. ext. 3: 122 n. 16

8.7. $13: 132$ n. 36

Xenófanes: 42 n. 58, 45 n. 63, 56, 175, 176 e nn. 146,$147 ; 177$ e n. 150 , 370

Frr. Diels-Kranz

1: 236

2: 176 e n. 146

8: 56

21 A $1: 56$

32: 345 n. 79

Xenofonte: 10, 119 n. 15

An. 6. 3. 18: 200 n. 24

$H G$ 4. 1. 40: 248 n. 29

Hierão: 184 e n. 162

Mem.3.13. 5: 101

Mem. 3. 13. 6: 101

Mem. 4.2.10: 52 n. 77, 53

Smp. 3. 5-6: 52 e n. 77

Smp. 3. 6. 4-7: 52-53

Pseudo-Xenofonte

Ath. 3. 4: 94 n. 88

Zopyrus Medicus, apud Oribasium

14. $61.1: 362$ n. 19 
(Página deixada propositadamente em branco) 


\section{ÍNDICE DE AUTORES MODERNOS}

Acosta-Hughes, B.: 162 n. 114, 319 n. 8,339 ก. 65

Ahrens, H. L.: 336

Albini, U.: 322 n. 16

Alcock, S. E.: 101 n. 12

Alessandrì, S.: 99 n. 4

Allen, T. W.: 20 n. 11, 34 n. 37, 39 n. 50,41 n. 54

Aloni, A.: 87 n. 64, 149, 233 n. 115, 291 n. 84,301 n. 93,302 n. $97,305,306$ n. 104,307 n. 105,309 n. 109, 310 e nn. 111,$113 ; 311$ e nn. 114,115

Amigues, S.: 345 n. 79

Ampolo, C.: 344 n. 77

Andersen, Ø.: 25 n. 19

Anderson, W. D.: 68 n. 12

André, J.-M.: 21 n. 15, 99 nn. 2 e 4, 102 n. 14

Andrewes, A.: 66 n. 4, 67, 68 n. 10, 72 n. 23, 78 n. 38, 85, 93 n. 82, 101 n. 12

Araújo, L. M.: 102 n. 14

Arnott, W. G.: 74 n. 26

Arrighetti, G.: 81 n. 46, 82 n. 47, 301 n. 92

Asheri, D.: 21 n. 15, 303 n. 98, 307 n. 105, 311 n. 116,312 n. 118

Assaël, J.: 23 n. 17

Austin, N.: 175 n. 143,176 n. 145, 248 n. 31
Babut, D.: 192 n. 2, 195 n. 14, 205-206 n. 35,212 nn. 58 e 62,217 n. 76, 222 n. 85

Balasch, M.: 198, 211, 212, 213 n. 62

Barbier, R.: 345 n. 79

Barchiesi, A.: 297 n. 82, 312 n. 118

Bardollet, L.: 91 n. 75

Barigazzi, A.: 150 n. 80, 229 e n. 105, 277 n. 49

Barker, A.: 83 n. 52

Barrett,W. S.: 155 n. 96, 156 nn. 97 e 98

Barrigón, Ma C.: 119 n. 14, 196 n. 17, 215, 229 n. 103, 229, 230 nn. 110 e 111,231 e n. 113, 234 n. 119, 235 n. 123, 236, 241 nn. 5 e 6, 245 nn. 20 e 22,247 n. 28,248 n. 31,319 n. 8 , 321,322 n. 15,323 n. 17,324 nn. 18 e 19,337 n. 56,359

Barron, J. P.: 29 n. 28,89 n. 70, 91 n. 75, 92 n. 80

Bartol, K.: 229 nn. 103 e 105, 230 nn. 106, 107 e 110, 231

Baslez, M.-F.: 21 n. 15, 99 nn. 2 e 4, 102 n. 14

Baumann, H.: 345 n. 79

Bearzot, C.: 312 n. 117

Bell, J. M.: 117 n. 11, 162 n. 113, 173 n. 140, 174 n. 142, 175 n. 143, 176 n. 147, 177 n. 151,184 e nn. 163,164

Belloni, L.: 25 n. 19 
Mobilidade poética na Grécia antiga: uma leitura da obra de Simónides

Beresford, A.: 206 n. 35

Bergk, Th.: 65 n. 2, 134, 169, 197, 213 n. 64,247 n. 27,257 n. $5,273,275$, 286 e n. $63,320,335,335-336$ e n. 52,339 n. 63,364 n. 26

Bernabé, A.: 66 n. 3

Bernardakis, G. N.: 285 n. 61

Bernardini, P. A.: 126 n. 23, 127 n. 27, 130 nn. 30 e 31,142 n. 59,154 n. 94 , 175 n. 144,176 n. 146,241 n. 5,247 n. $28,267,335$ n. 51,359

Bickerman, E. J.: 12

Bilinski, B.: 247 n. 28

Boardman, J.: 67 n. 7, 93 n. 85, 138 n. 52,244 n. 12,264 n. 24

Boas, M.: 122, 132 n. 34, 179 n. 154, 275 n. 46, 282 n. 57, 283, 292

Boeckh, A.: 106, 213 n. 64, 289 n. 69, 348

Boedeker, D.: 288 n. 65, 305, 309 n. 109,310 nn. 112 e 113,311 nn. 115 e 116

Boegehold, A.: 278 e n. 51

Bond, G. W.: 338 n. 62

Bonifazi, A.: 112 n. 47

Bowen, A.: 274 n. 45,275 e n. 46

Bowie, E. L.: 87, 89 n. 69, 309 e n. 109.

Bowra, C. M.: 10, 50 n. 71, 65 nn. 1 e 2, 66 n. 4, 67 nn. 7 e 9, 68 n. 10, 81 n. 46, 107 n. 30, 108 nn. 31 e 33, 109 nn. 35 e 36,116 nn. 6 e 9, 117 n. 10 , 122 n. 17,125 n. 19,128 e n. 28,131 n. 33,133 n. 37,134 e n. 38,137 n. 49,139 nn. 54 e 55,140 e n. 57,145 n. 69,146 n. 72,147 n. 74,148 nn. 75 e 76,149 n. $78,150,169$ n. 128 , 170 e n. 129,177 n. 149,192 n. 4, 195 n. 14, 200 e n. 22, 201, 206 e n. 40, 211, 212 n. 58, 213 n. 62,217 n. 73, 219 n. 78, 240, 243 e n. 10, 244 n. 17,245 nn. 21 e 23,247 n. 26 , 248 n. 30,253 n. 43,261 n. 15,263 nn. 17 e 18,264 n. 23,265 nn. 26 e 27, 266 nn. 29-32, 272 nn. 40 e 41, 277 nn. 48 e 49,278 n. 51, 286 n.
63, 287 n. 64, 292 n. 74, 322 n. 16, 329,330 n. 39,335 n. 50,336 nn. 52 e 53,337 n. 58,342 n. $73,349,358$ n. 8,364 n. 26

Brannan, P. T.: 99 n. 4

Braswell, B. K.: 319 n. 7

Bravi, L.: 277 n. 50, 282 n. 55, 285 n. 61,290 n. 71

Bremer, J. M.: 112 n. 48, 177 n. 149

Bremmer, J. N.: 300 n. 90, 301 n. 92

Brillante, C.: 116 n. 7, 164 n. 117, 233 n. 114, 234 nn. 119 e 120, 235 nn. 124 e 126, 236 n. 127, 237 n. 132, 301 n. 92,309

Brown, A. S.: 235 n. 123

Brown, Ch. G.: 285 n. 61

Brunn, H.: 247 n. 28

Buck, C. A.: 34 n. 37,116 n. 10, 126 n. 22

Budelmann, F.: 81 n. 44

Buongiovanni, A. M.: 206 n. 36, 210 n. 51, 212 n. 61,214 n. 66,215 nn. 69 e 70

Burford, A.: 21 n. 15

Burkert, W.: 10, 15 n. 2, 16 n. 3, 21 n. 15, 34 n. 37, 36, 38 nn. 45 e 47; 39 e nn. $48,49,50,51 ; 50$ n. 70,53 n. 80 , 55, 57 n. 86,58 n. 93,71 n. 21,82 n. $47,84,227,319$ n. 7,331 n. 41,333 n. 44,362 n. 18

Burnett, A.: 111 e nn. 42, 43, 46

Burzacchini, G.: 222 n. 86, 227 n. 97, 230 n. 107, 234 n. 118, 263 n. 20, 297 n. 82,301 n. 92

Busolt, G.: 160 n. 108

Buxton, R. G.A.: 44 n. 62

Cahn, H. A.: 75 n. 28

Campbell, D. A.: 10, 12, 70 nn. 17-19, 71,72 e n. 23,74 e n. $26,75,81$ e nn. 45,$46 ; 83$ n. 49,87 n. $64,89,90$ n. 72,91 e n. 75,92 n. 77,93 n. 85 , 104 n. $24,107,125$ n. 20,131 n. 33, 134 n. 38,139 nn. 54 e 55,141 n. 57 , 144 n. 64,145 n. 66,148 n. 76,150 
n. 81,152 n. 83,153 n. $90,155,161$ n. 109,162 n. 114,169 n. 129,170 , 184 n. 163, 191, 192 n. 2, 193 nn. 4, 5 e 7; 200 n. 23, 201, 202 n. 29, 206 nn. 36, 38 e 40; 207 e nn. 41, 42; 208, 210 nn. 50 e 54, 213 n. 64, 216 n. 71, 217 nn. 73-76, 219 e n. 80, 223, 239, 241 n. 6,253 n. 45,254 n. 48, 255, 257 e n. 5,259 nn. 9 e 10 , 261, 263 n. 17,265 nn. 26 e 27, 266 n. 30,268 n. 34,269 n. 37,272 nn. 40 e 41,278 n. 51,286 n. 63,289 n. 68, 289, 322 e n. $16,326,327$ n. 28 , 331 n. 42,335 n. 50,337 n. 58,339 n. $63,346,357$ n. 6,358 n. 8,360 e n. 14,361 e n. 17,364 n. 26

Capra, A.: 297 n. 82, 299 n. 87, 301 nn. 92 e 93,302 n. 96,309

Carey, C.: 105 n. 26, 111 e nn. 42, 43, 45

Carson, A.: 197 n. 19, 200 n. 23, 212 e n. 61, 213 n. 64, 215 n. 70

Cartledge, P.: 66 n. 5, 101 n. 12

Càssola, F.: 33 nn. 34 e 35, 34 n. 37, 36 n. 39,36 n. 41,39 n. 48,44 n. 61 , 53 nn. 80 e 81,54 e n. 82,57 nn. 85 e 88,58 n. 93,59 n. 94,327 n. 31 , 328 n. 32

Casson, L.: 102 n. 14

Castro, J.M. C.: 119 n. 15

Catenacci, C.: 229 e nn. 103, 105; 230 e nn. 106, 110, 111; 231 e n. 113, 237 n. 132, 307 n. 105, 308 n. 107, 361 n. 17

Caven, B. M.: 172 n. 135

Chantraine, P.: 12,15 n. 2, 20 n. 13, 58 n. 92,180 n. 155,209 n. 49,251 n. 38,300 nn. 91 e 92,335 n. 49, 343 n. 74, 345 n. 79, 363 nn. 19 e 21

Christesen, P.: 153 n. 90, 253 n. 46

Cingano, E.: 49 n. 68,80 n. 44, 83 n. 50, 84 n. 53,85 nn. 58 e 59,90 nn. 71 e 73, 92 n. 75

Cipolla, F.: 263 n. 20

Clarke, M.: 357-358 n. 6

Clay, J. S.: 33 e n. 35,35 n. 38,36 nn. 39 e 41, 301 n. 92

Cohn, L.: 129-130

Constantinidou, S.: 96 n. 95

Cook, J. M.: 34 n. 37

Cook, R. M.: 27 n. 21

Corsini, E.: 146 n. 72

Crotty, K.: 212 n. 61

Crowther, N. B.: 248 n. 29

Crusius, O.: 83 n. 50

Cruz Andreotti, G.: 99 n. 2

Cuartero, F. J.: 100 n. 7

Curti, M.: 297 n. 82, 299 n. 87, 301 nn. 92 e 93, 309

D’Agostino, V.: 181 n. 158

D'Alessio, G. B.: 65 n. 1, 66 n. 2, 67 n. 7

D'Alfonso, F.: 70 n. 20, 80 n. 44, 82 n. 48,83 n. 50,84 nn. 53,55 e $56 ; 85$ nn. 58 e 59,88 n. 67,234 n. 118

D'Angour, A.: 75 n. 30, 95 n. 92

D’Avino, R.: 363 n. 19, 364 n. 25

Danielewicz, J.: 230 n. 106

Darcus, S. M.: 230 nn. 108 e 109

Daux, G.: 126 n. 22

Davies, M.: 66 n. 3, 80 n. 44, 83 n. 49, 320 e n. 10

Davison, J. A.: 222 n. 85, 223 n. 89, 330 n. 39,336 n. 53

Dawe, R. D.: 23 n. 17, 26

De Heer, C.: 194 n. 8

De Martino, F.: 65 n. 1, 67 n. 8

Delatte, L.: 85 n. 59

Des Places, É.: 212 nn. 58-60, 215

Di Marzio, M.: 361 n. 17

Dickie, M.: 212 nn. 60 e 61

Diehl, E.: 240, 277 n. 49

Diggle, J.: 333 n. 43

Dillon, M.: 92 n. 75, 126 n. 22

Dodds, E. R.: 21 n. 15, 22 n. 16

Donlan, W.: 200 nn. 22 e 23, 208 n. 44, 212 e n. 58 
Mobilidade poética na Grécia antiga: uma leitura da obra de Simónides

Dragoumis, S. N.: 278 n. 51

Drees, L.: 127 n. 25

Duchemin, J.: 91 n. 75, 355 n. 1

Dunant, C. C.: 143 n. 61

Dunbabin, T. J.: 66 n. 4, 67 n. 7

Easterling, P. E.: 29 n. 28, 33 n. 34, 36 n. 39

Edmunds, S. T.: 226 n. 94

Edwards, M. W.: 355 n. 1

Egoscozábal, C.: 194 n. 10, 324 n. 22

Ehrenberg, V.: 42 n. 58, 44 n. 62, 58 e n. 93

Elmsley, P.: 341

Else, G.: 58 n. 92

Étienne, R.: 288 n. 65

Farnell, L. R.: 16 n. 3, 310 n. 110

Fearn, D.: 245 n. 21

Fernández-Galiano, M.: 23 n. 17

Ferreira, J. R.: 9, 11, 41 n. 54, 77 n. 34, 91 n. 74, 101 n. 9, 106 n. 28, 136 n. 47, 139 nn. 52, 53 e 55, 219 n. 77, 259-260 nn. 11 e 12

Ferreira, L. N.: 75 n. 28,109 n. 34, 184 n. 164,285 n. 61,318 n. 4,337 n. 55 , 345 n. 79,363 nn. 22 e 23,364 n. 25

Ferreira, N.: 11

Fialho, M. C.: 9, 101 n. 11, 219 n. 77

Fileni, M. G.: 174 n. 141

Finley, M. I.: 176 n. 146, 240 n. 3

Fisher, N. R. E.: 230 n. 110

Floyd, E. D.: 110 n. 40

Foley, J. M.: 44 n. 62

Fonseca, C. A. L.: 56 n. 84

Fontenrose, J.: 152 n. 83, 247 nn. 26 e 28

Ford, A.: 58 nn. 90 e 91

Fourmont, M.: 289 n. 69

Fowler, B. H.: 356 n. 4, 359 n. 12

Fowler, R. L.: 87 n. 64

Franceschetti. A.: 69 n. 12

Francis, E. D.: 261 n. 16
Franco, J.: 345 n. 79

Fränkel, H.: 58 n. 92, 127 n. 26, 210 n. 50,217 n. 73,222 n. 85

Führer, R.: 330 n. 39

Furley, W.: 36 n. 41

Gaertringen, F. H. von: 259 n. 11

Gallavotti, C.: 132 n. 34

García Romero, F.: 233 n. 114, 311 nn. 113 e 116

Garland, L.: 92 n. 75, 126 n. 22

Gastaldi, E. C.: 146 n. 72

Gauthier, Ph.: 143 e n. 61

Geisau, H.v.: 338 n. 61

Gentili, B.: 86 n. 60,105 n. 25, 165 n. 120, 200 n. 22, 202 n. 29, 203 e n. 33, 205 n. 34, 206 n. 38, 209 n. 48, 210 n. 50,212 n. 58,213 nn. 64 e 65 , 223, 233 n. 114,235 n. 122, 250 e nn. 33, 34, 35; 251 e nn. 37, 40; 267 n. 32,294 n. 78,337 n. 56

Gerber, D. E.: 10, 67 n. 7, 86 n. 49, 85 n. 58,87 n. 64,90 n. 72,91 n. 75,122 n. 17,127 nn. 24 e 25,139 n. 54 , 193 nn. 5 e 7, 195 n. 15, 196, 205 nn. 34 e 35, 206 nn. 38 e 40, 208 n. 44, 213 n. 64, 216 n. 72, 217 nn. 73, 75 e 76,219 e nn. 78, 80; 222 n. 85, 252, 263 n. 17,265 nn. 26 e 27, 266 n. 29,267 n. 33,269 n. 37,272 n. 41 , 286 n. 63,230 n. 39,335 n. 50,337 n. 58,342 n. 73

Giangrande, G.: 301 n. 92, 320 n. 10

Gildersleeve, B. L.: 83 n. 49

Giuliano, F. M.: 205 n. 35, 209 n. 46, 211 n. 56, 212, 213 nn. 62 e 63

Glare, P. G. W.: 12

Golden, M.: 248 n. 29.

Goldhill, S.: 179 n. 154,180 n. 155

Gómez Espelosín, F. J.: 99 n. 2, 102 n. 14

González González, M.: 363 n. 19

Gostoli, A.: 68 n. 11, 69 nn. 14 e 15, 70 n. 17,71 n. 21,79 n. 41,85 n. 58 
Gow, A. S. F.: 93 n. 85, 159 n. 106, 160 n. 108,161 n. 109,359 n. 9

Graham, A. J.: 67 n. 7

Grant, M.: 21 n. 15

Grant, P. J.: 74 n. 26, 169 n. 127, 362 n. 19

Graves, R.: 319 n. 6, 359 n. 9

Gray, V.J.: 184 n. 162

Graziosi, B.: 185 n. 166

Grenfell, B. P.: 153 n. 90, 183 n. 161, 241 n. 6

Griffiths, A. H.: 219 n. 77

Hägg, R.: 21 n. 15

Hainsworth, J. B.: 16 n. 4, 22, 26, 44 n. 62,319 n. 7

Halliday, W. R.: 34 n. 37,39 n. 50

Hamilton, R.: 128 n. 28

Hammond, N. G. L.: 67 n. 7,101 n. 12, 244 n. 12

Hammou, M.: 107 n. 29

Hansen, P. A.: 138, 141, 258 n. 8, 259, 277,292

Harmatta, J.: 72 n. 23

Harrell, S. E.: 89 n. 69, 165 n. 120

Harvey, A. E.: 80 n. 44, 263 n. 17

Haubold, J.: 185 n. 166

Hauvette, A.: 132 n. 34, 133, 139 n. 56, 140 n. 57,150 n. 81,154 n. 92,156 n. 100,165 n. 120,274 n. 45

Head, B. V.: 254 n. 47

Heath, M.: 111 e nn. 42, 43, 44

Helly, B.: 157 e n. 102, 158-160 e n. 108, 161 e n. 110,163 nn. 115 e 116,164

Henderson, W. J.: 130, 135 n. 44, 170 n. 129, 201 n. 26, 252 n. 42, 363, 364 n. 26

Henry, W. B.: 200 e n. 24, 201 e n. 28

Herington, C. J.: 144 n. 64

Herington, J.: 50 nn. 70 e 74, 51 n. 76, 52 n. 78,58 n. $93,65,73,80$ n. 42 , 104 n. 23, 107 n. 30, 108 e nn. 32,
33; 109 e n. 36,110 nn. 37 e $38 ; 111$ n. 42,131 n. 33,134 n. 42

Herman, G.: 270 n. 38

Hermann, G.: 213 n. 64, 341

Heubeck, A.: 25, 26

Hignett, C.: 271 n. 39, 273 n. 43

Holley, N. M.: 333 n. 44

Holloway, R. R.: 254 n. 47

Hölscher, U.: 202 n. 30

Hooker, J. T.: 71 n. 21, 72 n. 23

Hornblower, S.: 303 n. 98

Hubbard, M.: 170 n. 130

Hubbard, T. K.: 222 nn. 85 e 86, 223 e n. 91,225 n. 92,226 n. 96

Hummel, P.: 23 n. 17

Humphrey, J. W.: 345 n. 79

Hunt, A. S.: 153 n. 90, 183 n. 161, 241 n. 6

Hunter, R.: 21 n. 15, 119 n. 15, 158 n. 105, 184 n. 162, 233 n. 114, 234 n. 118 e 119,236 n. 127,237

Hutchinson, G. O.: 81 nn. 45 e 46, 82 e n. $47,83,85$ n. 58,89 n. 70,90 n. 71 , 94,119 n. 14,141 n. 59, 205 n. 35, 206 nn. 36 e 40, 207 n. 41, 209 n. 47, 212 nn. 58 e 61,213 n. 64, 215 n. 68, 300 n. 92,330 n. 39,331 n. 42,334 n. 47,335 nn. 50,$51 ; 336$ nn. 52,53 e 55,337 nn. 56 e 59,375

Huxley, G. L.: 116 n. 6, 117 nn. 10 e 11, 137 n. 50,143 e n. 62,146 n. 73,148 n. 75,157 n. 104,162 n. 112,164 n. 117,169 n. 128,176 n. 147, 244 nn. 15,17 e 19,245 n. 21,248 n. 30,254 n. 49,292 n. 74

Ieranò, G.: 75 n. 31,77 nn. 33 e 35, 85 n. 59,90 n. $73,94,95$ n. 91

Irigoin, J.: 91 n. 75

Irwin, E.: 240, 342 n. 72, 356 n. 4, 363 nn. 19 e 22

Jabouille, V.: 320 n. 8

Jacoby, F.: 260 n. 12, 286 n. 63

Janko, R.: 19 n. 10,33 n. 34,38 n. 45, 
Mobilidade poética na Grécia antiga: uma leitura da obra de Simónides

39 e nn. 49,$50 ; 50$ n. $70,55,327$ n. 31,357

Jeanmaire, H.: 73 n. 25

Jeffery, L. H.: 30 n. 32

Jenner, E. A. B.: 91 n. 75

Jesus, C. A. M.: 107 n. 29, 149 n. 79, 174 n. 141,233 n. 117,300 n. 91, 356 n. 4,363 n. 20

Johansen, K. F.: 94 n. 88

Johnston, R. W.: 206 n. 40

Johnstone, H.: 202 n. 31

Jurenka, H.: 213 n. 64

Kadaré, I.: 89 n. 69

Kaldellis, A.: 152 n. 86

Kegel, W. J. H. F.: 122 n. 17, 126 n. 23, 217 n. 73,263 n. 20,265 n. 28,337 n. 59

Keil, B.: 280 n. 54

Kemp, J. A.: 80 n. 43, 86 n. 62

Kirk, G. S.: 15 n. 1,18 e n. 7, 19 e n. 8 , 33 n. 34,34 n. 37,36 n. 39,39 nn. 50 e 52,42 n. 57,56 n. 84,58 n. 93

Kirkwood, G. M.: 169 n. 127

Kiso, A.: 18 n. 7

Kitto, H. D. F.: 119 n. 15

Kitzinger, R.: 21 n. 15

Klausen, R. H.: 324 n. 21

Knox, B. M.: 29 n. 28, 33 n. 34, 36 n. 39

Koniaris, G. L.: 41 n. 56

Kossatz-Deissmann, A.: 133 n. 37

Koster, W. J. W.: 243 n. 9

Kowerski, L. M.: 145 n. 69, 228 n. 102, 236 n. 130, 294 n. 78,309 n. 109

Krummen, E.: 16 n. 3, 85 n. 58, 89 n. 69

Kurke, L.: 105 n. 26

Kurtz, D. C.: 93 n. 85, 264 n. 24

Kyriakou, P.: 300 n. 90

Lachenaud, G.: 274 n. 45

Lamberton, R.: 27 n. 21

Lambin, G.: 16 n. 3

Lasserre, F.: 69 n. 14,70 n. 17, 95 n. 91
Latte, K.: 73 n. 25

Lauriola, R.: 300 nn. 89 e 90, 302 n. 97

Lavelle, B. M.: 141 n. 57

Lazenby, J. F.: 271 n. 39, 273 n. 43

Leão, D. F.: 9, 99 n. 4, 100 n. 9, 136 n. 48, 142 n. 59, 219 n. 77, 224 n. 91 , 230 n. 111,243 n. 11,244 n. 13, 356 n. 2

Lefkowitz, M.: 74 n. 26, 110 e n. 39, 111 nn. 42, 43, 44; 144 n. 64, 162 nn. 112 e 113,165 n. 121,173 n. 140, 177 n. 150

Lesky, A.: 33 nn. 33 e n. 34, 36 n. 41, 42 n. 58,45 n. 64,117 nn. 10 e 11,122 n. 17,125 n. 19,126 n. 23,128 n. $28,144,148$ n. 75,168 n. 125,184 n. 164,185 n. 166,213 n. 64,245 n. 21,349

Lewis, D.: 141 n. 58, 259 nn. 9 e 11, 278 n. 51,292 n. 72

Liddell, H. G.: 12

Lloyd-Jones, H.: 125 n. 20, 126, 200 e n. 22,222 n. 85,263 n. 19,297 n. 82,299 n. 88,301 n. 92,310 n. 111 , 360 n. 14

Lobel, E.: 125 e n. 20, 126, 143 n. 63, 155 e n. $96,193,199-200$ e nn. 21, 24; 201 e n. 28,202 n. 29, 203, 229, 230, 250 e nn. 34, 35; 251 nn. 36 e 40, 297 n. 81, 299 n. 86, 320, 321, 341 n. 70,360 e n. 14,361

Lopes, R.: 361 n. 17

Lorenzoni, A.: 346 n. 82

Lourenço, F.: 16 e n. 4, 17 n. 5, 20 n. 11, 109 n. 34, 111 n. 42, 112 n. 47, 192 n. 2, 252 n. 42,320 n. 8, 356 nn. 4 e 5,362

Luppe, W.: 299 n. 87, 303

Macan, R. W.: 103 n. 17, 244 nn. 12 e 13

Mace, S.: 233 nn. 114 e 115, 234 nn. $117,118,119$ e 120,235 n. 124,236 nn. 127 e 128, 237 n. 132

MacLachlan, B. C.: 89 n. 70, 92 n. 75, 
93 n. 85

MacLeod, C. W.: 17 e n. 5

Maddoli, G.: 172 n. 139

Maehler, H.: 169 e n. 129

Maffre, J.-J.: 330 n. 40, 333 n. 45

Magueijo, C.: 242 n. 7

Manfredini, M.: 99 n. 4, 274, 275 nn. 46 e 47, 277 nn. 49 e 50, 278 n. 51 , 279 n. 52,280 n. $54,281,284$ n. 59 , 344 n. 77

Manieri, A.: 343 nn. 74 e 76, 345 n. 79, 363 n. 22,364 n. 25

Marasco, G.: 99 n. 4, 102 n. 14

Marchesi, I.: 181 n. 158

Marindin, G. E.: 362 n. 19

Martelli, M. F. A.: 148 n. 76

Martínez, M.: 349 n. 87, 356 n. 4

Marzullo, B.: 252 e nn. 41, 42; 253 n. 43,320 e n. 10

Mathiesen, T. J.: 66 n. 5, 72, 158 n. 105

McAuslan, I.: 39 n. 52

Mcdermott, W. C.: 272 n. 40

McMullin, R. M.: 147 n. 74

Meiggs, R.: 141 n. 58, 259 nn. 9 e 11, 278 n. 51,292 n. 72

Meritt, B. D.: 138 e n. 52, 139 e n. 54, 292 e n. 75

Merkelbach, R.: 213 n. 64, 336 n. 55

Michel, C.: 116 n. 9

Miller, A. M.: 33 n. 35

Molyneux, J.: 10, 117 n. 13, 119, 131 n. 33,141 n. 59,142 n. $60,143,145$ nn. 67 e 69,150 nn. 80 e 81,151 n. 82,153 n. 91,156 n. 101,157 n. 102 , 159 n. 107,160 n. 108,161 n. 111 , 162 n. 112,163 n. 115,165 n. 120 , 167,168 n. 125,169 n. 127,170 nn. 129 e 131,171 nn. 132 e 133,172 nn. $137,138,139 ; 175$ n. 143,179 n. 154, 240 nn. 3 e 4, 241 n. 6, 242 n. 8, 243 nn. 9, 10 e 11, 244 nn. 12, 14, 15 e $17 ; 245$ nn. 19 e 21, 246 n. 24 , 247 nn. 26,27 e 28,248 n. 30,251 n. 37,254 n. $48,259-260$ n. 11,263 n. 20,266 n. $30,267,270,272$ n. 41 , 273 n. $44,275,277$ e nn. 48,$49 ; 278$ n. $51,282,286$ n. 63,288 n. 67,290 n. 71,292 n. 74

Moretti, L.: 138 n. 50, 142, 152 e nn. 83-86, 153 n. 87,154 n. 94,172 e n. 137,240 n. 5,241 n. 6,248 n. 29 , 253 n. 46,254 n. 48

Morgan, C.: 30

Morgan, K. A.: 111-112 n. 47

Morrison, J. S.: 157 n. 102, 159 n. 106, 160 e n. 108,161 nn. 110 e 111,163 n. 117

Mosino, F.: 102-103 e n. 18, 253 nn. 43 e 45,254 n. 48

Mossé, C.: 89, 93 n. 82

Most, G. W.: 205 n. 35, 208 n. 44, 211 nn. 56 e 57,212 n. 61,213 n. 62,214

Müller, C.: 253

Müller, K. O.: 80 n. 44

Mulroy, D.: 206 n. 40

Murakawa, K.: 20 n. 13

Murray, G.: 363 n. 23

Murray, P.: 22 n. 16, 23 n. 17, 50 n. 73, 51 n. 76,58 n. 93

Musti, D.: 66 nn. 3 e 4, 67 n. 7

Myres, J. L.: 259 n. 11

Nagy, G.: 29 n. 25, 37

Nascimento, A. A.: 320 n. 8

Nenci, G.: 49 n. 68

Nercessian, A.: 18 n. 7

Nietzsche, F.: 41 n. 56

Nisbet, R. G. M.: 170 n. 130

Nisetich, F. J.: 108 n. 32, 109 n. 35

O'Sullivan, N.: 41 n. 56,45 n. 65

Oates, W. J.: 364 n. 26

Obbink, D.: 145 n. 69, 228 n. 102, 236 n. 130,294 n. 78, 302 n. 97, 307 n. 105

Oleson, J. P.: 345 n. 79

Oliveira, F.: 91 n. 74, 142 n. 59 
Mobilidade poética na Grécia antiga: uma leitura da obra de Simónides

Oliver, J. H.: 259 nn. 9 e 11, 261 n. 16

Ormerod, H. A.: 100 n. 8

Osborne, R.: 101 n. 12

Page, D. L.: 10, 12, 25 n. 19, 92 n. 75, 93 n. $85,118,121,132,133,134,139-$ $141,150,152$ e n. 85,153 e nn. 90 , 91; 154,155 e n. 95,156 nn. 99 e 100,162 e n. 114,165 n. 120,172 nn. 138 e 139, 182, 184 n. 163,191 , 200, 207 n. 41, 209, 239 e n. 1, 243 nn. 9 e 10, 244 n. 17,245 nn. 21 e 22, 250, 255, 256 e n. 3,257 e n. 5 , 258, 259 e nn. 9-11, 260 nn. 12-14, 261 e n. 16, 263 n. 19, 269 nn. 36 e 37,270 e n. 38, 271, 272 e nn. 40, 41; 273 e n. 44, 274, 276, 277 e nn. 48, 49; 278 e n. $51,279,280$ n. 53 , 282 e nn. 55 e 57,284 nn. 58 e 59 , 285 n. 62,286 e n. $63,287-289$ e n. 68, 290 n. 71, 292, 293 e n. 76, 319, 321,322 n. 16,325 n. 23,330 n. 39 , 331 n. 42, 335, 336 e nn. 52, 53; 339 n. $63,348,357$ n. 6

Pagliaro, A.: 58 n. 92

Palmisciano, R.: 264 n. 21, 265 n. 28, 266 n. 29, 267 n. 33

Palumbo Stracca, B. M.: 155 n. 95, 284 n. 58,285 n. 61

Papadopoulos, J. K.: 318 n. 3

Papadopulos-Kerameus, A.: 346 n. 82

Pardini, A.: 193 nn. 6 e 7

Parke, H.W.: 39 n. 49, 94 n. 88, 304 n. 101, 323 n. 17, 345 n. 77

Parker, R. C. T.: 30 n. 30

Parker, V.: 67 n. 7

Parry, A.: 356 n. 4

Parry, H.: 208 n. 44, 211 n. 56, 212 nn. 60 e 62,213 n. 64,215 n. 69

Parsons, P. J.: 10, 91 n. 75, 93 n. 85, 141 n. 59,143 n. 63,145 n. 69,156 n. 98 , 165 n. 121,173 n. 140,177 n. 149 , 222 e nn. 86, 87; 223, 225 n. 92, 226, 227 n. 97, 229 n. 104, 230 n. 107, 232 e n. 114, 233 e n. 116, 234 nn. $117,118,119$ e $120 ; 235$ nn. 124 e
125, 236 nn. 127 e 130, 237 n. 132, 294, 294 n. 80, 297 n. 82, 298, 299 e nn. 86 e 87, 300-301 e nn. 92-94, 302 e n. 95,303 n. 98,304 n. 102, 305, 306 e n. 104,310 n. 111, 337 n. 59

Patzer, H.: 58 n. 92

Pavese, C. O.: 56 e n. 84, 57 n. 85, 67 n. 8, 175 n. 143, 294 n. 79, 297 n. 82, 298 n. 84,299 nn. 86 e 87,303 n. 98 , 304 n. 100, 306 n. 104, 308 n. 107, 309 n. 108, 310 nn. 110 e 111, 311 n. 115,335 n. 51

Pédech, P.: 99 n. 2

Peek, W.: 139, 259 n. 11, 285 n. 62

Pellizer, E.: 200 n. 23, 222 n. 85

Pereira, A. M. R. R.: 158 n. 105

Pérez Jiménez, A.: 99 n. 2

Perrotta, G.: 193 n. 7, 194 e nn. 8, 9,11; 216 n. 72, 217 nn. 73, 75 e 76, 267 n. 32,330 n. 39,335 n. 50,336 n. 53 , 337 e nn. 57,59

Petrovic, A.: 141 n. 57, 271

Pettersson, M.: 71 n. 21, 72 e n. 23

Pfeiffer, R.: 42 n. 57, 50 n. 70, 53 n. 80, 80 n. 44,200 n. 23

Pfohl, G.: 289 n. 69

Piccirilli, L.: 99 n. 4

Pickard-Cambridge, A.: 94 nn. 88 e 89, 131 n. 33,132 e n. 35,134 e nn. 38, 40, 42; 135 e nn. 43,45

Piérart, M.: 288 n. 65

Pinheiro, A. P. E.: 41 n. 54, 185 n. 167, 206 n. 35

Pizzocaro, M.: 16 n. 4, 23 n. 17

Pleket, H. W.: 176 n. 146, 240 n. 3

Podlecki, A. J.: 34 n. 37, 72 n. 23, 77, 89 nn. 69 e 70,93 n. 84,99 n. 4, 126 n. 21,139 nn. 53 e n. 56,144 n. 64,146 nn. 72 e 73,150 n. 80,159 n. 107 , 164 n. 117,165 n. 120,170 e n. 131 , 171 n. 134,176 n. 147,241 nn. 5 e 6, 245 nn. 20 e 22,251 n. 37, 252 n. 41, 253 n. 44, 254 nn. 48 e 49, 256 
n. 2,258 e n. 8,259 n. 11,261 n. 16 , 264 e n. 23,265 nn. 26 e 28,266 n. 29,267 n. 33,272 n. 41,275 e n. 46 , 277 n. 49,278 n. 51,280 n. 54,281 , 290 n. 71,292 n. 74,344 n. 77

Pollard, J.: 359 n. 9, 361 n. 17, 362 n. 18

Poltera, O.: 10, 119 nn. 14 e 15, 145 n. 67,148 n. 77,180 n. 155,192 n. 1 , 193 n. 7, 202 n. 30, 203 n. 32, 206 n. 40, 216 n. 72, 217 n. 73, 234 n. 118 , 249 n. 32,252 n. 42,294 n. 80, 299 nn. 86 e 88, 301 nn. 92 e 94, 302 n. 97, 318 n. 3, 320 nn. 9 e 10, 322 n. 16,325 nn. 23 e 25,326 n. 27,327 n. 31,335 nn. 49,50 e 51,336 n. 52 , 338 n. 61, 339 e nn. 63, 64; 340, 341 e n. 69,343 n. 75,345 n. 79, 346 n. 81,348 n. 85,349 n. 87,350 n. 88 , 351 e n. 90,359 nn. 9 e 10, 361 nn. 16 e 17,363 n. 19

Pontani, F.: 264 n. 22, 319 nn. 6 e 7, 320 nn. 9 e 10

Powell, B. B.: 58 n. 89

Prato, C.: 223, 233 n. 114, 235 n. 122, 294 n. 78

Preger, Th.: 152 n. 85, 280 e n. 53

Pretagostini, R.: 79 n. 41, 105 n. 25

Price, S. D.: 93 n. 85

Pritchett, W. K.: 102 n. 14

Privitera, G. A.: 75 n. 30, 76 n. 32, 77 n. 35,95 n. 91,96 e n. 94,320 n. 9

Pülhorn, W.: 338 n. 62

Pulquério, M. O.: 81-82 n. 46

Race, W. H.: 106, 108, 112 n. 47, 126, 127 nn. 24 e 27,153 e n. 89, 156 n. 97,216 n. 71,240 n. 2,245 n. 22 , 339

Raubitschek, A.: 152 nn. 85 e 86

Rausa, F.: 138 n. 52, 152 n. 86, 240 n. 3

Raven, J. E.: 56 n. 84

Rawles, R.: 162 n. 114, 284 n. 60, 299

Reeker, H.-D.: 99 n. 4

Renehan, R.: 41 n. 56

Resinski, R.: 362 n. 19
Richardson, N. J.: 15 n. 2, 41 n. 56, 42 n. 57,45 nn. 63 e 65

Richter, G. M. A.: 75 n. 28, 93 n. 85, 139 ก. 52

Robbins, E.: 74 e n. 27, 85 n. 58, 167, 182, 184, 185 n. 166,197 n. 19, 214 n. 67,269 n. 37,330 n. 39,337 nn. 58 e 59,339 n. 65

Robert, L.: 288 n. 65

Roccos, L. J.: 318 n. 4

Rocha Pereira, M. H.: 9, 11, 21 n. 15, 28 n. 22,49 n. 69,52 n. 77,55 n. 83,58 n. 93,68 n. 12,74 e n. 27,76 n. 32 , 77 n. $34,84,88$ n. 68,90 n. 72,91 n. 74,93 n. 85,94 n. 88,95 n. 93,101 n. 11,104 n. 22,105 n. 25,106 n. 28 , 127 n. 25,128 n. 28,132 n. 35,136 n. 46,142 n. 59,165 n. 121,168 n. 126, 176-177 e n. 148,193 n. 4, 216 n. 71,217 n. 73, 222 n. 84, 228, 230 n. 108,234 n. 117,235 n. 125,236 n. 128,254 n. 47,272 e n. 42,299 n. 89,331 n. 41, 342 n. 73, 346 n. 80, 349 n. 87

Rodrigues, N. S.: 99 n. 4, 100 n. 5, 102 n. 14

Rodríguez Adrados, F.: 100 n. 7, 363 n. 23

Roller, L. E.: 30 n. 31

Romilly, J.: 274 n. 45

Rose, H. J.: 16 n. 3, 247 nn. 26 e 27, 248 e n. 30

Rosen, M. R.: 29 n. 25

Rosenmeyer, P. A.: 336 nn. 54 e 55

Rosenmeyer, T. G.: 87 n. 64

Rossi, L.: 196 n. 18

Rougé, J.: 102 n. 14

Roux, G.: 116 n. 10

Rubio Tovar, J.: 99 n. 2

Rueda González, C.: 110 n. 41

Ruhnken, D.: 33 e n. 33

Rumpel, I.: 58 n. 91

Russo, J.: 20 e n. 12,23 n. 17 
Mobilidade poética na Grécia antiga: uma leitura da obra de Simónides

Rutherford, I.: 15 n. 2, 21 n. 15, 125 e n. 20,126 e nn. 21,$22 ; 134$ n. 38,145 n. 69,150 n. 80,193 n. 6,225 n. 93 , 228 n. 102,230 n. 107,235 n. 124 , 236, 288 n. 65,294 n. 78, 299 n. 86, 302 n. 97,307 n. 105,308 n. 107, 311 n. $113,312,321$ e nn. 11, 12; 323 n. 17,324 n. $20,325,326$ n. 26 , 360 nn. 14 e 15

Salmon, J. B.: 66 n. 4

Salvato, E.: 312 n. 117

Sbardella, L.: 310 n. 110

Schachter, A.: 288 n. 65,312

Schmid, M. J.: 112 n. 47

Schmidt, D. A.: 110 n. 37

Schneider, J.: 92 n. 75, 122 n. 16, 167 n. 123, 168 n. 125,170 n. 131,318 n. 3

Schneider, K.: 78 n. 37

Schneidewin, F. W.: 193 n. 5, 212 n. 62, 213 n. 64,247 n. 27, 273, 275, 279

Schofield, M.: 56 n. 84

Schrader, C.: 274 n. 45

Schröder, O.: 169

Scodel, R.: 206 n. 35

Scott, R.: 12

Scully, S. P.: 25 n. 19

Seaford, R.: 96 n. 95

Sealey, R.: 49 e n. 70, 53 n. 80, 57 n. 86, 58 n. 93

Séchan, L.: 338 n. 62

Segal, Ch.: 185 n. 166, 212 n. 58, 213 n. 64,338 n. 61

Shapiro, H.A.: 50 n. 70, 57 n. 88, 79-80 n. 42,136 n. 47

Shaw, P.-J.: 310 e n. 110

Sherwood, A. N.: 345 n. 79

Shipley, G.: 89 n. 70

Sider, D.: 222 nn. 86 e 87, 223 nn. 88 e 91, 225 nn. 92 e 93, 227 nn. 97 e 99, 228 n. 102,234 n. 118,235 n. 122 , 294 n. 78, 309 n. 109

Sikes, E. E.: 34 n. 37,39 n. 50
Silk, M. S.: 336 n. 55

Silva, M. F. S.: 93 n. 82, 101 n. 13, 107 n. 29,149 n. 79,174 n. 141,242 n. 7,363 n. 20

Simon, E.: 94 n. 88

Slater, W. J.: 162 n. 112, 173 n. 140, 179 n. 154,234 n. 120

Smith, R. R. R.: 91 n. 74

Snell, B.: 169, 210 n. 53, 211 n. 57, 215 n. 69,219 n. 77,318 n. 4,324 n. 21

Snyder, J. M.: 93 n. 85

Soares, C.I. L.: 77 n. 36,93 n. 82

Sordi, M.: 157 e n. 102, 158, 163 n. 115, 164 n. 117,214 n. 67,250 n. 35

Soutar, G.: 356 n. 4

Souza, Ph. de: 100 n. 8

Stanford, W. B.: 272 n. 40, 364 n. 27

Steffen, W.: 110 n. 37

Stehle, E.: 300 n. 90

Steiner, D.: 265 n. 26

Stella, L. A.: 115, 119 e n. 14, 132, 139 n. 54,146 n. 72,149 n. 78,159 n. 107,168 n. 125,169 n. 128,170 , 171 n. 132,248 n. 30, 292 n. 74

Stewart, A. F.: $138-139$ n. 52

Stoneman, R.: 169 n. 128

Strassler, R. B.: 141 n. 58

Stuart Jones, H.: 12

Suárez de la Torre, E.: 115 n. 2, 165 n. 121, 182, 185 n. 166, 299-300 n. 89, 301 n. 92, 310-311 n. 113, 333, 337 n. 58

Svensson, L.: 74 n. 26,169 n. 127,362 n. 19

Szegedy-Maszak, A.: 99 n. 4

Tarditi, G.: 58 n. 92

Tedeschi, A.: 107 n. 30, 108 n. 31, 109 nn. 34 e 36,110 nn. 37 e 38

Teodorsson, S.-T.: 274 n. 45

Thiersch, F.: 110 n. 40

Thomas, R.: 127 n. 25

Thomopoulos, J.: 143 n. 61 
Thompson, D'A. W.: 74 n. 26, 359 n. 9, 361 n. 17,362 n. 18

Torelli, M.: 66 nn. 3 e 4, 67 n. 7

Touloupa, E.: 362 n. 18

Treu, M.: 201

Tschiedel, H. J.: 34 n. 37

Vallet, G.: 102 n. 16, 165 n. 120, 253 e n. 44,254 e n. 47

Van Groningen, B. A.: 247 n. 25, 284 n. 58

Van Thiel, H.: 15 n. 1, 19 n. 10, 192 n. 2

Vannicelli, P.: 271 n. 39

Velardi, R.: 50 n. 73, 51 nn. 75, 76; 52 n. 78

Verdam, H. D.: 208 n. 44

Vernant, J. P.: 210 n. 55, 215 n. 70

Vickers, M.: 261 n. 16

Vigneri, V.: 112 n. 47

Visa-Ondarçuhu, V.: 172 nn. 136, 137 e 139

Vox, O.: 65 n. 1, 67 n. 8

Von der Mühll, P.: 20 n. 11

Wade-Gery, H. T.: 30 n. 29, 38 n. 47, 39 n. 50,72 n. 23,268 n. 34,269 n. $37,272,274,288$ n. 66,289 n. 68 , 290 n. 71

Wærn, I.: 336 n. 55

Walcot, P.: 27 n. 21, 30 n. 31, 31 n. 32, 39 n. 52

Webster, T. B. L.: 73 n. 25, 107, 110 n. 37

Welcker, F. G.: 85 n. 55

West, W. C.: 293 n. 77

West, M. L.: 10, 12, 16 n. 3, 27 n. 21, 28 e n. 22,29 e nn. $23,24,26,27$; 30 e n. 29, 33 e nn. 33, 34; 34 n. 37, 36 n. 41,38 e nn. 45,$47 ; 39$ nn. 50 e $52,40,41$ e nn. 54,56 ; 42 n. 58 , 43 n. 59,44 nn. 60 e 61,47 n. 67 , 52 n. 78,53 n. 80,66 n. 3,67 n. 7 , 68 n. 12,69 n. 14,78 n. 40,81 n. 45 , $82 \mathrm{nn} .46$ e $47,83,84$ e n. 54,85 n. $59,87,103$ n. 19,104 n. 25,126 n.
24, 144 n. 64, 145 nn. 66 e 69, 149, 158 n. 105,177 n. 149, 191, 192 n. 2, 195 n. 14,196 n. 17,201 e n. 28, 222 e n. 85,$86 ; 223,225$ nn. 92 e 93, 226, 227 e nn. 98, 99; 229 e nn. 103, 105; 230 e nn. 106, 107; 231 e n. 112,232 e n. 114,233 n. 117,234 e nn. 119-121, 235 nn. 124-126, 236 e n. 127,237 nn. 131 e 132, 240 n. 4, 245 n. 21, 250 n. 33, 255, 263 e n. 19, 265 n. 26, 267 n. 33, 293, 294 e nn. 78-80, 297 n. 82, 298, 299, 302, 303 e n. 99, 304 e n. 100, 276, 306 nn. 103 e 104, 309 e n. 109, 310 nn. 110 e 111, 311, 317 n. 2, 319 n. 7, 322,324 n. 21,327 n. 31, 330 n. 39, 349 n. 87,357 n. 6

West, S.: 25 n. 19,349 n. 87

White, H.: 132 n. 35

Wilamowitz-Moellendorff, U. von: 33 n. 34,82 e n. 48,84 e n. 54,108 e n. 33,111 n. 42,142 n. 60,145 n. 69, 170 n. 131, 184 e n. 163, 206 n. 38,212 nn. 58 e 62,213 n. 63,217 nn. 73 e 76,222 n. 85,244 n. 17 , 245 n. $22,246,277$ n. 49,285 n. 61 , 288,320

Wild, J. P.: 345 n. 79

Wilhelm, V.A.: 289 n. 69

Willcock, M. M.: 15 n. 1, 16 n. 3, 18 nn. 6 e 7, 19 n. 10, 39 n. 52, 58 n. 91, 106, 169 n. 127,175 n. 144

Wilson, P.: 18 nn. 6 e 7, 19 n. 8

Winter, J. C.: 41 n. 56

Winterton, R.: 222 n. 85

Woodbury, L.: 89 nn. 69 e 70, 92 nn. 77 e 80, 175 nn. 143 e 144, 176 n. 147, 177 n. 149,205 n. 35,206 n. 38,208 n. 44,212 n. 58,218

Wurm, Ch.: 261

Yatromanolakis, D.: 233 e n. 115, 236 n. 127

Young, D. C.: 108 nn. 31 e 33

Zadorojnyi, A. V.: 147 n. 74

Zanker, P.: 44 n. 62, 92 n. 77, 93 nn. 84 
Mobilidade poética na Grécia antiga: uma leitura da obra de Simónides

$$
\text { e } 85,119 \text { n. } 15
$$

Zimmermann, B.: 75 n. 30, 76 nn. 32 e

n. $33,77,134$ n. 39

Zuntz, G.: 137, 138 n. 51 


\section{ÍNDICE GERAL}

Abdera: 92

Acaia-Ftiótida: 157 n. 103

Acaia: 130, 330

Acanto: 365

Acarnânia: 107 n. 29, 269

Acarnas: 50

Achilleion: 312

Acrísio: 330, 331

Adimanto, arconte: 119, 131, 138

Adimanto, comandante coríntio: 281, 282 e n. 55

Adónis: 16 n. 3

Adriano, Imperador: 41 n. 55

Aédon/Procne: 362 n. 18

Afrodite (vide Cípris): 16 n. 4, 26, 37, 40, 199,202 e n. $31,283,284$ n. 58,285 e n. 61,319 e n. 7,320 e n. $9,328,355$

Agamémnon: 15, 24-26, 298, 350

Agatarco: 153, 163, 247 n. 27

Agelau de Tégea: 86 n. 60

Agrigentinos: 171

Agrigento: 87, 106, 109, 119, 129, 164, $165,167,170,171$ e n. 134,175

Ájax: 278

Alcedo ispida: 358

Alcibíades: 88 n. 68, 254 n. 49

Alcimedonte de Egina: 153 n. 91, 245 n. 22
Alcímidas de Egina: 105 n. 27

Alcínoo: 15, 21-26, 37, 42, 355

Alcíone: 359 n. 9

Alcmena: 148, 246, 328

Alcmeónidas: 139 n. 56

Alectoris chukar: 74 n. 26

Alectoris graeca: 74 n. 26

Alévada(s): 159, 160 n. 108, 167, 251

Alevas: 159, 160

Alevas Ruivo: 159

Alexandre (vide Páris): 296, 299

Alexandre I da Macedónia: 110

Alexandre, o Grande: 288 n. 65

Alexandre Poliistor: 69 n. 14

Alfeu: 18, 321 n. 13

Alípio: 104 n. 25

Alo: 157 n. 103

Amarinceu: 30 n. 31

Amársias: 344

Amazonas: 344, 346

Ambelaki: 278 n. 51

Amintor: 329

Amorgos: 222 e nn. 85, 86; 355

Amphiarea: 86 n. 62

Anauro: 351

Anaxágoras: 184

Anaxilas de Régio: 91 n. 74, 129, 172 e 
Mobilidade poética na Grécia antiga: uma leitura da obra de Simónides

n. $135,177,178,253$ e n. 44,254 e nn. 48,49

Ândrocles, rei da Messénia: 67

Andrómaca: 17, 104, 192 n. 2

Andros: 125,126 e n. 22, 143, 370

Anfiarau (vidente): 20 n. 14

Anfiarau: 351

Anfictíones: 86, 87, 269 n. 37, 271 e n. 39,272 n. 41

Anfidamante: 28, 29 e n. 27, 43-46, 67, 87

Anfífanes: 46

Anfigenia: 18

Anfílito: 66 n. 4

Anfímaco: 348

Antenor: 138 e n. 52

Antestérias: 94 n. 88

Anteu: 80 n. 42,324 n. 22

Antínoo: 19, 20, 21, 369

Antíoco, rei da Messénia: 67

Antíoco: 159, 160 e n. 108, 163 e n. 117, 235 e nn. 124,126

Antíope: 346

Antioquia: 112, 198

Antióquide, tribo: 131

Antípatro: 76

Antissa: 68 n. 11

Antístenes: 52, 53

Apodeixeis: 71,73 e n. 25

Apolas: 163

Apolo ou Febo Apolo: 15 e n. 2, 16 n. 3, 33,34 e n. 37,35 e n. 38,36 e n. 40 , 37-39 n. 49, 46, 47, 58, 67, 72 n. 23, 79 n. 41,85 e n. 59,86 n. 60,88 n. 66, 99 n. $1,102,106,116$ e nn. 8,10; $122,124,130$ n. 30, 142, 210, 217 n. 73, 250, 251, 291 e n. 72, 296, 298, 299 n. $87,317,318,321$ e n. 13,322 , 323, 326 e n. 26, 360, 370

Apollo Karneios: 71 n. 21

Apollo Pythaeus: 72 n. 23
Apolo Acestor: 322 e n. 15

Apolo Délio: 34 n. 37, 66

Apolo Pítico: 31 n. 32, 126, 141

Apolo Ptoo: 34 n. 37

Apolodoro, mestre de Píndaro: 104

Apolónia: 152 n. 84

Apóstolos: 34 n. 37

Aqueus: 15, 16 n. 4, 21 n. 14, 27, 328 n. 32,349 n. 87

Aquiles: 15, 16 e n. 4, 17 n. 5, 30 n. 31, 192 n. $2,199,235$ n. $125,269,294$, 297, 298 e nn. 84, 85; 299 n. 87, 301, 308, 309, 310 nn. 110 e 111; 312, $328,316,349$ e n. $87,350,355,359$ n. 9,372

Arcádia: 30, 71, 73 e n. 25, 81, 86, 87, 108, 131 n. 32, 257, 327, 329

Arcésilas de Cirene: 339

Arene: 18

Ares: 16 n. 4, 37, 287, 305, 319 e n. 7, 320

Argeu de Ceos: 107

Argivos: 47, 49

Argo: 342

Argólida: 96

Argonautas: 318 n. 3, 339-341

Argos: 37, 46, 49, 53 n. 80, 71, 72 n. 23, 73 e n. 25,86 e n. $61,87,106,131$ n. 32,142 n. $59,154,330,350$

Aríon: 57 n. 87, 75-81, 88, 95 n. 92, $100,102,104,135,162$ n. 113,177 n. 149,369

Aristides, corego: 131

Aristoclides de Egina: 109

Aristogíton: 138,139 e n. 53

Aristómenes de Egina: 153

Aríston: 116

Arles: 161

Arquédice: 140,141 n. 57

Arquémoro/Ofeltes: 335, 338, 373

Arquenauta: 156 
Árquias: 112

Ártemis: 34, 35, 72 n. 23, 274, 275 e n. 46, 284 n. $60,289,290$ n. 70,321 e n. 13,360

Ártemis Órtia: 74

Artemísio, cabo: 274, 275, 281

Artemísio, naumaquia: 144, 145 e n. 69, 150 n. 80, 274-275, 281

Asclépios: 21 n. 14, 51

Ascra: 27, 42

Ásia Menor: 73, 74 n. 26, 92, 99 n. 1

Ásia: 112, 274, 305, 312 e n. 118

Ásine: 106

Ásio: 297

Assos: 41

Astidamia: 329, 372

Astilo de Crotona: 129, 172, 239-241

Astipaleia: 152 n. 85, 162 n. 111

Atalanta: 91 n. 75

Atena ou Palas Atena: 116 n. 9, 142 n. 59, 177 n. 149, 256, 296, 299, 305, 321 n. 13,322

Atenas: 31 n. 32, 38, 46, 47 n. 67, 50 n. $70,51,58,59,77,79$ n. 40,85 n. $55,93,94$ e n. 88,95 e n. 91,96 , 101, 104-106, 119, 122, 126, 131, 134,135 e n. $43,136-138$ e n. 50 , 139-144 e n. 64,146 n. $72,147,149$ n. $78,150,157,214,219$ n. $77,242-$ 244 e nn. 15,$17 ; 246,248,257,259$ n. 10,261 e n. $16,275-277$ n. 49, 278, 282, 306 n. 104, 311, 312, 344 n. 77,370

Ateneu, atleta: 321

Atenienses: 85, 101, 106, 125, 126, 138, $142,144,145$ n. $69,150,151,243$, 244, 255-258, 260 e n. 14, 261 e n. 16, 274, 275, 277, 286, 287, 291 n. 72, 293 n. 77, 304 n. 102, 370

Ática: 20 n. 13, 94, 115, 125, 137, 243, 244 n. $17,249,303$ e n. 100

Atlas: $326-328$

Atreu: 29 n. 26
Atrida(s): 24

Augias: 330

Aúlis: 27, 28, 43

Aurora: 355

Automedes de Fliunte: 338

Bada: 133

Baquíadas: 66 n. 4

Bátidas: 339

Belerofonte: 18 n. 6, 348

Bem-aventurados: 232 n. 114, 234 n. 118 Bem-aventurados, Ilhas dos: 235 e nn. 123,$125 ; 349$ n. 87

Beócia: 27, 28, 30-31 n. 32, 43, 45, 125, 196 n. 17, 216, 217, 299, 303 n. 100, 304,312

Bias: 219 n. 77

Bizâncio: 81, 134, 276, 277 n. 48, 312

Bóreas: 145 n. 69

Bósforo: 340

British Museum, Londres: 50 n. 72

Cadmo, tirano de Cós: 118, 119

Cálais: 145 n. 69

Calcas: 20 n. 14

Calcídios: 43, 68 n. 10

Cálcis: 28, 29, 30, 41-45 n. 65, 47, 100, 135

Cálias (fr. eleg. 91): 150 e n. 81

Cálias (anfitrião de Sócrates e Protágoras): 173

Calipso: 328,355

Cálon de Élis: 102 e n. 16

Camarina: 253 n. 46

Cambises: 144, 145

Caos: 319

Caríbdis: 195

Cários: 348 n. 86

Caristo: $129,142,143,152$ nn. 83 e 86 , 163,247 e nn. 26,$28 ; 248,317$

Carneias: 68 n. 11, 69, 71 e n. 21, 72 n. 23,74 
Mobilidade poética na Grécia antiga: uma leitura da obra de Simónides

Carteia: 116 e n. 9,117

Cásmilo de Rodes: 153, 154

Castor: 91 n. 75,127 n. 26, 181, 247, 317 e nn. 1,2

Cátana (actual Catânia): 81, 102

Cédon: 277 n. 49

Cefalénia: 86

Ceíce: 359 n. 9

Ceos: 94, 106, 107, 109, 110 n. 37, 115 e n. 2,116 e nn. $8,9,10 ; 121,126$, 136, 141-143 e nn. 61, 62; 144 n. 64, 146-148, 158, 160, 169 e n. 128 , 170 e n. $129,176,181,222$ n. 85 , 248, 254 n. 49,257

Cépsis: 71 n. 21, 180 n. 157

Cerâmico: 285 n. 62

Cérilo, poeta: 96

Cesareia: 118

Chelidonismos: 336 n. 55

Chermes ilicis: 345 n. 79

Chipre: 16 n. 3, 40, 312

Cíclades: 44

Cicleu, pai de Aríon: 75

Cilene: 327 e n. 30

Cime: 27

Címon de Clonas: 156 n. 99

Címon, filho de Esteságoras: 138 n. 50

Címon, filho de Milcíades: 258

Cineto: 38 e n. 47,39 e nn. 48, 50; 50, 53 n. 80

Ciparíssia: 18

Cípris (vide Afrodite): 283, 317

Cípselo: 66 n. 4

Cirene: 105, 240 n. 3, 339

Citera: 71-73

Cleantes de Assos: 41

Cleobulo: 218, 219 e nn. 77, 78, 79

Cleômbroto: 297

Cleomedes de Astipaleia: 152 n. 85, 162 n. 111

Cleómenes: 243 e n. 11, 244 n. 12
Clio: 323, 324 e n. 21, 325 n. 23

Clístenes de Sícion: 49, 85

Clitemnestra: 24 e n. 19, 25

Clítias: 84 n. 55

Clitómaco: 153

Clonas, poeta: 88

Clonas, top.: 156 n. 99

Cnossos: 78 n. 40, 285 n. 62

Cólofon: 42, 43 e n. 59, 71-73, 176, 221, 223 e n. 91,355

Cólquida: 339-341 e n. 70, 372

Constantino, Imperador: 292 n. 72

Constantinopla: 152 n. 86, 257 n. 5, 292 n. 72

Copto: 152 n. 86

Corcira: 26, 151, 152 e n. 85, 153

Corésia: 116

Coríntios: 77, 146, 151, 276, 277, 280 n. 54, 281-284 e n. 60, 291 n. 72, 306, $307,310,348$

Corinto: 21 n. 15, 34 n. 36, 46, 65, 66 e n. 4,68 n. $10,75-78$ e n. 39,86 n. 60 , $96,103,105$ n. 27,130 e n. 30,134 n. $41,135,155,156,219$ n. $77,277-$ 279, 282-284 e n. 58, 285, 290, 297, 303, 306, 307, 310, 321, 341, 348

Corvus corax: 169 e n. 127

Cós: 118

Crânon: 158, 160, 162, 163 e n. 115, 163,181

Creofilo: 46

Creondas: 159 n. 106

Creonte, pai de Escopas: 159 n. 106, 160, 204

Creso: 89 n. 70,99 n. 4, 184, 194 n. 12

Creta: 21, 68 n. 12, 73, 152 n. 85, 318 n. 3, 343, 372

Crio de Egina: 129, 153 n. 91, 241-246, 317,374

Crisa: 85

Crítias: 94

Crítios: $132,138,139$ e n. 52 
Crómio do Etna: 252 n. 42

Crónio, monte: 91 n. 75

Cronos: 250

Crotona: 21, 129, 152, 172, 240, $241 \mathrm{n}$. 5

Dalila: 161 n. 111

Dâmeas de Crotona: 172

Dânae: 330-337, 342, 356, 372, 373

Dânaos: 296, 299, 308, 312, 313, 348

Dândis de Argos: 154 e nn. 93, 94

Dario: 140, 144, 145, 243

Deífobo: 348, 372

Dejanira: 322 n. 15,362 n. 19

Delfos: 33, 41 n. 55, 43, 44, 46, 69, 80 n. $43,85,86$ e nn. 60,$61 ; 87,88$ e n. 65, 99 n. 1,103 n. $17,106,124-126$ e n. 22,134 nn. 40 e 41, 154, 156, 165 n. 120, 172, 210, 250, 291 e n. 72,311 n. 113, 318, 321 e n. 13, 323, 324 n. $18,325,326,370$

Delfos, $1^{\text {a }}$ Guerra Sagrada: 85

Delfos, 3a Guerra Sagrada: 291-292 n. 72

Délios: 360

Delos: 33, 34 e n. 37; 35-37, 39, 40, 46, 65-68, 99 n. 1, 106, 116 nn. 9 e 10, 125,134 e n. 41,235 n. 122,321 e n. $13,360,370$

Delos, Simaquia: 275, 306 n. 104

Delta do Nilo: 99

Deméter: 95, 317, 318

Demétrio de Cépsis: 71 n. 21

Democedes: 21 e n. 15

Demócrito de Naxos: 276

Demódoco: 21, 22, 24-26, 37, 44 n. 62, 82,319 n. 7

Dexâmeno: 329, 330

Diágoras de Rodes: 105 n. 27, 249

Dicearco: 76

Díctis: 333

Dídime: 99 n. 1
Diodoro, capitão coríntio: 281

Diogneto de Creta: 152 n. 85

Diomedes: 30, 235 n. 125

Dionísias: 94, 105, 132, 134 e n. 41, 135 n. 43

Dionísio de Siracusa: 54

Dionisódoto de Esparta: 72

Diónisos: 40, 76, 78 n. 40, 103 n. 17, 134 n. 40, 161, 317, 317, 322

Diónisos Melanaigis: 95 n. 91

Dioscuros (vide Tindáridas): 162, 163, 181,247 e nn. 26, 27; 249 n. 32, 303 e n. 98,317

Diotimo, pai de Mílon: 172

Díseris: 159-161, 163, 233 n. 115, 235

Dodona: 99 n. 1

Dórion: 17, 18, 19

Dórios: 305

Doro: 304, 305

Dótion: 19 n. 8

Drácon: 211

Éace: 89, 92

Eácio: 129, 164, 250 e n. 35, 251, 317

Eântides: 140

Ecália: 18, 19, 21 n. 14

Eceu: 329

Édipo: 30 n. 31, 101, 349

Efarmosto: 266 n. 31

Éfeso: 51, 52 n. 77

Éfira: 306

Egeu, Mar: 74 n. 26, 99, 157 n. 103

Egeu, rei mítico de Atenas: 344, 346

Egina: 105 e n. 27, 106, 109, 129, 131 n. 32, 152, 153 e n. 91, 242, 243 e nn. 9, 10; 244 e n. 15,245 n. 22, 246, $249,276,317,370,374$

Eginetas: 243

Egipto: 16 n. 3, 99 e n. 4, 100 n. 6, 112, 152 n. 86,183

Egisto: 24,25 n. 19

Eiresione: $336-337$ n. 55 
Mobilidade poética na Grécia antiga: uma leitura da obra de Simónides

Eleia: 304

Elêusis: 131 n. 32, 297, 304 n. 100

Eleutheria, festival: $287-288$ e n. 65,310 e n. 113

Élide: 17,30 n. 31,330

Elidenses: 125

Élis: 102

Eménidas: 109, 171

Énalo: 79 n. 40

Endymatia: 71,73 e n. 25, 89

Eneias (chorodidaskalos): 108, 110, 111 e n. 43

Epeus: 30 n. 31

Épi: 18

Epidauro: 51, 131 n. 32

Epigraphicum Museum, Atenas: 141 n. 58

Epiménides de Festos: 21 e n. 15, 56

Epiro: 99 n. 1

Equecrateia: 160

Equecrátides: 159-161 e n. 110, 163, 232 e n. 114, 233 e n. 115, 234 e n. 119,235 e nn. 124, 126, 127; 370

Equecrátides, pai de Orestes da Tessália: 161 n. 110

Equêmbroto da Arcádia: 30, 86-87

Erasístrato: 116

Éreso: 164 n. 119

Erétria: 29, 129, 142, 143 e n. 61

Erétrios: 29 n. 27, 141 e n. 59, 142 e n. 60

Ergotimo: 84 n 55

Erínia: 195

Eritimo: 155, 156

Eros: $318-320$

Escópadas: 85, 157 e n. 102, 158 n. 105, 159 e n. $106,160,162,163$ e n. 115 , $167,182,195$ e n. 13

Escopas: 129, 157 e n. 102, 158, 159 e n. $106,160,161-163$ e n. 116,164 e nn. 118,$119 ; 173,181,200,204$,
207 n. 42,212 n. $62,213,214$ n. 67 , 247 n. $27,317,370$

Esfinge: 57 n. 86

Esmirna: 42

Esparta: 20 n. 13, 53 n. 80, 54, 68 e n. 9 , 69-71 e n. 21,72 e n. 23, 73, 74 e n. 26, 80, 81, 83, 90, 101, 151, 219 n. $77,243,262,264$ e nn. 23, 25; 265 e n. 27,266 e nn. 29 e 31,267 e n. 33, 268, 270, 273, 278, 297, 299, 302, 303 e n. 98, 305, 308, 310 nn. 110, 112 e 113, 312, 321

Espartanos (vide Lacedemónios): 70 e n. $17,71,72$ n. $23,104,106,151$, 220, 260, 262, 266, 267, 271, 273, 286, 287, 302-304 n. 102, 305, 306 n. 104,310 n. 110

Esperqueu: 268

Esteságoras: 138 n. 50

Estinfalo: 107

Estrepsíades: 241-242

Etíopes: 133 n. 37

Etna: 108, 110, 112, 131 n. 32, 144 n. 64,252 n. 42

Etna, ninfa: 318

Eubeia: 27, 29 e n. 23, 38, 43, 45, 68 n. 10, 131 n. $32,141-143$ e nn. 60, 62; $248,275,289,322,370$

Eudemo de Rodes: 228 n. 101

Eufórion: 163

Eufrónio: 80 n. 42

Eufrónio, gramático: 76

Eumeu: 19, 20, 21 e n. 14, 22, 24, 26, $36,70,369$

Euricleia: 227

Eurídice, mãe de Ofeltes: 338, 339 n. 63,356

Eurípilo: 163

Euripo, estreito: 28, 157 n. 103

Êrito, rei da Ecália: 18, 19

Europa, mit.: 134

Europa: 312 n. 118 
Eurotas: 297

Eutidemo: 53

Eválcides de Erétria: 129, 141 e n. 59, 142,143

Evângelo de Tarento: 80 n. 43

Exéquias: 78 n. 40

Farsalo: 161, 163 e n. 115

Feaces: 26

Fédon, arconte: 168 n. 125

Fegeu: 46

Fémio: 23-26, 40, 55, 57 n. 86, 211, 212

Fenícia: 16 n. 3

Fénix: 227, 350, 359 n. 9

Féreclo: 344 e n. 77

Ferenico: 108

Festos: 21

Fidipo: 250

Filácides de Egina: 249

Filas: 329

Filedes: 49

Filíades de Mégara: 274, 276-277 e n. 48

Filipe da Macedónia: 288 n. 65

Filócleon: 131

Fílon: 151-152 e nn. 85, 86

Fíntis: 66,67 e n. 7

Flia: 146

Fliunte: 96, 106, 131 n. 32, 338

Focílides: 118

Fócios: 291 n. 72

Ganictor, filho de Anfidamante: 43, 45

Ganictor, filho de Fegeu: 46

Ganimedes: 90

Geia: 319

Gela, cidade e rio: 144 n. 64, 167, 241 n. 6

Gélon: 110 n. 37, 151, 165 n. 120, 240 n. 5

Gimnopédias: 71, 72 e n. 23, 73, 75

Gláucias de Egina: 151, 152 e nn. 83, 86
Glauco da Lícia: 223, 306, 307 e n. 105, 348

Glauco de Caristo: 129, 142, 143, 152 nn. 83 e $86,163,246-249,317$

Górgias: 41 n. 56

Gortina: 70, 71, 72 n. 23, 100, 167

Graças: 324 n. 22

Grécia (vide Hélade): 19, 20 n. 13, 21 n. $15,28,31,55,59,78,101,105$, $106,112,129,151,155,157$ n. 103, $158,243,267,282,310$ n. 110, 311, 361 e n. 17

Gregos (vide Helenos): 42 n. 58, 44, 45, 51, 55, 74, 119 n. 15,165 n. 121 , 166, 223, 242, 243 n. 11, 246, 248, 260, 278, 286, 293, 304, 312, 370

Guerra Lelantina: 29 e n. 27

Guerras Medo-Persas: 86 n. 62, 122, 124, 139, 143, 149, 150, 157, 159, 255, 257 n. 5, 263, 277 e n. 49, 281, 291, 293 n. 76, 302, 312 n. 118, 344 n. $77,370,371$

Hades: 195 n. 14, 286, 349 n. 87

Hagésias de Siracusa: 107, 108, 253 n. 46

Hagesidamo: 106

Hagia Triada: 68 n. 12

Halicarnasso: 154 n. 93, 241, 330 e n. 39, 331, 361, 373

Haliterses: 20 n. 14

Harmódio: 138, 139 e n. 53, 235 n. 125

Hecateu: 99

Hécuba: 17, 347

Heféstias: 94 n. 88

Hefestos: 15, 26, 318 e n. 3

Heitor: 15, 17, 19 n. 10, 31, 104, 192 n. 2, 209, 299 e n. 87,303 n. 98,334 n. 46

Hélade (vide Grécia): 28, 47, 56, 122 , 124,134 e n. $41,140,143,156,254$, 262, 265, 273, 278, 279-281, 283, 285-289, 291, 292, 293, 297, 302, 370, 371 
Mobilidade poética na Grécia antiga: uma leitura da obra de Simónides

Heládio: 289, 290 n. 71

Helanódices: 162 n. 111, 248 n. 29

Helena: 17, 19 n. 10, 90, 240, 299, 320 n. 9,324 n. $22,348,349$ n. 87,372

Helenos (vide Gregos): 47, 87, 253, 254, 260 e n. $14,273,276,279,283,287$, 288 e n. $65,289,291,349$

Helesponto: 312

Hélicon: 27, 28, 30 e n. 32, 45, 88, 326

Hélios: 308

Helos: 18

Hera: 73 n. 25, 74, 201 n. 27, 296, 299, 324 n. 22,357

Hera Lacínia: 241 n. 5

Héracles: 80 n. 42, 86, 87, 91 n. 75, 127, 247,249 e n. $32,259,304,305,321$, 322 n. 15, 329, 330, 346

Heraclidas: 250

Hermes: 174, 326, 327 e nn. 29, 30; 328

Hermíone: 76, 93-95 e n. 91, 104, 131, 135, 136, 370

Heródoto de Tebas: 130 n. 31

Híades: 328

Hidra de Lerna: 330

Hierão de Siracusa: 105-108 e nn. 31, 33; 109, 110 n. 37, 112, 122, 131, 144 e n. $64,149,164,165$ e n. 120 , 166,167 e n. 124,168 e n. 125,169 e n. 128,170 e n. 131,171 n. 134 , 172 e n. 135,176 n. 147, 177, 183, 239-241 e nn. 5,$6 ; 361,370$

Hílico: 115 e n. 2, 176

Hímera: 70 n. 19, 81 e n. 45, 82 n. 46, $83,90,102,117$ n. $12,351,372$

Hiparco: 49, 93 e n. 84, 95, 122, 136139 e nn. 53, 56; 140, 157, 177, 370

Hiperbóreos: 234 n. 118, 318

Hípias (filósofo): 102

Hípias, filho de Pisístrato: 94, 95, 122 , $138-141$ e n. 57,157 e n. 104,214 , 370

Hipócleas da Tessália: 159
Hípoclo: 140

Hipódico de Cálcis: 135

Hipólita: 346

Hipónoo: 329

Hipsípile: 338, 339 n. 63, 340

Hísias: 72 n. 23

Homéridas: 38 e n. 47, 39 n. 50, 42 n. $58,47,50,52,53$ e n. $80,54,57$ n. $87,58,59$

Horas: 324 n. 22

Iâmida(s): 53 n. 80, 297, 304 e n. 101

Íamo: 53 n. 80, 304

Icmálio: 21 n. 14

Ida, monte: 307

Idas: 318

Idomeneu: 21 n. 14, 297, 348, 372

Ifigénia: 350

Ífion de Corinto: 156 e n. 99

Ílion: 348 e n. 85

Iolaia: 240 n. 2

Iolau: 91 n. 75, 127, 266 n. 31

Iolco: 339, 351, 356

Íon: 51, 52, 55, 59, 80 n. 43

Iónia: 34 n. 37, 129, 141

Iónios: 34-36, 142

Ios: 43, 44, 46, 47 n. 67

Iris: 319

Istmo de Corinto: 154, 156, 278, $280 \mathrm{n}$. 54, 291 n. 72, 297, 303 e n. 100, 310

Ítaca: 20 n. 14, 23, 25, 26, 343

Itália: 73 n. 24, 77, 82 n. 46

Itome: $65,66,67,68$ n. 9

Itomeias: 65,66

Iúlis: 115 e n. 1, 116, 143 n. 61

Jasão: 339-341, 372

Jocasta: 101

Jogos Ístmicos: 78 e n. 37, 106, 107, 127, 141 n. 59, 153, 170, 248 n. 29, 361

Jogos Nemeus: 127, 141 n. 59, 248 n. 29,338 
Jogos Olímpicos: 106, 141 n. 59, 248 n. $29,253,254$ n. 49

Jogos Píticos: 69, 85, 86 e nn. 60, 61; 87, 107, 127, 141 n. 59, 170, 248 n. 29,361

Jogos Teoxénios: 130 n. 30

Kastoreion: 127 n. 26, 317 n. 1

Krater François: 84 n. 55

Lacedemónia: 71, 350

Lacedemónios (vide Espartanos): 127 n. $26,268,271,291$ e n. 72

Lácon de Ceos: 107

Lacónia: 74, 310 n. 110

Laio: 101

Lâmpsaco: 140

Larissa: 159, 163, 235 n. 126

Lelanto: 29

Lemnos: 338, 340

Leócrates: 163, 247 n. 27

Leófron: 254 n. 49

Leónidas: 150, 262, 264 n. 25, 265 e n. 28, 266 e n. $31,267,269$ nn. 35 e $36,270,271,308,309$ n. 108,310 n. 111

Leontinos: 91 n. 75

Leóprepes: 115 e n. 2, 131, 151, 179, 268

Lequeu: 341

Lesbos: 27, 41, 68 e n. 11, 69, 70 n. 17, $71,73,75$ e n. $31,76,77,99$ n. 3, 104,167

Leto: 34,35 n. 38, 37, 72 n. 23, 281, 321 n. 13,360

Líbia: 99 n. 1

Liceu: 56

Lícia: 348

Licómidas: 146

Licurgo, legislador: 70

Licurgo, rei de Nemeia: 338

Licurgo, filho de Drias: 18 n. 6

Lídia: 74 n. 26, 99 n. 4
LIMC: 12,18 n. 7,75 n. 28,133 n. 37 , 318 nn. 3 e 4, 330 n. 40, 333 n. 45, 338 n. 62,362 n. 18

Lindos: 218, 219 e n. 77

Lino: 16 e n. 3

Lisímaco de Atenas: 142

Lisímaco de Erétria: 142-143 e n. 60

Lócrida: 46, 106

Lócrios: 273 e n. 43, 274

Locros: $71-73$ e n. $24,78,81$

Louvre, Paris: 74, 80 n. 42

LSJ: 15 n. 1, 18 n. 7, 20 n. 13, 34 n. 37, 132 n. 35,141 n. 59, 194 n. 10,195 n. 14, 197, 198-199 e n. 20, 209 n. 49, 210,220 n. 81,230 e n. 108,234 n. $117,234-235$ n. 121,235 n. 122 , 260 n. 13, 261, 264 e n. 26, 265 n. 27, 266 n. 32,273 n. 43, 301 n. 92, 362 e n. 19

Macáon: 21 n. 14

Macedónia: 110, 250 n. 35, 288 n. 65

Magna Grécia: 73, 78, 81, 87, 89, 105, 106, 129, 154, 164, 165, 171, 254, $311,356,370,372$

Magnésia: 341

Maia: 326, 327 e nn. 30, 31; 328

Mao Zedong: 89 n. 69

Maratona: 131 n. 32, 142 n. 59, 261 e n. 16

Maratona, batalha: 101, 138 n. 52, 143-144 e n. 64,150 e n. 80 , 244 e n. 12, 256-262, 292 n. 75, 293 e n. 77

Mardónio: 297 n. 82, 303 n. 100

Marpessa: 318 e n. 4

Masístio: 297 n. 82

Matapan, cabo: 75 n. 28

Medeia: 318 n. 3, 339-341, 349 e n. 87, 372

Mediterrâneo: 78 n. 40, 99 e n. 3, 96

Médon: 23, 25

Medos: 257, 260, 260 n. 14, 268, 270, 
Mobilidade poética na Grécia antiga: uma leitura da obra de Simónides

$273,274,276,278,281,283,284$ n. $60,291,297,304,305$

Mégacles: 150 e n. 81

Mégara: 131 n. 32, 274, 276, 282, 289, 290 e n. $71,297,303$

Megarenses: 289, 290

Megístias: 107 n. 29, 141 n. 57, 143, 268, 269 e nn. 35, 37; 271, 272 n. 41,273 e n. $44,282,308$

Melampo, citaredo: 86

Melampo, vidente: 53 n. 80

Melampódidas: 53 n. 80

Melanipe: 346

Melanípides de Melos: 135 e n. 44

Meleagro: 117 n. 12, 350, 351

Melesígenes: 44

Melos: 135

Mémnon: 133 e n. 37

Menelau: 15, 21 n. 14, 23, 90, 297, 303 e n. 98,349 n. 87,359

Meneptólemo de Apolónia: 152 n. 84

Mentes: 44

Messana (actual Messina): 102, 253, 254

Messénia: 15, 19, 65-68 e n. 9, 253

Messénia, $1^{\text {a }}$ Guerra: 67-68 e nn. 7, 9

Messénia, 2a Guerra: 67 n. 7

Messénios: 66, 68 e nn. 9, 10

Metauro: 81

Metimna: 75 e n. 28, 76, 135

Metona: 294

Metrodoro de Cépsis: 180 n. 157

Mícale: 289

Micenas: 81, 299, 350

Midas de Agrigento, auleta: 87

Midas, rei da Frígia: 46, 68 n. 11, 218, 219 e n. 79

Milcíades: 138 n. 50,244, 257 e n. 5, 258

Mileto: 99 e n. 1, 184, 219 n. 77

Mílon de Crotona: 152, 172 e nn. 136, 137,139
Mínias: 339

Minos: 318 n. 3

Minotauro: 344 e n. 77

Mis: 34 n. 37

Mitilene: 78 n. 38, 207 n. 43, 208, 219 e n. 77

Mnemósine: 324 nn. 19, 21 e 22

Mnesímaque: 330

Moira: 201 n. 27

Musa(s): 17 n. 5, 18 e n. 6, 19 e n. 9,22, 24, 27, 28, 30 e n. 32,36 n. 41, 45, 57 n. $87,58,65,67,84$ n. $55,92,116$ n. $9,136,148,175,176,232,233$ e n. $117,297,300,301$ e n. 94,302 e n. $97,309,322-326$ e n. 26,328 n. 34, 364, 370

Museu Arqueológico de Florença: 84 n. 55

Museu Nacional de Atenas: 79 n. 40

Museo Nazionale Archeologico, Nápoles: 88 n. 68,139 n. 52

Museu, poeta: 42 n. 58, 95

Museum of Art, Rhode Island School of Design: 333 n. 45

Museum of Fine Arts, Boston: 18 n. 6, 80 n. 42

Nastes: 348

Náucratis: 99 e n. 3

Nausícaa: 325

Nausítoo: 344

Náxios: 276

Naxos: 44, 276, 277 e n. 49

Nemeia: 46, 50, 154, 245 e n. 22, 250, 338

Nereides: 234 n. 117

Nereu: 294, 297

Nérito, monte de Ítaca: 343

Nesiotes: 132, 138, 139 e n. 52

Nestor: 17

Nicasipo: 109 e n. 35

Nicérato: 52, 53 
Nícocles: 38 n. 44

Nicoladas de Corinto: 130 e nn. 30, 32; 155 e n. 95,290

Ninfas: 234 n. 117

Níobe: 18 n. 6

Niseus: 289

Niso: 290, 297

Ny Carlsberg Glyptotek, Copenhaga: 93 n. 85

OCD: 12,16 n. 3,30 n. 30,91 n. 75,138 n. 52,157 e n. $102,159,169$ n. 129 , 172 n. 135,219 n. 77,345 n. 77

Oceânide: 328 n. 34

Ocidente: 68 n. 10,74 n. 26, 81

Oinóe: 46

Óleno: 330

Oligétidas de Corinto: 155-156, 321

Olímpia: 50 n. 71, 54, 85, 101, 102, 106, $125,126,129,152-155,171,172$, 228 n. 101, 240, 241 n. 6, 243 n. 9 , 245 e n. 22,248 n. $29,250,253,254$ e n. 49, 291 n. 72,304 n. 101, 321 n. 13

Olimpo, poeta: 26, 71, 83

Onomácrito: 95

Opunte: 273

Orcómeno: 86 n. 62

Orestes, Orestas da Tessália: 161 n. 110

Orestes, mit.: 81

Oretes: 93

Orfeu: 18, 26, 42 n. 58, 69 n. 14, 88, 341, 342 e n. $71,343,356,372$

Oriente: 274

Orilas: 130 e n. 31

Oríon: 328

Oritia: 145 n. 69

Órmeno: 329

Oropo: 86 n. 62

Oscofórias (Oschophoria): 344-345 n. 77

Oxirrinco: 347

Pã: 257 e n. 5, 258, 322
Pafos: 40

Palâncio: 81

Palto: 133

Panateneias: 49, 51, 55, 59, 86 n. 62, 94 n. 88,130 n. $32,137,139$ n. 53,142 n. 59

Pandíon: 297

Pandora: 224

Panedes: 43, 45

Páris (vide Alexandre): 298, 325 n. 24

Parnes: 125, 321 n. 13

Paros: 100

Pátroclo: 30 e n. 31, 296-298, 312

Pausânias de Esparta: 149, 151, 257 n. 5, 288 n. 65, 291-292 e n. 74, 297, 303, 308, 310 nn. 111 e 113, 311 e n. 114,312

P(e)lêiades: 300, 326, 327 n. 30, 328, 329 e nn. 35,36

Pelene: 130 e n. 30,142 n. 59

Peleu: 91 n. 75, 308, 310 n. 111

Pélias: 90 n. 71, 91 n. 75, 340, 350, 351

Pélion: 289, 343

Peloponeso: 19 e n. 8, 46, 67, 69-71, 75 e n. $28,78,81$ e n. $46,87,89,95$ n. 91,271 e n. 39,273

Pélops: 297

Penélope: 20, 21 n. 14, 23, 24

Peneu: 322

Pentecostes: 34 n. 37

Periandro de Corinto: 21 n. 15, 75, 77, 78 n. $39,79,95$ e n. $93,156,184$, 219 n. 77

Péricles: 86 n. 62, 93 n. 85, 184

Peripatéticos, filósofos: 117 n. 11

Persas: 9, 122, 138, 140, 142, 143 e n. 63, 146, 156 n. 101, 255-257, 259 e n. 10, 260 n. $13,262,266$ n. 29, 273, 276, 278-280 n. 54, 283, 284 n. 60, 285, 287, 288-290, 291 n. 72, 294, 302, 303, 304 e n. 100, 370, 371

Perses, irmão de Hesíodo: 28 
Mobilidade poética na Grécia antiga: uma leitura da obra de Simónides

Perseu: 318, 331-337, 372, 373

Pérsia: 94, 141

Piéria: 300, 322

Piérides, Musas: 297, 300, 302, 328

Pigres de Halicarnasso: 361

Pilos: 17, 18

Pintor de Andócides: 80 n. 42

Pintor de Berlim: 80 n. 42

Pintor de Brygos: 80 n. 42

Pintor de Cleófrades: 50 n. 72

Pintor de Sísifo: 104-105 n. 25

Pirro: 250, 251

Pisa: 125,321 e n. 13

Pisístrato: 49, 93, 95, 137, 138 e n. 50, 153 n. $88,157,177$

Pisístrato, filho de Hípias: 141

Pisístratos: 49, 50 n. 70, 93 e n. 84, 94, 122,131 n. 33, 136 n. 47, 137 e n. 50, 139-141, 157

Pítaco de Mitilene: 81 n. 45, 202, 204, 206, 207 n. 43, 208, 212 e n. 62,219 e n. 77

Pitágoras de Régio, escultor: 240

Pitágoras: 56

Pitagóricos, filósofos: 206 n. 40

Pítia: 43, 44, 46

Píton: 33,86 n. 60,88 n. $66,124,318$, 370

Planura Elísia (Campos Elísios): 349 e n. 87,372

Plateias: 151,286-288 n. 65, 292, 302-304, 308, 310 e n. 110,311 e n. 114, 312

Plateias, batalha: 9, 147, 149, 151, 228 n. 102, 236, 267, 285-313

Plateias, 'Elegia de Plateias': 151, 265, 267, 293-313, 317, 322, $328,350,371,372$

Podalírio: 21 n. 14

Poiessa: 116

Polícrates de Samos: 39 e n. 49, 89 e n. 70,90 n. 72,92 e n. 77,93 e nn. 81, 82, 84; 168, 233 n. 114, 265, 313
Polícrito (avô e neto): 243, 244 n. 17

Polidamante: 19 n. 10

Polideuces/Pólux: 91 n. 75, 181, 246, 247, 317 e n. 2

Polifido: 20 n. 14

Poliido: 20 n. 14

Polimnesto de Cólofon: 71-73, 88

Políxena: 350, 372

Polizelo: 167 e n. 124

Ponto: 117

Ponto Euxino: 340

Pórtico Pintado (Stoa Poikile): 261 n. 16

Poséidon: 124,279, 291 n. 72,321 n. 13, $322,339,340$ e n. 67,343 n. 74,361 e n. 16,370

Prexídice: 161

Príamo: 17, 199, 296, 299 n. 87, 347

Priene: 219 n. 77

Prometeias: 94 n. 88

Prónomo: 80 n. 42, 88 e n. 68

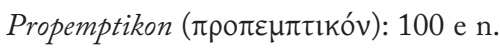
6, 170 e n. 130

Protágoras: 173, 185, 205 e n. 35, 207, 213 e n. 63

Proteu: 349 n. 87

Psâmis de Camarina: 253 n. 46

Ptéleo: 18

Quélidon/Filomela: 362 n. 18

Quercus coccifera: 345 n. 79

Quercus ilex: 345 n. 79

Queroneia: 277 n. 50

Quílon de Esparta: 210 n. 53, 219 n. 77

Quios: 33, 35, 36 e n. 39, 38, 39, 42, 47, 50,53 e n. 80,103 n. 17,162 n. 112 , 216, 222, 223, 227, 283

Régio: 42 n. 57, 71, 83, 89 e n. 70, 90 e n. 72,91 n. 74,93 n. $83,102,129$, $172,240,253$ e n. $44,254,350$

Rénea, ilha: 39 n. 49

Rodes: 105 e n. $27,146,147,153,154$, 219, 228 n. 101, 249, 318, 329, 339, 
340 n. 67,342 n. 71,349 e n. 87 , 363 n. 23

Roma: 180

Sácadas de Argos: 71, 86-89

Salamina: 50 n. 71,244 n. 17, 276-278 e n. $51,279,280$ n. $54,281,289,304$ n. 102,344

Salamina, batalha: 115 n. 1, 118$119,144,145$ e nn. 67,$69 ; 146$ e n. $72,147,150$ e n. $80,243,244$, 258, 275-285, 292, 293 n. 77

Samos: 39, 89 e n. 70, 90, 92, 93 e n. 84,168

Sansão: 161 n. 111

Sardes: 74 n. 26, 92, 93

Sarpédon: 269, 297

Seleuco, gramático: 350, 351

Serifos: 331,333

Sete (contra Tebras): 338

Sete Sábios: 21 n. 15, 95 e n. 93, 96, 207 n. 43,219 e n. 77,374

Sibota: 66

Sicília: 54, 77, 102, 112, 119, 131, 143, 144 n. $64,149,157,164,167-169$ e n. $128,170,171$ e n. 134,177 n. 149 , 184, 254 n. 49, 318, 359, 369, 370

Sícion: 49, 57 nn. 86 e 89, 85, 88, 96, 130,131 n. 32,142 n. 59

Sicofanta: 363

Sídon: 25 n. 19, 102

Sigeu: 312

Simo, pai de Alevas: 159

Simplégades: 340

Siracusa: 38, 54, 55, 91 n. 75, 102, 105, $107-109,110$ n. 37,131 n. 32,144 n. $64,164,166,168,171,176$ n. 147 , 178,241 e n. 6,253 n. 46,361

Síria: 133

Sócrates: 26, 50-53, 55, 59, 80 n. 43, 94, 105,163 n. 116, 165, 173, 205 e n. 35, 209 n. 46

Sofistas: 52, 56, 176 e n. 148, 185, 200 n. 23
Sono: 357

Sosístrato: 51 n. 76

Staatliche Antikensammlungen, Munique: 78 n. 40,105 n. 25

Sylloge Simonidea: 150

Tales de Mileto: 56, 99, 184, 219 n. 77

Taletas de Gortina: 70-72 e n. 23, 167

Talos: 318 n. 3

Taltibíadas: 53 n. 80

Taltíbio: 53 n. 80

Taminas: 142

Tâmiris: 17,18 e nn. 6 e 7,19 e 9,21,26, $28,40,88,369$

Tânagra: 86 n. 62

Tarento: 77,80 n. 43

Targélias: 94 n. 88

Tasos: 355

Tauroménio: 167, 284 n. 58

Teárides: 54

Tebanos: 290

Tebas: 20 n. 14,30 n. 31,31 n. $32,58,73$, $88,104,105,108-110,128$ n. 27, 130 n. 31,131 n. $32,153,171,175,196$ n. 17,226 n. 95,266 n. $31,327,338$

Tégea: 86 n. 60

Tegeatas: 287

Telémaco: 22, 23, 25, 79 n. 40

Télemo: 20 n. 14

Temístocles: 139 n. 56, 145, 146 e nn. 71,$72 ; 147,149$ n. 78, 181, 182, 244, $258,282,312$ n. 117,344 n. 77

Tempe: 157 e n. 103

Ténaro: 75 n. 28,78 n. 39

Ténedos: 105, 328

Teoclímeno: 20 n. 14

Teogneto: 153 e n. 91

Teos: 92, 93 e n. 85, 94, 136, 143, 161

Teóxeno: 230 n. 111, 233 n. 114, 328

Tera: 44

Téron de Agrigento: 106, 164, 167, 168 n. $125,170,171$ 
Mobilidade poética na Grécia antiga: uma leitura da obra de Simónides

Termópilas: 150, 220, 264 e n. 23, 265 e n. 26,266 e n. 29,267 e n. 32,269 n. $36,270,271,273,274,373$

Termópilas, batalha: 261-274, 277, 286, 309 n. 108

Terpíades: 24

Teseu: 343, 344, 346, 372

Téspias: 86 n. 62

Téspios: 274, 276

Tessália: 19 e n. 8, 85, 94, 106, 122, 129, 156 e n. 101,157 e n. 103, 158-160, 162, 163 e n. 116, 164, 180, 181, 209 n. 46, 214, 233, 250, 251 e n. $36,343,370$

Tessálios: 251

Téssalo de Corinto: 155

Téssalo, rei da Tessália: 250

Tessalonica: 74 n. 26

Tétis: 294, 301 n. 92

The Metropolitan Museum of Art, Nova Iorque: 80 n. 42

Timodemo de Acarnas: 50 e n. 71

Tindáridas (vide Dioscuros): 163, 181,297

Tiranicidas: $132,138,139$

Tírea: 72 n. 23

Tirésias: 20 n. 14

Tisâmeno: 304-306 n. 104

Tísias: 82

Titãs: 328

Tlepólemo: 329

Tórax: 159

Trácia: 18, 92, 100, 356

Trasibulo: 109 e n. 35,171

Trigeu: 174

Trio: 18

Tróia: 26, 28, 29, 54, 90, 133 n. 37, 196 n. $17,298,299,302,306,308,310$ n. 111,312 e n. $118,313,347$

Troianos: 15 n. 2, 303 n. 98, 312 n. 118, 347,348

Trós: 252 n. 42
Ulisses: 15, 16 n. 4, 19, 20 n. 14, 21-26, 29 n. $26,40,41,79$ n. $40,211,212$, $325,328,355$

Urânia, Musa: 16 n. 3, 361

Urano: 250, 319

Vulci: 50 n. 72

Xantipa: 156 e n. 100

Xantipo: 93 n. 85

Xenócrates de Agrigento: 109, 129, 170,171 e nn. 132,$133 ; 175$

Xenócrito de Locros: 71-73 e n. 24, 78

Xenodamo de Citera: 71-73

Xenófilo: 131

Xenofonte de Corinto: 105 n. 27, 155, 156,283

Xerxes: $144,145,157$ n. 103,284 n. 58

Zacintos: 79 n. 40

Zancle: 253

Zéfiro: 319

Zetes: 145 n. 69

Zeus: 18, 28, 50, 53, 99 n. 1, 102, 121, $125,134,149$ e n. 79,169 e n. 128 , 201 n. $27,232,242,245$ n. 22, 249, 259, 291 n. 72, 297, 299, 305, 306, $317,318,321$ e n. 13, 322, 324 e n. $21,325,327,329-331,333,337$, 349 e n. $87,355-357$ e n. $6,358,359$

Zeus Ámon: 99 n. 1,109

Zeus Ceneu: $321-322$ e n. 15

Zeus Ithomatas: 66 e n. 5,67

Zeus Libertador (Eleutherios): 287, 288 n. 65,310 e n. 113

Zeus Nemeu: 46

Zeuxipo: 152 n. 86 


\section{ÍNDICE DE TERMOS GREGOS}

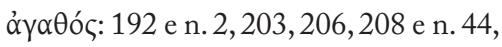
209, 212 e n. 59, 214, 215

ảyévelol: 248 n. 29

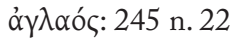

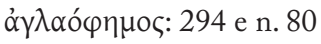

áyvós: 290 n. 70, 324 e n. 19

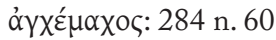

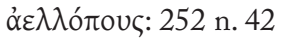

ảévoos: 219 n. 80

Aiótıc: 250 e n. 35

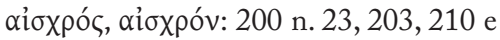
n. $51,214,215$

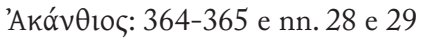

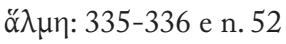

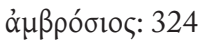

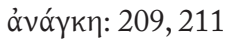

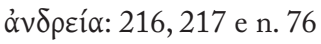

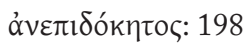

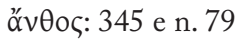

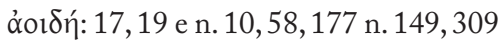

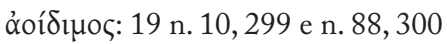

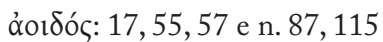

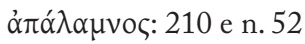

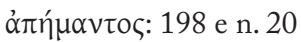

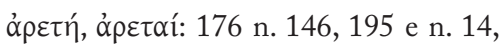

212 e n. $59,216,263,265,371,374$

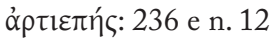

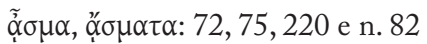

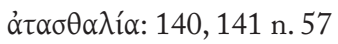

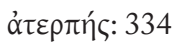

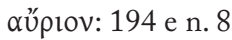

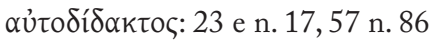

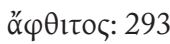

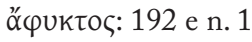

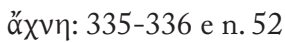

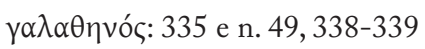

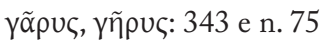

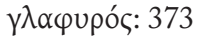

$\delta \alpha 1 \delta \alpha ́ \lambda \varepsilon \circ$ s: 333 e n. 46

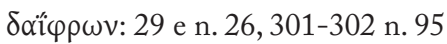

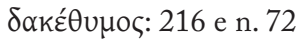

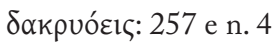

$\delta \alpha \sigma \pi \lambda \eta ́$ ఢ: 195

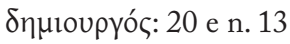

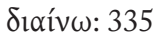

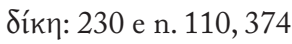

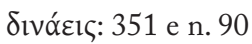

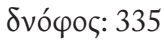

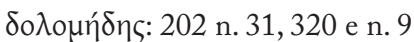

Incluem-se neste índice, não exaustivo, os termos gregos comentados ou com algum significado nos versos de Simónides. 
Mobilidade poética na Grécia antiga: uma leitura da obra de Simónides

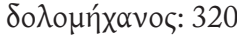

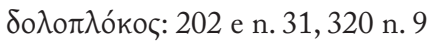

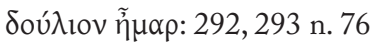

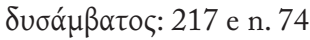

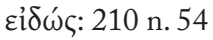

हivó $\lambda$ เos: 294

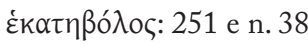

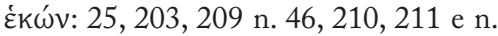
57

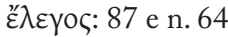

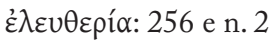

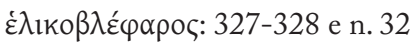

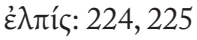

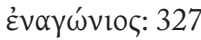

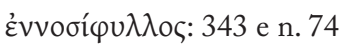

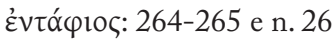

ह้ँ́aıvoৎ: 263 e n. 18

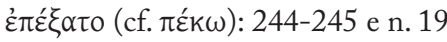

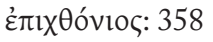

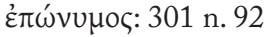

Épavvóc: 325 e n. 24

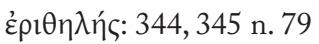

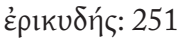

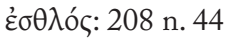

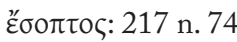

عن̉ăүท́s: 234-235 e n. 121

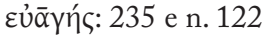

घủańs: 235 e n. 122

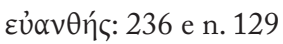

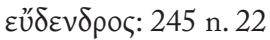

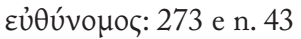

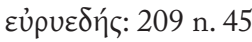

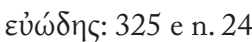

ทंठovท́: 221

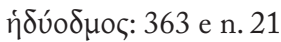

ทेंo५: 335

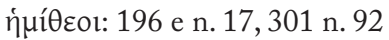

ทंpíov: 261

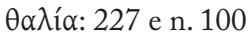

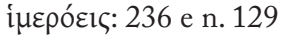

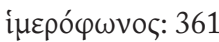

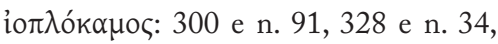
339 n. 63

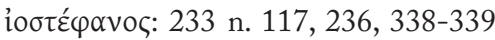
e n. 63

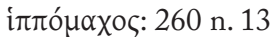

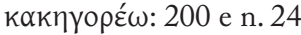

какós: 192 e n. 2, 210 e n. 51, 212, 214

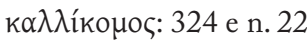

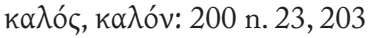

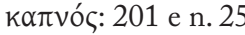

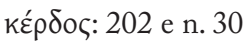

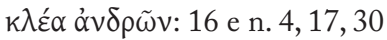

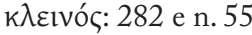

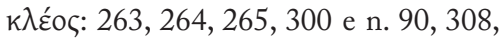
$313,324,371$

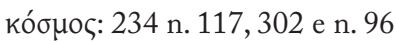

кuáveos: 342 e n. 72, 363 e n. 22, 363

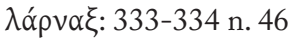

$\mu \varepsilon \gamma \alpha \lambda \eta \gamma о \rho \varepsilon ́ \omega: 200$ e n. 24

$\mu \varepsilon \gamma \alpha \lambda \eta ́ \tau \omega \rho: 29$

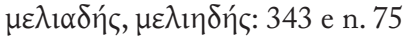

$\mu \varepsilon \lambda i ́ \varphi \rho \omega v: 301-302$ n. 95

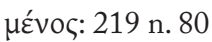

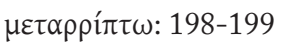

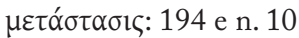

$\mu \eta \delta$ ' ó $\gamma \alpha v: 210$ e n. 53

$\mu \nu \tilde{\eta} \mu \alpha: 180$ e n. 155

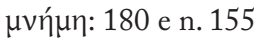

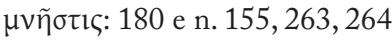

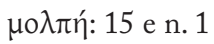

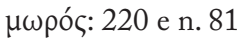

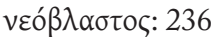

vท́лı५: 226 e n. 94

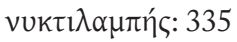

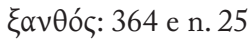

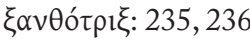

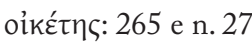

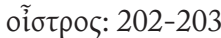


ő $\lambda$ ßıс: 194 e n. 8

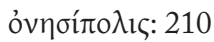

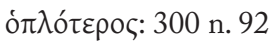

oủpóvios: 328 e n. 34

oúpeเо૬: 327 e n. 31

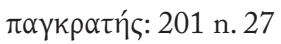

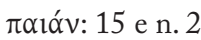

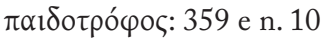

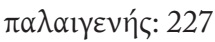

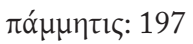

$\pi \alpha v \delta \alpha \mu \alpha ́ \tau \omega \rho: 264$ e n. 22

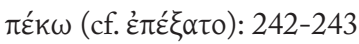

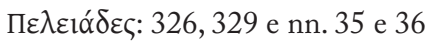

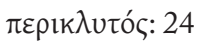

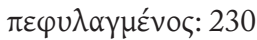

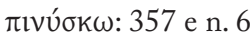

$\pi \lambda$ oṽนo५: 195 e n. 14

тoín: 231 n. 112

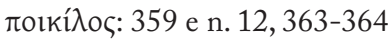

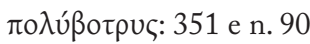

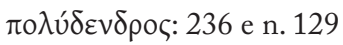

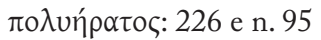

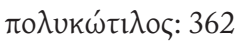

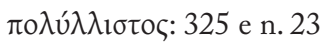

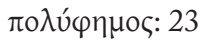

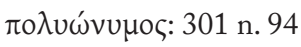

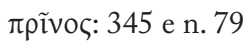

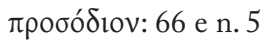

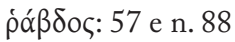

р́ó $\tau \tau \omega: 58$ e n. 92

jo $\alpha \omega \delta \varepsilon \dot{\varepsilon} \omega: 44,55,56$

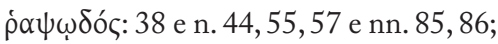

58 e nn. 92,93

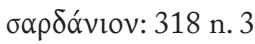

бұкós: 266 e n. 32, 267 n. 33

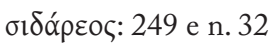

борós: 261

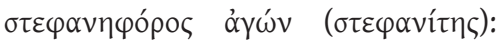
141 n. 59

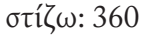

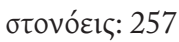

бчраүí́: 36 e n. 39

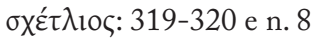

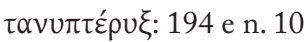

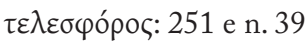

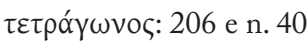

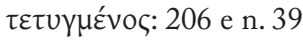

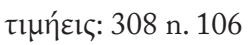

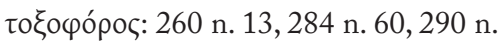
70

траүо́тоus: 258 е n. 7

üßpı: 140,230 e n. 110

úyı́́s: 209 e n. 49, 210, 211, 371

úppóc: 345 e n. 78

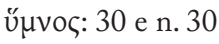

úrépßı⿻: 259

фаркі́: 234 e n. 118, 236

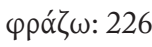

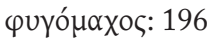

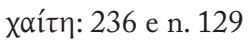

$\chi \propto \lambda$ ко́үончос: 334

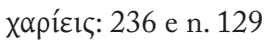

$\chi \lambda \omega \rho \alpha u ́ x \eta v: ~ 362$ e n. 19, 363

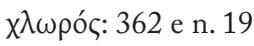

хрóvos: 264 e n. 22, 374

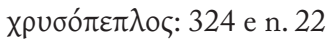

хрибóৎ: 201 e n. 26,308 n. 106

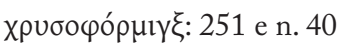

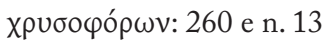

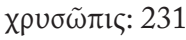

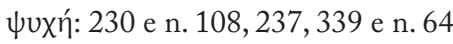

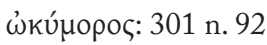


(Página deixada propositadamente em branco) 


\section{Volumes publicados na Colecção Humanitas SUPPLEMENTUM}

1. Francisco de Oliveira, Cláudia Teixeira e Paula Barata Dias: Espaços e Paisagens. Antiguidade Clássica e Heranças Contemporâneas. Vol. 1 - Linguas e Literaturas. Grécia e Roma (Coimbra, Classica Digitalia/CECH, 2009). 288 p.

2. Francisco de Oliveira, Cláudia Teixeira e Paula Barata Dias: Espaços e Paisagens. Antiguidade Clássica e Heranças Contemporâneas. Vol. 2 - Linguas e Literaturas. Idade Média. Renascimento. Recepção (Coimbra, Classica Digitalia/CECH, 2009). 199 p.

3. Francisco de Oliveira, Jorge de Oliveira e Manuel Patrocínio: Espaços e Paisagens. Antiguidade Clássica e Heranças Contemporâneas. Vol. 3 - História, Arqueologia e Arte (Coimbra, Classica Digitalia/CECH, 2010). 331 p.

4. Maria Helena da Rocha Pereira, José Ribeiro Ferreira \& Francisco de Oliveira (Coords.): Horácio e a sua perenidade (Coimbra, Classica Digitalia/CECH, 2009). $180 \mathrm{p}$.

5. José Luís Lopes Brandão: Máscaras dos Césares. Teatro e moralidade nas Vidas suetonianas (Coimbra, Classica Digitalia/CECH, 2009). 461 p.

6. José Ribeiro Ferreira, Delfim Leão, Manuel Tröster \& Paula Barata Dias (eds): Symposion and Philanthropia in Plutarch (Coimbra, Classica Digitalia/CECH, 2009). $573 \mathrm{p}$.

7. Gabriele Cornelli (Org.): Representações da Cidade Antiga. Categorias históricas e discursos filosóficos (Coimbra, Classica Digitalia/CECH/Grupo Archai, 2010). 173 p.

8. Maria Cristina de Sousa Pimentel e Nuno Simões Rodrigues (Coords.): Sociedade, Poder e Cultura no Tempo de Ovídio (Coimbra, Classica Digitalia/CECH/ $\mathrm{CEC} / \mathrm{CH}, 2010) .288 \mathrm{p}$.

9. Françoise Frazier et Delfim F. Leão (eds.): Tychè et pronoia. La marche du monde selon Plutarque (Coimbra, Classica Digitalia/CECH, École Doctorale 395, ArScAn-THEMAM, 2010). 298 p.

10. Juan Carlos Iglesias-Zoido: El legado de Tucídides en la cultura occidental. Discursos e historia (Coimbra, Classica Digitalia/CECH, ARENGA, 2011). 301 p.

11. Gabriele Cornelli, O pitagorismo como categoria historiográfica (Coimbra, Classica Digitalia/CECH, 2011). 265 p.

12. Frederico Lourenço, The Lyric Metres of Euripidean Drama (Coimbra, Classica Digitalia/CECH, 2011). 451 p.

13. José Augusto Ramos, Maria Cristina de Sousa Pimentel, Maria do Céu Fialho, Nuno Simões Rodrigues (coords.), Paulo de Tarso: Grego e Romano, Judeu e Cristão (Coimbra, Classica Digitalia/CECH,/CHUL, CEC, 2012). 306 p. 
14. Carmen Soares e Paula Barata Dias (coords.), Contributos para a história da alimentação na antiguidade (Coimbra, Classica Digitalia/CECH, 2012). $116 \mathrm{p}$.

15. Carlos A. Martins de Jesus, Claudio Castro Filho, José Ribeiro Ferreira (coords.), Hipólito e Fedra - nos caminhos de um mito (Coimbra, Classica Digitalia/CECH, 2012). 228 p.

16. José Ribeiro Ferreira, Delfim F. Leão, \& Carlos A. Martins de Jesus (eds.): Nomos, Kosmos E Dike in Plutarch (Coimbra, Classica Digitalia/CECH, 2012). 277 p.

17. José Augusto Ramos \& Nuno Simões Rodrigues (coords.), Mnemosyne kai Sophia (Coimbra, Classica Digitalia/CECH/CHUL, 2012). 200 p.

18. Ana Maria Guedes Ferreira, O homem de Estado ateniense em Plutarco: o caso dos Alcmeónidas (Coimbra, Classica Digitalia/CECH, 2012). 396 p.

19. Aurora López, Andrés Pociña \& Maria de Fátima Silva (coords.), De ayer a hoy: influencias clásicas en la literatura (Coimbra, Classica Digitalia/CECH, 2012). $594 \mathrm{p}$.

20. Cristina Pimentel, José Luís Brandão \& Paolo Fedeli (coords.), O poeta e a cidade no mundo romano (Coimbra, Classica Digitalia/CECH/CEC, 2012). 240 p.

21. Francisco de Oliveira, José Luís Brandão, Vasco Gil Mantas \& Rosa Sanz Serrano (coords.), A queda de Roma e o alvorecer da Europa (Coimbra, Imprensa da Universidade de Coimbra, Classica Digitalia, 2012). 252 p.

22. Luísa de Nazaré Ferreira, Mobilidade poética na Grécia antiga: uma leitura da obra de Simónides (Coimbra, Imprensa da Universidade de Coimbra, Classica Digitalia, 2013). 472 p. 
(Página deixada propositadamente em branco) 


\section{$Q R=$ \\ COMPETE}

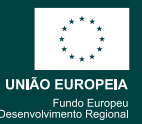

OBRA PUBLICADA
COM A COORDENAÇÃO
CIENTÍFICA

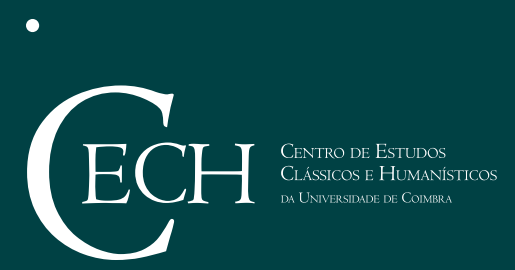

- U

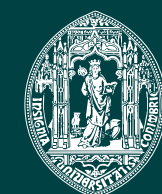

C -

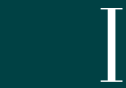

IMPRESSA DA UNIVERSDADE DE COIMBK

U 